\title{
Comprehensive Survey of Sedimentation in \\ Lake Mead, 1948-49
}

GEOLOGIGAL SURVEY PROFESSIONAL PAPER 295

Prepared in collaboration with the U.S. Department of the Interior, Bureau of Reclamation; U.S. Department of the Navy, Chief of Naval Operations, Bureau of Ships, Bureau of Ordnance, Bureau of Naval Personnel, Hydrographic Office, and Navy Electronics Laboratory; U.S. Department of Commerce, Coast and Geodetic Survey; University of California, Scripps Institution of Oceanography

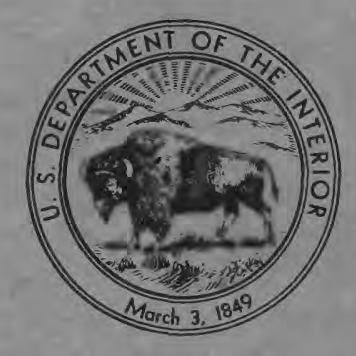



Comprehensive Survey

of Sedimentation in

Lake Mead, 1948-49

By W. O. SMITH, C. P. VETTER, G. B. CUMMINGS, and others

GEOLOGICAL SURVEY PROFESSIONAL PAPER 295

Prepared in collaboration with the U.S. Department of the Interior, Bureau of Reclamation; U.S. Department of the Navy, Chief of Naval Operations, Bureau of Ships, Bureau of Ordnance, Bureau of Naval Personnel, Hydrographic Office, and

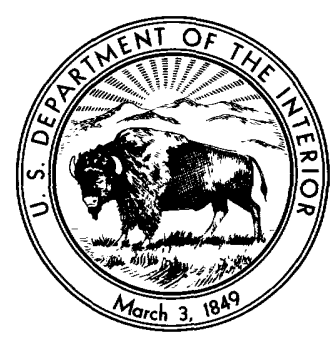
Navy Electronics Laboratory; U.S. Department of Commerce, Coast andGeodetic Survey; University of California, Scripps Institution of Oceanography

UNITED STATES GOVERNMENT PRINTING OFFICE, WASHINGTON : 1960 


\section{UNITED STATES DEPARTMENT OF THE INTERIOR \\ FRED A. SEATON, Secretary \\ GEOLOGIGAL SURVEY}

Thomas B. Nolan, Director

For sale by the Superintendent of Documents, U.S. Government Printing Office Washington 25, D.C. 


\section{F O R E W O R D}

Reservoirs are becoming an increasingly prominent feature of the American landscape. Built for flood mitigation and to change a fluctuating river into a dependable source of water for irrigation, power, and other purposes, they are predestined, like natural lakes, to be destroyed sometime following their creation. Sedimentation sooner or later robs most lakes and reservoirs of their capacity to store water. The significance of sedimentation in the life of Lake Mead, the largest artificial reservoir in the world, was realized when the plan for the reservoir was conceived, and an aerial survey of the floor was made in 1935 before the reservoir filled with water. The survey provided a base for the study of future sedimentation.

A casual view of the magnificent expanse of Lake Mead in its desert environment gives no more than a hint of the complex actions and interactions within and near the lake that are critical in relation to the long-term service for which the lake was impounded. The reservoir impounds sediment, dissolved salts, and heat as well as water. Each of these has important effects on the usefulness of the reservoir. Accurate appraisal of the magnitude of the impounded items is the key to longtime successful reservoir management. Such appraisals take the form of budgets, showing the balance between income, outgo, and storage. The sediment budget affects the life of the reservoir, the salt budget affects the chemical quality and usefulness of the impounded water, and the heat budget affects evaporation and the water balance. This report, although centered about the sediment budget, treats the other items to some extent, but each in time will require separate inquiry. The importance of evaporation already has led to a separate report on the heat budget. These problems relate to all reservoirs; but, because of the great size of Lake Mead, the importance and complexity of the problems there reach major proportions. The lake offers an opportunity to test and apply principles that can be derived from study of the sediment, salt, and heat balances. For these reasons the Bureau of Reclamation, the steward of the reservoir on behalf of the people of the country, asked the Geological Survey to lead a joint study by many scientists of the diverse and complicated aspects of Lake Mead. The resulting report is unique in its field because it represents a study by a diversified group of research scientists trained in several different fields of research, including oceanography, hydrology, and geology, working together on a common problem. Such pooling of talents promises to become more common in future hydrologic research because the results of this study have proved the synergistic value of collaboration.

The specific results of the study are food for speculation about future accumulations of sediment and the movement of salt. We have assurances that Lake Mead will not be filled with sediment for at least 350 years and that it will not become a salt lake. The wealth of information in this report undoubtedly will be useful in the operation, not only of Lake Mead, but of many other reservoirs already built or in prospect.

Carl G. Paulsen Chief Hydraulic Engineer February 1957 


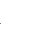




\section{PREFACE}

This report on the Lake Mead comprehensive survey of 1948-49 includes a planned collection of papers or chapters that cover fully the intensive field investigations in those years, in which several agencies participated. The technical direction of the comprehensive survey was by the U.S. Geological Survey, with general supervision by C. G. Paulsen, chief of the Water Resources Division, and R. W. Davenport, chief of the Technical Coordination Branch of that Division. W. B. Langbein, hydraulic engineer of the Technical Coordination Branch, contributed importantly to the initial conception of the comprehensive survey and advised in the general supervision. W. O. Smith, physicist of the Water Resources Division, as project chief for the Lake Mead survey was responsible for the overall direction of the program. C. P. Vetter, as Chief of the Office of River Control, Bureau of Reclamation, the contracting agency, approved the general scope of the investigations. He also assisted in the coordination of the field activities and served as principal consultant on reservoir engineering problems. G. B. Cummings, Chief of the Sonar Design Branch of the Bureau of Ships, was in charge of the activities of the Navy Department and served as principal consultant with respect to the echo-sounding and communication problems. Messrs. Smith, Vetter, and Cunmings constituted a project staff representing the three agencies principally involved in the Lake Mead survey. These men had primary responsibility for setting the policy of the report, determining what chapters would be included and indicating their general scope; a large proportion of their time was occupied with the project throughout the period of the field investigations.

The project required the services of many consultants who advised in matters pertaining to their respective scientific specialties. Several of these men participated in the development of plans for the survey; most of them visited the area at various times during the survey to consult with members of the field staff. Several of the consultants have contributed technical reports, which appear in succeeding chapters. Consultants within the Geological Survey included: C. S. Howard, staff chemist, Quality of Water Branch, Water Resources Division; C. B. Hunt, chief (during the in- vestigation), General Geology Branch, Geologic Division; H. V. Peterson, staff geologist, Technical Coordination Branch, Water Resources Division; R. M. Wilson, chief, Geodesy and Control Surveys Section, Topographic Division; K. O. Emery, also professor of geology, University of Southern California; and C. R. Longwell, also professor of geology, Yale University.

For the Bureau of Reclamation the following men advised on specific engineering problems: J. W. Stanley, of the Office of River Control; E. A. Moritz, director of Region III; L. R. Douglas, assistant director, and C. P. Christensen, director of power of the Boulder Canyon project.

Consultants for the Navy Department included: Gunnar Leifson, head, and M. R. Ullom, assistant head, of the Survey Branch, Hydrographic Office; Lt. W. R. Brooks, U.S.N.R., and C. E. Nicholson, engineer in the Research and Development Section, Bureau of Ordinance; E. C. LaFond and R. W. Dietz, of the Oceanography Section, and R. D. Russell, consultant on geophysics-all of the Navy Electronics Laboratory in San Diego, Calif.; and C. E. Mongan, Jr., then with the Sonar Design Division of the Bureau of Ships, and now physicist with the Edo Corporation.

Other consultants on the Lake Mead survey included E. J. Parkin, mathematician of the Division of Geodesy, for the Coast and Geodetic Survey; F. D. Sisler, research associate of the Microbiology Division, Scripps Institution of Oceanography, University of California; W. C. Blaisdell, vice president of Bludworth Marine Division of National-Simplex-Bludworth, Inc.; R. P. Geddes, Jr., marine manager of Pacific Division, Bendix Aviation Corporation; and N. B. McLean, president of Edo Corporation.

In field operations of the Geological Survey at Boulder City, F. C. Ames, resident engineer, and his assistant, F. W. Kennon, were responsible for maintenance of vertical control, signaling at horizontal control points, drafting of control maps, layout of lines to be sounded, and plotting of the results of soundings. These men also computed the reservoir-area and capacity tables, using methods developed for the Lake Mead survey by J. L. Speert, geodetic engineer, Topo- 
graphic Division. The third-order triangulation necessary for horizontal control was done by W. P. McIntosh and J. P. Minta, under the supervision of R. M. Wilson. The survey of the Lower Granite Gorge was made by F. W. O'Bannon, chief of party, under the supervision of L. C. Pampel. Investigations of the geologic changes since Hoover Dam was constructed were made by $\mathrm{H}$. R. Gould, resident geologist, under the supervision of K. O. Emery. Studies of the sediments were made by Gould, partly at the University of Southern California. Irving Sherman assisted in the analyses of sediments in a laboratory set up in Hoover Dam. Chemical analyses to determine dissolved solids in the water were made in the Geological Surrey laboratory at Salt Lake City under the direction of C. S. Howard.

Underwater soundings were conducted by Lt. C. C. McCall, Bureau of Ordnance, with a Navy crew of seven petty officers (Chief minemen: J. M. Dickison, J. D. M. Freitas, A. B. Holmes, H. E. Knudsen, G. B. Labagnara, C. D. Malone, and M. L. Perez) under the general supervision of Gunnar Leifson of the Hydrographic Office. Enderwater photographic investigations were also made by Lt. McCall. D. W. Pritchard of the Nary Electronics Laboratory directed monthly cruises on the lake for salinity and thermal surveys. E. R. Anderson assumed active charge of these surveys when Mr. Pritchard became associated with the Chesapeake Bay Institute, and he prepared the report on physical limnology in collaboration with Mr. Pritchard.

Biological and biochemical studies of the sediment were made under the direction of F. D. Sisler of the Scripps Institution of Oceanography. The changes in the earth's crust since Hoover Dam was constructed were determined on the basis of precise leveling by the Coast and Geodetic Survey in 1935 and releveling in $1940-11$ and $1949-50$, under the supervision of $\mathrm{E}$. J.
Parkin. Analyses of these leveling data were made by C. R. Longwell.

Some of the papers presented herein rely to an important degree upon data obtained in other parts of the Colorado River basin. Included in this category are discussions of the geologic setting, by C. R. Longwell; the drainage basin tributary to Lake Mead, by H. E. Thomas; the water budget for Lake Mead, by W. B. Langbein; physical and chemical characteristics of the inflowing water, by C. S. Howard; life of the reservoir, by H. E. Thomas, H. R. Gould, and W. B. Langbein; and the sediment problem in reservoirs, by Thomas Maddock, Jr.

This report in advance form (Smith, Vetter, Cummings, and others, 1954), was made available to the public in 1954 by placing it in the open files of the Geological Survey and by reproduction by the Bureau of Reclamation, Boulder City, Nev., for distribution for official use and review by cooperating agencies and others concerned. H.E. Thomas, of the Geological Survey, did the final technical editing of this report both in its advance form and for the present publication. The original draft of the report was assembled by W.O. Smith. Base data obtained as part of this investigation, which will be of use for comparison with future surveys of Lake Mead but is too detailed for inclusion in this report, are contained in the Geological Survey open-file report "Supplemental Base Data for Lake Mead: Comprehensive Survey of 1948-49." This report was also reproduced by the Bureau of Reclamation, Boulder City, Nev., in very limited quantity for reference work. The maps showing the bottom of Lake Mead as determined by the survey were printed only as overlay sheets to the Soil Conservation Service maps of 1935. A summary of the conclusions of this investigation is given in Geological Survey Circular 346, "First Fourteen Years of Lake Mead" (Thomas, 1954). 


\section{CONTENTS}

Summary of results, by W. O. Smith, C. P. Vetter, and G. B. Cummings

Page

1

Part 1. Introduction

A. The Lake Mead problem, by C. P. Vetter

Page

Reference cited.

B. Organization of the work and equipment, by W. O.

Smith.

Mapping the bottom of the reservoir..........

Determining the character of sediments..........

Measuring the salinity and thermal characteristics of

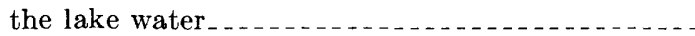

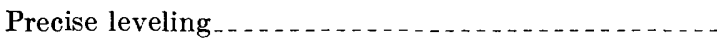

Comments on operations

Communication facilities, by Lt. C. C. McCall, USN.

Reference cited.

C. Geologic setting of Lake Mead, by C. R. Longwell. -

Location and topography

Stratigraphy

Precambrian rocks

Paleozoic and Mesozoic rocks

Cretaceous (?) and early Cenozoic (?) rocks...

Overton fanglomerate. ................

Horse Spring formation.
C. Geologic setting of Lake Mead-Continued Stratigraphy-Continued

Middle and late Cenozoic rocks............... Muddy Creek formation...............

Hualpai formation Chemehuevi formation................

Volcanic rocks and related intrusive bodies.... Structure of the bedrock ..................... Summary of geologic history

References cited.....................................

D. Drainage basin tributary to Lake Mead, by H. E.

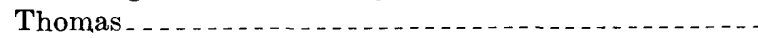

Physiography _.............. Geology _... . . . .

Water

Sediment $\ldots \ldots$

Suspended load

Bed load

Live storage

Dead storage

References cited

Part 2. Geodetic Surveys

E. Precise leveling, by E. J. Parkin

Adjustments

Hoover Dam level net.

F. Interpretation of the leveling data, by C. R. Longwell

Pertinent geologic features..................

Pattern of the changes in level.

Part 3. Hydrographic Survers

G. Survey of the lake, by Gunnar Leifson Outline of procedures, by M. R. Ullom and F. C.

Ames.

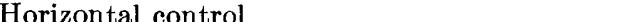

Plotting of soundings

Sounding procedures

Horizontal control, by R. M. Wilson

Program for triangulation ................

Description of operations . . . . . . . . . . . . .

Summary of results

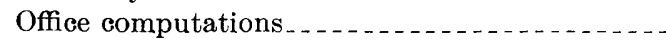

Vertical control, by F. C. Ames

Collection of water-stage records

Gage installations ..........................

Water-stage recorders ...............

Development of a common gage datum ......

Analysis of water-stage records.

Seiches . . . . . . . . . . . . . .

Tides.

Wind effects

Slope effects
Page

31

31

32

33

33

33
F. Interpretation of the leveling data-Continued

Possible causes of changes in level ..............

Comparison between measured and predicted subsidence....................................

Effect of subsidence upon reservoir capacity ......

References cited
Page

39

40

40

42

43

44
G. Survey of the lake-Continued

Vertical control-Continued

Evaluation of discrepancies . . . . . . . . . . . .

Selection of reference datum. . . . . . . . .

Sounding operatiors, by Lt. C. C. McCall, USN Low-frequency depth-recording equipment, by W. C.

Blaisdell ...................................

NJ-8 Depth-recording equipment...........

Recorder............................

Driver-rectifier or signal sender..........

Transmitting and receiving transducers....

Motor-alternator set....................

NK-6 Portable depth-recording equipment....

Recorder. . . .

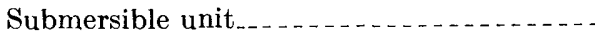

High-frequency depth-recording equipment, by

Robert P. Geddes, Jr. and Birt Blackman.......

NGB-3 Depth-recording equipment.........

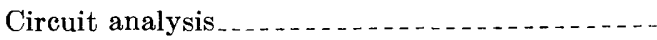

Page

56

57

58

59

59

59

62

62

63

63

63

66

66

66

67

Page 
Part 3. Hydrographic Surveys-Continued

G. Survey of the lake-Continued

Evaluation of the echo sounding, by G. B. Cummings and C. E. Mongan, Jr

Analysis of records

Summary of results, by F. C. Ames

Evidence of sediment accumulation

Evidence of slumping . . . .

Evidence of erosion -

References cited.

H. Survey of Lower Granite Gorge, by L. C. Pampel

Outline of operations

Total volume of sediment.

Distribution of sediment

References cited

I. Reservoir storage

Significance of area, capacity, and sediment tables,

by J. W. Stanley . . . . .

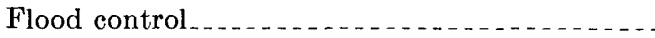

Irrigation and domestic use

Power generation
Page

I. Reservoir storage-Continued

Particle sizes in suspended load . . . . . . . . .

Seasonal variations......................

Correlation of analyses of deposited and suspended sediment..................

Suspended load from other sources . . . . . . . . .

Temperature of the inflowing water

Dissolved solids in the inflowing water.........

Seasonal variations

Annual variations

Density currents............................

Initial evidence, $1935-36$

Record of density currents

References cited.......................... 113

L. Chemistry of the water, by C. S. Howard $\ldots$

Program of investigation ................... 115

Dissolved solids in the lake water . . . . . . . 115

Seasonal variations...................... 115

Geographic variations................ 118

Variations with depth ................. 119

Relation to temperature of the lake water.... $\quad 119$

Effect of reservoir storage upon water quality _.... 121

Comparison of chemical constituents in the inflowing and outflowing water..........

Concentration by evaporation ..........

Precipitation of dissolved constituents $\ldots$...

Solution of reservoir bed and bank materials
Computations, by J. L. Speert, F. C. Ames, and F. W.

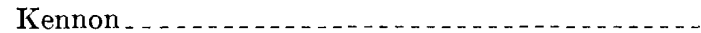

Original area and capacity computations.......

Review and revision of the original computations....................................

Area and capacity computations for 1948-49

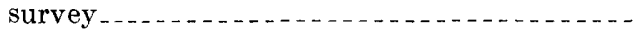

Computation of sediment and auxiliary tables.

Tables, by F. C. Ames, F. W. Kennon, and W. B.

Langbein. . . . . . . . . . . . . . . . . . . . . . .

Reference cited....................................

J. Water budget, W. B. Langbein

Method of computing the budget .............

Inflow

Outflow . . . . . . . .

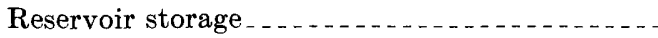

Statistical analyses

Evaporation . . . . . .

Transpiration

Precipitation .

Evaluation of bank storage . . .

References cited.

\section{Page}

L. Chemistry of the water-Continued

Effect of reservoir storage upon water quality-Con. Stabilization of water quality by reservoir storage

References cited ...................................

Page

\section{4}

85

85

86

M. Circulation and evaporation, by E. R. Anderson and

D. W. Pritchard

Circulation

Techniques for determining circulation .......

Tonguelike distributions. .............

Wüst's core method......................

$T-S$ relations.

Observational program . . .

Analysis . . . . . . . . . . . . . . . . . . . 127

Spring

Summer . . .

Fall $\ldots \ldots \ldots$

Winter . . . .

Summary of the circulation patterns _... _. . 139

Evaporation ............................. 141

Techniques for determining evaporation _.... 141

Energy budget......................... 141

Radiation from sun and sky .......... 142

Reflected sun and sky radiation......... 142

Effective back radiation ............. 142

Advected energy ..................... 142

Energy storage ..................... 143

Bowen ratio ............... 143

Summary _... . . . . . . . . . . . 143

Calculation of rates of evaporation....... 143

Comparison with rates of pan evaporation _... 145

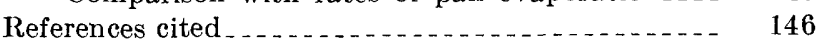


Part 5. Sediments

N. Character of the accumulated sediment, by $H$. R.

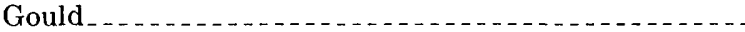

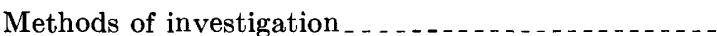

Miscellaneous observations ....................

Laboratory studies.

Water content and air-dry moisture content.... Specific gravity of sediment particles.......... Density, porosity, and specific weight. .......

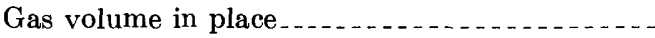

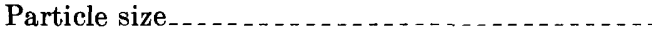

Distribution of sediment Colorado delta. . . . . . .

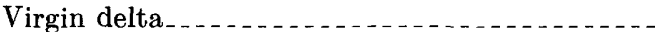
Deposits from small tributaries.............

Physiography of the deltas.....................

Colorado delta. Topset beds . . . . . Foreset beds . . . . . . . . . . . . . . Bottomset beds

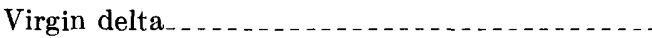

Growth and structure of the deltas

Colorado delta . . . . . . . . . . . . . . . . . Growth in February and March 1935 Growth from April 1935 to March 1936... Growth from April 1936 to July 1937 ..... Growth from July 1937 to December 1948 . -

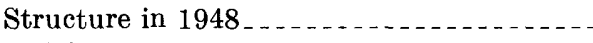
Virgin delta.

Physical properties....................... Texture and stratification. ................... Water content and porosity . . . . . . . . . . Specific weight. Gas content

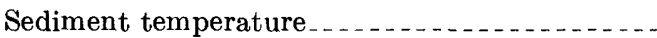

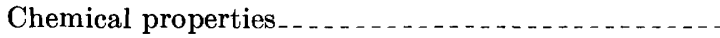
Chemical analyses.......................... Spectrographic analyses . . . . . . . . . . . . . .

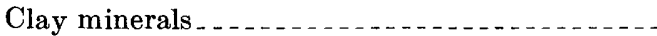
Calcium carbonate. Organic content . . . . . .

References cited

O. Bacteriology and biochemistry of the sediments, by

F. D. Sisler .

Physical and chemical character.

Bacterial populations...............................

Total population.

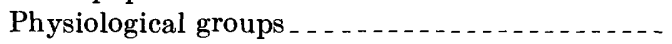

Biochemical oxygen demand . . . . .

Migration of bacteria . . . . . .

Effects of biochemical action ..................

Heating of sediments

Evolution of gas...............

Compaction of sediments _. . .

Summary and discussion .......................

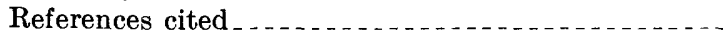

P. Amount of sediment, by $\mathrm{H}$. R. Gould

Volume

Weight

Rate of sedimentation
Page
P. Amount of sediment-Continued

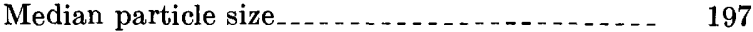

Average chemical composition 197

Potential economic use . . . . . . . . . . _ . . . 199

Q. Turbidity currents, by H. R. Gould ........... 201

Relation to river discharge and lake stratification _. - 202

Overflows.............................. 202

Interflows.......... 203

Underflows. . . .

Velocity, density, and thickness . . . . . . . . . . . . 204

Amount of sediment and distance of travel...... 205

Change in slope and width of the channel_........ 206

Size of suspended particles. . . . . . 206

Virgin River turbidity currents.

References cited............................ 207

R. Erosion in the reservoir, by H. R. Gould . . . . 209

Landslides . . . . . . . 209

Wave-cut terraces . . . . . . . . . . . . . . . 212

Solution

Erosion of the delta surface . . . . . . . . . . . . . 213

References cited......................... 213

$\mathrm{S}$. Sedimentation in relation to reservoir utilization, by

H. R. Gould . . . 215

Sediment-storage capacity above the permanent

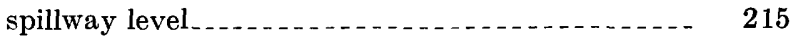

Sediment compaction ...................... 217

Pattern of sedimentation in the future......... 218 Complete filling . . .

Half way point in reservoir filling

Filling to sills of lower outlet gates at Hoover Dam

Terminal slope and residual storage Amount of erosion required for filling Lake Mead _. $\quad 228$

References cited............................. 229

T. Life of the reservoir, by H. E. Thomas, H. R. Gould, and W. B. Langbein

Projection of observed rates of sediment accumulation

"Normal" rate of sediment accumulation........ 232

Evaluation of existing records._._. Gaging of suspended sediment at Grand Canyon

Ungaged increments of sediment....... 233

Variations in rate of sediment inflow ......... 234

Variations in sediment load and runoff ... 234

Variations in relation of sediment to runoff_ $\quad 235$

Variations resulting from water development.

Variations in rate of sediment outflow . . . . . . 240

Probable rates of sediment accumulation in the

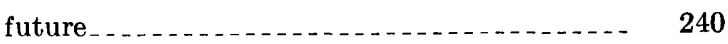

Miscellaneous changes in reservoir volume _..._... 241

Downwarping of the reservoir floor . . _...... 241

Dissolving of materials of the reservoir floor _.. $\quad 243$

References cited ............................ 244

U. The sediment problem in reservoirs, by Thomas Maddock, Jr. . .

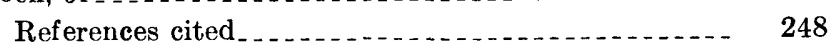
8

Index (1)

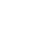




\section{ILLUSTRATIONS}

[Plates 1, 3, 4, 7, 12-14, 18-20, 24, and 26 are in pocket]

Plate 1. Geologic maps of the Lake Mead area, Arizona-Nevada. $A$, The Lake Mead area; $B$, The reservoir floor.

2. Steeply dipping strata of Carboniferous age along Grand Bay, Lake Mead.

3. Hoover Dam level net, levelings of $1935,1940-41$, and 1949-50.

4. Map of Lake Mead area, showing approximate boundaries between exposed bedrock and alluviated basins, and profiles along lines of leveling.

5. A, Boulder Canyon and Virgin Basin, Lake Mead; $B$, Shore signal used during the Lake Mead survey ........

6. Black Canyon and Boulder Basin of Lake Mead .

7. Map showing locations of gages used to establish water-stage elevations during the 1947-49 survey.

8. NJ-8 recorder, opened for inspection or servicing reflector hanging from case cover

10. $A, \mathrm{NK}-6$ recorder, showing carefully positioned spiral wire on drum; $B, \mathrm{NK}-6$ submersible unit, carrying transmitting and receiving transducers

11. $A$, NGB-3 depth recorder, inside view; $B$, NGB-3 depth recorder, showing recording unit

12. Comparative river-bed data along profile line 79D-109D in Boulder Basin.

13. Annual profiles of sediment distribution along Colorado River channel through Lake Mead, 1937 to 1948.

14. Map of Lower Granite Gorge, Lake Mead.

15. $A$, The Tonto platform; $B$, Sounding of cross section at range 24

16. Views of Lower Granite Gorge upstream from North Separation Canyon. $A$, In $1939 ; B$, In October 1948.....

17. Convergence of Colorado River and Lake Mead in Pierce Basin, November 1948.....

18. Map showing average station locations for cruises during Lake Mead survey 1948-49.

19. Map showing coring and sampling positions in Lake Mead, 1947-49.

20. Map and sections showing sediment distribution in Lake Mead, 1947-49.

21. $A$, One of many tributaries sealed off by natural levee, behind which a narrow lake has formed; $B$, Upstream view of the 1948 terrace, in which the Colorado River has entrenched itself

22. Closeup view of the 1948 terrace being cut back by the Colorado River in Pierce Basin.

23. Gas pits in the 1948 terrace near the delta front. $A$, General view; $B$, Closeup view of one of the large gas pits..

24. Map of Pierce Basin, showing pre-Lake Mead topography, 1935, and topography of accumulated sediments, 1949.

25. $A$, View of The Temple, Ariz., in 1934; B, View in 1948, showing fresh landslide scars on the face of The Tempel.-

26. Graphs showing relation between computed density of Colorado River water at Grand Canyon gaging station and arrival of turbid underflows at Hoover Dam.

27. Landslide on the north wall of Virgin Canyon near the mouth

28. Prominent landslide on the east side of Gregg Basin near the mouth of Hualpai Wash

29. $A$, Solution and terracing of gypsum reefs near the mouth of Detrital Wash; $B$, Solution cavities in siltstone and gypsum of the Muddy Creek formation in Las Vegas Bay.

Figure 1. Map of Colorado River basin, showing location of Lake Mead

2. Major physiographic features of the Lake Mead region

3. Structural relations of principal bedrock units; profile along line $\mathrm{A}-\mathrm{B}-\mathrm{C}$ of plate 1

4. Map of drainage basin tributary to Lake Mead, showing source areas of sediments as inferred from surface geology

5. Streamflow entering Lake Mead during water year 1948

6. Suspended sediment inflow to Lake Mead during water year 1948

7. Sediment carried by the Colorado River in water years 1931-50

8. Contours showing changes in altitude, 1935 to 1950

9. Boulder Basin triangulation net, 1947-48

10. Virgin Basin triangulation net, 1947-48

11. Overton Arm triangulation net, 1947-48

12. Triangulation net in the Virgin Canyon-Pierce Ferry area, 1947 48

13. Variations of water stage at auxiliary gages and at Hoover Dam gage with respect to true lake elevations at Lake Mead.

14. Block diagrams illustrating electronic circuits and principle of echo sounding. $A$, Principle of echo sounding; $B$, Operation of echo sounder

15. Typical cross sections in Lower Granite Gorge, 1935 and 1948-49

16. Profiles of the thalweg of Lower Granite Gorge, 1935 and 1948 49

17. Index map showing basins for which separate capacity and sediment tables have been prepared

18. Stage and usable storage of Lake Mead, 1935 to 1948

19. Relation between unmeasured inflow to Lake Mead and runoff of Virgin River at Littlefield, Ariz 
Figure 20. Relation of net residual (bank storage) to annual change in reservoir contents _

21. Comparison of reservoir capacity curve with gross storage curve computed from difference between inflow and outflow.

22. Relation of annual runoff to sediment load at Grand Canyon

23. Discharge, temperature, dissolved solids, and suspended sediment records for Colorado River at Grand Canyon, October 1947 to February 1949

24. Periods of reported density currents and elevation of sediment surface at Hoover Dam, 1935 to 1950

25. Water temperature at the intake towers of Hoover Dam during four periods in 1948

26. Temperature and dissolved solids in Virgin and Boulder Canyons, 1948

27. Dissolved solids and discharge at the Grand Canyon and Willow Beach gaging stations on the Colorado River during the year ended September 30, 1935

28. Typical seasonal salinity distribution and circulation patterns in Lake Mead

29. Temperature and salinity data from selected stations on Lake Mead, spring and summer.

30. Typical seasonal salinity distribution and indicated circulation in Overton Arm, Lake Mead.

31. Secchi-disc readings at Lake Mead, cruise IV, May 25-31, 1948

32. Salinity distribution at surface of Lake Mead, cruise IV, May 25-31, 1948

33. Temperature distribution in Lake Mead at depth of 10 feet, cruise IV, May 25-31, 1948

34. Salinity distribution at surface of Lake Mead, cruise VII, August 22-26, 1948

35. Temperature distribution in Lake Mead at depth of 10 feet, cruise VII, August 22-26, 1948

36. Temperature and salinity data from selected stations on Lake Mead, fall and winter

37. Salinity distribution at surface of Lake Mead, cruise X, November 27-30, 1948

38. Temperature distribution in Lake Mead at depth of 10 feet, cruise X, November 27-30, 1948

39. Salinity distribution at surface of Lake Mead, cruise I, February 25-29, 1948

40. Temperature distribution in Lake Mead at depth of 10 feet, cruise I, February 25-29, 1948.

41. Average monthly values of energy-budget parameters as computed for Lake Mead, 1948-49

42. Average monthly values of $Q_{e}$ and $Q_{h}$

43. Comparison of evaporation as computed from energy budget with pan evaporation

44. Relation of core length to depth of penetration by gravity-core sampler

45. Typical cumulative size-frequency curve for silt and clay samples from the sediment accumulated in Lake Mead.-

46. Fathograms obtained by low-frequency echo-sounding equipment in Gregg, Virgin, and Boulder Basins........

47. Longitudinal section through the Colorado delta, showing relation of bottomset beds to topset and foreset beds-

48. Textural characteristics of the surficial deposits of the Colorado delta along the thalweg.

49. Typical vertical sections of the bottomset beds of the Colorado delta, showing the variations in water content and median particle size

50. Specific weight of the sediment deposit in the Colorado delta along the thalweg.

51. Relations of gas content, organic co delta

52. Vertical distribution of temperature in the bottomset beds of the Colorado delta

53. Cumulative curves showing estimated average size distribution of the accumulated sediment in each of the eig selected lake areas.

54. Cumulative curves showing the estimated average size distribution of the accumulated sediment in several of the lake areas combined.

55. Distribution of density during underflow of November 1948 in vertical section at mile 301.9, in Virgin Canyon.

56. Percentage distribution of sediment transported by turbidity currents in relation to distance from the east end of the lake, measured along the buried Colorado River channel

57. Diagrammatic representation of the surface of the sediment that would be accumulated in Lake Mead when the lake is filled to permanent spillway level

58. Water content and approximate specific weight of silt and clay, plotted as a function of depth

59. Curve showing the estimated sediment-storage capacity of Lake Mead when the accumulated sediment reaches the elevation of the permanent spillway crest at Hoover Dam

60. Cumulative curve showing the estimated weight of sediment, and of coarse and fine components, when the reservoir becomes filled with sediment.

61. Hypothetical bottom topography of Lake Mead at its terminal stage

62. Monthly sediment load, discharge, and water temperature at Grand Canyon, 1935-49

63. Relation of monthly runoff to sediment load at Grand Canyon.

64. Actuarial projections for Lake Mead, showing estimated dates when it will be completely filled with sediment.-

65. Weighted average salinity of inflowing and outflowing water of Lake Mead since 1935 
TABLE 1. Subsidence at points near lake shore with respect to Hoover Dam

2. Revisions of 1935 area and capacity tables

3. Area of Lake Mead as a function of elevation, 1948-49

4. Usable capacity as a function of elevation, 1948-49

5. Lake Mead reservoir volumes by basins, 1948-49

6. Sediment volumes in Lake Mead by basins, 1948-49.

7. Comparative data showing areas, capacities, and sediment volumes as a function of elevation

8. Comparative summary, 1935 and 1948-49

9. Lake Mead water budget, 1935 to 1950

10. Annual runoff and suspended load of Colorado River near Grand Canyon, Ariz

11. Chemical analyses of water samples of inflow and outflow, and from various points and depths in Lake Mead.-

12. Reported density currents in Lake Mead, and antecedent conditions at Grand Canyon, 1935 to 1949

13. Specific conductance of water at four points in Lake Mead, 1937 and 1938

14. Dissolved solids in surface samples from Lake Mead, 1948

15. Preliminary energy budget for Lake Mead.

16. Monthly evaporation as determined from energy budget

17. Comparison of evaporation with other pertinent factors

18. Distribution of cores and samples from the sediment accumulated in Lake Mead

19. Penetration depths and core lengths obtained by gravity core sampler

20. Penetration depths and core lengths obtained by piston core sampler

21. Combined Udden and Wentworth size classification.

22. Median particle diameters of samples from bottomset beds of Colorado delta, as determined by analyses in dispersed medium and in untreated lake water .

23. Chemical analyses of samples from the sediment deposits in Lake Mead

24. Characteristics of calcium carbonate and organic matter in selected samples from the Colorado delta ..........

25. Characteristics of sediment between intake towers at Hoover Dam.

26. Increase in temperature by bacterial action.

27. Volume, weight, and particle size of sediment in individual basins, Lake Mead

28. Estimated average chemical composition of the sediment accumulated in the Colorado delta, 1935-48 .......-

29. Estimated weight, volume, and specific weight of the sediment in Lake Mead when filled under conditions assumed. 


\title{
COMPREHENSIVE SURVEY OF SEDIMENTATION IN LAKE MEAD, 1948-49
}

\author{
By W. O. Smıth, C. P. Vetrer, G. B. Cummings, and others
}

\section{SUMMARY OF RESULTS}

By W. O. Smith, C. P. Vetter, and G. B. Cummings

This report presents the results of studies of Lake Mead and its environs made in 1948-49. In the hydrographic surrey of the lake, depths were measured by echo sounding. The equipment operating at 50 kilocycles gave a consistent indication of the top of the sediment, with error of less than 2 feet. The instruments operating at 14.25 kilocycles produced an echo from the sediment surface and, where the sediments were dominantly silt and clay of moderate to high water content, produced an echo from the bottom of the old river bed as well. In the Boulder Basin, complete penetration of some 140 feet of soft sediment was obtained.

Area and capacity tables, prepared on the basis of this hydrographic survey, show that the total capacity of the reservoir was reduced 4.9 percent during the first 14 years after Hoover Dam was completed, but that the usable capacity was reduced only 3.2 percent. Practically all this reduction was caused by accumulation of sediment in the reservoir. Studies of inflow and outflow indicate that the reservoir has a total storage capacity about 12 percent greater than that shown by the areacapacity table, because of "bank" storage (ground-water storage) in the bottom and sides of the reservoir. Thus the total capacity in 1949 was greater than the quantity shown by the original 1935 area and capacity table, even though large quantities of sediment had been deposited in the reservoir during the 14 years.

The sediment accumulated in Lake Mead has formed two deltas. One extends from Bridge Canyon to Hoover Dam along the thalweg of the Colorado River; the other, of much smaller size, extends along the inundated Virgin River channel. Most of the sediment brought into Lake Mead is supplied by the Colorado River and accumulates in its delta, which thickens progressively from Bridge Canyon to Pierce Basin, where it attains a maximum thickness of 270 feet. Topset beds make up the surface of this part of the delta. The foreset beds that make up the delta front in Pierce Basin dip sharply beneath the lake surface for a distance of about $1 \frac{112}{2}$ miles, measured along the course of the submerged Colorado River channel. From the foot of the delta front to Hoover Dam the slope of the bottomset beds ranges from 9 feet per mile, between the delta front and the mouth of Iceberg Canyon, to less than 1 foot per mile, in the southern part of Boulder Basin. The bottomset beds in 1948 had a minimum thickness of 45 feet in the Temple Bar area, increasing progressively to 106 feet at the dam.

According to computations of the volume and weight of the accumulated sediment, about 2,000 million tons was deposited in the reservoir in 14 years; this is within 2 percent of the amount calculated from measurements of the suspended sedi- ment carried by the inflowing rivers. It is estimated that the sediment capacity of the reservoir, when filled to the permanent spillway crest, is about $\mathbf{7 5 , 0 0 0}$ million tons. This quantity is 37 times as great as the amount which occupied 4.9 percent of the reservoir capacity in 1948-49. The prediction is based on estimates that the sediment-storage capacity is about 25 percent greater than the water-storage capacity, and that the mean specific weight of the sediment will ultimately be nearly 50 percent greater than in 1948-49, owing to compaction of the clay and silt. The sediment contributed by the Colorado River averages about 45 percent sand and 55 percent silt and clay. Practically all the clay and much of the silt has been transported by turbidity currents into the lowest parts of the reservoir.

The sediment level at the dam will reach the elevation of the lower outlet gates and the present dead-storage space will be filled when the total accumulation becomes about seven times as great as the amount brought into the lake from 1935 to 1948. The water-storage capacity below the permanent spillway crest will then be about 22 million acre-feet. This prediction is based on certain assumptions, of which an important one concerns reservoir operation. It is assumed that the average operating level will be at spillway level, 35 feet higher than at present, and on that assumption it is predicted that approximately 20 percent of the total sediment load will be deposited above the level of the permanent spillway crest. Lower arerage operating levels will reduce the proportion of sediment deposited in the upper part of the reservoir, extend the delta front downlake, reduce the area available for deposition of silt and clay, and result in a more rapid rise of the sediment level at the dam.

If the sediment carried by the river in the years 1926-50 represents the long-term average rate of accumulation in Lake Mead, it will be more than 4 centuries before the reservoir is filled with sediment to the level of the permanent spillway crest. The rate of sedimentation since the first year of Lake Mead (1935) has been about 20 percent lower than this 25-year average, and if that rate continues in the future, the life of the reservoir will be correspondingly greater. Construction of upstream reservoirs to capture some of the infiowing sediment, or transportation of sediment in the outflow through Hoover Dam, would also increase the life of the reservoir.

The total bacterial population in the sediment near the dam was found to exceed 1 million bacteria per gram at all depths, which is comparable with the bacterial population in raw sewage. Near the mud surface there is a mininum of 10 million bacteria per gram. By contrast, the water less than a foot above the sediment surface contained only 100 bacteria per gram. By comparison with marine and natural lake muds, the Lake Mead sediments are unique in containing a high bacterial population distributed uniformly throughout a deep and loosely packed layer. Laboratory tests indicate that the abundance 
and activity of the microflora have contributed to the heating of the fresh sediment layer in Lake Mead, and also that they affect the hydrogen-ion concentration of the water in the sediment, which in turn influences the rate of sediment compaction.

In the flrst 12 years of Lake Mead, the dissolved mineral matter in the outflowing water was significantly greater than the average in the inflowing water, owing in part to solution of gypsum and rock salt from the bed of the reservoir. Currently the increased dissolved solids in the outflowing watel can be accounted for almost entirely by evaporation from the reservoir, which is about 5 to 7 percent of the annual inflow. The water from Lake Mead is generally of better quality than the water that was diverted from the river for irrigation prior to regulation by Hoover Dam, because it represents an average of the poor water of low stages and the excellent water from melting snow. Since 1935 the concentration of dissolved solids in the inflow has ranged from 225 to 1,720 parts per million, but in the outflow from Lake Mead the concentration has ranged only from 621 to $824 \mathrm{ppm}$. The "alkali" problem of the areas downstream that are irrigated with the Colorado River water has been decreased to an appreciable extent because of this stabilization.

Oceanographic techniques were utilized to establish the general features of the circulation in Lake Mead. Analysis of the data collected during 12 monthly cruises on Lake Mead indicates a distinct and orderly cyclic progression in the distribution of properties and in the implied circulation, which can be related to the seasonal changes of weather and river inflow.

The changes in elevation measured by precise leveling since 1935 indicate that the weight of water and sediment in the reservoir has caused some subsidence. and that there has also been an extensive tilting subsidence involving the entire lake basin and extending tens of miles farther south. The amount of lowering of bench marks around the reservoir, calculated with respect to a bench mark at Cane Springs, Nev., has been relatively small. Hoover Dam was lowered about 0.4 foot between 1935 and 1950 , and bench marks along the shores of the Boulder and Virgin Basins of the lake (which have 60 percent of the reservoir storage capacity) have been lowered as much as 0.6 foot. On the other hand, bench marks near the Overton Arm and east of Virgin Canyon have not dropped as much as those near the dam. It is conchuded that the differential subsidence has not changed the reservoir capacity appreciably.

Since 1941 there has been more subsidence at the dam than at any of the six locations-where the level net provides data as to elevations-near the shore of the reservoir. The leveling operation of 1941 was performed while the reservoir was filled nearly to capacity, and the differential rise at these six locations by 1950 may be an indication of elastic rebound with reduced load.

Lake Mead had a noteworthy predecessor in the geologic past. The Colorado River was dammed during the Pleistocene epoch, forming a lake that was deeper and more extensive than Lake Mead, in which there was delta deposition similar to that which has begun since the completion of Hoover Dam. The lower part of the Chemehuevi formation (deposited in that lake) consists chiefiy of banded clay, presumably deposited as bottomset beds in a deep lake. This clay is thin in Iceberg Canyon and thicker downstream ; extensive remnants occur near Davis Dam, about 60 miles below Hoover Dam. Sand overlies the clay, and composes most of the thickness of the formation in upstream areas. The upper part of the formation consists of river gravel and cobbles, presumably deposited after the lake was filled with fine sediment. Some of these gravels are about 300 feet above the high-water level of Lake Mead. The cobbles in the upper part of the Chemehuevi formation were transported by a larger and more powerful stream than the present Colorado River, which apparently carries nothing coarser than fine gravel into the deltaic fill in the Lower Granite Gorge. 


\title{
A. THE LAKE MEAD PROBLEM
}

\author{
By C. P. Vetrer, U.S. Bureau of Reclamation
}

Lake Mead is the reservoir formed by the construction of Hoover Dam in Black Canyon of the Colorado River, about 30 miles east of Las Vegas, Nev. The lake covers parts of southern Nevada and northwestern Arizona (fig. 1.) At Hoover Dam, the Colorado River constitutes the boundary between the States of Arizona and Nevada; upstream from the dam, the reservoir inundates about 70 miles of this boundary. Visitors to Hoover Ham, who number more than 400,000 annually, doubtless agree that here is a modern miracle of science and engineering. Perhaps relatively few realize that Hoover Dam is a pioneering project among large dams, and that Lake Mead is correspondingly the first of the very large reservoirs. Construction of Hoover Dam was authorized by Congress in 1928, and major construction began on March 11, 1931. The bypass gates were closed on February 1, 1935, and Lake Mead began to form.

For the Bureau of Reclamation, this date marked the end of the period when planning, design, and construction at the dam were the dominant activities related to the reservoir, and the beginning of a period when operation and maintenance were the chief functions. Whereas most projects include diversion works for irrigation or other uses, the water released at Hoover Dam is not immediately used for such purposes, but it continues down the natural river channel to lower dams and diversion works. The only use of water near Hoover Dam is for power generation, and the only other diversions from the reservoir are by pumping directly from the lake, for use in the conmunities of Henderson and Boulder City.

Downstream from Hoover Dam six other dams control the Colorado River. Of these, Davis Dam forms Lake Mohave with a usable capacity of 1,810,000 acrefeet, and Parker Iam forms Havasu Lake, capable of holding 688,000 acre-feet; the others are diversion dams that provide no effective storage. All are dependent upon Hoover Dam for regulation of the river. It is essential, therefore, that the river below the dam be controlled by coordinating the operations of the control structures and rectifying and maintaining the river channel between structures.
These operational and physical control activities on the Colorado River are the responsibility of the Bureau of Reclamation and the charge of the Office of River Control (redesignated "Regional River Control Division" in 1954) in Boulder City, Nev. Although the principal duties of that office are operation and construction, the need for investigations of various natures to provide data for its other activities was recognized by Congress in the basic legislation under which the office operates. This authorization for the Office of River Control to sponsor investigations constituted the justification for the initiation of the sediment investigations on Lake Mead.

When Hoover Dam was designed and constructed, some allowance was made for sediment accumulation in the deepest portion of the reservoir. This sedimentstorage space is located entirely below the sills of the lowest outlet gates, which are at an elevation of 895 feet, and at the time of closure of the dam amounted to 3,223,000 acre-feet. Any accumulation of sediment in the reservoir at elevations above the lowest outlet gates reduces the usable storage space of the reservoir and thereby its capacity for regulating the flow of the Colorado River. It was realized from the beginning that no means were available for assuring that sediment would accumulate first in the designated storage space. But at the time reliable knowledge of the movement of sediment-laden water within a large storage reservoir was practically nonexistent.

The amount of the sediment load entering the lake was known, in tons per day or year. Since 1926, except for a short interruption during the war, the Geological Survey has obtained suspended-sediment samples from the Colorado River in Grand Canyon above the mouth of Bright Angel Creek (265 miles upstream from Hoover Dam). Since September 1, 1947, the Survey has also collected sediment samples from the Virgin River. These two rivers carry the great bulk of the sediment that reaches Lake Mead. At times of cloudbursts, sediment may enter at many points by way of the numerous washes that terminate in the lake, but the total quantity received from these small tributaries over an extended period of time is a small 


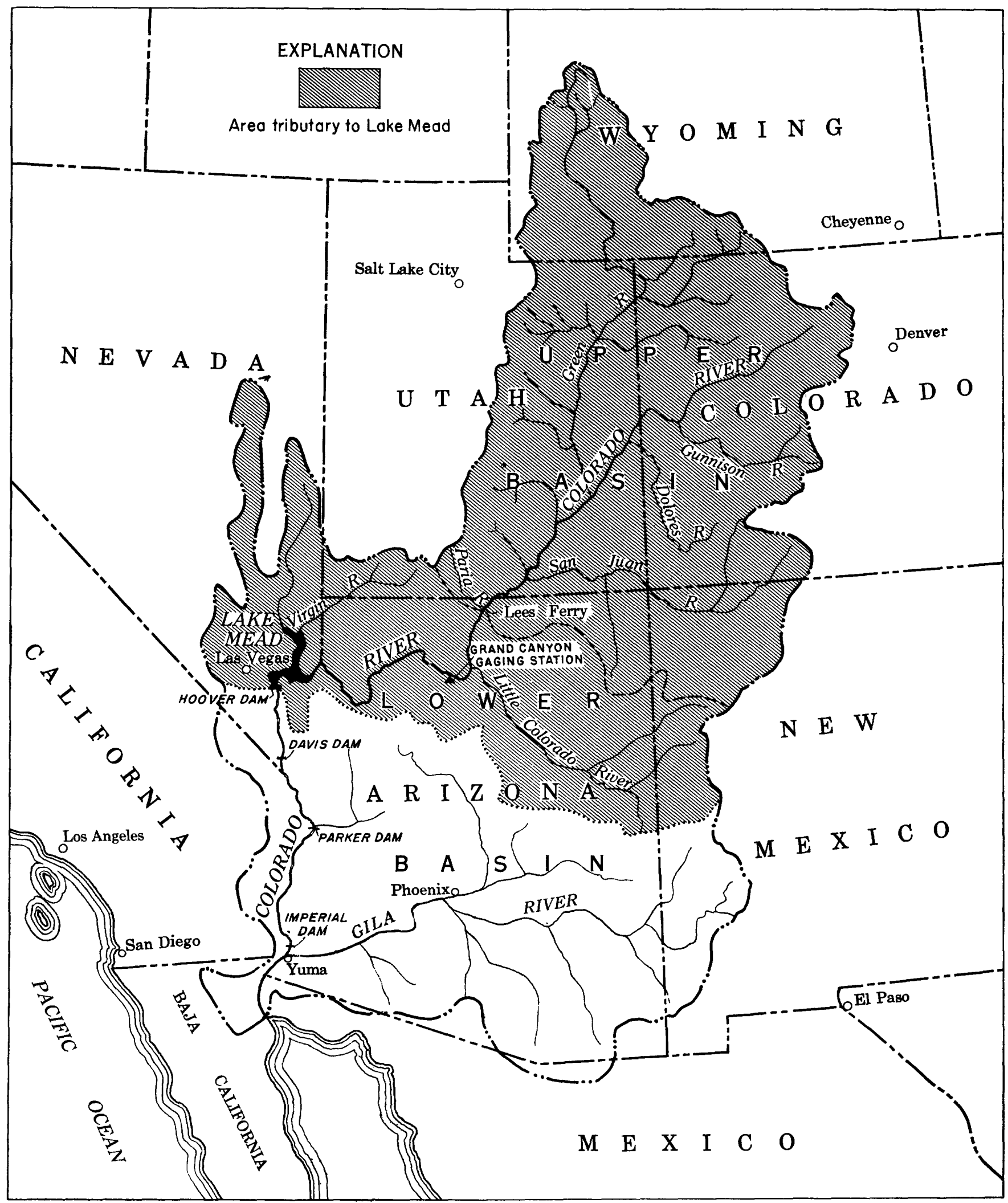

Figure 1.-Map of Colorado River basin, showing location of Lake Mead. 
proportion of the load entering from the two main sources, despite the fact that the rate of inflow may be high while a cloudburst lasts. Fairly reliable information is available, therefore, as to the total weight and composition of sediment entering the lake during any given period. No detailed information, however, was available prior to the 1948-49 survey as to the distribution of this sediment within the reservoir, or the space actually occupied by the sediment.

During the first year of operation of Lake Mead it was established that at certain times muddy subsurface flows moved the entire length of the reservoir, eventually reaching Hoover Dam. Accordingly, in 1937 the National Research Council established a Committee on Density Currents, which in turn appointed a Subcommittee on Density Currents in Lake Mead. In response to a request from the subcommittee and under its auspices, the Bureau of Reclamation conducted an investigation of the flow of density currents within Lake Mead, beginning in 1938. The results of the investigation are given in reports of the subcommittee entitled "Lake Mead Density Currents Investigations" (National Research Council, 1949). The approximate velocity and density of these currents were established, and large accumulations of fine silt and clay were found along the entire length of the original river channel, reaching a maximum thickness at the dam. At the same time it was disclosed that, in addition to the material carried far into the reservoir by density currents, large volumes of coarser material were accumulating in the upper reaches of the reservoir, where the muddy flow enters. The fact that silt and clay in large quantities were being moved great distances into Lake Mead gave additional impetus to the desire for an early survey of the sediment distribution throughout the entire lake.

At the same time another problem arose. The water entering Lake Mead carries large quantities of dissolved solids; water released through the Hoover Dam powerplant and outlet valves carries dissolved solids away from the lake. From the time the lake was first filled, careful accounts have been kept of the amount of dissolved solids that entered the lake and the amount that left the lake. The difference between these two quantities should represent solids still present in the lake. This theoretical concentration was soon found to be much less than the actual concentration estab- lished by frequent sampling of the lake water. The only explanation would seem to be that soluble materials along the lake's bottom or shores were being dissolved. Since the Lake Mead water is used for both domestic and agricultural purposes, it is obviously of the greatest importance to watch closely the salinity of the lake to insure that, so far as can be controlled by selective operation of the outlet gates, water of the best possible quality be made available to downstream users. Thus, there was need for a survey of the dissolved solids in the lake.

During World War II it was not practical to secure personnel and equipment to conduct such large-scale investigations as a civilian project, but as soon as personnel and equipment became available again, the need for thorough sedimentation and salinity surveys of Lake Mead was again given consideration. It was recognized that the services of many specialists would be needed for the satisfactory execution of such a project, and that not all the required experts were available within the Bureau of Reclamation or even within the Department of the Interior. After some preliminary negotiations, a meeting was held in Boulder City, Nev., in September 1947, attended by representatives of the Departments of the Interior, Navy, and Commerce, at which a tentative program was outlined. It was proposed that the Office of River Control should have general responsibility for the work for the Bureau of Reclamation, and that execution of the necessary technical program should be by the Water Resources Division of the Geological Survey. The plan was approved by the Secretaries of the Interior and Navy in October 1947. Shortly thereafter the Geological Survey and the Navy had their respective crews on the lake and work was in full swing.

It is noteworthy that in this undertaking many Federal and some private agencies worked together efficiently and harmoniously to bring the work to successful completion. The many important results of the Lake Mead investigations are outlined in the succeeding pages.

\section{REFERENCE CITED}

National Research Council. Interdivisional Committee on Density Currents. Subcommittee on Lake Mead, 1949, Lake Mead density currents investigations $1937-40$, v. 1,$2 ; 1941-$ 46, v. 3; Washington, U.S. Bur. Reclamation, 3v., 904 p. 



\title{
B. ORGANIZATION OF THE WORK AND EQUIPMENT
}

\author{
By W. O. Sмгтн, U.S. Geological Survey
}

The purpose of the field operations at Lake Mead during 1948-49 was the collection of basic data which, in conjunction with pertinent data collected at other times or at other places within the drainage basin, would permit analysis of the effects of the development of this huge reservoir. The survey program included: (1) mapping of the bottom of the reservoir; (2) computation of reservoir area and capacity tables; (3) determination of the extent and distribution of the bottom sediments and their physical and chemical properties; (4) determination of salinity and thermal characteristics of the lake waters; and (5) precise leveling to determine changes since 1935 in elevations of stations in the Hoover Dam level net.

Field headquarters for the survey were maintained at Boulder City in space provided by the Bureau of Reclamation. The shop and supply facilities of the Bureau were used extensively in connection with many phases of the project, and laboratory space was provided by the Bureau in the powerhouse at the dam. Extensive assistance in both service and use of heavy equipment was also provided by the Bureau of Reclamation.

\section{MAPPING THE BOTTOM OF THE RESERVOIR}

The reservoir formed by Hoover Dam includes a main body of deep water and a narrow, seasonal extension up the Lower Granite Gorge of the Colorado River. Most of the bottom of the main body has been inundated continuously since the first filling of the reservoir; but the bottom of the extension is covered by shallow water only when the lake is at its highest stage, and at other times consists only of the channel that carries the inflowing river water, and bordering areas that are above water level. Because of the contrasting characteristics of these two parts of the reservoir, two groups were organized for the mapping of the bottom: the one in the lake, employing echo-sounding techniques and equipment with locations fixed by sextant observations, and the other along the river, using lead-line sounding and land-survey methods and equipment.

The mapping of the bottom of the lake required the establishment of horizontal and vertical control, and a comprehensive system of soundings. The horizontal control used for the 1935 survey of the reservoir site by the Soil Conservation Service was reviewed, a new network of control stations was established, and shore signals were erected for the new survey.

The new control stations were established in 1947-48 by a triangulation party that was in the field for about a year, working ahead of the other parties involved in the hydrographic survey. Equipment included what was necessary to execute third-order triangulation, materials and tools for the installation of more than 300 permanent station markers, an automobile for overland transportation, and a boat suitable for transportation on the lake from Boulder City to the shoreline control stations, most of which were inaccessible except by boat. Camping equipment and supplies sufficient for periods of a week to 10 days were also required.

For the erection of shore signals a three- to four-man party was required intermittently throughout the survey. This crew was also responsible for establishment of auxiliary control stations as needed, and for transit observations of boat positions when necessary. The signal party consisted of one or two engineers, and two subprofessional helpers. Equipment included a car for overland transportation, a boat suitable for transportation around the lake, transits for observation of signal and boat positions, and the materials and tools necessary for the erection and maintenance of the shore signals.

Vertical control required installation and maintenance of several water-stage recorders, the leveling necessary to tie in certain of these gages to the Coast and Geodetic Survey precise level net, and the determination of daily lake elevations for conversion of soundings to bottom elevations. This work required a three- to four-man party intermittently throughout the survey. Equipment requirements were the same as for the signal party, with the addition of the water-stage recorders and the stilling wells and shelters necessary for simultaneous operation of five gages.

The sounding operations involved a comprehensive system of sounding lines covering the entire lake, operated by a trained party of seven men. This work was done by Navy personnel. 
A 38 -foot picket boat, modified to accommodate the sounding equipment and the operating crew, was used as the sound boat. The cabin was enlarged by removing the after bulkhead and mounting the recorders so as to leave room for a recording table and the sound observer. A platform was built above the cabin and engine compartment to provide space for the plotter, recorder, boat officer, and three anglemen. Hydrographic equipment necessary to the navigation of the sound boat along designated range lines or courses included sextants, protractors, sounding clock, compass, etc. Several types of echo-sounding equipment were used in the survey of the lake. The NJ-8 depth recorder equipment and the NK6 portable depth recorder equipment, developed for the Navy Department by the Bludworth Marine Division of National-Simplex-Bludworth, Inc., used a frequency of $14.25 \mathrm{kc}$ for the transmission of sound through the water, and could be operated in a depth range of 2 to 1,200 feet. The NGB-3 depth-recording equipment, developed for the Navy Department by the Pacific Division, Bendix Aviation Corp., operated at a frequency of $50 \mathrm{kc}$ and could record depths between $21 / 2$ and 300 feet.

During the course of operations in Boulder Basin it was possible to base all field parties at Boulder City. For operations in other areas it was necessary to provide facilities for the parties in the field for periods of a week to 10 days. A floating base was formed by a 21 by 105 -foot barge, constructed from 5-by 7 -foot steel pontoons. Its facilities included a combined galley and mess room, bunk space for 16 men, a small office, and a small workshop. The barge was self propelled, and was provided with gasoline winches for handling anchor, derrick, and core-sampling equipment, and with motor generator units for obtaining electric power and lights. A twin-engine 45-foot picket boat furnished transportation to the barge from Boulder City or the nearest access road; a landing craft (LCVP) transported supplies and equipment; and a second self-propelled steel barge, about 35 by 14 feet in size, housed fuel-storage tanks. Three 24-foot plane-personnel boats were used for the topographic work and for the geologic and general limnologic investigations.

Preparation of charts and maps, for use in the sounding operations and the final plotting of field data, required the full-time services of an engineer-draftsman, part-time services of a second draftsman, and a considerable proportion of the time of two engineers. Determination of contour areas and preparation of area and capacity tables for the lake required part-time services of one engineer and two subprofessional assistants.
The field party for the survey of Lower Granite Gorge also had a floating base of operations: a barge built of four aluminum pontoons and decked over by a 20 - by 50 -foot floor. Tents were pitched over 18 - by 20 -foot frames at each end of the barge, for use respectively as sleeping quarters and kitchen for the working crew. The barge was assembled and equipped at the boat landing near Boulder City and then was towed to its first position in Granite Gorge, about 5 miles below Bridge Canyon. As the survey progressed downstream the barge was moved several miles at a time to the best available location.

Other floating equipment used on the river survey included a Higgins 29-foot inboard-motorboat for transporting men and supplies from Pierce Ferry to the floating base of operations; a Penn Yan 18-foot inboard-motorboat, with sounding equipment mounted in the bow, for making underwater cross sections; a 16foot air boat, powered by a 135-horsepower aircooled engine; and two outboard-motorboats, used as work boats by the survey crew.

\section{DETERMINING THE CHARACTER OF SEDIMENTS}

The determination of the chemical and physical properties of sediments deposited in Lake Mead required numerous samples, obtained by both surface sampling and core sampling. The locations for sampling were selected, preliminary examinations made, and samples preserved by the resident geologist, H. R. Gould, with assistance of other members of the field staff as required.

Most of the core samples were taken with a gravitytype sampler similar to those used in oceanographic work. The manipulation of this core sampler required a crew of about six men; it was performed by the Navy party under direction of Lt. C. C. McCall. Sampling was done from the large pontoon barge, which was provided with winches and a derrick for handling the heavy equipment, and which had sufficient space for assembly and removal of cores.

Early in 1949 a piston-type core sampler was developed by W. O. Smith after Kullenberg's design (1947) and constructed for use in Lake Mead. This sampler provided samples of greater length, and more nearly approaching undisturbed conditions, than samples obtained with the gravity-core sampler. Pistoncore samples were collected and analyzed under the supervision of W. O. Smith, assisted by all personnel on the project except the topographic party. The full Navy crew was needed for handling the equipment.

A laboratory was set up in Hoover Dam for making analyses of the samples, including determinations of the percent of sediment by dry weight, weight of 
sediment per unit volume of sample, grain densities, and mechanical (particle-size) analyses. Equipment included a large assortment of laboratory apparatus suitable for making the above analyses on a large number of samples.

Photographs were made of the sediment surface, other bottom features, and certain engineering structures, using underwater cameras and the necessary gear for operating them in water as deep as 450 feet.

Early in the investigation it was learned that the temperatures of the bottom sediments, particularly in the vicinity of Hoover Dam, were considerably higher than those of the water near the bottom of the lake. To determine the cause of the high temperatures, a study of the bacteriology and biochemistry of the bottom sediments was made. Samples were collected from a 100 -foot vertical section of the sediments near the dam; they were analyzed in the laboratories of the Scripps Institution at La Jolla, Calif.

For measuring the temperatures of the bottom sediments, a mud bathythermograph was designed and constructed by the Navy Electronics Laboratory. This instrument was patterned after the conventional bathythermograph but modified by the addition of a pointed nose, weighted so as to penetrate the sediment to considerable depth, and by relocation of the temperaturemeasuring capillary tubing to reduce hysteresis caused by mud clinging to the instrument.

\section{MEASURING THE SALINITY AND THERMAL CHARACTER- ISTICS OF THE LAKE WATER}

Surveys of the salinity and thermal characteristics of the lake were made by the Navy Electronics Laboratory. Personnel of the Oceanographic Section made 12 monthly cruises beginning in February 1948 for field observations and collection of samples. The water samples collected during the cruises were analyzed in the Salt Lake City laboratory of the Geological Survey.

\section{PRECISE LEVELING}

The Coast and Geodetic Survey ran precise levels to stations of the Hoover Dam level net in three different periods, in order to ascertain the extent of deformation of the earth's crust resulting from the impounded water in Lake Mead. Levels were run in 1935, when the reservoir had just begun to fill; in $1940-41$, when the reservoir held about 85 percent of its capacity; and in 1949-50, when the reservoir storage ranged from 60 to 70 percent of capacity.

The topographic and hydrographic work of the 194849 survey is based upon the primary leveling of 1935 , and no adjustments have been made for changes doc- umented by the releveling of subsequent years. The effects of crustal deformation since 1935 upon the capacity of Lake Mead must therefore be evaluated separately.

\section{COMMENTS ON OPERATIONS}

On the whole, the operations progressed as outlined at the initial conferences except for delays caused by adverse weather, principally strong winds. Past records of wind movement and information from local boatmen indicated that strong winds were infrequent except during March, and it was thought during initial planning that field operations would be possible fully 95 percent of the time. Actually strong winds occurred very frequently throughout the spring and summer of 1948. Records at Boulder City indicated a total wind movement well above the average from January to August, except in June, when it was about average. In fact, monthly totals of wind movement for February through May were higher than any recorded in the preceding 5-year period, and movement in March and April was 140 percent of average.

As a result, sounding and sampling operations were possible only about two-thirds of the time in the first 6 months of the survey. Strong winds hampered the triangulation work to a lesser extent, but they caused considerable discomfort and annoyance and made maintenance of shore signals more difficult than had been anticipated. The work of the water-sampling crew was occasionally delayed and frequently rendered difficult by wind and wave action.

Although wind was a frequent source of delay and annoyance, there were periods when gentle winds or calm prevailed. However, from about the middle of May until the middle of September, the heat and glare enervated the men and added to the difficulties of sounding and triangulation. Visibility of shore signals and triangulation flags was so poor in midday that triangulation and sounding crews could work only during the early forenoon and late afternoon. Other delays were occasioned by difficulties with sounding equipment and boats, but these were not excessive, falling in the range of normal operational difficulties.

The personmel that were based on the pontoon barge were fortunate in comparison with those of the triangulation party or the parties that made monthly cruises on the lake and made shore camps each night. Camping operations at all seasons and in all kinds of weather proved quite unsatisfactory and consumed disproportionately large amounts of time of the technical personnel. For any future operation of a similar nature on Lake Mead or in similar primitive environments, it would be very desirable to provide a boat 
sufficiently large to permit a crew of 4 or 5 men to live aboard for 1- to 2 -week periods.

\section{COMMUNICATION FACILITIES}

$$
\text { By Lt. C. C. McCaLL, USN }
$$

Radio communications were necessary for effective operation both in midlake and along the shore, because the lake was almost entirely inaccessible by roads. The survey covered a lake area of about 200 square miles, of which only Boulder Basin could be surveyed from Boulder City. Through radio communication, weather reports were received and transmitted daily, equipment and stores were ordered in advance, and contact was available with personmel based in Boulder City. Radio communications among the small boats engaged in the hydrographic surveying, sampling, erecting signals, and topographic surveying were essential in the surveying operations and also insured against delay or disaster in the event of breakdown or trouble that might otherwise maroon them in some remote part of the lake.

The Department of the Interior was assigned a frequency for the Lake Mead operations by the Interdepartmental Radio Advisory Committee. Arrangements for use of certain radio frequencies were made with the Secretary of the Federal Communication Commission. A nongovernment frequency, assigned to the Department of Water and Power, City of Los Angeles, was also used on a temporary sharing basis during the course of the survey. The Department of Water and Power and the staff of its radio station KIKH at Boulder City generously lent assistance at all times throughout the survey.

The transmitter selected for installation on the barge was operated by the 115-volt a-c power supply from two gasoline-driven generators installed on the barge for electrical power. Portable radio transmitting and receiving sets were installed in the small boats engaged in various phases of the work connected with the sur- vey. The effective range of these sets was about 15 miles while operating on Lake Mead, but both the range and reception were variable, depending on the location of the boat in the lake and on climatic conditions. Boulder City stations were unable to communicate with the small boats after they had passed through Boulder Canyon into the Virgin Basin, and the radios were used chiefly in the Boulder Basin or within the vicinity of the barge. The 45 -foot picket boat was equipped with a permanently installed radio receiving and transmitting set that had a greater range than the portable sets installed on the other boats.

Six portable radio transmitting and receiving sets were used during the surveys of bays and inlets too small to set up signals for sounding with the regular sound boat. These sets were effective within a 4-mile radius and were far superior to "hand flag" signals in surveying by the transit method, which requires that the survey boat be kept on course by continuous observations from two points and that these observations be transmitted continuously to the boat.

The radio equipment used on the boats and barge in the Lake Mead survey was furnished by the Bureau of Ships, Navy Department, and responsibility for its installation and maintenance was assigned to the Electronics Section of the Long Beach Naval Shipyard. After the original installation, however, the equipment was operated and maintained by two of the chief petty officers assigned to the survey crew.

In the lower Granite Gorge two-way radio communication was maintained between the barge and the Bureau of Reclamation's Office of River Control in Boulder City. The radios were operated on regular morning and afternoon schedules, with the Boulder City station on a standby basis during office hours so that contact could be made in case of emergency on the job in the canyon.

\section{REFERENCE CITED}

Kullenberg, B., 1947, The piston core-sampler : Svenska Hydrog.Biol. Komm. Skr., 3d ser., Hydrografi, v. 2, pt. 2, p. 1-46. 


\title{
C. GEOLOGIC SETTING OF LAKE MEAD
}

\author{
By C. R. Longweld, Yale University
}

\section{LOCATION AND TOPOGRAPHY}

The Colorado River emerges abruptly at the Grand Wash Cliffs in northwestern Arizona from the deep canyon it has cut into the tabular blocks of the Colorado Plateaus, and continues on a tortuous but generally westward course for nearly 50 miles (straightline distance) into the Basin and Range province (fig. 2). There it turns sharply southward and enters Black Canyon, where Hoover Dam now impounds the water to form Lake Mead. The lake occupies the 80-mile stretch of the river valley between the dam and the mouth of the Grand Canyon. Initially it reached nearly 40 miles farther eastward, between the canyon walls; but sediments brought in by the stream have displaced the lake water within that narrow space. West of the Grand Wash Cliffs, several arms of the lake reach to varying distances up tributary valleys. The longest branch, in the Virgin River valley, extends more than 30 miles north from the main body of the reservoir.

From the mouth of Grand Canyon the Grand Wash Cliffs, rising like steep giant stairs to heights 5,000 or more feet above their base, extend far northward and southeastward, marking the abrupt western edge of the Colorado Plateaus. Between the cliffs and Hoover Dam the major topographic features are mountain ridges that trend generally north, and intervening wide basins whose floors have low relief. From east to west these major units are the Grand Wash trough, which includes Gregg Basin, Iceberg Canyon, Grand Bay, and Pierce Basin of Lake Mead; the Virgin Mountains, traversed by Virgin Canyon of Lake Mead; the VirginDetrital trough, which includes Virgin Basin and Overton Arm of Lake Mead; the Black Mountains, traversed by Boulder Canyon of Lake Mead; and the Callville Basin, in which is located Boulder Basin of Lake Mead (pl. 1). The Colorado River has cut deep canyons through the resistant mountain ridges, whereas in the adjacent basins the river valley is comparatively wide and low walled. Accordingly, the main body of Lake Mead consists of alternating narrow and wider segments.
The Grand Wash Cliffs form the highest and steepest topography adjacent to the lake. To the west, high points of the Virgin Mountains rise more than 3,000 feet above the lake, but the river valley is cut through low parts of the range, where it forms canyons only a few hundred feet deep. The head of Boulder Canyon, at the east front of the Black Mountains, has abrupt walls that reach 1,500 feet above the lake, but farther west the slopes adjoining this canyon have more moderate relief. Black Canyon has abrupt walls that reached nearly 900 feet above the river, but less than half of that height is seen from the surface of the lake. In the wide intermont basins the slopes toward the lake are in general no more than 300 feet per mile.

Besides the Colorado River, two perennial streamsthe Virgin River and Muddy Creek-flow into Lake Mead. All other tributary valleys are normally dry and furnish runoff only at times of exceptional storms.

\section{STRATIGRAPHY}

Bedrock in the area near the lake is highly varied in kind and in mode of origin (pl. 1). Rock materials of the highlands are in general older and more resistant than those flooring the basins. In fact, a considerable part of the material exposed in the basins consists of detritus that was eroded from the highlands and is still either unconsolidated or only moderately lithified. In general these younger deposits are inconspicuous, for either they are covered by the lake water or they underlie slopes and low hills bordering much of the lake shore. However, because of their close association with the lake, these weak deposits are more important to the present study than the older and generally more resistant rock units, which form most of the conspicuous cliffs and ridges in the area.

\section{PRECAMBRIAN ROCKS}

The oldest bedrock consists of banded and micaceous metamorphic rocks (gneisses and schists), injected and locally engulfed by granite and related igneous rock. In large part both the metamorphic and the granitic rocks are of Precambrian age; at many localities they 


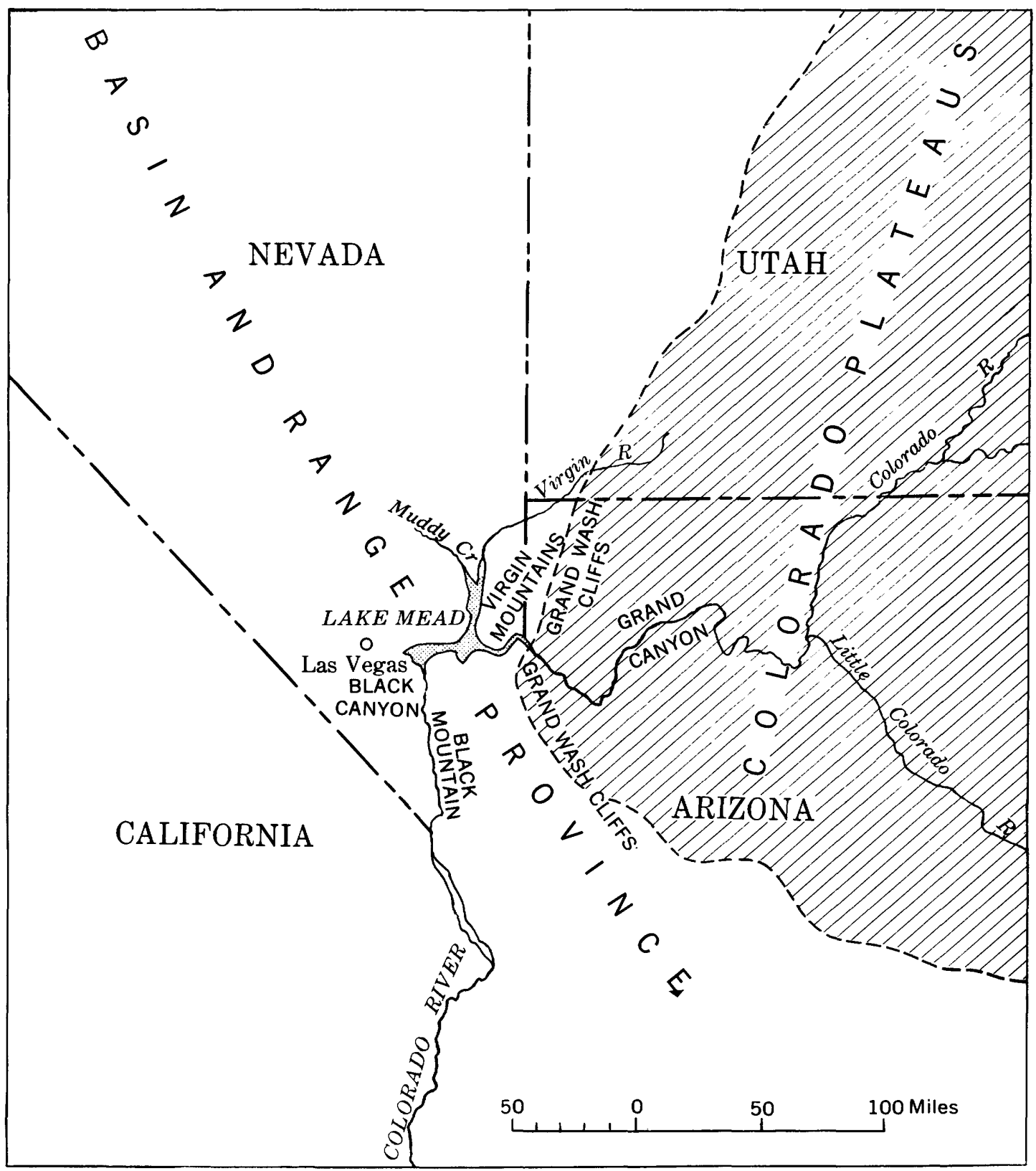

FIGORE 2.-Major physiographic features of the Lake Mead region.

lie beneath Cambrian strata with depositional contact. The complex Precambrian basement was well exposed in the lower part of the Grand Canyon before the reservoir was filled (Longwell, 1936), and it appears at the base of the Grand Wash Cliffs several miles south of the lake. In the southern block of the Virgin Mountains the old crystalline rocks are exposed continuously over a wide area. Along the eastern side of this block, west and northwest of Iceberg Canyon, the crystalline rocks pass beneath steeply tilted Cambrian beds. Since the basal sandstone and conglomerate of Cambrian age con- tain fragments derived from the underlying crystalline rocks, these rocks must have been formed and laid bare by erosion before the Cambrian seas spread over the region.

In the Black Mountains, Cambrian strata have not been found in normal contact with the older crystalline rocks, although on the south side of Boulder Canyon a large block containing Cambrian beds has been faulted down against granite and gneiss. South and east of the lake, the high part of the range consists chiefly of gneiss, schist, and granitic rocks that can be considered 
with confidence to be Precambrian in age, for they have all characteristics of the basement complex in the Virgin Mountains and the Grand Wash Cliffs. Cambrian and younger strata that must have covered the metamorphic and granitic rocks of the Black Mountains have been removed by erosion, except in the downfaulted block near Boulder Canyon. The Precambrian complex has been intruded by masses of younger igneous rock, but the intrusives have not been differentiated on plate 1. In addition to granitic rocks, bodies of gray monzonite, locally brown or reddish from alteration, are exposed over large areas south of Lake Mead, and on the western flank of the Black Mountains between Boulder and Black Canyons. These intrusive bodies are not older than Cretaceous and may be as young as early Cenozoic.

\section{PALEOZOIC AND MESOZOIC ROCKS}

North of the Colorado River, essentially the full thickness of Paleozoic strata, more than 5,000 feet, is exposed in the Grand Wash Cliffs. These strata consist chiefly of marine limestone and dolomite. The basal unit, which lies unconformably on Precambrian metamorphic and igneous rocks, consists of crossbedded coarse-grained sandstone 200 to 300 feet thick. Above this unit is a persistent section, several hundred feet thick, of greenish shale intermixed with sandy beds and grading upward into mottled and gray limestone. Marime fossils found in this section date the basal part as Early Cambrian, the upper shales and a considerable thickness of overlying limestone as Middle Cambrian, and higher limestone as Late Cambrian. Fossils at still higher levels in the towering cliffs identify rocks of Devonian and Carboniferous age. The Carboniferous rocks, which include strata of resistant sandstone as well as limestone, cap the lower Grand Wash Cliff at an altitude more than 3,000 feet above the lake.

Red sandstome and shale in the lower part of the Permian system are comparatively weak; they have been eroded back from the summit of the lower cliff, forming a platform 2 miles or more in width. The wide bench extends to the upper Grand Wash Cliff, which is capped by the Kaibab limestone (fig. 3). The red beds of Permian age are nonmarine, at least in part, for they contain fossils of land plants. The sand, silt, and clay that make up the red beds probably were deposited on flood plains and in wide deltas bordering the Permian sea. The later advance far inland is revealed by the Kaibab limestone, which carries a profusion of fossil marine shells.

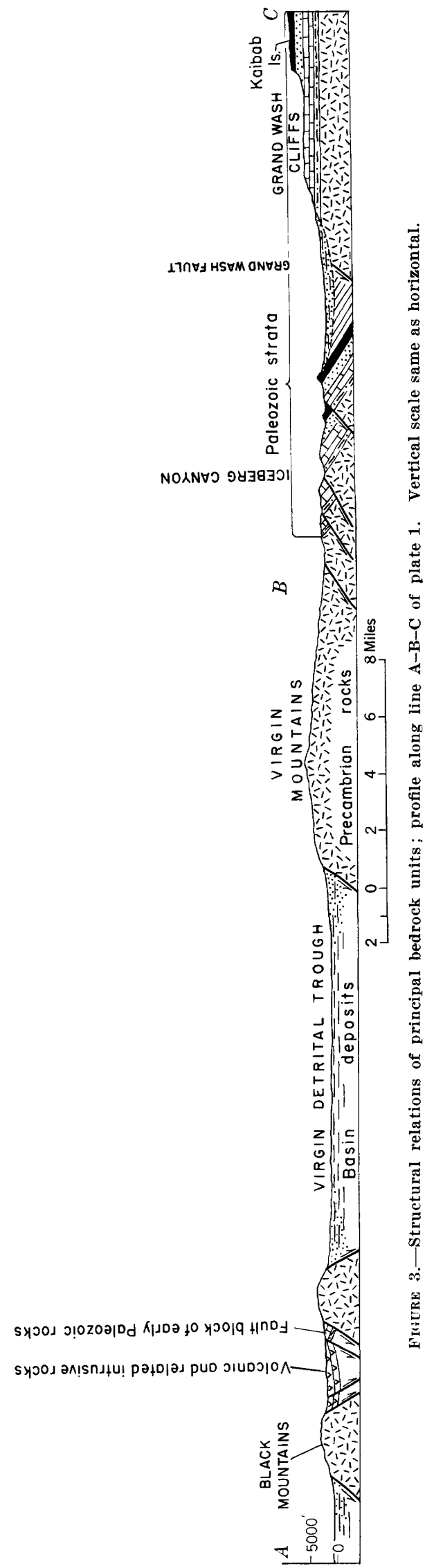


The stratified formations exposed in the Grand Wash Cliffs correspond closely to the rock units that form the walls of the Grand Canyon at El Tovar and Bright Angel Creek (Noble, 1922),.150 miles farther east. However, there is gradual thickening westward in the Plateaus, and at the Grand Wash Cliffs the total Paleozoic section is about 1,500 feet thicker than at the classical localities farther east. Rocks of Paleozoic age underlie some areas west of the Grand Wash Cliffs also, but they are everywhere steeply inclined, in contrast to the nearly horizontal attitude in the walls of the Grand Canyon.

Farther north in the Grand Wash trough, and also on both sides of Overton Arm of Lake Mead, rocks of Mesozoic age are exposed over considerable areas. The best of these exposures is in the Valley of Fire, several miles southwest of Muddy Creek. Triassic and Jurassic strata, made up largely of shale and sandstone, are strongly colored, like the corresponding units on the Plateaus. The Moenkopi formation, of Early and Middle(?) Triassic age, consists of several hundred feet of thin-bedded limestone, shale, sandstone, and gypsum, overlain by a like thickness of brownish and reddish shale and sandstone. At the base of the Upper Triassic section are conglomerate and coarse sandstone, in which are many fossil tree trunks. This unit, typical of the Shinarump member of the Chinle formation, grades upward into the varicolored shales and sandstones of the Chinle formation, the upper part of which includes thick beds of gypsum. Above lies the Aztec sandstone of Jurassic(?) age, which normally is brick red, although locally chemical action has changed or even removed the color. The Aztec, 2,500 or more feet thick, is strikingly similar to the Navajo sandstone of Zion National Park, in southwestern Utah.

Strata of Cretaceous age are exposed over an area of several square miles about 5 miles southwest of Muddy Creek. These beds, which consist of sandstone, conglomerate, and shale, with some volcanic ash, are more than 3,500 feet thick. A conglomerate at the base contains cobbles and boulders derived from several older formations, evidence that deformation had brought a thick section of pre-Cretaceous rocks up into the zone of erosion (Longwell, 1949). Although strata definitely dated as Cretaceous have not been reported from any other locality near Lake Mead, a thick section north of Las Vegas Wash and only a few miles northwest of Callville Basin is probably of Cretaceous age. The beds at that locality consist of conglomerate, reddish-brown sandstone and siltstone, and fresh-water limestone. A conglomerate at the base contains cobbles and boulders of all earlier units, down to and including the Precambrian.
CRETACEOUS(?) AND EARIY CENOZOIC(?) ROCKS

\section{OVERTON FANGLOMERATE}

Adjacent to the Virgin and Muddy Mountains and extending into the hilly area northwest of Callville Basin, a thick section of deposits ranging in character from coarse conglomerate to limestone rests discordantly on Cretaceous and older deposits. In the northern part of the Muddy Mountains, the basal portion of the younger section consists of coarse debris that was laid down in alluvial fans on the flank of a rising mountain ridge. It is known as the Overton fanglomerate of Cretaceous(?) or Tertiary (?) age. The deposit, locally more than 2,000 feet thick, contains many individual blocks of limestone 20 or more feet in diameter, and exceptional masses hundreds of feet long. A high ridge southwest of Muddy Creek, cut through by several small tributary streams, affords excellent exposures of the formation in its entire thickness. The persistent coarseness of the debris making up the deposit, from base to top, indicates that high relief was maintained through the period of accumulation. Considerable thicknesses of gray volcanic ash are evidence of volcanic activity.

\section{HORSE SPRING FORMATION}

Above the Overton fanglomerate are beds of fine sand and silt, grading upward into a thick section of thin-bedded limestone and soft white dolomite that are interbedded locally with gypsum, magnesite, borate minerals, and other materials, some of them unusual in sedimentary sequences. This assemblage is known as the Horse Spring formation of possible Tertiary age. The limestone layers contain many nodules and lenses of silica, some of which are opalescent. Beds of white volcanic ash and flows of dark lava occur at several horizons in the section. Much of the limestone has the open porosity characteristic of travertine, with algallike patterns of concentric laminae. Many features of the section, including its content of chemical precipitates such as borate minerals, strongly indicate deposition in lake waters. Rather abrupt lateral changes in the character of deposits suggest a chain of lakes with shifting boundaries. Although the formation has been severely deformed and locally removed by erosion, large outcrops distributed from the east flank of the Virgin Mountains southwest ward to the vicinity of Las Vegas Wash indicate that the deposits initially covered a wide area. The thickest exposed sections are on the flanks of the Muddy Mountains, in a belt north and west of Bitter Spring Valley (pl. 1A). Steeply tilted limestone of the formation contains the large borate deposits at the West End mine, several miles north of 
Lake Mead in Callville Basin. Smaller deposits of borates have been found north of Bitter Spring Valley.

\section{MIDDLE AND LATE CENOZOIC ROCKS}

\section{MUDDY CREEK FORMATION}

The most extensive of the sedimentary beds that floor the wide intermont basins are grouped in the Muddy Creek formation, of probable Pliocene age. These deposits consist chiefly of sand, silt, and clay that are only moderately consolidated. Near ridges of older bedrock these fine-grained sediments grade into and are interlayered with coarse rubble that was deposited in alluvial fans on the lower parts of steep slopes. Except in these marginal zones, the sediments are in thin, regular layers that suggest deposition in shallow lake water. Included are layers of gypsum that constitute a large thickness, particularly in the wide area east of Boulder Canyon. Beds of nearly pure rock salt were exposed along Virgin Valley until they were covered by the water of Lake Mead. A thick deposit of glauberite, included between layers of clay, was prospected west of the Virgin River, about 5 miles south of Muddy Creek.

The Muddy Creek formation records a long and varied history. Flows of basaltic lava and also beds of volcanic ash are included, locally in great thickness, particularly around the north end of the Black Mountains. At a number of localities in Callville Basin, older beds in the formation were steeply tilted and then beveled by erosion; they now lie below younger beds with sharp angular discordance. On the west side of the basin, two such angular interruptions within the formation are as pronounced as the break between the Muddy Creek and older deposits. Evidently there were strong crustal movements both before and during the time of deposition. The climate during that time was generally arid, as indicated by the abundant gypsum, salt, and other saline materials in the Muddy Creek formation.

Low-grade deposits of manganese oxide occur in the Muddy Creek formation, at several localities northeast of Boulder Canyon and in the southwestern part of Callville Basin. The most promising of the deposits now known was exploited during and after World War II in the Three Kids district, south of Las Vegas Wash. There the ore occurs in definite beds in the lower part of the Muddy Creek formation; the oxide appears to have been laid down as a sedimentary deposit in a shallow lake (Hunt and others, 1942; McKelvey and others, 1949).

The deposits of the Muddy Creek formation are so varied that no local section would represent the formation as a whole. Before the Lake Mead basin was flooded, gypsum and anhydrite beds hundreds of feet thick were exposed in a lowland area of 50-60 square miles, centered near the mouth of the Virgin River. Although gravels mantled much of the surface, the thick saline deposits are probably continuous under an even larger area of the reservoir floor in Virgin Basin. Abundant gypsum was exposed also in the Virgin Valley, now occupied by Overton Arm of Lake Mead, and several domes with cores of rock salt near the Virgin River channel suggest large bodies of that mineral at some depth beneath the valley floor. Thus saline beds of large but undetermined thickness are an important element in the lowest known part of the Muddy Creek formation. Higher clastic deposits are widespread in the intermont basins, with maximum thickness in excess of 1,000 feet. Gypsum either in pure layers or admixed with clay occurs at many horizons in this part of the section also.

Other deposits in basins adjoining the lake are in part contemporaneous with the Muddy Creek formation, but the relation is not everywhere clear. West of Virgin Canyon, and also extending eastward into the Grand Wash trough, thick accumulations of coarse fan debris, now firmly cemented, were derived chiefly from the Precambrian and Paleozoic bedrock of the Virgin Mountains, and in smaller amounts from the Grand Wash Cliffs. Some of this coarse material moved out from the southern Virgin Mountain block in landslide masses, which locally plowed into soft gypseous sediments that were accumulating on the adjacent basin floors. Coarse fan material containing very large blocks of granite and gneiss was moved eastward from the Virgin Mountains almost to the base of the Grand Wash Cliffs. This coarse rubble grades upward into fine gravel, silt, and clay, which north of Lake Mead is gypseous.

\section{HUALPAI FORMATION}

A freshwater limestone, locally hundreds of feet thick, rests upon the clastic deposits of the Muddy Creek formation and older rocks. This limestone has been described as the Hualpai limestone of Pliocene(?) age (Longwell, 1936, pp. 1429-1440). As stated in this original description, the Hualpai limestone is the highest unit of the (Tertiary) basin deposits, and is in thin and rather regular beds, many of which have the porous structure characteristic of travertine. The formation is distributed over an irregular area, measuring 25 miles from east to west and a comparable distance from north to south. The Hualpai limestone, in contrast to the complex assemblage of deposits that preceded its deposition, is a homogeneous formation over a wide area. Near the base it contains scattered pebbles and sand, and locally it includes thin beds of 
shale and siltstone; but in the main the formation consists of limestone, nearly aphanitic and with considerable porosity, in beds that are thin and remarkably regular. The original maximum thickness cannot now be estimated with any assurance, but certainly it exceeded 1,000 feet. The original horizontal extent must have been much greater than the area delimited by present outcrops.

The Hualpai limestone caps many flat-topped buttes that are prominent in the eastern part of the Lake Mead area; examples are The Temple and Napoleons Tomb, which rise abruptly on opposite margins of the lake west of Virgin Canyon. The thick type section of the limestone is exposed south of Virgin Canyon, along Hualpai Wash; and good outcrops appear in bluffs along the road that leads from U.S. Highway 466 to Pierce Ferry. Near this road, from the lake southward, are excellent exposures of the coarse fan debris, the higher siltstone and clay, and the capping limestone. All these deposits are in nearly horizontal beds, which on the east side of the basin overlap the edges of Paleozoic strata in the lower Grand Wash Cliff and on the west are deposited against and partially conceal Tassai Ridge, which is made of Paleozoic strata tilted steeply east ward in a downfaulted block (fig. 3). This block was entirely buried beneath the younger deposits before the Colorado River and its tributaries removed large quantities of the weak basin deposits as they cut their valleys to present levels. The weakness of the material is demonstrated by extensive slumping from the steep walls of The Temple during the few years that the waters of Lake Mead have been in contact with the lower half of this high butte, which is made chiefly of cemented coarse rubble capped by Hualpai limestone (pl.25).

The limestone has rather thin, irregular beds containing concentric forms that suggest algal growth while the limy deposit was forming. These forms weather out as nearly spherical balls, from $1 / 2$ to 3 or more inches in diameter. Although some of the limestone is compact, much of it is full of small cavities that are locally coated with black manganese oxide. It has the appearance of gray to reddish-brown travertine. The character and distribution of the deposit strongly suggest that it was formed in a lake that had considerable width from north to south and extended westward from the Grand Wash Cliffs probably to the Black Mountains.

\section{CHEMEHUEVI FORMATION}

Since the Colorado River valley was first cut approximately to its present form, sediments have been deposited that record important events in the regional history. The most extensive of these deposits, known as the Chemehuevi formation of Pleistocene age, consists of clay, silt, and gravel that once filled the valley to a height several hundred and perhaps a thousand feet above the river bed at the site of Hoover Dam. Remnants of the formation are distributed along the valley below the dam (Lee, 1908, pl. 3B), and many others were visible between the dam and the Grand Canyon until most of them were covered by the waters of Lake Mead. The highest of these, east of a looping bend in the valley south of Iceberg Canyon, is more than 200 feet above the high level of the lake.

In its lower part the Chemehuevi formation consists chiefly of banded clay, which must have been deposited in a deep lake; near Hoover Dam and farther downstream, these clays are several hundred feet thick. Above them the deposit consists chiefly of sand, with river gravel near the top. Farther upstream, near Iceberg Canyom and in the Grand Wash trough, sand makes up the greater part of the thickness; clay in the lower part is thin. Presumably the narrow part of the lake in the Grand Canyon was soon filled with river sediments, and the front of the delta continued to advance down the lake. At a distance from this front only the fine sediments, carried in suspension or by turbidity currents, were laid down. Eventually the lake was filled with these fine sediments, and the river deposited its gravels widely at the higher level. Later the stream cut down to the bottom of its old valley, and the weak sediments of the Chemehuevi were removed except for remnants in the more protected places. Many remnants of gravel-covered terraces record stages in the history of downcutting.

In the vicinity of Hoover Dam there is clear evidence that the river flowed at a level higher than the rim of Black Canyon.. Along the east flank of the prominent hill known as Sugarloaf, on the Arizona side southeast of the dam, a large bar made of gravel that is typical of the Colorado River reaches an altitude well above 1,500 feet, or fully 900 feet above the low-water stage of the river at the damsite. The pebbles and cobbles are derived from many types of rock, some of which are not known to crop out nearer than 50 miles upstream from the bar; all are rounded and smoothed in the fashion characteristic of coarse debris rolled on the bottom of a large and powerful stream; and all, even those composed of weak limestone, show negligible effects of weathering. About half a mile northeast of the Sugarloaf bar and only a little lower in altitude, large potholes have been worn to a depth of several feet into resistant volcanic rock by the action of a swift stream carrying coarse gravel along its bottom. Such gravel, like that in the channel of the 
moderm Colorado River, partly fills the potholes and forms bars nearby.

The potholes and gravel deposits in their locations above the rim of the canyon indicate that the canyon was filled, and that on the high surface of the fill the river wandered from its old course, to which it became readjusted with renewed downcutting. Presumably the fill consisted of the Chemehuevi formation, even though none of this weak material now remains on the steep slopes near Hoover Dam. In protected areas farther south along Black Canyon, remnants of river gravel and also clay and sand of the Chemehuevi occur far above the river. Large remnants of the Chemehuevi extend far back from the river on both sides of Pyramid Canyon, near the new Davis Dam, 60 miles downstream from Hoover Dam. Clay from the Chemehuevi formation was used in large quantities in the construction of this earth-fill dam.

Many remnants of the Chemehuevi lie along the Virgin and Muddy Valleys. Possibly of contemporaneous origin are light-colored clays that are widespread in the low ground around Las Vegas. The Chemehuevi formation, particularly the basal banded clay and overlying sand, records a deltaic deposition that appears to be strikingly parallel to that which is occurring in Lake Mead since the completion of Hoover Dam.

The cause of ponding of the Colorado River to make the great Chemehuevi Lake has not been determined. It occurred during the Pleistocene epoch, or Great Ice Age, when all of western United States had a more pluvial climate than at present. Perhaps the large quantities of coarse gravels in the upper part of the Chemehuevi were transported by a much larger and more powerful stream than the present Colorado River, which apparently carries nothing coarser than sand into the deltaic fill near the mouth of the Grand Canyon.

\section{VOLCANIC ROCKS AND RELATED INTRUSIVE BODIES}

No igneous rocks of Paleozoic age are known in the region. None have been identified in the formations of Triassic or Jurassic age, though possibly some of the clays of Triassic age contain altered volcanic ash, as is true of the clay of the Chinle formation in parts of the Colorado Plateaus (Allen, 1930). The Cretaceous rocks southwest of Muddy Valley contain considerable volcanic ash that is little altered, as well as clays that have the characteristic properties of bentonite. These Cretaceous formations show, by recurring conglomerates made up of fragments from many older formations, that strong crustal disturbance was in progress during their deposition. Volcanic activity would logically accompany such disturbance.

Both the Overton fanglomerate of Cretaceous(?) and Tertiary (?) age and the Horse Spring formation of Tertiary (?) age include beds of volcanic ash. These formations (on pl. 1B mapped with the Tertiary volcanic rocks) record continued crustal movements. North of Las Vegas Wash there are extensive flows of basaltic lava in Cretaceous (?) beds below the Horse Spring formation. These are the oldest lavas that have a known relation to sedimentary formations; however, some of the undated volcanic rocks in the Black Canyon area may well be older.

The northern part of the Black Mountains is made chiefly of volcanic rocks cut by dikes and other intrusive bodies. Near the Virgin River valley many of the lavas are interbedded with the Muddy Creek formation of Pliocene age; but much of the igneous complex is older than the Muddy Creek. The walls of Boulder Canyon reveal a thick sequence of lavas, strongly tilted, and intruded by sills and dikes. In large part this assemblage has been altered chemically, probably by circulating hot vapors and solutions connected with the igneous action. Large masses of the rock have been reduced to soft claylike material, which is highly colored. Similar alteration has affected the igneous rocks near the head of Black Canyon; the west and south flanks of Fortification Hill are spectacular from the resulting coloration.

The walls of Black Canyon near Hoover Dam display a great thickness of lavas and related volcanic rocks, steeply inclined to the northeast. From the vicinity of Callville Basin southward for hundreds of miles, volcanic and other igneous rocks underlie large areas in a wide belt reaching far east and west of the Colorado River. In fact, the course of the river westward from the Grand Wash trough marks a general boundary between regions that differ strikingly in character of bedrock. North of this boundary are great thicknesses of sedimentary formations, in which marine limestones are abundant. In the wide belt to the south these formations are almost entirely lacking; in their place above the Precambrian basement are thick sections of volcanic materials, with local accumulations of gravel and other waterlaid sediments.

In the vicinity of Black Canyon the igneous rocks are of many kinds. A large area around Boulder City is underlain by quartz monzonite, a granular rock that resembles granite but contains less quartz. This large mass was formed at considerable depth below the surface, where slow cooling of the molten rock permitted growth of large mineral grains. Similar bodies are exposed on the west flank of the Black Mountains. North 
of Boulder City, and also east of Hoover Dam, the inclusion of large block of limestone of Paleozoic age in igneous bodies proves that sedimentary formations, now widespread farther north, extended also across the Black Canyon area when the igneous masses were intruded. Because erosion to great depth was required to lay bare the coarse-grained igneous rock, presumably there was large uplift of the area from Callville Basin southward during or after emplacement of the igneous masses. Erosion after the uplift carried away the sedimentary formations, leaving only isolated remnants.

Volcanism may have been active while uplift and erosion were in progress. The volcanic rocks now preserved represent eruptions in a late stage of the erosional history, for these rocks rest on intrusive bodies in the Hoover Dam area and on Precambrian basement a few miles farther south. Lavas, breccias, tuffs, and glasses make up the volcanic section. The lavas range in composition from dark basalt, through brownish andesite and other intermediate types, to light-colored rhyolite. Fragmental materials, from coarse breccia to fine-grained tuff, record explosive activity. Obsidian, perlite, and other forms of glass are abundant at many localities. There was vigorous erosion during the volcanism, and deposition of gravel in local valleys or basins. Such gravels, firmly cemented and with volcanic rocks both below and above, are exposed in steep cliffs along the highway east of the dam. Cuts along the highway give excellent exposures of the varied lavas and related rocks-dark basalt and andesite, brown and reddish latite, tuff ranging in color from almost white to green, and glass that varies from shades of gray to black. In total thickness the volcanic rocks measure thousands of feet.

The history of volcanism was long and complex. Thick sections were tilted, eroded, and buried by later accumulations. In the area from the dam southward, at least four distinct generations of volcanic rocks are recognized. Centers of eruption are marked by plugs, dikes, and irregular intrusive bodies cutting the older units. Although none of these rocks along the river have been definitely dated, they are in large part older than the Muddy Creek formation and therefore probably were erupted before middle Cenozoic time. The oldest may be contemporaneous with the ash deposits in Cretaceous rocks of the Muddy Mountains. Lavas of the Muddy Creek and younger formations are chiefly dark basalts; a good example is the thick section of flows capping Fortification Hill, near Hoover Dam. Extensive sheets of basaltic lava are included in nearly unconsolidated gravels southeast of Lake Mead, and some beds of volcanic ash occur in the Chemehuevi formation of Pleistocene age.

\section{STRUCTURE OF THE BEDROCK}

In contrast with the nearly horizontal attitude and the continuity of strata over large areas of the Colorado Plateaus, the older formations west of the Grand Wash Cliffs are in many places broken, steeply tilted, and folded. The most complicated deformation is found in the Muddy Mountains, where wide plates of limestone of Paleozoic age have been thrust many miles over younger formations, crumpling, shattering, and locally overturning the beds. Although the deformation occurred before the Horse Spring formation was laid down, later disturbances folded and tilted this formation also. These crustal movements occurred in the Cretaceous period and perhaps continued into early Cenozoic time, as part of a regional upheaval that affected a wide belt west of the Colorado Plateaus and extended northward into the Northern Rocky Mountains.

Following this early deformation there were repeated movements on steep fractures, on some of which the total displacement is measured in thousands of feet. Volcanic eruptions occurred in this period of unrest, and sections of the volcanic rocks were broken and tilted. In the east flank of the Virgin Mountains, some of the formations are repeated as a result of movement along faults of large displacement. Along the west side of Iceberg Canyon, limestone beds of Carboniferous age are inclined about 70 degrees eastward; directly east of this canyon are much older beds with similar inclination (pl. 2). The beds on the west were dropped nearly 5,000 feet along a fault inclined at a low angle toward the west. A similar fault 2 miles farther east is responsible for another repetition of formations. From the relation of these tilted blocks to the strata exposed in the Grand Wash Cliffs, the greatest fault in the group is considered to be hidden by younger sedimentary material that floors the basin directly west of the cliffs. This great fracture, along which the Kaibab limestone was dropped thousands of feet below its position in the upper cliff, is known as the Grand Wash fault (fig. 3).

The main block of the Black Mountains either was lifted along major faults or remained high while blocks on both sides were depressed (fig. 3). The southern Virgin Mountains block was rotated about its long axis; the east side subsided thousands of feet, and the west side was lifted in almost equal measure. Much of the faulting occurred before the Muddy Creek formation and related basin sediments were deposited; but there was additional movement during that deposition and later. The higher masses have been subjected to erosion, and the resulting rock debris has been washed into the basins. This interplay of block 


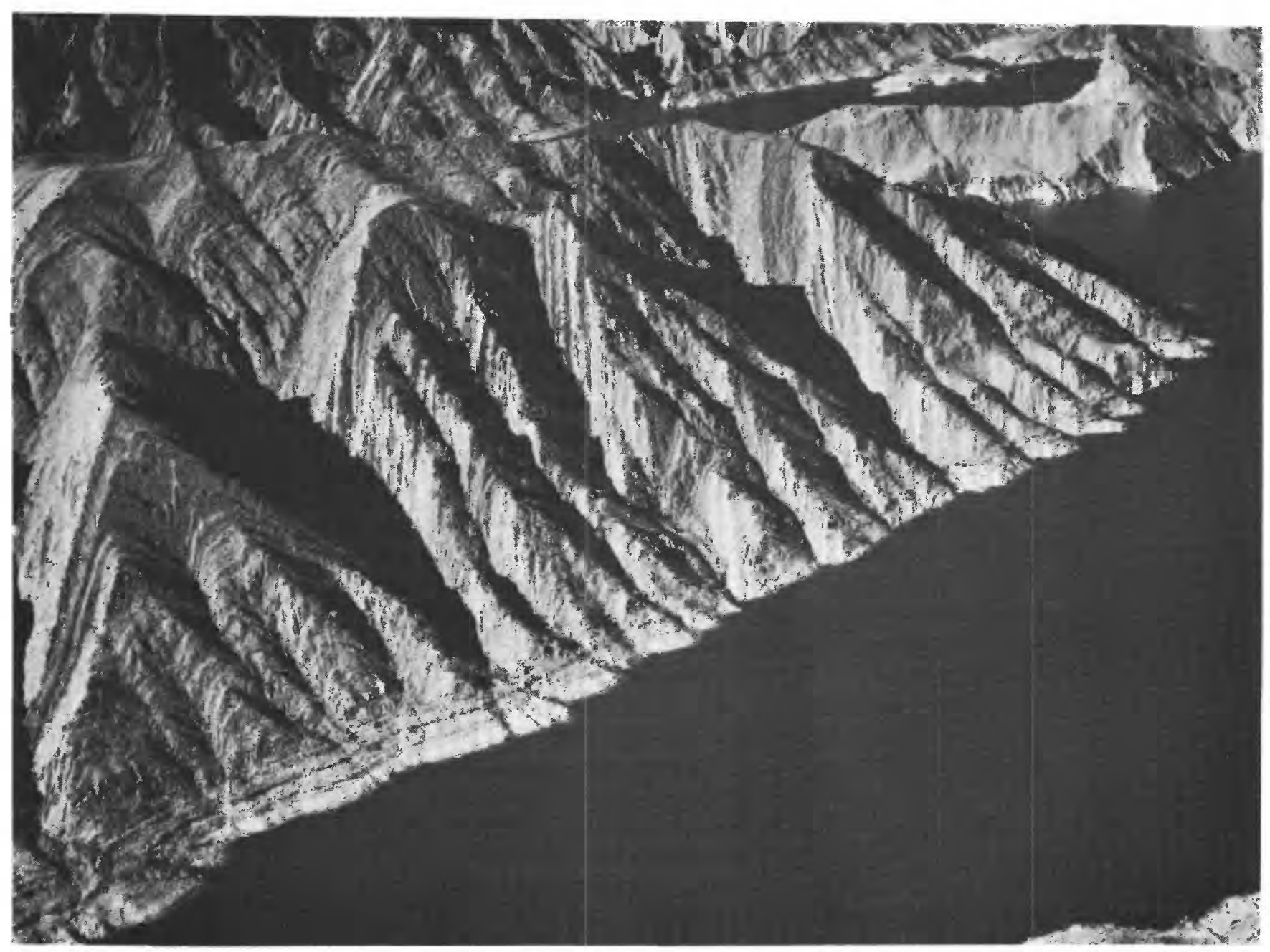

STEEPLY DIPPING STRATA OF CARBONIFEROUS AGE ALONG GRAND BAY, LAKE MEAD

Similar strata form the west wall of Iceberg Canyon, in background. Airphoto by Bureau of Reclamation. 
movement, erosion, and sedimentation during much of Cenozoic time has produced the characteristic features of the Basin and Range province. Some of these features are exceptionally well revealed in the Lake Mead area, because the Colorado River and its tributaries have removed from the basins much of the concealing sedimentary fill.

Movement on some large faults in southern Nevada is still in progress, as is indicated by broken alluvial slopes at the bases of steep range fronts. Differential vertical movements in the vicinity of Lake Mead, revealed by precise leveling since 1935, may in part reflect the added load of water and sediment in the lake basin. However, these movements may have been in progress before the Hoover Dam was built, and the added weight may or may not have had an appreciable modifying effect.

\section{SUMMARY OF GEOLOGIC HISTORY}

During all of the Paleozoic and much of the Mesozoic era of geologic history, a lapse of time reckoned to be about 400 million years, the Lake Mead area was part of a wide region that subsided slowly. During much of this time the region was the floor of a wide sea. Sedimentary deposits accumulated, but continued subsidence kept the region either below or slightly above sea level. By Early Cretaceous time the sedimentary section, made up of limestone, shale, and sandstone, was many thousands of feet thick; all these thick formations were essentially horizontal over a vast area. Mountain-making forces then came into play, buckling and telescoping the strata in a wide belt. Coarse debris eroded from growing mountain ridges formed thick alluvial deposits, and sediments of finer grain accumulated in lakes. Volcanic actirity began, and through a long time it added complexity to the bedrock geology. Contemporaneously there was uplift and depression of crustal blocks on great fractures. Debris washed from the high blocks was deposited in the basins, and eventually the mountain ridges were almost buried in their own debris.

The date of establishment of the Colorado River as a through-flowing stream is not yet known (Longwell, 1946). It is able to flow through the wide desert re- gion because its upper reaches receive abundant water from high mountains and plateaus. The Rocky Mountain region attained its present height by successive major uplifts, the latest of which occurred in late Cenozoic time (Atwood and Mather, 1932). Probably this elevation of the region brought on a more pluvial climate, and the Colorado River developed as a channel to carry the surplus water toward the southwest. The Grand Canyon was cut as the river lowered its channel across the rising plateaus (Dutton, 1882). In the Basin and Range region to the west the river became incised across hard-rock ridges such as the Black Mountains, while erosion remored much of the weaker basin fill on either side to make the lowlands of Callville Basin and the Virgin-Detrital trough. Thus Boulder Canyon and similar deep, narrow segments of the river valley have maintained their form because of resistant bedrock in their walls, whereas the valley has grown wide and low walled in the intermont basins that were filled with weak sediments.

\section{REFERENCES CITED}

Allen, V. T., 1930, Triassic bentonite of the Painted Desert: Am. Jour. Sci., Jth ser., r., 19, p. 283-288.

Atwood, W. W., and Mather, K. F., 1932, Physiography and Quaternary geology of the San Juan Mountains, Colorado: U.S. Geol. Survey Prof. Payer 166, 173 p.

Dutton, C. E., 1882, Tertiary history of the Grand Canyon district: U.S. Geol. Survey MIon. 2, $250 \mathrm{pp}$.

Hunt, C. B., McKelvey, V. E.. and Wiese, J. H., 1942. The Three Kids manganese district, Clark Count, Nevada: U.S. Geol. Survey Bull. 936, p. 297-319.

Lee, W. T., 1908, Geologic reconnaissance of a part of western Arizona : C.S. Geol. Survey Bull. 352.92 p.

Longwell, C. R., 1936, Geology of the Bollder Reservoir floor: Geol. Soc. America. Bull. v. 47, p. 1393-1476.

1946, How old is the Colorado River?: Am. Jour. Sci., v. 244 , p. $817-835$.

1949, Structure of the northem Muddy Mountain area, Nevada : Geol. Soc. America, Bull., v. 60, p. 923-967.

McKelvey, V. E., Wiese, J. H., and Johnson. V. H., 1949, Preliminary report on the bedded manganese of the Iake Mead region, Nevada and Arizona: T.S. Geol. Survey Bull. 948-D. p. $83-101$.

Noble, I. F., 1922, A section of the Paleozoic formations of the Grand Canyon at the Bass Trail: C.S. Geol. Survey Prof. Paper 131, p. 22-74. 


\title{
D. DRAINAGE BASIN TRIBUTARY TO LAKE MEAD
}

\author{
By H. E. Thomas, U.S. Geological Survey
}

Lake Mead is in the Lower Colorado River Basin, as defined in the Colorado River Compact of 1922. ${ }^{1}$ Hoover Dam is about 354 miles downstream from Lee Ferry, which is the Compact point marking the lower limit of the Upper Colorado River Basin. The Lower Basin, however, provides only a very small proportion of the water that flows into Lake Mead; these contributions come from the Little Colorado River, the Virgin River, small perennial or ephemeral creeks, and some fairly large springs in northern Arizona. In an average year about 95 percent of the inflow to Lake Mead comes from the Upper Basin. Thus the water that accumulates in Lake Mead comes from an area that extends far beyond the limits of the area encompassed by the reservoir survey of 1948-49. Basic water data collected by the Geological Survey in cooperation with the States of Arizona, Colorado, Nevada, New Mexico, Utah, and Wyoming constitute a broad general outline of the hydrologic conditions in that large tributary area, but they are far from adequate for comprehensive planning of water-resource development above Lake Mead. This section summarizes these existing data and provides a background of information as to the source of the water and sediment in Lake Mead.

The part of the Colorado River drainage basin tributary to Lake Mead comprises about 168,000 square miles, or 5 percent of the continental area of the United States. If this vast area has one characteristic in common, it is perhaps the lack of hospitality to mankind. Very little of the area is desirable for habitation, and the lands occupied by the basin are accordingly among the least populated parts of Colorado, Wyoming, Utah, New Mexico, and Arizona.

The basin has a greater range in physical characacteristics than is to be found in most other areas of comparable size on the North American continent. Physiographically, it includes several of the highest

\footnotetext{
1 The agreement concerning the apportionment of the use of the waters of the Colorado River System dated November 24, 1922, executed at Santa Fe, N. Mex., by Commissioners for the States of Arizona, California, Colorado, Nevada, New Mexico, Utah, and Wyoming, approved by Herbert Hoover as representative of the United States of America, and proclaimed effective by the President of the United States of America, June 25, 1929.
}

$4969180-60-3$ peaks of the Rocky Mountains as well as high mountain valleys and broad upland plains, extensive plateaus and spectacular canyons, broad alluvial valleys, and desert ranges. Climatologically, the basin presents the extremes of year-round snow cover and heavy precipitation on the higher peaks of the Rockies, and desert conditions in which annual precipitation is commonly less than 5 inches. The temperature range is from the temperate-as in the mountain meadows of Colorado and Wyoming, where there is a scanty 90 -day growing season-to the semitropical-as near Lake Mead, where only occasional winter frosts occur. Geologically, the rocks in the basin are of a wide variety of types, ranging in age from Precambrian to Recent.

As might be expected in a region of such diverse physical characteristics, there are some areas with very high rates of runoff, and other areas that yield practically no water to the Colorado River; also certain areas in which the streams are generally clear, and other areas that are major contributors of the sediment that enters Lake Mead.

\section{PHYSIOGRAPHY}

The drainage basin tributary to Lake Mead includes parts of five physiographic provinces as outlined by Fenneman (1930). The easternmost part of that basin is within the Southern Rocky Mountains province, which comprises high mountain ranges and intermontane valleys. Characteristically, this part of the basin receives heavy precipitation, and most of it is covered by forest and alpine flora. Many of the largest streams of the Colorado River system-the Yampa, White, Colorado, Gunnison, Dolores, and San Juan Rivers-rise in this mountainous province.

The northwestern part of the Colorado River basin lies within the Middle Rocky Mountains province. Like the Southern Rockies, this province is composed of high forested mountain ranges and intermontane valleys. Because of its generally higher latitude, the growing season in these valleys is shorter than in valleys of the Southern Rockies, and the annual evaporation rate is less. In this province are the headwaters of the Green River and many of its important tributaries. 
Between the Middle and Southern Rocky Mountains is the Wyoming Basin, a physiographic province characterized by elevated plains in various stages of erosion, and isolated low mountains. Precipitation is generally less than 20 inches a year, and the basin is classed as semiarid. Most of the streams draining this area are intermittent; they contribute only small quantities of water to the Colorado River system, chiefly during annual freshets.

The central part of the drainage basin tributary to Lake Mead is within the Colorado Plateaus province. Some of these plateaus are high and forested, and they receive a moderate amount of precipitation; others are lower canyoned plateaus of high relief; and large areas are rather thoroughly dissected. The precipitation over most of the plateau country is scant. Sonoran types of vegetation-including piñon, sagebrush, and grasses-provide sparse cover, leaving large areas of bare or thinly mantled rock. The streams rising in the plateau country make relatively small annual contributions to the flow of the Colorado River; the Little Colorado River is the largest of these contributors. In drainage basins where steep, barren or sparsely vegetated slopes are prevalent, rainstorms may produce high runoff for short periods. This is particularly true of the southern part of the drainage basin, where intense summer rainstorms may produce flash floods that constitute a substantial proportion of the annual runoff.

The lowest part of the drainage basin tributary to Lake Mead is in the Basin and Range province; the lake itself is almost entirely within this province. The climate here is arid, and the desert mountains and valleys contribute practically no water to the lake except after exceptional rainstorms. Two perennial streams enter Lake Mead within the province: Muddy Creek, which has a sustained flow from springs, and the Virgin River, which derives most of its water from high plateaus and from the Pine Valley Mountains in southwestern Utah.

\section{GEOLOGY}

The geology of the drainage basin tributary to Lake Mead is sufficiently diverse that its problems attract specialists in all phases of the earth sciences. Rocks in the area range in age from Precambrian to Recent and in type through a wide assortment of igneous, sedimentary, and metamorphic. Deposits of economic value in the basin include gold, silver, lead, zinc, copper, molybdenum, antimony, vanadium, and uranium; coal, petroleum, natural gas, oil, shale, and rare hydrocarbons; phosphate rock, potash, salt, gypsum, helium, and carbon dioxide; and construction materials. The broad, simple structures and easily recognized strata of the plateau country attract the hobbyist without formal training in geology; yet the complex structures of many of the mountain ranges are brain teasers for the ablest geologists and geophysicists.

The geologic formations of the tributary drainage basin are significantly related to the water and the dissolved and suspended materials that enter Lake Mead. A negligible proportion of the runoff is derived by direct precipitation upon the stream channels. Somewhat larger quantities may result from overland runoff, particularly from bare rock or impervious mantle rock. Most of the runoff is derived from melting of winter accumulations of snow in the higher mountains, but nearly all this water moves for at least a short distance through the soil or underlying ground-water zones before reaching the streams. The quantity of runoff generally is only a minor fraction of the precipitation upon the region and represents the excess of water beyond the requirements for transpiration by plants and for direct evaporation. Pervious rock materials that absorb a large proportion of the precipitation may subsequently be dewatered by evapotranspiration draft or by discharge of ground water to streams. Thus the geology is a significant factor in the precipitation-runoff relations throughout the tributary basin.

The chemical constituents carried by the river are derived in part by solution of rock materials over which the river and its tributaries flow. Thus the Colorado River in its annual flood stages laps against beds of gypsum in Cataract Canyon in southeastern Utah, and some of that rock is dissolved and carried away in the river. Some tributaries likewise flow directly over soluble bedrock, and as a result their waters have a high mineral content-a fact that is suggested by the names given to several small streams in the basin, such as Onion Creek, Salt Wash, Saleratus Wash, and Gypsum Canyon. However, outcrops of soluble bedrock in stream channels occupy a very small proportion of the total channel area, and the quantity of dissolved materials derived from them is also a small fraction of the total dissolved solids carried into Lake Mead.

Most of the dissolved material in the river is derived from ground water. The most obvious sources are saline springs along the main stem and tributary channels, springs rising from limestones or igneous rocks, fault springs, and return flow of irrigation water. Ground water seeping into the river and its tributaries carries a large proportion of the total dissolved solids of the river. Types of rock that are important contributors of dissolved materials include evaporites, shales, and sandstones. These rocks crop out principally in the Colorado Plateaus and the Wyoming Basin. 
The geologic formations cropping out within the drainage basin are also the ultimate sources of the sediment carried by the Colorado River and its tributaries. The formations include a great variety of rock types, ranging from highly indurated to loosely cemented or unconsolidated rocks. Individual sedimentary formations commonly include a wide range in textures, both horizontally and vertically. A thorough appraisal of the sediment-producing characteristics of any part of the basin would require detailed geologic mapping of those formations and, in addition, mapping in corresponding detail of the soil or mantle conditions, the vegetative cover, and the topography. Such mapping has not yet been completed for any major part of the Colorado River basin.

A rough comparison of the sediment-producing capabilities of various parts of the basin may be made on the basis of the generalized outcrop areas as shown on the geologic map of the United States. Extensive areas, especially near the boundaries of the basin, are underlain by indurated rocks that are resistant to erosion. For the most part these rocks form the mountain ranges and are of Paleozoic age or older. However, there are also extensive areas of volcanic rocks, including some that are remote from mountainous areas, which are for the most part of Tertiary or Quaternary age. Generally the streams rising in these areas are fairly free of sediment at all seasons. The rocks most common to the areas that produce relatively clear water are crystalline and metamorphic types, lavas, limestones, and wellcemented sandstones and conglomerates.

Much of the drainage basin in the Colorado Plateau, and nearly all of the Wyoming Basin, is underlain by shale, mudstone, and clay-rocks which upon weathering yield predominantly silt- and clay-sized particles. The silt-producing formations are chiefly of Mesozoic and Tertiary age. The Little Colorado, San Rafael, and Dirty Devil Rivers drain basins in which fine textured materials predominate.

A classification of the drainage basin according to capabilities of producing sediments, as inferred from geologic maps, is presented in figure 4. Although the rock outcrops and the mantle rock formed from them constitute the ultimate source of the sediment load carried by the river, it is likely that only an insignificant part of the load comes directly from those sources. Indeed, the main stream and tributaries rarely come in contact with bedrock except in their headwaters, and instead the bed and banks of the channels are formed of stream-borne sediment, or alluvium. Geologic reconnaissances show that the area covered by alluvium is only a very small proportion of the total area of the basin, but that, rather generally throughout the basin, the river and its tributaries are cutting both downward and laterally into the alluvial deposits of past centuries. These alluvial deposits are believed to constitute the immediate source of much of the sediment now moving toward Lake Mead.

\section{WATER}

The Colorado River is most impressive in its canyons below the mouth of the San Juan River-in Glen Canyon, or in Marble Canyon or Grand Canyon where tourists most commonly view it. Viewed from the rim of one of these canyons, the river is a thin ribbon of water that is dwarfed by the massiveness of the setting.

The great plateau country of northern Arizona and southeastern Utah provides a scenic environment and much sediment for the river, but little more. Of the water that enters Lake Mead, only slightly more than 5 percent is contributed by the small streams of Arizona, Nevada, New Mexico, and southern Utah. All the rest comes from Colorado, Wyoming, and northern Utah by way of the main stem of the river or its principal tributaries. Indeed, more than three-fourths of the annual inflow to Lake Mead is derived from the high headwater areas of streams that rise in the numerous ranges of the Rocky Mountain chain.

For the most part the arid plateau land contributes only enough water to the river to offset the rather sizable losses from the river due to evaporation and transpiration. Along extended segments of the river there is practically no inflow during most of the year, and because of the evapotranspiration draft the river passes through those reaches with a net loss during most of the year.

The sources of the inflow to Lake Mead during the 1948 water year are shown graphically in figure 5. It is evident from this diagram that the main stem of the Colorado in Utah and Arizona, as well as the channel of the Green River below the Uinta Basin and the channel of the San Juan River below the mouth of the Animas River, serve principally as conduits for water that has originated in headwater areas to the north and east.

The concentration and chemical character of dissolved solids in the streams vary considerably throughout the year. As a rule the concentration is greatest during periods of low flow and least during flood periods. Howard (1948) has shown that there is a progressive downstream increase in concentration of dissolved solids both in the Colorado River and in its principal tributaries. These increases are caused chiefly by natural ground-water inflow and by return water from agricultural and industrial developments. Large increases are recorded, for example, in a short reach of the river near Grand Junction, Colo., where 
there is considerable return flow of irrigation water to the stream.

\section{SEDIMENT}

Historically the sediment has always been a conspicuous feature of the Colorado River, as indicated by the name "colored river", first applied by the early Spanish explorers. At all times the observer is likely to be impressed by the murkiness of the water of the main stem and its principal tributaries-generally tawny brown, perhaps reddish or grayish, but characteristically muddy.

The rock materials which the streams have transported and deposited during the latest geologic epoch are classified by geologists as Recent alluvium. This alluvium forms the flood plains that flank the main stems and tributaries along many miles of their courses; it constitutes the islands, bars, and shoals in the river and underlies the river channel. In places where the channel is constricted, the alluvium may be as much as 200 feet thick, as shown by test borings at prospective dam sites. And in the broad valley plains the Recent alluvium may form the surficial material in a belt as much as 3 miles wide.

The ultimate source of the Recent alluvium is the older rock formations of the drainage basin, and the fragments that result from their weathering. Where gradients are steepest-chiefly in the small tributary channels-a stream may flow directly over bedrock for some distance; and in other reaches the channel may be bordered by bedrock walls. In these places the stream itself becomes the eroding agent, and acquires some sediment directly from bedrock. Overland flow over bare or impermeable rock material may also carry sediment into the streams.

It is likely that only a negligible proportion of the sediment in Lake Mead has moved continuously from its original source. Generally the process of sediment transportation is a series of short travels, with intervening deposition and reexcavation. Typically a stream that is eroding along a certain reach will carry some of that sediment only to a reach having lesser gradient, and the sediment remains there until a greater volume of water can carry it farther. The tributaries quite generally have higher gradients than do the main stems, and boulders and blocks that can be moved by those tributaries may come to rest opposite their mouths, in the main stems. Practically all of the rapids in the Colorado and Green Rivers in Utah are caused by this accumulation of coarse detritus at the mouths of tributaries.

Climatologic conditions are a factor contributing to the discontinuity and irregularity of sediment transportation. Many of the minor tributaries that drain the Colorado Plateaus have high peak discharges during
August, September, and October, following intense rainstorms, and may carry heavy loads of sediment to the Colorado River at that time. That river ordinarily is at relatively low stage during those months and is unable to carry the heavy load; consequently, much of the sediment may be dropped along its channel. Transportation of such debris may not be resumed until the high main-stem flows of the succeeding year. The mechanics of sediment transportation are complex, and there is not necessarily a close correlation between precipitation over the drainage basin, runoff, and sediment load in a designated period.

In its relation to the stream system, the alluvium may be classified as (1) sediment "in transit"-sediment moving either as suspended load or as bed load moving along the channel bottom; (2) sediment in "live storage"-sediment that is temporarily at rest in bars, islands, stream banks, and bottoms, where the annual fluctuations in streamflow may readily place it in transit again; and (3) sediment in "dead storage"-alluvium that has remained in place for a long time beneath flood plains or far beneath the channel bed, where reexcavation and further transportation are unlikely unless there are appreciable changes in runoff, gradient, or other controlling factors.

\section{SUSPENDED LOAD}

Data concerning the sediment load during the water year 1948, based on samples collected daily or oftener, have been obtained by the Geological Survey at eight stations in the drainage basin tributary to Lake Mead. During the year records were begun at half a dozen other localities, which permit a more thorough analysis of the transportation of sediment by the river and its tributaries during subsequent years.

The suspended load during 1948 is shown graphically on figure 6. Although the data are inadequate to show how much sediment is carried by several of the tributaries that are suspected of being important contributors, comparison with figure 5 shows that the streams that yield most of the water do not carry a proportionate share of sediment. In 1948 the flow of the Colorado River at Cisco, Utah, plus that of the Green River at Green River, Utah, was more than three-fourths of the total that entered Lake Mead (fig. 5) ; but the sediment passing those two points was less than a quarter of the amount entering the lake. On the other hand, the records for three tributaries in the southern part of the basin-the Little Colorado, Paria, and San Juan Rivers-show that these streams yield a far greater proportion of the suspended sediment than of the water that reaches Lake Mead. It is inferred from the sediment "pickup" along the main stem in southern Utah and 
The geologic formations cropping out within the drainage basin are also the ultimate sources of the sediment carried by the Colorado River and its tributaries. The formations include a great variety of rock types, ranging from highly indurated to loosely cemented or unconsolidated rocks. Individual sedimentary formations commonly include a wide range in textures, both horizontally and vertically. A thorough appraisal of the sediment-producing characteristics of any part of the basin would require detailed geologic mapping of those formations and, in addition, mapping in corresponding detail of the soil or mantle conditions, the vegetative cover, and the topography. Such mapping has not yet been completed for any major part of the Colorado River basin.

A rough comparison of the sediment-producing capabilities of various parts of the basin may be made on the basis of the generalized outcrop areas as shown on the geologic map of the United States. Extensive areas, especially near the boundaries of the basin, are underlain by indurated rocks that are resistant to erosion. For the most part these rocks form the mountain ranges and are of Paleozoic age or older. However, there are also extensive areas of volcanic rocks, including some that are remote from mountainous areas, which are for the most part of Tertiary or Quaternary age. Generally the streams rising in these areas are fairly free of sediment at all seasons. The rocks most common to the areas that produce relatively clear water are crystalline and metamorphic types, lavas, limestones, and wellcemented sandstones and conglomerates.

Much of the drainage basin in the Colorado Plateau, and nearly all of the Wyoming Basin, is underlain by shale, mudstone, and clay-rocks which upon weathering yield predominantly silt- and clay-sized particles. The silt-producing formations are chiefly of Mesozoic and Tertiary age. The Little Colorado, San Rafael, and Dirty Devil Rivers drain basins in which fine textured materials predominate.

A classification of the drainage basin according to capabilities of producing sediments, as inferred from geologic maps, is presented in figure 4. Although the rock outcrops and the mantle rock formed from them constitute the ultimate source of the sediment load carried by the river, it is likely that only an insignificant part of the load comes directly from those sources. Indeed, the main stream and tributaries rarely come in contact with bedrock except in their headwaters, and instead the bed and banks of the channels are formed of stream-borne sediment, or alluvium. Geologic reconnaissances show that the area covered by alluvium is only a very small proportion of the total area of the basin, but that, rather generally throughout the basin, the river and its tributaries are cutting both downward and laterally into the alluvial deposits of past centuries. These alluvial deposits are believed to constitute the immediate source of much of the sediment now moving toward Lake Mead.

\section{WATER}

The Colorado River is most impressive in its canyons below the mouth of the San Juan River-in Glen Canyon, or in Marble Canyon or Grand Canyon where tourists most commonly view it. Viewed from the rim of one of these canyons, the river is a thin ribbon of water that is dwarfed by the massiveness of the setting.

The great plateau country of northern Arizona and southeastern Utah provides a scenic environment and much sediment for the river, but little more. Of the water that enters Lake Mead, only slightly more than 5 percent is contributed by the small streams of Arizona, Nevada, New Mexico, and southern Utah. All the rest comes from Colorado, Wyoming, and northern Utah by way of the main stem of the river or its principal tributaries. Indeed, more than three-fourths of the annual inflow to Lake Mead is derived from the high headwater areas of streams that rise in the numerous ranges of the Rocky Mountain chain.

For the most part the arid plateau land contributes only enough water to the river to offset the rather sizable losses from the river due to evaporation and transpiration. Along extended segments of the river there is practically no inflow during most of the year, and because of the evapotranspiration draft the river passes through those reaches with a net loss during most of the year.

The sources of the inflow to Lake Mead during the 1948 water year are shown graphically in figure 5. It is evident from this diagram that the main stem of the Colorado in Utah and Arizona, as well as the channel of the Green River below the Uinta Basin and the channel of the San Juan River below the mouth of the Animas River, serve principally as conduits for water that has originated in headwater areas to the north and east.

The concentration and chemical character of dissolved solids in the streams vary considerably throughout the year. As a rule the concentration is greatest during periods of low flow and least during flood periods. Howard (1948) has shown that there is a progressive downstream increase in concentration of dissolved solids both in the Colorado River and in its principal tributaries. These increases are caused chiefly by natural ground-water inflow and by return water from agricultural and industrial developments. Large increases are recorded, for example, in a short reach of the river near Grand Junction, Colo., where 


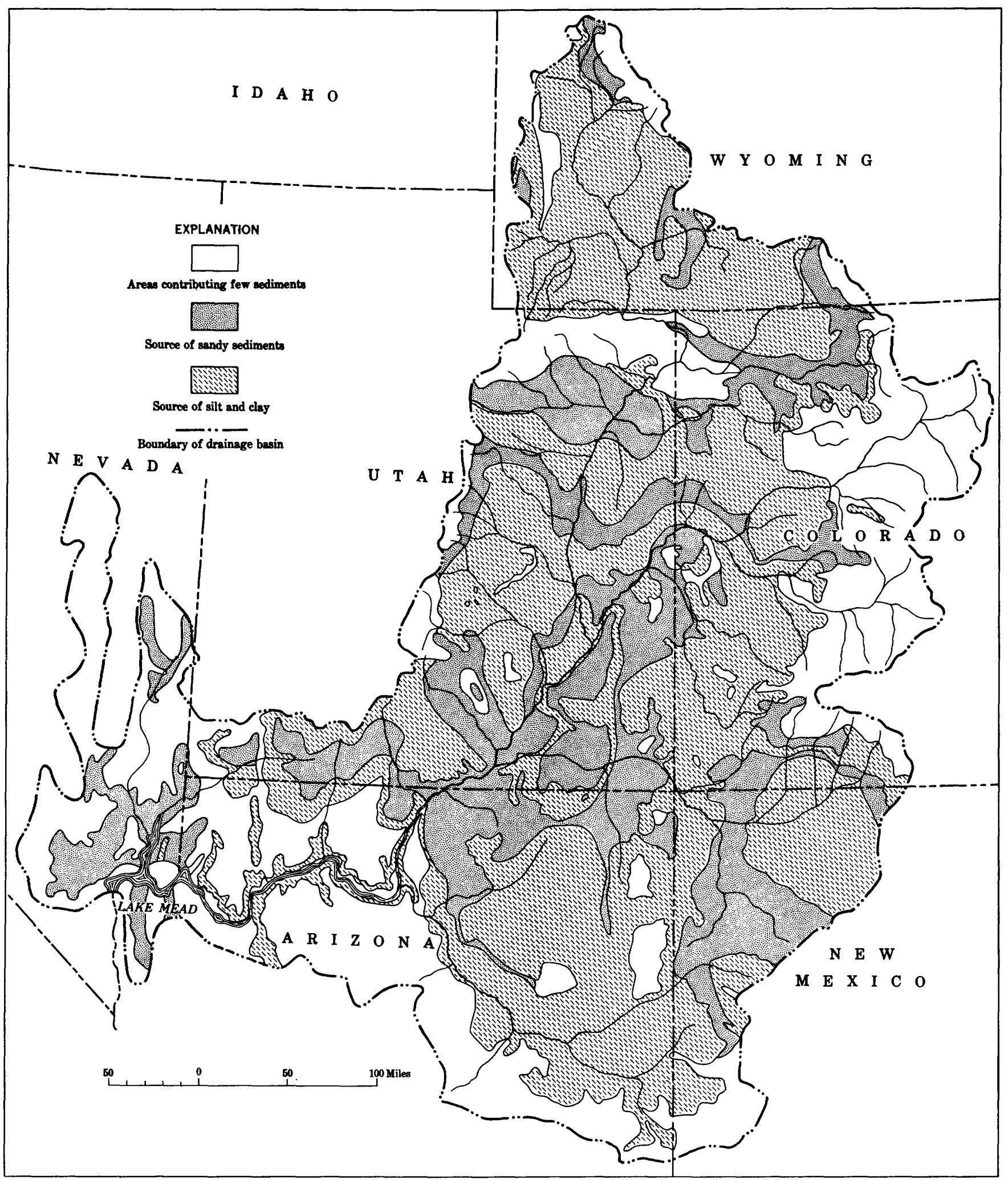

Figure 4.- Map of drainage basin tributary to Lake Mead, showing source areas of sediments as inferred from surface geology. 


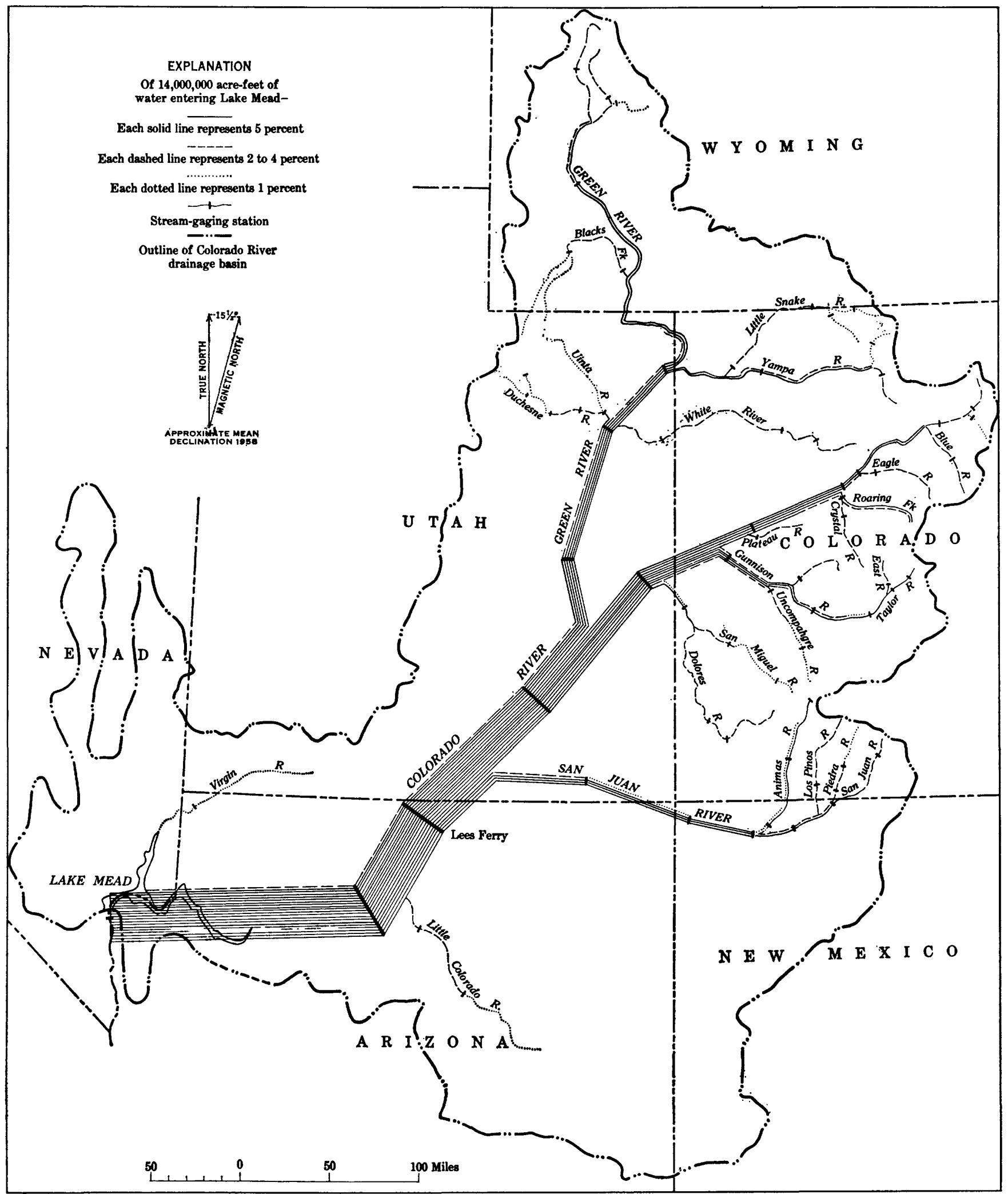

Figura 5.-Streamflow entering Lake Mead during water year 1948. 
there is considerable return flow of irrigation water to the stream.

\section{SEDIMENT}

Historically the sediment has always been a conspicuous feature of the Colorado River, as indicated by the name "colored river", first applied by the early Spanish explorers. At all times the observer is likely to be impressed by the murkiness of the water of the main stem and its principal tributaries-generally tawny brown, perhaps reddish or grayish, but characteristically muddy.

The rock materials which the streams have transported and deposited during the latest geologic epoch are classified by geologists as Recent alluvium. This alluvium forms the flood plains that flank the main stems and tributaries along many miles of their courses; it constitutes the islands, bars, and shoals in the river and underlies the river chanmel. In places where the channel is constricted, the alluvium may be as much as 200 feet thick, as shown by test borings at prospective dam sites. And in the broad valley plains the Recent alluvium may form the surficial material in a belt as much as 3 miles wide.

The ultimate source of the Recent alluvium is the older rock formations of the drainage basin, and the fragments that result from their weathering. Where gradients are steepest-chiefly in the small tributary channels-a stream may flow directly over bedrock for some distance; and in other reaches the channel may be bordered by bedrock walls. In these places the stream itself becomes the eroding agent, and acquires some sediment directly from bedrock. Overland flow over bare or impermeable rock material may also carry sediment into the streams.

It is likely that only a negligible proportion of the sediment in Lake Mead has moved continuously from its original source. Generally the process of sediment transportation is a series of short travels, with intervening deposition and reexcavation. Typically a stream that is eroding along a certain reach will carry some of that sediment only to a reach having lesser gradient, and the sediment remains there until a greater volume of water can carry it farther. The tributaries quite generally have higher gradients than do the main stems, and boulders and blocks that can be moved by those tributaries may come to rest opposite their mouths, in the main stems. Practically all of the rapids in the Colorado and Green Rivers in Utah are caused by this accumulation of coarse detritus at the mouths of tributaries.

Climatologic conditions are a factor contributing to the discontinuity and irregularity of sediment transportation. Many of the minor tributaries that drain the Colorado Plateaus have high peak discharges during
August, September, and October, following intense rainstorms, and may carry heavy loads of sediment to the Colorado River at that time. That river ordinarily is at relatively low stage during those months and is unable to carry the heavy load; consequently, much of the sediment may be dropped along its channel. Transportation of such debris may not be resumed until the high main-stem flows of the succeeding year. The mechanics of sediment transportation are complex, and there is not necessarily a close correlation between precipitation over the drainage basin, runoff, and sediment load in a designated period.

In its relation to the stream system, the alluvium may be classified as (1) sediment "in transit"-sediment moving either as suspended load or as bed load moving along the channel bottom; (2) sediment in "live storage"-sediment that is temporarily at rest in bars, islands, stream banks, and bottoms, where the annual fluctuations in streamflow may readily place it in transit again; and (3) sediment in "dead storage"-alluvium that has remained in place for a long time beneath flood plains or far beneath the channel bed, where reexcavation and further transportation are unlikely unless there are appreciable changes in runoff, gradient, or other controlling factors.

\section{SUSPENDED LOAD}

Data concerning the sediment load during the water year 1948, based on samples collected daily or oftener, have been obtained by the Geological Survey at eight stations in the drainage basin tributary to Lake Mead. During the year records were begun at half a dozen other localities, which permit a more thorough analysis of the transportation of sediment by the river and its tributaries during subsequent years.

The suspended load during 1948 is shown graphically on figure 6. Although the data are inadequate to show how much sediment is carried by several of the tributaries that are suspected of being important contributors, comparison with figure 5 shows that the streams that yield most of the water do not carry a proportionate share of sediment. In 1948 the flow of the Colorado River at Cisco, Utah, plus that of the Green River at Green River, Utah, was more than three-fourths of the total that entered Lake Mead (fig. 5) ; but the sediment passing those two points was less than a quarter of the amount entering the lake. On the other hand, the records for three tributaries in the southern part of the basin-the Little Colorado, Paria, and San Juan Rivers-show that these streams yield a far greater proportion of the suspended sediment than of the water that reaches Lake Mead. It is inferred from the sediment "pickup" along the main stem in southern Utah and 


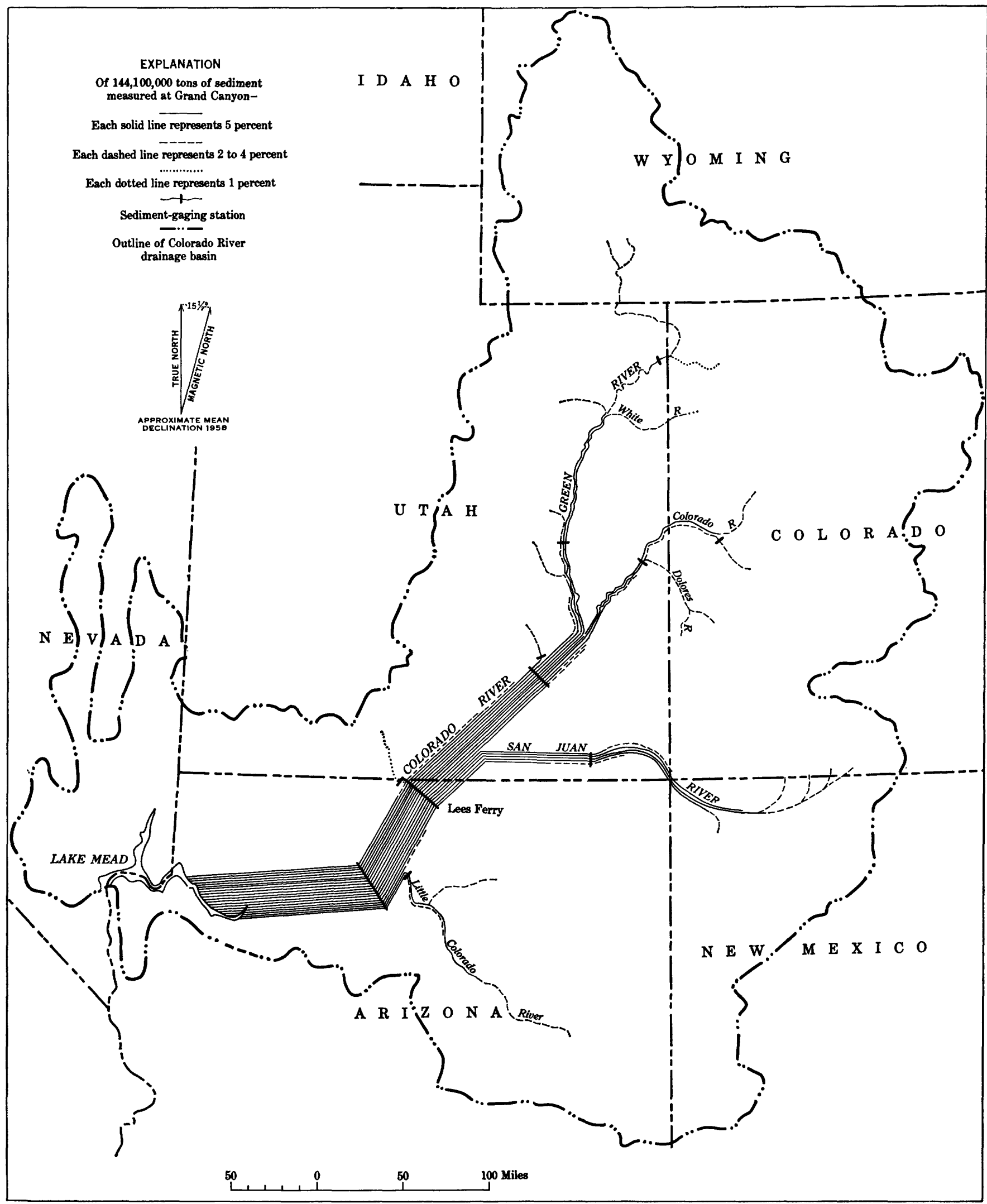

Fradre 6.-Suspended sediment inflow to Lake Mead during water year 1948. 
Arizona that other small tributaries in this area are likewise important contributors of sediment.

The areas from which the bulk of Lake Mead sediment is derived are in the Colorado Plateaus province in Arizona, southeastern Utah and New Mexico. These areas are generally remote from the highest parts of the basin and include the areas having least precipitation and least runoff in the drainage basin. If the reservoir sedimentation is to be controlled, it would appear that the control must be in these areas.

Long-term records of suspended sediment are available at four stations in the tributary drainage basin. These records indicate that the sediment transported during the water year 1948 was close to the average annual load in the period 1930-48. Probably more than 95 percent of the sediment entering Lake Mead passes through the Grand Canyon, where records of the suspended load have been obtained since 1925. Beginning with the water year 1930 , similar records have been obtained for the Colorado River at Cisco, the Green River at Green River, and the San Juan River at Bluff, all in Utah. The annual variations in suspended load at
Grand Canyon and the proportions of that load that pass the three upstream stations are depicted in figure 7 .

In the period of record at Grand Canyon, the year of highest runoff (1929) was also the year of greatest sediment contribution, and the year of least runoff (1934) was also the year of least sediment transportation. There are striking variations in the proportions of the load that pass the three upstream stations from year to year, though it is generally true that the San Juan River carries less water and more sediment than either the Green River or the Colorado River above its junction with the Green. There is a noteworthy contrast between 1939 and 1943 , two years of approximately equivalent sediment load at Grand Canyon. In 1943 the load measured at the three upstream stations amounted to onethird, but in 1939 to more than two-thirds, of the quantity measured at Grand Canyon.

\section{BED LOAD}

In many of the canyons of the Colorado and its principal tributaries, the stream bed is composed predominantly of sand and gravel, boulders, and huge blocks

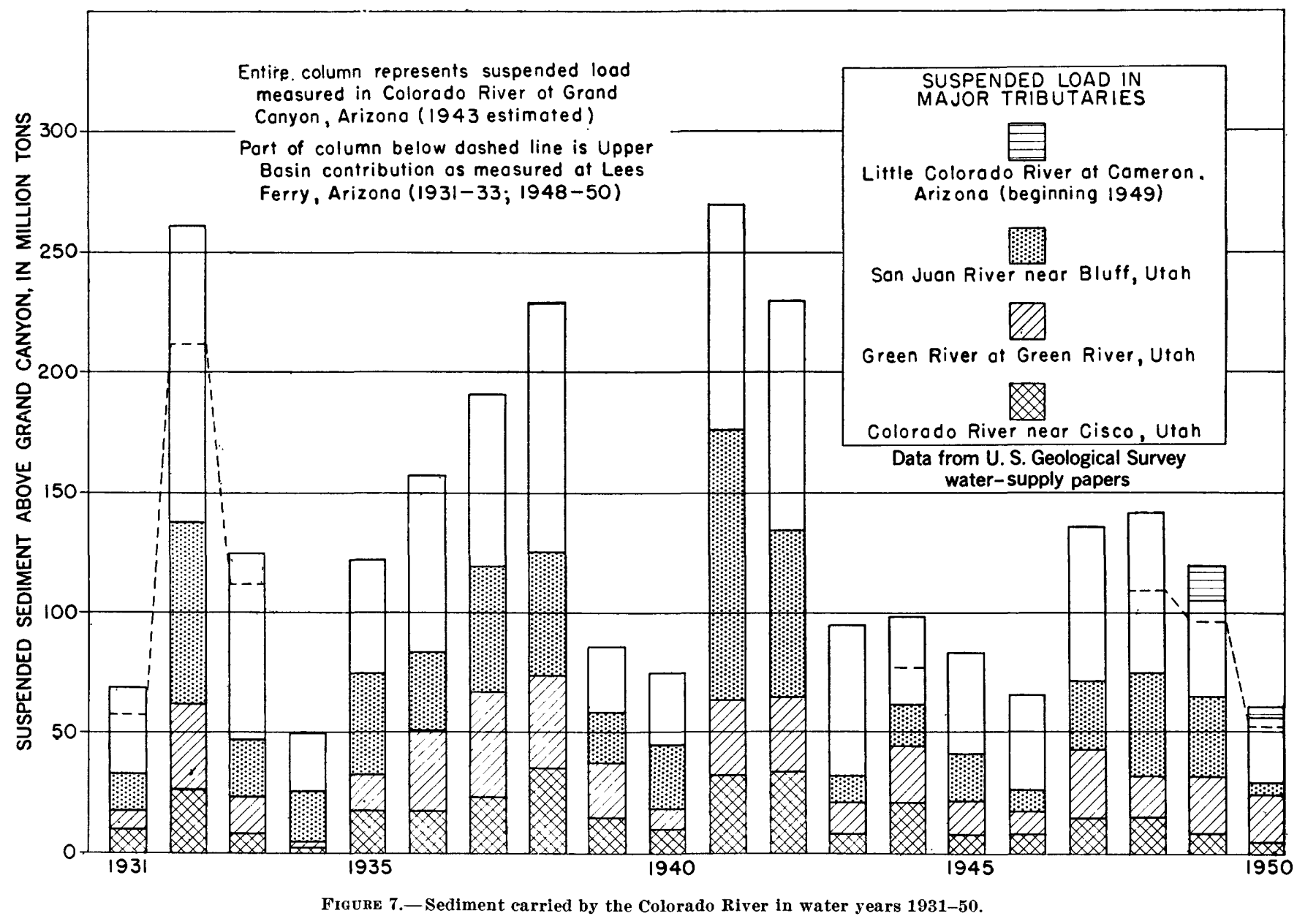


and one might conclude that if the river moves such material it must have truly magnificent power. Actually, the water moves around the larger obstacles, and if they are displaced at all it is for a negligible distance. Individual boulders can be identified in the same positions as when they were photographed more than 40 years ago. Other evidence that gravel or larger size fragments are not carried far by the main stem may be deduced from the distribution of rocks of certain distinctive types. As an example, pebbles of trachyte or of basalt in Glen Canyon may be identified in the deposits of the Colorado River, but only a few miles below the lowest tributary that drains the outcrop areas of those rocks, which are, respectively, in the Henry Mountains and on the plateau near Navajo Mountain. Finally, gravel is rare among the river deposits in the lower parts of reaches of low gradient, of which Glen Canyon and the Uinta Basin are good examples. It is concluded that for the most part the gradients along the river are insufficient for large-scale movement of gravel in the bed load.

Although the movement of gravel in the larger streams, expressed in ton-miles, is considered to be small, the total transportation of sediment along the bed may be significant. This bed-load transportation is not included in determinations of suspended load. It is likely that it represents a higher proportion of the total sediment in transit at some gaging stations than at others. For example, along the main stem of the Colorado River suspended load is being measured in the Grand Canyon, where turbulent flow, rapids, and high gradients occur throughout a long reach of the river; at Lees Ferry, where smooth flow and low gradients are characteristic of the river upstream in Glen Canyon, and steeper gradients and turbulent flow are the rule downstream in Marble Canyon; and at Hite, in the upper part of Glen Canyon, where stream gradients are gentle and where the river might be expected to drop some of its suspended load after a turbulent course through Cataract Canyon. Comparing these broad physical characteristics at the three stations, it might appear that the proportion of bed load should be least in the turbulent flow of Grand Canyon, and greatest at Lees Ferry where the velocity is increasing near the head of Marble Canyon. It is likely, however, that the proportion of bed load is determined partly by the changes in gradient and velocity in the immediate vicinity of the sampling points, and data are not available as to these factors at the established gaging stations.

\section{LIVE STORAGE}

Aerial photographs taken in different years commonly show many changes in the channel during the intervening period: meanders may have enlarged in some places and the channel straightened elsewhere, islands and bars shown on earlier photographs may have disappeared or changed in shape, and new ones may have appeared on the later photographs. Marked changes are noted in comparisons between the topographic maps of 30 or more years ago and aerial photos taken in the 1930's. Channel sections measured during stream-gaging operations showed marked differences from season to season, and sometimes from week to week, particularly in certain reaches of the streams. All these are evidences of the marked changes in live storage of sediment in the stream channel.

It appears that streams on a rising stage carry increased sediment in transit, and on a falling stage they drop the sediment from suspension, thus increasing the live storage. At some places, as for instance along the San Juan River at Shiprock, N. Mex., the channel scour is so great at peak discharge that the gage height may be very little above, or even lower than, the height recorded when discharge of the stream is at minimum.

No quantitative surveys or even detailed reconnaissances have been made to determine the volumes that may be involved in this type of "live" storage along the channel. It is probable, however, that the total volume along the main-stem channels may be many times the average annual deposition of sediment in Lake Mead.

\section{DEAD STORAGE}

By far the greater part of the Recent alluvium along the Colorado River and its tributaries above Lake Mead is not readily accessible for further movement downstream. This alluvium underlies the channel at depths that are not reached by the normal scouring action of the river but that have been penetrated in test drilling; and it forms the flood plains, which are known to antedate the first visits of white men by many centuries, and which in many places are covered by profuse vegetation. Even this alluvium has by no means reached a permanent resting place, however. Under natural conditions the only resting place for sediment was at the mouth of the river in the Gulf of California; but the creation of Lake Mead above Hoover Dam has afforded a temporary substitute for this resting place. The alluvium upstream from Lake Mead is merely interrupted in its movement downstream, but much of it will not be dislodged until some major change occurs in the basin: a change in climate or vegetative cover resulting in markedly greater seasonal or annual runoff ; increased stream gradients due either to diastrophic movements or to further downward cutting of the channels; or modification of the natural conditions by development projects. In con- 
sequence of water-resources development, for example, the release of clear water below Hoover Dam caused erosion of the river channel, which had been stable under natural conditions when the river carried a heavy sediment load.

At some places in the Colorado River basin, gradational processes are now at work on sediment that has long been in "dead" storage. Streams are eroding some flood plains that had become fairly stable fea. tures of the landscape, but it is not known whether major changes in climate, vegetative cover, or physiography are involved. Detailed analysis of the areas of renewed erosion and their recorded history may result in establishing the date when remewed erosion began, and the causes of that erosion.

\section{REFERENCES CITED}

Fenneman, N. M., 1930, Physical divisions of the United States: U.S. Geol. Survey map, scale 1 : 7,500,000.

Howard, C. S. 1948, Quality of water in the Upper Colorado River Basin, Trans. Am. Geophys. Union, v. 29, p. 375-378. 


\title{
E. PREGISE LEVELING
}

\author{
By E. J. Parkin, U.S. Coast and Geodetic Survey
}

The first geodetic leveling in the Hoover Dam area for the purpose of studying the expected deformation of the earth's crust caused by the tremendous load of impounded water was run in March and April 1935, its funds supplied by the Bureau of Reclamation. Because this leveling was run to establish a basic net that could be releveled to determine the actual amount of the movement, it was executed under special instructions stipulating a maximum tolerance of $3.0 \mathrm{~mm} \sqrt{K}$ between the forward and backward runs (where $K$ is the length of the section in kilometers), instead of $4.0 \mathrm{~mm} \sqrt{K}$, which is usual for first-order leveling. The 1935 leveling was done at the time the reservoir had just begun to fill, and the elevations therefore represent the condition at the time of nearly minimum load.

The level net was rerun in October 1940 to April 1941 , also with the aid of Bureau of Reclamation funds. During the period, the water storage in the reservoir ranged from about 23.3 million to 24.5 million acre-feet, or about 85 percent of capacity. The latest leveling of the network was run, partly with Bureau of Reclamation funds, between December 1949 and July 1950. In those months the reservoir storage ranged from 17.5 million to 20.8 million acre-feet, and thus was less at all times than during the 1940-41 leveling. Both the levelings of $1940-41$ and $1949-50$ were run with the same tolerance, $3.0 \mathrm{~mm} \sqrt{\bar{K}}$.

\section{ADJUSTMENTS}

The network of leveling in 1935 was adjusted to the sea level datum of 1929 by holding fixed the elevations resulting from previous adjustments for a ring of junctions on the perimeter of the net. This "supplementary" adjustment was made to obtain elevations consistent with the surrounding control, and the elevations thus obtained are those which are published for use of the gemeral public.

It was considered advisable, from the standpoint of future study, that a "special" adjustment should be made in which the elevations would be free of the effects of warping due to fitting to the older net. Accordingly a second adjustment was made, in which only one elevation from the first adjustment was held fixed. The elevations resulting from this special adjustment are the ones used as a basis for comparison with elevations determined subsequently.

The total amount of leveling in the net in 1935 was 711 miles, of which 83 miles of spur lines did not enter into the adjustment. The average rate of distribution of adjustment corrections derived from the special adjustment was $0.19 \mathrm{~mm}$ per kilometer. The maximum rate on a line of appreciable length was $0.39 \mathrm{~mm}$ per kilometer on a line $59 \mathrm{~km}$ long.

The leveling of 1940-41 followed as nearly as possible the same routes as the leveling of 1935. A new line in Arizona, extending from a point 15 miles north of Chloride to a point 6 miles west of Pattersons Well, was added to the net. Since the lake was filled nearly to capacity at the time of this leveling, it was necessary to install tide gages at four locations on the lake shore to provide connections for the lines across the lake.

To produce elevations for comparison with those of the 1935 survey, a special adjustment was made to the 1940-41 net, holding fixed only the elevation of bench mark R1 (at Cane Springs, Nev.) derived from the special adjustment of the 1935 leveling. The two circuits on either side of one line, formed by the water comnection between the gages at Hualpai Wash and the Lake Shore mine and the leveling from that point to the junction 10 miles east of St. Thomas, Nev., showed closures of nearly 0.1 meter and of opposite sign. Since these closures are nearly twice the allowable limit, this line was omitted from the special adjustment.

The total amount of leveling in the 1940-41 net was 715 miles, of which 117 miles, not included in the adjustment, is accounted for by spur lines and the omitted line. The average rate of the adjustment correction was 0.11 $\mathrm{mm}$ per kilometer. The maximum rate was $0.25 \mathrm{~mm}$ per kilometer on a line $128 \mathrm{~km}$ long. After the completion of the adjustment, the fitting of the omitted line required that a correction of $95.6 \mathrm{~mm}$ be distributed in this $54-\mathrm{km}$ line, yielding a rate of $1.77 \mathrm{~mm}$ per kilometer. The $3.0 \sqrt{K}$ criterion would allow a rate of $0.41 \mathrm{~mm}$ per kilometer on this line.

The latest leveling of the network was done in 194950 and covered substantially the same routes. During this season's work the line in Arizona from a point 
10 miles south of Chloride via Kingman and Hackberry to 6 miles west of Pattersons Well, as well as the spur line from Moapa, Nev., to Beaver Dam Creek, Ariz., were omitted. Tide gages were again operated to provide connections across the lake.

The "special" adjustment of the 1949-50 net to provide elevations for comparison with previous work was made by holding fixed only one elevation. This was again the elevation of bench mark $\mathrm{R} 1$ at Cane Springs resulting from the "special" adjustment of the 1935 leveling.

The total amount of leveling in the 1949-50 survey was 582 miles of which 39 miles of spur lines was not included in the adjustment. The average distribution rate was $0.14 \mathrm{~mm}$ per kilometer and the maximum on a line of appreciable size was $0.29 \mathrm{~mm}$ per kilometer on a line $29 \mathrm{~km}$ long.

It is to be noted that all three sets of elevations, derived from the "special" adjustments and used for purposes of comparison, are therefore based on the same elevation of bench mark R1 at Cane Springs, Nev.

\section{HOOVER DAM LEVEL NET}

The routes of the leveling that constitute the Hoover Dam net are shown on plate 3 except for the line (added in 1940-41) from 15 miles north of Chloride to 6 miles west of Pattersons Well. The locations of the bench marks to which levels were run in 1935 and again in 1940-41 are accurately plotted with their designations. The figures given in parentheses are the differences in millimeters between the 1935 elevations and the elevations determined in $1940-41$. In each case the elevation is derived from the appropriate "special" adjustment. A negative sign with the difference indicates that the later elevation is less than the 1935 elevation-that is, the mark has settled. Conversely, a plus sign indicates that the later elevation is greater. Because of the high rate of correction distributed on the 1940-41 leveling of the line from the Lake Shore mine to 10 miles east of St. Thomas, caution is advised against drawing definite conclusions from the divergences shown along this one line.

The figures in brackets given with the designations are the divergences between the 1935 elevations and those determined during the 1949-50 leveling, the elevations being those resulting from the "special" adjustments. As in the previous case, the negative sign indicates settlement of the mark and positive sign upward movement. 


\title{
F. INTERPRETATION OF THE LEVELING DATA
}

\author{
By C. R. Longweld, Yale University
}

Leveling data from the Hoover Dam net are presented graphically in two ways. First, the net is divided into 19 segments, and along each segment the data on altitudes are represented in profile in plate 4 . For the entire net, differences in level are available covering the interval 1935 to $1940-41$. These differences, along each segment of the net, are shown by the relation of a dotted line to a straight line marked 0 . Similarly, the total differences for the interval 1935 to $1949-50$ are shown by the relation of a dashed line to the straight zero line, in all segments of the net for which these differences are available. Segments are crooked in various degrees, and in constructing each profile the locations of stations were projected at right angles to the straight zero line of the profile. Profiles then were shifted somewhat, to avoid interference with each other and with other features of the map. Leveling values are in millimeters, hence the vertical scale of profiles is grossly exaggerated.

The second graphic presentation is by use of contours in figure 8 . Since large extrapolation from available stations is required, these contour maps can be accepted as rough approximations only; additional values for areas between lines of the present net would no doubt alter the positions of contours appreciably and make the over-all patterns more complex. Nevertheless the maps probably depict reasonably well the major changes, and supplement usefully the profiles of plate 4 .

Construction of the profile for the southern Virgin Mountains was made with due regard for the warning by E. J. Parkin against drawing firm conclusions from the 1935 to 1941 divergences along the line from the Lake Shore mine to St. Thomas Gap, because corrections on this line are in excess of the allowable limit.

\section{PERTINENT GEOLOGIC FEATURES}

The entire area covered by the level net lies within the Basin and Range province, which is characterized by large faults, some of them the locus of important movement within late geologic and even within historic time. No accurate geologic map of the area is available; but the locations of some faults are known, and the general boundaries between major outcrops of bedrock and allu- viated basins are shown in plate 4 . Alluvium extends to considerable depth in the interior parts of nearly all wide intermont basins; and in some basins that are bounded by large faults, the thick alluvial cover reaches to the borders of adjacent ranges. On the other hand, in some wide areas the alluvium above bedrock is thin or of only moderate thickness. Thus some but not all of the highland boundaries shown in plate 4 mark important changes in subsurface conditions.

The eastern lines of the level net are near the major Grand Wash fault zone, which separates the Basin and Range province from the Colorado Plateaus. Thick alluvial deposits lie along this zone. Opposite the mouth of Grand Canyon these deposits are broken by a fault, about 5 miles west of the high cliffs that mark the western edge of the plateaus. The greater part of Lake Mead lies west of this weak zone, and we should like to know whether the added weight may have caused depression relative to the plateau mass, which appears to be an exceptionally stable tectonic unit. Unfortunately, no part of the level net is on the plateau block (but see p. 74). Also, since the net was not established until filling of the lake began, it is not possible to distinguish changes in level that may be related to the lake from changes that may have been in progress before the Hoover Dam was built.

\section{PATTERN OF THE CHANGES IN LEVEL}

Although the individual changes in level are small, the general consistency of the over-all pattern is impressive. A conspicuous feature brought out by the profiles of plate 4 and the contours of figure 8 is a broad basinlike depression centering in the vicinity of Boulder Canyon. The general form of this depression and the amount of closure-about $70 \mathrm{~mm}$-remained strikingly unchanged from $1940-41$ to $1949-50$, although the area as a whole continued to subside during that interval, and a pronounced regional tilt extended to, and apparently beyond, the southern limit of the level net. During the interval from 1935 to 1941 the general tilt was southeastward; the vicinity of Corn Springs was not involved and subsidence near Nipton and Searchlight was small and irregular, 


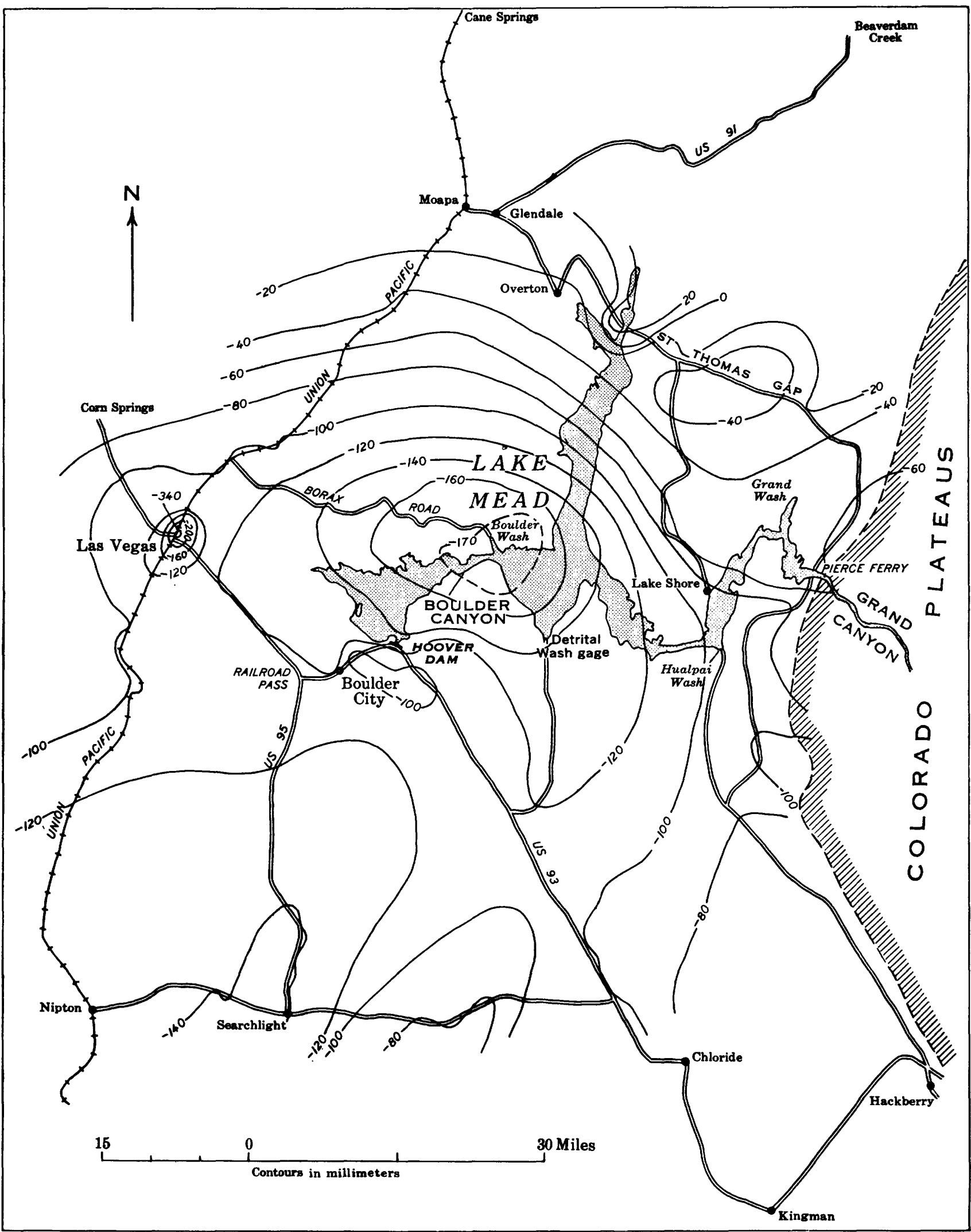

Figure 8.-Contours showing changes in altitude, 1935 to 1950 . 
whereas the depression near Hackberry was exceeded only in the basin near Boulder Canyon. In 1950 the area of general depression reached west of the level net (fig. 8), and along the south side of the net the recorded maximum was near Searchlight; data for the Hackberry-Kingman area are not available.

During the interval from 1941 to 1950 the total area affected by subsidence was considerably enlarged, and the over-all tendency was tilting toward the southwest. The basin that centered near Boulder Canyon was maintained but not appreciably deepened. There is a suggestion of a basin or a southward-plunging trough west of Searchlight, but the values from the level net are too few and too small to give a trustworthy picture.

The sharply localized cone of depression centered at Las Vegas involves the largest changes in level recorded in the survey. This cone, superimposed on the wider pattern of disturbance, probably has a separate explanation-the withdrawal of water from the artesian basin that has supplied the Las Vegas community. The maximum depression revealed between 1935 and $1940-41$ was $100 \mathrm{~mm}$ at station $\mathrm{K} 169$; during the period from 1941 to 1950 the maximum lowering increased to $350 \mathrm{~mm}$ at station L169 and the cone widened appreciably. This result is in accord with the accelerated use of water attending rapid growth of the community. Because this cone is not related to the major problem considered here, it is not given further attention in this report.

A pronounced feature that persisted through the second and third surveys of the net indicates a positive movement west of St. Thomas Gap, astride the narrow arm of Lake Mead. Positive values persist through more than 5 miles of the traverse, and reach a maximum of $36.5 \mathrm{~mm}$. Though the values are small, reality of the uplift is strongly supported by the nearly identical patterns for 1940-41 and 1949-50.

The evidence generally indicates contimued subsidence in all parts of the level net since 1935, and actual uplift is shown at only a few locations other than the one cited above. At a few other places a downward tendency before 1940-41 was in part reversed during the later interval. Several abrupt changes, both downward and upward, affecting single stations or a few neighboring stations, may reflect local slumping or earth flowage. The most pronounced of these changes, near the Hualpai Wash gage, is recorded in the data for both 1940-41 and 1949-50; one station (H129) shows depression of $470 \mathrm{~mm}$, whereas the stations $\mathrm{J} 129$ and $1245 \mathrm{~B}$ directly north and south of it have gone up slightly. The abrupt drop of station U120 near the Detrital Wash gage may have resulted from solution of saline deposits that underlie that area. Most of these isolated changes are not represented in the profiles of plate 4.

Changes along the lines Moapa-Cane Springs and Moapa-Beaverdam Creek are too small and erratic for confident representation on the contour maps.

\section{POSSIBLE CAUSES OF CHANGES IN LEVEL}

The shifting of large loads at the earth's surface is a matter of much concern in geologic study. Generally such shifts are extremely slow from the human viewpoint, and evidence bearing on the effects of waxing and waning icecaps, the filling of a geosynclinal trough, or the growth and disappearance of a great lake such as Bonneville is incomplete and in several respects equivocal. Repeated checking of the Hoover Dam level net furnishes quantitative data that are rarely obtainable.

The original capacity of Lake Mead, below the permanent spillway at altitude 1205.4 feet, was about 28.8 million acre-feet of water. Thus far the reservoir has filled to overflowing in only one season, and the average level of the lake surface is considerably below the maximum. However, the volume of sediment, with density higher than that of the displaced water, increases continuously. For practical purposes the weight of the water in the lake may be taken as about 40,000 million tons, distributed over an area of 232 square miles. Only a small fraction of this area is in the narrow, upstream part of the lake, and more than 60 percent of the weight, about 25,000 million tons, is concentrated in the wide Virgin and Boulder Basins, which lie directly east and west of Boulder Canyon. The total area of these basins is about 85 square miles, and the load added to this area averages more than 10 tons per square foot, or 140 pounds per square inch. As the two long arms of the lake diverge at a large angle from the Virgin Basin east of Boulder Canyon, the center of gravity of the lake lies in the vicinity of this basin in a very real sense. Significantly, the broad subsidence with closure revealed in the data of 1940-41, and persisting through 1949-50 (fig. 8), appears to center in the area east of Boulder Canyon.

Complex causes may of course contribute to the differential subsidence. The bedrock floors of some intermont basins are grabens, and slow movement on one or more of the bounding faults may be still in progress. Even though all of the faults may have been "dead" when the dam was built, the added weight of the lake may be causing adjustment along some of the old fracture zones. Of interest in this connection are the reports of investigations of seismic activity and subsidence in the Lake Mead area, conducted by the Coast and Geodetic Survey in cooperation with the Bureau of Reclamation during the years 1935 to 1948 . These 
reports (Carder, 1945; Carder and Small, 1948) show a concentration of epicenters of several hundred local earthquakes in the Boulder Basin and a less prominent concentration in the Gregg Basin of Lake Mead. It was concluded from these studies that the local earthquakes in the Boulder Basin were caused by downfaulting of an underlying crustal block along previously established fault planes that were probably active during pre-Pleistocene time. The renewed activity has been ascribed to the sudden loading of about 12,000 million tons of water on the floor of the Boulder Basin. Likewise, the earthquakes in the Gregg Basin are caused apparently by local subsidence; but the relation between settling and reservoir loading is not so clearly defined as in the Boulder Basin.

A cause independent of bedrock may lie in the compaction of thick sedimentary fill in the intermont basins. Settling in excess of upbuilding possibly was proceeding in one or more basins, and permeation of water from the rising lake may well have accelerated the process. Another logical cause of subsidence may be elastic yielding in the bedrock itself. We may conjecture also some plastic yielding at depth, although the load, in unit value and in areal extent, seems inadequate to produce such an effect, particularly within a short time.

Though there is no way of knowing how much compaction of sediments may have occurred beneath wide bodies of the lake water, inspection of profiles along critical lines of leveling does not favor such compaction as the chief cause of the basining that centers east of Boulder Canyon, as represented in figure 8 . The most instructive profile is that along the Borax Road, ending eastward at Boulder Wash (pl. 4). In its western part this line of stations is on alluvial fill, in some places probably fairly thick, elsewhere a thin cover on bedrock. In its eastern part the line runs for several miles on bedrock. Despite this varied terrane the eastward slope of the profile, during each of the intervals between surveys, is remarkably uniform. Moreover, the average slope and the maximum depression along this traverse are greater than along the line ending northward at the Detrital Wash gage, a line that is on thick sedimentary fill throughout its length. The eastward slope toward Hoover Dam is comparable, along a line that is on or near bedrock much of the distance from Railroad Pass to the dam. If this slope were projected from the dam to the head of Boulder Canyon, this profile would reach about the same level as that ending at Boulder Wash.

No traverses are favorably situated for checking the slope westward and southward toward the central area of the lake, and the pattern of contours depicting the northern and eastern parts of the basin of subsidence therefore has no satisfactory basis. Evidence from the available traverses, however, suggests strongly that the bedrock floor is involved in the sinking, with a uniformity that would not be expected if the yielding were for the most part localized along faults. Thus the concept of broad elastic yield in the bedrock is favored, and persistence of the basining, without perceptible accentuation after the 1940-41 survey, strengthens this concept. Nevertheless, adjustments within the basin alluvium may have been considerable, at least locally. ${ }^{2}$ The broad bulge along the arm of the lake west of St. Thomas Gap may reflect slow flowage toward the lake of the basin sediments after they became saturated. Possibly this bulge extends farther down the lake than can be inferred from data on the one available line of stations.

The extensive tilting subsidence, which involves the entire reservoir area and extends at least tens of miles farther south, presents a more difficult and elusive problem than the localized basining. We may surmise that this tilting is connected with a regional movement, which perhaps was in progress before the dam was built. Large extension and considerable change in pattern of the tilting between 1941 and 1950 suggest the possibility that the Lake Mead load may exert a "trigger" effect in starting or accelerating movement along regional zones of weakness. Concentration along definite lines does not appear in the present data, but the small scale of movement and the wide spacing of lines in the level net do not favor recognition of critical details at this early stage of the study. In several parts of the area, subsidence in the intermont basins exceeds that on adjacent highland blocks. An example is the depression west of Searchlight, which on both profiles corresponds generally to the alluvial cover between the McCullough Range and the Eldorado Mountains. East of Searchlight the profiles do not reflect the differences in geology that are suggested on plate 4. However, the wide belt of alluvium between the Eldorado and Black Mountains is deceptive; for the most part this alluvium forms a thin veener on bedrock. The 1941 to 1950 change in profile has a relative "high" that extends continuously from Searchlight to the east border of the Black Mountains, and a pronounced depression farther east, on thick alluvium. The long traverse from Moapa southwestward to Nipton, Calif., also has interest in this connection. If we omit the Las Vegas cone, the profiles on this traverse have fairly

\footnotetext{
2 The entire level net is above the highest shoreline of the lake, and none of the releveling therefore measures compaction of the alluvium underlying the original floor of the reservoir.
} 
continuous slope to the southwest, except in a stretch on or near bedrock east of the Bird Spring Range.

In general, therefore, subsidence has been at a maximum in areas of thick alluvial deposits. This may reflect continuous compaction of these deposits, or sinking of bedrock floors of some intermont basins, or both. However, this differential effect seems to be superimposed on widespread tilting that affects both the ranges and the intervening basins. We must recognize also that the measurements in the Hoover Dam net are relative to the Cane Springs bench mark, which is assumed to be fixed but actually may be either sinking or rising in relation to sea level.

More positive analysis of the present leveling data does not seem warranted. Presumably there will be further checking of the net after several years, and results will be awaited with interest. If the basining effect centering in the lower part of Lake Mead should persist without essential change in form and amplitude, interpretation of it as a result of elastic yield will be strengthened. More pronounced sinking of intermont areas in relation to adjacent ranges will suggest movement of bedrock floors, particularly if abrupt changes in profile should coincide with known faults. The recent advent of Lake Mohave, extending between Hoover Dam and the new Davis Dam about 65 miles downstream, adds an important element for study of further southward tilting that may occur. Although the volume of the new lake is far less than that of Lake Mead, the addition of appreciable load to the area directly south of Hoover Dam may well accentuate the southward tilt, and will complicate the interpretation of future tilting movement.

\section{COMPARISON BETWEEN MEASURED AND PREDICTED SUBSIDENCE}

A paper by Westergaard and Stevens (1934) gives an account of theoretical computations made for the Bureau of Reclamation before the completion of Hoover Dam, in an attempt to estimate the subsidence that might result from filling of the lake. On the assumption of purely elastic yield in a strong granitic outer shell, the computations indicated that basining would extend considerably beyond the limits of the lake from a center near the mouth of the Virgin River, and that maximum sinking would be about 10 inches. Further assumption of adjustment by deep-seated flow under the downbending of a strong upper layer led to calculation of possible additional basining amounting to about 2 feet in the central area.

The general form and extent of the actual downwarping between 1935 and 1950 is remarkably similar to that predicted on assumption of elastic yield $4969180-60-4$
(Raphael, 1954). The maximum subsidence, however, was only 7 inches $(175 \mathrm{~mm})$, at a center in the upper part of Boulder Canyon, about. 6 miles west of the predicted center. Probably the slow subsidence has continued since 1950 , and eventually it may amount to as much as the 10 inches calculated for elastic yield. Perhaps the load is not sufficient to set up plastic adjustment at great depth; or such adjustment, if it should occur, may be too slow to be detected within one generation.

\section{EFFECT OF SUBSIDENCE UPON RESERVOIR CAPACITY}

The precise leveling of 1935 constitutes the basis for the altitudes shown on the topographic maps of the reservoir area, and for the tables of reservoir area and capacity that were computed from those maps (p. 89, 90). It also forms the basis for the altitudes of the reservoir bottom as determined in the 1948-49 hydrographic surveys, described on pages 39-72. The computations of area and capacity do not include adjustments for any changes in altitudes of the basic reference marks as documented by the releveling of 1940-41 and 1949-50.

The measured changes in altitudes of bench marks since 1935 are too small to affect the determinations of bottom altitudes at any point. Excepting the abrupt changes at some isolated bench marks (which have been ascribed on page 35 to withdrawal of ground water at Las Vegas, or to local slumping or earth flowage, or to solution of saline materials) the maximum recorded divergences have been of the order of $175 \mathrm{~mm}$, or less than 0.6 foot. This maximum divergence is within the limit of error of any of the methods used in determining bottom elevations or computing reservoir capacity. Original capacity of the reservoir was determined by interpolation of 10-foot contours drawn by multiplex methods from aerial photographs, and the bottom altitudes as determined in 1948-49 are based largely on echo sounding, which is accurate only within limits of 1-3 feet, depending upon the recording equipment used.

With reference to bench mark R1 at Cane Springs, $\mathrm{Nev}$, the 10 bench marks on Hoover Dam dropped an average of $60 \mathrm{~mm}$ between 1935 and $1940-41$, and $62 \mathrm{~mm}$ farther between 1940-41 and 1949-50, a total subsidence of 0.4 foot. If there had been no change in the altitude of the reservoir bottom, this lowering of the dam would have had the effect of reducing the capacity of the reservoir at spillway level by approximately 60,000 acre-feet.

The effect of subsidence upon reservoir capacity, however, is measured by the difference between the subsidence at Hoover Dam and that of the reservoir bottom. The Hoover Dam level net approaches the shore of 
Lake Mead at six places, and the differential subsidence at these locations with reference to Hoover Dam is shown in table 1.

$$
\begin{aligned}
& \text { TABLE 1.-Subsidence at points near lake shore, with respect to } \\
& \text { Hoover Dam } \\
& \text { [Subsidence greater than at Hoover Dam is indicated by the minus sign }(-) \text { ] }
\end{aligned}
$$

\begin{tabular}{|c|c|c|c|}
\hline \multirow[t]{2}{*}{ Location } & \multicolumn{3}{|c|}{$\begin{array}{l}\text { Differential subsidence, in milli- } \\
\text { meters (average at several bench } \\
\text { marks) }\end{array}$} \\
\hline & $1935-41$ & $1941-50$ & $1935-50$ \\
\hline $\begin{array}{l}\text { Boulder Wash, Boulder Canyon } \\
\text { Detrital Wash, Virgin Basin } \\
\text { Hualpai Wash, Gregg Basin } \\
\text { Lake Shore mine, Gregg Basin } \\
\text { Pierce Ferry, Pierce Basin } \\
\text { St. Thomas, Overton Arm }\end{array}$ & $\begin{array}{l}-60 \\
-35 \\
+10 \\
+30 \\
-5 \\
+85\end{array}$ & $\begin{array}{r}+5 \\
+15 \\
+20 \\
+10 \\
+70 \\
+65\end{array}$ & $\begin{array}{r}-55 \\
-20 \\
+30 \\
+40 \\
+65 \\
+150\end{array}$ \\
\hline
\end{tabular}

From these data it appears that there has been a considerable range in differential subsidence in various parts of the reservoir. The over-all subsidence at Hoover Dam was less than that in the part of the reservoir centering about Boulder Canyon, but greater than that in the upper reaches of the reservoir. It is perhaps significant that since 1941 subsidence at the dam has been more than at any of the six locations where the level net provides data as to near-shore elevations of the reservoir. The leveling of 1941 occurred while the reservoir was filled nearly to capacity, and the differential rise since that year may be an indication of elastic rebound when that load was reduced.

The data from the level net are inadequate for volumetric computations concerning the effect of subsidence upon reservoir capacity, but some inferences may be drawn from figure 8 , which is based on those data. The contours indicate that subsidence has exceeded 120 $\mathrm{mm}$ (the amount of subsidence at the dam) in an area that includes all of Boulder Basin, Boulder Canyon, and Virgin Basin, and part of the Temple Bar area between Virgin Basin and Virgin Canyon. This area comprises more than 60 percent of the total area of the reservoir; nearly 75 percent of the water is stored within this area when Lake Mead is filled to spillway level, and the proportion increases with decrease in lake stage. The increased storage capacity of this area, owing to differential subsidence, is believed to be more than enough to offset the reduction of storage in the other smaller areas where subsidence has been less than at the dam; but in any case the change in over-all capacity would doubtless be of very small magnitude.

In the 1948-49 hydrographic survey, all bottom elevations were computed with reference to a datum established at Hoover Dam. Thus, to the limit of accuracy of the depth-recording equipment, these elevations are true with respect to the contemporaneous position of the dam and do not require correction for the differential subsidence in various parts of the reservoir since 1935 .

\section{REFERENCES CITED}

Carder, D. S., 1945, Seismic investigations in the Boulder Dam area, 1940-44, and the influence of reservoir loading on local earthquake activity: Seismol. Soc. America Bull., v. 35, p. 175-192.

— and Small, J. B., 1948, Level divergences, seismic activity, and reservoir loading in the Lake Mead area, Nevada and Arizona: Am. Geophys. Union Trans., v. 29, p. 767-771.

Raphael, J. M., 1954, Crustal disturbances in the Lake Mead area: U.S. Bur. Reclamation Eng. Mon. 21, 14 p.

Westergaard, H. M. and Adkins, A. W., 1934, Deformations of the earth's surface due to weight of Boulder Reservoir: U.S. Bur. Reclamation Tech. Memo. 422. 


\title{
G. SURVEY OF THE LAKE
}

\author{
By Gunnar Leifson, U.S. Navy Hydrographic Office
}

The hydrographic survey of Lake Mead was undertaken to obtain the data necessary (a) for determination of the volume and distribution of sediment deposits, and the occurrence and extent of other changes in reservoir boundaries; and (b) for the preparation of new reservoir area and capacity curves. The survey was conducted in accordance with well-established principles of hydrographic surveying, employing conventional methods of lead-line sounding in the canyon section (Lower Gramite Gorge) east of longitude $113^{\circ} 57^{\prime}$ (as described by L. C. Pampel, p. 73) and advanced techniques of echo sounding in the main part of the lake west of that longitude.

The part of Lake Mead west of longitude $113^{\circ} 57^{\prime}$, extending from Pierce Ferry for about 65 miles to Hoover Dam, is in general a chain or series of wide basins connected by short narrow canyon sections. Plate $5 A$ illustrates conditions in Boulder Canyon and Virgin Basin. In this part of the reservoir, lake conditions exist at all stages, with depths ranging up to 450 feet and widths ranging from 650 feet in Boulder Canyon to about 5 miles in the basin areas. The water is generally clear, and the only velocities are the very low ones resulting from circulation of water in the lake and those induced by density-current action (pp. 109-125).

In this main part of the lake the surveying techniques were essentially those of deep-water hydrographic surveying controlled by sextant observation on control points on shore. Serious consideration was given to the employment of Shoran equipment for position control in these areas. Although the employment of Shoran would have reduced materially the amount of horizontal control survey needed, it would also have required specialized personnel and camp parties. After due consideration, this plan was abandoned in favor of more orthodox methods. In the more confined areas of the small bays and canyons, the boat positions were determined and the courses controlled by observations from two transit stations ashore, or from one transit station with the aid of one sextant reading made aboard the boat.

In the general sense, a hydrographic survey involves a large number of operations, all planned to obtain the information requisite for production of a nautical chart. Such surveys include, besides the accurate charting of the ocean bottom, the measurement of tides and currents, magnetic measurements, geodetic control surveys, and even topographic surveys, for the topography of land areas adjacent to the shore and visible from seaward is important as an aid to navigation. In accomplishing his work the hydrographer is at a disadvantage as compared with the topographer, in that the area he wishes to map is hidden from view ; because it is obviously impractical to measure the depth at every point, the submarine relief has to be deduced from a systematic series of depth measurements spaced at such intervals that the slope between measurements can be considered uniform.

In modern hydrographic practice, depths are measured almost exclusively by some form of automatic recording echo sounder. These sounders are manufactured in a variety of types suitable for recording depths ranging from a few feet to 24,000 feet. Corrections must be applied to the recorded depths for position of water surface above or below the assumed datum, for depth of projector below the water surface, and for true velocity of sound in the water being surveyed. The equipment is normally installed permanently in the hull of a boat, and in modern practice on the ocean the boat is operated at a speed as high as 10 knots (12 miles per hour), sea conditions permitting. This speed would be excessive on inland lakes, where the work is characteristically close to shore.

Numerous methods are available for fixing the position of the sounding boat at regular intervals along a sounding line. In harbor and coastal areas the threepoint sextant fix method is standard practice. This method has the advantages that no parties are needed on shore; the boat position is immediately available to the boat operator; and, as only angles are used, accurate scale of work sheet is immaterial. The three-point fix depends on the geometric fact that the angle subtended by a chord is the same at all points on the circumference of the circle. The measurement of two simultaneous angles defines the boat position at the intersection of two position circles. If the two circles 
intersect at a satisfactory angle, an accurate position is determined. If the two circles are coincident, no fix is obtained. Some judgment, therefore, is required by the hydrographer in the selection of shore objects for the fix. For convenience in the rapid graphic plotting of the boat position, sextant angles are always observed on three shore objects, the center object being common to the two observations.

All the corrections that must be applied to recorded depths are not generally known at the moment of survey, hence all field data must be replotted. The replotting is done at some convenient location ashore, where corrections can be computed and work can be done with greater care than is possible in a boat. This operation is called the smooth plot. The best grades of paper, plastic, or metal sheets are used. The sheets are provided with a polyconic projection grid of meridians and parallels computed on the spheroid of reference in use for the area surveyed.

In the survey of Lake Mead, where the principal objective was not navigational information but rather a determination of volume of sedimentation as well as area and capacity, the hydrographic survey is reduced to its most elementary form-namely, measuring true depths below a known datum plane and fixing the position of these measured depths in true relation to the geodetic control net on shore.

In the summer of 1947, when the Geological Survey informally requested the Navy Hydrographic Office to participate in the Lake Mead survey, the Hydrographer, Rear Admiral R. O. Glover, designated the writer as the representative of the Hydrographic Office for the hydrographic aspects of the project-especially the application of standard hydrographic techniques to the survey of the lake.

The guiding principle in the preliminary planning was to hold the cost of the survey to a minimum without sacrificing accuracy. In accordance with this policy, portable shore signals were designed that could be moved ahead as the survey progressed. The location of the shore signals was to be permanently marked and referenced so that any future survey would be on the identical datum with the planned operation. The scale of the field work was also planned to be the same as the existing topographic sheets of $1: 12,000$. This scale would permit a continuous field check between the hydrographic profiles and the topographic maps without the necessity of scale conversion, and would also reduce the labor of the final area-capacity computations. The spacing between boat lines was tentatively set as 200 yards for the Boulder Basin area. It was felt that this spacing, being only slightly more than the maxi- mum depth, would reveal any unusual bottom formation.

The results of preliminary lines run in Boulder Basin were inspected by the writer in April 1948. It was apparent from the sketchy information that the lake bottom was more regular than had been anticipated, and also that the amount of sediment present in the narrow canyon areas would have only a nominal effect on the volume and area-capacity computations. In order to advance the estimated completion data, therefore, it was decided to complete the work in Boulder Basin with lines at 200-yard spacing as planned, increase spacing of lines in other basins to 300 yards, and run four parallel lines through the canyons with supplementary cross lines as necessary. When this program was adopted, the writer's contact with the survey was completed.

An interesting aspect of the hydrographic survey of the lake was the opportunity for a comparison of results of the hydrographic and topographic surveys. The number of times a hydrographer has the advantage of an excellent topographic map of a survey area are indeed few. It was gratifying to see the close agreement between echo-sounding profiles and the corresponding cross sections laid down on the topographic maps.

\section{OUTLINE OF PROCEDURES}

By M. R. Ullom, U.S. Navy Hydrographic Office, and F. C. Ames, U.S. Geological Survey

This section describes the general features of the hydrographic survey of the lake west of longitude $113^{\circ} 57^{\prime}$, including accounts of the fieldwork, the preparation of maps, and the calculation of sediment volumes. The more technical features of the lake survey, including details of the methods used and the results obtained, are covered in other sections of this chapter.

The part of Lake Mead west of longitude $113^{\circ} 57^{\prime}$ consists of several major basin areas connected by narrow canyon sections. Within these major subdivisions there are numerous small bays and coves along the shores of the basins, and narrow inlets or side canyons in the canyon sections. Owing to the great difference in size and shape of these areas and the differences in sight distances involved, it was necessary to survey the different areas separately, using slightly different techniques in each type of area.

\section{HORIZONTAL CONTROL}

The first step in the survey was the establishment of a network of horizontal-control stations along the shorelines of the lake at elevations close to the highwater line. Locations for these control stations were chosen with these basic criteria in mind: To provide 


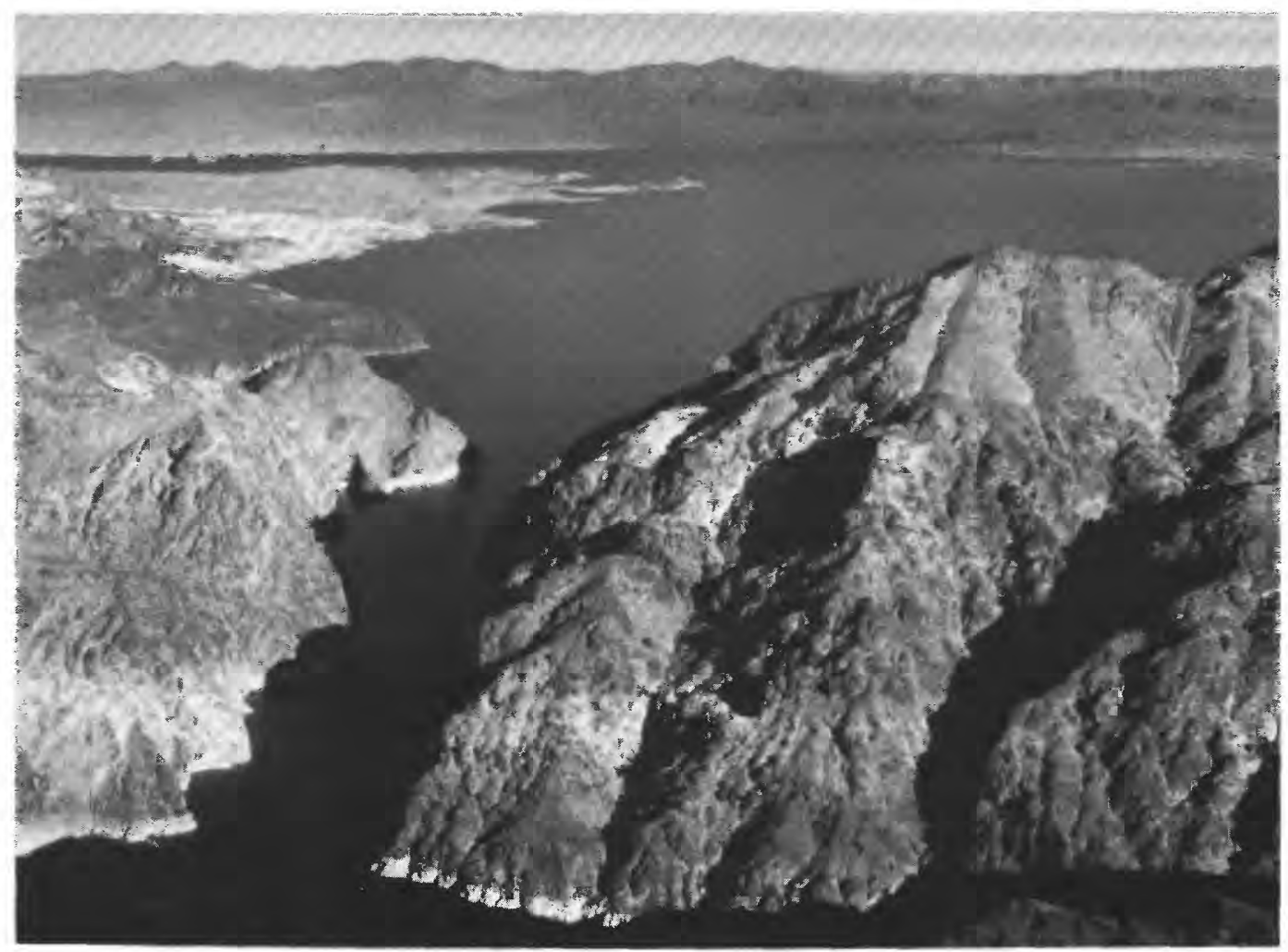

A. BOULDER CANYON AND VIRGIN BASIN, LAKE MEAD Airphoto by Bureau of Reclamation.

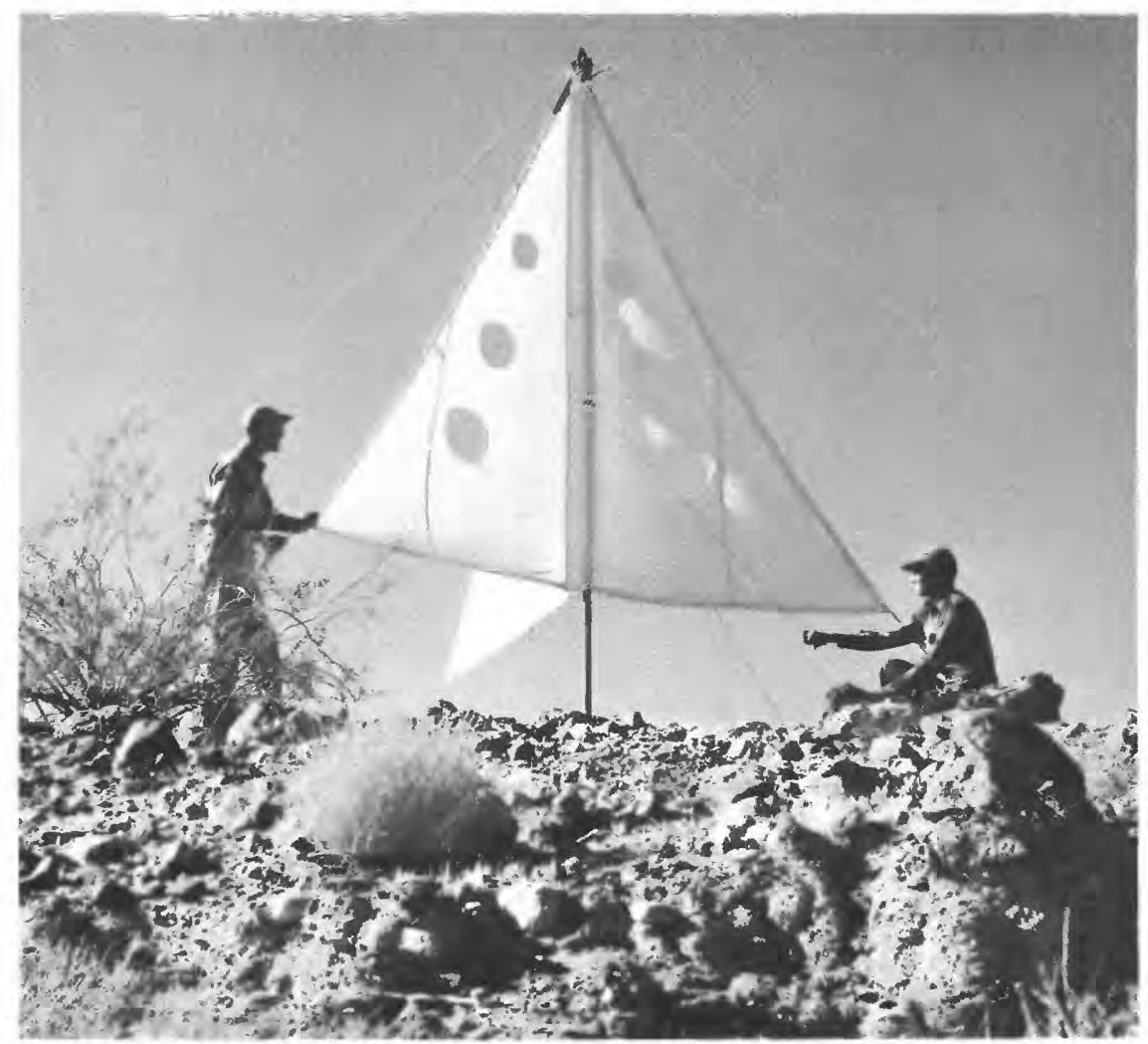

B. SHORE SIGNAL USED DURING THE LAKE MEAD SURVEY

Photograph by Bureau of Reclamation. 
good spacing and good alinement for use with the type of boat-position observations planned in each area, and to provide good triangulation figures. Geodetic positions of the stations were determined by third-order triangulation, as described by R. M. Wilson (p.44).

To permit sextant observation of the control stations from the sounding boat, it was necessary to erect and maintain flags or targets, called shore signals. The erection of signals constituted a major task of the hydrographic survey, inasmuch as 312 control points were employed as locations for shore signals. In the basin areas it was necessary that these signals be visible to the naked eye at distances up to 5 miles and a large signal designed by the Navy Hydrographic Office was used (pl. $5 B$ ). This consisted essentially of a 16-foot mast with three triangular sections of cloth spaced at 120-degree intervals around it. The mast was made of light iron tubing, 2 inches in diameter, jointed in the middle and guyed with 7 cables-3 secured to the center of the mast and 4 at the top. Height of the cloth triangles was 12 feet and the horizontal side was 5.5 feet. Skirts of various colors and material were tried; and it was found that white indianhead cloth was superior to all others, because it withstood the buffeting of wind remarkably well and possessed the highest visibility of any tried. Seventeen signals were built with white indianhead skirts and moved from place to place along the lake shore as the survey progressed. In the more confined areas where sight distances were 1 mile or less, smaller and more easily erected signals were used.

As the work progressed it was found that additional stations were needed in a few areas because of limitations of visibility, height of stations above the water surface, size and rate of change of angles along the prescribed sounding courses, and changes in plans regarding type of boat-position observations to be used. Such elaboration of shore control was found necessary in Black, Boulder, and Iceberg Canyons; in the narrower parts of Las Vegas Wash; near the Boulder Islands; and around the shores of some of the larger bays. Forty-eight additional control points were established, and were cut in with comparative rapidity by intersection from the nearest triangulation stations of the third-order net. A closing error of 1 minute was considered satisfactory for the relatively small triangles involved.

Several auxiliary stations were set up by the shore signal party as needed. Most of these stations were located by reading all three angles of the triangle formed by the new station and two of the basic triangulation stations. Some were located by intersection from the basic triangulation stations (closing angle at the new station not observed), and a few were located by the three-point-fix method. All angle observations were made with an engineer's transit, except at a few canyon stations where sight distances were short and transit setups extremely difficult; at such points three-point-fix observations were made by sextant. In general the auxiliary stations established by the shore signal party were marked by iron pins and rock cairns when they were located above the high-water line, but were left unmarked when located below the high-water line.

\section{PLOTTING OF SOUNDINGS}

Two sets of map sheets of the lake were prepared for use on the survey. One set, called boat sheets, was used for delineation of the sounding lines to be run, and for field plotting of the boat courses actually sailed. The other set, called smooth sheets, was used for the final smooth plotting of the boat courses, entry of the bottom elevations as computed from the echo-sounding recorders, and delineation of contour lines as indicated by the sounding data. The grid for both the boat and smooth sheets was a polyconic projection computed from the tables given in Special Publication 5 of the Coast and Geodetic Survey (1935). This projection was used primarily to conform with the maps prepared for the Soil Conservation Service by Fairchild Aerial Surveys in 1935, and to permit a direct visual comparison between the two surveys. The scale of boat sheets and smooth sheets was 1:12,000, or 1,000 feet to the inch, which was also the same as for the 1935 maps.

Prior to sounding, 19 boat sheets were prepared covering the same areas as the smooth sheets, or some smaller area contained on a single smooth sheet. The boat sheets were simply penciled charts of parts of the lake, drawn on standard cloth-backed detail paper. Data shown on these sheets were the same as on the smooth sheets, except that the contour delineated below the 1,200-foot level was the 10 -foot contour nearest the anticipated lake elevation at the time that the area would be sounded. The highest 10-foot contours around hazardous shoals were also traced from the 1935 topographic maps, to serve as an aid to navigation. The desired positions of sounding lines were then indicated for the guidance of the soundboat officer during sounding observations. Guided by a study of the 1935 topographic maps, sets of parallel sounding lines were drawn on boat sheets, oriented so that a maximum of bottom definition would be obtained with a minimum of effort on the part of the sounding crew. In areas where relatively weak three-point fixes might inadvertently be used by the sextant men, the stronger 
three-point fixes were determined in the field office and appropriately indicated on the sounding lines.

The smooth sheets are of finest quality drawing paper, two sheets bonded to a central sheet of aluminum foil, averaging 40 by 60 inches in size. Eleven sheets were laid out to cover the lake, basin by basin, insofar as possible within the limitations of conveniently handled sheet sizes. Sheets were overlapped sufficiently to allow duplicate plotting of at least the two control stations nearest the margins, to insure ease of plotting the three-point fixes over the junction between sheets. Data initially plotted on each sheet included the polyconic grid system by 1-minute intervals, shore-line and island contours at elevations 1,150 and 1,200 feet as determined from the 1935 maps of the Soil Conservation Service, and the locations of the third-order triangulation stations. Auxiliary control stations were plotted as they were established, and smooth plotting of the sounding data was accomplished as rapidly as those data became available.

\section{SOUNDING PROCEDURES}

The echo-sounding equipment provided continuous soundings along designated lines or courses. Soundings were run along parallel lines, as described in detail by C. C. McCall (p. 58). In the bays radial lines were spaced to give not more than about 400 -yard intervals at the outer ends of the radials, and in the narrow parts of the canyons radial lines were spaced 70-100 yards apart. As the sounding work progressed the elevations determined from each day's soundings were compared with the 1935 map elevations, and if the comparison showed a need for additional sounding lines, they were indicated on the boat sheets and the soundings were obtained before operations were moved to new areas.

Three types of echo-sounding instruments were used, each having a different oscillation frequency-one low enough to be only slightly above the sonic range, and the others in the supersonic range. The low frequency was used to determine the interface between sediment and original bottom, as well as the interface between water and present sediment surface. Excellent results were obtained in sediment thicknesses up to 90 feet, in Boulder Basin and certain other areas where the sediment was not too dense; figure 46 shows fathographs obtained respectively in Gregg Basin, Virgin Basin, and Boulder Basin. The high-frequency instruments gave the best definition of bottom configuration in areas where the bottom was rough and steeply sloping. The echo-sounding records are analyzed by G. B. Cummings and C. E. Mongan, Jr. (p. 68).

True depths to the water-sediment interface were determined at intervals by picking up samples of that interface in a modified Foerst sampler (p. 151) suspended on a measured line. The recorded depths, properly adjusted for sound velocity, were found to agree with these measured depths very closely even over the least dense sediments, indicating that the sound impulse was reflected from the actual top of the sediment.

In the basins and larger bays, determination of boat positions was accomplished by the three-point-fix method, with angles measured by sextants aboard the sounding boat. This method was selected because it required the least number of control stations ashore, thus minimizing the horizontal-control and signalerection work. The method also had the distinct advantage of permitting the officer in charge of soundings to observe and plot his position at frequent intervals, thus enabling him to follow preselected lines without the aid of range stations or instructions from a shore party.

Control by three-point fix was impractical in some areas because of the large number of shore signals that would have been required, or because of the excessive rate of change of the angles to be observed when operating close to the signals. In the bays or coves, control was maintained by means of two transits set up on shore at triangulation stations located in such a way as to give good intersection angles at the boat over as large an area as possible; lines were run radially from one transit and positions along the lines were observed with the second transit. In canyon reaches, control was accomplished by using one transit and one sextant. The transit was set up to direct the boat along selected radial lines, and the sextant was used to observe the angles at the boat between the transit station and successive control stations along the canyon wall. This method required nearly as many stations as would the three-point fix method, but it minimized the rate of change of the angles observed by the sextant operator and provided greater accuracy than would have been attainable by three-point fixes. Hydrographic sextants with worm-gear drive vernier wheels were used for all sextant observations, and engineer's transits were used for the transit observations. Angles were read to the nearest minute of arc on both instruments.

In the broader basins observations for boat position, or fixes, were obtained at intervals of 2 minutes. In the open water areas away from shore the sounding boat was run at 5 to 6 miles per hour and the 2 -minute fix frequency provided a fix point approximately every 1,000 feet. Near shore or in areas with numerous shoals, the boat speed was reduced to about 3 miles per hour, and fixes occurred at about 500-foot intervals. In some of the canyons and coves, where very close control was 
desired, fixes were made at 1-minute intervals and boat speeds varied from about 2 to as much as 6 miles per hour.

The sound traces were read at 15 -second intervals, and the readings were recorded in sounding journals, together with fix times, angles, and other data. Final scaling for use in smooth-sheet plotting was accomplished in the office and no fixed time interval was adhered to, except for entries at the "fix" points. Intermediate readings were made at 50 -foot depth intervals over long stretches of uniform slope and at important breaks in slope. In this final scaling a movable scale, calibrated to read elevation, was set over the chart in such a way as to incorporate the draft, index, and soundvelocity corrections with the lake elevation for the day, and bottom elevations were read directly from the sounding charts.

In most of the reservoir area the bottom slope appeared to have a negligible effect on recorded depths. However, on very steep slopes and especially near canyon walls and underwater chiffs, some foreshortening of actual depth was detectable, and in some places stray echoes and side echoes from the walls were quite pronounced. In a few places, where the canyon wall extended from water surface to sediment surface at a fairly uniform steep slope, echoes were recorded from both sediment surface and side wall, even when the boat was known to be many feet shoreward of the true intersection between sediment and side wall.

\section{HORIZONTAL CONTROL}

By R. M. Wilson, U.S. Geological Survey

Accurate location of position was a prerequisite, not only in the hydrographic surveys, but in many other phases of the Lake Mead survey. A horizontal reference system is essential for correlation of various observations with those made at other times or places. The system must be physically permanent, so that measurements and observations separated by long intervals of time may be compared without doubt as to their relative positions.

When Hoover Dam was constructed, the available topographic maps included river plans at a scale of 1:31,680, showing 50-foot contours below elevation 1,200 feet (U.S. Geol. Survey, 1924). Plans for an accurate contour map of the entire reservoir area were given active attention late in January 1935 , only a few days before the gates of the new dam were closed and water began to accumulate to form Lake Mead. The contract for the mapping was awarded to Fairchild Aerial Surveys by the Soil Erosion Service, later to become the Soil Conservation Service, of the United States Department of Agriculture. Detailed topo- graphic maps were prepared from aerial photographs (U.S. Soil Cons. Service, 1935; Brown, 1941), based upon the framework of an extensive triangulation net which was established by the Fairchild Aerial Surveys (1935).

One of the objectives of the 1947-48 triangulation for the Lake Mead investigations was to recover as many of the Fairchild stations as could be tied in economically, and so test the precision of their coordinates. One consideration that made these ties a particularly urgent requirement was that many of the Fairchild stations were below the spillway elevation of the dam and were submerged when Lake Mead was filled with water; the remaining points of the Fairchild triangulation thus represented only disjointed fragments of the original triangulation system. Confirmation of the accuracy of the Fairchild triangulation was also desired for the survey of Lower Granite Gorge (p. 73), which was referenced to several of the Fairchild stations.

For similar reasons, it was desirable to tie in points of other previous surveys to the basic and common datum. Stations established by the Bureau of Reclamation, by Brock and Weymouth, and by the Los Angeles Department of Water and Power were also tied in wherever possible, so that all these surveys might be coordinated on a common datum. The Bureau of Reclamation was particularly interested in these ties, as a basis for determining whether there were any significant errors in the earlier surveys which might have introduced discrepancies or uncertainties into the capacity table for the reservoir, or which might affect future comparisons with the contour map made in 1935 .

Another purpose of the new triangulation was to establish convenient reference points for the 1948-49 hydrographic survey, and to mark them permanently so that similar studies in the future can be referred to the same marks. Most of these reference points were located just above the high-water mark of the reservoir for two reasons. First, they are most easily reached there by boat transportation; and second, sextant angles read from a boat on the lake to the shoreline stations should be very nearly in a horizontal plane in order to avoid the corrections that otherwise would be necessary.

\section{PROGRAM FOR TRIANGULATION}

The plans for the 1947-48 triangulation provided that the work should be accurate within third-order limits, as defined by the Board of Surveys and Maps in 1933-that is, triangles should close with a maximum error of 10 seconds, and an a verage error seldom exceeding 5 seconds. A study of available maps of the area revealed, however, that triangulation of thirdorder precision could not feasibly be carried near water 
level through the narrow parts of the channels and arms of Lake Mead. It was deemed permissible therefore to tie in the shore reference points with narrow arcs of triangulation, sometimes consisting of only a chain of single triangles. These sections of the survey could then be tied together by third-order triangulation at higher levels, which in turn would connect to the first-order Coast and Geodetic Survey stations.

It was recognized in planning the program that the triangulation control must be kept well in advance of other phases of the work. The hydrographic surveys and the sounding and sampling operations in Lake Mead would require established shore control points for defining the positions of observations taken in those operations. It was important, therefore, to start the geodetic control early and have shore reference points established in areas where the other phases were to begin, in order to avoid delay in the hydrographic survey. Because of this requirement, preliminary position computations were made as the triangulation progressed, leaving until later the least-squares adjustments and the final computation of coordinates.

The techniques employed in the hydrographic survey influenced the selection of a system of coordinates for expressing the position of reference points. The Navy personnel who made the soundings were familiar with the reading of sextant angles to shore points for boat positions. These positions were then plotted on the boat sheets by the use of three-armed protractors and similar graphic means. The boat sheets were prepared on a polyconic map projection, and the control points were plotted in their appropriate positions in terms of geographic coordinates.

The use of rectangular coordinates was considered, but rejected. Had the state plane coordinate systems been used, it would have been necessary to divide the survey into two parts, one for Nevada and the other for Arizona, or alternatively, to map the entire survey in the system for one of these States, overlapping it into the other State. A coordinate system established particularly for Lake Mead and its surrounding area might have been feasible, but it would have been confusing because of the state systems already in existance in the area. It was decided, therefore, to use the basic geodetic coordinates. If at some time in the future it becomes desirable to refer these coordinates to some other system, the appropriate transformation can then be made.

\section{DESCRIPTION OF OPERATIONS}

In the field work to establish the horizontal control needed for the project, it was necessary to compute the positions of the new triangulation stations nearly as fast as the field observations developed, in order to make them useful during the subsequent phases of the investigation. The field work began in November 1947 and continued without interruption until December 1948. All field computations were completed by March 1949.

The work was begun in Boulder Basin and in Black Canyon just above Hoover Dam. Much ingenuity was required for carrying the low-level chain of triangles through Black Canyon, for the walls of this canyon are very steep and suitable station locations are hard to find (pl. 6). Many of the lines of sight were very short, particularly in the narrow chains through the canyons, so that great care had to be exercised at each station in centering of signal and instrument. This centering was always accurate to one-half inch or less.

All the narrow chains of triangles through the canyons were connected adequately at frequent intervals by the higher level third-order triangulation. This higher level triangulation from Boulder Basin eastward across the Virgin Canyon and to Pierce Basin was, in turn, connected at frequent intervals with the first-order triangulation net of the Coast and Geodetic Survey. The long arc of third-order triangulation up Overton Arm was tied rigidly to first-order Coast and Geodetic Survey stations to the north. Care was taken to make sure that no arcs of triangulation were left outstanding as unchecked spurs.

The instrument used was a Wild $\mathrm{T}-1$ repeating transit. Angles were generally measured five times direct and five times reversed. The signals for sights of 3 miles or more consisted of wooden 2- by 2-inch poles 8 feet in height. These poles carried a flutter flag about a yard square, and cross targets about 1 foot square. For shorter distances, sections of 1-inch pipe, 4 feet long and painted white, were used. All signals were guyed in position by wires.

\section{SUMMARY OF RESULTS}

The triangulation for horizontal control can be considered in four major areas: Boulder Basin, Virgin Basin, the long and winding channel from Virgin Canyon to Pierce Basin, and the long northward extension called Overton Arm. Considered as the sum of linear longitudinal distances through the triangulated arcs, the total is approximately 180 miles. In addition to the shoreline triangulation included in the mileage, there was also the higher level, large-figure triangulation required to maintain over-all accuracy and to connect with the Coast and Geodetic Survey first-order arcs.

In Boulder Basin several Coast and Geodetic Survey lines served as bases. These lines were CASH-PROM, PROM-HEM, R O U G H-H E M, HEM-CASH, VEGA-LA MESA, LA MESA-BOULDER, and E8- 
SUGARLOAF (fig. 9). Except for the chain of single triangles through Black Canyon, the net consisted entirely of central-point and quadrilateral figures, and strong figures were easily obtained in most of the area. Boulder Canyon (pl. 5A) presented a problem because of its narrow, twisting shape. However, a continuous chain of quadrilaterals was carried at water level up to the very narrow part of the canyon, which is about a mile long. Since it would have been both uneconomical and time consuming to force a strong system through this narrow section of the canyon, the main net was carried at a higher level to connect with a length derived from the Coast and Geodetic Survey base BOULDER-BONELLI. An outer continuous system was also established in Boulder Basin area and extended to Virgin Basin in order to tie in the lakeshore net wherever possible and to facilitate the problem of leastsquares adjustment. Figure 9 shows the triangulation net established for this region.

The shoreline of Virgin Basin was easily adapted to strong figures. The principal problem centered about a method to reduce the long line BOULDER-BONELLI with the least possible loss of accuracy. From this line it was necessary not only to control Virgin Basin, but also to establish strong bases from which to extend the net northward up Overton Arm and eastward to Pierce Basin. In addition, a base must serve as a tie needed for the net which was extended from Boulder Basin over Boulder Canyon and into Virgin Basin. The quadrilateral that was finally used reduced this long base, and by subsequent reductions using strong figures, adequate bases were obtained for the above-mentioned purposes. Figure 10 shows the triangulation in the Virgin Basin area.

The Overton Arm net was extended northward from the base established in Virgin Basin, by means of strong quadrilateral and central-point figures, and a tie was effected to the Coast and Geodetic Survey line GLENBM Z50. This was the easiest part of the survey, because Overton Arm is relatively straight and fairly uniform in width. Figure 11 shows the triangulation in the Overton Arm area of the lake.

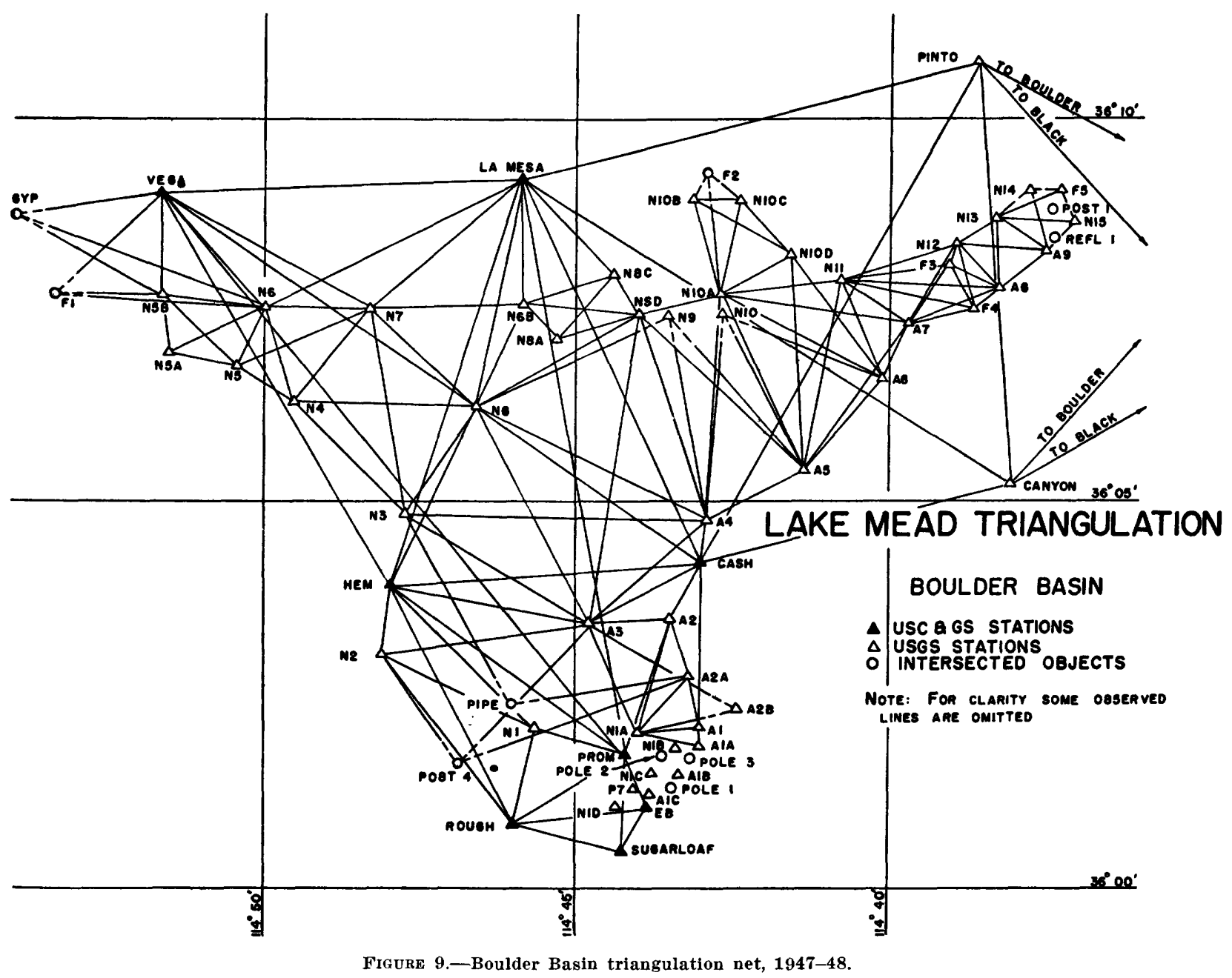




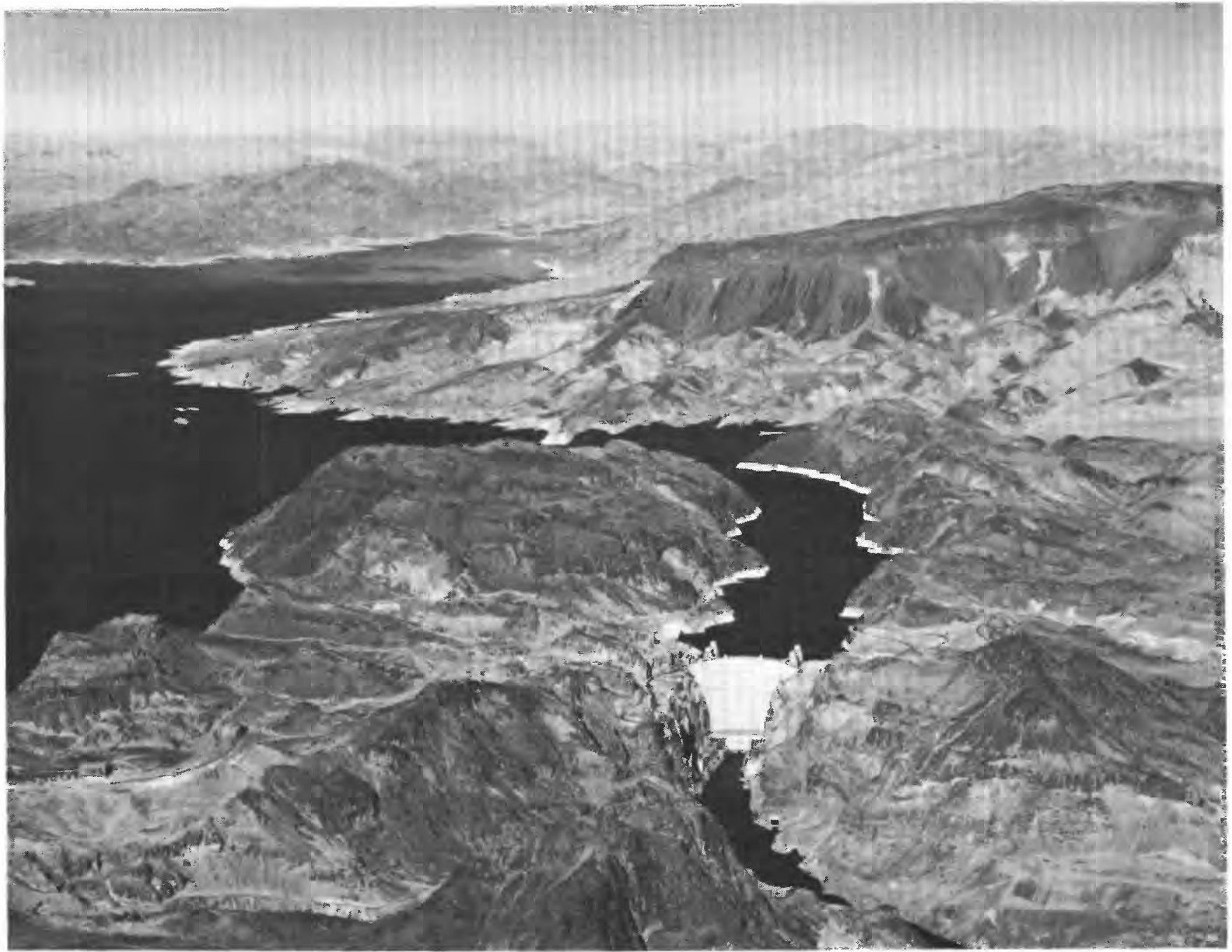

BLACK CANYON AND BOULDER BASIN OF LAKE MEAD

Photograph by Bureau of Reclamation. 


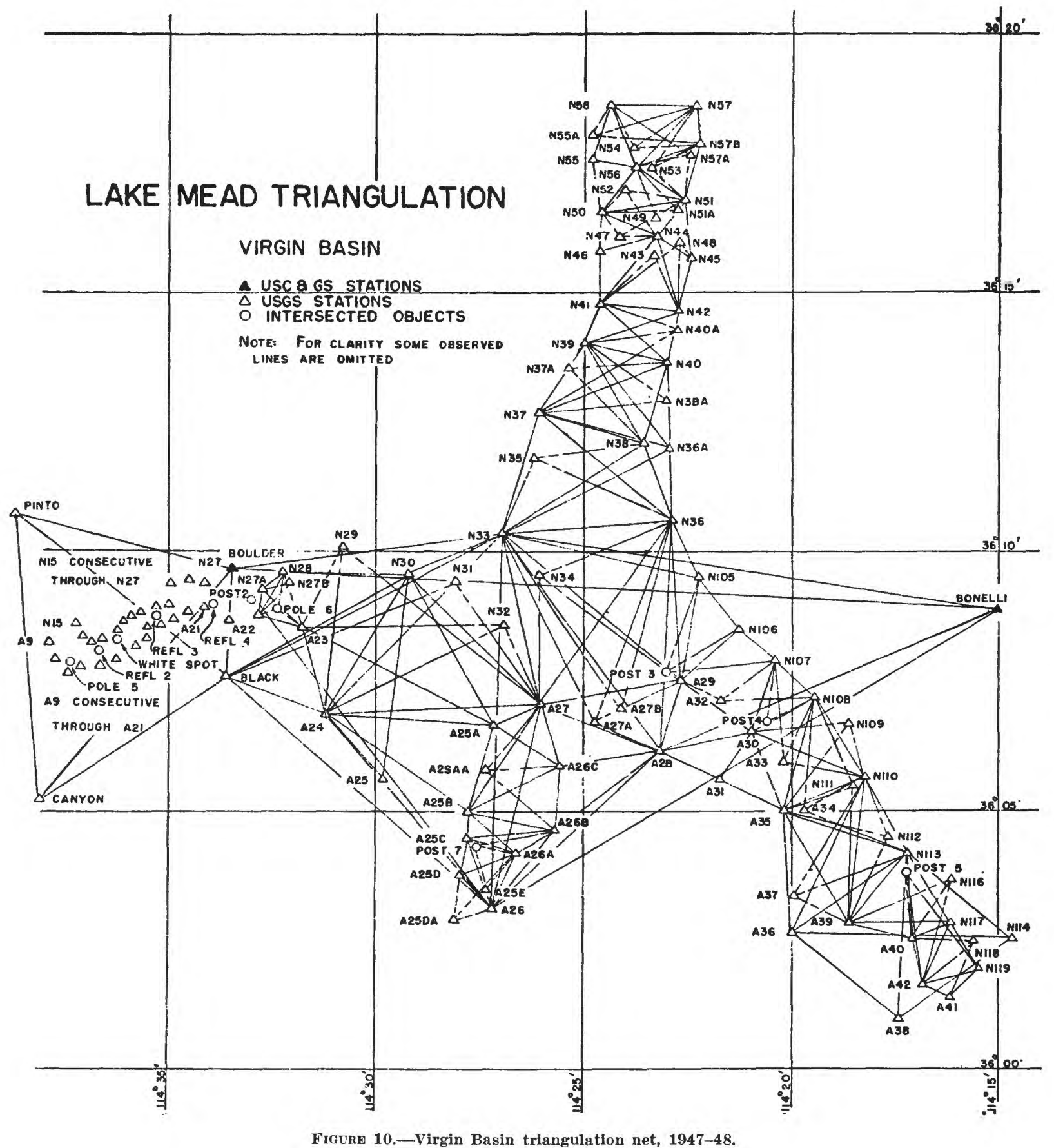

The area from Virgin Canyon to Pierce Basin was the most difficult section of the entire project. Because of the narrow, tortuous canyons (pl. 3), and alternate expansion and contraction in the width of the reservoir, it was necessary to carry a single-triangle chain near water level, and an additional outer net of large figures, in order to maintain third-order accuracy. These single-triangle chains, of course, were tied at both ends. The base for the beginning of this net was derived from the BOULDER-BONELLI base in Virgin Basin.
From that base a net of quadrilaterals was extended to Virgin Canyon, and then large single triangles were carried forward to tie to the main net near Hualpai Wash. From Hualpai Wash a chain of quadrilaterals was extended to Sandy Point, but from there to Pierce Basin single triangles were used almost exclusively. Figure 12 shows the triangulation in the area included between the Virgin Basin and Pierce Ferry.

Between Hualpai Wash and Pierce Ferry, four Coast and Geodetic Survey stations were used as basic control 


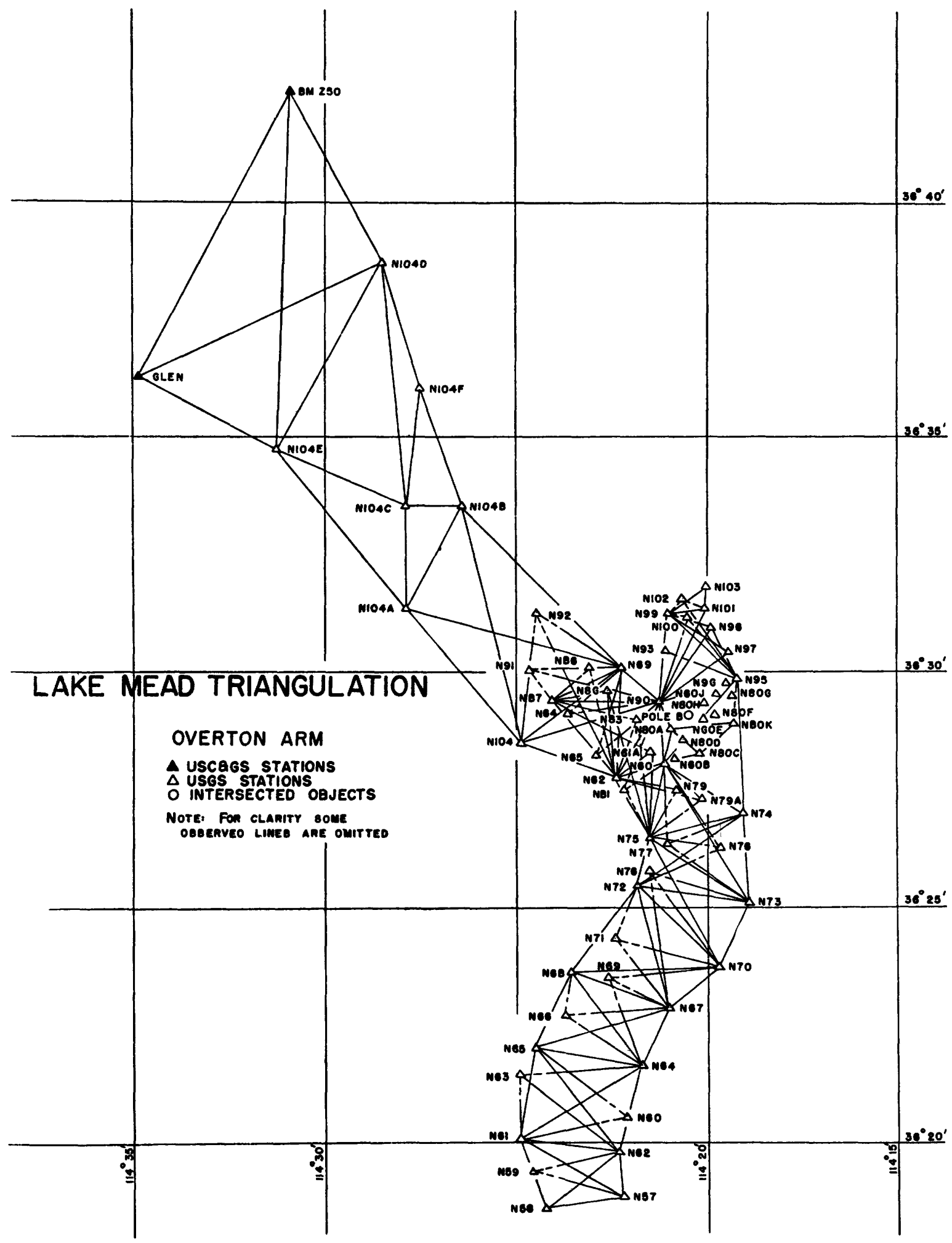

Figure 11.-Overton Arm triangulation net, 1947-48.

to establish the shore base lines needed to begin and tie the various single triangle nets. These stations were BONELLI, GRAND WASH, TUT, and RAMPART. By establishing two or three additional high- point stations, a strong net consisting of central-point figures was obtained. This net served as a tie, near Hualpai Wash, for the net carried forward from Virgin Basin; as a starting point for the single-triangle net 


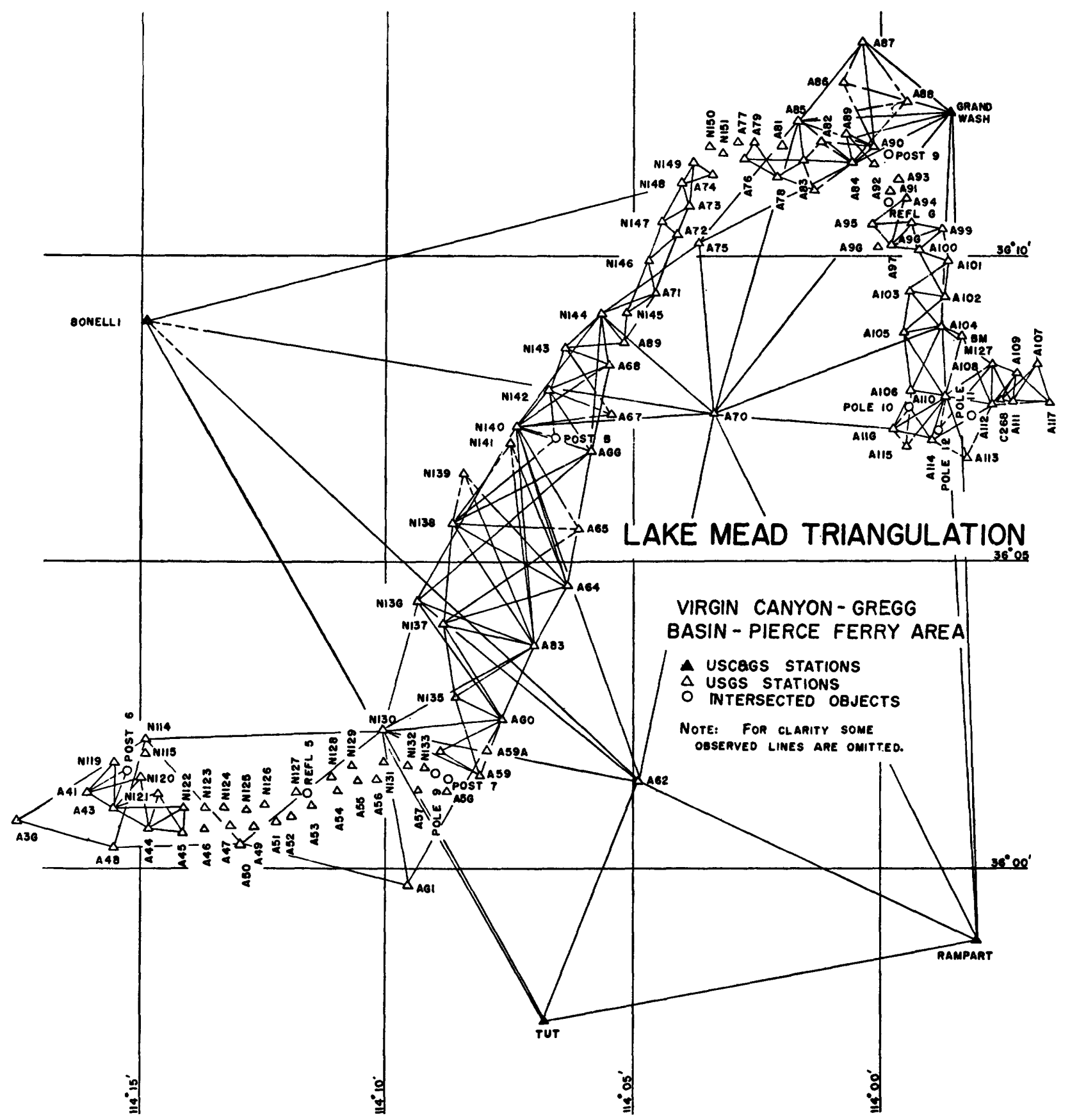

Frgune 12.-Triangulation net in the Virgin Canyon-Pierce Ferry area, 1947-48.

near Sandy Point; and as a tie for the single-triangle net at Pierce Ferry.

Altogether, 336 new reference points and triangulation stations were established, each marked with the standard bronze tablet of the Geological Survey. All new tablets were stamped with a designating letter and number and the year established: for a station on the Arizona shore designated as "A50 1948," the "A" indicates that the station is in Arizona, the number " 50 " being the serial number of the station, and " 1948 " the year the station was established. Stations on the Nevada shore are similarly stamped except that the letter "N" is used to desigmate the State. All stations are numbered approximately in consecutive order eastward from Hoover Dam. Letters after the number merely designate stations that were added after the mumbering system was established for an area. No reference marks were set.

A brief description was written for each station that was marked with a tablet. Airline distances were 
given from various prominent objects around the lake, the object in which the tablet was placed was noted, and the distance above or below the high-water mark was recorded. However, by far the easiest way to find these stations would be to plot the positions on topographic maps, and to look for them with the aid of the map. A list of coordinates for all stations, with azimuths and distances between them, has been lithographed by the Geological Survey (McIntosh, 1951). The geographic positions of all stations are also listed in the supplemental base data report.

In addition to those permanently marked points, about 35 navigation lights or other objects were located by intersection only and were not marked by tablets. Fifteen stations of the Coast and Geodetic Survey were recovered and occupied. Twenty-six of the stations established by Fairchild Aerial Surveys were tied in, also four stations of Brock and Weymouth, one station of the Bureau of Reclamation, and two stations of the City of Los Angeles. The position closures involved in all these ties were well within third-order limits, which indicates excellent work in the earlier triangulation by the Fairchild Aerial Surveys and by others in this area. The analysis discloses that the Fairchild triangulation is dependable and accurate, and was entirely adequate for use in making the maps under the original contract, presumably also for the horizontal control in the 1948-49 survey of Lower Granite Gorge (p. 74).

In the higher level net of the 1947-48 triangulation, which was composed of large figures, there were 171 triangles for which the average closure was $4.23 \mathrm{sec}-$ onds. In the shore-level net, including some very short sights and small triangles, there were 346 triangles with an average closure of 5.03 seconds. The maximum triangle closure in the latter work was 24 seconds, but only 39 triangles had closures over 10 seconds.

\section{OFFICE COMPUTATIONS}

The closure discrepancies that appeared at the ends of the various arcs and systems were removed by an adjustment that was undertaken and completed in several parts and stages. Some of these parts involved rigorous least squares, and others involved less rigorous but faster methods that appear justified in view of the very small closure errors developed. For this adjustment, the work was divided into main-scheme and secondary systems.

The unadjusted observations in Boulder Basin gave such consistent values at the check stations that no adjustment was deemed necessary. An arc of large quadrilaterals and central-point figures, extending from triangulation stations LA MESA and CASH eastward to GRAND WASH and RAMPART, was adjusted by least squares to serve as a base for the subordinate work. This arc included 11 new stations and 7 Coast and Geodetic Survey stations. The position changes introduced by the adjustment amounted to less than 1 foot in either latitude or longitude except for two of the new stations at the eastern end. At each of these two stations, the adjusted positions differed from their preliminary values by approximately 2 feet.

The Overton Arm net was held at the southern end by its tie to the main-scheme adjustment and at the northern end by the tie to line GLEN-BM Z50. Inasmuch as there were no other intermediate factors to control the adjustment and the preliminary computations appeared to be internally consistent, it was deemed adequate to adjust the entire Overton Arm net as a single unit by the method of "isodiffs" (Speert, 1938). For this purpose line N33-N36, of the least-squares adjustment, was treated as a single tie, and line GLEN-BM Z50 was treated similarly. The whole net was then swung into azimuth to fit these two ties, and the necessary scale factor was applied to all computed lengths to make the over-all length of the net fit these two ties. A correction was determined for the position of each station from its location on the "isodiff" graph. All azimuths in the net received the same correction and all lengths the same proportional increase. At both ends of the net, in the figures adjoining the two fixed bases, individual corrections were computed for each line into both ends of the fixed bases.

A special study was made of each of the narrow chains of triangles and quadrilaterals along the canyons and smaller basins. A small position discrepancy at any point might very easily have thrown the work outside of third-order limits because of the unusually short lines involved in these figures. Wherever position discrepancies appeared that approached or exceeded third-order limits when concentrated in the closing line of a chain, that chain was adjusted by the "isodiff" method to distribute the accumulated error and to avoid any undue concentration at the closing point.

\section{VERTICAL CONTROL}

\section{By F. C. Ames, U.S. Geological Survey}

Vertical control was required in the hydrographic survey of the lake for conversion of the sounded depths to the corresponding bottom elevations above a selected reference plane or datum. All soundings were referenced to the water surface at the time and place of sounding, and a prerequisite for vertical control was the collection of adequate records of the water-surface 
elevation at those times and places. On a small singlebasin lake, records at one or two locations might be adequate, but on a large multibasin lake such as Lake Mead, it was felt that there might be significant differences in elevation of the water surface in different parts of the lake at times, owing to the influence of wind, differences in barometric pressure, the flow of water through the lake, or other causes. To determine the occurrence, nature, and extent of these possible differences, records of water level were maintained at several points around the lake.

In this section of the report are described the collection and analysis of water-stage records at the various gage sites, the correlation of the water-stage records, and the magnitude of the errors that might occur in converting the recorded soundings to elevations above reference datum. A permanent gage at Hoover Dam provides a continuous record of water-surface elevations at the dam. The operations and analyses discussed in this section established the fact that this record is sufficiently accurate to be used without adjustment for conversions of sounded depths to bottom elevations. In determining whether adjustments are needed, it is to be noted that the records of the echo sounders operating in the foot scale could be scaled to about the nearest half foot, but in the fathom scale only to the nearest 2 or 3 feet.

\section{COLLECTION OF WATER-STAGE RECORDS}

Records of water-surface fluctuations were obtained from recording gages located at strategic points around the lake. A permanent gage had been in operation at Hoover Dam since 1935, and this was used as the basic reference gage during the 1948-49 survey. The gage, which had been used in the survey of 1935 (Brown, 1941, p. 393), thus served as a direct tie between the two surveys, after correction for differences in the gage settings with respect to datum as described on page 57 . As the work progressed, auxiliary gages for the determination of local variations in water level were installed at the other points indicated in plate 7 .

Three of the auxiliary gages were maintained at fixed locations throughout the course of the survey: gage 3, in a cove on the southeast shore of the Boulder Basin; the Boulder Wash gage, at the western end of Virgin Basin; and the Pierce Ferry gage, in a cove at Grapevine Wash in Pierce Basin. The primary function of the gages at Boulder Wash and Pierce Ferry was to provide information as to changes in relative water levels along the length of the reservoir. Gage 3 in Boulder Basin was originally intended as temporary only, but early records indicated variations between true lake stage and the stage as read from the Hoover
Dam gage. Therefore gage 3 was left in place throughout the survey to provide continuous data regarding these variations.

The other auxiliary gages were operated in conjunction with the hydrographic survey, during which they were moved from place to place as the sounding party progressed from one basin to another. The primary function of the temporary gages was to provide a record of local variations in water level that might be of sufficient magnitude to require attention in the conversion of soundings to bottom elevations.

\section{GAGE INSTALLATIONS}

The gage at Hoover Dam is a Stevens remote-registering gage with the actuating Selsyn motor mounted over a stilling well built into the dam. The gage indicator dial and a Stevens water-stage recorder are located in the watermaster's office in the powerhouse.

All auxiliary gages were installed in portable stilling wells and shelters, as portability was a major requirement for the equipment at the temporary locations, and it was anticipated that fairly short stilling wells would accommodate the range in stage likely to occur during the period of operation at any selected location. A reconnaissance at the two locations originally selected for more permanent installations indicated that the difficulties and costs of erecting stilling wells to cover the anticipated 50-foot range in stage would far exceed the difficulties and cost of moving short portable wells up and down the banks. Accordingly, all stilling wells were fabricated from 24-inch diameter, galvanized, corrugated iron culvert pipe. The bottoms of the wells were closed and intake action was restricted in order to damp out surges due to wind on the lake. A staff gage consisting of enamel gage sections was bolted to each stilling well to serve as a reference gage. Instrument shelters were fabricated from 1-inch lumber and bolted to the top of the stilling wells.

The wells for the temporary locations were 10 feet long; with a crew of four men no great difficulty was encountered in moving these up and down the banks or from one location to another. The wells for the more permanent locations were 16 feet long, in two 8-foot riveted sections joined by standard band couplers. The handling of these wells proved rather awkward and difficult for the crew of four, even with the aid of light block-and-tackle equipment. During periods of rising stage the removal of these long wells from the lake for reerection on higher ground was particularly difficult, because it was not feasible to provide power equipment at the isolated sites for the 1 or 2 hours that would have been required for each move. Except for the press of other work it would have been better to use 10-foot wells 
at all locations, even though more frequent moves would have been required. A minor difficulty with the long wells was the excessive intake action around the band coupler, which permitted considerable surge in the well when the water surface was above the coupler, as much as 0.3 foot when the lake was rough. The surge obscured the indication of seiche patterns to some extent but did not detract from the value of the record for determinations of lake stage.

Initially the gages were located in narrow, very well protected coves, to avoid pounding by waves and to minimize surge induced by wave action. Subsequent observations indicated rapid reduction of wave height toward the heads of even fairly open coves, and it was found that gages could be located safely in small coves opening directly to the main lake. Installation was made by standing the well on the bottom near the center line of the cove, and supporting it with three guy wires attached to stakes or other anchors in the banks, a few feet higher than the top of the well. All gages were transported and serviced with the aid of a Navy airplane-personnel boat, because there were no access roads to the selected sites.

\section{WATER-STAGE RECORDERS}

Two types of water-stage recorders were used for the auxiliary gages: the Stevens Type F weekly recorder, and the Stevens Type A-35 continuous recorder. The Type $\mathrm{F}$ recorders were used at locations 1,2 , and 3 in Boulder Basin, where the gages were easily reached from Boulder City for the necessary weekly servicing. The Type A-35 instrunents were used at all other locations.

On both types of recorder the stage can be interpolated readily to the nearest 0.01 foot, and the mechanical linkage is such that the probable error from lost motion does not exceed 0.01 foot. The Type A-35 has a time scale of 2.4 inches per day, by means of which time can be interpolated to the nearest $10 \mathrm{~min}$ utes without difficulty. Time-travel error on these instruments seldom exceeds 1 hour per month; with the aid of monthly inspection, corrections can be applied with confidence to the smallest interval to be interpolated. The Type $\mathrm{F}$ recorder has a time scale of 1.2 inches per day; the time can be interpolated to about the nearest 20 minutes; and time-travel error seldom exceeds 30 minutes per week. Thus the records obtained from both types of recorder may be expected to be correct within 10 to 20 minutes in time, and within 0.01 foot in gage height. However, the accuracy of elevations derived from the gage-height records at Lake Mead may be somewhat less (p. 55).

\section{DEVELOPMENT OF A COMMON GAGE DATUM}

The auxiliary gages were set initially to a convenient arbitary datum, tied in to local reference marks by differential leveling. Whenever it was necessary to move a gage up or down slope, the relation between gage scale and reference marks was redetermined as a check against possible disturbance subsequent to the initial setting, and after each move the new relation was determined and recorded to permit eventual reduction of all readings to a common datum.

The true elevation of the zero of each gage with respect to the common datum for the survey was determined by comparing daily mean gage heights at the auxiliary gage with daily mean elevations at the Hoover Dam gage, and averaging the results over long periods. The accuracy of this determination rests on the validity of the assumption that the lake has a level surface during periods of calm weather and small flow through the lake.

At Boulder Wash and at Pierce Ferry it was possible to determine apparent elevations for the gage zeros by leveling from nearby bench marks. The elevations of the bench marks were derived by interpolation between the leveling of $1940-41$ and that of 1949-50, in order to minimize the effect of differential settlement. Elevations thus obtained were 0.02 foot higher at Boulder Wash and 0.03 foot higher at Pierce Ferry than the elevations obtained by the water-level transfer from Hoover Dam, differences that are so small as to be within the allowable limits of accuracy of the leveling and of the average water-level determinations. The leveling has thus served to confirm the horizontality of the lake surface during periods of calm weather and small flow through the lake.

Determination of the elevation of the zero of each auxiliary gage was as follows: The average difference between daily mean auxiliary gage heights and daily mean elevations at Hoover Dam for the first 10 to 20 days of record was taken as a trial figure. The figure was added to each daily mean gage height as the record accumulated, the difference between the apparent elevation thus obtained and the elevation at the dam was computed, and the differences were plotted on a "difference-time" chart (fig. 13). If, after 60 days or more, any predominance of plus or minus values was noted, appropriate correction of the trial figure was made to bring the average daily difference to zero. Comparison of differences was continued for the entire period of record at each gage, to establish the validity of the adjusted value as closely as possible, and to discover any tendency of the average difference to depart from zero during periods of changing discharge through the lake. 
COMPREHENSIVE SURVEY OF SEDIMENTATION IN LAKE MEAD, 1948-49

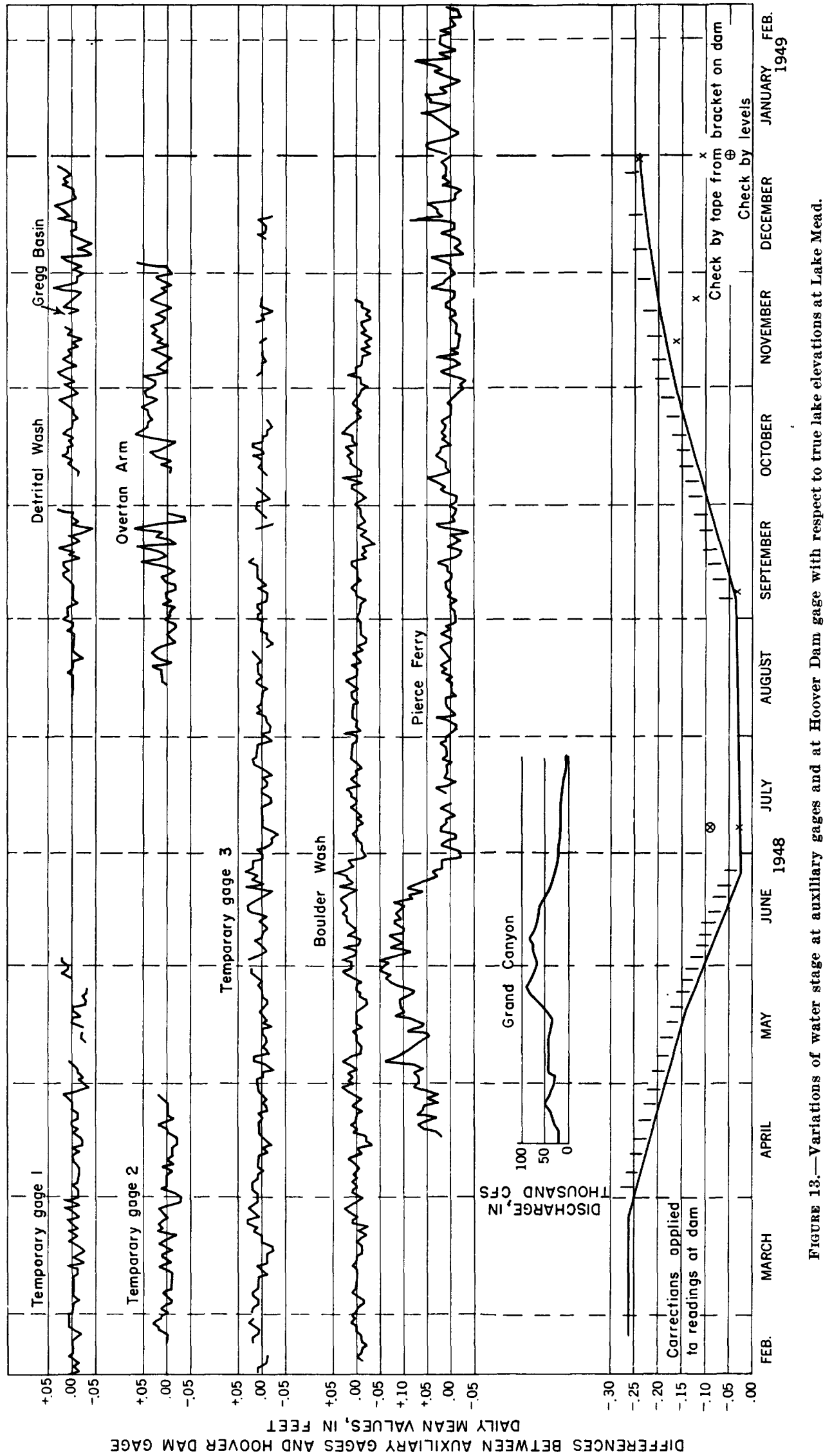


One result of these comparisons was the discovery of a gradual change in the relation between the gage readings observed at Hoover Dam and at the auxiliary gages in Boulder Basin and in Boulder Wash. The rate of change of this relation was most rapid in May and early June; it remained fixed during July and August, and then started to reverse in September, returning to its original value by December (fig. 13). The discovery led to detailed study of the conditions of operation of the gage at the dam.

The Bureau of Reclamation had found by periodic leveling that the relation between true lake stage and the Hoover Dam gage reading had been variable throughout the period, and that the variation appeared to follow a seasonal pattern: the gage readings were higher in winter than in summer with respect to true water-surface elevation. The range of the variation appeared to be about 0.25 foot, which was approximately the amount of variation observed between the auxiliary gages and the permanent gage during the 1948-49 survey. In an effort to confirm the variation and determine its cause, a reference-mark bracket was installed at the dam to permit frequent checks of the gage reading by simply measuring down to the lake surface with a steel tape. Such checks were made periodically after September 1948. These data indicated that the source of error must be in the Hoover Dam gage or the stilling well in which it operated.

One source of error was found to be the result of differences between the density of water in the lake and water in the gage well, resulting from differences in water temperature. The intake to the well, at elevation 940 feet, is generally 200-260 feet below water surface; and for interconnected water columns of such height, small differences in density cause appreciable differences in relative water levels. Computations based on temperatures in the lake at the dam and in the gage well, observed at various seasons in previous years, indicated a difference in relative water levels of about 0.01 foot in summer and about 0.11 foot in winter, the well water being warmer and therefore higher in both seasons. Computations made on the basis of additional temperature observations during the 194849 survey confirmed this value, which would account for an annual variation of 0.10 foot.

Efforts to determine the source of the remaining 0.15 foot of error led to a check on the calibration of the gage mechanism. In direct comparison between the change in gage-dial reading and the measured travel of the float tape, over as wide a range as possible, it was found that the calibration of the gage was correct so long as the holes in the tape remained properly alined with the spines on the float wheel. However, during changes of stage there is a marked tendency for the perforated tape to ride up on the spines. A second test, to determine the calibration error introduced by operation with the tape out of the spines, showed the error to be 0.0039 foot per foot change in stage. With a normal annual range in lake stage of roughly 40 feet, the total error between high and low stage is about 0.15 foot. The calibration error and the change in relative water levels due to density changes are additive, and the sum of the two equals the observed range of error in gage reading with respect to true lake elevation.

\section{ANALYSIS OF WATER-STAGE RECORDS}

Most of the large changes in water stage resulted from changes in storage in the reservoir, and were recorded uniformly by gages in all parts of the lake. Some patterns of fluctuation, however, indicate variations of the water surface from a level plane, and are recognized by variations between the stages recorded at the several gages.

\section{SEICHES}

The water-level records reveal considerable seiche action in the lake during periods of moderate to strong winds. There appear to be several seiche patterns, varying from very short-period, small-amplitude oscillations to fairly long-period cycles of variable amplitude. No detailed technical analysis of these seiche phenomena has been made, but the following general observations indicate the complex behavior shown by the graphs.

The long-period seiches are recorded strongly at all gages in Boulder Basin (including the gage at Hoover Dam), and at Pierce Ferry near the other end of the main part of the lake. The general shape of the graphs is roughly sinusoidal, but the detailed pattern is usually quite irregular, with many superimposed small-amplitude variations. At times the slopes of the rising and falling limbs of the oscillations are quite dissimilarthat is, the time interval from crest to trough differs from that from trough to crest. Frequently the shapes of successive cycles are quite different.

The approximate period of these long-period seiches varies from $31 / 2$ to 4 hours, and normally a crest is recorded in Boulder Basin at the same time as a trough at Pierce Ferry. Sometimes the seiche cycle at Pierce Ferry leads the corresponding cycle in Boulder Basin by $180^{\circ}$, and sometimes the reverse is true, presumably depending on the source of the disturbance generating the seiche. The amplitudes of the long-period seiches vary from a barely perceptible sinuosity of the trace, up to $0.10-0.15$ foot in Boulder Basin, and up to 0.300.35 foot at Pierce Ferry. Normally gage 1 showed the 
greatest amplitude of any gage in Boulder Basin, though exceptions were noted. The maximum recorded amplitude was about 0.6 foot at Fierce Ferry on the night of December 3-4, 1948, during a period of very strong wind with gusts estimated at velocities up to 60 miles per hour. The time interval between the first two crests was barely $31 / 4$ hours, increasing to 4 hours between subsequent crests.

The long-period seiches recorded at Pierce Ferry and in Boulder Basin are presumably controlled by, and travel throughout, the length of the lake. All the seiches shown at Pierce Ferry were reflected on the Gregg Basin gage during its short period of operation, but with considerably smaller amplitude, and sometimes with extensively modified patterns. Only a small number of the long-period seiches were recorded on the Detrital Wash and Overton Arm gages, and very few are discernible at all on the gage at Boulder Wash: When the seiches did appear on these gages the amplitude was always much less than at the ends of the lake.

The short-period seiches detected on the various graphs had periods of about 18 to 20 minutes at Pierce Ferry and about 25 minutes at Boulder Wash, Gregg Basin, and Detrital Wash. The amplitudes seldom exceeded 0.05 foot and were normally only 0.01 to 0.03 foot. These may be single-basin seiches controlled primarily by conditions within the basin.

Between the two extremes of short- and long-period cycles, various other frequencies occurred from time to time at all locations. These cannot be correlated between gages, and a detailed analysis would undoubtedly be very complex and difficult.

\section{TIDES}

The records were examined superficially but unsuccessfully for indication of tidal fluctuations. Any such fluctuations are completely obscured by the more pronounced variations due to other causes. In particular, the variable rate of rise or fall in lake level resulting from variable outflow for power generation tends to mask any diurnal fluctuations that might be caused by tides.

\section{WIND EFFECTS}

In the preliminary planning for the survey it had been anticipated that sustained winds of moderate to strong intensity might cause fairly large differences in water-surface elevations between leeward and windward sections of the lake. Because the axis of prevailing winds in the Lake Mead area is north and south, the gages in Boulder Basin and in the Virgin BasinOverton Arm section were located in such a way as to indicate any north-south pileup of water.
The longest reach between gages in Boulder Basin was the 8 miles between Hoover Dam and gage 2; no differences attributable to wind were detected in this reach, even under the influence of many strong south winds during March and April 1948. The reach between gages in the Virgin Basin-Overton Arm section, about 22.5 miles, is completely exposed to the northsouth winds and is entirely open except for a constriction at the Overton Islands, about 8 miles south of the Overton Arm gage. Even in this reach the observed differences in water-surface elevation were negligible. The greatest difference noted was 0.20 foot at $6 \mathrm{p} . \mathrm{m}$. on September 24, 1948, after several hours of a south wind at 30 to 35 miles per hour. Following these negative results it was deemed unnecessary to measure possible pileup in the 13-mile Gregg Basin-Iceberg Canyon reach, which is also oriented approximately north and south.

\section{SLOPE FFFECTS}

The records indicate that the stage at Pierce Ferry increases with respect to the stage at Hoover Dam in approximately direct proportion to the inflow. There was a sustained positive difference between the lake surface at Pierce Ferry and at the other gages throughout the period of high inflow from A pril to July 1948. This difference increased 0.14 foot during a change of inflow from about 5,000 cfs to $90,000 \mathrm{cfs}$, and appears to bear a direct relation to the flow, changing about 0.01 foot for each increment of $6,000 \mathrm{cfs}$ of discharge at Grand Canyon (fig. 13).

The differences between gages represent the slope, or fall, of the water surface downlake from Pierce Ferry. A large part of this fall probably takes place in the canyon sections above Virgin Basin. The record at the Gregg Basin gage does not cover the period of high inflow, and evaluation of fall between that point and the dam is not possible. Changes in fall between the Boulder Wash gage and the dam are too small to be detectable in the record available. During period of low flow (5,000-10,000 cfs) the fall from Pierce Ferry to Hoover Dam apparently is about 0.01 to 0.02 foot.

\section{EVALUATION OF DISCREPANCIES}

From the discussion above, it is evident that the conversion of sounded depths to bottom elevations by referencing to the record of the Hoover Dam gage is subject to some error, by reason of the variation of the lake surface from a horizontal plane and because of the failure of the Hoover Dam gage to record the true water surface at the dam.

The factors that might cause the elevation of water surface at the dam to differ from that at other points in the lake are as follows: 
1. Slope of the lake surface, practically nil most of the year, may increase to 0.20 foot with inflow of $120,000 \mathrm{cfs}$. The water surface at Hoover Dam gage at that time would be 0.20 foot lower than the water surface at Pierce Ferry.

2. Seiche action may cause a variation of 0.15 foot in Boulder Basin, and twice as much at Pierce Ferry, but with a period of 3 to 4 hours such variations would be averaged out in the daily mean water-surface elevation.

3. Wind action has caused a maximum observed pileup of 0.2 foot in the long, north-trending Overton Arm, but only negligible effects in Boulder Basin.

4. The lake stage rises rapidly during the annual freshet in the Colorado River. In 1948 the stage rose more than 0.5 foot during each day from May 20 to June 20, and a maximum daily rise of 1.08 feet occurred May 27. The use of daily means or of midday gage heights may introduce errors of as much as 0.15 foot in conversions of soundings made early or late in the day.

The maximum operational error in the Hoover Dam gage readings is about 0.25 foot, which is the same order of magnitude as the variations from horizontal surface caused by seiches, wind, or inflow. In the analysis of variations of the lake surface from the horizontal it was of course necessary to correct for these operational errors in the Hoover Dam gage; the graphs of figure 13 show the variations between the auxiliary gages and the corrected gage record or true water surface at the dam.

The errors that might be introduced in the determination of bottom elevations because of all these factors are much less than the total of the maximum errors listed above. Thus wind effects and slope effects were found to be negligible in Boulder and Virgin Basins; a fortuitous combination of seiche effects, hourly change in water level, and operational error at the dam gage could cause an error of no more than 0.5 foot in the conversion of individual soundings in those basins. The survey of Pierce Basin and other areas in the eastern part of the lake was undertaken during a period of low inflow, when slope effects were negligible; here, too, the conversion of individual soundings might be in error by as much as 0.5 foot, by reason of maximum seiche action and errors in the dam gage. In Overton Arm, individual soundings might include some effect of wind pileup, but there the seiche action would be negligible, so that the total error would be no greater than in other parts of the Lake.

A maximum error of 0.5 foot is of no practical sig nificance in the computation of elevations of the reser- voir bottom, because it is within the limit of accuracy of the soundings. The Hoover Dam gage record was thus sufficiently accurate to be used without correction for conversion of the sounded depths to bottom elevations, and adjustment of the preliminary bottom elevations, as computed daily throughout the course of the survey, was not required.

\section{SELECTION OF REFERENCE DATUM}

When the gage at Hoover Dam was installed in 1935, it was referenced to sea-level datum by leveling from bench marks whose elevations were derived originally from the general adjustment of 1912. This datum is known locally as the powerhouse datum.

Since 1935 the setting of the gage has been checked periodically by leveling from convenient bench marks to the lake surface and comparing the elevation obtained with the gage reading. Different evaluations of the bench-mark elevations have resulted in differences in gage settings. Comparisons between the elevation figures actually used from time to time and the true elevations above the datum of 1929 , leveling of 1935 , indicate that the difference was only 0.18 foot during the 1935 survey made for the Soil Conservation Service, and was about 0.5 foot from 1937 to 1948 . Starting in September 1948, correct elevations above powerhouse datum have been used and the resulting difference has been 0.55 foot. The temporary datum planes have been high in all cases. The gage readings on which the channel cross sections for the 1935 survey were based are in error by less than 0.2 foot, and well within the limits of accuracy of the computations. Gage readings during the present survey, when referenced to powerhouse datum, require an adjustment of plus 0.55 foot to correct them to the datum of 1929 , leveling of 1935 .

So far as the computations of capacity are concerned, the method of vertical control used in the hydrographic survey permits the computer to choose his reference plane (provided he adheres to the same reference plane consistently). Specifically, the method of survey ties the elevation of reservoir bottom to the dam, and the capacity is fixed by the relation of the dam to the reservoir, rather than by the relation of either to sea level.

In chapter I the tables of area and usable capacity are computed for elevations based on powerhouse datum, and the elevation of the spillway (1205.4 feet) and of the gates in raised position (1221.4 feet) are referenced to the same datum. However, the tables of capacity and sediment storage by basins, and the comparisons between 1935 and 1948, are computed for elevations based on the datum of 1929 , leveling of 1935, which was the datum used in the original (1935) computations of reservoir capacity. From this datum the elevations 
at the dam as well as all elevations of reservoir bottom are 0.55 foot greater than those measured from powerhouse datum; the capacity of the reservoir is of course the same regardless of the datum used, but the capacity at each indicated elevation, if measured above the datum of 1929 , is slightly less than if measured above powerhouse datum.

If the gage readings (and hence the bottom elevations) are computed on the basis of the elevations determined by more recent leveling (such as the leveling of 1941 or 1950), then the storage at each indicated elevation will be somewhat greater than that for the same elevation above powerhouse datum, but the capacity when full remains the same because the elevation of the spillway is less by the same amount.

\section{SOUNDING OPERATIONS}

\section{By Lt. C. C. McCall, USN}

Sounding operations were carried out in the manner prescribed by the Navy Hydrographic Office. Each of the Navy personnel on the survey received preliminary training at the Hydrographic Office in the methods and techniques of conducting a hydrographic survey. The training included instruction in horizontal-angle readings by use of the sextant, correct timing procedure, the proper keeping of records in a sounding journal, and plotting by use of the three-armed protractor. Upon their arrival at Lake Mead, the group was given final instruction and training in teamwork by M. R. Ullom of the Hydrographic Office. After several days of training, the sounding crew was running lines that would meet the standards required for a hydrographic survey. This trained crew conducted all sounding operations throughout the survey.

At the start of each day's work the following checks were made on the equipment used on the survey: sextants, for accuracy; motor speeds of echo depth sounders (a check that was repeated at intervals during the day) ; and zero setting of the recorder. Calibration of the echo-sounding instruments was also checked daily by use of a "check bar" lowered on an accurately measured cable to depths of $30,60,90$, and 120 feet. From these readings the velocity of sound in water was determined for the day's sounding operations. A few comparisons were made with wire-line soundings over relatively flat areas of hard bottom, and these indicated agreement with the bar checks. The relation of recorded depth to true depth varied with the water temperatures, and these variations were found to follow closely the differences in computed sound velocities for the various temperatures. Recorded soundings were corrected accordingly before conversion to bottom elevations.
In preparation for running each sounding line, the sounding boat was maneuvered to the line position by study of approximate fixes plotted on the boat sheet, on which the sounding lines had already been drawn. After the boat was on position to start the line, the sounding clock and echo sounder were started and a fix was taken. When the sound boat was underway every effort was made to follow the straight course.

Boat speeds during sounding operations varied with the conditions. When sounding over hard bottom in open water, a speed of approximately 5.5 miles per hour was maintained. However, over thick sediment deposits it was sometimes necessary to slow to approximately 3.5 miles per hour to get a clear recording on the sound trace. During close inshore sounding, the boat speed was reduced to about 2 miles per hour to give a safety factor against possible grounding. Most of the hazards to navigation had been marked on the boat sheets from the topographic maps of the Fairchild Survey, but, from early experience in Boulder Basin, it was found necessary to keep a sharp lookout from the bow of the sounding boat when approaching the shoreline.

During the travel of the sounding boat along a line, fixes were taken at intervals of 2 minutes. Anglemen read angles between three established signals placed on the shoreline. The left angleman observed the angle between the left and center signals; the right angleman, the angle between the center and right signals. These angles were observed by using a sextant in the horizontal position, and the images of the signals were continually superposed during the counting period. The angles were read to the plotter, who set them upon a three-arm protractor and plotted boat position on the boat sheet. The line was acceptable if one fix was missed but not acceptable if two consecutive fixes were missed.

Soundings were recorded in the sounding journal every 15 seconds and fixed or marked on the sound trace every 2 minutes or whenever a fix was taken. At this time the number of the fix was recorded on the chart and also in the sounding journal. A check was made between the soundman and the recorder every fifth fix to make certain that all recordings were in continuity and agreement.

As the end of each 2-minute sounding interval was approached, the recorder gave the anglemen a 30 -second warning, then a 10 -second warning, and at the 5 -second mark would start counting the remaining seconds, until the end of the 2-minute interval was reached, when he would call "Mark." At this time the anglemen read to the recorder the angles observed, and those angles were plotted immediately to determine whether the boat was traveling along a satisfactory course. 
Each of these plots was numbered on the boat sheet with the identical fix number recorded by the recorder and the soundman.

In calm water it was possible to run a full line without a course change, but in rough weather it was necessary at times to make changes in course in order to follow the designated line. These course changes were made as near to a fix as possible, or to the 1-minute interval halfway between fixes, to facilitate the processing of the smooth sheets.

\section{LOW-FREQUENCY DEPTH-RECORDING EQUIPMENT}

By W. C. Blaisdell, National-Simplex-Bludworth, Inc.

Two types of low-frequency depth-recording equipment were used at Lake Mead-namely, the U.S. Navy type NJ-8 depth recorder equipment and the U.S. Navy type NK-6 portable depth recorder equipment. Both were designed to produce rapid, accurate, automatic, and permanent records of depths of water by the method of ultrasonic echo sounding. They were selected for use in Lake Mead because the frequency of $14.25 \mathrm{kc}$ used for the transmission of sound through water insured great penetrating power, making it practicable to obtain reflections from the top layer of any sediment or other body of distinctive density. By this means an accurate record in depth of each successive change in the density of the medium was obtained.

An annular reflector reflects all the transmitting energy from the transducer pack vertically downward, causing high intensity of the beam through the medium. Similarly, the use of the same type of reflector in the receiving transducer enables it to pick up very small returning echoes. In addition, the intensity of the reflected signal can be adjusted so as to differentiate clearly between the mediums of reflection.

\section{NJ-8 DEPTH-RECORDING EQUIPMENT}

The NJ-8 depth-recording equipment is a permanently installed, rapid-recording, echo-sounding instrument designed for use in shallow to moderately deep water, operating at 2 ranges: 200 feet and 200 fathoms. It meets Navy requirements in shock and vibration tests. It consists essentially of 4 separate units: a recorder cabinet containing the graphic recording mechanism and echo amplifier, a signal sender, and the transmitting and receiving transducers. A 115-volt ( \pm 0.5 percent), 60-cycle ( \pm 1.5 cycles), single-phase, a-c power supply of approximately 260 watts is required. If the ship's power supply is $24,32,115$, or 230 volts dc, a suitable motor-alternator set, having a power consumption of approximately 600 watts, and a fuse and relay cabinet for remote starting of the alternator are supplied.

\section{RECORDER}

Recorder cabinet.-The recorder cabinet, which houses the recording mechanism as well as the amplifier chassis, is of three-piece cast-aluminum construction. The entire front breaks open into two doors (pl. 8). The upper door provides access to the recorder mechanism and the lower door allows for the servicing of the amplifier. Both doors are drawn securely shut against a rubber gasket by a locking handle. Interlock switches close the power circuits.

The operating controls, located on the covers, consist of a four-position rotary power switch, a two-position range switch, a gain control, and a fix button. The rotary power switch, in successive positions, disconnects the power supply from the entire equipment, maintains the amplifier ready for operation, and connects power to the mechanism drive motor. The range switch in "feet" position provides for depth recordings up to 200 feet, and in "fathoms" position to 200 fathoms. Depressing the "fix" button records a horizontal line the full width of the chart for reference purposes.

The record paper is of a dry facsimile type, impregnated with conductive materials and surface coated with an electro-sensitive substance that turns black upon the passage of electricity. The recording is visible through a shatterproof glass port on the cover, and this port may be raised to record bearings or other pertinent data.

Recorder mechanism.-This unit is resiliently mounted in the upper part of the cabinet. The mechanism consists of a $1 / 50-\mathrm{hp}, 1,800-\mathrm{rpm}$ synchronous motor, a gear box and positive clutch, a drum upon which a spiral wire is carefully positioned, a positivedriven paper-propulsion device, a main adjustable keying assembly, a cam-actuated auxiliary keying switch and associated phasing switch, a zero button, a printer bridge assembly, and a fathoms-marking contact.

The drum, paper-propulsion device, and cam shaft are driven by the motor through the positive clutch and reduction gear box. The drum rotates at $600 \mathrm{rpm}$ on the feet range and $100 \mathrm{rpm}$ on the fathoms range, and the cam shaft rotates at one-third the speed of the drum. Because an impulse is transmitted with each revolution of the cam shaft, recordings are made at rates of 200 per minute on the feet range and $331 / 3$ per minute on the fathoms range. The paper-propulsion device positions the recording chart paper by guide rollers and moves it over the drum and under the printer blade at the rate of 1 inch per minute on the feet range and $1 / 6$ inch per minute on the fathoms range. 


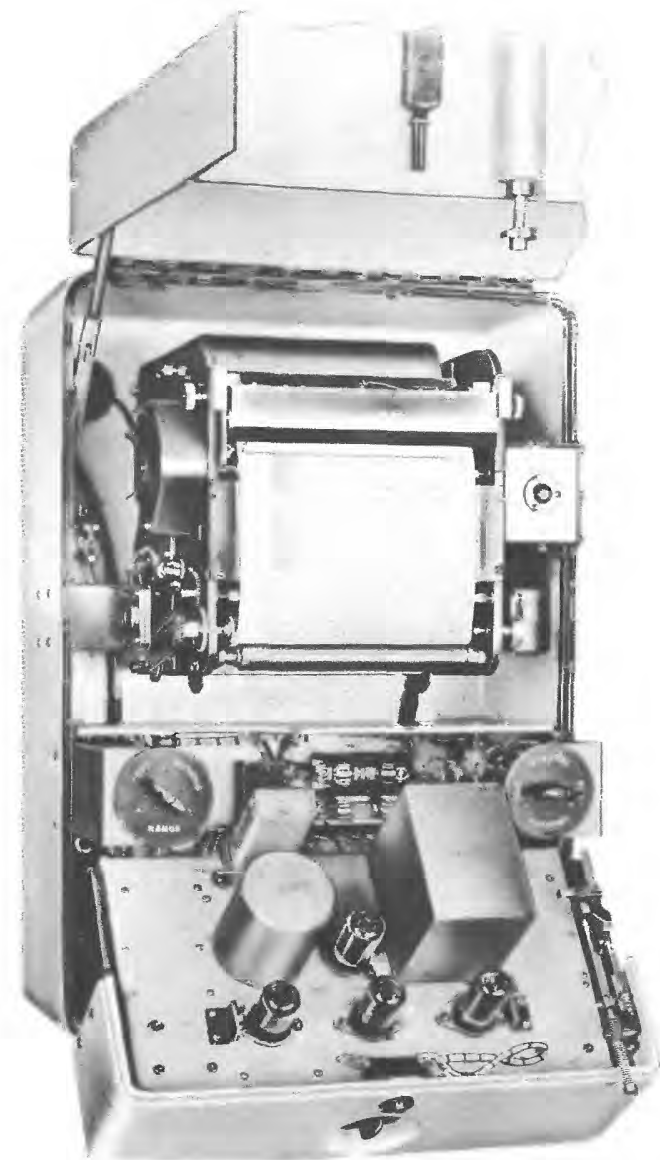

NJ-8 RECORDER, OPENED FOR INSPECTION OR SERVICING 


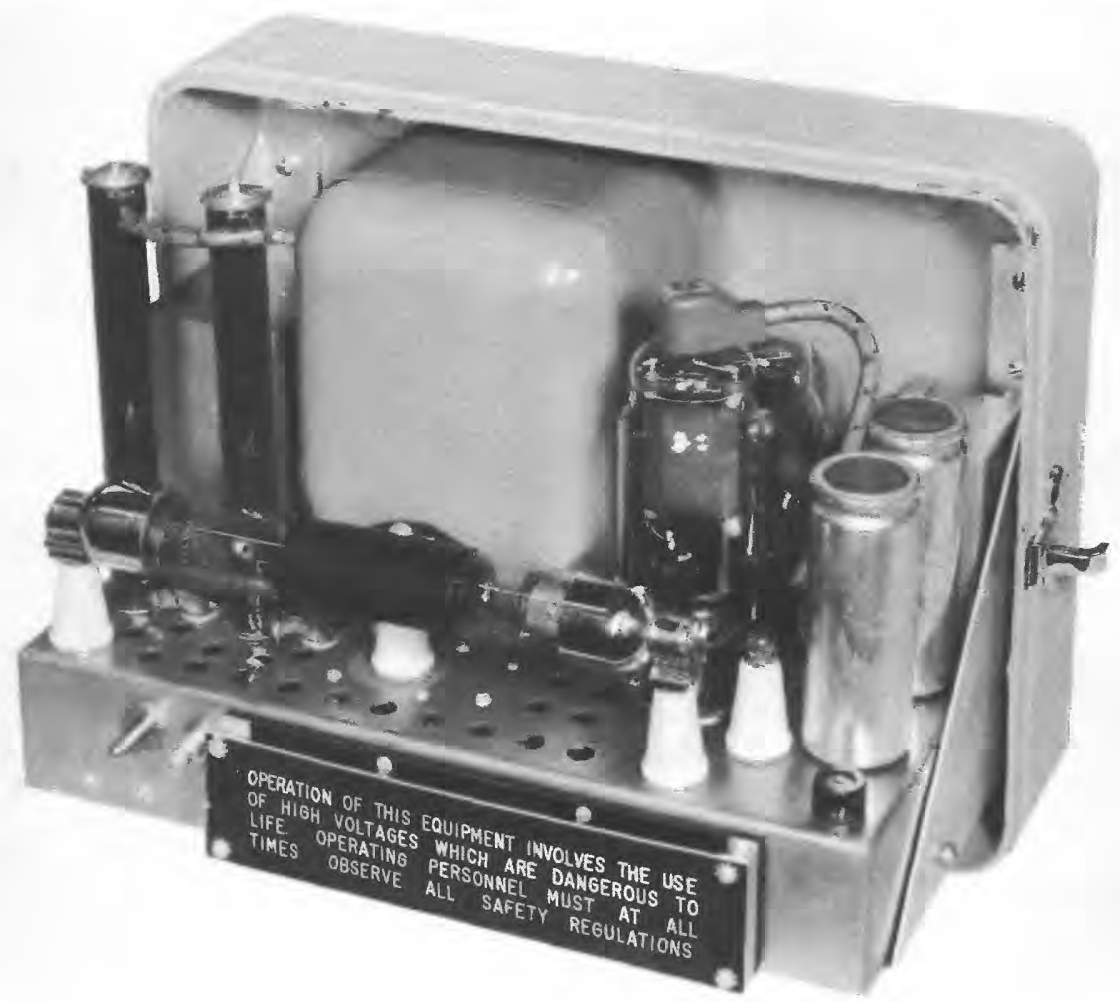

A. NJ-8 DRIVER-RECTIFIER, SHOWING HORIZONTALLY MOUNTED STROBOTRON TUBE

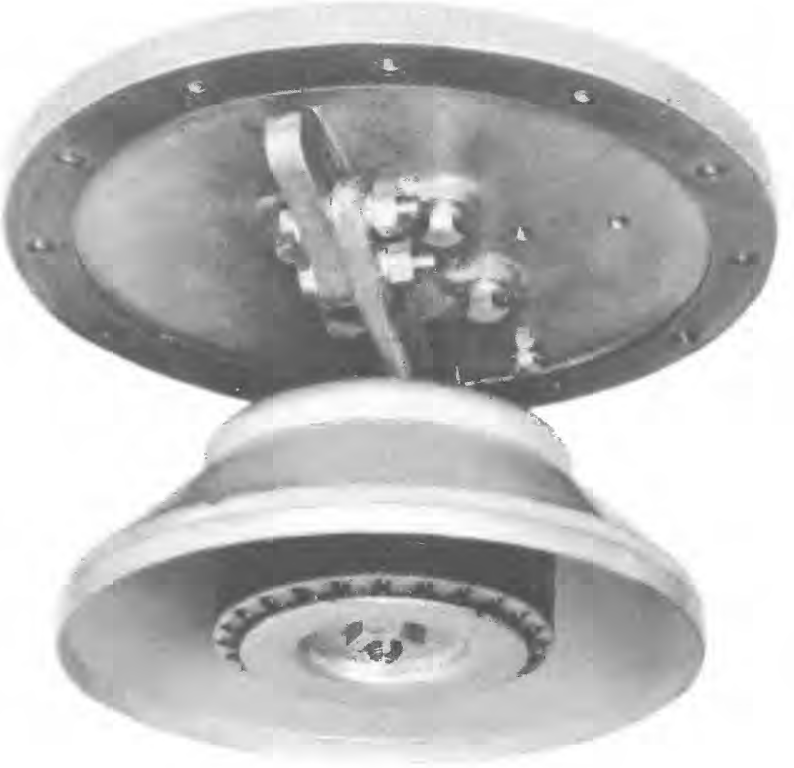

B. NJ-8 TRANSDUCER, SHOWING CONICAL REFLECTOR HANGING FROM CASE COVER Inside the reflector can be seen the stack of torroidally wound nickel laminations. 
The auxiliary keying switch is in series with the main keying brush and is closed by the cam for a short interval, once each revolution of the cam shaft. The switch is adjustable for proper closure and synchronization so that when this switch and cam are properly adjusted with reference to each other and to the main keying assembly, the keying circuit is closed with every third revolution of the recording drum and an impulse is sent to the transmitting transducer.

The phasing switch is in series with the amplifier output and the printer blade. This switch can be adjusted in the same manner as the auxiliary keying switch so that recording is limited to the first revolution of the drum after keying, thus avoiding false depth recordings. The cam-rise surface is of such length that recording is obtained the full length of the drum. Thus, proper synchronization between transmitted and received signals is obtained, and the position of the recording on the chart is a direct indication of the depth of the water below the transducers.

The printer bridge assembly contains the printer bar, to which is fastened the printer blade, two pilot lights for illuminating the observation area, and an adjustable fathom-marking stylus. When the range switch is in the fathoms position, voltage from the amplifier power supply is applied to this stylus, and when it is adjusted so that it rests on the chart paper, a recording is made. Thus a vertical line is recorded in the left margin of the paper as a reference that the recordings are in fathoms. After a recording has been removed from the instrument it is possible to distinguish between feet and fathoms by means of this marginal identification. The printer blade and spiral wire are in contact through the paper at only one point at any given instant. An electrical impulse, received by the printer blade at the moment of contact, ares through the paper, leaving a permanent black dot. Successive dots form the chart recordings. The range marking in the left margin is recorded in the same manner.

Echo amplifier.-The amplifier is a self-contained unit consisting of a tuned input transformer, four resistance-coupled voltage-amplification stages, and a power stage with a tuned output transformer. It has its own power transformer and rectifier tube for plate supply.

It is designed to receive a signal pulse at $14.25 \mathrm{kc}$ and, subject to the setting of the gain control, to amplify this signal voltage sufficiently to produce a permanent record on the recorder chart by the arcdischarge method. The amplifier components are mounted on an aluminum chassis, which is shockmounted on the lower door of the recorder cabinet.

\section{DRIVER-RECTIFIER OR SIGNAL SENDER}

A resiliently mounted cabinet, with a cast bronze base and a ventilated sheet metal cover, encloses the electronic circuits that produce the electrical impulses required by the transmitting transducer. The filtered supply from a low-voltage rectifier tube stores energy in a capacitor, which, in turn, is discharged through the strobotron transformer each time the keying contacts are closed in the recorder. The resulting pulse, delivered to the strobotron ( $\mathrm{pl} .9 \mathrm{~A}$ ), causes this tube to flash through the discharge tube transformer, in turn producing an extremely high potential pulse that is applied to the discharge tube. Ionization of the gas in this tube causes it to conduct, thereby releasing to the transmitting transducer, in the form of an intense pulse, the energy that has been stored in the capacitor by the high-voltage rectifier. The very high current induced in the transducer produces the magnetostriction effect desired.

Part of the output energy of the signal relay is fed back to the recorder mechanism through the zero-depth button to the printer blade, for the purpose of recording a zero-depth mark on the chart.

\section{TRANSMITTING AND RECEIVING TRANSDUCERS}

The transmitting transducer converts electrical impulses from the echo sender, under the control of the keying switches in the recorder, into pressure waves that pass through the water to the bottom and from there are reflected back to the receiving transducer. The receiving transducer converts the pressure waves to electrical impulses, which, when amplified, mark the chart in the recorder.

Each transducer consists of a stack of torroidally wound nickel laminations (pl. $9 B$ ), mounted in a reflector lined with cellular rubber, which, in turn, is mounted on an adjustable bracket, allowing compensation for a dead rise of the bottom hull plate up to $15^{\circ}$. This unit is enclosed in a cylindrical housing that is bolted to a leveling ring, which must be welded to the outer skin plate of the ship with the transducer diaphragm in contact with the water. The housing is filled with castor oil.

The transducers may be mounted either fore and aft or athwartships across the keel. For accurate shoal soundings they should not be placed more than 6 feet apart. The operating frequency of the transducers, $14.25 \mathrm{kc}$, is outside the range of interference from ordinary water noises such as chafing objects.

The impulses from the echo sender set up a magnetic field in the laminations of the transmitting transducer. The laminations contract as the field increases and expand as the field decreases. The effect is known as 
magnetostriction, which sets up mechanical vibrations that are transmitted through the liquid within the transducer housing. These vibrations are transmitted to the water and thence to the bottom, where they are reflected back to the receiving transducer.

The receiving transducer is identical with the transmitting transducer; it is mounted in the same way but is premagnetized by a momentary impulse of direct current. The reflected vibrations are transmitted to the liquid in contact with the laminations, causing expansion and contraction of these laminations and thereby a change in the magnetic field in the receiving transducer. This change in the magnetic field induces an electrical impulse in the winding of the transducer, and the impulse is transmitted to the input of the echo amplifier through the interconnecting wires.

\section{MOTOR-ALTERNATOR SET}

The speed of the mechanism is strictly dependent upon the frequency of the output of the motoralternator set, and proper operation of the equipment can be attained only when this frequency is held within 0.5 cycle of 60 cycles per second. Frequency regulation is accomplished by means of a centrifugal governor, operating across a resistor in series with the shunt field in the motor of this unit, so that speed changes cause the contacts to open or close, thereby tending to oppose speed changes by field compensation.

A magnetic controller, suitable for use with the motor-alternator set, is supplied as an accessory for use when required. It contains a relay for remote starting of the motor-alternator set, a capacitive filter for prevention of radio interference, and protective fuses in the d-c supply to the motor-alternator set. The relay operates from the ship's d-c supply under the control of the power switch on the cover of the recorder.

\section{NK-6 PORTABLE DEPTH-RECORDING EQUIPMENT}

The NK-6 depth-recording equipment is a semiportable supersonic, rapid-recording, echo-sounding instrument designed for use in shallow to moderately deep water and for temporary installation in a launch or vessel.

The instrument operates in two ranges, 200 feet and 200 fathoms. It consists essentially of three separate units: a recorder cabinet, containing the graphic recording mechanism, signal sender, echo amplifier, and motor-speed indicator; a submersible unit containing the transmitting and receiving transducer; and a 12volt storage battery. The power consumption is approximately 120 watts at 12 volts dc.

\section{RECORDER}

Cabinet.-All essential parts of the NK-6 recorder, except the transmitting and receiving transducers and the battery, are in one metal case, which has an additional canvas cover for protection from the weather. The operating controls consist of a four-position rotary power switch, a two-position range switch, a gain control and a "fix" button. A motor-speed indicator and voltmeter are located on the cover. The recording is visible through a shatterproof glass port on the cover and this port may be opened to record bearings or other pertinent data on the chart.

Recorder mechanism. - This unit is resiliently mounted in the left compartment of the recorder case. It consists of a $3600 \mathrm{rpm}$, series-wound, governor-controlled, 1/30-hp drive motor; a gear box and positive clutch; a drum upon which a spiral wire is carefully positioned; a positively driven paper-propulsion device; a main keying assembly; the cam-actuated auxiliary keying switch and associated phasing switch; a printer bridge assembly; a fathoms-marking contact, to record a vertical line in the left margin of the chart; and a two-hole permanent magnet alternator directly connected to the drive motor shaft, which furnishes a-c power to operate the reed tachometer used for the motor-speed indicator (pl. 10A).

The drum, paper-propulsion device, paper, method of marking, cam shaft, and auxiliary keying and phasing switches of the NK-6 equipment are similar to and operate like corresponding equipment in the N.J-8 recorder mechanism.

When the range switch is set on fathoms, the fathoms solenoid operates and transfers the clutch in the gear box from the feet to the fathoms position and reduces the speed of the drum and cam shaft. It also applies voltage from the rectifier circuit of the driverrectifier to the fathom-marking contact. This contact is adjustable so that when it is properly positioned with respect to the spiral wire on the drum, a recording is made on the chart paper. Thus, a vertical line is recorded in the left margin of the paper as a reference that the recordings are in fathoms. When the range switch is in feet position, the feet solenoid operates and transfers the clutch to the feet position.

Signal sender and echo amplifier.-The unit is resiliently mounted in the right-hand compartment of the sounding recorder.

The driver-rectifier section of the chassis consists of a nonsynchronous vibrator, which in conjunction with the step-up transformer and the full wave rectifier tube, furnishes high voltage to charge a capacitor and also screen and plate supply for the receiveramplifier. At the instant the main keying brush 


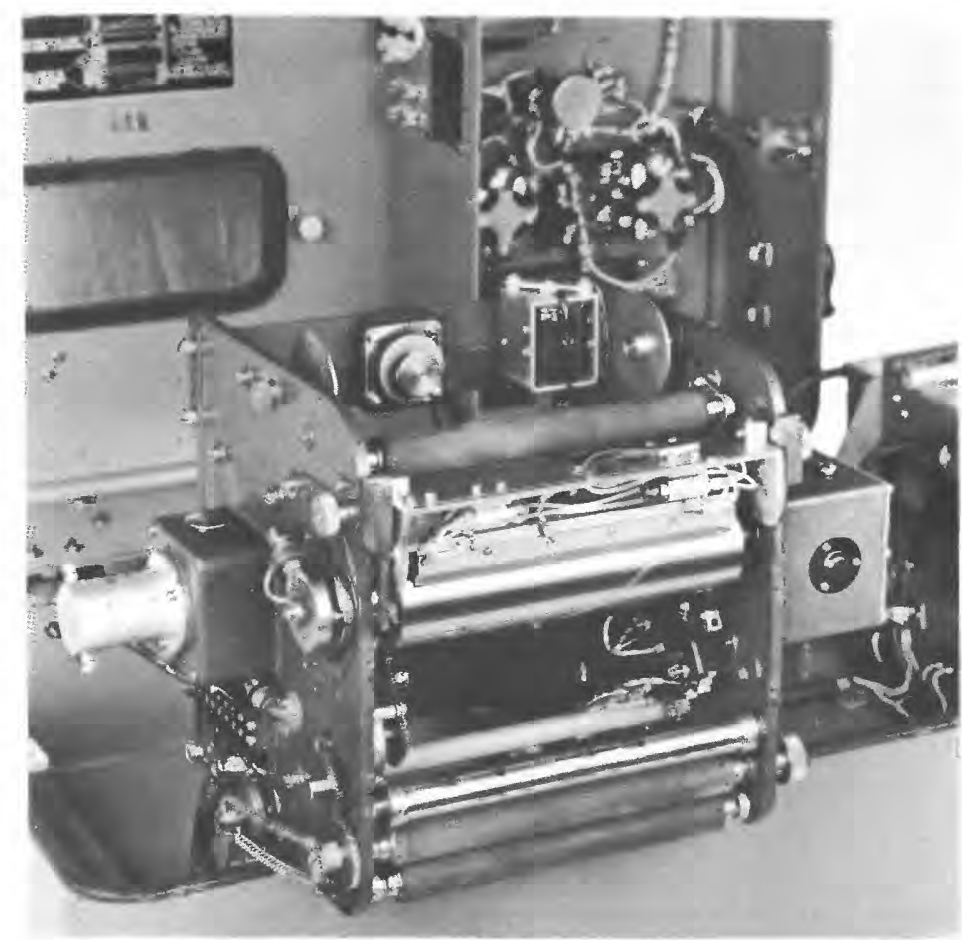

A. NK-6 RECORDER, SHOWING CAREFULLY POSITIONED SPIRAL WIRE ON DRUM

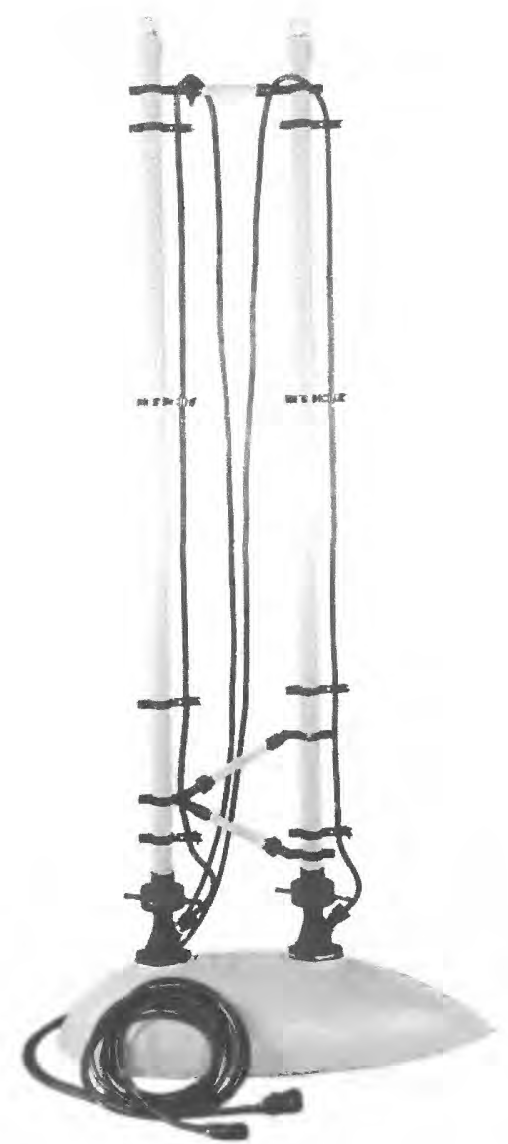

B. NK-6 SUBMERSIBLE UNIT, CARHYING TRANSMITTING AND RECEIVING TRANSDUCERS This is a portable overside-mounting arrangement. 


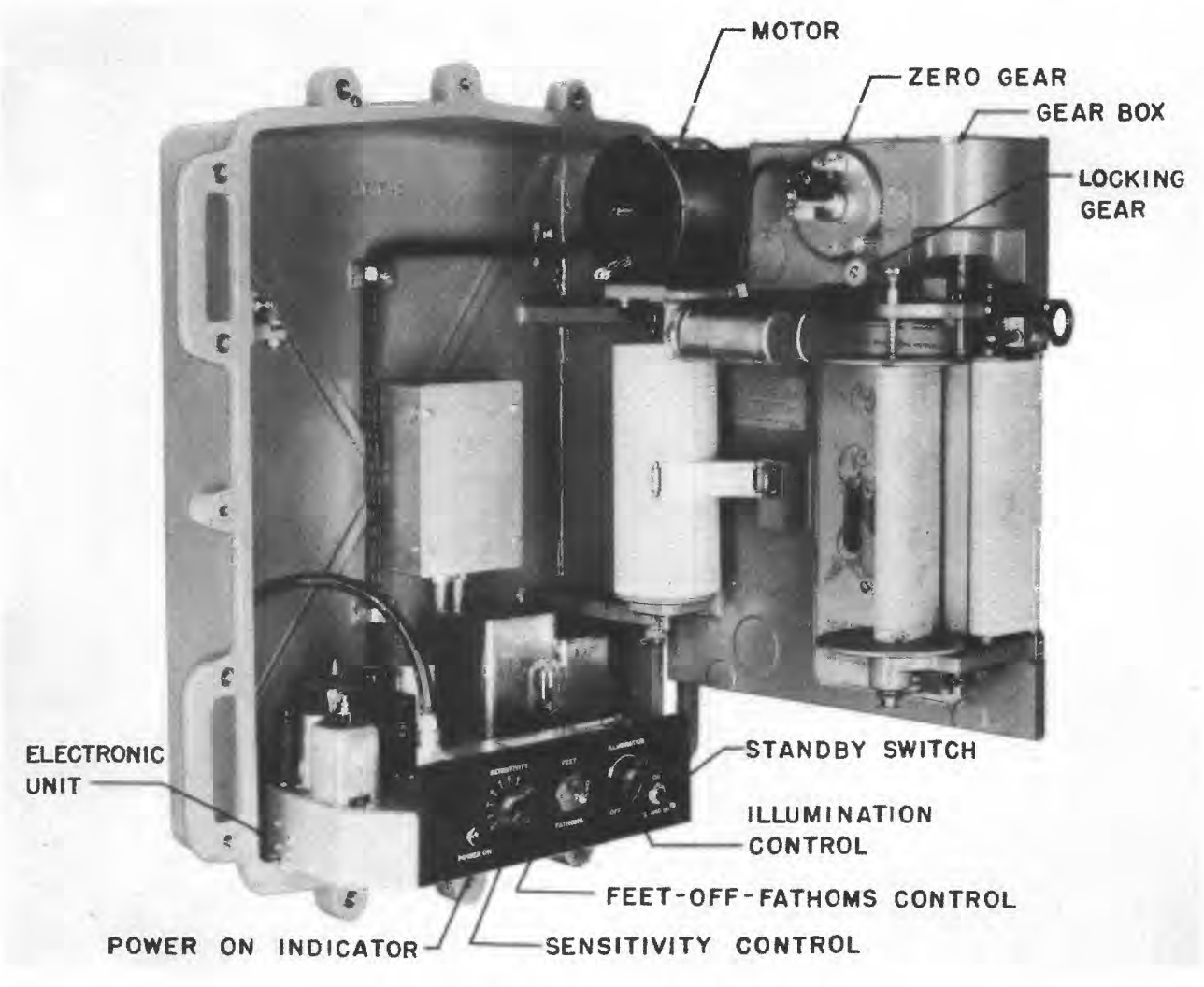

A. NGB-3 DEPTH RECORDER, INSIDE VIEW

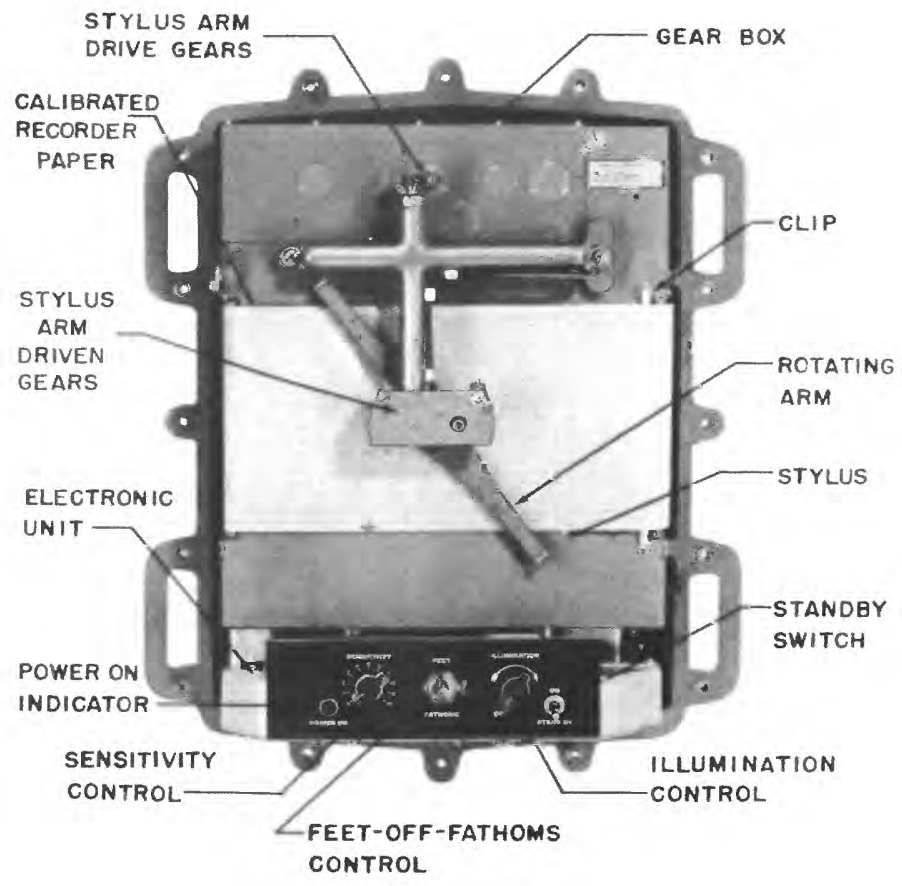

B. NGB-3 DEPTH RECORDER, SHOWING RECORDING UNIT 
and the auxiliary keying switch make contact, current flows through the primary of the step-up transformer, and induces a voltage in the secondary which ionizes the gas in the gaseous discharge tube (strobotron), thereby discharging the capacitor through the transmitting transducer. A part of the discharge is impressed on the cathode of the first tube in the amplifier to record a zero signal on the recording chart paper.

The reflected impulse is conducted from the receiving transducer to the input transformer of the amplifier section of this chassis. The amplifier is a threestage resonant type, tuned to a frequency of $14.25 \mathrm{kc}$. The second stage is resistance coupled, and the input, output, and third stages are transformer coupled. The output is connected through an isolating capacitor and the phasing switch to the printer blade. The sensitivity of the amplifier is controlled by adjustment of the gain potentiometer, which varies the bias of the second stage. The signal energy is amplified sufficiently to produce a permanent record on the chart by the arcdischarge method.

\section{SUBMERSIBLE UNIT}

The submersible unit (pl. 10B) consists of a transmitting and receiving transducer in a streamlined cast aluminum housing, 37 inches long and 14 inches wide. Each of these transducers is magnetostrictive and consists of a stack of thin annular nickel stampings, mounted on a spindle inside an air-filled reflector and immersed in castor oil. Each pack is torroidally wound with an energizing coil of neoprene insulated wire. The operating frequency of the transducer is $14.25 \mathrm{kc}$. The transmitting and receiving transducers are identical in all respects, except that the receiving unit is permanently magnetized. This submersible unit should be installed so that its bottom is at least 2 feet below the water surface and on a horizontal plane and its axis parallel with the center line of the vessel. There should be at least 1 foot clearance between it and the vessel.

\section{HIGH-FREQUENCY DEPTH-RECORDING EQUIPMENT}

By Robert P. Geddes, Jr., and Birt Blackman, Bendix Aviation Corp.

\section{NGB-3 DEPTH-RECORDING EQUIPMENT}

The principal high-frequency depth-recording equipment used at Lake Mead was the U.S. Navy type NGB-3 depth-recording equipment. It is designed to measure depth in water by the echo method and to chart that information on recording paper. The instrument operates at a frequency of $50 \mathrm{kc}$. It receives and amplifies the echo, measures the intervening time interval, and records this interval as a depth measure- ment that is subject to correction for temperature and other factors. It can record depths between the limits of $21 / 2$ feet and 50 fathoms. This equipment was selected because of the sharp definition it developed between the water and the top of the sediment layer, even when the sediment layer was thin and the difference in density slight.

This depth recorder is designed for two depth ranges: from $2 \frac{1}{2}$ to 50 feet, and from 1 to 50 fathoms. When the "feet" range is used, ultrasonic impulses are sent out at the rate of 576 per minute. When the "fathoms" range is used, 96 pulses per minute are transmitted. The equipment comprises a principal housing, a transducer (the diaphragm of which is submerged in water), and interconnecting cables. The principal housing is $233 / 4$ inches high, $183 / 4$ inches wide, 11 inches deep, and weigh about 90 pounds. The recording unit and the electronic chassis are inside the housing ( $\mathrm{pl} .11 \mathrm{~A}$ ). The electronic chassis has a subchassis, which mounts a vibrator power supply unit that is interchangeable with other units having different input voltages; a 24-volt unit drawing 2.75 amperes was used in the survey.

The recording unit ( $\mathrm{pl} .11 B)$ has a pivoted rotating arm, which carries the marking stylus. The arm is driven at high or low speed depending upon the "feetoff-fathoms" switch setting. Calibrated paper is pulled horizontally across the face of the platen and over a stainless-steel grounding plate. The recording of echoes is accomplished by means of an are that burns the paper surface at the point of contact between stylus, paper, and stainless-steel grounding plate, causing the initial pulse and returning echoes to appear as a dark trace. The calibration of the paper is in either feet or fathoms at option. The initial mark on the "feet" position appears as a long dark trace at 0 to approximately the $21 / 2$-foot mark on the paper. The initial trace on the "fathoms" position appears as a narrower and much darker trace and can be distinguished readily as a fathom trace, thereby identifying the marks left on the paper as definitely in feet or fathoms.

The transducer is $81 / 4$ inches high and 5 inches in overall diameter, and it weighs approximately 3 pounds. It is connected to the electronic unit contained in the principal housing by means of a twin-axial cable. The electrical energy is converted into 50-kc mechanical impulses in the transducer crystals. Returning echoes are reconverted into electrical energy by the transducer and are delivered to the electronic unit through the transducer cable. In operation the transducer diaphragm is pointed downwards with a tilt not over $5^{\circ}$ from horizontal. The transducer may be completely submerged in water. 


\section{CIRCUIT ANALYSIS}

The electrical circuits of the NGB-3 depth recorder are shown diagrammatically in figure 14. Primary power is channeled to the power supply through a jack in the principal housing and is fed to a "hash" filter circuit, composed of inductors and capacitors. One leg is in each side of the line and the winding is such that the two fields cancel out. Primary power continues through the jack and switch to where the power supply is plugged in. All input power supplies must furnish 110 volts ac at 60 cycles for the synchronous induction motor, 250 volts de at 15 milliamperes to power the electronic unit, and 6 volts for the filaments and lamps. The power supply includes a typical full-wave rectified circuit using a 6X5GT tube. Transformers are furnished with an electrostatic shield between the primary and secondary windings, and an electrostatic lamination shield is built into each transformer. Each is fed to the feet-off-fathoms switch, and current for phase 2 field of the synchronous motor flows through the electronic unit jack and principal housing plug. A 3- microfarad power-factor correcting capacitor is connected across the 110-volt a-c line to provide proper phase relation. The motor phase-shifting capacitor is connected in series with phase 1 winding of the synchronous motor and connects back to the feet-offfathoms switch. Reversal of the motor is accomplished by reversing the position of phase 1 winding of the motor across the 110-volt a-c line.

The single-phase induction motor operates with no electrical connection to the rotor. It has two stator windings in which a rotating field is established. The rotor turns mechanically because of the reaction of heavy circulating current against the rotating field around it. A capacitor in series with phase 1 winding provides a calculated phase lag for motor starting. Direction of rotation is reversed by reversing the connections of phase 1 stator winding in the switch.

Timing.-Timing of the outgoing initial impulse is originated by a contact cam mounted on a shaft extending through the rear of the gear box assembly. The switch closes at the instant that the stylus arm is

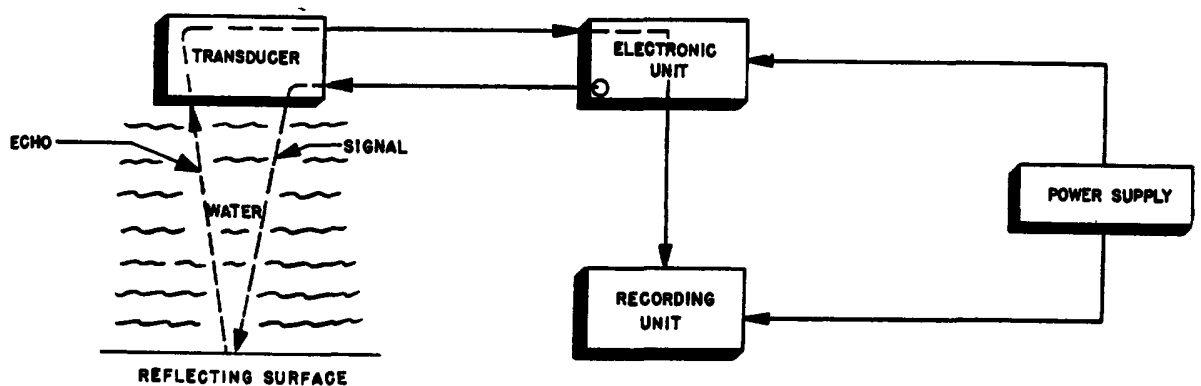

A

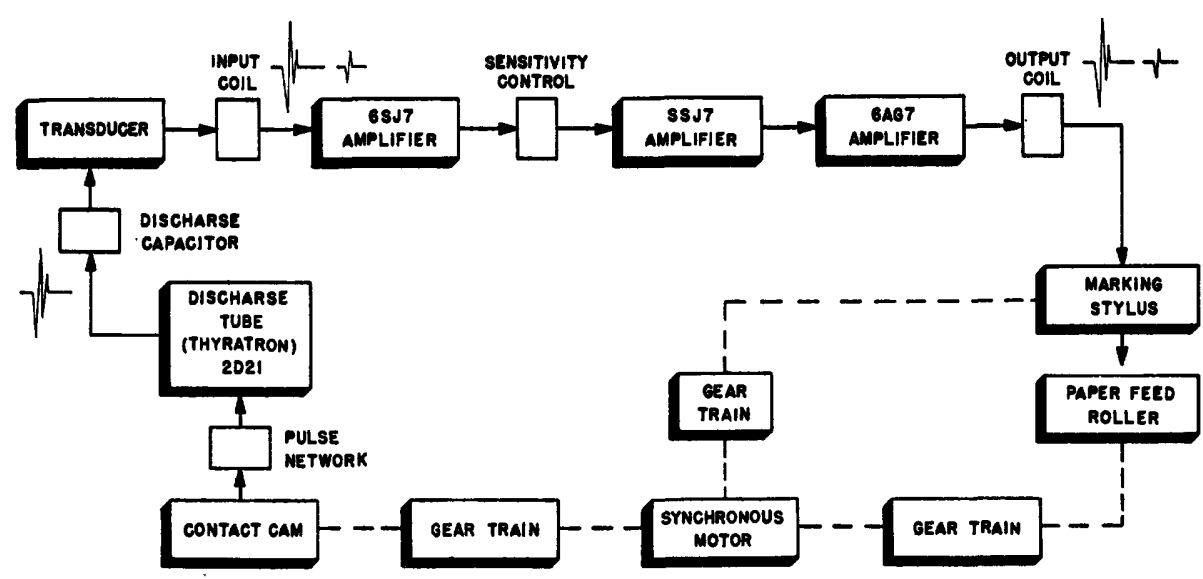

B

FigURe 14.-Block diagrams illustrating electronic circuits and principle of echo sounding. $A$, Principle of echo sounding; $B$, Operation of echo sounder. 
rotating past the 0 mark on the calibrated paper. Coaxial cable is connected through connectors and jacks to the pulsing capacitor. The pulse is received at the thyratron tube grid, as this grid is negative and is merely driving the tube into a region of greater cutoff. However, when the switch is opened a sharp positive pulse appears momentarily at the control grid, causing it to fire and discharge the capacitor through the autotransformer type of inductor in the transducer housing. At the same time, a voltage appears across the seriesresonant circuit, causing a neon glow tube to fire and rapidly quench the oscillations that have begun to take place in the entire circuit. A short initial pulse is thus fed through the electronic unit amplifier and appears as a zero mark on the calibrated paper.

Transmission.-Shock excitation is produced in the autotransformer transducer coil in the process of discharge through the thyratron. A large pulse of electrical energy shock excites the 50-kc resonant circuit in the transducer and produces a dampened wave. The crystal assembly in the transducer converts the electrical energy into 50-kc mechanical energy by virtue of its piezoelectric property. This energy goes into the surrounding castor oil in the transducer, which in turn transfers it through the rubber diaphragm into the water.

Reception.-The signal progresses through the water to a reflecting surface and returns to the transducer in the form of an echo. The crystal assembly in the transducer, having reversible piezoelectrical properties, converts this reflected energy back into electrical form. The output of the transducer unit goes back through the cable system in the reverse direction. The incoming pulse appears across the grid and is amplified in a conventional manner through electronic tubes. The sensitivity control is placed in the control grid of one of these tubes and serves to regulate over-all gain in the amplifier. Actual marking of the paper occurs in the same sequence as for the initial pulse previously described.

\section{EVALUATION OF THE ECHO SOUNDING}

By G. B. Cummings and C. E. Mongan, Jr., U.S. Bureau of Ships

The sonar equipment and methods used to determine the depth of water and thickness of sediment in Lake Mead are based on the echo-sounding principle: a pulse of sound energy is emitted from a projector, travels through the water, is reflected, and returns as an echo to the projector, which has been arranged in the meantime to receive the echo. The echo can then be recorded in various ways, such as on a cathode ray screen or on the paper chart of a recorder.
Several factors were considered in choosing the echo sounders used. The difference in density between the water and the top of the sediment layer was very small in some localities, and relatively high-frequency ultrasonic waves (50 kc or more) were required for the accurate determination of the depth to this interface between the water and the sediment. In contrast, relatively low-frequency waves $(14.25 \mathrm{kc})$ were used to penetrate the sediment layers down to the hard bottom. It was also desirable to arrange for switching and cross hookups between the component parts of several equipments, in order to provide flexibility of use and continuous operation.

Most of the sounding of Lake Mead was done with the Navy type NGB-3 depth-recording equipment, operated at $50 \mathrm{kc}$, and by the Navy model NJ-8 depthrecording equipment, operated at $14.25 \mathrm{kc}$. The Navy model NK-6 portable depth-recording equipment, which also operates at $14.25 \mathrm{kc}$, was used for some observations. In addition, depth-recording equipment with a frequency of $88 \mathrm{kc}$ was used experimentally.

The NJ-8 echo depth sounder had been installed by the Naval Base at San Diego prior to shipping the boat to Boulder City. The transducers were installed in the bottom of the hull of the picket boat, amidship and as close to the keel as possible. During the first phase of the survey this installation was satisfactory, but later on portable transducers were used with the NJ-8.

The first sounding operations were made with the NJ-8 exclusively; it was found that this equipment gave a very clear picture of the sediment deposits in the old river bottom. As this was a desired finding, it was decided to use only the NJ-8 when the surveying was over the old river bed. When it was not over the old river bed, the NK-6 or NGB-3 was used for sounding. The NK-6 is designed to use the same transducers as the NJ-8, and switching arrangements were developed to use the same transducers and power supply for both equipments. The NK-6 gave a very good recording trace and was much simpler and easier to maintain than was the NJ-8. Sounding operations utilizing the NGB-3 recorder produced a sound-trace recording that was dark and easy to read.

\section{ANALYSIS OF RECORDS}

The NGB-3 equipment, operating at $50 \mathrm{kc}$, gave a consistent indication of the top of the sediment. Sound of this frequency did not penetrate the sediment. Where the sediment was very thin, the trace of the interface was slightly fuzzy. Independent determinations showed that the transition layer was 1 to 4 inches thick. 
The instruments operating at $14.25 \mathrm{kc}$ produced an echo from the water-sediment interface and an echo from the bottom of the sediment. Additional echoes were recorded at some locations in the lake, which were attributed to changes in density of the layers of sediment. In the soft sediment of the Boulder Basin, penetration of 140 feet of sediment was obtained near the old cofferdam at Hoover Dam. This sediment had a specific gravity of about 1.2, and a 50-pound weight dropped easily through it. Up the lake 20 miles east of the dam, the reflections were poor and were not consistently obtained from the bottom of the sediment. Here the sediment was more compact, and a 50-pound weight would penetrate only 3 to 4 feet. However, some of the sediments farther uplake were penetrated, as for instance near Pierce Ferry, where on one occasion there was reflection from the bottom of a sediment layer 130 feet thick. The average thickness of sediment in the old river bed was about 70 feet.

Standard methods of computing sound velocity in waters of differing salinity were checked and found to be adequate. Water that contained a concentration of $700 \mathrm{ppm}$ of mineral salts (about average for Lake Mead water) was considered pure water. Corrections for sound velocity were made to all charts prior to transferring the depth information to the smooth sheets.

A comparison of the sonar depths with readings from sounding lines indicate an accuracy within 1 to 3 feet. The observations, showing reflections from the interface at one frequency and penetration of the sediment at another frequency, present an acoustic problem that has not yet been solved. It seems clear that the difference of impedance at the interface is inadequate to explain the effects. The thermal structure of the lake is such that there is too small an increase in temperature at the interface to account for the reflections. It seems plausible, therefore, than an energy-absorption process is going on in the sedimentary layer, and that such a process is a function of the particle size, the water content, and the frequency of the sound. The details of this functional relation have not yet been established. Data, obtained by Raitt ${ }^{3}$ by sending low-frequency pulses through marine sedimentary layers, indicate that the transmission losses in the sediment are less at lower frequencies. This observation would be in accordance with the trend of the observations made at Lake Mead.

Observations made during the survey indicate:

1. The high-frequency equipment $(50 \mathrm{kc})$ showed the top of the sediment within 2 feet of accuracy; thus, the top of the sediment was established over a large area.

2 . The low-frequency equipment $(14.25 \mathrm{kc})$ pene-

\footnotetext{
${ }^{3}$ Raitt, Russell, 1949, Unpublished report of researches: San Diego. California University Marine Physical Laboratory.

$4969180-60-6$
}

trated through the sediment to the hard bottom below. It showed a reflection at the top of the sediment and also one at the bottom; thus, this equipment confirmed the results obtained with the high-frequency equipment and gave a series of measurements that could be coordinated with the botton contours obtained from the survey of 1935 .

3. A third equipment, which operated at a high frequency $(88 \mathrm{kc})$, was used to a limited extent on an experimental basis; it indicated the sediment level within 1 foot of accuracy and otherwise gave results that were complementary and confirmatory to those obtained by the other instruments.

4. The depths obtained by the Navy depth-recording equipments were in close agreement with the results obtained by cable and reel depth measurements where the depths permitted the latter observations to be made.

5. Core measurements and samples showed that the top of the sediment-water interface is quite sharp. This is in accord with the soundings obtained by the highfrequency devices.

Much additional research will probably be necessary to answer fully all questions raised by this survey, some of which are indicated in the discussion above. It is apparent, however, that a suitable device for a sediment and bottom-structure survey can be designed as a result of this survey. It would combine in one instrument the following characteristics :

1. Variable frequency $(10-80 \mathrm{kc})$, with separate transducers, if necessary, for successful penetration of and discrimination between layers.

2. Variable power (15 watts to 1 kilowatt) to implement 1 above.

3. A suitable recorder, with time-fix indication.

4. A cathode ray indicator with suitable photographic attachment and visual viewer. This device would assist in bottom-structure analysis by returnpulse analysis techniques.

Such an equipment can be built and would solve a majority of the survey problems showing characteristics similar to those found in the Lake Mead survey.

\section{HYDROGRAPHIC SURVEY: SUMMARY OF RESULTS}

By F. C. Ames, U.S. Geological Survey

A map of Lake Mead just before it began to fill in 1935 was prepared by the Soil Conservation Service (1935) from topographic surveys by Fairchild Aerial Surveys, Inc. The map was published in 52 sheets, at a scale of $1: 12,000$ with contour intervals of 5 and 10 feet, together with an index sheet at a scale of $1: 250,000$. The data obtained in the present surveys (1948-49) were used to draw new contour lines wherever signifi- 
cant changes since 1935 were noted. The new contours-at intervals of 5 and 10 feet for the gently sloping sediment surface and 50 feet elsewhere-and the sediment boundaries have been printed (U.S. Geological Survey, 1951) on overlay sheets to fit 43 of the numbered sheets of the 1935 map, the only ones affected. Both surveys were used by the Coast and Geodetic Survey (1952) in the preparation of navigation charts of Lake Mead in six sheets at a scale of 1:48,000.

The sounding records obtained in 1948 reveal a range of depths from the shallowest water in which the sounding boats could operate, about 3 feet, to a maximum of nearly 450 feet above the sediment surface in Boulder Basin when the lake was at a high stage. The elevation of the sediment surface was lowest at the dam. In Boulder Basin, where both the sediment surface and the prelake topography were recorded on the sound traces, the indicated elevations of the prelake topography checked very closely with the 1935 map elevations, as shown in plate 12, a representative profile in Boulder Basin.

\section{EVIDENCE OF SEDIMENT ACCUMULATION}

Nearly all of the significant changes in reservoir bottom between 1935 and 1948 have resulted from deposition of sediment by the Colorado River. The evidence indicates that these sediments are confined almost entirely to the old river channel, except in Pierce Basin, Grand Wash Bay, and small parts of Boulder Basin. The general distribution of sediment contributed by the Colorado River is therefore well shown by profiles along the centerline of the former river channel-the thalweg - as presented in plate 13. This profile shows the maximum sediment thickness in 1948 to be about 270 feet along the thalweg in Pierce Basin, near longitude $113^{\circ} 57^{\prime}$. Downlake from this point the sediment surface slopes, steeply at first and then progressively more gently, toward Hoover Dam. Comparison with the Colorado River profile in 1935 shows that the sediment along the thalweg attains a minimum thickness of 45 feet in the Temple Bar area and increases progressively toward the dam, where it is more than 100 feet thick. According to the section normal to the former river channel, the sediment surface is practically level, though slightly concave upward. In parts of Gregg Basin the sediment surface is from 1 to 3 feet higher near its edge than along the thalweg.

In Pierce Basin, Grand Wash Bay, and some parts of Boulder Basin, some sediment has been deposited on side slopes above the main body of the fluvium. In the lower part of Pierce Basin, sediment occurs in the bottoms of former washes and on benches as much as 30 feet higher than the sediment surface in the thalweg. In Grand Wash Bay some sediment has been deposited nearly 2 miles from the old Colorado River channel, at elevations as high as 50 feet above the sediment surface in the channel. In Boulder Basin between longitudes $114^{\circ} 42^{\prime}$ and $114^{\circ} 44^{\prime}$, a thin layer of sediment has evidently been deposited on small flat benches in the original bottom, at elevations as much as 10 feet higher than the sediment surface along the thalweg.

The Virgin River has deposited sediment from the high-water line of the reservoir south to latitude $36^{\circ}$ $25^{\prime}$, but there is no measurable quantity of sediment in any part of the former Muddy Creek channel.

\section{EVIDENCE OF SLUMPING}

Aside from the accretion of sediment, the Lake Mead reservoir has, in general, remained relatively unchanged since the original survey in 1935 . Only four slump areas of any consequence are noted, three in Boulder Basin and one in Virgin Canyon. The largest of these is an area along the north shore of Boulder Basin near latitude $36^{\circ} 08^{\prime}$, longitude $114^{\circ} 40^{\prime}$, where lateral displacements between original and new contours amount to several hundred feet. About 12,000 acre-feet of earth between elevations 925 and 1,220 feet have slumped, of which some probably came to rest below the present sediment surface at elevation 750 feet (p. 209).

The two other Boulder Basin slump areas are much smaller. One is on the north shore near latitude $36^{\circ} 07^{\prime}$, longitude $114^{\circ} 44^{\prime}$, where there was slumpage of 500 to 600 acre-feet of material that in 1935 had stood between elevations 1,050 and 1,250 feet. At the other, east of Boulder Islands near latitude $36^{\circ} 03^{\prime}$, longitude $114^{\circ} 45^{\prime}$, occurred the movement of 300 to 400 acre-feet of material that had been between elevations 750 and 900 feet.

Near the middle of Virgin Canyon is a slump area that extends about 2,000 feet along the north side, where the steeply sloping side-wall material has slipped downward about 40 feet (p. 209). There is also surface evidence of two or three minor slips on the south side of Virgin Canyon. The tops of all these slide areas are entirely above the reservoir flow line, and it is not known precisely how the slides have affected reservoir capacity. The echo-sounding equipment could not show the precise position of side walls below water because of the steepness of the side slopes. Furthermore, in such a canyon section it is questionable if the original map would be an accurate frame of reference. A dependable estimate of underwater change could have been determined only by lead-line soundings along a 
series of cross sections monumented and defined prior to the earth movement. The direction and amount of slippage revealed above water, however, indicate that decrease in the reservoir capacity could have been no more than a few hundred acre-feet.

\section{EVIDENCE OF EROSION}

Stream erosion since 1935 has been great enough in one locality to cause some increase in the reservoir area. At the mouth of Detrital Wash the channel above the average lake level has been scoured in places to depths of about 10 feet. This cutting, which probably occurred during extreme floods on the lower Colorado River in 1939 (Gatewood, 1945), has enlarged the area of the reservoir at an elevation of 1,230 feet by about 100 acres. The material scoured from Detrital Wash has undoubtedly accumulated on the lake bottom, but apparently in such a thin layer that it could not be detected by comparison of the 1948 topography with the pre-Lake Mead topography.

Some minor alterations of shoreline are clearly attributable to wave action. A few steep-sided headlands of rather loosely cemented sand and gravel are subject to under cutting and caving along the north shore of Boulder Basin and on the east shore of Overton Arm near latitude $36^{\circ} 20^{\prime}$. Blocks of material have fallen away and lie at the base of such headlands, but it is not known how much of this disintegration occurred as a result of normal weathering long before Lake Mead was formed, and how much has occurred as a result of wave cutting. At any rate, such areas are so small that quantitative determination of the volumes of rock moved by waves was beyond the scope of the current survey.

Except for these gravel headlands and the rockwalled canyons, most of the lakeshore slopes moderately and consequently is not subject to serious undercutting and caving. Certainly caving above the high-water line at elevation 1,220 feet is rare indeed. Therefore it may be said with assurance that the reservoir has not suffered any net decrease in capacity worthy of consideration as a result of wave action.

There remains the visual evidence of compensating changes in the capacity-elevation relation caused by wave-built terraces. Such changes are the result of the shifting of material from one elevation to another below the high-water line. The lake stage fluctuated between 1,154 and 1,193 feet during the course of the hydrographic survey, and most of the reservoir bottom within this range could not be adequately mapped by sound boat because it was either near shore or above the shoreline. Consequently, data are not at hand from which a quantitative statement might be adduced regarding littoral change. Such sounding as was accomplished alongshore within the operating range did not reveal important alterations which might be attributed to wave erosion at any place. However, small wave-built terraces do exist at intervals all around the lake and it is likely that, in the aggregate, these terraces represent the movement of a considerable quantity of material within the operating range of the reservoir, which is generally between elevations 1,150 and 1,200 feet.

A simple analysis indicates that the volume of material in these terraces is small and that wave action is negligible as an agent affecting reservoir capacity change at Lake Mead. Boulder Basin, whose shores exhibit more terracing than any other basin of the lake, has a perimeter of about 300,000 feet. Let it be assumed that one-third of the perimeter, or 100,000 feet of shore, has an average slope of $20^{\circ}$ and is terraced by 3 -foot vertical steps between elevations of 1,150 and 1,200 feet. Let it then be assumed that all the material in the terraces was carried below 1,150 feet, and that the outer edge of each terrace lies in the original shore plane. Both these assumptions exaggerate the true conditions and imply an earth movement much larger than actually occurs. Even so the change involved is only 480 acre-feet, which is less than 0.03 percent of the 1,453,000 acre-feet that can be stored in Boulder Basin between elevations 1,150 and 1,200 feet.

In addition to the shore proper, islands and some underwater peaks are subject to wave erosion. Such erosion is quite evident in places, where 10 to 50 feet of material has been stripped away from the tops of some prominences. Erosion of this nature is most marked in Las Vegas Bay, where islands and offshore shoal areas are far more numerous than in the rest of the lake, and where a considerable proportion of the material can be dissolved by the lake water. Hence, the proportion of material removed from shoals and islands in Las Vegas Bay is far greater than the average for the entire lake. It is estimated that only about 50 acre-feet of island and shoal erosion has occurred in that bay between longitudes $114^{\circ} 45^{\prime}$ and $114^{\circ} 50^{\prime}$ and between elevations 1,150 to 1,180 feet. The reservoir capacity of the same area and between the same elevations is 211,600 acre-feet. Thus even in the area of maximum observed erosion the alteration of offshore features is a negligible element of reservoir change.

\section{REFERENCES CITED}

Brown, C. B., 1941, Mapping Lake Mead: Geog. Rev., v. 31, p. $385-405$. 
Fairchild Aerial Surveys, Inc., 1935, List of geographic positions of triangulation stations established in connection with the aerial survey of the Lake Mead area.

Gatewood, J. S., 1945, Floods of September 1939 in Colorado River basin below Boulder Dam: U.S. Geol. Survey WaterSupply Paper 967-A.

McIntosh, W. F., 1951, Arizona-Nevada triangulation for the Lake Mead investigation, third order: Sacramento, Calif., U.S. Geol. Survey mimeo rept., $32 \mathrm{p}$.

Speert, J. L., 1938, Readjustment of triangulation datum: Am. Soc. Civil Engineers Trans., v. 103, p. 1002-1018.

U.S. Coast and Geodetic Survey, 1935, Tables for a polyconic projection of maps and lengths of terrestrial arcs of meridians and parallels based upon Clark's reference spheroid of 1866 : U.S. Coast and Geod. Survey Spec. Pub. 5, 189 p.
- 1952, Lake Mead: U.S. Coast and Geod. Survey Charts $5457 \mathrm{~A}$ and $\mathrm{B}, 5458 \mathrm{~A}$ and $\mathrm{B}$, and $5459 \mathrm{~A}$ and $\mathrm{B}$, scale $1: 48,000$.

U.S. Geological Survey, 1924, Plan and profile of the Colorado River from Lees Ferry, Ariz., to Black Canyon, Ariz.-Nev. : U.S. Geol. Survey River Survey Map, 21 sheets (14 plans, 7 profiles), scale $1: 31,680$, contour interval 50 feet.

1951, Lake Mead sedimentation survey. (Overlay for 43 sheets of Soil Conservation Service maps of 1935 , showing sediment surface in 1948-49. Reproduced for official use. Available for examination in offices of the Geological Survey, Washington, D.C., and Bureau of Reclamation, Boulder City, Nev.)

U.S. Soil Conservation Service, 1935, Topographic maps of Lake Mead area: Sheets 1-52 at scale $1: 12,000$, and index sheet at scale $1: 250,000$. 


\title{
H. SURVEY OF LOWER GRANITE GORGE
}

\author{
By L. C. Pampel, U.S. Bureau of Reclamation
}

The upper section of Lake Mead lies in a deep, rugged canyon known as Lower Granite Gorge. This section is about 40 miles long, extending between Bridge Canyon and a point just above Pierce Ferry. During the 1948-49 survey the width of water surface in the canyon ranged from about 200 feet at the upper end to about 2,200 feet at the lower end. At the maximum designed water-surface elevation of 1,229 feet, the water-surface area in the Lower Granite Gorge section is about 3 percent of the total water-surface area of the whole lake, and the original storage capacity in this section was about 2 percent of the total original lake capacity. However, a large proportion of this original storage space has been filled with sediment, and prior to 1948 it had been estimated that Lower Granite Gorge contained one-fourth to one-half the total sediment in Lake Mead. The 1948-49 survey indicates that the gorge section contains about onethird of the total volume or one-half the total weight of the sediment deposited up to that time. A map of this section of the lake is shown in plate 14. Longitude $113^{\circ} 57^{\prime}$ constitutes the dividing line between the surveys of the lake and of Lower Granite Gorge.

In general the canyon walls are quite steep, and in places they rise as vertical cliffs. The height of the first rim or break in the walls, called the Tonto platform, decreases from about 600 feet near Bridge Canyon and Spencer Canyon to only 100 feet near Pierce Ferry. The canyon walls extend on up from this first bench to elevations approaching 6,000 feet, or nearly 4,000 feet above the river.

During the survey the velocity of the water at the lower end of Lower Granite Gorge at range 174 (pl. 14 ), varied from practically nil in September 1948, when the lake surface was at an elevation of 1,180 feet, to a maximum of approximately 10 feet per second in March 1949, when the lake level reached 1,150 feet. When the lake was at the higher level, the inflow was about 5,000 cfs and the water was 29 feet deep. At the lower lake level, the depth at range 174 was only 6.1 feet and the inflow about 10,000 cfs.

\section{OUTLINE OF OPERATIONS}

The survey of Lower Granite Gorge was separated from the survey of the rest of the lake because of the difference in character of the terrain and the different equipment required to make the survey. The long, narrow gorge and the irregular sediment surface made the detailed delineation of contours impractical from the standpoint of time required and costs involved. Furthermore the boats used in the lake survey were not suitable for use in the water in the gorge section, which required shallow-draft boats equipped with special rubber impellers in the cooling-system water pumps to operate in the shallow, sediment-laden water.

The survey of Lower Granite Gorge required a combination of hydrographic and land surveying techniques. It was conducted from a barge, used as a floating base of operations. At the beginning of the survey in October 1948, the barge was towed up the river to mile 242 (about 5 miles downstream from the Bridge Canyon damsite). It was moved downstream as the work progressed.

The numerous sand bars just under the silty water surface, and the continual shifting of the river channel, made navigation of Lower Granite Gorge difficult while men and supplies were transported to and from the floating base of operations. The current and the waves, commonly called "sand waves," near the junction of the river with the lake proper increased gradually as the surface of the lake receded, thus making navigation upstream increasingly difficult. When the lake surface was at about 1,180 feet and the inflow approximately 5,000 cfs, the Higgins boat could make the 39 miles upstream from Pierce Ferry to the first camp location in 7 to 8 hours. By December the lake level had dropped to 1,165 feet and, with the inflow still about 5,000 cfs, about the same time was required for travel only 23 miles upstream from Pierce Ferry. In March when the lake level had declined to 1,150 feet and the inflow had increased to $10,000 \mathrm{cfs}$, the Higgins boat could not negotiate the channel even in the first 2 miles above the delta front. At this time only the 16foot outboards and the airboat were able to navigate upstrean through the shallow delta area at the head of the lake and the swift water immediately above. It is obvious that any future surveys of this area could best be made in the late summer and early fall, when the lake level is high and the inflow is near the annual minimum. 
The prime purpose of the survey was, like that of the lake survey, to determine the volume of sediment that had accumulated in the reservoir since 1935 , a volume that would also measure the reduction in water-storage capacity since that year. The techniques employed in the two surveys were quite different, however. The lake survey depended upon mapping the position of the reservoir bottom in 1948 above a reference plane approximately at sea level, and computation of sediment volume from differences in bottom contours since 1935 . In the Lower Granite Gorge survey, by contrast, the position of the sediment surface was determined with respect to an overhead reference plane corresponding to the maximum designed water-surface elevation, and the computations led first to a determination of the amount of original capacity that was not filled with sediment in 1948. The volume determinations were made by the average end-area method described below, based on 175 cross sections or sediment ranges. Excepting the six ranges farthest upstream and nearest to Bridge Canyon rapids, these ranges were spaced at intervals of 620 to 2,260 feet (averaging 1,220 feet) throughout Lower Granite Gorge. As in the lake survey, adequate horizontal and vertical control were essential in the survey of Lower Granite Gorge for accurate, three-dimensional determinations of the position of the sediment surface at each point of measurement.

The horizontal control for the resurvey of the Lower Granite Gorge section of Lake Mead between Bridge Canyon and Pierce Ferry was based on the triangulation net established in 1935 for preparation of the original topographic maps of the Lake Mead area (Fairchild Aerial Surveys, Inc., 1935), and on a net established in 1942 for use in the Bridge Canyon investigations (U.S. Bureau of Reclamation, 1943). The latter net was tied to the Fairchild net when it was established.

Little difficulty was encountered in locating the Fairchild triangulation stations from the river; at most of them the original 2 - by 2 -inch timber pole was still in place. After one point was located by inspection from the river level, a second could usually be sighted by use of the transit. The Fairchild triangulation points at the upper end of the canyon section, near the Bridge Canyon Dam site, were located on or above the Tonto platform at elevations of $1,800-2,200$ feet above sea level, or about 600 to 1,000 feet above the river. (Pl. 15 A.) Near Pierce Ferry and the lower end of the gorge, the horizontal and vertical control was tied to Fairchild stations at elevations as low as 1,400 feet.

A total of 43.8 miles of stadia traverse was run, starting at the Bridge Canyon damsite and ending at a point a few hundred feet west of longitude $113^{\circ} 57^{\prime}$.
Traverse stations were located 1,000 to 1,500 feet apart on sand bars or points on the canyon wall just above the water surface. These points were not marked permanently, and were flagged only until the ends of the range lines had been marked on the canyon walls with a cross of white paint. Sediment ranges crossing the river channel were established at most, but not all, of the traverse stations. Ties were made to the Fairchild triangulation points at an average distance between ties of 2.4 miles. These ties were made by triangulation to the Fairchild stations, using a Wild T-2 theodolite and reading to single seconds. All three stations of each triangle were occupied, and two direct and two reverse readings were made of each angle, both horizontal and vertical.

Vertical control was based on bench marks set by the Bureau of Reclamation for use in its Bridge Canyon investigations. That line of levels was a closed circuit, carried in from the Coast and Geodetic Survey station $\mathbf{J}-96$, which is about 9 miles northwest of Peach Springs, Ariz. The leveling for the 1948-49 survey was started from bench mark 2-G, established by the Bureau of Reclamation at the Lower Separation damsite, one of the four sites investigated during the Bridge Canyon investigations. The vertical control was carried along the canyon near water level by means of differential leveling.

The stadia traverse through the gorge indicated a measurable difference between the datum used in the Bridge Canyon investigations and the datum upon which the elevations of the Fairchild stations are based. It was found that the elevations obtained from the Bridge Canyon datum were 0.94-1.80 feet lower than the elevations determined from the Fairchild ties. The Bureau of Reclamation earlier had found a difference of 1.1 feet, in the same direction, between the Fairchild stations and the levels carried in from Coast and Geodetic Survey station J-96 for the Bridge Canyon investigations. These differences may be caused chiefly by differential subsidence since the precise leveling to station J-96 in 1935 . That station is east of the Hoover Dam level net and was not included in the releveling subsequent to 1935. It is upon the Colorado Plateau block, which is considered to be a remarkably stable tectonic unit (p. 33). Thus these differences may be a measure of the relative movement of the Lake Mead region with respect to that block.

Differential subsidence is indicated also by a determination of the lake level near range 174 in Pierce Basin, on March 13, 1949. As determined from the line of levels carried down the canyon from bench mark $2-G$, the elevation of the lake was 0.56 foot lower than the elevation shown by the gage at the dam. Assuming that. 


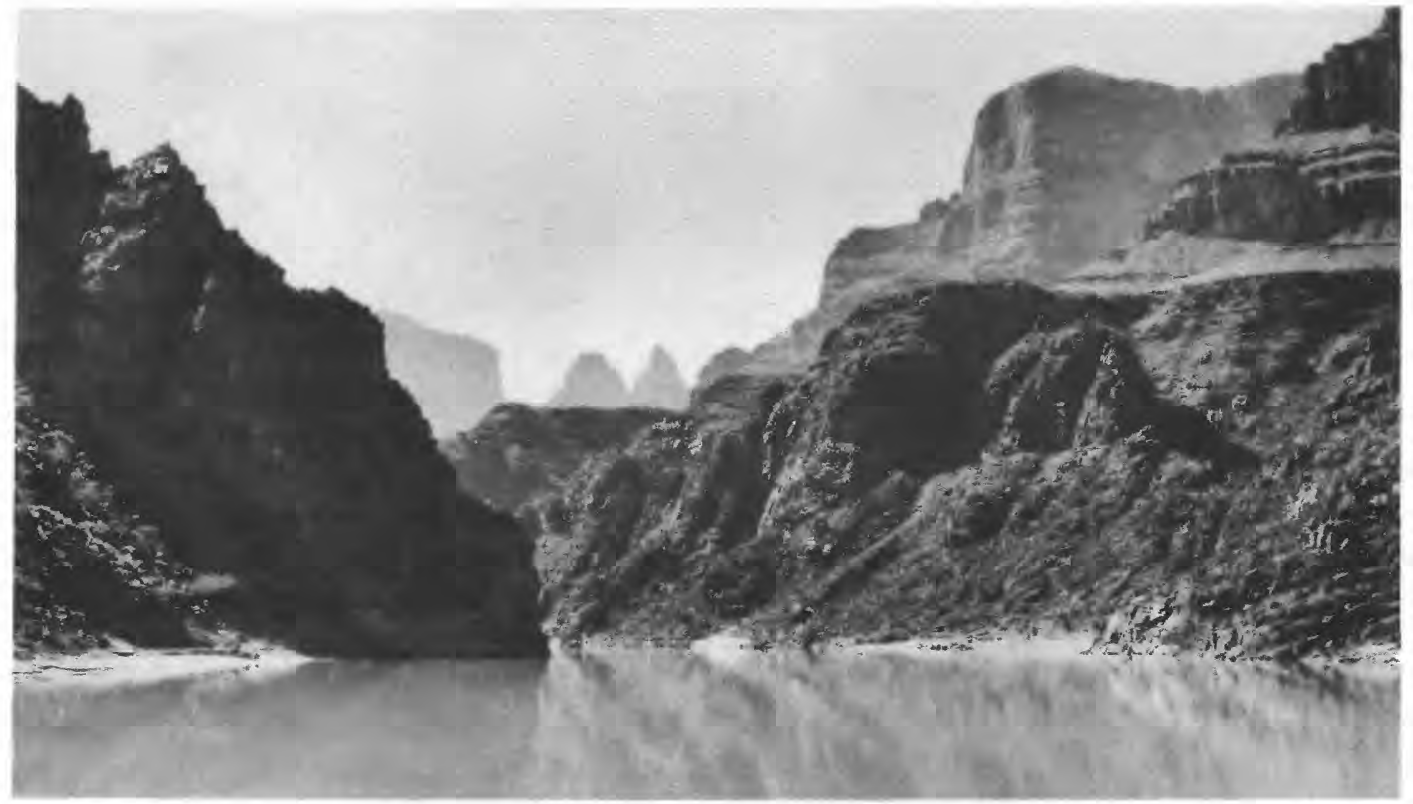

A. THE TONTO PLATFORM

Fairchild triangulation stations used as control were located on this platform, the relatively flat area above first break in canyon walls. Photograph by Bureau of Reclamation.

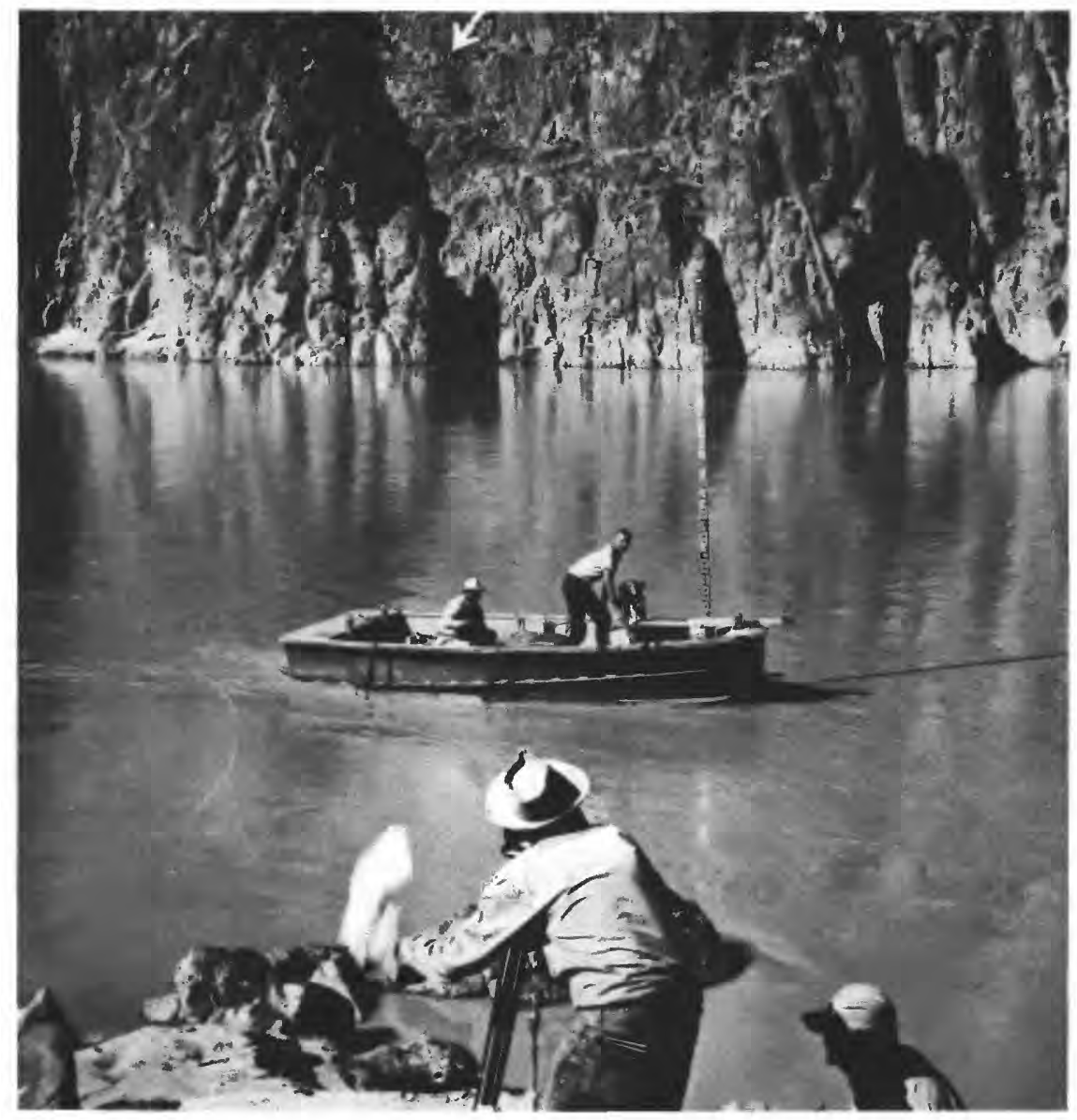

B. SOUNDING OF CROSS SECTION AT RANGE 24

Instrumentman signals with white flag the instant sounding is to be taken and reads stadia distance. White cross on canyon wall (indicated by arrow) marks end of range line. Photograph by Bureau of Reclamation. 
there was no slope in the lake surface at that time of low inflow, it appears that 0.56 foot was a measure of the difference between the Bridge Canyon datum and the gage datum at the dam. These discrepancies in datum are small enough to be well within the limits of accuracy of the methods used to determine sediment volumes and residual storage capacity in Lower Granite Gorge.

Cross sections were taken along 175 sediment ranges, which were spaced as deemed necessary to give representative sections and were generally $1,000-1,500$ feet apart. No sections were taken above the Bridge Canyon rapids, as visual observation indicated no sediment deposit upstream from this point. All ranges cross the canyon, and the zero end of each is on the left bank of the river. Both ends of each range were marked on the canyon wall above the high-water mark with a white-painted cross. Plate 14 shows the locations of several of the ranges.

Soundings below water surface were obtained by means of a hand reel mounted on the front of the Pen Yan inboard boat, and a sounding cable with a 30- or 50 -pound weight attached. The 50-pound weight was used in the faster water at the lower end of the canyon section. Stadia distances from a point on shore to the sounding boat were observed with a transit at the time of each sounding. A skilled boatman was required to hold the boat on the range line as the boat progressed slowly across the channel under its own power ( $\mathrm{pl} .15 B$ ). The portion of the cross section above the water surface and up to the maximum designed water-surface elevation of 1,229 feet was made by conventional surveying methods, using both differential and trigonometric leveling, and stadia distances. The elevations at the upper ends of the ranges were determined by vertical angles in order to reduce the number of instrument setups. Reference marks were left at or near the ends of each range line. It is estimated that on a future survey a 4 - or 5-man crew could complete about 8 cross sections a day, now that the horizontal and vertical control have been established for the range lines.

The geodetic positions of the corners of each of the original 5-minute topographic sheets of Lower Granite Gorge were converted to coordinates based on the transverse Mercator projection for Arizona, West (Adams and Claire, 1935) and the transverse Mercator grid was plotted on those sheets. Similar coordinates were computed for all stadia traverse points and for the Fairchild triangulation stations to which those points were tied. Because each sediment range line included one of the traverse points, it was possible, after plotting the positions of the points, to plot also the location of each of the range lines. The transverse Mercator projection was used on the river survey in preference to the polyconic projection because of the greater ease of computing coordinates of the many traverse stations. It worked very nicely on this particular survey because the central meridian for Arizona, West-longitude $113^{\circ} 45^{\prime}$ - fell near the midpoint of the Lower Granite Gorge section of Lake Mead.

The differences in plane azimuth and horizontal position found when the stadia traverses were tied to the Fairchild triangulation net were generally not excessive. In most cases the difference in the plane azimuth was less than 1 minute of arc, and the differences in the $x$ and $y$ directions of the coordinates were each under 30 feet. The differences in plane azimuth were adjusted back through each traverse before the coordinates of the stations were computed. The errors in horizontal position of four traverse points were also adjusted back through the traverses; but errors at other points were too small to warrant adjustment, and all the error was thrown in at the station where the tie was made to the Fairchild net.

\section{TOTAL VOLUME OF SEDIMENT}

The cross section at each of the sediment ranges was plotted upon cross-section paper, and the area for 10-foot increments in elevation from the top of the sediment deposit to the maximum designed water-surface elevation of 1,229 feet was determined by planimeter or by observation. The distances between ranges were scaled along the original (preinundation) thalweg. The storage volume remaining between each pair of ranges was determined for each 10 -foot zone by multiplication of the average of the cross-section areas measured at the two ranges, and the distance between them (the "average end-area" method). The total storage capacity remaining in Lower Granite Gorge up to elevation 1,229 feet was 219,000 acre-feet.

Cross sections were taken from the topographic maps for each of the ranges and plotted on the same crosssection paper, in order to show a comparison between the 1935 and 1948 surveys. Figure 15 shows cross sections at four typical ranges as taken during this survey, compared with those taken from the 1935 topographic maps of the Lake Mead area.

The agreement between the portions of the cross sections above the sediment deposits is considered quite satisfactory in view of the several factors that make precise correspondence improbable. Appreciable dis- 
SURVEY OF LOWER GRANITE GORGE

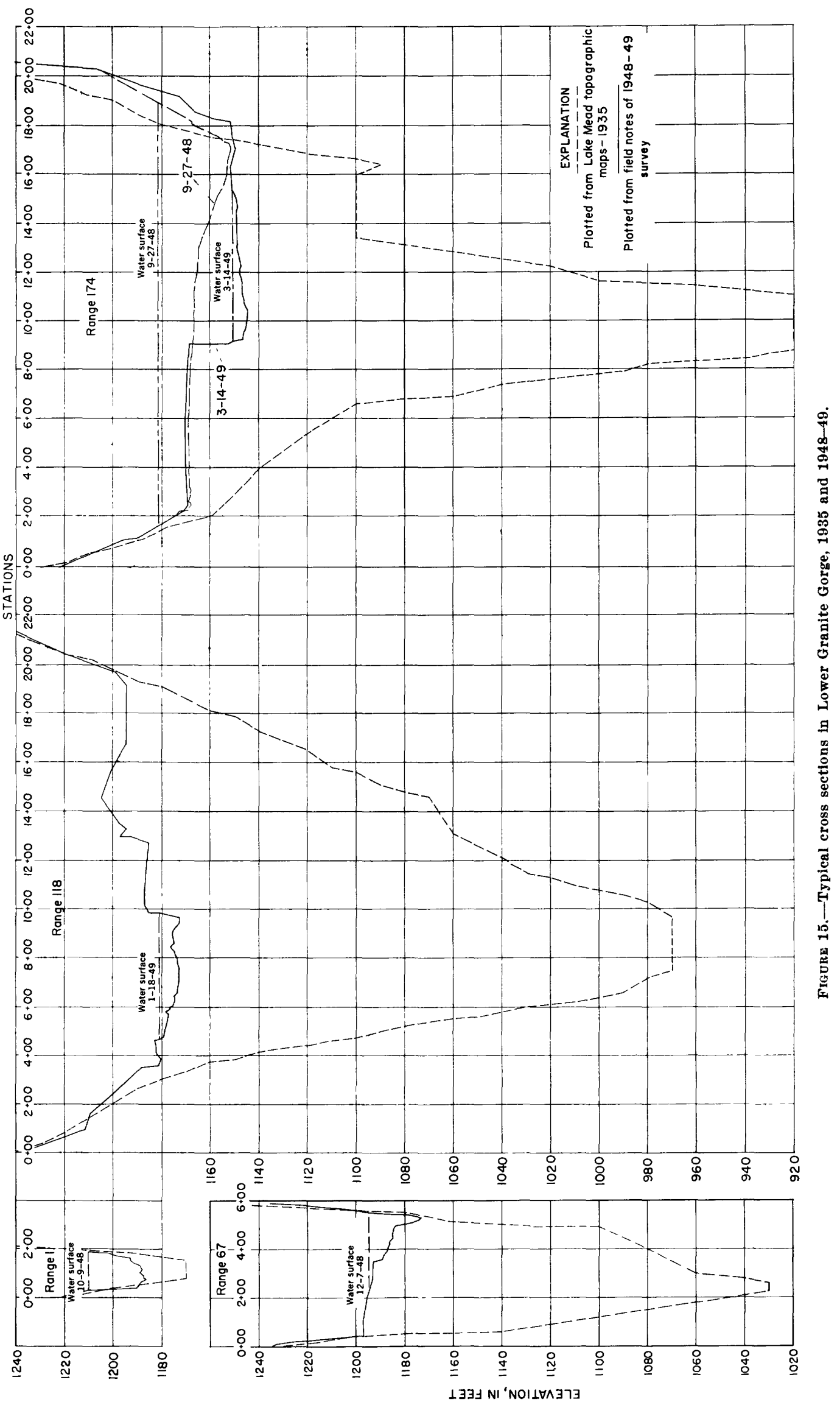


crepancy is to be expected between canyon cross sections prepared from the actual field data of a surveyed range and cross sections obtained from the same range plotted on a map of 1:12,000 scale, even if both the map and the 1948 traverse were perfectly exact; both the plotting of the range line and subsequent scaling of horizontal distances thereon would be subject to errors as great as 20 feet, because the $1: 12,000$ map scale limits plotting and scaling to this order of precision. Furthermore, one should not expect too high a fidelity in the original stereoscopic plotting of the extremely rugged terrain that characterizes the Lower Granite Gorge area. In places the canyon is so irregular that relatively small horizontal shifts in the position of plotted ranges cause material changes in cross sections along those ranges. No effort was made to define from the cross-sectional data the disparity between the 1935 and 1948 surveys. However, it seems to be negligible for the canyon as a whole in the light of evidence discussed elsewhere in this report (p. 86).

The original storage capacity of Lower Granite Gorge was computed by the Soil Conservation Service, using the modified prismoidal (or prismatoid) formula,

$$
V=\frac{h}{3}(A+\sqrt{A B}+B),
$$

in which $V$ is the capacity in acre-feet, $h$ is the contour interval in feet, $A$ is the area of lower contour in acres, and $B$ is the area of upper contour in acres. The volumes were computed by 10 -foot lifts from the areas enclosed by the 10-foot contours as determined from the original topographic maps. By this method the total original storage capacity (below elevation 1,229 feet) was computed to be 760,000 acre-feet.

The amount of sediment deposited in Lower Granite Gorge since the closure of Hoover Dam was determined by subtracting the remaining storage capacity $(219,000$ acre-feet) from the original. This difference amounted to 541,000 acre-feet.

Because this computed sediment volume of 541,000 acre-feet represents the difference between volumes computed respectively by the modified prismoidal formula and the end-area method, an evaluation of its accuracy requires a comparison of the two methods. Therefore the capacities between the 1,180- and 1,190foot and between the 1,190- and 1,200-foot contours on sheet 49 of the 1935 topographic map of Lake Mead were computed by both methods. The average endarea method gave a slightly smaller volume in both cases, approximately 11 percent less in the first case and 8 percent less in the latter. Judging by this comparison, the computed sediment volume is not accurate beyond two places and should be rounded off to 540,000 acre-feet. Even so, this figure is probably a maximum, and the true volume of sediments in Lower Granite Gorge may be less by several thousands of acre-feet.

\section{DISTRIBUTION OF SEDIMENT}

The thickness of sediment varies from none at the foot of the Bridge Canyon rapids at mile 235, to 16 feet at the Bridge Canyon damsite at mile 237.3, and to a maximum depth of 270 feet near the junction of the canyon section with the main lake at mile 278 . The variation in thickness of the sediment in Lower Granite Gorge is presented graphically in figure 16, which compares the original 1935 and the 1948-49 longitudinal profiles of the thalweg. Also shown on this diagram is the approximate upper limit of sediment deposition in the gorge during 1948-49, based on interpretation of the cross sections at the sediment ranges.

The profile of the thalweg in 1948-49 had a uniform slope of about 1.26 feet per mile in a 27 -mile reach below Separation Canyon (miles 242-269 below Lees Ferry). Downstream from mile 269 toward Pierce Basin, the slope of the thalweg profile increased to 2.2 feet per mile. This part of the gorge was surveyed in the early part of 1949 as the level of Lake Mead was declining toward the seasonal minimum of 1,145.5 feet (reached on April 15), and the increased slope was doubtless achieved by erosion of the channel as the water flowed toward the receding lake.

The apparent depression in the thalweg profile above Separation Canyon (miles 240-235) is based on data obtained in October 1948, several months after the peak inflow, and when the lake level was about at elevation 1,180 feet. The increased depth of channel in this reach, more than 15 miles upstream from the quiet lake water, may be analogous to the deepening of channels following flood stages, noted in other streams by Leopold and Maddock (1953).

The profile of highest sediment deposition also has a slope of about 1.2 feet per mile east of mile 267 . Many of the highest sediment surfaces in the gorge probably were formed in 1941 and 1942, when Lake Mead reached maximum elevations of 1,220.4 and $1,213.5$ feet respectively. Some sediment has been deposited above these highest lake levels east of the mouth of Salt Creek (mile 255). The highest observed river sediment is a bar at elevation 1,236 feet, on the right bank of the canyon at sediment range 17 (mile 242). Some of these high-level sediments are shown in plate 16, which offers views of the gorge upstream from North Separation Canyon, in 1939 and in 1948. The 


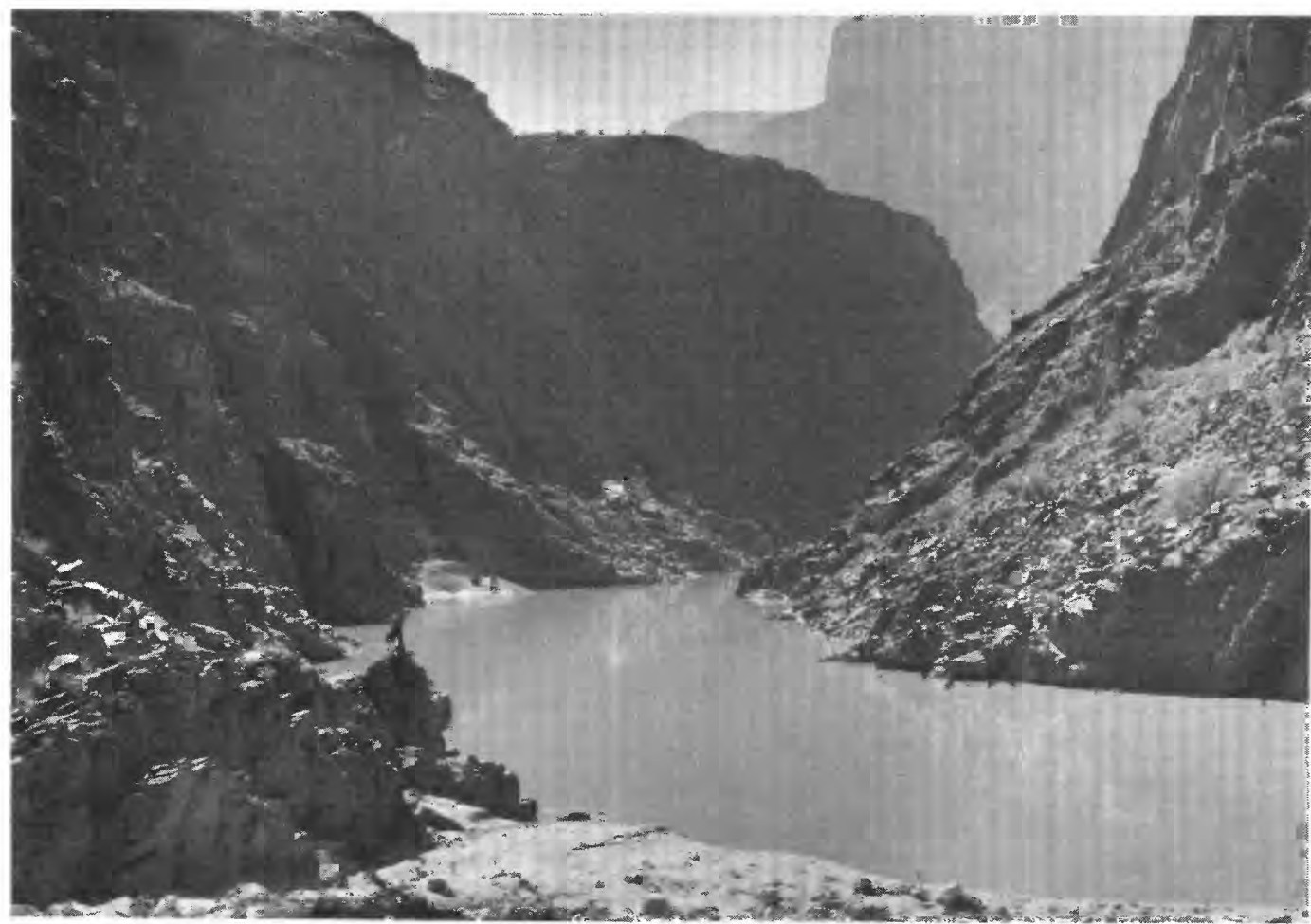

A. IN 1939

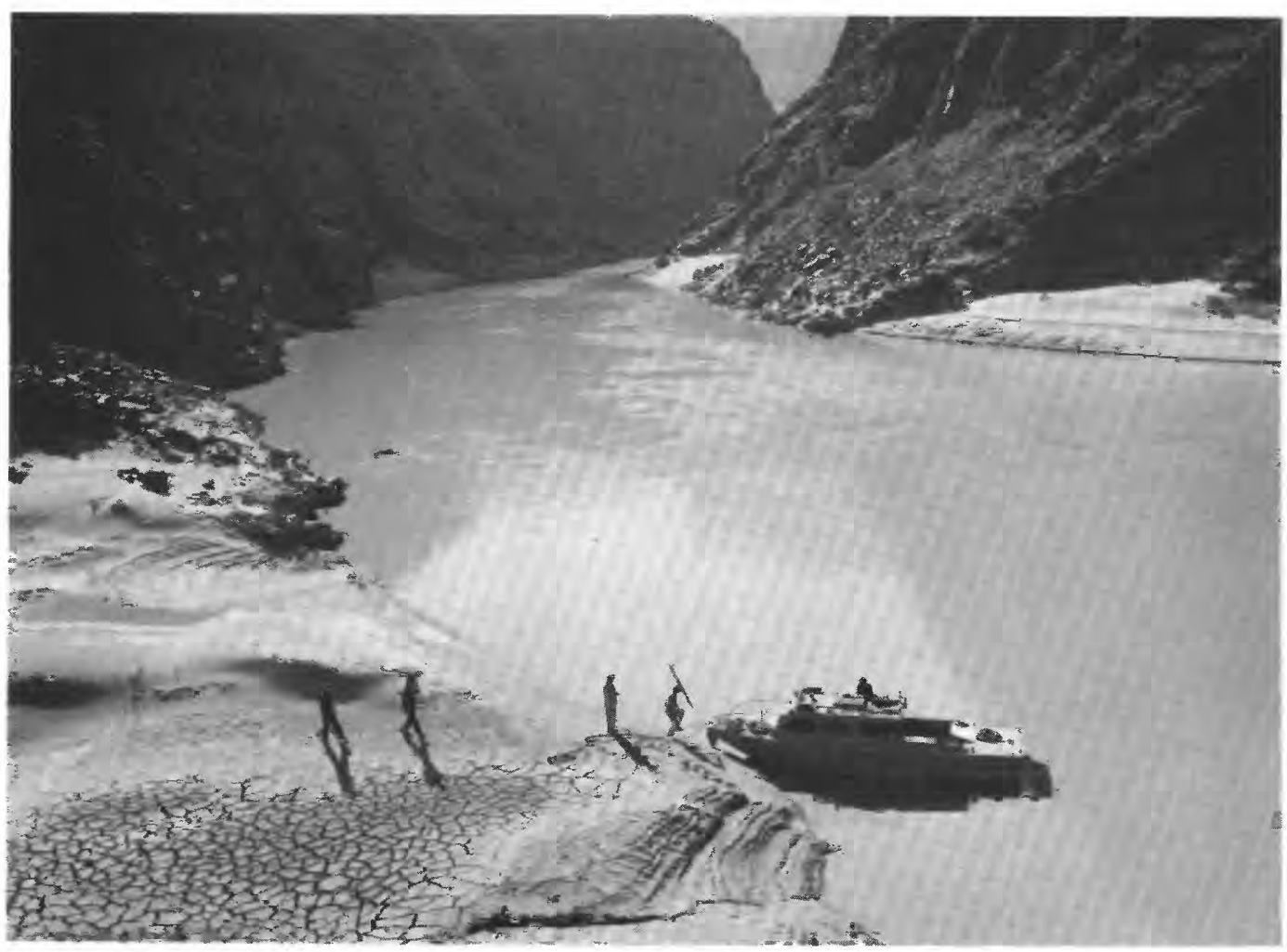

B. IN OCTOBER 1948

VIEWS OF LOWER GRANITE GORGE UPSTREAM FROM NORTH SEPARATION CANYON 


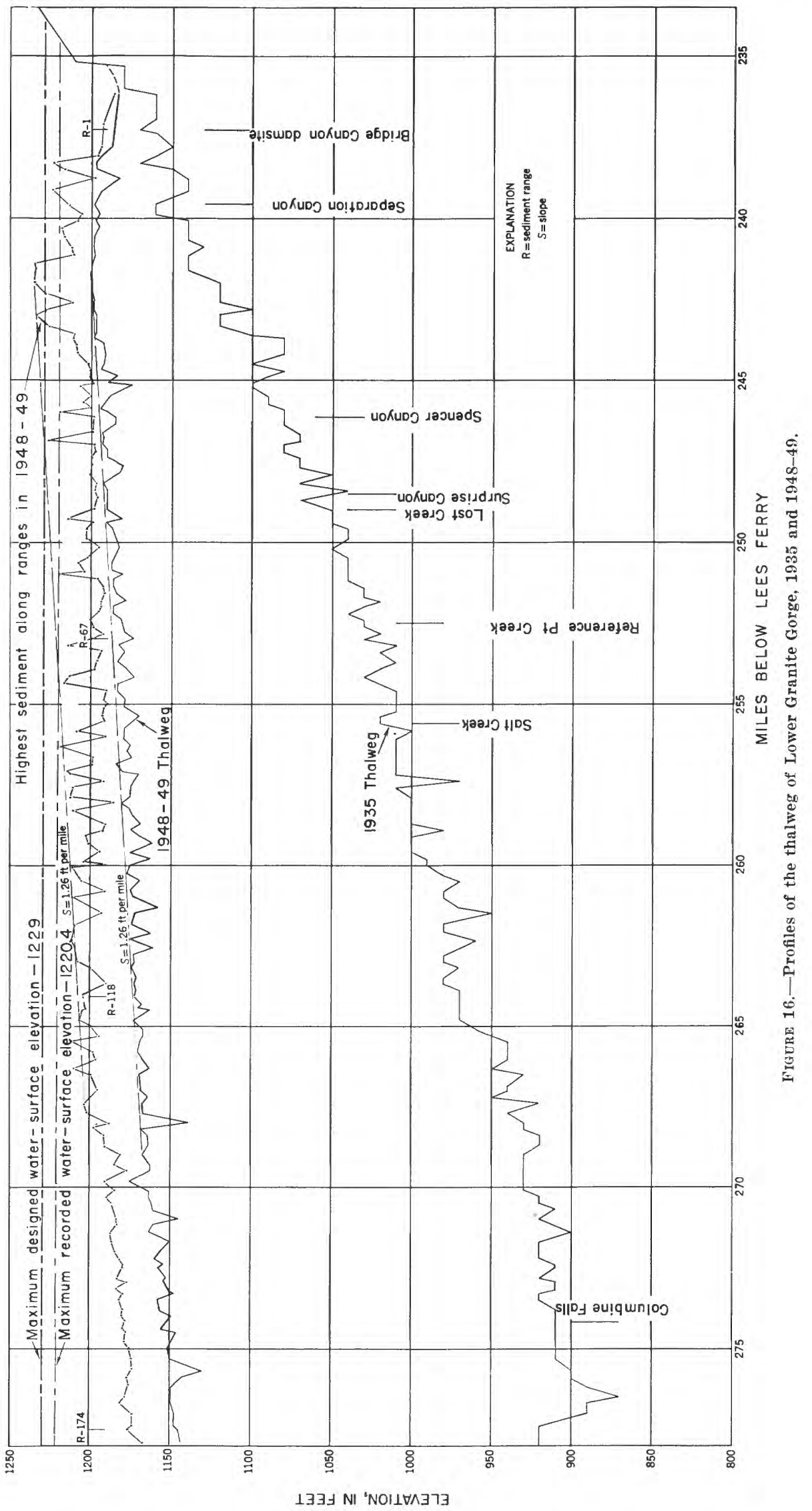


zone between elevations 1,220 and 1,229 feet was occupied by 1,275 acre-feet of sediment in 1948-49.

The cross sections along the 175 sediment ranges also provide a means of computing the area of the topset beds of the delta that has been built by the Colorado River since 1935 (Chapter $\mathrm{N}$ ). On most of these cross sections the width of the sediment deposit is apparent by inspection. The area of sediment between each pair of ranges was computed by multiplying the average end-width by the thalweg distance between the ranges, and the total area of the delta east of latitude $113^{\circ} 57^{\prime}$ was then derived. The total area thus computed amounts to 4,360 acres.

\section{REFERENCES CITED}

Adams, O. S., and Claire, C. N., 1935, Manual of traverse computations on the transverse Mercator grid: U.S. Coast and Geodetic Survey Spec. Publ. 195, 242 p.

Fairchild Aerial Surveys, Inc., 1935, List of geographic positions of triangulation stations established in connection with the aerial survey of the Lake Mead area.

Leopold, L. B., and Maddock, Thomas, 1953, Hydraulic geometry of stream channels and some physiographic implications: U.S. Geol. Survey Prof. Paper 252, 56 p.

U.S. Bureau of Reclamation, 1943, Control for triangulation and surveys, Bridge Canyon project: Boulder City, Nev., Regional Planning Office, Region 3, Drawings 359-D-211, and 359-D-212. 


$$
\text { • }
$$




\section{RESERVOIR STORAGE}

\section{SIGNIFICANCE OF AREA, CAPACITY, AND SEDIMENT} TABLES

By J. W. Stanley, U.S. Bureau of Reclamation

An area and capacity table actually comprises two tabulations-an area-elevation and a capacity-elevation table. As the names imply, these tables show areas of the water surface and volumes of water in the reservoir at various elevations of the water surface. For most reservoirs the areas considered are the total plane areas within contours representing various water-surface elevations at the dam. The capacity-elevation table gives volumes of water that the reservoir will contain at various water-surface elevations. These capacity tables refer only to volumes below level water surfaces, and do not take account of the increase in river channel or lake storage which exists above such levels as a result of the backing-up effect of the lake.

The areas and capacities of a reservoir at various elevations may change with time, chiefly because of deposition of sediment brought in by the feeder streams. When the deposit of sediment becomes so great that the area-capacity tables are too inaccurate for further use, it becomes necessary to resurvey the bottom and side slopes of the reservoir, and from the data thus gained to compute new area and capacity tables. The percentage of the capacity that can be lost before a resurvey is necessary depends upon the degree of accuracy to which the capacity must be known. For example, if it is necessary to know within close limits at all times the capacity of the reservoir, resurveys will be necessary at brief intervals of time; on the other hand, if approximate knowledge of capacity will suffice, resurveys need be made only occasionally.

Operation of a reservoir for multiple purposes is predicated on the attainment of the greatest practical efficiency regarding water use. The area and capacity table is the key which determines the holdorer storage that might tide over prolonged periods of drought. In addition it is an essential tool in the translation of forecasts of probable inflow into usable data for the guidance of those responsible for planning and scheduling future operations, on both long-and short-term basis, for each individual purpose. For this latter use, the reservoir eapacity between any two elevations of water surface, as indicated by the area and capacity table, is more important than the total capacity below any single elevation; thus, up-to-date tables that are accurate throughout the full operating range are essential. In the following paragraphs is discussed in some detail the economic importance of area and capacity tables for Lake Mead for the various functions involved.

\section{FLOOD CONTROL}

The functions of river regulation and flood control are in the first priority among the purposes for which Hoover Dam was authorized. Critical areas, in which great investments of private capital exist, and which might suffer appreciable damage in the event of flood flows, include Needles, Calif.; the Palo Verde irrigation district near Blythe, Calif.; both sides of the Colorado River near Yuma, Ariz.; and the Colorado River flood plain below the International Boundary.

During the period of the comprehensive survey, and indeed during the first 19 years of Lake Mead's history, the desired flood control was accomplished by reserving 9,500,000 acre-feet of space in the reservoir, below elevation 1,229 feet, to be available on April 1 of each year. Of this amount, to insure protection against exceptional summer floods, 2,500,000 acre-feet of space must normally be available on August 1 of each year. Elevation 1,229 is the maximum designed water level; it is 7.6 feet above the top of the spillway gates in raised position. The volume represented in this 7.6-foot layer at the top of the reservoir $(1,200,000$ acre-feet $)$ is uncontrolled storage, which would flow from the reservoir over the tops of the raised spillway gates at maximum rates approaching $65,000 \mathrm{cfs}$. The controlled storage space originally reserved for floods amounted to $8,300,000$ acre-feet on April 1, and 1,300,000 acre-feet on August 1. In terms of controlled storage, the upper 59 feet of the original reservoir was reserved for flood control, and storage for other purposes was not allowed to reach into this reserved zone as of April 1 of each year. By August 1 only the upper 8 feet of the controllable space was reserved for protection against floods. Any sediment deposited in this upper part of the reservoir since 
1935 , even in the zone of uncontrolled storage, reduced the lower limit of the flood-control reserve, and therefore the upper limit of the storage available for other purposes. Accurate area and capacity data for the upper levels of Lake Mead are necessary to determine the lower limit of the flood-control reserve, which changes when revised area and capacity data are determined.

Flood control regulations for Hoover Dam and reservoir, negotiated with the Corps of Engineers and published in the "Federal Register" of February 18, 1954, have superseded the originally established April 1 flood-control reserve of 9,500,000 acre-feet. The new regulations provide a flexible flood-control operating procedure based on inflow forecasts and represent no reduction in flood-control benefits.

\section{IRRIGATION AND DOMESTIC USE}

Second in priority among the uses of Hoover Dam and Lake Mead is the combined function of irrigation and domestic uses. The importance of this function is evident from the fact that regulation and delivery of water supply to about 800,000 acres of fertile land (some of which is cropped for 12 months each year) depend primarily upon Lake Mead and Hoover Dam. Approximately 500,000 acres of this total is located in the United States, and the other 300,000 acres is in Mexico. The Imperial and Coachella Valleys, and the Palo Verde Valley at Blythe, all in California, include some of the most productive agricultural areas in the United States. In addition, a large portion of the domestic water supply for the coastal area of southern California, which has an estimated population of about $3,500,000$, is diverted from the Colorado River below Hoover Dam through the Colorado River aqueduct of the Metropolitan Water District of Southern California. Although some reregulation of river flow is accomplished by Davis and Parker Dams, most of the regulation required to satisfy the downstream requirements for irrigation and domestic use must be accomplished at Hoover Dam.

In 1950 the annual release required from Hoover Dam for downstream use was about $6,600,000$ acre-feet, which includes losses in transit by evaporation, transpiration, and seepage. Average annual releases from Hoover Dam currently are about twice this amount, chiefly because the States of the Colorado River Upper Basin are not yet utilizing the water to which they are entitled under the Colorado River Compact of 1922. As the entire basin approaches full development of its water resources, it will be more and more essential that accurate area-capacity information be available for use in planning operations so that river flows are adequate, especially during the summer when irrigation and domestic requirements are greatest. Even in the present stage of development it may become necessary during years of low inflow to limit releases from Hoover Dam to those required by downstream interests, thus curtailing power generation. During such critical periods accurate planning is essential to secure the most efficient water use.

\section{POWER GENERATION}

Last in priority among the uses of Lake Mead and Hoover Dam is hydroelectric power generation. In spite of this low priority, the revenue derived from the sale of electrical energy must repay the cost of the dam and appurtenant works. In view of this situation and of the extreme importance of power generation at the Hoover powerplant to the economy of the Southwest, it is necessary that schedules for powerplant operation be programmed very carefully to secure the maximum generation (and consequently maximum revenue to the project) that can be produced from the available water supply. Accurate area-capacity information for all elevations of Lake Mead is necessary to translate forecasts of future inflow into terms of hydrostatic head on the powerplant at critical times in the future, and thereby into water releases necessary to generate the energy required to meet estimated future loads. Further, the amount of water stored in the reservoir in the elevation band usable for power generation must be known, in order to maintain for use during possible periods of drought enough reserve storage water to permit generation of the firm obligation under conditions established in the contracts with the several power allottees. Annual revenue from the sale of electrical energy at Hoover powerplant averages approximately $\$ 9$ million ( $\$ 8,771,847$ during the fiscal year ended June 30, 1948). A close estimate cannot be made of the loss of revenue which might result from inaccurate area-capacity data. However, the above figure for annual revenue-together with the fact that, in terms of generation at Hoover powerplant, 1 acrefoot of water is about equal to 1 barrel of fuel oil utilized in an efficient steam generating plant-gives an indication of the relative importance of accurate information.

\section{COMPUTATIONS}

By J. L. Speert, F. C. Ames, and F. W. Kennon, U.S. Geological Survey

The computations of the area, capacity, and sediment tables are divided into several phases: (1) The original area and capacity computations; (2) review and re- 
vision of these computations; (3) area and capacity computations for the 1948-49 survey; and (4) computation of sediment tables and auxiliary tables from the results of (2) and (3). The final tables based on these computations are given in the section on tables.

\section{ORIGINAL AREA AND CAPACITY COMPUTATIONS}

The original computations were based upon the set of topographic maps compiled by the Soil Conservation Service from aerial photographs. The set comprises 525 -minute quadrangles, of which 44 include areas covered by Lake Mead at its maximum designed watersurface elevation. These maps are at scale $1: 12,000$, and have 10 -foot contour intervals, except in very flat areas where 5 -foot intervals are shown.

The areas between contours on each of the 44 sheets were determined by the Soil Conservation Service by the weight-apportioning method: successive annular strips of map paper between contours were trimmed and weighed, beginning with the highest contour $(1,230$ feet) and proceeding downward (Brown, 1941).

The capacity table was computed for 10 -foot vertical increments by the prismatoid formula,

$$
\mathrm{V}=\frac{10}{3}(A+\sqrt{A B}+B)
$$

in which $A$ and $B$ are the upper and lower areas of the horizontal surfaces bounding the 10-foot segment of volume. This formula represents the definite integral between the limits $h_{1}$ and $h_{2}$ of the equation $A=c h^{2}$, in which $h_{2}-h_{1}=10$ feet, $A$ is the contour area at elevation $h$ above the lowest point of the reservoir, and $c$ is a constant. Areas and volumes at 1 -foot intervals were then interpolated between the 10 -foot values on the assumption, consistent with the equation $A=c h^{2}$, that the square roots of these quantities varied in proportion to $h .^{4}$

Although the area-elevation curve for Lake Mead exhibits the general shape defined by $A=c h^{2}$, there are several reversals of curvature, as indicated by second differences alternating in sign. The prismatoid formula 1 yields results which are too small for all parts of the reservoir where the area-elevation curve is linear or concave upward. But, since the sinuousity is not pronounced and the 10-foot thickness of the successive volume increments is quite small in comparison with the total depth of the reservoir, such errors probably do not exceed the errors inherent in the observed data.

4 The Soil Conservation Service computations are described in detail in a memorandum to G. C. Dobson, Chief, Sedimentation Dirision, from Gene A. Zwerner, Assistant Engineer, Reservoir Section of that dirision, dated May 24, 1940, and on file in its Washington office.

$$
4969180-60-7
$$

\section{REVIEW AND REVISION OF THE ORIGINAI COMPUTATIONS}

The review of the computations of the original area and capacity tables included rechecking of some of the original data and comparison with data obtained during the 1948-49 hydrographic survey. That survey, undertaken largely in a water medium, has its own limitations that prevent a rigid check of the earlier data. So far as could be determined in the review, the topographic maps and the computations based thereon are valid and of generally high quality. No significant errors were found in the data from 34 of the 44 map sheets. In the large areas of the reservoir, where there has been negligible accumulation of sediment, the original computations were generally considered to be of sufficient accuracy to be adapted to the $1948-49$ survey.

Nevertheless, some errors were found in the area and capacity tables that had been in use prior to 1949 . Before the original capacities could be compared with the new capacities for the determination of sediment volumes, it was necessary to revise the original tables by correction of all known errors. The source of most errors was in the area tables, but their revisions necessitated corresponding revisions of the capacity tables.

Contour areas that were obviously erroneous were replanimetered. These areas covered parts of 10 map sheets. Such errors were relatively small and tended to be compensating, except for areas on map sheet 42 -the contour areas on that sheet between elevations 870 feet and 1,040 feet were inadvertently omitted in the original tabulation. The resulting maximum error in the original cumulative capacity values occurred in the elevation range between 1,050 feet and 1,150 feet. It amounted to about 30,000 acre-feet, or about 0.3 percent of the original capacity at elevation 1,050 feet.

$A$ section of about 3 or 4 square miles of the reservoir area was not printed on map sheet 5 , and it is not known how values of contour areas for this sheet were determined; the 1948 survey data made it possible to complete the map sheet. The subsequent planimetering of 50-foot contours checked closely the area values for those contours as determined by the Soil Conservation Service. On sheet 22 the flat Virgin River delta is represented by 5-foot contours; errors in contour area on this sheet were apparently caused by mistaking some 5-foot contours for 10 -foot contours.

Of the remaining eight sheets corrected, the errors were all found in the lowest contours-namely, those crossing or immediately adjacent to the old river channel. A number were depression contours in the channel itself. The occurrence of all these errors in the lowest reservoir sections is probably not purely fortuitous. The weight-apportioning method used to deter- 
mine original contour areas would tend to be least reliable for the lowest contours, because only the 50-foot contours were numbered on the maps, and progressive trimming of 1-minute quadrangles would, in most instances, reach a point where no numbered contours remained on the trimmed portion of the map below the lowest 50-foot contour. Thus, unless an operator was extremely careful he might easily become confused when working with the lowest contours.

It was concluded that there was no reason to doubt the general accuracy of the Soil Conservation Service tabulation of reservoir area except those parts that included the few lowest contour areas of each map sheet. Therefore, the bottom areas of each map sheet were carefully compared with the originally tabulated values. The review so made is believed thorough enough to justify the conclusion that no errors of any consequence remain uncorrected.

After the original area table was corrected, it was necessary to revise the original capacity table to conform with it. Revised capacities were computed for 10-foot vertical increments by two different methods: (a) The prismoidal formula 2 (p. 87), used to compute the new capacity table; and (b) the prismatoid formula 1 (p. 85), used in the original computations and used as a check on method a. Except for the lowest 30 feet, all 10-foot volume increments computed by both methods checked within 1 percent, and the cumulative totals checked even better. For example, at elevation 1,150 feet, the two computed values for cumulative volume agreed within 1 part in 20,000.

Table 2 shows the revisions made in the 1935 area table, and the resultant modifications in the capacity

TABLE 2.-Revisions of 1935 area and capacity tables

\begin{tabular}{|c|c|c|c|c|}
\hline \multirow{2}{*}{ Elevation } & \multicolumn{2}{|c|}{$\begin{array}{l}\text { A rea of lake surface, in } \\
\text { thousands of acres }\end{array}$} & \multirow{2}{*}{ Difference } & \multirow{2}{*}{$\begin{array}{l}\text { Resulting } \\
\text { changes in } \\
\text { capacity, in } \\
\text { thousands } \\
\text { of acre-feet }\end{array}$} \\
\hline & Original & Revised & & \\
\hline & & & -0.2 & $\begin{array}{r}0 \\
-1\end{array}$ \\
\hline 670 & $\begin{array}{l}1.1 \\
5.3\end{array}$ & $\begin{array}{l}1.0 \\
5.5\end{array}$ & $\begin{array}{r}-.1 \\
+.2\end{array}$ & $\begin{array}{r}-1 \\
0\end{array}$ \\
\hline $740 \ldots$ & 6.3 & 6. 2 & -.1 & +1 \\
\hline $750 \ldots$ & 8.2 & 8.1 & -.1 & 0 \\
\hline $760 \ldots$ & 9.3 & 9.2 & -.1 & -1 \\
\hline $830 \ldots$ & 20.8 & 20.7 & -.1 & -4 \\
\hline 860 & $\begin{array}{r}26.7 \\
32.3\end{array}$ & $\begin{array}{l}26.6 \\
32\end{array}$ & -.1 & $\begin{array}{l}-4 \\
-4\end{array}$ \\
\hline $900 \ldots$ & $\begin{array}{l}34.3 \\
34.3\end{array}$ & $\begin{array}{l}34.4 \\
34.4\end{array}$ & +.1 & -3 \\
\hline 910 & 36.7 & 36.9 & +.2 & -2 \\
\hline $920 \ldots$ & 39. 1 & 39. 3 & +.2 & -1 \\
\hline $930 \ldots$ & 41.5 & 41.7 & +2 & +1 \\
\hline $\begin{array}{l}940 \ldots \ldots \\
950 \ldots \ldots\end{array}$ & $\begin{array}{l}43.8 \\
46.2\end{array}$ & $\begin{array}{l}44.0 \\
46.4\end{array}$ & $\begin{array}{r}+.2 \\
+.2\end{array}$ & $\begin{array}{l}+3 \\
+5\end{array}$ \\
\hline 960... & 48.8 & $\begin{array}{l}4.4 \\
49.0\end{array}$ & +2 & +8 \\
\hline $970 \ldots \ldots$ & 51. 2 & $\begin{array}{l}51.5 \\
54.4\end{array}$ & $\begin{array}{r}+.3 \\
+.2\end{array}$ & $\begin{array}{l}+10 \\
+12\end{array}$ \\
\hline - & 57.2 & $\begin{array}{l}3.4 \\
57.5\end{array}$ & $\begin{array}{l}+.2 \\
+.3\end{array}$ & +15 \\
\hline 1000 & 60.2 & 60.5 & +.3 & +18 \\
\hline .............. & 63.7 & 64.0 & +3 & $\begin{array}{l}+21 \\
+24\end{array}$ \\
\hline $\begin{array}{l}1020 \ldots \ldots \\
1030 \ldots \ldots\end{array}$ & 70. 3 & $\begin{array}{l}67.2 \\
70.7\end{array}$ & $\begin{array}{r}+.3 \\
+.4\end{array}$ & $\begin{array}{l}+24 \\
+26\end{array}$ \\
\hline $1040 \ldots$ & 73.8 & 74.2 & & +30 \\
\hline & 124.7 & 124.4 & & +30 \\
\hline $1170 \ldots . .$. & 129. 6 & 129.4 & & +27 \\
\hline $1180 \ldots \ldots$ & 134.8 & $\begin{array}{l}134.6 \\
139\end{array}$ & $=$ & +24 \\
\hline 1190 & 140.0 & 139.9 & & \\
\hline
\end{tabular}

table. The revisions make very slight changes in the capacity of the reservoir below 930 feet, most of which is dead storage. Original capacity above that level has been generally increased above the original tabulation by these revisions; the increase amounts to about 30,000 acre-feet in the zone 1,040 to 1,160 feet, and to 23,000 acre-feet at elevations above 1,190 feet.

\section{AREA AND CAPACITY COMPUTATIONS FOR 1948-49 SURVEY}

Owing to the shape of the reservoir, two distinct methods were employed for the preparation of the new area and capacity tables, according to the two types of basic data available. For the lake portion of the reservoir, west of longitude $113^{\circ} 57^{\prime}$, the $1948-49$ survey provided new contour maps from which new contour areas at 10 -foot vertical intervals could be obtained. For Lower Granite Gorge, east of longitude $113^{\circ} 57^{\prime}$, only vertical cross sections were available at average horizontal intervals of 1,200 feet. The present capacity of the western portion of the reservoir is over 100 times that of the eastern portion.

Comparison of the old and new contours revealed that practically all of the sedimentation occurred along the former chamnel, and practically none remained on the slopes. As a result, the new contours agreed in shape and position with the old ones except in their upstream parts, where the contours crossed the lowest part of the reservoir bed. By taking advantage of this condition, it was possible to lighten considerably the task of determining the new contour areas. In the original tabulation by the Soil Conservation Service, the contour areas of the 10-foot contours were tabulated for each 5 -minute quadrangle of the reservoir basin. Extensive planimetry of the new contours was not required. It was necessary only to select the 5-minute quadrangles containing the upstream loop of each contour, where it differed from the original, and to planimeter the area on these quadrangles. The rest of each contour area (the downstream part) was obtained from the original tabulations, revised where necessary as described above.

The method employed for the computation of volumes required area values at half-foot intervals. These half-foot contour areas were interpolated between the planimetered 10 -foot values by standard interpolation formulas involving second and third differences. For the lowest 50 feet of the reservoir, where the area-curve reversals were most pronounced, third differences were required; for the remainder of the range in depth, second differences were adequate to develop a smooth interpolation. Each of the 20 interpolated values in each 10-foot range was computed by increments from the preceding value, so that the interpolation was self- 
checking at each 10 -foot level. The process was well adapted to rapid computation with an automatic calculating machine.

With the table of contour areas available at half-foot intervals, volumes were computed in 1-foot increments by the prismoidal formula,

$$
V=\frac{h}{9}\left(A_{1}+4 A_{2}+A_{3}\right)
$$

in which $h$ is the vertical increment or 1 foot, $A_{1}$ and $A_{3}$ are the top and bottom areas of the segment, respectively, and $A_{2}$ is the middle area. For the range in depth above elevation 800 feet, it is noted that, within any 1-foot range, the variation of area with respect to height is essentially linear; hence formula 2 can be simplified to $V=h A_{2}$. In other words, the volume in acre-feet of each 1 -foot increment is numerically equal to the area of its midsection in acres. The 1-foot volume increments for the upper 430 feet of depth were therefore determined in this way, and the total was checked by computing the same volume in 10-foot increments from elevation 800 feet to elevation 1,230 feet by formula 2. The totals differed by only 48 acre-feet.

The 1948 capacity of Lower Granite Gorge, east of longitude $113^{\circ} 57^{\prime}$, was computed in 10 -foot vertical increments by the end-area method, whereby the volume of each increment is the product of the average of the areas of the vertical end sections and the length of the reach. In the few cases where relatively large bays were included within a reach, the volumes of the bays were computed from the original contour maps and were added to the volume computed for the reach by the end-area method.

After the capacity table at 10 -foot intervals was prepared, intermediate 1-foot values were interpolated by second differences, by the method used for interpolating the half-foot area values described above. Reservoir areas at each foot of elevation were taken as equal numerically to the mean of the 1-foot incremental volumes immediately above and below the respective contour planes. As an indication of the precision attained in this computation, it is interesting to note that the contour area of the canyon section at elevation 1,230 feet, which is above practically all river-deposited sediment, was determined to be 5,177 acres, as against 5,183 acres determined for the same contour area from the original data of the Soil Conservation Service-a difference of about 0.1 percent.

The area and capacity values for the east and west portions of the reservoir were combined to form the area and capacity trables for Lake Mead.

\section{COMPUTATION OF SEDIMENT AND AUXILIARY} TABLES

The 1948 sediment-volume table was prepared by taking the difference, at 10 -foot vertical intervals, between the revised original capacities and the new capacities.

In addition to these tables (1948 area and capacity, 1948 sediment volume, and revised original area and capacity) two other tables were prepared to aid in the analysis of sediment distribution and other limnological studies. One shows the 1948 capacity by basins; the other, the 1948 sediment volume by basins. The basins for which the capacity tables were prepared differ in some instances from those used for the sediment data (fig. 17).

All values appearing in these tables for individual basins were computed by the prismatoid formula 1 rather than by the prismoidal formula 2 , because computations had been substantially completed before an alternative to equation 1 had been chosen, and recomputation was not considered justifiable. The sum of volumes by basins tor each 10-foot elevation agreed closely with the value derived for the lake as a whole. The basin tables have been made consistent with tables for the entire lake by distributing the small discrepancies between them among the several basins in proportion to their relative sizes.

\section{TABLES}

By F. C. Ames, F. W. Kennon, and W. B. Langbein, U.S. Geological Survey

The following tables of the surface area, capacity, and sediment volume of Lake Mead were prepared from the results of the first resurvey of the reservoir, for which fieldwork was begun in March 1948 and completed in March 1949.

Tables 3 and 4 are the principal tables prepared for use in operation of the reservoir. They contain data on the surface area and the usable contents of the reservoir referred to Powerhouse datum, to which the gage at Hoover Dam is set. Table 3, showing reservoir areas referred to Powerhouse datum, was prepared by interpolating between the 1948 area values determined on the datum of 1929 , leveling of 1935 . Table 4, expressing usable reservoir capacity based on Powerhouse datum, was prepared by interpolating between appropriate entries in the 1948 capacity table after subtracting dead storage of $2,620,000$ acre-feet.

Tables 5 and 6 give water content and sediment volume of individual basins in terms of the same datum that was used in the 1935 original survey, in order to facilitate study of changes. Table 7 presents a com- 


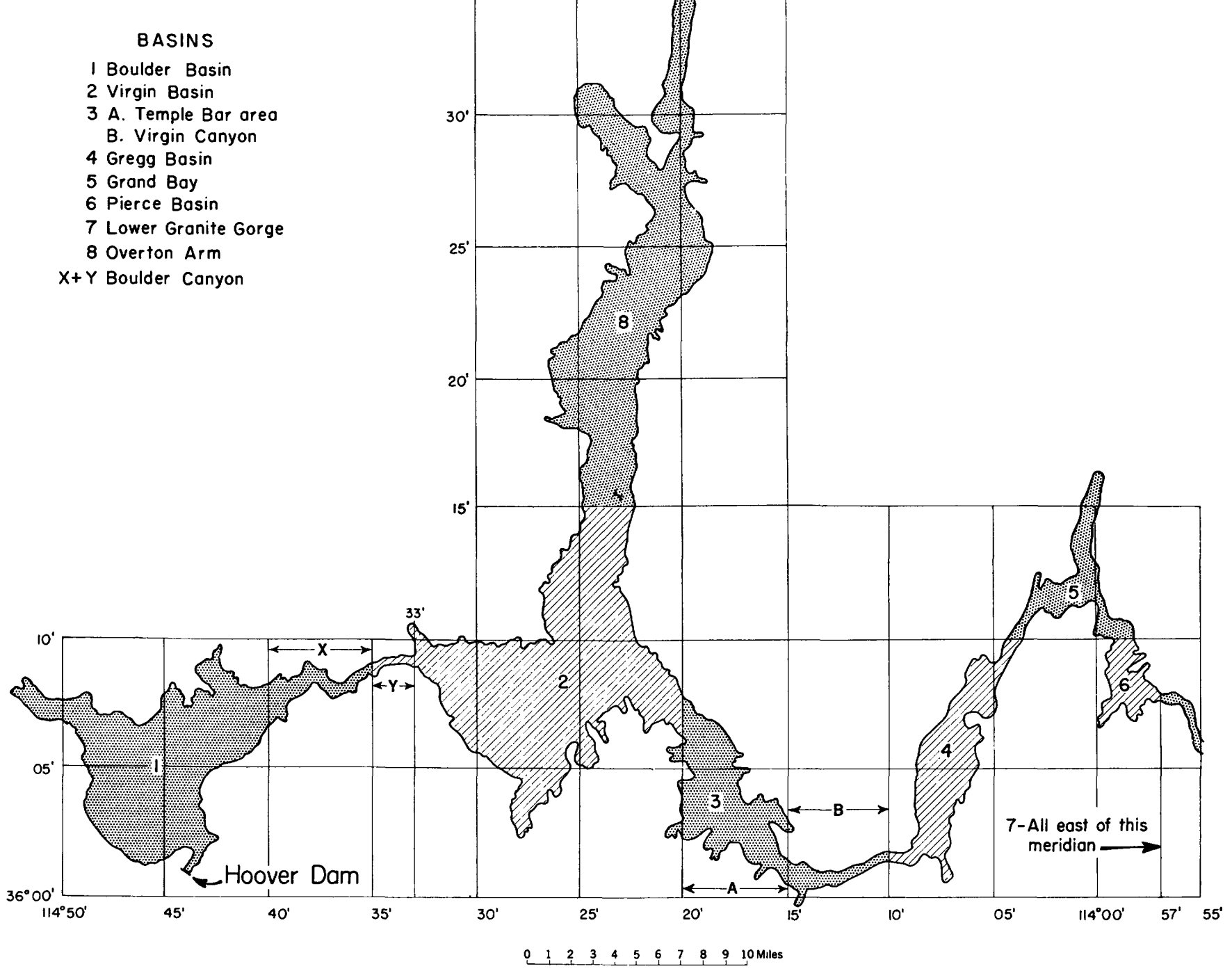

Figure 17.-Index map showing basins for which separate capacity and sediment tables have been prepared.

parison of the original area and capacity data with those of the 1948 survey, together with 1948 sediment volumes, all as a function of elevations referred to the datum of 1929, leveling of 1935 . Subtract 0.55 foot from the elevations in these three tables to obtain stages corresponding to the gage at Hoover Dam (Powerhouse datum).

Table 8 summarizes the significant items of change between 1935 and 1948. It shows the elevations above mean sea level of various features of operational significance, with respect to both the Powerhouse datum and the datum of 1929, leveling of 1935 . The significant changes in storage of water and sediment are also summarized. Thus, the maximum storage controlled by the spillway gates in raised position decreased from $31,250,000$ acre-feet in 1935 to $29,827,000$ acre-feet in 1948. The dead storage, below the lowest outlets in the intake towers, was decreased 603,000 acre-feet during the 14-year interval, because of deposition of sediment. The higher flood-control level for August 1 on the 1948-49 capacity table as compared with the 1935 table reflects the effect of scour at Detrital Wash and the fact that the flood-control capacity is $2,500,000$ acre-feet instead of $2,506,000$ acre-feet as used with the old table.

\section{REFERENCE CITED}

Brown, C. B., 1941, Mapping Lake Mead: Geog. Rev., v. 31, p. $385-405$. 
TABLE 3.-Area of Lake Mead, in thousand acres, for indicated rise, in feet, of lake level, 1948-49 [Elevations of lake surface are in feet above mean sea level, adjustment of 1912 (powerhouse datum); add 0.55 foot to convert to datum of 1929, leveling of 1935]

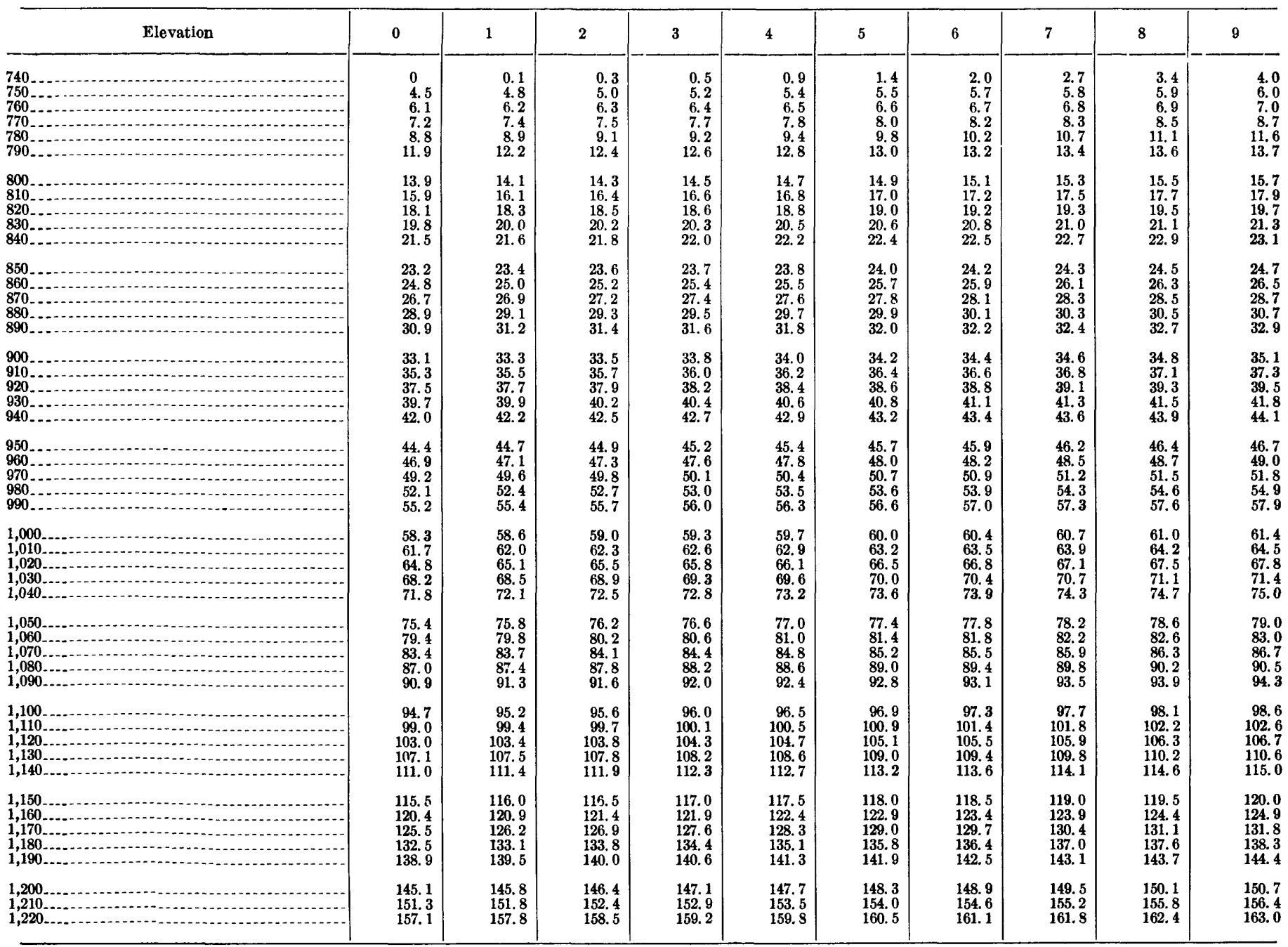


TABLE 4.-Usable capacity of Lake Mead, in thousand acre-feet, for indicated elevations, $1948-49$

[Elevations are in feet above mean sea level, based on adjustment of 1912 (powerhouse datum); add 0.55 foot to convert to datum of 1929 , levelimg of 1935 . Dead storage below elevation 895 feet is $2,620,000$ acre-feet]

\begin{tabular}{|c|c|c|c|c|c|c|c|c|c|c|}
\hline Elevation & 0 & 1 & 2 & 3 & 4 & 5 & 6 & 7 & 8 & 9 \\
\hline $\begin{array}{l}890 \\
9000 \\
900\end{array}$ & $\begin{array}{r}163 \\
505 \\
868 \\
1,255 \\
1,663\end{array}$ & $\begin{array}{r}196 \\
540 \\
906 \\
1,295 \\
1,705\end{array}$ & $\begin{array}{r}229 \\
576 \\
944 \\
1,335 \\
1,748\end{array}$ & $\begin{array}{r}263 \\
611 \\
982 \\
1,375 \\
1,790\end{array}$ & $\begin{array}{r}297 \\
647 \\
1,020 \\
1,415 \\
1,833\end{array}$ & $\begin{array}{r}331 \\
683 \\
1,059 \\
1,456 \\
1,876\end{array}$ & $\begin{array}{r}32 \\
365 \\
720 \\
1,098 \\
1,497 \\
1,919\end{array}$ & $\begin{array}{r}64 \\
400 \\
757 \\
1,137 \\
1,538 \\
1,963\end{array}$ & $\begin{array}{r}97 \\
434 \\
794 \\
1,176 \\
1,579 \\
2,007\end{array}$ & $\begin{array}{r}130 \\
469 \\
831 \\
1,215 \\
1,621 \\
2,051\end{array}$ \\
\hline $\begin{array}{l}950 \\
960 \\
970 \\
980\end{array}$ & $\begin{array}{l}2,095 \\
2,552 \\
3,032 \\
3,539 \\
4,075\end{array}$ & $\begin{array}{l}2,139 \\
\mathbf{2}, \mathbf{5 9 9} \\
\mathbf{3}, 081 \\
\mathbf{3}, \mathbf{5 9 1} \\
\mathbf{4}, 130\end{array}$ & $\begin{array}{l}2,184 \\
2,646 \\
3,131 \\
3,644 \\
4,186\end{array}$ & $\begin{array}{l}2,229 \\
2,693 \\
3,181 \\
3,696 \\
4,242\end{array}$ & $\begin{array}{l}2,275 \\
2,741 \\
3,231 \\
3,749 \\
4,298\end{array}$ & $\begin{array}{l}2,320 \\
2,789 \\
3,282 \\
3,803 \\
4,355\end{array}$ & $\begin{array}{l}2,366 \\
2,837 \\
3,333 \\
3,857 \\
4,411\end{array}$ & $\begin{array}{l}2,412 \\
2,885 \\
3,384 \\
3,911 \\
4,468\end{array}$ & $\begin{array}{l}2,458 \\
2,934 \\
3,435 \\
3,965 \\
4,526\end{array}$ & $\begin{array}{l}2,505 \\
2,983 \\
3,487 \\
4,020 \\
4,584\end{array}$ \\
\hline $\begin{array}{l}1,000 \\
1,010 \\
1,020 \\
1,040\end{array}$ & $\begin{array}{l}4,642 \\
5,242 \\
5,874 \\
6,539 \\
7,239\end{array}$ & $\begin{array}{l}4,700 \\
5,304 \\
5,939 \\
6,607 \\
7,311\end{array}$ & $\begin{array}{l}4,759 \\
5,366 \\
6,004 \\
6,676 \\
7,383\end{array}$ & $\begin{array}{l}4,818 \\
5,428 \\
6,070 \\
6,745 \\
7,456\end{array}$ & $\begin{array}{l}4,877 \\
5,491 \\
6,136 \\
6,814 \\
7,529\end{array}$ & $\begin{array}{l}4,937 \\
5,554 \\
6,202 \\
6,884 \\
7,602\end{array}$ & $\begin{array}{l}4,997 \\
5,617 \\
6,269 \\
6,954 \\
7,676\end{array}$ & $\begin{array}{l}5,058 \\
5,681 \\
6,336 \\
7,025 \\
7,750\end{array}$ & $\begin{array}{l}5,119 \\
5,745 \\
6,403 \\
7,096 \\
7,824\end{array}$ & $\begin{array}{l}5.180 \\
5,809 \\
6,471 \\
7,167 \\
7,899\end{array}$ \\
\hline $\begin{array}{l}1,050 \\
1,060 \\
1,070 \\
1,090\end{array}$ & $\begin{array}{r}7,974 \\
8,748 \\
9,562 \\
10,414 \\
11,304\end{array}$ & $\begin{array}{r}8,050 \\
8,828 \\
9,646 \\
10,501 \\
11,395\end{array}$ & $\begin{array}{r}8,126 \\
8,908 \\
9,730 \\
10,589 \\
11,486\end{array}$ & $\begin{array}{r}8,202 \\
8,988 \\
9,814 \\
10,677 \\
11,578\end{array}$ & $\begin{array}{r}8,279 \\
9,069 \\
9,899 \\
10,765 \\
11,670\end{array}$ & $\begin{array}{r}8,356 \\
9,150 \\
9,984 \\
10,854 \\
11,763\end{array}$ & $\begin{array}{r}8,434 \\
9,232 \\
10,069 \\
10,943 \\
11,856\end{array}$ & $\begin{array}{r}8,512 \\
9,314 \\
10,155 \\
11,033 \\
11,949\end{array}$ & $\begin{array}{r}8,590 \\
9,396 \\
10,241 \\
11,123 \\
12,043\end{array}$ & $\begin{array}{r}8,669 \\
9,479 \\
10,327 \\
11,213 \\
12,137\end{array}$ \\
\hline $\begin{array}{l}1,100 \ldots \\
1,110 \\
1,120 \ldots \ldots\end{array}$ & $\begin{array}{l}12,232 \\
13,201 \\
14,210 \\
15,261 \\
16,351\end{array}$ & $\begin{array}{l}12,327 \\
13,300 \\
14,313 \\
15,368 \\
16,462\end{array}$ & $\begin{array}{l}12,422 \\
13,399 \\
14,417 \\
15,476 \\
16,574\end{array}$ & $\begin{array}{l}12,518 \\
13,499 \\
14,521 \\
15,584 \\
16,686\end{array}$ & $\begin{array}{l}12,614 \\
13,599 \\
14,625 \\
15,692 \\
16,798\end{array}$ & $\begin{array}{l}12,711 \\
13,700 \\
14,730 \\
15,801 \\
16,911\end{array}$ & $\begin{array}{l}12,808 \\
13,801 \\
14,835 \\
15,910 \\
17,025\end{array}$ & $\begin{array}{l}12,905 \\
13,903 \\
14,941 \\
16,020 \\
17,139\end{array}$ & $\begin{array}{l}13,003 \\
14,005 \\
15,047 \\
16,130 \\
17,253\end{array}$ & $\begin{array}{l}13,102 \\
14,107 \\
15,154 \\
16,240 \\
17,368\end{array}$ \\
\hline $\begin{array}{l}1,150 \\
1,160 \\
1,170 \\
1,180 \\
1,190\end{array}$ & $\begin{array}{l}17,483 \\
18,663 \\
19,892 \\
21,186 \\
22,543\end{array}$ & $\begin{array}{l}17,599 \\
18,783 \\
20,019 \\
21,319 \\
22,682\end{array}$ & $\begin{array}{l}17,715 \\
18,904 \\
20,146 \\
21,452 \\
22,822\end{array}$ & $\begin{array}{l}17,832 \\
19,026 \\
20,274 \\
21,586 \\
22,963\end{array}$ & $\begin{array}{l}17,949 \\
19,148 \\
20,403 \\
21,721 \\
23,104\end{array}$ & $\begin{array}{l}18,067 \\
19,271 \\
20,532 \\
21,857 \\
23,245\end{array}$ & $\begin{array}{l}18,185 \\
19,394 \\
20,661 \\
21,993 \\
23,387\end{array}$ & $\begin{array}{l}18,304 \\
19,518 \\
20,791 \\
22,129 \\
23,530\end{array}$ & $\begin{array}{l}18,423 \\
19,642 \\
20,922 \\
22,267 \\
23,674\end{array}$ & $\begin{array}{l}18,543 \\
19,767 \\
21,054 \\
22,405 \\
23,818\end{array}$ \\
\hline 1,200 & $\begin{array}{l}23,963 \\
25,445 \\
26,986\end{array}$ & $\begin{array}{l}24,108 \\
25,597 \\
27,144\end{array}$ & $\begin{array}{l}24,254 \\
25,749 \\
27,302\end{array}$ & $\begin{array}{l}24,401 \\
25,901 \\
27,461\end{array}$ & $\begin{array}{l}24,548 \\
26,054 \\
27,620\end{array}$ & $\begin{array}{l}24,696 \\
26,208 \\
27,780\end{array}$ & $\begin{array}{l}24,845 \\
26,363 \\
27,941\end{array}$ & $\begin{array}{l}24,994 \\
26,518 \\
28,103\end{array}$ & $\begin{array}{l}25,144 \\
26,673 \\
28,265\end{array}$ & $\begin{array}{l}25,292 \\
26,849 \\
28,427\end{array}$ \\
\hline
\end{tabular}


TABLE 5.-Reservoir volumes in Lake Mead, by basins, 1948-49

[Elevations are in feet above mean sea level, datum of 1929, leveling of 1935]

\begin{tabular}{|c|c|c|c|c|c|c|c|c|c|c|c|}
\hline \multirow[b]{2}{*}{ Elevation } & \multicolumn{11}{|c|}{ Reservoir volumes, in thousand acre-feet, for indicated basins [Symbols in parentheses refer to fig. 17] } \\
\hline & $\begin{array}{l}\text { Boulder } \\
\text { Basin } \\
(1-\mathbf{X})\end{array}$ & $\begin{array}{l}\text { Boulder } \\
\text { Canyon } \\
(\mathbf{X}+\mathbf{Y})\end{array}$ & $\begin{array}{l}\text { Virgin } \\
\text { Basin } \\
(2-Y)\end{array}$ & $\begin{array}{c}\text { Temple } \\
\text { Bar area } \\
\qquad(3 A)\end{array}$ & $\begin{array}{l}\text { Virgin } \\
\text { Canyon } \\
\text { (3B) }\end{array}$ & $\begin{array}{c}\text { Gregg } \\
\text { Basin } \\
(4)\end{array}$ & $\begin{array}{c}\text { Grand } \\
\text { Bay } \\
(5)\end{array}$ & $\begin{array}{c}\text { Pierce } \\
\text { Basin } \\
(6)\end{array}$ & $\begin{array}{l}\text { Granite } \\
\text { Gorge } \\
(7)\end{array}$ & $\begin{array}{l}\text { Overton } \\
\text { Arm } \\
(8)\end{array}$ & Total \\
\hline $\begin{array}{l}740 \\
750 \\
770 \\
780\end{array}$ & $\begin{array}{r}0 \\
15 \\
66 \\
123 \\
182 \\
243\end{array}$ & $\begin{array}{r}3 \\
10 \\
20 \\
29\end{array}$ & $\begin{array}{r}1 \\
11 \\
40\end{array}$ & - & (n) & a & - & & \begin{tabular}{l}
$-\cdot$ \\
$-\cdot$ \\
\hdashline- \\
\hdashline- \\
$\cdots-$
\end{tabular} & $\begin{array}{ll}-1 \\
\cdots\end{array}$ & $\begin{array}{r}15 \\
69 \\
134 \\
213 \\
312\end{array}$ \\
\hline $\begin{array}{l}800 \\
810 \\
830\end{array}$ & $\begin{array}{l}310 \\
380 \\
454 \\
532 \\
614\end{array}$ & $\begin{array}{l}39 \\
50 \\
61 \\
72 \\
83\end{array}$ & $\begin{array}{r}92 \\
159 \\
237 \\
324 \\
419\end{array}$ & $\begin{array}{r}6 \\
19 \\
35\end{array}$ & 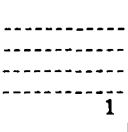 & $\ldots$ & 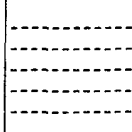 & $\begin{array}{l}-- \\
-- \\
- \\
--\end{array}$ & $\mid$\begin{tabular}{l}
-- \\
\hdashline- \\
\hdashline- \\
\hdashline- \\
$\cdots$
\end{tabular} & (n & $\begin{array}{r}441 \\
589 \\
758 \\
947 \\
1,152\end{array}$ \\
\hline $\begin{array}{l}850 \\
860 \\
880\end{array}$ & $\begin{array}{r}700 \\
791 \\
886 \\
986 \\
1,091\end{array}$ & $\begin{array}{r}96 \\
109 \\
122 \\
136 \\
151\end{array}$ & $\begin{array}{r}522 \\
633 \\
752 \\
878 \\
1,011\end{array}$ & $\begin{array}{r}53 \\
72 \\
93 \\
115 \\
140\end{array}$ & $\begin{array}{r}4 \\
8 \\
12 \\
17 \\
21\end{array}$ & $\begin{array}{r}1 \\
5 \\
15 \\
31\end{array}$ & $-\cdots$ & $-\cdots$ & \begin{tabular}{l}
$-\cdot$ \\
\hdashline- \\
\hdashline- \\
\hdashline-
\end{tabular} & 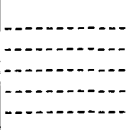 & $\begin{array}{l}1,375 \\
1,614 \\
1,870 \\
2,147 \\
2,445\end{array}$ \\
\hline $\begin{array}{l}900 \\
910 \\
920\end{array}$ & $\begin{array}{l}1,201 \\
1,317 \\
1,439 \\
1,565 \\
1,697\end{array}$ & $\begin{array}{l}166 \\
182 \\
199 \\
215 \\
234\end{array}$ & $\begin{array}{l}1,151 \\
1,298 \\
1,454 \\
1,620 \\
1,793\end{array}$ & $\begin{array}{l}166 \\
194 \\
225 \\
258 \\
293\end{array}$ & $\begin{array}{l}26 \\
32 \\
37 \\
43 \\
49\end{array}$ & $\begin{array}{r}53 \\
79 \\
108 \\
141 \\
178\end{array}$ & 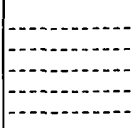 & $-\cdots$ & 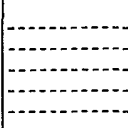 & $\begin{array}{r}1 \\
3 \\
6 \\
11 \\
16\end{array}$ & $\begin{array}{l}2,764 \\
3,105 \\
3,468 \\
3,853 \\
4,260\end{array}$ \\
\hline \begin{tabular}{|c|}
950 \\
960 \\
970 \\
980
\end{tabular} & $\begin{array}{l}1,835 \\
1,979 \\
2,129 \\
2,284 \\
2,445\end{array}$ & $\begin{array}{l}252 \\
272 \\
292 \\
312 \\
334\end{array}$ & $\begin{array}{l}1,974 \\
2,163 \\
2,360 \\
2,565 \\
2,778\end{array}$ & $\begin{array}{l}330 \\
369 \\
411 \\
455 \\
503\end{array}$ & $\begin{array}{l}56 \\
63 \\
70 \\
77 \\
85\end{array}$ & $\begin{array}{l}218 \\
261 \\
305 \\
353 \\
402\end{array}$ & $\begin{array}{r}1 \\
3 \\
7 \\
14\end{array}$ & 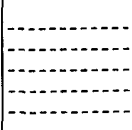 & 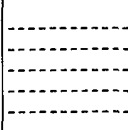 & $\begin{array}{r}25 \\
38 \\
55 \\
76 \\
104\end{array}$ & $\begin{array}{l}4,690 \\
5,146 \\
5,625 \\
6,130 \\
6,665\end{array}$ \\
\hline 1,000 & $\begin{array}{l}2,612 \\
2,785 \\
2,964 \\
3,149 \\
3,340\end{array}$ & $\begin{array}{l}356 \\
379 \\
403 \\
428 \\
453\end{array}$ & $\begin{array}{l}3,000 \\
3,231 \\
3,471 \\
3,721 \\
3,982\end{array}$ & $\begin{array}{l}552 \\
605 \\
660 \\
719 \\
779\end{array}$ & $\begin{array}{r}94 \\
102 \\
111 \\
121 \\
131\end{array}$ & $\begin{array}{l}453 \\
507 \\
564 \\
622 \\
683\end{array}$ & $\begin{array}{l}24 \\
36 \\
51 \\
69 \\
87\end{array}$ & 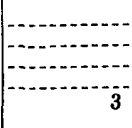 & 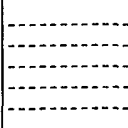 & $\begin{array}{l}139 \\
182 \\
233 \\
292 \\
361\end{array}$ & $\begin{array}{l}7,230 \\
7,828 \\
8,458 \\
9,121 \\
9,819\end{array}$ \\
\hline $1,1,050$ & $\begin{array}{l}3,537 \\
3,741 \\
3,950 \\
4,166 \\
4,388\end{array}$ & $\begin{array}{l}479 \\
506 \\
534 \\
562 \\
592\end{array}$ & $\begin{array}{l}4,251 \\
4,530 \\
4,818 \\
5,116 \\
5,424\end{array}$ & $\begin{array}{r}843 \\
910 \\
980 \\
1,054 \\
1,131\end{array}$ & $\begin{array}{l}141 \\
152 \\
163 \\
175 \\
187\end{array}$ & $\begin{array}{r}747 \\
814 \\
884 \\
955 \\
1,030\end{array}$ & $\begin{array}{l}107 \\
127 \\
150 \\
174 \\
199\end{array}$ & $\begin{array}{r}9 \\
16 \\
27 \\
40 \\
54\end{array}$ & 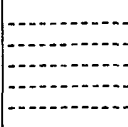 & $\begin{array}{l}439 \\
528 \\
630 \\
744 \\
869\end{array}$ & $\begin{array}{l}10,553 \\
11,324 \\
12,136 \\
12,986 \\
13,874\end{array}$ \\
\hline $1,1,100$ & $\begin{array}{l}4,618 \\
4,855 \\
5,099 \\
5,352 \\
5,612\end{array}$ & $\begin{array}{l}622 \\
653 \\
686 \\
719 \\
752\end{array}$ & $\begin{array}{l}5,741 \\
6,068 \\
6,403 \\
6,748 \\
7,103\end{array}$ & $\begin{array}{l}1,212 \\
1,296 \\
1,384 \\
1,476 \\
1,571\end{array}$ & $\begin{array}{l}199 \\
212 \\
226 \\
240 \\
255\end{array}$ & $\begin{array}{l}1,108 \\
1,189 \\
1,273 \\
1,360 \\
1,450\end{array}$ & $\begin{array}{l}226 \\
255 \\
286 \\
318 \\
353\end{array}$ & $\begin{array}{r}70 \\
88 \\
107 \\
129 \\
152\end{array}$ & (- & $\begin{array}{l}1,004 \\
1,150 \\
1,309 \\
1,480 \\
1,662\end{array}$ & $\begin{array}{l}14,800 \\
15,766 \\
16,773 \\
17,822 \\
18,910\end{array}$ \\
\hline $\begin{array}{l}1,150 \ldots 0 \\
1,170 \\
1,180\end{array}$ & $\begin{array}{l}5,878 \\
6,152 \\
6,434 \\
6,725 \\
7,024\end{array}$ & $\begin{array}{l}787 \\
823 \\
859 \\
896 \\
935\end{array}$ & $\begin{array}{l}7,467 \\
7,842 \\
8,229 \\
8,627 \\
9,036\end{array}$ & $\begin{array}{l}1,670 \\
1,772 \\
1,878 \\
1,987 \\
2,100\end{array}$ & $\begin{array}{l}270 \\
285 \\
302 \\
319 \\
336\end{array}$ & $\begin{array}{l}1,542 \\
1,638 \\
1,737 \\
1,837 \\
1,941\end{array}$ & $\begin{array}{l}391 \\
430 \\
473 \\
516 \\
563\end{array}$ & $\begin{array}{l}177 \\
205 \\
234 \\
267 \\
301\end{array}$ & (n) & $\begin{array}{l}1,857 \\
2,069 \\
2,297 \\
2,544 \\
2,812\end{array}$ & $\begin{array}{l}20,039 \\
21,216 \\
22,443 \\
23,733 \\
25,087\end{array}$ \\
\hline 1,210 & $\begin{array}{l}7,331 \\
7,647 \\
7,973 \\
8,308\end{array}$ & $\begin{array}{r}973 \\
1,013 \\
1,054 \\
1,096\end{array}$ & $\begin{array}{r}9,456 \\
9,887 \\
10,333 \\
10,791\end{array}$ & $\begin{array}{l}2,216 \\
2,336 \\
2,459 \\
2,585\end{array}$ & $\begin{array}{l}355 \\
374 \\
394 \\
415\end{array}$ & $\begin{array}{l}2,047 \\
2,156 \\
2,267 \\
2,381\end{array}$ & $\begin{array}{l}611 \\
661 \\
715 \\
770\end{array}$ & $\begin{array}{l}337 \\
375 \\
414 \\
456\end{array}$ & $\begin{array}{r}77 \\
122 \\
169 \\
219\end{array}$ & $\begin{array}{l}3,099 \\
3,410 \\
3,742 \\
4,100\end{array}$ & $\begin{array}{l}26,502 \\
27,982 \\
29,520 \\
31,121\end{array}$ \\
\hline
\end{tabular}


TABLE 6.-Sediment volumes in Lake Mead by basins, 1948-49

[Elevations are in feet above mean sea level, datum of 1929, leveling of 1935]

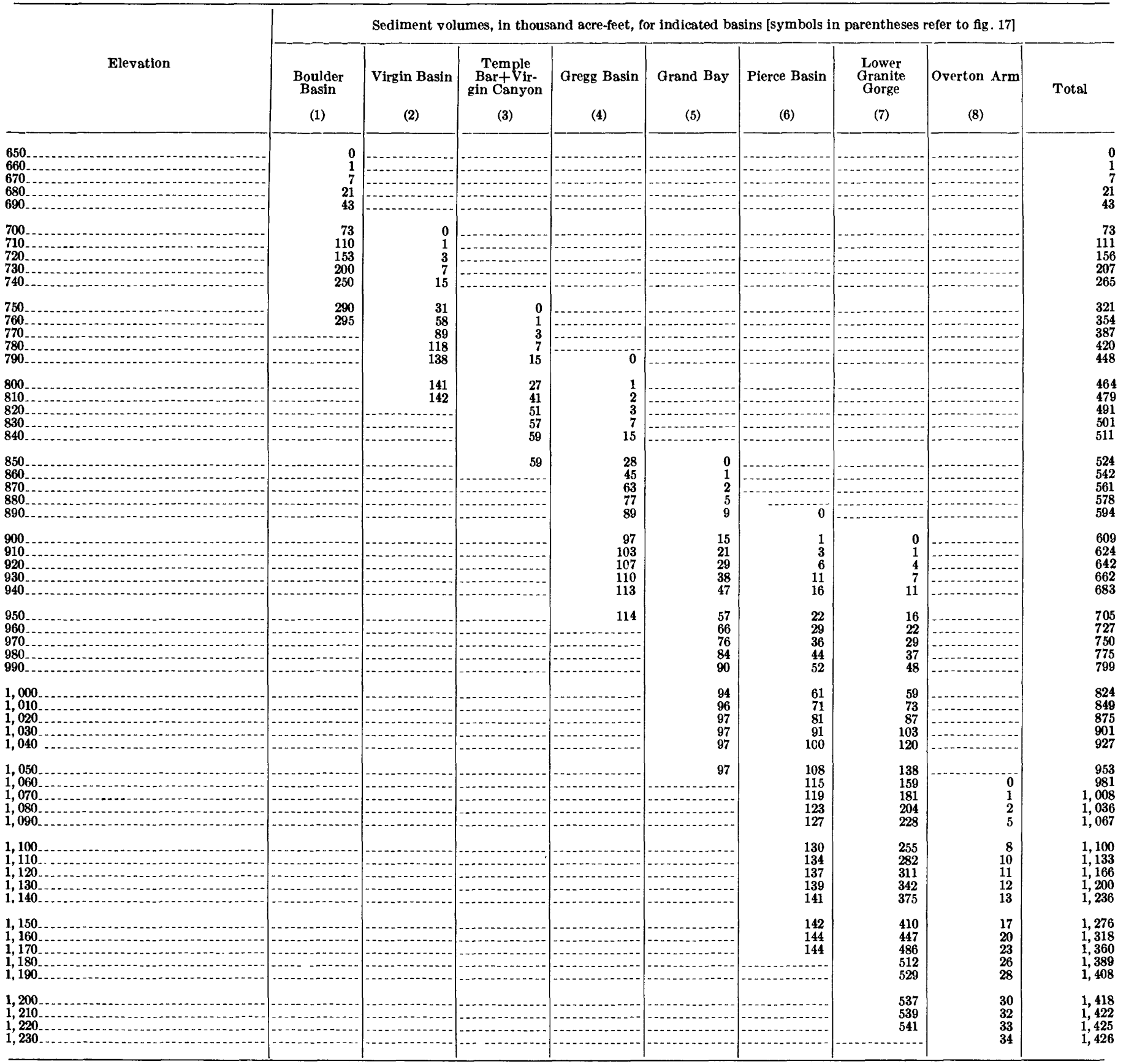


TABLE 7.-Comparative data showing areas, capacities, and sediment volumes as a function of elevation

\begin{tabular}{|c|c|c|c|c|c|c|}
\hline \multirow{3}{*}{ Elevation 1} & \multirow{3}{*}{$\begin{array}{l}\text { Original } \\
\text { contour } \\
\text { areas } \\
\text { (thou- } \\
\text { sand } \\
\text { acres) }\end{array}$} & \multirow{3}{*}{$\begin{array}{l}\text { Original } \\
\text { capacity } \\
\text { (thou- } \\
\text { sand } \\
\text { acre-feet) }\end{array}$} & \multirow{3}{*}{$\begin{array}{c}1948-49 \\
\text { contour } \\
\text { areas } \\
\text { (thou- } \\
\text { sand } \\
\text { acres) }\end{array}$} & \multirow{2}{*}{$\begin{array}{c}1948-49 \\
\text { capacity }\end{array}$} & \multicolumn{2}{|c|}{$\begin{array}{l}1948-49 \text { sediment } \\
\text { volume }\end{array}$} \\
\hline & & & & & $\begin{array}{l}\text { Within } \\
\text { 10-foot } \\
\text { zone }\end{array}$ & $\begin{array}{l}\text { Cumu- } \\
\text { lative }\end{array}$ \\
\hline & & & & \multicolumn{3}{|c|}{ Thousand acre-feet } \\
\hline 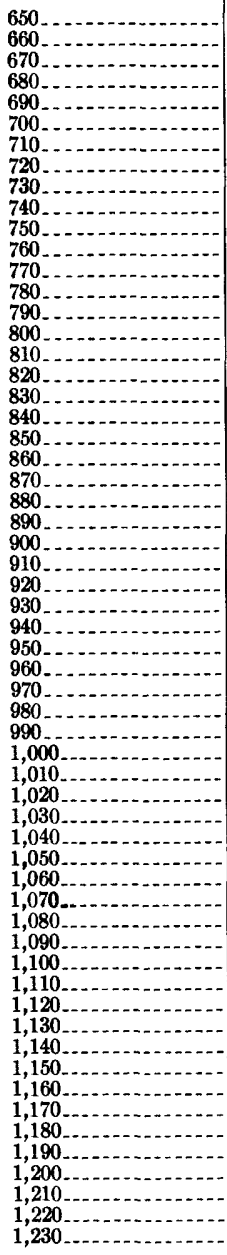 & $\begin{array}{r}0 \\
20.2 \\
21.0 \\
1.7 \\
2.5 \\
3.5 \\
4.1 \\
4.8 \\
25.5 \\
26.2 \\
28.1 \\
29.2 \\
10.5 \\
11.9 \\
13.5 \\
15.5 \\
17.2 \\
19.0 \\
220.7 \\
22.5 \\
24.7 \\
226.6 \\
28.5 \\
30.4 \\
232.4 \\
234.4 \\
236.9 \\
239.3 \\
241.7 \\
244.0 \\
246.4 \\
249.0 \\
351.5 \\
254.4 \\
257.5 \\
260.5 \\
264.0 \\
267.2 \\
270.7 \\
274.2 \\
77.9 \\
81.9 \\
85.9 \\
89.8 \\
93.9 \\
97.8 \\
102.0 \\
106.1 \\
110.4 \\
114.5 \\
119.4 \\
2124.4 \\
2129.4 \\
2134.6 \\
2139.9 \\
145.2 \\
151.3 \\
156.8 \\
163.2\end{array}$ & $\begin{array}{r}0 \\
1 \\
7 \\
21 \\
43 \\
73 \\
111 \\
156 \\
207 \\
265 \\
336 \\
423 \\
521 \\
633 \\
760 \\
905 \\
1,068 \\
1,249 \\
1,447 \\
1,663 \\
1,899 \\
2,156 \\
2,431 \\
2,726 \\
3,039 \\
3,373 \\
3,729 \\
4,110 \\
4,515 \\
4,943 \\
5,395 \\
5,873 \\
6,375 \\
6,904 \\
7,464 \\
8,054 \\
8,677 \\
9,333 \\
10,022 \\
10,746 \\
11,506 \\
12,305 \\
13,144 \\
14,022 \\
14,941 \\
15,899 \\
16,899 \\
17,939 \\
19,022 \\
20,146 \\
21,315 \\
22,534 \\
23,803 \\
25,122 \\
26,495 \\
27,920 \\
29,403 \\
30,943 \\
32,544\end{array}$ & $\begin{array}{r}r \\
0.0 \\
4.3 \\
6.0 \\
78.1 \\
81.7 \\
11.8 \\
13.8 \\
15.8 \\
18.0 \\
19.8 \\
21.4 \\
23.1 \\
24.8 \\
26.6 \\
28.8 \\
30.8 \\
33.0 \\
35.2 \\
37.4 \\
39.6 \\
41.9 \\
44.2 \\
46.8 \\
49.1 \\
51.9 \\
55.0 \\
58.1 \\
61.5 \\
64.6 \\
68.0 \\
71.6 \\
75.2 \\
79.2 \\
83.2 \\
86.8 \\
90.7 \\
94.5 \\
98.7 \\
102.8 \\
106.9 \\
110.8 \\
115.2 \\
120.2 \\
125.1 \\
132.1 \\
138.5 \\
144.7 \\
151.0 \\
156.7 \\
3163.3\end{array}$ & $\begin{array}{r}0 \\
15 \\
69 \\
134 \\
213 \\
312 \\
441 \\
5899 \\
758 \\
946 \\
1,152 \\
1,375 \\
1,614 \\
1,870 \\
2,147 \\
2,445 \\
2,764 \\
3,105 \\
3,468 \\
3,853 \\
4,260 \\
4,690 \\
5,146 \\
5,625 \\
6,130 \\
6,665 \\
7,230 \\
7,828 \\
8,458 \\
9,121 \\
9,819 \\
10,553 \\
11,324 \\
12,136 \\
12,986 \\
13,874 \\
14,800 \\
15,766 \\
16,773 \\
17,822 \\
18,910 \\
20,039 \\
21,216 \\
22,443 \\
23,733 \\
25,087 \\
26,502 \\
27,982 \\
29,520 \\
31,121\end{array}$ & $\begin{array}{r}1 \\
6 \\
14 \\
22 \\
30 \\
38 \\
45 \\
51 \\
58 \\
56 \\
33 \\
33 \\
33 \\
28 \\
16 \\
15 \\
12 \\
10 \\
10 \\
13 \\
18 \\
19 \\
17 \\
16 \\
15 \\
15 \\
18 \\
20 \\
21 \\
22 \\
22 \\
23 \\
25 \\
24 \\
25 \\
25 \\
26 \\
26 \\
26 \\
26 \\
28 \\
27 \\
28 \\
31 \\
33 \\
33 \\
33 \\
34 \\
36 \\
40 \\
42 \\
42 \\
29 \\
19 \\
10 \\
4 \\
3 \\
1\end{array}$ & $\begin{array}{r}0 \\
1 \\
7 \\
21 \\
43 \\
73 \\
111 \\
156 \\
207 \\
265 \\
321 \\
354 \\
387 \\
420 \\
448 \\
464 \\
479 \\
491 \\
501 \\
511 \\
524 \\
542 \\
561 \\
578 \\
594 \\
609 \\
624 \\
642 \\
662 \\
683 \\
705 \\
727 \\
750 \\
775 \\
799 \\
824 \\
849 \\
875 \\
901 \\
927 \\
953 \\
981 \\
1,008 \\
1,036 \\
1,067 \\
1,100 \\
1,133 \\
1,166 \\
1,200 \\
1,236 \\
1,276 \\
1,318 \\
1,360 \\
1,389 \\
1,408 \\
1,418 \\
1,422 \\
1,425 \\
1,426\end{array}$ \\
\hline
\end{tabular}

1 Elevations are in feet above mean sea level, datum of 1929, leveling of 1935 .

2 Revised value (see table 2).
3 Larger than original area because of scour at Detrital Wash.
TABLE 8.-Comparative Summary, 1935 and 1948-49 Elevation and capacity

\begin{tabular}{|c|c|c|c|c|}
\hline \multirow{2}{*}{ Reference lovel } & \multicolumn{2}{|c|}{$\begin{array}{l}\text { Elevation, in feet above } \\
\text { mean sea level }\end{array}$} & \multicolumn{2}{|c|}{$\begin{array}{l}\text { Total capacity, in } \\
\text { acre-feet }\end{array}$} \\
\hline & $\begin{array}{l}\text { Power- } \\
\text { house } \\
\text { datum }\end{array}$ & $\begin{array}{l}\text { Datum of } \\
1929 \text {, level- } \\
\text { ing of } 1935\end{array}$ & $1935^{1}$ & $1948-49$ \\
\hline Maximum designed water surface & \multirow{5}{*}{$\begin{array}{l}1,229.00 \\
1,221.40 \\
1,213.14 \\
1,213.17 \\
1,205.40 \\
1,162.83 \\
1,162.19\end{array}$} & \multirow{5}{*}{$\begin{array}{l}1,229.55 \\
1,221.95 \\
1,213.69 \\
1,213.72 \\
1,205.95 \\
1,163.38 \\
1,162.74\end{array}$} & \multirow{3}{*}{$\begin{array}{l}32,471,000 \\
31,250,000 \\
29,965.000\end{array}$} & \multirow{2}{*}{$\begin{array}{l}31,047,000 \\
29,827,000\end{array}$} \\
\hline Top of spillway, gates raised & & & & \\
\hline Flood-control level August 1 (1948). & & & & \multirow{2}{*}{$\begin{array}{l}28,547,000 \\
27,376,000\end{array}$} \\
\hline $\begin{array}{l}\text { Permanent splllway crest } \\
\text { Flood-control level A pril } 1 \text { (1935) }\end{array}$ & & & \multirow{2}{*}{$\begin{array}{l}28,794,000 \\
22,958,000\end{array}$} & \\
\hline $\begin{array}{l}\text { Flood-control level A pril } 1 \text { (1948) } \\
\text { Sills of upper outlets in intake }\end{array}$ & & & & $21,547,000$ \\
\hline towers. & $1,045.00$ & $1,045.55$ & $11,162,000$ & $10,222,000$ \\
\hline 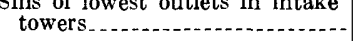 & 895.00 & 895.55 & $3,223,000$ & $2,620,000$ \\
\hline
\end{tabular}

Storage of water and sediment, in acre-feet

\begin{tabular}{|c|c|c|c|c|}
\hline \multirow{2}{*}{ Reference level } & \multicolumn{2}{|c|}{1935} & \multicolumn{2}{|c|}{$1948-49$} \\
\hline & Water & Sediment & Water & Sediment \\
\hline Flood-control reserve, Augu & $2,506,000$ & 0 & $2,500,000$ & 3,000 \\
\hline $\begin{array}{l}\text { Permissive usable contents, } \\
\text { August } 1\end{array}$ & $26,742,000$ & 0 & $25,927,000$ & 820,000 \\
\hline Flood-control reserve, A pril 1.... & $9,500,000$ & 0 & $9,500,000$ & 96,000 \\
\hline $\begin{array}{l}\text { Permissive usable contents, } \\
\text { A pril } 1\end{array}$ & $19,735,000$ & 0 & $18,927,000$ & \\
\hline Dead storage & $3,223,000$ & 0 & $2,620,000$ & 603,000 \\
\hline $\begin{array}{l}\text { Total storage below permanent } \\
\text { spillway }\end{array}$ & $28,794,000$ & 0 & $27,376,000$ & $1,418,000$ \\
\hline $\begin{array}{l}\text { Total storage below spillway } \\
\text { gates in raised position }\end{array}$ & $31,250,000$ & 0 & $29,827,000$ & $1,425,000$ \\
\hline
\end{tabular}

1 Original survey by the Soil Conservation Service, revised capacity, see table 7. 



\title{
J. WATER BUDGET
}

\author{
By W. B. Langbein, U.S. Geological Survey
}

The water budget of Lake Mead is an account of its operation for its basic function of regulating the highly variable flow of the Colorado River for the benefit of flood control, irrigation, domestic use, and hydroelectric power generation. This regulation of the flow is brought about through storage of water in years of high runoff to supplement the flow during the years of low runoff (fig. 18).

Lake Mead in 1935 had a total controlled capacity of $31,250,000$ acre-feet (to top of spillway gates in raised position), and a usable capacity of $28,027,000$ acre-feet. By 1948 the usable capacity had been reduced to $27,207,000$ acre-feet because of deposition of sediment. The annual inflow into the lake in the 14year period since Hoover Dam was completed (193548 inclusive) averaged about $13,000,000$ acre-feet. The usable capacity therefore has been equal to 215 percent, and is still nearly 210 percent of the average yearly flow through the reservoir. This storage ratio is indicative of a long detention time for river regulation and control.

Setting up the water budget of the lake requires an accounting of all items of inflow, outflow, and storage. In an ideal case, all these items would be measured independently and continuously, which would permit striking a daily balance at the close of each day's business, as is done in a financial institution. The extent to which this can be done in practice is limited because there are certain items that cannot be measured. Of the inflow items there is a significant amount of runoff into the reservoir that cannot be measured in a practical way. The outflow is measured continuously except for evaporation, for which measurement was not begun until 1952. Storage volumes in the reservoir are known from the 1935 and 1948-49 surveys, but preliminary consideration early in the history of the lake indicated a significant amount of bank storage in the sediments in the reservoir and in the sand, gravel, and rock materials underlying the reservoir. It is, therefore, inevitable that the water budget must include estimates for some items in lieu of measurement, leaving in the balance certain residuals that are indicative of net errors or items not directly accounted for. It is also impossible to obtain accurate balances for daily or even monthly periods, because of uncertainties as to time of travel of water from the points of measurement to the lake, and because of the uncertainties as to the seasonal distribution of the unmeasured inflow and of evaporation. The shortest practical period for which the budget can be set up therefore is a year. Table 9 sets up the annual budget for Lake Mead since its creation.

\section{METHOD OF COMPUTING THE BUDGET}

The water budget of table 9 is developed by (1) measuring or estimating all the accretions to Lake Mead and adding them to derive the "total inflow"; (2) similarly evaluating the depletions from the lake and deriving the "total outflow"; (3) computing the difference between inflow and outflow, and comparing that quantity with the recorded change in reservoir storage. These comparisons yield significant "residual" quantities, which may be in part due to the errors in estimations of certain items but appear to be also a measure of hidden assets or liabilities that have not been evaluated in the budget.

\section{INFLOW}

Most of the inflow to the lake is measured at the gaging station on the Colorado River near Grand Canyon, 145 river miles above Lake Mead. A gaging station is also operated on Bright Angel Creek, which enters the Colorado River below the gaging station near Grand Canyon, and another is operated on the Virgin River at Littlefield, Ariz. The sum of the flows past these three stations is shown under measured inflow $\left(I_{m}\right)$.

Below the Littlefield gaging station the Virgin River traverses open desert valleys for about 40 miles to the lake and is subject to natural losses and some diversion for irrigation. No other tributaries to Lake Mead or to the Colorado River below the Grand Canyon are measured. There is thus about 25,000 square miles of tributary area from which the runoff into the lake is unmeasured. Of this area, about 10,000 square miles can be said to be desert land which yields negligible runoff. The unmeasured inflow from the remaining area is doubtless very small in comparison with the total 
COMPREHENSIVE SURVEY OF SEDIMENTATION IN LAKE MEAD, 1948-49

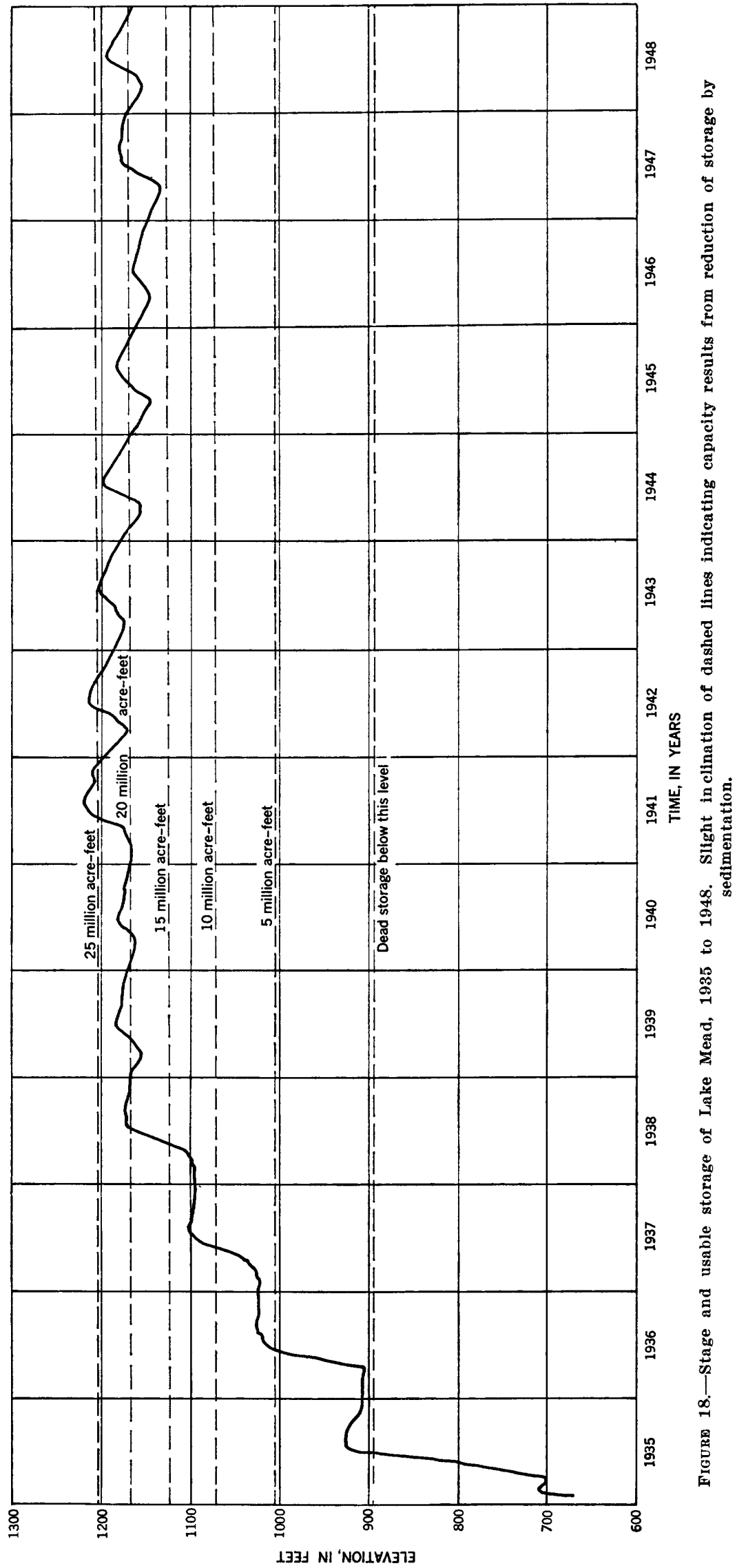


TABLE 9.-Lake Mead water budget, 1935 to 1950

[All quantities in thousands of acre-feet, except as indicated]

\begin{tabular}{|c|c|c|c|c|c|c|c|c|c|c|c|c|c|c|c|}
\hline \multirow{3}{*}{ Water year } & \multirow{3}{*}{$\begin{array}{c}\text { Mean } \\
\text { surface } \\
\text { area, in } \\
\text { thou- } \\
\text { sands of } \\
\text { acres }\end{array}$} & \multicolumn{4}{|c|}{ Inflow } & \multicolumn{4}{|c|}{ Outflow } & \multicolumn{2}{|c|}{$\begin{array}{l}\text { Inflow minus } \\
\text { outflow }\end{array}$} & \multicolumn{3}{|c|}{ Reservoir storage } & \multirow{3}{*}{$\begin{array}{r}\text { Residual } \\
I-O-\Delta S\end{array}$} \\
\hline & & \multirow[b]{2}{*}{$\begin{array}{l}\text { Mea- } \\
\text { sured } \\
I_{m}\end{array}$} & \multirow[b]{2}{*}{$\begin{array}{c}\text { Unmea- } \\
\text { sured } \\
I_{u}\end{array}$} & \multirow[b]{2}{*}{$\begin{array}{c}\text { Precipi- } \\
\text { tation } \\
\text { on lake } \\
I_{0}\end{array}$} & \multirow[b]{2}{*}{$\begin{array}{l}\text { Total } \\
\text { inflow } \\
I I\end{array}$} & \multirow[b]{2}{*}{$\begin{array}{c}\text { Evapo- } \\
\text { ration } \\
\text { (esti- } \\
\text { mated) } \\
O_{0}\end{array}$} & \multicolumn{2}{|c|}{ Measured $O_{m}$} & \multirow[b]{2}{*}{$\begin{array}{c}\text { Total } \\
\text { outflow } \\
0\end{array}$} & \multirow[b]{2}{*}{$\underset{I-O}{\operatorname{Annual}}$} & \multirow[b]{2}{*}{$\begin{array}{l}\text { Cumu- } \\
\text { lative }\end{array}$} & \multirow{2}{*}{$\begin{array}{c}\text { Stage at } \\
\text { end of } \\
\text { water } \\
\text { year, in } \\
\text { feet above } \\
\text { sea level, } \\
\text { power- } \\
\text { house } \\
\text { datum }\end{array}$} & \multirow{2}{*}{$\begin{array}{l}\text { Reser- } \\
\text { voir } \\
\text { content } \\
\text { at end } \\
\text { of water } \\
\text { year } 1\end{array}$} & \multirow[b]{2}{*}{$\begin{array}{c}\text { Net } \\
\text { change } \\
\triangle S\end{array}$} & \\
\hline & & & & & & & $\begin{array}{l}\text { Hoover } \\
\text { Dam }\end{array}$ & $\begin{array}{l}\text { Pump- } \\
\text { ing }\end{array}$ & & & & & & & \\
\hline $\begin{array}{l}1935 \\
1936 \\
1937 \\
1938 \\
1939 \\
1940 \\
1941 \\
1942 \\
1943 \\
1944 \\
1946 \\
1947 \\
1948 \\
1949\end{array}$ & $\begin{array}{r}21 \\
49 \\
82 \\
111 \\
131 \\
131 \\
141 \\
144 \\
141 \\
135 \\
130 \\
124 \\
123 \\
132 \\
126 \\
128\end{array}$ & $\begin{array}{r}10,417 \\
12,476 \\
12,692 \\
15,953 \\
9,799 \\
7,641 \\
17,404 \\
17,504 \\
11,642 \\
13,739 \\
12,063 \\
9,233 \\
13,950 \\
14,006 \\
14,547 \\
11,228\end{array}$ & $\begin{array}{l}266 \\
174 \\
468 \\
573 \\
238 \\
290 \\
900 \\
400 \\
301 \\
314 \\
268 \\
147 \\
338 \\
133 \\
241 \\
163\end{array}$ & $\begin{array}{r}6 \\
16 \\
37 \\
31 \\
79 \\
48 \\
119 \\
43 \\
49 \\
45 \\
64 \\
24 \\
32 \\
37 \\
62 \\
23\end{array}$ & $\begin{array}{r}10,689 \\
12,666 \\
13,197 \\
16,557 \\
10,116 \\
7,979 \\
18,423 \\
17,947 \\
11,992 \\
14,098 \\
12,395 \\
9,404 \\
14,320 \\
14,176 \\
14,850 \\
11,414\end{array}$ & $\begin{array}{r}150 \\
350 \\
585 \\
790 \\
930 \\
930 \\
940 \\
1,045 \\
982 \\
990 \\
870 \\
845 \\
825 \\
985 \\
875 \\
925\end{array}$ & $\begin{array}{r}5,556 \\
6,282 \\
5,826 \\
6,168 \\
8,473 \\
7,694 \\
11,730 \\
17,880 \\
12,515 \\
14,465 \\
12,947 \\
11,295 \\
10,666 \\
12,755 \\
13,200 \\
12,940\end{array}$ & $\begin{array}{r}1 \\
1 \\
1 \\
1 \\
1 \\
1 \\
1 \\
3 \\
16 \\
17 \\
17 \\
9 \\
7 \\
8 \\
7 \\
7 \\
7\end{array}$ & $\begin{array}{r}\mathbf{5}, 707 \\
6,633 \\
6,412 \\
6,959 \\
\mathbf{9}, 404 \\
\mathbf{8 , 6 2 5} \\
12,671 \\
18,928 \\
13,513 \\
15,472 \\
13,826 \\
12,147 \\
11,499 \\
13,747 \\
14,082 \\
13,872\end{array}$ & $\begin{array}{r}+4,982 \\
+6,033 \\
+6,785 \\
+9,598 \\
+712 \\
-646 \\
+5,752 \\
-981 \\
-1,521 \\
-1,374 \\
-1,431 \\
-2,743 \\
+2,821 \\
+429 \\
+768 \\
-2,458\end{array}$ & $\begin{array}{r}4,982 \\
11,015 \\
17,800 \\
27,398 \\
28,110 \\
27,464 \\
33,216 \\
32,235 \\
30,714 \\
29,340 \\
27,909 \\
25,166 \\
27,987 \\
28,416 \\
29,184 \\
26,726\end{array}$ & $\begin{array}{l}920.75 \\
1,024.6 \\
1,097.65 \\
1,173.8 \\
1,178.95 \\
1,174.4 \\
1,209.85 \\
1,205.0 \\
1,195.70 \\
1,187.10 \\
1,177.95 \\
1,157.65 \\
1,178.02 \\
1,180.82 \\
1,186.86 \\
1,168.77\end{array}$ & $\begin{array}{r}4,140 \\
9,621 \\
15,639 \\
24,272 \\
24,956 \\
24,351 \\
29,357 \\
28,637 \\
27,277 \\
26,067 \\
24,827 \\
22,217 \\
24,832 \\
25,209 \\
26,035 \\
23,617\end{array}$ & $\begin{array}{r}+4,140 \\
+5,481 \\
+6,018 \\
+8,633 \\
+684 \\
-605 \\
+5,006 \\
-720 \\
-1,360 \\
-1,210 \\
-1,240 \\
-2,615 \\
+2,615 \\
+377 \\
+826 \\
-2,418\end{array}$ & $\begin{array}{r}+842 \\
+552 \\
+767 \\
+965 \\
+28 \\
-41 \\
+746 \\
-261 \\
-161 \\
-164 \\
-191 \\
-133 \\
+206 \\
+52 \\
-58 \\
-40\end{array}$ \\
\hline
\end{tabular}

1 Original capacity table, used without correction for datum difference (see Surface Water Supply of the United States, Part 9, Colorado River Basin, for the years 1940-49). This introduces no significant error as the differences in yearly content are used here, and the difference in datum is indistinguishable on fig. 21.

inflow, but it must be taken into account in preparing a budget for the reservoir. The actual amount is unknown, but it doubtless varies from year to year; and provided the record of the Virgin River can be used as a satisfactory index, it can be used to estimate the unmeasured inflow according to the formula: $I_{u}$ (unmeasured inflow) $=a I_{v}+b$, in which $I_{v}$ is the measured inflow of the Virgin River. The evaluation of the constants $a$ and $b$ is explained in the section on "statistical analyses." The estimates determined in this way are given as unmeasured inflow $\left(I_{u}\right)$.

The precipitation on the lake is computed from the rainfall recorded at three locations about the lake, multiplied by the mean surface area during each year. Allowance was made for the higher rainfall during months when the surface area of the lake is least, but the resulting estimates of precipitation are subject nevertheless to large error because rainfall over the lake is highly variable. Precipitation is a very small item in the budget, and great accuracy, although desirable, is not essential.

\section{OUTFLOW}

The water released through Hoover Dam constitutes practically all the outflow from Lake Mead; it is adequately measured at the gaging station 1 mile below the dam, originally built by the Bureau of Reclamation and now operated by the Geological Survey in cooperation with the Bureau. The quantities are given in table 9. The quantities diverted by pumping from the lake for use at Henderson and Boulder City are also shown.

There is some depletion of storage by evaporation from the surface of the lake and by transpiration from the small areas of vegetation in some spots around the lake shore. To the extent that the rate of evaporation is a constant, the estimated annual evaporation may be evaluated by multiplying the mean surface area of the reservoir (with due allowance for the higher rate of evaporation in summer) by the annual rate of evaporation. The annual rate of evaporation has been estimated by the methods explained in the section "Statistical analyses," and the volumes of evaporation are the results of these computations.

\section{RESERVOIR STORAGE}

The stage of Lake Mead at the end of each water year and the corresponding contents according to the original capacity table are listed under "Reservoir storage." These volumes include water plus sediment, which is proper inasmuch as the inflow includes the volume of sediment particles of the suspended load.

\section{STATISTICAT ANATYSES}

Algebraically the water budget may be set up as follows:

$$
I_{m}+I_{u}+I_{p}-\triangle S=O_{e}+O_{m}
$$

in which $I_{m}$ is the measured surface inflow, $I_{u}$ is the unmeasured inflow, $I_{p}$ is the precipitation on the lake surface, $\triangle S$ is the increase in storage, $O_{e}$ is the evaporation, and $O_{m}$ is the measured surface outflow.

Of these quantities $I_{u}$ is unknown, and the bank storage component of $\triangle S$ is also unknown. These factors can be resolved provided they can be related to 
known variables. There is a strong possibility that the unmeasured inflow can be related to the record of the Virgin River at Littlefield, Ariz.; and total storage can be expressed as a constant times the measured change in reservoir contents, it being assumed, subject to test, that the bank storage is proportional to the annual changes in reservoir storage.

In lieu of formal least-square analysis, these relations were defined by a graphical method of converging approximations. In other words, preliminary assumptions were introduced for the unmeasured inflow, and net storage changes were then computed and related to the storage changes in the reservoir basin as given by the capacity table. This result indicated, for example, that total storage change is about 12 percent greater than that given by the capacity table. Using this result, calculations were made of the unmeasured inflow, which was then graphically related to the flow of the Virgin River. The points defined a satisfactory relation, quite different from the initial assumption. Now using these graphs, the process was repeated, which yielded results not very different from those obtained during the second approximation. The process was therefore not repeated. The results are given in figure 19 .

The efficacy of the method used depends on the mutual independence of the factors used-Virgin River runoff and storage change--and the range through which these factors vary. The independence is not as great as might be desired. Greater variations in the record prior to the filling of the reservoir would have been invaluable for evaluating the unmeasured inflow. The flow of the Virgin River is roughly correlated with changes in storage, because large increments in reservoir storage tend to occur in wet years when flow of the Virgin River is high, and vice versa. Nevertheless there is enough independence to make the derived relations useful.

\section{EVAPORATION}

Evaporation is an important item in the water budget of Lake Mead. Estimates of annual water loss made from several different assumptions have ranged from as much as 100 to as little as 64 inches. The inadequacy of these estimates had long been recognized, and the plans for the 1948-49 survey envisaged the collection of data that might provide a basis for comparison with the records of pan evaporation that had been collected at Lake Mead since 1935. As described on page 141, a reconnaissance energy budget was derived, which afforded a means of calculating evaporation during the period of the survey. But analysis of the possible errors introduced in estimating some important

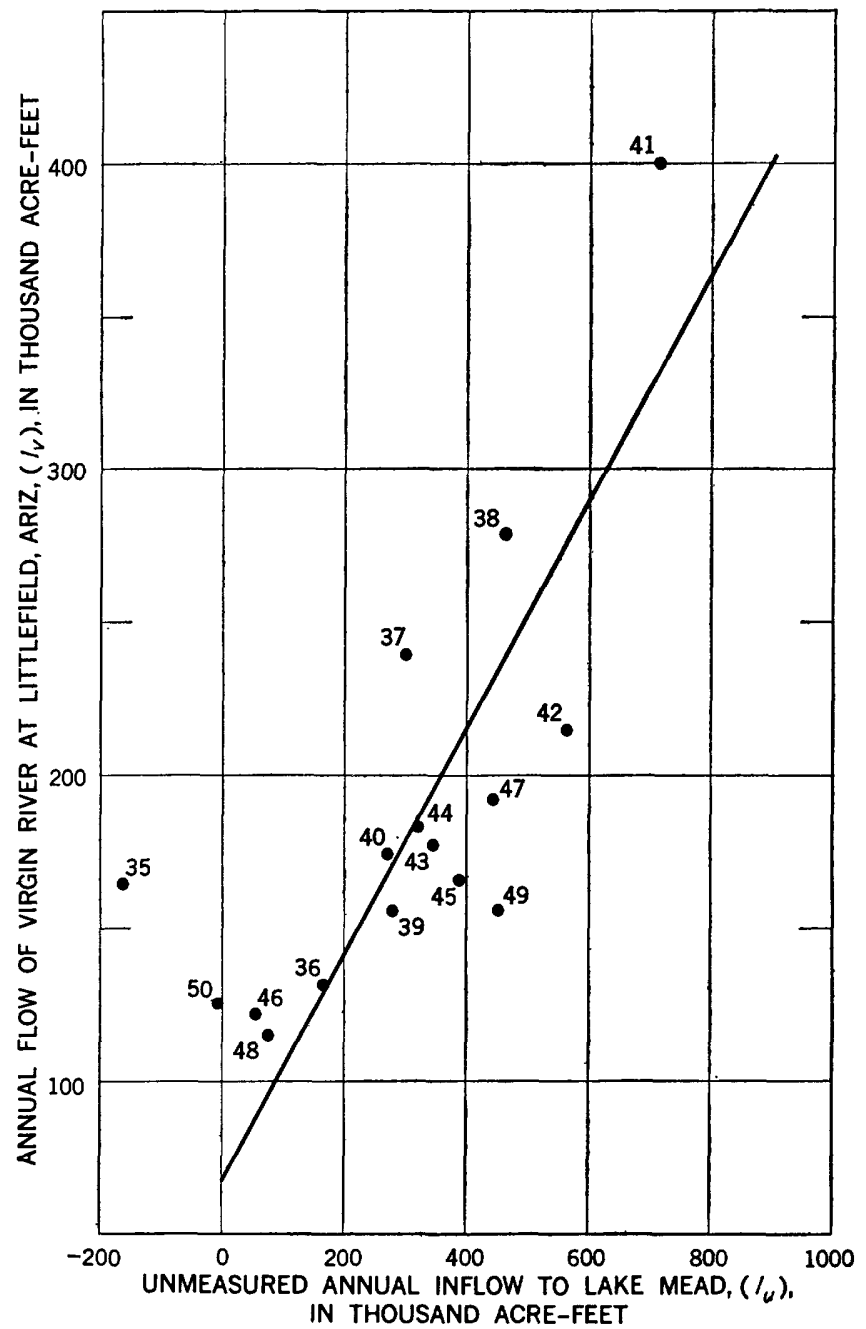

Figure 19.--Relation between unmeasured infiow to Lake Mead and runoff of Virgin River at Littlefield, Ariz.

items of the energy budget led the authors of that reconnaissance to conclude that their estimates may be in substantial error.

Recognizing the important need for accurate information, intensive research into the problem of evaporation from reservoirs was undertaken in 1950 and 1951 at Lake Hefner, in Oklahoma, a reservoir that was well suited to the proof and test of new methods of measuring evaporation loss (U.S. Geol. Survey, $1954 \mathrm{a}$ and b). After these tests, investigations were begun in March 1952 for the purpose of determining evaporation from Lake Mead as accurately as possible, applying the methods tested at Lake Hefner, specifically adapted to fit conditions at Lake Mead. The Geological Surrey, Bureau of Reclamation, and Weather Bureau collaborated in that investigation, the results of which have been published (U.S. Geol. Survey, 1956). The total evaporation determined for the 1953 water year was 875,000 acre-feet, or 85.5 inches 
over the average area of the lake during that year. The investigations also provided a means for making estimates of annual evaporation from the lake during previous years, and for keeping monthly records of evaporation in the future, within limits such that annual figures will not be more than 10 percent in error.

\section{TRANSPIRATION}

The change in ecologic conditions brought about by the formation of Lake Mead has sustained the introduction of a new species of vegetation into the desert wasteland that became its shores. The saltcedar, Tamarix gallica, is a lusty water-loving exotic that has been able to displace native species rapidly wherever water is accessible, notably along streams and canals, and in areas of shallow water table. Around Lake Mead it is seen at various places below the high-water line established in 1941: in coves and bays of shoaling water, on some islands far from shore, along the beaches in Las Vegas Wash and Overton Arm, and along both sides of Lower Granite Gorge where it contrasts with the creosote bush (Covillea tridentata) and other xerophytes above the high-water line.

No studies were made during the 1948-49 survey to determine the areal extent of the saltcedar growth around the reservoir, or the quantity of water that might be consumed by it. Research in southern Arizona (Gatewood and others, 1950; Robinson, 1958) indicates that the saltcedar is an extravagant water user and, acre for acre, may transpire more water than is evaporated from a free water surface. Thus, if the area covered by saltcedars is sufficiently large, there could be significant losses from the reservoir in addition to the quantities evaporated from the reservoir surface.

Fluctuations in the level of the reservoir are somewhat discouraging to all types of vegetation, but saltcedar fares better than most. Plants on islands in Las Vegas Bay flourish even when the reservoir level has dropped 60 feet below them (pl. 29), and it seems that they are able to follow the water down with their roots. On a rising stage, a saltcedar plant can be drowned if it is completely submerged for an extended period, but in 1952 some plants in Las Vegas Wash survived a period of several weeks in water as much as 5 feet deep, while only the topmost. branches reached above the lake level.

From these casual observations, it may be concluded that the zone in which saltcedar can become established ranges from the high-water line at 1,221 feet elevation down perhaps to the average operating level at 1,170 feet. The area of reservoir bed between these eleva- tions is more than 30,000 acres. Reconnaissance trips on the lake, however, indicate that only a small proportion of this area is actually covered by saltcedar. The rock walls below the high-water line are almost invariably barren, and they appear to predominate around the shore. If as much as 10 percent of this 30,000 acres is occupied by saltcedar-and this is probably a very liberal estimate - the annual loss by transpiration would be of the order of 20,000 acre-feet, which is less than 3 percent of the evaporation from the free water surface and well within the limit of error of the evaporation calculations.

\section{PRECIPITATION}

Rain gages maintained by the Office of River Control in conjunction with its evaporating pans show marked variations in precipitation in various parts of the Lake Mead region. Random variations in monthly totals, particularly during the summer, doubtless reflect the intense but local cloudburst storms that are common in the region.

The variations in annual precipitation from one locality to another give some indication of the geographic distribution of rainfall. The precipitation recorded at Pierce Ferry, at the base of the Grand Wash Cliffs, may be two to four times as great as that at stations around Boulder Basin of Lake Mead. Between 1936 and 1949 the average annual precipitation at Pierce Ferry was 6.8 inches, compared with 3.7 to 3.8 inches at gages near the western end of the lake. It is not known whether the rate of precipitation increases sharply near the base of the Colorado Plateaus, or whether there is a progressive increase eastward from Boulder Basin.

The values shown in table 9 are based on three available records around the lake. It is not known to what extent the 3-station average represents the actual precipitation upon the lake, but, as already pointed out, these quantities are in any event a very small proportion of the total inflow. Even in the year of greatest annual precipitation, 1941, the quantity contributed to the reservoir was considerably less than 1 percent of the measured inflow from tributaries.

\section{EVALUATION OF BANK STORAGE}

The annual changes in reservoir contents shown in table 9 are similar in amount to those representing the differences between inflow and outflow. If all items of the budget had been accounted for and accurately measured, the quantities in these two columns would be identical. Actually there are significant differences 


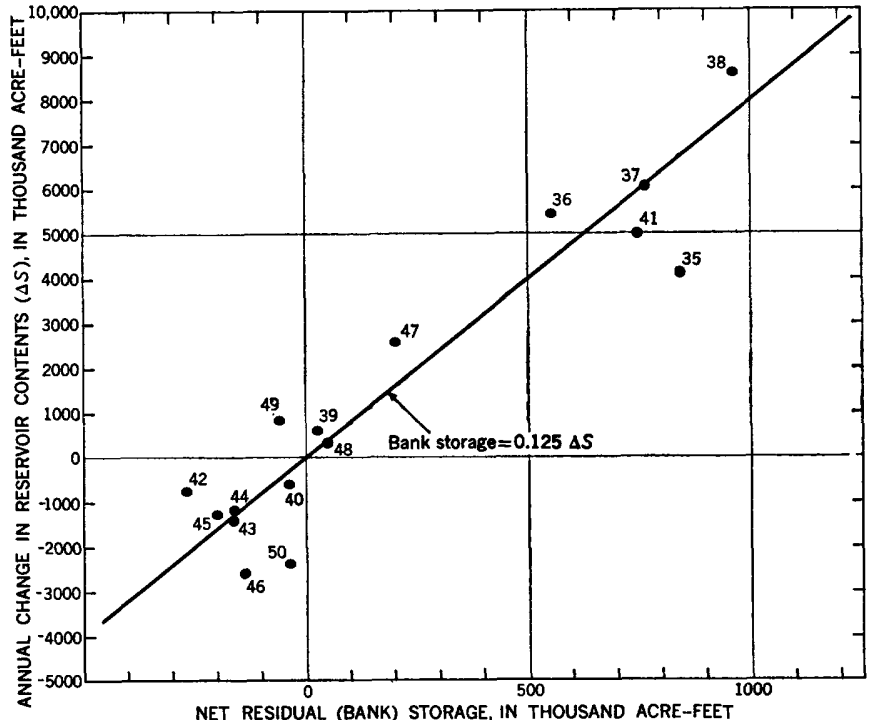

Frgdre 20.-Relation of net residual (bank storage) to annual change in reservoir contents.

in most years, and these differences are listed as "residuals." They vary in magnitude and sign, in a manner quite comparable to the net changes in reservoir contents. These residuals are plotted against the annual change in reservoir contents on figure 20 . Although each residual, being the difference between two large figures, parts of which are estimates, is subject to large relative errors, nevertheless the points on figure 20 show a consistency which indicates that the actual errors are not large. The conclusion may be drawn that on an annual basis more water enters into or is withdrawn from storage than is indicated by the capacity table. In other words, Lake Mead has a significant amount of storage space in addition to the volumes which were calculated from the hydrographic survey of 1948-49, or even the original reservoir survey of 1935.

The unsurveyed storage in Lake Mead is the volume in which water can be stored in the banks or bottom of the reservoir, as determined during the hydrographic survey of 1948-49. It corresponds to bank storage along a river, with all the phenomena of filling and draining of interstices as the lake rises and recedes. It includes the water in the volume that has been filled by sediment daring the interval from 1935 to 1948 , and it includes voids in the gravel and sand and other rock materials that underlie the sides of the reservoir. Inasmuch as all this unsurveyed storage is in the banks of the reservoir, it is properly classed as ground-water storage, of the kind generally known as bank storage.

The magnitude of this bank storage is indicated in table 9 by comparison of the reservoir storage at end of year as indicated by capacity table, and the total storage as given by the cumulative difference between inflow and outflow. The data from both columns are plotted in figure 21 against corresponding lake stages. The gross storage, computed from the difference between outflow and inflow, indicates the total detention in the Lake Mead basin, subject to errors of estimation and measurement as explained. Since the inflow includes the volume of the solid particles of the suspended sediment, the detention necessarily includes sediment plus water. The sediment solids (about 2,000 million tons) occupy a volume of about 550,000 acre-feet; the bulk volume $(1,426,000$ acre-feet $)$ is the sum of the sediment solids volume plus the volume of the interstitial water.

As of September 30, 1941, when the highest year-end stage was reached, the total storage computed from inflow-outflow differences was $33,216,000$ acre-feet. compared with reservoir contents of $29,357,000$ acrefeet as computed from the original capacity curve. The difference of about $3,859,000$ acre-feet is presumed to represent the bank storage plus sediment storage. As shown in chapters $\mathrm{N}$ to $\mathrm{T}$, the sediment particles carried into the reservoir between 1935 and 1948 have a total estimated volume of 550,000 acre-feet. The water storage beneath the reservoir sides and bottom when the lake is filled to capacity is therefore of the order of $3,300,000$ acre-feet.

Not all the 3,300,000 acre-feet of ground-water storage is usable storage. About 875,000 acre-feet is held within the interstices of the sediments deposited within the lake, of which about 40 percent lie below the dead storage level. The effect of continued sedimentation below this level will be to reduce the proportion of water in existing sediment by compaction, but to increase the over-all quantity of interstitial water at the expense of reservoir dead storage.

The bank storage is not available during shortperiod changes in water level. It takes time for the water to permeate and drain the sediments containing this storage, and only a small proportion is available during the usual seasonal change in reservoir contents. Detailed analyses of bank storage associated with monthly or seasonal fluctuations in reservoir levels cannot be made until more is known of the distribution of evaporation and unmeasured inflow during the year. However, preliminary studies indicate that bank storage of the extent indicated is available only for yearto-year changes in reservoir contents.

In general, under present conditions and with the estimates now available for evaporation, precipitation, and unmeasured inflow, the annual change in gross 


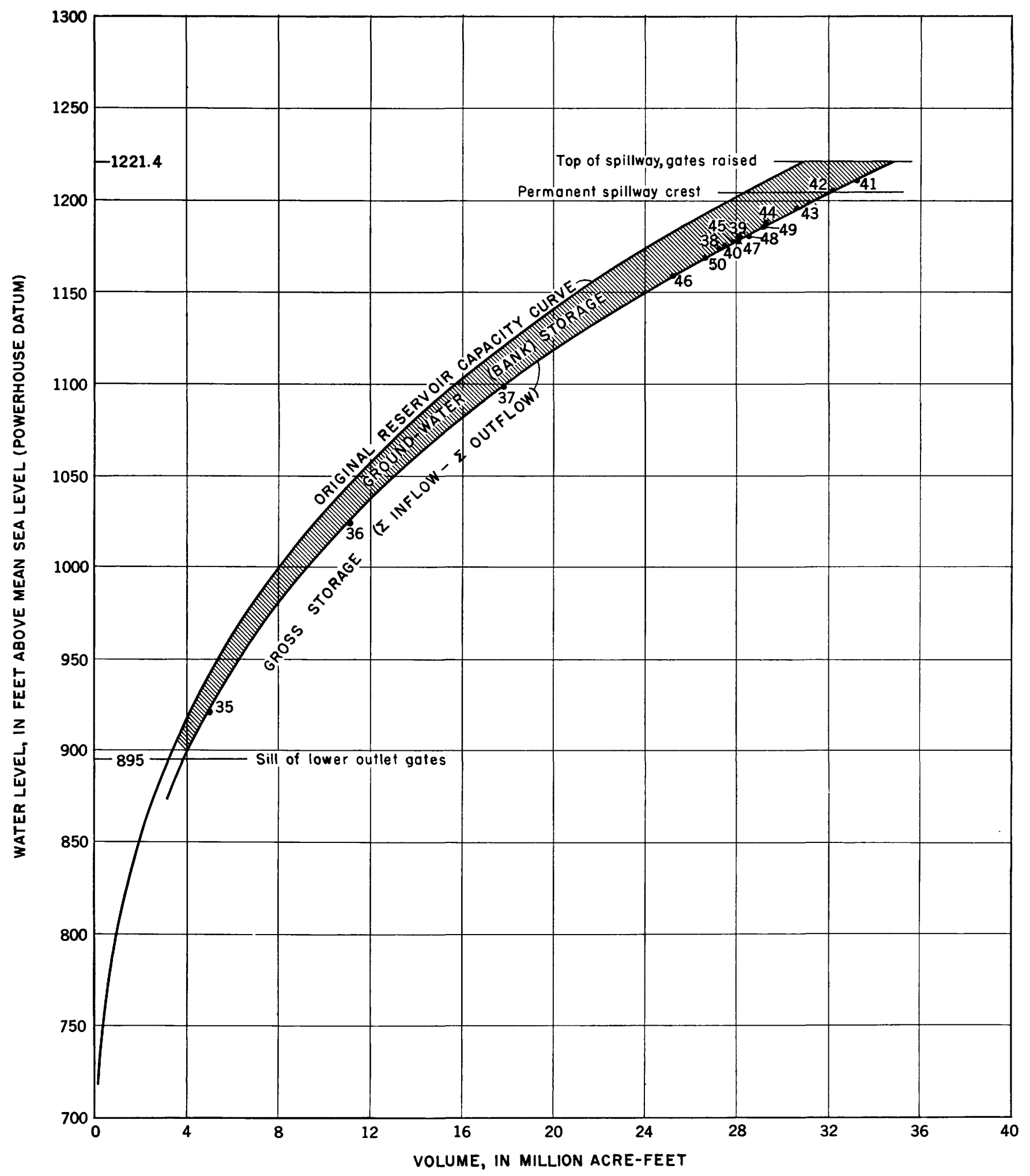

Figurg 21.-Comparison of reservoir capacity curve with gross storage curve computed from difference between inflow and outflow. 
storage averages about 12 percent more than the change in reservoir contents indicated by the capacity table, which adds materially to the degree of river regulation afforded by the reservoir. Thus, under present conditions, as shown by figures 20 and 21 , there is a considerable variation in usable bank storage with change in lake levels. From September 1941 to September 1946 there was a net decline of 52.2 feet in reservoir level. Reservoir contents declined 7,140,000 acre-feet, but the gross storage contributing to the discharge at Hoover Dam amounted to 8,050,000 acre-feet, indicating a recovery of 910,000 acre-feet from bank storage during this 5-year drawdown.

\section{REFERENCES CITED}

Gatewood, J. S., Robinson, T. W., Colby, B. R., Hem, J. D., and Halpenny, L. C., 1950, Use of water by bottom-land vegetation in lower Safford Valley, Arizona: U.S. Geol. Survey Water-Supply Paper 1103, 204 p.

Harbeck, G. E. and others, 1958, Water-loss investigationsLake Mead studies: C.S. Geol. Survey Prof. Paper 298.

Robinson, T. W., 1958, Phreatophytes: U.S. Geol. Survey WaterSupply Paper 1423, 84 p.

U.S. Geological Survey, 1954a, Water-loss investigations-Lake Hefner studies, Technical report: U.S. Geol. Survey Prof. Paper 269, 156 p.

1954b, Water-loss investigations-Lake Hefner studies, Base data report: U.S. Geol. Survey Prof. Paper 270, $300 \mathrm{p}$. 


\title{
K. GHARACTER OF THE INFLOWING WATER
}

\author{
By C. S. Howard, U.S. Geological Survey
}

\section{SOURCES OF INFLOW}

Almost all the inflow to Lake Mead comes from the Colorado River and is measured at the Grand Canyon gaging station, some 190 miles above the uppermost basin (Pierce Basin) of the lake. The discharge of the Virgin River at Littlefield, Ariz., averages less than 2 percent of the discharge measured at Grand Canyon, and as indicated by figure 19, the unmeasured inflow of other tributaries to Lake Meade is generally less than twice as great as the measured discharge of the Virgin River. Thus the water measured at the Grand Canyon gaging station probably constitues more than 95 percent of the total inflow to Lake Mead. The inflow from side canyons and tributaries below Grand Canyon, including the Virgin River, is probably not in sufficient volume to have any significant effect on the physical and chemical characteristics of the water in Lake Mead.

Records of sediment and dissolved solids as well as of river discharge have been collected at the Grand Canyon station since 1925, and records of temperature have been maintained since 1936 ; these serve as the basis for the study of the physical and chemical characteristics of the water flowing in the river and stored in the lake.

Records of sediment at the Grand Canyon and at other gaging stations in the Colorado River basin for the period 1925-41 have been published in two watersupply papers of the Geological Survey (Howard, 1930 , p. $15-44$, and 1947) ; all records are for the suspended loads only and there is practically no information on the amount of material carried by the Colorado River as bed load. Analytical records of the chemical character of the Colorado River water for the period 1925-11 have also been published (Howard, 1928, 1930, p. 1-14, and 1932; U.S. Geol. Survey, 1943). The records of chemical analyses, water temperatures, and suspended sediment since 1941 have been published in water-supply papers dealing with the quality of surface waters of the United States (U.S. Geol. Survey, 1943 and later.).

\section{SEDIMENT CARRIED BY THE INFLOWING WATER SUSPENDED LOAD IN THE COLORADO RIVER}

The annual loads of suspended sediment carried past Colorado River near Grand Canyon, Ariz., during the period 1926-50 are given in table 10 (see also fig. 7). The records show that 1,990 million tons of suspended sediment passed the Grand Canyon station during the period February 1, 1935, to February 28, 1949. These dates mark respectively the beginning of storage in Lake Mead and the completion of the 1948-49 survey of the reservoir. Presumably all the sediment passing Grand Canyon in this interval was trapped in Lake Mead except for the quantity, estimated at less than 10 million tons, that passed through the dam during 1935-36 when water was discharged from the bottom of the reservoir (p. 109). However, this is not a full measure of the sedimentation in Lake Mead because the sediment carried by the Virgin River and minor tributaries is not included.

TABLE 10.-Annual runoff and suspended load of Colorado River near Grand Canyon, Ariz.

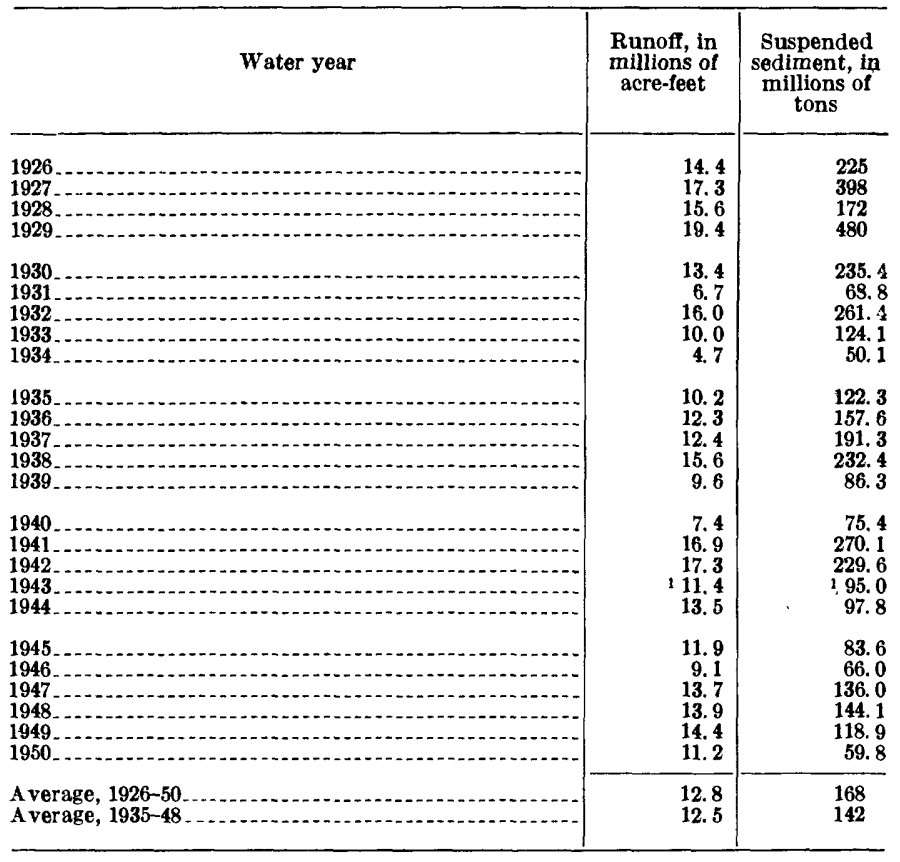

${ }^{1}$ Estimated from records for Colorado River at Lees Ferry, Ariz. 
On the basis of total sedimentation of 1,990 million tons by February 1949, the deposition in the lake has been at an average rate of 142 million tons a year. This average rate is of interest to all who would like to forecast the future of Lake Mead, but it hides some tremendous variations in sedimentation rates-daily, seasonal, and annual. Acceptance of an average figure, without consideration of these variations and the reasons for them, can result in forecasts that are basically unreliable.

Since 1926 the annual suspended load (measured at Grand Canyon) has varied from about 50 million tons in 1934, when annual runoff was less than 5 million acre-feet, to nearly 500 million tons in 1929 , when annual runoff was more than 19 million acre-feet. The range in sediment load was therefore tenfold, whereas the range in discharge was only fourfold. Plotting of the annual runoff against sediment load (fig. $22)$ shows that the sediment load is not directly proportional to the runoff but increases more rapidly with increasing discharge. The points are widely dispersed, but they indicate that from 1941 to 1950 the sediment load was generally less at equivalent runoff than in the preceding 15 years. Daines (1949), by doublemass analysis of the records of annual runoff and suspended load at Grand Canyon, also found a fairly consistent relation from 1930 to 1941, and a different but likewise consistent relation from 1942 to 1948 . The differences are not adequately explained by available hydrologic data, but it is possible that they may result at least in part from variations in distribution of precipitation and runoff in the Colorado River basin (p. 235).

The sediment concentrations and loads entering Lake Mead during the 1948-49 survey were less than the average for the period of record at Grand Canyon. On only a few occasions were there any high concentrations of sediment. The maximum daily mean sediment concentration at Grand Canyon was 2.60 percent on August 8, 1948, during a short period of increased inflow. The total load of sediment during that rise was about 7 million tons, or 75 percent of the monthly load and 5 percent of the total load for that year. At a lower concentration (not over 1.76 percent) for a longer period of time and at a higher rate of discharge in April 1948, the total load was over 30 million tons, which was about 21 percent of the annual load. The concentration of sediment and its relation to discharge for part of the period of the survey are shown graphically in figure 23 .

\section{PARTICLE SIZES IN SUSPENDED LOAD}

Size analyses of the particles of suspended sediment have been made on samples collected at Grand Canyon since 1935, and published records (Howard, 1947; U.S. Geol. Survey, 1943 and later) generally include analyses of 40 to 100 samples each year. Similar data were obtained for the samples collected at the Willow Beach and Topock stations (below Hoover Dam) while they were operated as sampling points. The methods of making the size determinations have not been uniform. For most samples, the proportions of sandsized particles (diameter greater than 62 microns) was determined by sieve analysis, but the sieve sizes used since 1944 are different from those used in earlier years. For determination of the silt- and clay-sized particles, a dispersing procedure was used for some of the samples, but others were settled in the native water or in water having a chemical character and concentration of dissolved solids similar to those of the native water.

Laboratory tests have shown that in an undispersed sample a large percentage of the finer particles will have a much faster settling rate (that is, will act like coarser particles) than in a similar sample after dispersion. It is difficult to evaluate the analytical records based on dispersed samples, because in a reservoir the material will settle in an undispersed or partly dispersed condition. It is known that there will be some variation in the state of dispersion of the suspended material as it moves into and through the reservoir water, but the extent of this variation is not known. Since the variation applies especially to the fine particles, it is of interest to note that there was considerable difference in the nature of the material carried during the two periods in 1948 mentioned above. In the load of 7 million tons carried in August 1948, more than 60 percent of the particles were finer than 8 microns, whereas about 50 percent of the load of 30 million tons in April 1948 consisted of particles coarser than 62 microns. The determinations were made on dispersed samples but it is evident that the material carried in April consisted largely of the faster settling particles. Thus the movement into and distribution within the reservoir of the material carried during these two periods would not be the same.

Even if the size distribution of particles in individual samples could be measured accurately, the estimation of total quantities of a given size transported by the river would be subject to considerable error, because of the great variability of the sediment load from time to time and from place to place in both concentration and particle size. 


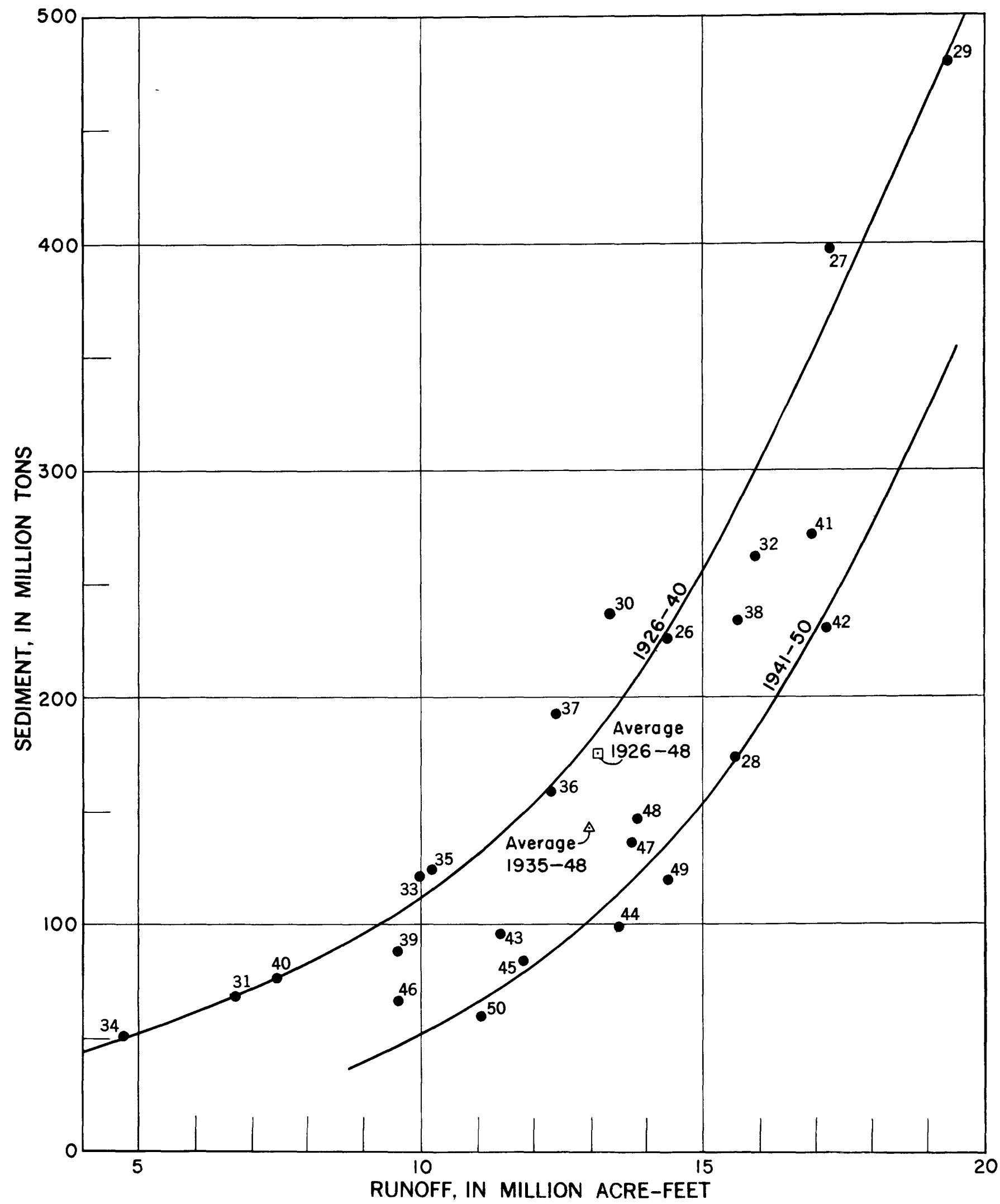

Figure 22.--Relation of annual runoff to sediment load at Grand Canyon. 


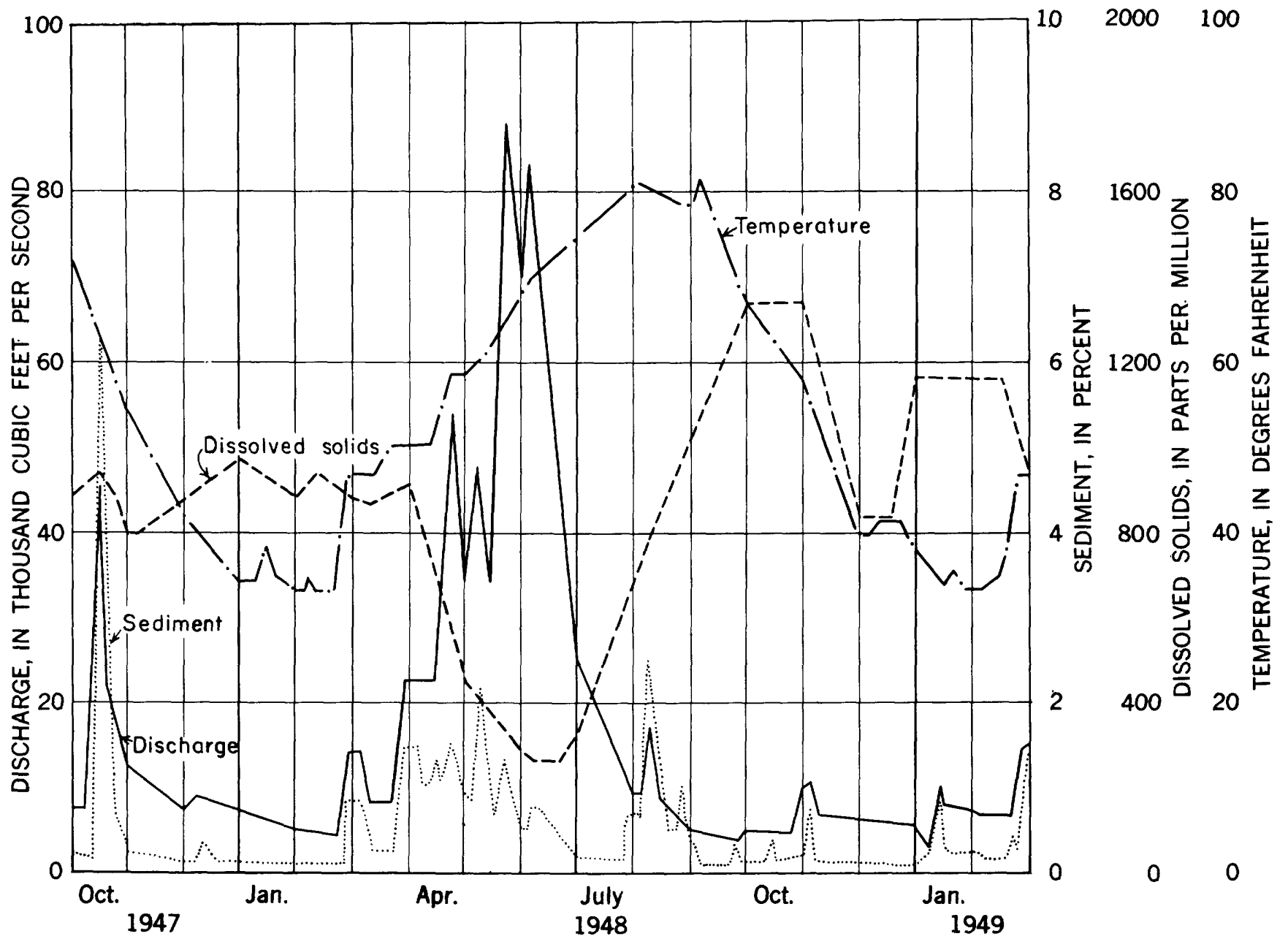

FiguRe 23.-Discharge, temperature, dissolved solids, and suspended sediment records for Colorado River at Grand Canyon, October 1947 to February 1949.

SEASONAL VARIATIONS

In winter, from November to March, the river discharge is usually near the minimum for the year, ranging from 3,000 to $10,000 \mathrm{cfs}$. Sand particles larger than 62 microns rarely compose more than 10 percent of the suspended load, and the clay fraction (smaller than 4 microns) is likely to make up half or more of the total.

The period April to July is the time of greatest volume of flow. Sand particles ordinarily constitute at least 20 percent of the sediment load, and during peak discharges the sediment load may be more than 50 percent sand and less than 10 percent clay. Even at these high discharges, however, the suspended load includes few particles larger than medium sand (500 microns in diameter).

From August to October the discharge of the river may drop to less than $5,000 \mathrm{cfs}$, or it may increase to $30,000 \mathrm{cfs}$ or more for short periods because of flood runoff from cloudburst storms. Regardless of the discharge, the distribution of particles of various sizes in the suspended load is generally similar to that from November to February, with less than 20 percent larger than 62 microns.

CORRELATION OF ANALYSES OF DEPOSITED AND SUSPENDED SEDIMENT

There is some uncertainty about the proper method of correlating the reported sizes of the finer particles of suspended material with those determined from deposited samples. The difficulty of determining the sizes of particles whose diameters are less than 30 microns has been discussed (Howard, 1948). Many samples of deposited material have been dried after deposition, either in place or after collection. If the material has been dried it is necessary to disperse the samples to obtain a satisfactory sample for size analysis, especially if a large proportion is less than 30 microns in diameter. It is difficult to obtain a uniform state of particle dispersion, and for that reason complete dispersion is attempted. The particles then are in a condition which is not representative of any con- 
dition existing in nature, and the analytical results are of questionable value for correlation with results obtained from analysis of material in transport. It is true that the samples of suspended material can also be dispersed and the analytical results compared or correlated with the results obtained on the dispersed samples of deposited material. This sort of correlation has limited application, and is questionable if one wishes to compute the volume of deposit that will be occupied by a given amount of suspended load, for the sediment is transported and deposited under conditions in which the water has different chemical characteristics and dispersing properties.

Data collected during the Lake Mead survey show the particle size and weight-volume relation for materials deposited in the reservoir (p. 195). So far as particles larger than 30 microns and particularly the sand-sized ones are concerned, direct correlation should be possible with the data on suspencied load in the Colorado River at Grand Canyon. However, there may be some uncertainty in the correlation of data concerning the smaller silt and clay particles, because of differences mentioned in the paragraph above.

\section{SUSPENDED LOAD FROM OTHER SOURCES}

It has already been mentioned that probably more than 95 percent of the total inflow of water to Lake Mead comes from the Colorado River and is measured at the Grand Canyon gaging station. All the evidence indicates that a similarly large proportion of the sediment entering the lake also passes this station. Thus a comparison of the sediment loads measured at Grand Canyon and at Topock, Ariz. (115 miles below Hoover Dam), during the 10 years prior to 1935 indicates that the inflow of sediment from tributaries below Grand Canyon was probably only a very small part of the total load carried past the Hoover Dam site.

Beginning in 1948 the suspended load in the Virgin River has been measured at Littlefield, Ariz. The measured loads of 652,000 tons in the water year 1948, $1,310,000$ tons in 1949 , and $1,690,000$ tons in 1950 amounted respectively to $0.45,1.10$, and 2.83 percent of the quantities measured in the Colorado River at Grand Canyon. In confirmation, the amount of sediment in the Virgin delta (in Overton Arm above the Lower Narrows, p. 157), as calculated by the volumetric survey of 1948 , was about 24 percent of the total sediment in Lake Mead (p. 195). This sediment was evidently derived almost entirely from the Virgin River, for there is evidence that sedimentation by Muddy Creek, which also flows into Overton Arm (p. 157), is negligible in amount.

Minor tributaries or washes have doubtless contrib- uted some sediment to Lake Mead, but the only direct evidence obtained during the 1948-49 survey is at Detrital Wash (p. 71, 171), where a cloudburst in 1939 caused erosion of several hundred acre-feet of sediment, which was doubtless carried into the reservoir. This quantity is negligible in comparison with the total sedimentation in the reservoir.

Although the sediment contribution to the lake from the part of the drainage basin below Grand Canyon was small during the years prior to 1948 , it is realized that this area may receive occasional storms of high intensity, which produce short but high peaks in runoff and sediment contribution. In some months, and perhaps in some years, its contribution of sediment to the lake may rise far above the rather small average. However, these occurrences have been too rare, at least in recent years, to have a significant over-all effect upon sedimentation in the lake.

\section{TEMPERATURE OF THE INFLOWING WATER}

Records of temperature of the Colorado River at Grand Canyon may be of questionable significance as an indication of the temperature of the water entering Lake Mead, because these records are obtained at a point that is about 190 miles above the reservoir. The records are, however, the only available records of temperature of the inflowing water. The temperature and discharge of the Colorado River at Grand Canyon for the period October 1947 to February 1949 are shown in figure 23. It will be noted that the water temperature was at a minimum of less than $40^{\circ} \mathrm{F}$ during January and February, rose above $60^{\circ} \mathrm{F}$ during the spring runoff, reached a peak of about $80^{\circ} \mathrm{F}$ in August and September, and then decreased. The temperature of the water at Grand Canyon has followed a similar pattern of annual fluctuation since 1936 , with a winter minimum ranging from $35^{\circ}$ to $40^{\circ} \mathrm{F}$, and a summer maximum of $75^{\circ}$ to more than $80^{\circ} \mathrm{F}$.

In late April the runoff consists of appreciable volumes of water with a temperature higher than that of the lake water. The concentration of suspended sediment during the spring runoff is relatively high, but the sediment consists largely of coarse particles that will be deposited at the head of the reservoir. The content of dissolved solids in the inflow during this period is decreasing, and by the end of April is usually lower than the dissolved-solids content of the lake water. As the inflow has a lower content of dissolved solids and is warmer than the lake water, it will be less dense than the water in the lake. Because of this difference in density, the inflowing water remains at the surface and floats downlake on top of the water stored in the reservoir. 


\section{DISSOLVED SOLIDS IN THE INFLOWING WATER}

Most of the dissolved mineral matter in the water of Lake Mead comes from the water flowing past the Grand Canyon gaging station, for which records of quality of the water are available since 1925. Practically nothing is known about the dissolved solids in the inflow from side canyons and small tributaries; this inflow is probably more mineralized than the main stream, but in any event it is not in sufficient volume to have any significant effect on the chemical characteristics of the lake water. The principal constituents of the dissolved solids in the Colorado River water and also in the Lake Mead water are calcium and magnesium; sodium and potassium; sulfate, bicarbonate, and chloride; and silica. When the reservoir was first planned there was some concern over the possibility of the boron content of the water being sufficiently high to cause trouble when the water was used for irrigation, but the boron content of the inflow and of the release is considerably below the maximum concentration that is suitable for irrigation. Similar concern was expressed about the posibility of the fluoride content of the water being high enough to mottle the enamel of teeth when used for drinking water by growing children, but the fluoride concentration has not been high enough to cause such damage. Other constituents are present in low concentrations, but they are not significant for this discussion.

\section{SEASONAL VARIATIONS}

Water passing the Grand Canyon gaging station shows a large seasonal range in concentration of dissolved solids. As a rule, the lowest concentration is found in the spring during the flood stages resulting from melting snow, and the maximum concentration is found during the periods of low flow when the runoff consists almost entirely of ground-water inflow. The concentration of dissolved solids may also be relatively high during floods, which come after heavy rains on the arid parts of the drainage area. Analyses representing these three conditions of river stage and a weighted average for the period of the 1948-49 survey are shown as numbers 1 to 4 , respectively, in table 11 .

The seasonal variations in dissolved solids in the Colorado River water during the 1948-49 survey are shown in figure 23. The concentration of dissolved solids ranged from 800 to $1,000 \mathrm{ppm}$ during the winter of $1947-48$, decreased to a minimum of $276 \mathrm{ppm}$ during June $11-20$, rose to $1,380 \mathrm{ppm}$ during October $11-20$, and then fluctuated between 800 and 1,200 ppm during the winter of $1948-49$.

The variations in concentration of dissolved solids during the period of the survey were less than have been recorded in some years since 1935 . In the water year 1942, the dissolved solids reached a 10-day minimum of $225 \mathrm{ppm}$ on June 11-20, and a maximum of $1,350 \mathrm{ppm}$ on September 21-30. In 1940, the range in concentration was even greater: from a minimum of $334 \mathrm{ppm}$ in the 10-day period June 1-10 to a maximum 1,720 ppm on September 1-10. The maximum 10-day average concentration in the period of record was $1,890 \mathrm{ppm}$ on September 21-30, 1934.

\section{ANNUAL VARIATIONS}

The annual average concentration of dissolved solids in the Colorado River also varies widely. In the pub-

TABLE 11.-Chemical analyses of water samples of inflow and outflow, and from various points and depths in Lake Mead, in parts per million

\begin{tabular}{|c|c|c|c|c|c|c|c|c|c|c|c|c|c|c|c|c|}
\hline \multirow{2}{*}{ Location of samples } & \multicolumn{5}{|c|}{ Inflow } & \multirow{2}{*}{$\begin{array}{c}\text { Pierce } \\
\text { Basin } \\
6\end{array}$} & \multicolumn{2}{|c|}{ Virgin Canyon } & \multicolumn{3}{|c|}{ Virgin Basin } & \multicolumn{4}{|c|}{ Boulder Basin, intake towers } & \multirow{2}{*}{$\begin{array}{c}\text { Out- } \\
\text { flow }\end{array}$} \\
\hline & 1 & 2 & 3 & 4 & 5 & & 7 & 8 & 9 & 10 & 11 & 12 & 13 & 14 & 15 & \\
\hline $\begin{array}{l}\text { Silica }\left(\mathrm{SiO}_{2}\right) \\
\text { Calcium }(\mathrm{Ca}) \\
\text { Magnesium }(\mathrm{Mg}) \\
\text { Sodium plus potassium }(\mathrm{Na}+\mathrm{K})\end{array}$ & $\begin{array}{l}13 \\
55 \\
11\end{array}$ & $\begin{array}{r}14 \\
156 \\
60\end{array}$ & $\begin{array}{r}20 \\
148 \\
34\end{array}$ & $\begin{array}{l}14 \\
87 \\
26\end{array}$ & $\begin{array}{l}16 \\
60 \\
13\end{array}$ & $\begin{array}{l}12 \\
40 \\
12\end{array}$ & $\begin{array}{l}88 \\
33\end{array}$ & $\begin{array}{r}114 \\
41\end{array}$ & $\begin{array}{l}\mathbf{1 3} \\
60 \\
16\end{array}$ & $\begin{array}{l}12 \\
96 \\
26\end{array}$ & $\begin{array}{l}91 \\
26\end{array}$ & $\begin{array}{l}11 \\
72 \\
23\end{array}$ & $\begin{array}{l}12 \\
94 \\
26\end{array}$ & $\begin{array}{l}92 \\
38\end{array}$ & $\begin{array}{r}121 \\
67\end{array}$ & $\begin{array}{l}12 \\
86 \\
27\end{array}$ \\
\hline $\begin{array}{l}\text { Bicarbonate }\left(\mathrm{HCO}_{3}\right) \\
\text { Sulfate }\left(\mathrm{SO}_{4}\right) \\
\text { Chloride }(\mathrm{Cl}) \\
\text { Nitrate }\left(\mathrm{NO}_{3}\right) \\
\end{array}$ & $\begin{array}{r}25 \\
167 \\
69 \\
19 \\
\quad .7 \\
\end{array}$ & $\begin{array}{c}222 \\
261 \\
596 \\
188 \\
\quad 9.9 \\
\end{array}$ & $\begin{array}{r}133 \\
271 \\
465 \\
58 \\
\quad .5 \\
\end{array}$ & $\begin{array}{r}90 \\
216 \\
224 \\
71 \\
2.5\end{array}$ & $\begin{array}{r}29 \\
200 \\
66 \\
17 \\
.9\end{array}$ & $\begin{array}{r}20 \\
117 \\
68 \\
17 \\
1.9\end{array}$ & $\begin{array}{c}109 \\
176 \\
301 \\
94 \\
2.0\end{array}$ & $\begin{array}{c}119 \\
372 \\
256 \\
96 \\
5.4\end{array}$ & $\begin{array}{c}42 \\
138 \\
140 \\
33 \\
2.1 \\
\end{array}$ & $\begin{array}{c}93 \\
164 \\
298 \\
73 \\
2.4 \\
\end{array}$ & $\begin{array}{r}87 \\
165 \\
283 \\
67\end{array}$ & $\begin{array}{r}60 \\
121 \\
223 \\
52 \\
1.3 \\
\end{array}$ & $\begin{array}{r}96 \\
167 \\
297 \\
72 \\
2.9 \\
\end{array}$ & $\begin{array}{c}94 \\
176 \\
307 \\
88 \\
2.3 \\
\end{array}$ & $\begin{array}{c}77 \\
408 \\
285 \\
80 \\
\quad .7\end{array}$ & $\begin{array}{r}95 \\
167 \\
280 \\
71 \\
2.3 \\
\end{array}$ \\
\hline do & 276 & 1,380 & 992 & 621 & 301 & 228 & 714 & 815 & 374 & 681 & 644 & 502 & 682 & 708 & 832 & 656 \\
\hline $\begin{array}{l}\text { Specific conductance } \\
\text { (micromhos) }\end{array}$ & 455 & 1,970 & 1,390 & 956 & 481 & 374 & 1,120 & 1,280 & 572 & 1,010 & 981 & 782 & 1,030 & 1,120 & 1,360 & 988 \\
\hline
\end{tabular}

1. Inflow: June 11-20, 1948, minimum concentration of dissolved solids at Grand

Canyon during period Oct. 1, 1947-Feb. 28, 1949 .
2. Inflow: Oct. 11-20, 1948, maximum concentration of dissolved solids at Grand Canyon during period Oct. 1, 1947-Feb. 28, 1949.

3. Inflow: A ug. 21-31, 1947, period of summer flood at Grand Canyon, mean discharge 29,570 cfs; mean discharge for previous composite period was $18,850 \mathrm{cfs}$ 4. Inflow: Weighted average for Grand Canyon during period Oct. 1, 1947-Feb. 28, 1949 .

5. Inflow: May 21-31, 1948; minimum conductance for period previous to May 28 was 455 on May 26.

6. Water at surface of lake: May 28,1948 , Pierce Basin.
7. Water near bottom of lake: Feb. 20, 1945, Virgin Canyon, depth 200 feet. 8. Water at bottom of lake: February 20, 1945, Virgin Canyon, depth 330 feet. (Sample at 325 feet had $180 \mathrm{ppm}$ of $\mathrm{HCO}_{3}$ and conductance of 1,160 .

9. Water at surface of lake :May 31, 1948, upper end of Virgin Basin, station 45.

10. Water at 320 feet depth: May 31, 1948, upper end of Virgin Basin, station 45 .

11. Water at surface of lake: Feb. 29, 1948, Virgin Basin, station 27.

12. Water at surface of lake: Sept. 23,1948 , intake towers.

13. Water at bottom of lake: Sept. 23,1948 , intake towers, depth 443 feet.

14. Water at bottom of lake: July 3,1945 , intake towers, depth 442 feet. 15. Water at bottom of lake: July 3, 1945, intake towers, depth 443 feet 16. Outflow: July 12-16, 19-20, 1948, typical release at Hoover dam. 
lished records of chemical analyses (U.S. Geol. Survey, 1943 and later), weighted-average analyses for the Grand Canyon station are shown for each water year. The weighted-average analysis is computed by multiplying the discharge at the time of sampling by the quantities of the individual constituents, adding the products for all samples collected during the year, and dividing by the sum of the discharges. In the period of record the concentrations of dissolved solids have ranged from a weighted average of $491 \mathrm{ppm}$ in the water year 1928 to $960 \mathrm{ppm}$ in 1934 .

Since Hoover Dam was completed in 1935, the weighted-average concentration of dissolved solids at Grand Canyon was greatest in 1940, the year of minimum runoff, and least in 1942, the year of greatest runoff. This weighted-average concentration has varied greatly from year to year; it decreased about 25 percent from 1940 to 1941, and increased by an even larger percentage from 1938 to 1939 .

\section{DENSITY CURRENTS}

A density current has been defined by Bell (1942b) as a gravity flow of a fluid through, under, or over a fluid of approximately equal density. Apparently this flow takes place with very little mixing of the two fluids. But in Lake Mead, the water through which the density currents flow have various differences in density, which may result from differences in temperature, content of dissolved material, or suspended material, or a combination of these three factors (p. 107).

Density currents were first recognized in Lake Mead within a few months after storage began in 1935 (Grover and Howard, 1938). In most of them the difference in density has been caused to a considerable extent by fine suspended material, so that the water in the current is turbid. In some density currents, even those that are heavily laden with suspended material, an increased content of dissolved solids contributes materially to the greater density.

The water stored in the lake forms the medium in which density currents can flow; the causative factor is the inflowing water, because of its different density, which in turn is dependent upon its suspended load, dissolved solids, and temperature. Thus, the characteristics of the inflow already discussed are the characteristics which under favorable conditions produce density currents in the lake. The following paragraphs describe the investigations that have been made of density currents in Lake Mead, the record of density currents, and their correlation with characteristics of the inflowing water.

\section{INITIAL EVIDENCE, 1935-36}

The first, and still the best, evidence of density currents flowing through the entire length of Lake Mead was obtained during the first 15 months of operation of Hoover Dam. During the first year, all water released from the reservoir was discharged through tunnels at or near the base of the dam and therefore was drawn from the bottom of the reservoir. Early in 1936 , some water was released through the intake towers at a level about 250 feet above the base of the dam, but discharge through one tumnel was continued until May 1. Then the gate in that tunnel was closed, and all outflow from the reservoir since that date has been through the intake towers or over the spillways.

The evidence of density currents during the period when water was discharged from the bottom of the reservoir has been described (Grover and Howard, 1938), on the basis of records obtained at the Grand Canyon gaging station and at the gaging stations on the Colorado River at Willow Beach, Ariz., and near Topock, Ariz., about 10 and 115 miles respectively below Hoover Dam.

Storage in Lake Mead began on February 1, 1935, and the sediment concentration at Grand Canyon ranged from about 0.10 percent to 0.38 percent in the period January 23 to February 5. The sediment concentration at Willow Beach dropped from 0.45 percent cn January 31 to 0.07 percent on February 5, chiefly because of obstruction of the flow of water, because there was not much storage in the early part of February. On the 20th, 23rd, and 24th of February the sediment concentration at Willow Beach was more than 0.15 percent, but for the remainder of the month it was less than 0.10 percent.

The first outstanding discharge of turbid water from Lake Mead occurred in March and April. On March 26 the sediment concentration at Willow Beach rose to 0.52 percent; except on the 29 th, it remained more than 0.30 percent for the rest of the month but dropped to 0.07 percent on the first of April. The increase in sediment concentration at Willow Beach seemd to be directly related to an increase in sediment concentration at Grand Canyon from 0.44 percent on March 17 to 1.72 percent on March 18; this was the first apparent density current flow in Lake Mead. A similar but more turbid flow occurred in mid-April with a sediment concentration of 1.15 percent at Willow Beach, following a steady increase in sediment concentration at Grand Canyon.

In September and again in October of that year similar density currents were indicated by increases in sediment concentration at the Willow Beach station, in each case about 8 days after increases at Grand 
Canyon. In these September and October flows there were also increases in the concentration of sulfate at Willow Beach following similar increases at Grand Canyon. Observations at the Topock gaging station showed increases in sediment and sulfate on the day following the increases noted at Willow Beach. The correlation of suspended load and of sulfate content at these stations above and below Lake Mead is illustrated by Grover and Howard (1938, fig. 2 ).

In 1936 the sediment concentration at Willow Beach increased from 0.02 percent on April 21 to 0.21 percent on April 22 and to 1.16 percent on April 23, reaching a peak of 1.44 percent on April 26. This followed and was directly related to an increase in sediment concentration at Grand Canyon from 0.22 percent on April 12 to 1.68 percent on April 18. The concentration at Grand Canyon had decreased to 1.26 percent on April 30; at Willow Beach the concentration dropped to 0.77 percent on April 30, and to 0.10 percent by May 1 and 0.01 percent by May 9. The concentration at Willow Beach has rarely been above 0.01 percent since May 1,1936 , the date on which the gates in the diversion tunnels were closed, and since which no water has been released from the bottom of the reservoir. In fact, the lowest elevation from which water can now be released from Lake Mead is at 895 feet, some 270 feet above the original bottom of the reservoir.

During the periods when turbid water was discharged from Lake Mead the reservoir was about 70 to 90 miles long and contained 4 to 5 million acre-feet of water. Apparently the turbid water flowed through the reservoir essentially unmixed. The four density currents of 1935 and 1936 carried a total suspended load estimated at 6 million tons, chiefly of clay and silt-sized particles finer than 20 microns in diameter. The absence of turbidity in the water released from the reservoir since May 1936 suggests that in the vicinity of the dam these density currents occur only near the bottom of the reservoir.

\section{INVESTIGATIONS, 1936-49}

The evidence in 1935 of density currents in Lake Mead led to a program of continuing investigation, including theoretical, laboratory, and field studies of the subject. The National Bureau of Standards made some preliminary studies of density currents and their causes, based on field data furnished by the Geological Survey and the Burean of Reclamation. This work led to consideration of the problem by others. In particular, the Soil Conservation Service made laboratory studies at California Institute of Technology, which are reported by Bell (1942a, b).
The Bureau of Reclamation and the Geological Survey made plans for field observations of density currents in Lake Mead. The National Research Council formed its Density Currents Committee, a group that acted in an advisory capacity for studies planned for Lake Mead and for the Elephant Butte reservoir on the Rio Grande. Especially through the efforts of C. P. Vetter, a comprehensive program of sampling and observations was outlined by T. C. Mead, of the Bureau of Reclamation, and the writer in the summer of 1937. This program called for temperature observations and the collection of samples at monthly intervals at Hoover Dam, Cape Horn in Black Canyon, Boulder Canyon, and Virgin Canyon. It was hoped that sufficient warning could be given when turbid water was known to be passing Grand Canyon to permit observations to be made and samples to be collected at the upper end of the reservoir, but this was found to be impractical. The program suggested "observations to be made at locations across the lake in the wider sections to determine the outer edge of the deposited silt, reference points to be established for five locations in the lake." The five locations specified were between the Virgin River and Hemenway Wash, at the boat landing near mile $352^{5}$ in Boulder Basin.

This program, with some modification, was the basis for the studies carried on for several years. Monthly samples were collected from various depths at Hoover Dam and from the surface at Pierce Ferry. Occasional trips (usually two or three each year) were made to other parts of the reservoir, including Boulder Canyon, Virgin Canyon, and the Lower Narrows in Overton Arm.

Published reports of the density current investigations (National Research Council, 1949, and Bureau of Reclamation, 1949, 1953) include sounding graphs that show temperature, specific conductance, density, and specific gravity at each observation station, and also graphs summarizing the data from all stations for 18 periods during which there was evidence that density currents were flowing in the reservoir. The sounding graphs for the area near Hoover Dam are based on monthly measurements since May 1937. In other areas of the lake, notably Boulder Canyon, Virgin Canyon, and Pierce Basin, the sounding graphs are based on measurements made monthly from January 1938 to June 1940, and once or twice a year thereafter. These infrequent measurements are insufficient to indicate the duration of the reported density flows, and nothing is known about such flows in the intervals between

\footnotetext{
${ }^{5}$ River distances on the Colorado River are measured downstream from the Geological Survey marker opposite the mouth of the Paria River, along the pre-Lake Mead channel of the river.
} 
measurements. The fact that several density movements are inferred during the periods of measurement is indicative that numerous other density currents may not have been recorded. H. R. Gould's graphs of daily densities at Grand Canyon (pl. 26), indicate that there are several periods in almost every year when conditions may have been favorable for development of density currents.

During the Lake Mead survey the observational and sample-collecting program was expanded; considerable emphasis was given to the collection of data in the upper end of the reservoir, particularly in the "convergence area" in the vicinity of Pierce Ferry (p. 126). Samples were collected and temperature observations made approximately once a month during the survey. The results of these observations and discussions of their significance are presented by Anderson and Pritchard (p. 125-146) and by Gould (p. 201-207).

\section{RECORD OF DENSITY CURRENTS}

The density currents observed in 1935 and 1936 (Grover and Howard, 1938) and those reported in subsequent years (National Research Council, 1949, and Bureau of Reclamation, 1949) are listed in table 12 , The antecedent characteristics are those which were observed at Grand Canyon during the reported period of the density current and the preceding week.

In every category, the periods listed cover a wide range. Density currents have been reported in each year since 1938, and in all months except January. Inflow to the lake during these periods has ranged from less than 7,000 to more than $90,000 \mathrm{cfs}$, and the temperature of the inflowing water has ranged from $34^{\circ}$ to $81^{\circ} \mathrm{F}$. During several periods the concentration of dissolved solids in the inflowing water has exceeded 1,100 ppm, but some density currents have been reported when the water had a very low concentration of dissolved matter. The peak concentration of suspended sediment at Grand Canyon has exceeded 1.2 percent in most periods, but density currents have also occurred when the inflow carried less than 0.2 percent of suspended matter. In periods during August through February, most of the suspended particles have been smaller than 20 microns in diameter; but in periods occurring in April through July the clay and fine silt has constituted only a small proportion of the total sediment in the inflowing water.

Some of these reported density currents occurred during or immediately prior to recorded increases in the amount of sediment at the face of the dam, but others are not clearly related to such increases. The accumulation of sediment at the dam is shown by monthly measurements of the position of the sediment surface between the intake towers (fig. 24). Since August 1937 the sediment surface has risen more than 15 feet in each of 8 periods; the amount of rise was more than 35 feet in the autumn of 1941 , and almost as much in the autumn of 1947 . Following each of these eight major rises, the elevation of the sediment surface has declined, rapidly at first and then more gradually, presumably due in large part to compaction of the accumulated sediment. Although minor fluctua-

TABLE 12.-Reported density eurrents in Lake Mead, and antecedent conditions at Grand Canyon, 1935 to 1949

\begin{tabular}{|c|c|c|c|c|c|c|c|}
\hline \multirow[b]{3}{*}{ Year } & \multirow[b]{3}{*}{ Reported period of density current } & \multirow{3}{*}{$\begin{array}{c}\text { Rise in sedi- } \\
\text { ment level } \\
\text { at Hoover } \\
\text { Dam, }{ }^{2} \text { in } \\
\text { feet }\end{array}$} & \multicolumn{5}{|c|}{ Antecedent characteristies at Grand Canyon ${ }^{1}$} \\
\hline & & & \multirow[b]{2}{*}{$\begin{array}{l}\text { Maximum } \\
\text { discharge, } \\
\text { in cfs }\end{array}$} & \multirow[b]{2}{*}{$\begin{array}{l}\text { Temper- } \\
\text { ature range, } \\
\text { in }{ }^{\circ} \mathrm{F} \text {. }\end{array}$} & \multirow[b]{2}{*}{$\begin{array}{c}\text { Maximum } \\
\text { dissolved } \\
\text { solids, }{ }^{3} \text { in } \\
\text { ppm }\end{array}$} & \multicolumn{2}{|c|}{ Suspended load } \\
\hline & & & & & & $\underset{\text { percent }}{\text { Maximum }}$ & $\begin{array}{c}\text { Dominantly } \\
\text { larger (L) or } \\
\text { smaller (S) } \\
\text { than } 20 \\
\text { microns }\end{array}$ \\
\hline 1935 & Mar. 25-Apr. 1.. & 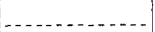 & 8,100 & & 1,010 & 1.72 & \\
\hline & Apr, $10-21$ & $\cdots$ & 15,600 & & 780 & 3. 16 & $\mathbf{L}$ \\
\hline & 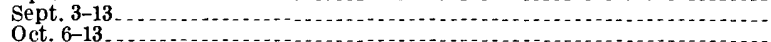 & (n) & 12,300 & $-\ldots \ldots$ & 1,130 & 5.02 & $\underset{S}{S}$ \\
\hline 1936 & $\begin{array}{l}\text { Oet. } 6-13 \\
\text { Apr. } 22-\mathrm{May} 1 .\end{array}$ & & $\begin{array}{l}18,100 \\
51,700\end{array}$ & & $1, \frac{130}{740}$ & $\begin{array}{l}5.09 \\
1.68\end{array}$ & $\stackrel{\mathrm{S}}{\mathrm{L}}$ \\
\hline 1938 & Nov. $16-$ Dec. 5 & 0 & $\begin{array}{r}01,100 \\
9,300\end{array}$ & $34-45$ & 1,050 & .14 & $\mathrm{~S}$ \\
\hline 1939 & Jan. 18-Feb. 3 & 44 & 6,800 & $36-39$ & 1,110 & .07 & $\mathrm{~S}$ \\
\hline & Mar. 15-Apr. 5... & 458 & 28,500 & $43-57$ & 980 & 2.12 & $\mathrm{~L}$ \\
\hline 1940 & June $20-28$ & 4511 & 31,900 & $66-75$ & 410 & .32 & $\vec{L}$ \\
\hline & $\begin{array}{l}\text { Apr. 30-May 5-- } \\
\text { May 21-June } 7 .\end{array}$ & $\begin{array}{l}0 \\
0\end{array}$ & 23,100 & $\begin{array}{l}60-64 \\
66-71\end{array}$ & $\begin{array}{l}660 \\
360\end{array}$ & 1.25 & $\mathbf{L}$ \\
\hline 1941 & June 2-Oct. 25. & 645 & $\begin{array}{l}40,500 \\
87,500\end{array}$ & $56-81$ & $\begin{array}{r}360 \\
1,080\end{array}$ & 6.36 & \\
\hline 1942 & Apr. 21-May 1 . & $\begin{array}{r}7 \\
2\end{array}$ & 68,700 & $53-60$ & 420 & 2.15 & $\mathbf{L}$ \\
\hline 1943 & - & 1 & & & & & \\
\hline 1944 & May 23-31 & 0 & 90,500 & $62-69$ & 400 & 1.47 & L \\
\hline 1945 & Feb. $19-28$ & 0 & 7,700 & $43-49$ & 1,090 & .42 & $\mathbf{S}$ \\
\hline 1946 & Mar. 18-29 & 2 & 9,500 & $47-54$ & 940 & .26 & $\mathrm{~S}$ \\
\hline 1947 & Feb. 24-Mar. 4. & 0 & 9,200 & $44-48$ & 1,000 & .30 & $\mathrm{~S}$ \\
\hline & Oct. $1-8$ & $\begin{array}{ll}6 & 35 \\
0\end{array}$ & 12,400 & $\begin{array}{r}71-72 \\
50-58\end{array}$ & $\begin{array}{r}910 \\
070\end{array}$ & .90 & S \\
\hline $\begin{array}{l}1940 \\
1949\end{array}$ & $\begin{array}{l}\text { Apr. 19-28 } \\
\text { Mar. 21-29. }\end{array}$ & $\begin{array}{r}0 \\
{ }_{5}^{2}\end{array}$ & $\begin{array}{l}53, \text { bou } \\
19,200\end{array}$ & $\begin{array}{l}50-58 \\
49-53\end{array}$ & $\begin{array}{r}1,070 \\
840\end{array}$ & 1. 07 & \\
\hline
\end{tabular}

1 As recorded during period of density current plus the preceding 7 days.

2 Rise is above trend of preceding monthly measurerrents.
3 A s shown in reported 10-day averages. 3 Rise occurred more than 30 days later than reported period of density current. 
PERIODS OF DENSITY CURRENTS
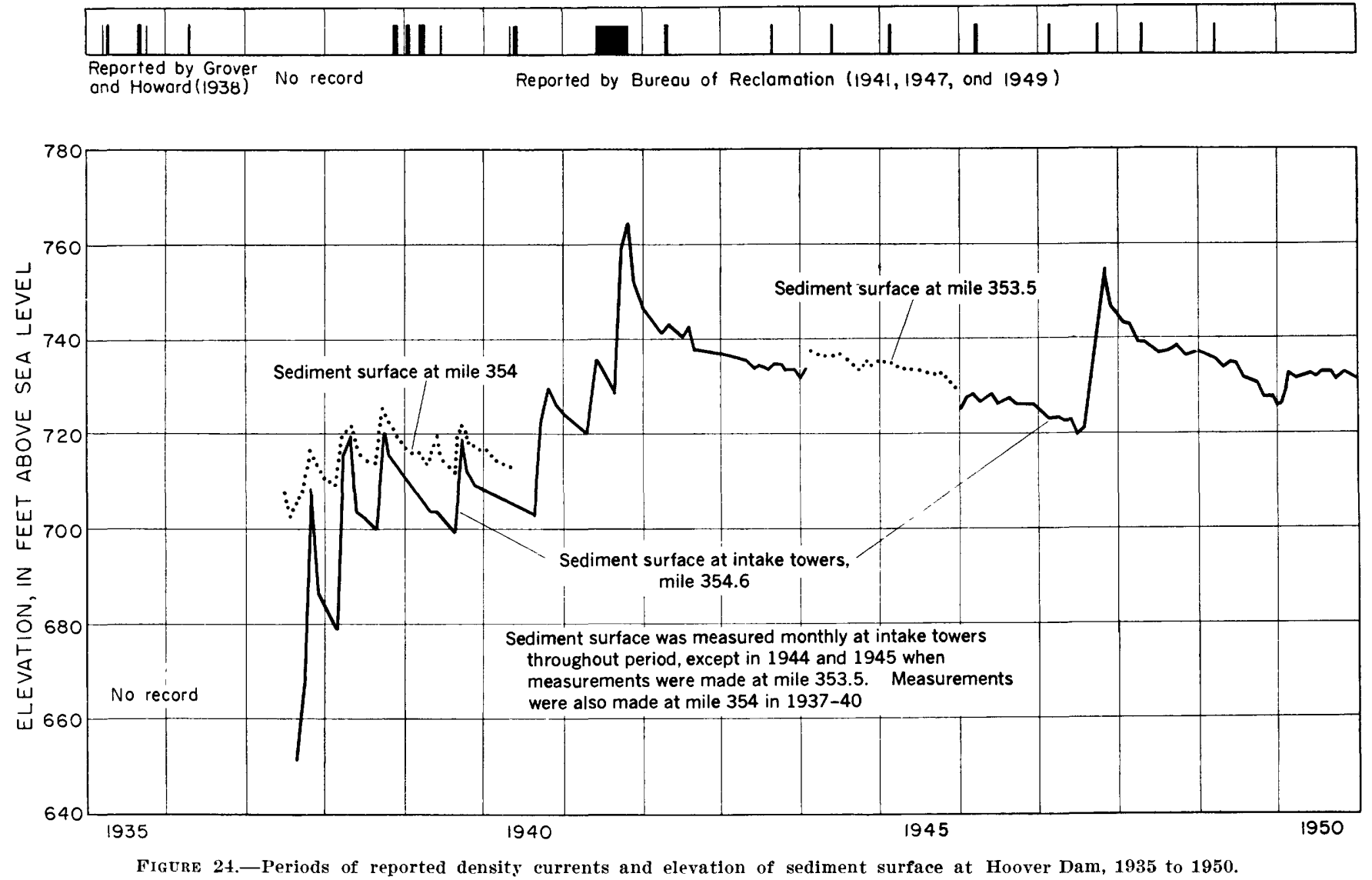

tions in the graph may result from the difficulty of determining precisely the actual sediment level, several small rises or interruptions in the general downward trend may indicate minor accretions of sediment at the dam. It is possible also that there is some redistribution of sediment in Boulder Basin subsequent to the periods of the density currents.

The difficulty of correlating the periods of reported density currents with the changes in level of the sediment surface at the dam is evident from inspection of figure 24. No reservoir observations were made during the three prominent rises of sediment level in 1937 and 1938. Several density currents are reported in the reservoir during the years 1938 to 1940 , but the sediment level at the dam showed no increase for these particular periods. Density currents were reported during the major rises of 1941 and 1947 , but in each instance the field observations were made subsequent to the begimming of rise in sediment level. The sediment surface declimed generally from 1942 to early 1947, and during 1948 and 1949.

The period of the Lake Mead survey was a relatively poor time to observe density currents in action. Only one density current, on April 19-28, 1948, is recorded during the period, and that one was unlike many of the earlier currents in that the greatest velocity of movement through Boulder Canyon was in the shallower water. The progressive downward trend in the position of the sediment surface indicates no accretions of sediment at the dam. It is possible that no major density currents traversed the entire length of the lake during the survey, and it thus appears that the combined effects of suspended and dissolved load and temperature of the inflowing water (as depicted on fig. 23) were not such as would cause extensive density currents. However, in the discussion of the chemical characteristics of the lake water (p. 115) evidence is given which indicates a density movement along the surface of the lake during the spring of 1948 .

Following the completion of the survey, the records at the intake towers show an increase in concentration of dissolved solids in deep waters between February and April 1949. The sediment surface at the intake towers rose slightly during May of that year, giving further evidence of the movement of a density current into and through the lake at this time. The calculated increases in density were from 2 to more than 6 percent and, though small, appear to have been 
the effects of appreciable density flows along the bottom of the lake.

In the early days of construction, a cofferdam was built 700 feet upstream from the face of Hoover Dam; its crest was at elevation 720 feet. The cofferdam was inundated by April 1935, but until 1940 it acted as a barrier to sediment moving toward the face of the dam along the bottom of the reservoir. The relative rates of sediment accumulation above and below the cofferdam since August 1937 are shown by comparison of the position of the sediment surface at the intake towers with that measured about half a mile upstream from the cofferdam, at mile 354 (fig. 24). During October 1937 the sediment level at the intake towers rose 42 feet; above the cofferdam it rose only 9 feet during that month, but it rose to within 3 feet of the top of the cofferdam, and it is apparent that large quantities of sediment surmounted that barrier and came to rest below it. The movement of sediment over barriers is described by Bell (1942). Three times during 1938 and 1939 the sediment level at mile 354 rose above the 720 -foot elevation, and each time the sediment surface at the intake towers rose to the level of the top of the cofferdam. Since October 1940 the cofferdam has been no barrier, because the sediment level at the intake towers has been higher than 720 feet.

The rapid rise of the top of the sediment layer between the intake towers ( 100 feet in the first 3 years of reservoir operation) was considered by some to indicate that within a very few years the sediment level would reach 895 feet, the lowest elevation from which water can be released through the intake towers. The additional rise of 40 feet in the single year 1941 doubtless caused further alarm. Howerer, the subsequent records indicate a gradual but progressive lowering of the sediment surface, with the result that by July 1947 it was down to the level of the top of the cofferdam, and 45 feet lower than the highest sediment level measured in 1941. Another major influx of sediment, recorded at the intake towers in the latter part of 1947 , has had a similar history. Throughout 1950 the sediment surface was more than 20 feet lower than its recorded position in October 1947.

\section{REFERENCES CITED}

Bell, H.S., 1942a, Density currents as agents for transporting sediment: Jour. Geology, v. 50, p. 514.

- $1942 \mathrm{~b}$, Stratified flow in reservoirs and its use in the prevention of silting: U.S. Dept. Agriculture Misc. Pub. 491, $46 \mathrm{p}$.

Daines, N. H., 1949, Study of suspended sediment in the Colorado River: U.S. Bur. Reclamation, Hydrology division mimeo. rept., $26 \mathrm{p}$.

Grover, N.C., and Howard, C. S., 1938, The passage of turbid water through Lake Mead: Am. Soc. Civil Engineers Trans. v. 103, p. 720-790.

Howard, C. S., 1928, Quality of water of Colorado River in 192526: U.S. Geol. Survey Water-Supply Paper 596, p. 33-43 [1927].

1930a, Quality of water of the Colorado River in 1926-28: U.S. Geol. Survey Water-Supply Paper 636-A [1929], p. 1-14. $1930 \mathrm{~b}$, Suspended matter in the Colorado River in 192528: U.S. Geol. Survey Water-Supply Paper 636 [1929], p. $15-45$.

1932, Quality of water of the Colorado River in 1928-30: U.S. Geol, Survey Water-Supply Paper 638, p. 145-158 [1931].

1947, Suspended matter in the Colorado River, 1925-41: U.S. Geol. Survey Water-Supply Paper 998, 165 p.

1948 , Lahoratory experiences with the bottom withdrawal tube method of size analysis, in Federal Inter-Agency sedimentation Conf., Denver, Colo., May 6-8, 1947, Proc.: U.S. Bur. Reclamation.

National Research Council, Interdivisional Committee on Density Currents, Subcommittee on Lake Mead, 1949, Lake Mead density currents investigations $1937-40$, v. 1,$2 ; 1940-46$, v. 3: Washington, U.S. Bur. Reclamation, 3 v., $904 \mathrm{p}$.

U.S. Bureau of Reclamation, 1949, Report of river control work and investigations in 1948 and 1949 : Office of River Control, Boulder City, Nev., p. 53-124, figs. 44-46.

1953, Report of river control work and investigations in 1950 and 1951: Office of River Control, Boulder City, Nev., p. 59-94, figs. $45-47$.

C'.S. Geological Survey, 1943 and later, Quality of surface waters of the Inited States, as follows:

\begin{tabular}{|c|c|c|c|}
\hline Water year & $\begin{array}{l}\text { Water-Supply } \\
\quad \text { Paper }\end{array}$ & Year published & Pages \\
\hline $1941 \ldots$ & 942 & 1943 & $56-68$ \\
\hline $1942 \ldots$ & 950 & 1944 & $39-6$ \\
\hline $1943 \ldots$ & 970 & 1945 & $80-125,159-167$ \\
\hline $1944 \ldots$ & 1022 & 1947 & $176-245$ \\
\hline $1945 \ldots$ & 1030 & 1949 & $265-323$ \\
\hline $1946 \ldots$ & 1050 & 1950 & $419-477$ \\
\hline $1947 \ldots$ & 1102 & 1952 & $569-637$ \\
\hline $1948 \ldots$ & 1133 & 1952 & $286-36$ \\
\hline
\end{tabular}




\title{
L. GHEMISTRY OF THE WATER
}

\author{
By C.S. Howard, U.S. Geological Survey
}

\section{PROGRAM OF INVESTIGATION}

The study of the chemistry of Lake Mead waters during this survey was a continuation and expansion of the studies begun in 1937 by the Bureau of Reclamation, the Metropolitan Water District of Southern California, and the Geological Survey. The study was originally set up as a part of the density-current studies and was carried out under the auspices of the Committee on Density Currents of the National Research Council. A preliminary report was issued in mimeographed form in October 1941, and the complete records for the work done between 1937 and 1946 were published in 1949 (National Research Council, 1949).

During the density-current studies (1937-46), samples were collected at points in Pierce Basin, Virgin Canyon, Boulder Canyon, Black Canyon (at both Cape Horn and the intake towers), and at one or more places in Overton Arm. Samples were collected in Pierce Basin and at the intake towers once a month and at other points two or three times each year. During the Lake Mead survey (1948-49), samples were collected at these points about once a month. The comprehensive sampling programs of both studies provided samples from different depths, especially at depths where field observations of temperature and specific conductance showed changes in the physical or chemical characteristics of the water. The samples were collected in a modified Foerst sampler (p. 151) or in Nansen bottles (p. 127).

All samples were analyzed for the total quantity of dissolved solids as indicated by the specific-conductance determination. Alkalinity was determined on the samples collected in the density-current studies. Sufficient other determinations were made to determine the nature and extent of variation in the chemical character of the available samples.

\section{DISSOLVED SOLIDS IN THE LAKE WATER}

\section{SEASONAL VARIATIONS}

Records obtained during the density-current investigations showed variations in chemical character and temperature of the water in the lake at different seasons. This was apparent in the early stages of storage at different depths at four places in the reservoir, as is showm in table 13, based on measurements in 1937 and 1938.

During the late winter (February-March) the concentration of dissolved solids in the lake water is fairly uniform throughout the lake, both in depth and areal distribution. In March 1948 there was less than a 30-percent variation in the concentration of dissolved solids from Pierce Ferry to the intake towers, at practically all depths. An analysis of lake water typical of this condition is shown as analysis 11 in table 11. It is likely that this uniformity in dissolved-solids concentration is related to the uniformity in temperature discussed on page 120 .

During the period of greatest inflow, usually from April to July, there is considerable variation in concentration of dissolved solids at different depths throughout the lake. It has been mentioned that the inflowing water may form density currents as it enters the lake. It seems that under certain conditions water with a heavy sediment content and low concentration

TABLE 13.-Specific conductance of water at four points in Lake Mead, 1937 and 1938

[In micromhos; multiply by 0.7 to obtain approximate quantity of dissolved solids in parts per million. Italic figures represent samples from bottom of lake]

\begin{tabular}{|c|c|c|c|c|c|c|c|c|c|c|c|c|c|c|c|c|}
\hline \multirow{3}{*}{$\begin{array}{l}\text { A pproximate elevation, in feet } \\
\text { above sea level }\end{array}$} & \multicolumn{4}{|c|}{ Virgin Canyon } & \multicolumn{4}{|c|}{ Lower Narrows, Overton Arm } & \multicolumn{4}{|c|}{ Boulder Canyon } & \multicolumn{4}{|c|}{ Black Canyon } \\
\hline & \multicolumn{2}{|c|}{1937} & \multicolumn{2}{|c|}{1938} & \multirow{2}{*}{$\frac{1937}{\text { Sept. }}$} & \multicolumn{3}{|c|}{1938} & \multicolumn{2}{|c|}{1937} & \multicolumn{2}{|c|}{1938} & \multicolumn{2}{|c|}{1937} & \multicolumn{2}{|c|}{1938} \\
\hline & Sept. & Nov. & Jan. & Mar. & & Jan. & Feh. & Mar. & Sept. & Nov. & Jan. & Mar. & Oct. & Dec. & Jan. & Mar. \\
\hline $\begin{array}{l}1,100 \text { to } 1,000 \\
950 \text { to } 850 \\
8000 \\
625\end{array}$ & $\begin{array}{r}850 \\
1,210 \\
1,620 \\
\end{array}$ & $\begin{array}{l}1,100 \\
1,330 \\
1,380\end{array}$ & $\begin{array}{l}1,090 \\
1,356 \\
1,410\end{array}$ & $\begin{array}{l}1,100 \\
1,270 \\
1,555\end{array}$ & $\begin{array}{r}760 \\
1,190\end{array}$ & $\begin{array}{l}980 \\
990\end{array}$ & $\begin{array}{l}1,030 \\
1,280\end{array}$ & $\begin{array}{l}1,030 \\
1,840\end{array}$ & $\begin{array}{r}710 \\
1,170 \\
1,190 \\
1,140\end{array}$ & $\begin{array}{r}810 \\
1,160 \\
1,270 \\
1,230\end{array}$ & $\begin{array}{r}960 \\
1,210 \\
1,240 \\
1,670\end{array}$ & $\begin{array}{l}1,030 \\
1,210 \\
1,330 \\
1,660\end{array}$ & $\begin{array}{r}840 \\
1,150 \\
1,210 \\
1,450 \\
1,560\end{array}$ & $\begin{array}{r}880 \\
1.140 \\
1,200 \\
1,240 \\
1,320\end{array}$ & $\begin{array}{r}920 \\
1,160 \\
1,190 \\
1,290 \\
1,470\end{array}$ & $\begin{array}{l}1,040 \\
1,210 \\
1,340 \\
1,430 \\
1,5.90\end{array}$ \\
\hline
\end{tabular}


of dissolved solids may sink toward the bottom as it enters the reservoir; then, because of a lessening of the velocity, some of the suspended load is deposited, and the inflowing water may then rise to the surface and continue downlake in the surficial layer.

During and after the spring-flood period, the surficial water has a lower concentration of dissolved solids than the deeper water in parts of the upper lake, including Overton Arm. Monthly observations show the progressive movement of this water into the lake. During the 1948 survey, water that had a dissolvedsolids concentration of about $300 \mathrm{ppm}$ was found as far downlake as mile 295 in late May and mile 320 in late July. Water of such low concentration has not been found at the intake towers, even in 1941 when some water went over the spillways. The progressive movement of the inflow of low concentration is shown by the italic figures in table 14 . The figures in each line indicate the seasonal variations in concentration of dissolved solids at specific sampling points; the variation is greatest near the head of the lake, and progressively less toward Hoover Dam.

At many places in the lake in spring, water may be found with a concentration of dissolved solids lower than in any prior inflow of that season. This is illustrated by analyses 5 and 6 in table 11, of waters whose major difference is in the concentrations of calcium and bicarbonate. It would appear that some of these constituents have precipitated out of the surface water owing to loss of carbon dioxide. Similar low concentrations have been noted in most of the years for which records are available. A similar phenomenon has been noted in the Conchas reservoir on the Canadian River in New Mexico.

By late summer (August-October), the water of low concentration of dissolved solids has moved downlake and reached a very low point. Since storage was effective in Boulder Basin, the concentration of dissolved solids in surficial water has always been higher than in the eastern part of the lake, showing that some mixing and probably some increase in solids through evaporation and solution have occurred. In late summer the surficial water at the head of the lake is more mineralized than that in Boulder Basin; except in the unlikely event of a large inflow of water of low mineralization, the water at the head of the lake will not reach a low mineralization again until the following spring.

In late summer, floods of considerable magnitude may bring in water that has a relatively high concentration of dissolved solids and very high concentrations of suspended sediment. The sediment in these floods commonly consists chiefly of very fine material, which will stay in suspension for long periods and may cause the movement of sediment in density currents through the lake. A flood of this nature caused the density flow noted in September and October of 1935, when storage in Lake Mead was first started (Grover and Howard, 1938). Since that date other floods carrying predominantly fine material have been observed at Grand Canyon; these floods could have furnished the material that has collected at the intake towers and at other places in Boulder Basin. Such a flood in late August 1947 probably caused the increase noted in the elevation of the top of the sediment layer at the intake towers between July 31 and August 28. There was only a slight change in concentration of dissolved solids at the bottom of the lake during this period.

Inflow from the Colorado River is least in November, December, and January; evaporation losses also are least. The principal change that takes place in the lake water in winter is a stabilization in concentration of

TABle 14.-Dissolved solids ( $\mathrm{ppm}$ ) in surface samples from Lake Mead, 1948

[Reported values where available, other values computed from reported conductance values and ratios of conductance to dissolved solids. Items in italic represent low concentrations and show progress of spring-flood water through the lake]

\begin{tabular}{|c|c|c|c|c|c|c|c|c|c|}
\hline Location & $\begin{array}{l}\text { Sampling } \\
\text { station } 1\end{array}$ & $\begin{array}{l}\text { Cruise I, } \\
\text { Feb. 25-29 }\end{array}$ & $\begin{array}{c}\text { Cruise II, } \\
\text { Mar. 31- } \\
\text { Apr. 14 }\end{array}$ & $\begin{array}{l}\text { Cruise III. } \\
\text { Apr. 23-28 }\end{array}$ & $\begin{array}{l}\text { Cruise IV, } \\
\text { May 25-31 }\end{array}$ & $\begin{array}{l}\text { Cruise V, } \\
\text { June 26-30 }\end{array}$ & $\begin{array}{l}\text { Cruise VI, } \\
\text { July 24-29 }\end{array}$ & $\begin{array}{l}\text { Cruise VIII, } \\
\text { Sept. 25-29 }\end{array}$ & $\begin{array}{l}\text { Cruise X, } \\
\text { Nov. } 27-30\end{array}$ \\
\hline $\begin{array}{l}\text { Colorado River at Grand Canyon } 2 \ldots \\
\text { Lake Mead. }\end{array}$ & & 929 & 678 & 453 & 301 & 334 & 701 & 1,300 & 1,180 \\
\hline 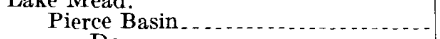 & ${ }^{3} 66-67$ & 646 & 725 & 393 & 217 & 277 & 530 & 958 & 1,110 \\
\hline Do & 65 & 632 & 735 & 463 & 220 & 245 & 474 & 756 & 734 \\
\hline Iceberg Canyon..... & $\begin{array}{l}61 \\
60\end{array}$ & 632 & $\begin{array}{l}681 \\
666\end{array}$ & 520 & 231 & $\begin{array}{l}236 \\
233\end{array}$ & $\begin{array}{l}457 \\
369\end{array}$ & $\begin{array}{l}672 \\
668\end{array}$ & $\begin{array}{l}720 \\
681\end{array}$ \\
\hline Gregg Basin & 55 & ...- & 652 & 593 & 289 & 229 & 340 & 572 & 626 \\
\hline Virgin Canyon & 50 & & 639 & 641 & 325 & 227 & 288 & 448 & 565 \\
\hline Virgin Basin ..... & 45 & 639 & & 647 & 374 & 253 & 305 & 398 & 487 \\
\hline Do ${ }_{\text {Do }}$ & $\begin{array}{l}32 \\
24\end{array}$ & 646 & & 64 & 416 & 369 & $\begin{array}{l}309 \\
349\end{array}$ & $\begin{array}{l}398 \\
408\end{array}$ & 486 \\
\hline Boulder Canyon & $\begin{array}{l}24 \\
18\end{array}$ & $666^{-}$ & 669 & $\begin{array}{l}649 \\
642\end{array}$ & $\begin{array}{l}534 \\
550\end{array}$ & $\begin{array}{l}501 \\
332\end{array}$ & 343 & 461 & $\begin{array}{l}502 \\
502\end{array}$ \\
\hline Boulder Basin . . & 16 & 673 & 668 & 648 & 665 & 352 & 464 & 486 & 530 \\
\hline $\begin{array}{l}\text { Do } \\
\text { Hoover Dam }\end{array}$ & 5 & & & 657 & 667 & 567 & 541 & $\begin{array}{l}508 \\
508\end{array}$ & $\begin{array}{l}532 \\
542\end{array}$ \\
\hline Colorado River below Hoover Dam. & & 672 & $\begin{array}{l}670 \\
666\end{array}$ & $\begin{array}{l}657 \\
666\end{array}$ & $\begin{array}{l}660 \\
660\end{array}$ & $\begin{array}{l}391 \\
660\end{array}$ & 646 & 612 & 678 \\
\hline
\end{tabular}

1 Station locations shown on plate 18

2 Reported value for normal composite period corresponding to sampling period in lake; usually the period during which the sampling was done. 


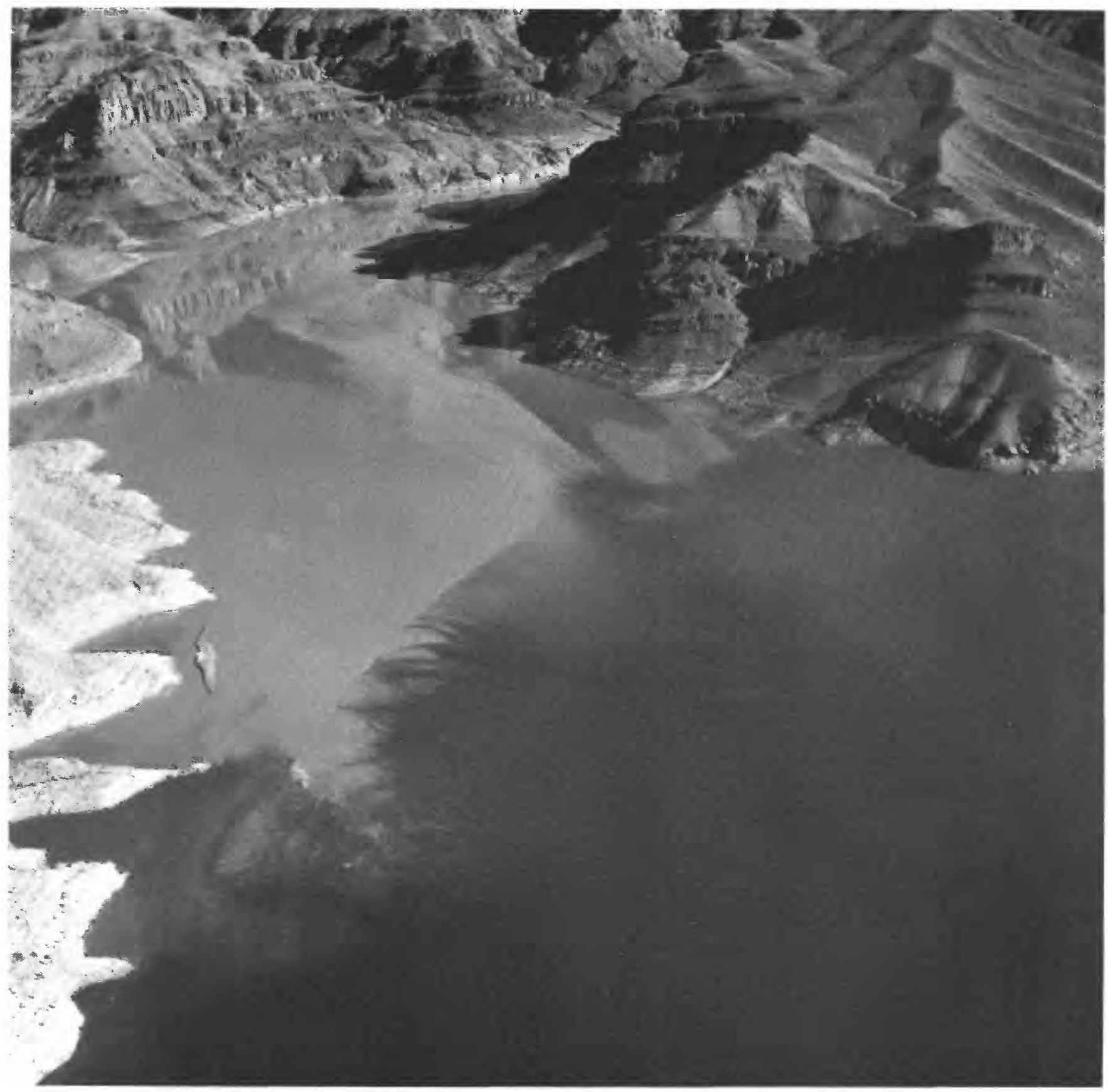

CONVERGENCE OF COLORADO RIVER AND LAKE MEAD IN PIERCE BASIN, NOVEMBER 1948

Note sharp contrast between lake and river where the turbid water rushes down along the lake bottom. The 1948 terrace just below water surface can be seen at right. Photograph by Bureau of Reclamation. 
the dissolved solids, caused chiefly by turnover. The surface water cools with decreasing air temperature, becomes more dense, and moves to greater depth in the lake. This causes a mixing of the water of the upper layers, and monthly samples during the survey of 1948 49 show a mixing to progressively greater depths. The results obtained in earlier studies also indicate that this mixing takes place progressively, the upper few feet being mixed first, followed by mixing to greater depths (see analysis 7 of table 11). The extent of the mixing in any season depends on the extreme air temperatures reached. In some years, as shown in January 1949, the mixing extends the entire depth at the intake towers, but in other years, such as 1943 , only the upper 150 to 200 feet of the lake seems to be affected. By the close of the winter season, just before the spring inflow, the lake water is as thoroughly mixed as it can be for the year (see table 13, measurements in March 1938). The process just discussed refers to the mixing of water from different depths at a specific locality within the lake. There is a uniformity of concentration of dissolved solids throughout the lake in the winter, as is shown by the measurements during cruises of February 25-29 and March 31-April 14, 1948 (table 14).

\section{GEOGRAPHIC VARIATIONS}

The chemical analyses of samples and the more numerous observations of specific conductance indicate variations in quality of water at different points in the lake.

In Pierce Basin, because of the turbulent conditions due to inflow and incomplete mixing where the river enters the lake, it is difficult to make observations, collect representative samples, and interpret the results of those observations and samples. In this area the water at the surface of the lake often has a mottled appearance, with the sediment appearing as "curds" throughout patches of clear water, and it is believed that this unmixed condition may exist over a considerable area. In some seasons the inflowing river water and the lake water form a distinct boundary (pl. 17). The circulation patterns in the area of convergence are described on page 135. During the Lake Mead survey the part of the lake near the mouth of Pierce Basin was generally near the convergence area, and samples were collected in this area each trip. Many of the samples represented the inflow (see analysis 6 of table 11), whereas others were obviously mixtures of inflowing and lake waters.

The variations in concentration of dissolved solids in the surficial lake water in various parts of the reservoir are indicated in the vertical columns of table 14 . The progressive movement of the spring flood waters into the lake is shown by printing in italic of the lowest concentrations of dissolved solids in this table. The effect of inflow of more mineralized waters, following the spring floods, is shown by the presence of such water at the surface in the upper reaches of the lake, particularly in September and October. Throughout the lake, the percentage variation in concentration of dissolved solids in the surface samples is least in February and March; in those months in 1948 the maximum difference of such concentration in samples from a point below the convergence area and one at the intake towers was about 10 percent. The composition of the lake waters is almost as uniform in early April. By contrast, the difference in concentration at these points in late May was about 300 percent.

The presence of soluble rocks underlying and bordering Overton Arm of the lake suggests that the quality of the water might be different and the concentrations of dissolved solids might be higher there than in most of the lake. Extensive rock outcrops in the southern part of Virgin Basin also might contribute to the salinity of the lake there. For that reason sampling points were selected within Overton Arm, and also in Virgin Canyon and Boulder Canyon, which are above and below the areas where gypsum outcrops are most abundant. Casual observations during boat trips indicated that some of the gypsum and salt cliffs previously seen along the edge of Overton Arm had disappeared, a circumstance that was particularly noticeable in the vicinity of the Calico salt mines (p. 123). Solution of that material has obviously changed the shoreline and increased the capacity of the lake, but the total volume change has been but a small part of the total capacity of the lake.

Observations have been made since 1937 in Boulder Canyon near mile 335, about 20 miles above Hoover Dam. There has always been a considerable variation from month to month in the specific conductance of the water at the Boulder Canyon sampling point. On May 24, 1939, the range in specific conductance was from 1,040 to 1,110 micromhos in the top 440 feet; but on June 23, 1939, the range was from 770 to 1,100 in micromhos in the same depth range. In January 1940 the range was from 1.030 to 1,110 micromhos for the entire depth. Observations made in Boulder Canyon during a trip in August 1950 showed that the range in conductance was from 635 to 1,074 micromhos in the top 415 feet of water. It appears that the concentration of dissolved solids at Boulder Canyon is always higher than at the sampling point in Virgin Canyon, but some of the values for Boulder Canyon are lower than has been found at the intake towers. Water in Boulder Canyon has a lower calcium and bicarbonate 
concentration than is found in the inflow, representing the effect of precipitation of calcium carbonate during storage.

The most complete records of temperature and dissolved solids are those collected in Black Canyon at the intake towers of Hoover Dam (mile 354.6). Although these records apply to only a small section of the lake, they are of considerable significance in indicating the changes that take place throughout the lake from season to season. All water released from the reservoir since May 1, 1936, has entered the intake towers at elevations 900 and 1,050 feet, ${ }^{6}$ except during 1941 , when about $3,122,000$ acre-feet flowed over the spillways in the period August 8 to December 1. As a rule samples have been collected and observations made at the intake towers once each month since May 1937, except during the war year's. These records show the stratification of water of different salinities and temperatures and the effects of mixing at certain times during the year.

\section{VARIATIONS WITH DEPTH}

Throughout the year, except during a short period in late winter or early spring, there is definite stratification of the water of Lake Mead, as shown by the existence of two or more layers of water of different salinity. The main body of water in the lake has a conductance of about 1,000 micromhos. Above this body of water there are commonly layers or strata of varying thickness, composed of waters of lower salinity which probably result from incomplete mixing of the main body with inflowing water. The quality of water at different depths in Virgin Basin and in Boulder Basin is shown by analyses 9 to 15 in table 11 .

At the bottom of the lake the specific conductance and alkalinity of the water are higher than in the main body of water. This more mineralized water, represented by analyses 8 and 15 in table 11, commonly has a higher temperature than the water in the main body of the lake. It is always associated with the sediment deposits, and usually samples of this water include large quantities of sediment. The increase in content of dissolved solids is mostly in calcium and bicarbonate; it is likely that these constituents have been dissolved from the sediment, inasmuch as organic matter in the sediment could furnish carbon dioxide that would assist in the solution of carbonates. It has been observed that dissolved solids and alkalinity, as well as temperature, increase with depth of penetration into the sediment; waters associated with sediment commonly have alkalinity greater than 300 ppm (expressed as $\mathrm{HCO}_{3}$ ). It has also been found that prolonged contact of water with the sediments produces

\footnotetext{
${ }^{6}$ Measured at the centers of the 10 -foot gates; the sills of the gates are 5 feet lower.
}

further increase in alkalinity and dissolved solids. Analyses of samples collected at the intake towers and stored in the laboratory showed an increase of $50 \mathrm{ppm}$ of alkalinity in the 2-month period July 25-September 25, 1949 , and a total increase of $178 \mathrm{ppm}$ during a 12-month period.

These changes in dissolved solids content of samples were noted in the early studies of the lake waters, and for that reason water samples that were collected at the bottom of the reservoir and had a muddy appearance were allowed to settle, and the clear water was decanted from the container as soon as possible after collection. Such samples were designated "decantates"; analyses of those samples represent the water in contact with the sediment at the time the sample was collected, or at the time of decantation, which was shortly after the collection. It is believed that the volume of this more mineralized water near the bottom is small, but it may have some effect on the average salinity of the lake water through mixing. Such mixing may be accelerated by the movement of density currents, which is generally along the bottom or very near the bottom of the lake.

\section{RELATION TO TEMPERATURE OF THE LAKE WATER}

The temperatures of water recorded at the surface in the main body of the lake have ranged from $53^{\circ} \mathrm{F}$ to $90^{\circ} \mathrm{F}$. These surface temperatures are affected by wave action, wind currents, and evaporation, but the trends follow pretty well, of course, the changes in atmospheric temperature. Seasonal temperature patterns at 10 -foot depth throughout the lake are shown in figures 33,35 , 38 , and 40. Large diurnal and seasonal fluctuations occur only in the surficial zone of the reservoir.

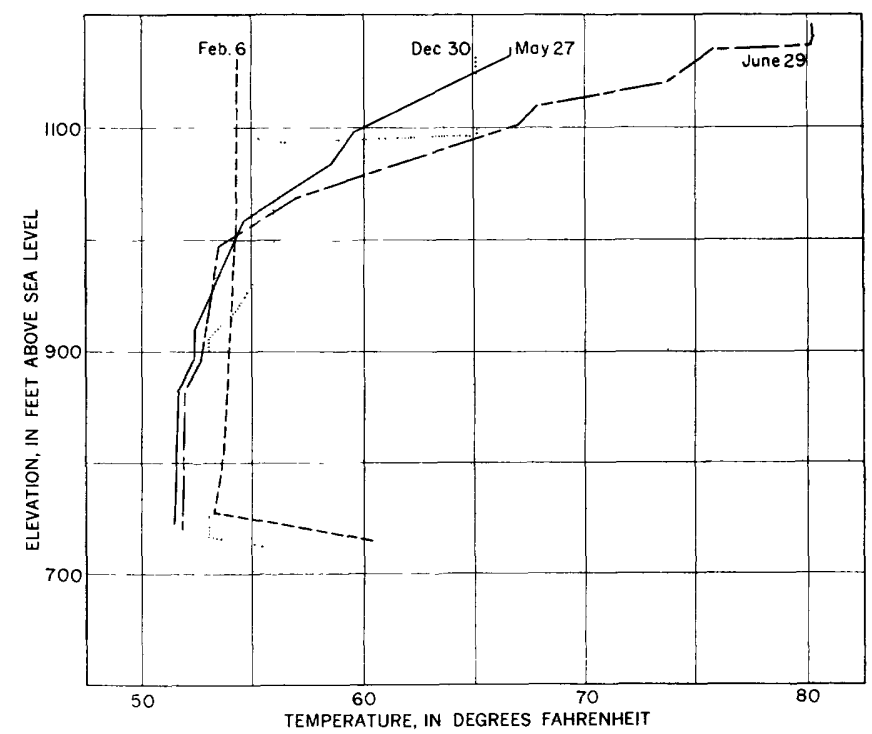

Figure 25.-Water temperature at the intake towers of Hoover Dam during four periods in 1948 . 


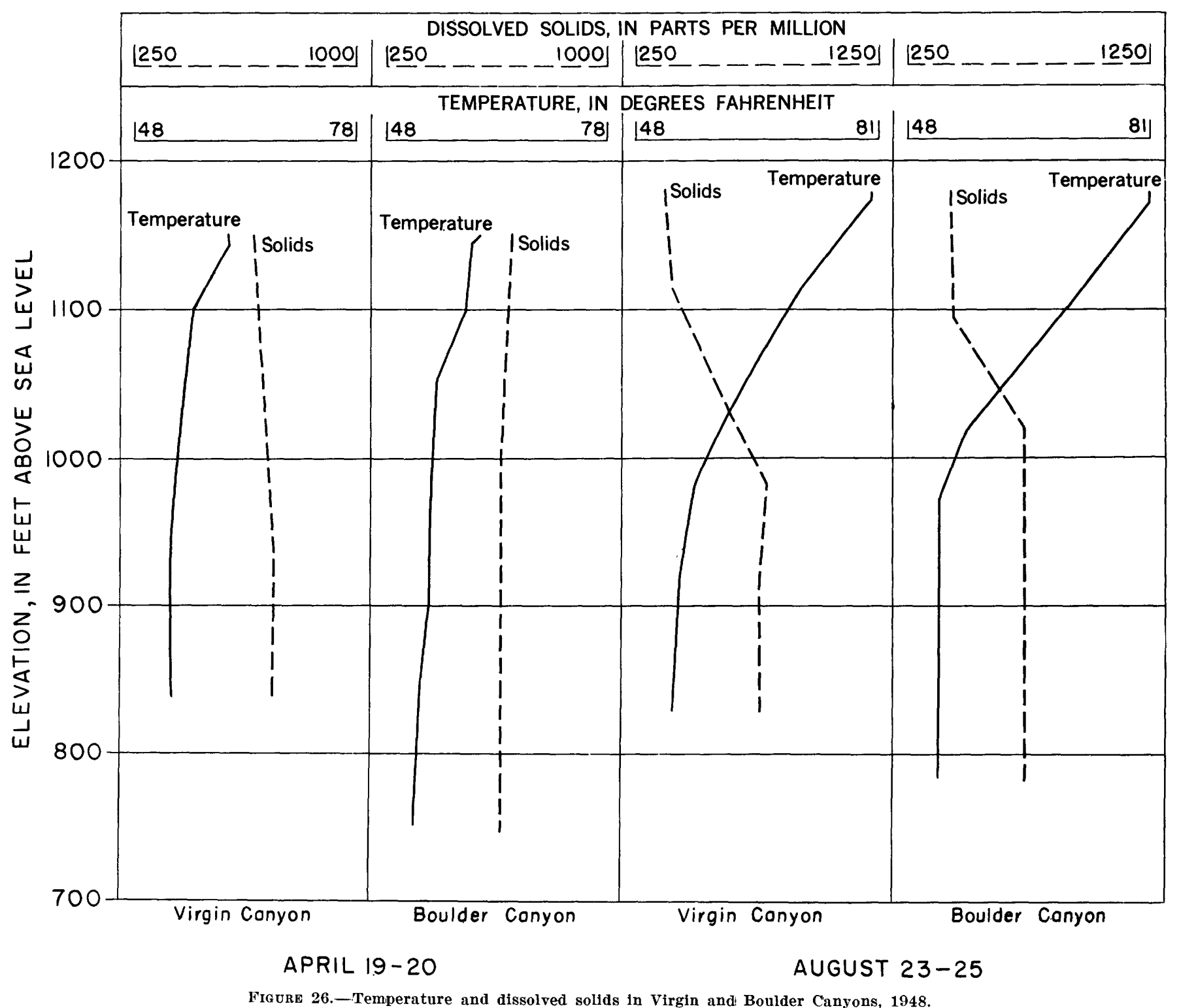

Water in the main part of the lake and at most depths has a fairly uniform temperature of about $52^{\circ} \mathrm{F}$. At the intake towers the range in temperature at depths greater than 150 feet (except at the bottom) is less than $4^{\circ} \mathrm{F}$. Seasonal variations in temperature throughout the range of depths at the intake towers are shown in figure 25. The warmer water at the bottom of the reservoir appears to be related to the biochemical activity in the accumulated sediment, which is described by F. D. Sisler (p. 187-193). The higher concentration of dissolved solids in this zone has been mentioned above.

The temperature of the water throughout the lake approaches uniformity in the winter, when the waters are more thoroughly mixed than at other times during the year. It has been pointed out that the content of dissolved solids is also most nearly uniform throughout the lake at this time in both depth and geographic distribution.

Throughout the year the greatest uniformity in temperature is recorded in the deeper waters of the reservoir, particularly in Boulder Basin, as indicated by figure 25 . The deeper waters also remain fairly uniform in content of dissolved solids, as shown by measurements of specific conductance. Figure 26 shows examples of the records of temperature and dissolved solids at various depths. In April 1948 the temperature and concentration of dissolved solids were fairly uniform at all depths, in both Boulder and Virgin Canyons. In August there was considerable variation in temperature and dissolved solids in the upper 150 feet of the reservoir, but below that depth both 
characteristics were uniform and only slightly different from those observed in April.

\section{EFFECT OF RESERVOIR STORAGE UPON WATER QUALITY}

The content of dissolved solids in the water released from Lake Mead would be equivalent to the weighted average of dissolved solids in the inflow from all sources, provided there were thorough mixing of all inflowing waters within the lake before release, and provided there were no changes during storage. Inasmuch as the reservoir is large enough to hold more than 2 years' a verage inflow, the content of dissolved solids would ordinarily represent the weighted averages of inflow for a period at least so long.

There is abundant evidence, however, that the mixing of waters is never quite complete, although in late winter the characteristics of the water are fairly uniform throughout the lake. Outstanding examples of nonmixing have been mentioned in the discussion of density currents, which may move inflowing water to the dam essentially without mixing with the lake water; the density currents are relatively rare phenomena, however. The variations in content of dissolved solids just described-areally, in depth, and in time of yearare also indications of the incompleteness of the mixing process in the reservoir.

Analyses of water released from the reservoir show a variation generally less than $100 \mathrm{ppm}$ in dissolved solids in the course of a single year. The variation is very small, in contrast to variations shown by analyses of the inflowing water, which commonly are greater than $1,000 \mathrm{ppm}$ in a single year. It is thus evident that there is a great amount of mixing of waters in Lake Mead. Anderson and Pritchard (p. 129) cite evidence for their further conclusion that most of this mixing is accomplished within and above the Virgin Basin of the Lake.

There is also eridence of changes within the lake that would result in changes in content of dissolved solids in the stored water. The white precipitates along the shores below the high-water line of the reservoir are conspicuous to visitors, although they represent a very small volume of material. Many may also have noted the disappcarance of rock materials in the bed or banks of the reservoir in some places; some of these were soluble gypsum or rock salt of the Muddy Creek formation. Evidences of removal by solution are discussed by H. R. Gould (p. 212). Finally, significant quantities of water have been lost from the reservoir by evaporation, with a resultant increase in concentration of dissolved solids in the water remaining in the reservoir. The effects of these chemical phenomena within the reservoir are shown by comparison of the analyses of the inflowing and the outflowing water (see analyses 4 and 16, table 11).

\section{COMPARISON OF CHEMICAL CONSTITUENTS IN THE INFLOWING AND OUTFLOWING WATER}

Analyses of the Colorado River water at the Grand Canyon gaging station represent pretty well the chemical character of the water flowing into Lake Mead. The inflow from tributaries and side washes is probably somewhat more mineralized than the water of the main stream; but the volume of water in the tributary inflow is small as compared to the flow at Grand Canyon, hence the quality of their water has little effect on the quality of the lake water. However, the total quantity of dissolved material brought into Lake Mead is somewhat greater than the quantity calculated from the records of the Grand Canyon station, because of the unmeasured amounts in this tributary inflow. The dissolved solids carried past the Grand Canyon station, based on annual weighted-average analyses, has ranged from $6,100,000$ tons in the water year 1934 (a year of serious drought) to $12,900,000$ tons in 1941. A total of $140,000,000$ tons was carried by the river in the 14 water years 1935-48. It is estimated that the dissolved solids in the unmeasured inflow to Lake Mead in this period was of the order of $8,000,000$ tons.

Analyses of the water flowing out of the reservoir are based on samples collected at the Topock gaging station, 115 miles downstream from Hoover Dam, in the water year 1934 (before the dam was completed); at the Willow Beach gaging station, 10 miles below the dam, from 1935 to 1939 inclusive; and at the gaging station immediately below the dam since 1939. In the water year 1934 the dissolved solids in the river below Hoover Dam amounted to 6,500,000 tons, slightly greater than the amount measured at Grand Canyon. In the 14 water years $1935-48$ the dissolved solids in the outflowing water totalled $136,000,000$ tons.

A comparison of the concentration and chemical character of dissolved solids in the inflowing and outflowing water shows the effects of changes within the reservoir. When storage was first started in 1935, water released from the reservoir had approximately the same concentration of dissolved solids as the water of the inflow, and the water released on those days showed variations in concentration of dissolved solids similar to the variations at Grand Canyon. This is illustrated by the graphs in figure 27. As soon as there was an appreciable volume of water in the reservoir (July 1935) the maximum concentration of dissolved solids in the outflow dropped below the maximum of the inflow. Since October 1, 1936 (5 months after the 

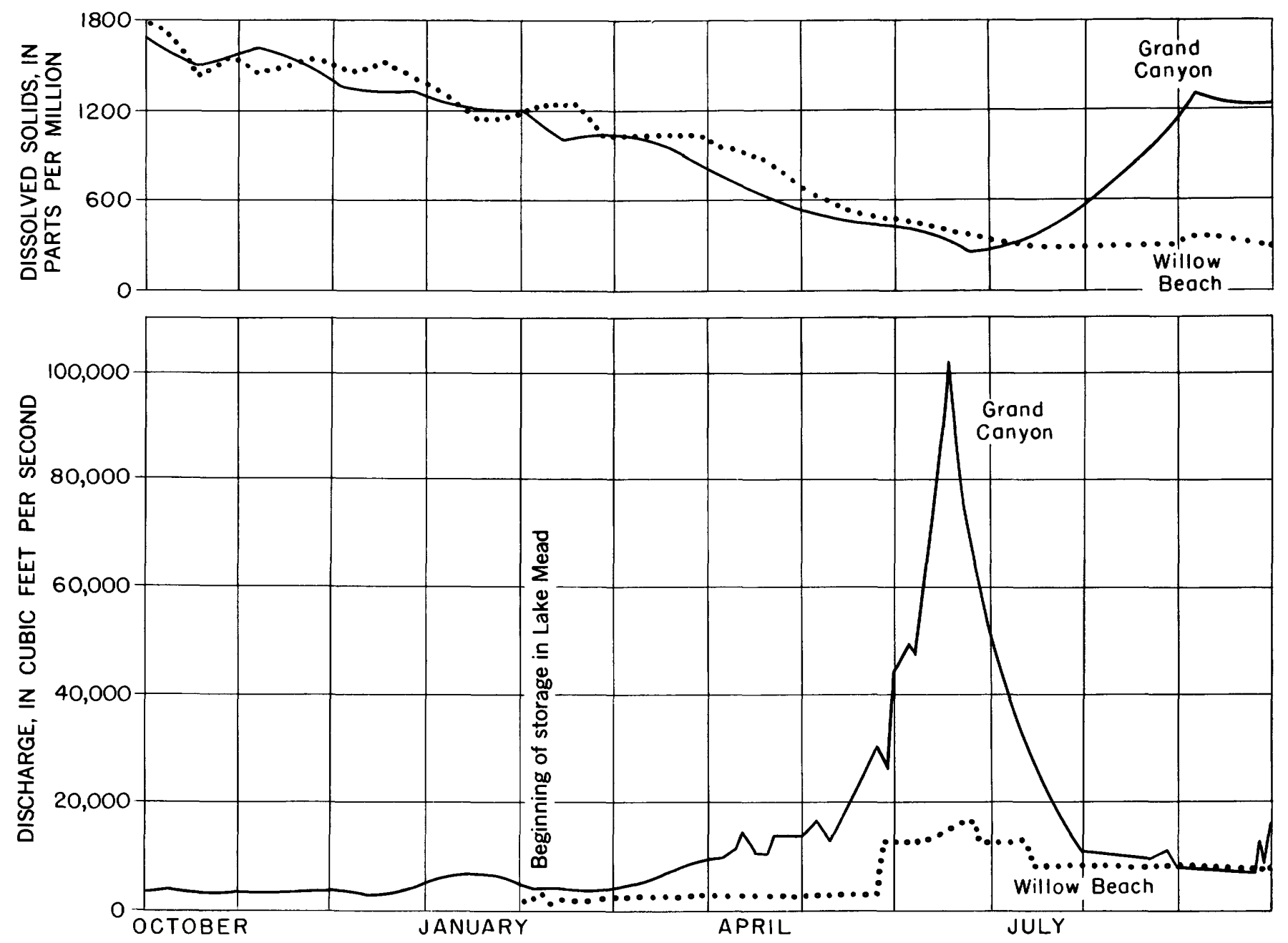

Figure 27.-Dissolyed solids and discharge at the Grand Canyon and Willow Beach gaging stations on the Colorado River during the year ended September 30,1935 .

tunnel gates were closed), the dissolved solids in the outflow have been less than $825 \mathrm{ppm}$, whereas the concentration of dissolved solids in the inflow has for short periods exceeded $1,700 \mathrm{ppm}$. The water released from Lake Mead in 1948 is represented by analysis 16 in table 11. It will be noted that this water is somewhat higher in dissolved solids than the average for the Grand Canyon station, represented by analysis 4 in the same table. Owing to the filling of the reservoir, however, the total outflow of dissolved solids was less than the total inflow.

The weighted-average concentration of dissolved solids in the outflowing water has been greater than that in the water at Grand Canyon in every year of the period 1937-49, except in 1946. Comparison of the published weighted-a verage analyses of the inflowing and outflowing waters (U.S. Geol. Survey, 1943 and later) provides some additional information as to the chemical changes occurring within the lake. There is little change in content of potassium, magnesium, or nitrate, although the outflowing water generally has a slightly higher concentration of each of these constituents. The content of bicarbonate is generally significantly less and the silica content is commonly 10 to 25 percent less in the outflowing water. On the other hand, the sulfate concentration in the outflowing water in several years has been more than 50 percent greater than in the inflowing water; this increase began in 1937 and continued through 1949. The calcium content in the outflowing water in some years has been 20 to 35 percent greater than that in the inflowing water. The sodium content in the outflowing water has also been as much as 25 percent greater in several year's.

These changes within the reservoir are correlative with the solution and precipitation of mineral matter by the lake waters and with the overall concentration resulting from evaporation. 


\section{CONCENTRATION BY EVAPORATION}

The evaporation losses from Lake Mead are about 5 percent of the average inflow to the lake, or about 700,000 to 900,000 acre-feet a year (p. 98 and table 17). The soluble salts from the evaporated water are left in the lake, for the most part in solution, thereby increasing the concentration of dissolved solids in the lake water. With such a high annual evaporation loss we can expect the lake to show a concentration of mineral matter appreciably higher than the average of the inflowing water. Any increase in concentration due to evaporation is offset to some extent by decreases due to precipitation of dissolved constituents.

Concentration by evaporation may account for the slight increases in concentration of such constituents as magnesium, potassium, and nitrate noted in the outflowing water.

\section{PRECIPITATION OF DISSOLVED CONSTITUENTS}

It is difficult to compute the magnitude of the changes caused solely by evaporation of the lake water, but it appears, from a study of the records of inflow, outflow, and quality of the lake water, that during the years of storage more than 1,000,000 tons of silica and more than $9,000,000$ tons of calcium carbonate have been precipitated in the lake. Analyses of the white leposit above the waterline and around the lake edge have shown that most of it is calcium, presumably carbonate, and that silica composes about 20 percent of the material. The cause for precipitation of silica is not known, but it seems likely that the calcium carbonate was precipitated by loss of carbon dioxide.

An attempt was made to observe the precipitation of calcium carbonate and silica through the collection of samples at various depths in the upper levels of the lake. The analytical results for the samples do not give much evidence of the precipitation process, possibly because the sampling was done too late in the season to detect the difference due to evaporation losses. Observers have noticed, however, that during the summer months the water near the surface has an opalescence that could be interpreted as an indication of the presence of finely divided precipitated material.

It is extremely unlikely that the white deposits above the waterline represent all the material precipitated from solution during storage. Much of the precipitated material has probably settled and is deposited on the bottom of the lake along with the suspended material.

Further evidence of the precipitation of calcium carbonate in the reservoir is found in the data in table 14 , showing the concentration of dissolved solids at the surface at different points in the lake, and in the analyses in table 11 . The dissolved-solids concentration shown by analysis 6 represents water with less dissolved solids than was present in the river at Grand Canyon at any time during the preceding 12 months. The calcium and bicarbonate in the surface samples (analyses 6, 9, 11, and 12) are generally less than are found in the river water at Grand Canyon (analyses 1-4). The marked decreases in silica and bicarbonate shown in the weighted-average analyses of the outflowing water constitute additional evidence of precipitation from the lake water.

\section{SOLUTION OF RESER VOIR BFD AND BANK MATERIALS}

The presence of large quantities of soluble rock material that cropped out within the reservoir area, particularly in Overton Arm, was recognized during the planning stages for Hoover Dam. This material consisted largely of gypsum (calcium sulfate) and some halite (sodium chloride) within the Muddy Creek formation. At one time it was suggested that the solution of these salts would increase to a serious extent the concentration of dissolved solids in the stored water. In the early studies a few samples of water were collected close to the bottom of the lake, particularly in the vicinity of the submerged Calico salt mines in Overton Arm of the lake. These samples showed a local concentration of dissolved solids somewhat higher than was found in water at lesser depths in that area, but they failed to show for any large masses of water a marked increase in concentration which could be attributed to dissolving of the rock material.

The water released from Lake Mead in almost every year has shown a higher concentration of dissolved solids than the average for the inflow. Assuming that the 24,600,000 acre-feet of water in Lake Mead at the end of water year 1948 carried 0.91 ton of dissolved solids per acre-foot, the total solids in the lake would be about 22,300,000 tons. About 12,000,000 tons of this is accounted for by the greater inflow than outflow (p. 121), during the filling of the lake. The remaining $10,000,000$ tons or so represents the net change, in dissolved solids in the lake itself-that is, the increases resulting from solution less the decreases due to precipitation of $10,000,000$ tons of calcium carbonate and silica from the stored water. The total increase, of the order of 20,000,000 tons, has been largely in calcium and sulfate, and considering the large quantities of gypsum along the lake bottom and shores, the increases are not surprising. The increased concentration of sulfate in the outflowing water, shown in the published weighted-average analyses, and the slight increases in calcium even though some calcium is known to be precipitated from the lake water, are 
doubtless partly the result of this solution. Similarly, the increased concentrations of sodium and chloride in the outflowing water are attributed partly to dissolving of halite.

STABILIZATION OF WATER QUALITY BY RESERVOIR STORAGE

Although there has been an increase in dissolved solids through the evaporation and solution processes described in the previous sections, there has also been a stabilization of the chemical quality during the period of storage, which has been of considerable value to the users of water below Hoover Dam. As a result of the stabilization, a lower tonnage of soluble salts has been delivered to the irrigated lands below Hoover Dam than would have been delivered if there had been no storage. This is because the concentration of soluble salts in the unregulated river water, as indicated by the Grand Canyon records, is higher than the concentration in the released water during the periods when most of the water is taken from the river for irrigation. Thus the "alkali" problem of the lands irrigated by the Colorado River below Lake Mead has been decreased to an appreciable extent.

\section{REFERENCES CITED}

Grover, x. C., and Howard, C. S., 1938. The passage of turbid water through Lake Mead: Am. Soc. Civil Fngineers Trans., v. 103 , p. $720-790$.

National Research Council, Interdivisional Committee on Density Currents, Subcoumittee on Lake Mead, 1949, Lake Mead density currents investigations $1937-10$, v. 1, 2; 1941-46, v. 3: Washington, U.S. Bur. Reclamation, 3 v., 9041 .

U.S. Geological Survey, 1943 et. seq., Quality of surface waters of the U.S., Water-Supply Papers as follows:

\begin{tabular}{|c|c|c|c|}
\hline $\begin{array}{l}\text { Water } \\
\text { year }\end{array}$ & $\begin{array}{l}\text { Water-Supply } \\
\text { Paper }\end{array}$ & $\begin{array}{c}\text { Year } \\
\text { published }\end{array}$ & Pages \\
\hline 1941 & 942 & 1943 & $56-68$ \\
\hline 1942 & 950 & 1944 & $39-64$ \\
\hline 1943 & 970 & 1945 & $80-125,159-167$ \\
\hline 1944 & 1022 & 1947 & $176-245$ \\
\hline 1945 & 1030 & 1949 & $265-323$ \\
\hline 1946 & 1050 & 1950 & $419-477$ \\
\hline 1947 & 1102 & 1952 & $569-637$ \\
\hline 1948 & 1133 & 1952 & $286-361$ \\
\hline
\end{tabular}




\section{GIRGULATION AND EVAPORATION}

By E. R. Anderson, U.S. Navy Electronics Laboratory, and D. W. Pritchard, Chesapeake Bay Institute, Johns Hopkins University

Late in 1947, representatives of the Geological Survey asked the Navy Electronics Laboratory (NEL) for assistance in both equipment and personnel, on the Lake Mead Sedimentation Survey, which was then being planned. The Laboratory's contribution, in addition to furnishing equipment and consulting services, was (1) to determine the general circulation of the lake from the distribution of temperature and salinity (dissolved solids), and (2) to establish a preliminary energy budget from which an estimate of evaporation could be made.

This section of the report presents a summary of the circulation and evaporation studies, together with the major conclusions. A brief discussion of the methods and techniques employed is included, but a detailed description of the methods and techniques, complete analysis of the data with respect to circulation and evaporation, and a summary of the basic data taken on the various limnological cruises are omitted; they are published in a technical report of the Navy Electronics Laboratory (Anderson and Pritchard, 1951).

\section{CIRCULATION}

\section{TECHNIQUES FOR DETERMINING CIRCULATION}

Suitable instrumentation and techniques are not available for determining the general circulation of a body of water, such as Lake Mead, by means of direct measurements of currents. However, oceanographers for many years have utilized the distribution of various properties and their variations, for determining the movement of water in the subsurface layers of the oceans, and especially for tracing masses of sea water moving from one region to another. The waters of all the oceans acquire their original characteristics when the water is in contact with the air or subject to heating and cooling at the surface. With the passage of time the original characteristics become changed by vertical and lateral mixing. The "conservativeness," 7 with respect to time and place, of the original tem-

\footnotetext{
TAs used in this report, the term "conservative" describes a property which changes relatively little from day to day.
}

perature and salinity distribution varies, depending upon the subsequent history of the mass of water.

It was considered that some of the oceanographic techniques would be useful for determining the general circulation of a lake such as Lake Mead. In this section the following techniques, which have been employed by oceanographers, will be briefly examined regarding their utility in such an application: (a) tonguelike distributions, (b) Wüst's "core method," and (c) temperature and salinity $(T-S)$ relations.

\section{TONGUELIKE DISTRIBUTIONS}

Without going into the dynamics of the development of ocean currents (Sverdrup and others, 1946), it may be stated that, in the northern hemisphere, the water of highest density is found on the left-hand side of a current. Thus, it is possible to interpret a tonguelike distribution in a horizontal plane as representing water movement. Considering a tongue of low temperature, and assuming that salinity is constant or its effect on density negligible, the currents will be directed along the temperature contours, not along the axis of the tongue as might be assumed if the dynamics of the system were ignored. Some modification may occur at the sea surface, where external factors may contribute toward maintaining the observed temperature distribution.

A tonguelike distribution of either temperature or salinity in a vertical section may also indicate flow. If an initial horizontal flow be assumed, then processes of vertical and horizontal mixing are important in developing the vertical tonguelike distribution. Hence the distribution is indicative of both horizontal and vertical motion.

Defant (1929) and Thorade (1931) examined analytically the relation between velocity and vertical mixing and, making certain simplifying assumptions, showed how horizontal flow and vertical mixing can produce and maintain this tonguelike distribution in a vertical plane. The tongue may curve up or down, although horizontal flow is assumed, and therefore the axis of the tongue need not coincide with 
the axis of maximum velocity. In addition, a tonguelike distribution in a vertical section may be developed by processes of horizontal and vertical mixing alone. However, in the case of relatively narrow restricted bodies of water, such as certain parts of Lake Mead, the effect of horizontal mixing would be minimized. As a result, the observed tonguelike distributions at Lake Mead are largely the result of horizontal flow and vertical mixing.

\section{WÜST'S CORE METHOD}

Wüst (1935) introduced the "Kernschicht-methode" or "core method" for studying the spreading out and mixing of water masses, a method that has been used successfully in studying the flow of deep water in the Atlantic Ocean. It does not involve any assumptions as to the character of the mixing and is especially useful in giving a qualitative picture of the spreading out of a well-defined water mass from a source region. The "core," as defined by Wüst, is that part of a layer of water within which temperature or salinity, or both, reach maximum or minimum values. For example, the water that flows out of the Mediterranean Sea has a high salinity, and the salinity maximum that is the "core" of the layer can be traced for great distances in the Atlantic Ocean. The decrease in the value of this maximum is caused by mixing processes, but the salinity is conservative for long periods of time and over great distances.

\section{TLS RELATIONS}

Helland-Hansen (1916) introduced the use of a temperature-salinity $(T-S)$ diagram in identifying oceanic water masses and demonstrated that, for any given water mass, a plotting of temperature versus salinity resulted in a characteristic curve.

Consideration of these techniques leads to the following conclusions: In the subsurface layers of a body of water, in the absence of internal chemical effects, the salinity distribution is conservative, being modified only by mixing processes. It is possible, by observing changes in the vertical distributions, to gain knowledge of the effective circulation in a vertical plane, but great cantion must be exercised regarding such details as the location of the axis of maximum velocity. The distribution of temperature can be looked upon in the same manner. However, in a lake, temperature is probably not conservative enough to be followed from one time to another because of diurnal and seasonal variations produced by the exchange of energy between the atmosphere and the lake.

In this study, the above three oceanographic techniques were utilized to establish the general features of the circulation in Lake Mead. The distribution of salinity proved sufficiently conservative to enable reasonably accurate conclusions to be drawn regarding the main features of the circulation in a vertical plane in Lake Mead.

\section{OBSERVATIONAL PROGRAM}

The objectives of this study prescribed the parameters to be measured. Bata concerning the distribution of temperature and salinity in the lake and in the river water, and of temperature, humidity, and wind velocity in the air just over the lake, were required. As an aid in following the circulation, especially in relation to sedimentation, Sechi-disc readings were made. Of particular importance with regard to the circulation in the upper portion of Lake Mead are the notes made by the survey parties as to the presence or absence of the "convergence" 8 above Pierce Ferry, the intensity of this convergence if present, and notations of any other related phenomena which lent themselves to description if not quantitative measurement.

As frequently happens in a study involving a series of observational surveys, the optimum procedure was not pursued in the first few surveys. For simplicity, the observational program that was finally evolved will be discussed first, and the departures from it in any particular cruise will be mentioned where necessary.

Plate 18 shows the station locations of the observational program as finally established. At the head of the lake, the location of station 66 on any particular cruise depended upon the location of the convergence. During periods of strong convergence several stations were taken, in and very near the convergence area; they have been designated as stations $66 \mathrm{a}$ to $66 \mathrm{~m}$. Stations 67 and 68 in Lower Granite Gorge were occupied only when the stage of the lake allowed reasonably safe navigation upriver. The inset maps on plate 18 indicated the location of the stations taken near the convergence on cruises I and II.

Twelve cruises were completed during the year the program was under way, as follows:

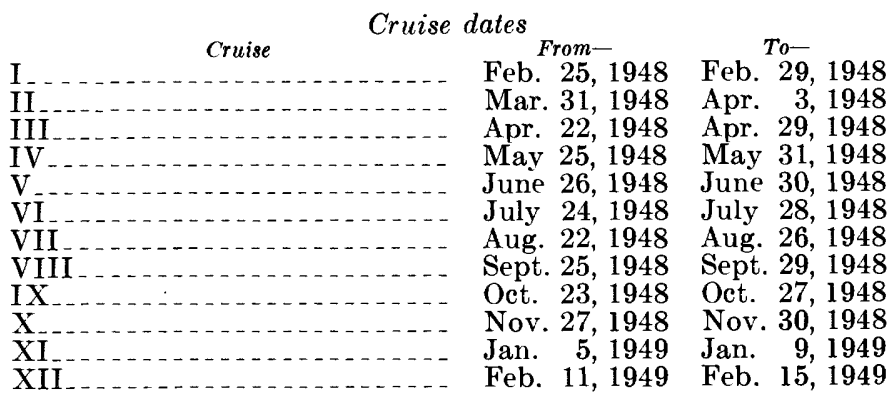

8 A convergence can be defined as the boundary between two converging currents; in this case, at certain sea sons, it is the boundary between Colorado River water and Lake Mead water (pl. 17). 
In the initial cruises, all stations shown in plate 18 were not occupied, and cross sections, particularly in Boulder Basin and Virgin Basin, only approximate the lines shown on the station-location chart. The stations along the old Colorado River channel, which proved in the analysis of the data to be most important, did not shift greatly from survey to survey.

The stations occupied on each cruise and the data collected at each are appended to the NEL technical report (Anderson and Pritchard, 1951). At all stations temperature measurements were taken with a bathythermograph, except that on some cruises the uppermost station at the head of the lake was reached by foot and only surface temperature and a surface-water sample could be obtained. At about half the stations on each cruise, samples of lake water were obtained at selected depths for analysis as described below; they are called "Nansen stations" because Nansen bottles were used to collect the samples. ${ }^{9}$ At each Nansen station from 1 to 11 samples were obtained, the number depending on depth, location, and season.

Bathythermograph ${ }^{10}$ observations provide a continuous record of temperature versus depth. At each station a bathythermograph was lowered to the bottom and thus a complete record of the temperature of the water column from surface to bottom was obtained for each station. Surface temperature was also taken with a surface-bucket thermometer, to provide a calibration check for the bathythermograph records. Wind speed and direction, present weather, cloud types and amount, air temperature, and wet-bulb temperature were also recorded as auxiliary data to the bathythermograph record.

For all surveys subsequent to cruise III (except on cruise $\mathbf{X}$, when the Secchi disc was lost during the survey), Secchi-disc ${ }^{11}$ readings were taken at each station to obtain a measure of the turbidity of the water; a few were taken on the third cruise.

Additional data were also used extensively. Records of the daily flow and temperature of the Colorado River and the Virgin River were provided by the Ge-

\footnotetext{
- Nansen bottles are metal bottles constructed so that a series of them may be attached to a hydrographic wire. When the bottles have been lowered to the desired depths, a small weight is dropped down the wire to trip a release catch on the upper part of the upper bottle, causing it to fall over, or reverse. A second weight, or "messenger," is released from this bottle in the reversing process, and falls down the wire to trip the next bottle. In reversing, valves at each end of the bottle close. thus trapping a sample of water. By this procedure, subsurface water samples can be obtained from several depths in one lowering.

${ }^{10} \mathrm{~A}$ bathythermograph consists of a stylus, attached to a Bourdon tube, which records the temperature on a smoked glass slide to witlin $0.1^{\circ} \mathrm{F}$. The slide is held in a frame attached to a pressure bellows, and hence the frame and slide move relative to the arc of the stylus as the depth changes.

11 A Secchi dise is a white-painted horizontal metal plate, $30 \mathrm{~cm}$ in diameter, which is lowered into the water; the depth at which it disappears from view is a measure of the turbidity of the surface layers.
}

ological Survey. Weather data covering the year studied were secured from the joint Weather BureauBureau of Reclamation station at Boulder City, Nev. The Bureau of Reclamation also provided records of the daily volume and temperature of outflow from the lake through Hoover Dam, and of evaporation from the several evaporation pans located on the lake. The Geological Survey supplied the information on volume and capacity used in the energy-budget study.

\section{ANALYSIS}

The primary parameters used were temperature and salinity. Temperatures obtained with the bathythermograph were used in the analysis. Although the bathythermograph is a solidly built field instrument and can be expected to give good relative data, frequent checks of depth are necessary. Because the bathythermographs employed in this study were calibrated for average sea water, an initial scale correction for depth had to be made to compensate for the density difference between lake water and average sea water. This correction was taken as 2.5 feet per 100 feet of depth. The framework holding the glass slide occasionally becomes displaced slightly from the calibrated position. In order to check this possible source of error in the depth scale, comparisons were made of the bottom depth as read from the bathythermograph slide, corrected for the density difference between lake water and sea water and for the observed depth as recorded from the reading of the meter wheel. The average depth correction for each cruise was obtained from the difference between these two values.

Temperatures were read from the corrected bathythermogram for each station at the surface, at 10, 25, $50,75,100,150,200,250,300$, and 400 feet, and at the naximum depth. These results were plotted on horizontal charts, ${ }^{12}$ by station location, for the surface and for depths of 10, 25, 50,100,200, and 300 feet. The depths of integer isotherms were also obtained from the bathythermogram and plotted in vertical sections, both along the old Colorado River channel and the Virgin River channel, and across the major basins and arms of the lake. These horizontal charts and vertical sections were contoured and studied. Some of the charts and sections are presented in this report in support of the discussion.

Conductivity measurements were made on the water samples collected on each cruise, primarily by $\mathrm{H}$. R. Gould, using the conductivity bridge provided by the staff of the Bureau of Reclamation at Hoover Dam.

\footnotetext{
12 The terms "horizontal chart" and "vertical chart" are used in this report to designate plots of distributions in the respective planes.
} 

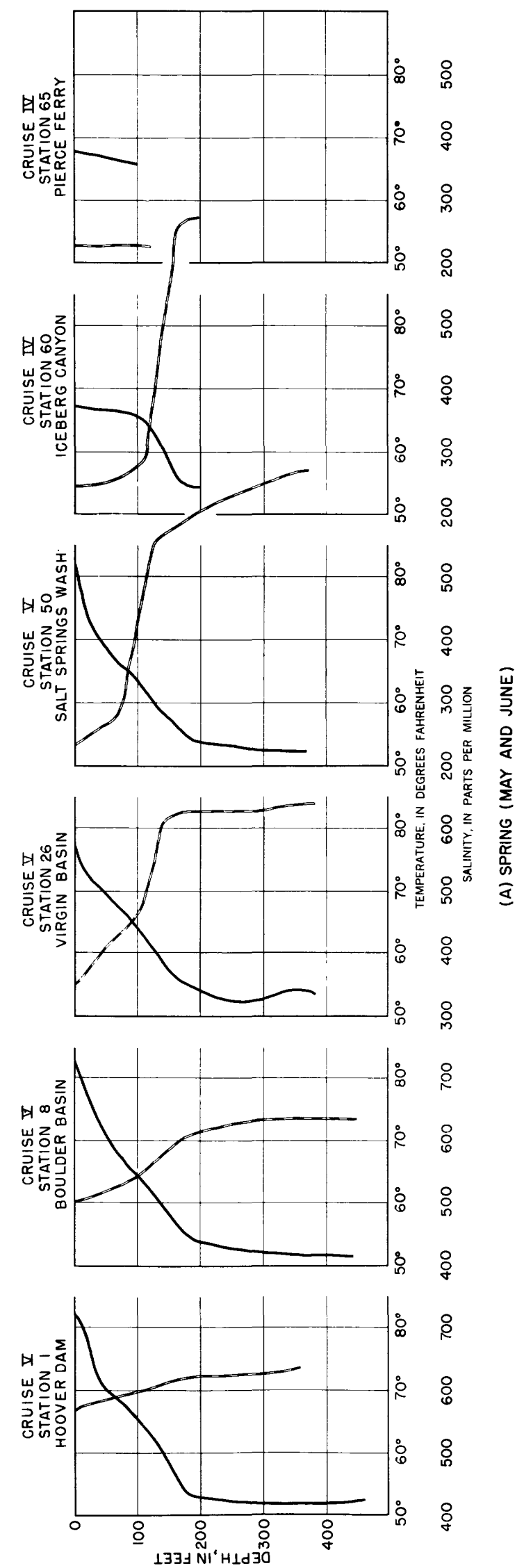
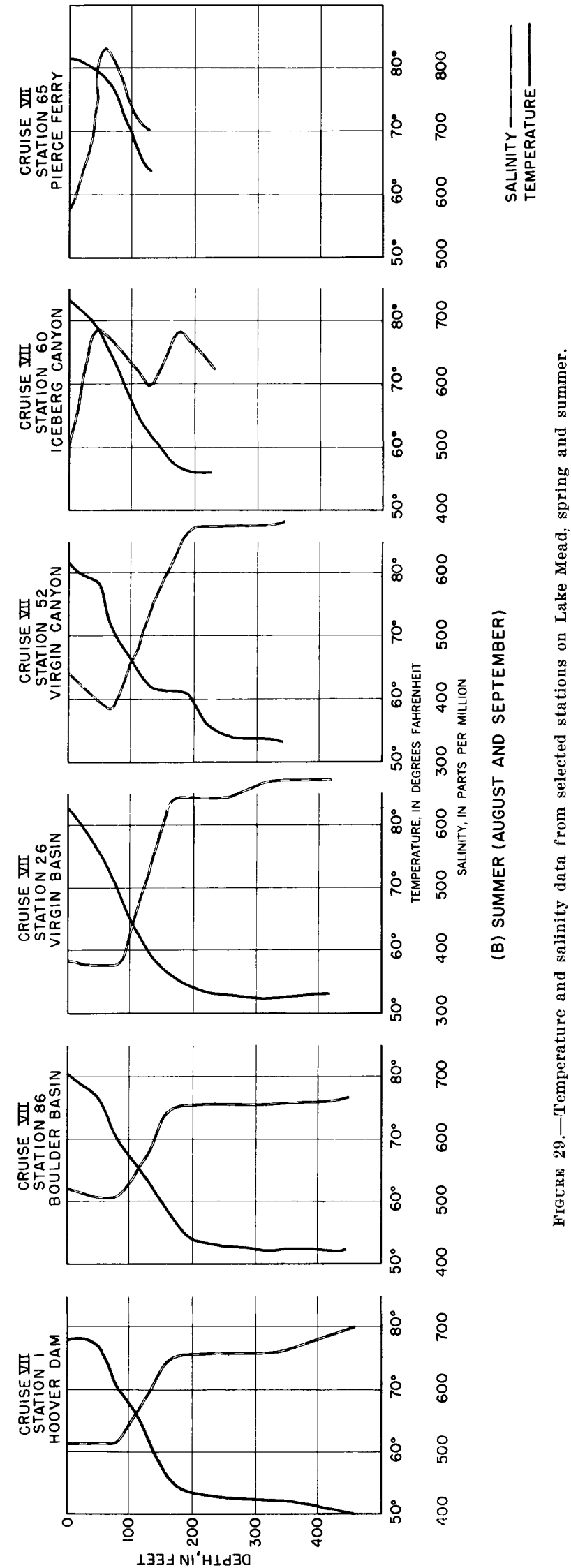
In the initial cruises, all stations shown in plate 18 were not occupied, and cross sections, particularly in Boulder Basin and Virgin Basin, only approximate the lines shown on the station-location chart. The stations along the old Colorado River channel, which proved in the analysis of the data to be most important, did not shift greatly from survey to survey.

The stations occupied on each cruise and the data collected at each are appended to the NEL technical report (Anderson and Pritchard, 1951). At all stations temperature measurements were taken with a bathythermograph, except that on some cruises the uppermost station at the head of the lake was reached by foot and only surface temperature and a surface-water sample could be obtained. At about half the stations on each cruise, samples of lake water were obtained at selected depths for analysis as described below; they are called "Nansen stations" because Nansen bottles were used to collect the samples. ${ }^{9}$ At each Nansen station from 1 to 11 samples were obtained, the number depending on depth, location, and season.

Bathythermograph ${ }^{10}$ observations provide a continuous record of temperature versus depth. At each station a bathythermograph was lowered to the bottom and thus a complete record of the temperature of the water column from surface to bottom was obtained for each station. Surface temperature was also taken with a surface-bucket thermometer, to provide a calibration check for the bathythermograph records. Wind speed and direction, present weather, cloud types and amount, air temperature, and wet-bulb temperature were also recorded as auxiliary data to the bathythermograph record.

For all surveys subsequent to cruise III (except on cruise $\mathbf{X}$, when the Secchi disc was lost during the survey), Secchi-disc ${ }^{11}$ readings were taken at each station to obtain a measure of the turbidity of the water; a few were taken on the third cruise.

Additional data were also used extensively. Records of the daily flow and temperature of the Colorado River and the Virgin River were provided by the Ge-

\footnotetext{
- Nansen bottles are metal bottles constructed so that a series of them may be attached to a hydrographic wire. When the bottles have been lowered to the desired depths, a small weight is dropped down the wire to trip a release catch on the upper part of the upper bottle, causing it to fall over, or reverse. A second weight, or "messenger," is released from this bottle in the reversing process, and falls down the wire to trip the next bottle. In reversing, valves at each end of the bottle close. thus trapping a sample of water. By this procedure, subsurface water samples can be obtained from several depths in one lowering.

${ }^{10} \mathrm{~A}$ bathythermograph consists of a stylus, attached to a Bourdon tube, which records the temperature on a smoked glass slide to within $0.1^{\circ} \mathrm{F}$. The slide is held in a frame attached to a pressure bellows, and hence the frame and slide move relative to the are of the stylus as the depth changes.

11 A Secehi dise is a white-painted horizontal metal plate, $30 \mathrm{~cm}$ in diameter, which is lowered into the water; the deptl at which it disappears from view is a measure of the turbidity of the surface layers.
}

ological Survey. Weather data covering the year studied were secured from the joint Weather BureauBureau of Reclamation station at Boulder City, Nev. The Bureau of Reclamation also provided records of the daily volume and temperature of outflow from the lake through Hoover Dam, and of evaporation from the several evaporation pans located on the lake. The Geological Survey supplied the information on volume and capacity used in the energy-budget study.

\section{ANALYSIS}

The primary parameters used were temperature and salinity. Temperatures obtained with the bathythermograph were used in the analysis. Although the bathythermograph is a solidly built field instrument and can be expected to give good relative data, frequent checks of depth are necessary. Because the bathythermographs employed in this study were calibrated for average sea water, an initial scale correction for depth had to be made to compensate for the density difference between lake water and average sea water. This correction was taken as 2.5 feet per 100 feet of depth. The framework holding the glass slide occasionally becomes displaced slightly from the calibrated position. In order to check this possible source of error in the depth scale, comparisons were made of the bottom depth as read from the bathythermograph slide, corrected for the density difference between lake water and sea water and for the observed depth as recorded from the reading of the meter wheel. The average depth correction for each cruise was obtained from the difference between these two values.

Temperatures were read from the corrected bathythermogram for each station at the surface, at 10, 25, $50,75,100,150,200,250,300$, and 400 feet, and at the rnaximum depth. These results were plotted on horizontal charts, ${ }^{12}$ by station location, for the surface and for depths of $10,25,50,100,200$, and 300 feet. The depths of integer isotherms were also obtained from the bathythermogram and plotted in vertical sections, both along the old Colorado River channel and the Virgin River channel, and across the major basins and arms of the lake. These horizontal charts and vertical sections were contoured and studied. Some of the charts and sections are presented in this report in support of the discussion.

Conductivity measurements were made on the water samples collected on each cruise, primarily by $\mathrm{H}$. R. Gould, using the conductivity bridge provided by the staff of the Bureau of Reclamation at Hoover Dam.

\footnotetext{
12 The terms "horizontal chart" and "vertical chart" are used in this report to designate plots of distributions in the respective planes.
} 
For each survey a number of water samples, representative of all locations and depths, were sent to C. S. Howard, Geological Survey, Salt Lake City, Utah, for complete chemical analysis. The average ratio of salinity (total dissolved solids in parts per million) to conductivity of the samples analyzed by Howard was used to compute the salinities of all the other samples. A study of these data indicates that the error in salinity as determined by this procedure was in most cases less than $10 \mathrm{ppm}$.

The salinity was plotted against depth, for each Nansen station. A smooth curve was drawn through the points and values read from the curve at the surface and at 25, 50,100, 200, 300, and 400 feet. The data were then used to prepare horizontal charts and vertical sections, just as for temperatures. From a study of the charts and sections it soon became evident that the longitudinal section made along the old Colorado River channel was the most important for the study of the seasonal cycle in the distribution of variables and in circulation. Most of the discussion deals with this longitudinal section.

Secchi-disc measurements were also plotted on a horizontal chart for each cruise, which was useful for determining the lateral spread of the inflowing water during the spring-flood runoff.

A $T-S$ diagram was constructed for each Nansen station. For each cruise, those $T-S$ diagrams that were very nearly the same were plotted on the same sheet, and the typical temperature-salinity relations for the various sections of the lake were determined. The typical relations have been plotted as "ribbons," showing the spread of observations used in constructing the typical $T-S$ diagram.

Analysis of the data collected during the whole year at Lake Mead indicated a distinct and orderly cyclic progression in distribution of properties and in the implied circulation, which can be related to the seasonal changes of weather and river inflow.

On the basis of this single year's data it appears that the conditions observed in the January, February, and March cruises are characteristic of the winter season; in the May and June cruises, of the spring season; in the August and September cruises, of the summer season; and in the November and December cruises, of the fall season. The months of April, July, and October appear to be transitional between winter and spring, spring and summer, and summer and fall, respectively.

Conditions for each season are discussed on the basis of representative charts of each season. In some cases, actual observed data for a particular month are used as representative of a particular season; in other cases, distributions representing a slightly smoothed mean seasonal condition are presented. The vertical section taken along the old Colorado River channel appears to be the most important section from the standpoint of evaluation of circulation. A slightly smoothed preentation of the distribution of salinity and circulation along this section is discussed.

\section{SPRING}

The progressive nature of the changes in salinity distribution and circulation is best presented by starting with spring conditions. The inflow from the Colorado River into the lake during 1948 increased from about 22,000 cfs on April 1 to an average of $48,000 \mathrm{cfs}$ during the period April 22-29, and to a peak of about 88,000 cfs in late May. Conditions characteristic of the spring season prevailed during May and June, though during June the inflow decreased slowly.

This high runoff results from spring melting, and the salinity of the inflowing water from the Colorado River is very low, having a value of approximately $220 \mathrm{ppm}$ during the May cruise. Although the sediment load carried by this high flow is large, the heavier particles apparently settle out quickly upon entering the lake. The temperature of the inflowing water is nearly the same as that of the surface lake water, but its density is lower because of its very low salinity. The inflowing water, therefore, spreads rapidly downlake along the surface, overriding the residual lake water of higher salinity and density. The distribution of salinity along the old Colorado River channel in spring is indicated by one of the diagrams of figure 28. The vertical gradient in salinity in the lake above Virgin Basin is large. In Iceberg Canyon the vertical variation in salinity is from less than $260 \mathrm{ppm}$ at the surface to more than $680 \mathrm{ppm}$ on the bottom. Above Iceberg Canyon there is a sharp vertical increase of $300 \mathrm{ppm}$ in the 50-foot layer between 80 feet and 130 feet.

The isohalines (lines of equal salinity) fan out vertically downlake. Between Virgin Canyon and Virgin Basin the vertical variation is from about $340 \mathrm{ppm}$ to slightly over $660 \mathrm{ppm}$, and the layer of sharp salinity gradient is here nearly 90 feet thick, with a change of $200 \mathrm{ppm}$.

In Virgin Basin the vertical gradient has decreased still further. The 400-, 500-, and 600-ppm isohalines, which are nearly horizontal in the lake above Virgin Basin, curve upward in Virgin Basin, resulting in the largest horizontal gradient in salinity that was found along this section. In the lower end of Virgin Basin the increase from $400 \mathrm{ppm}$ to $500 \mathrm{ppm}$ along the surface indicates the front of the downlake spread of the lower-salinity inflow from the Colorado River. 

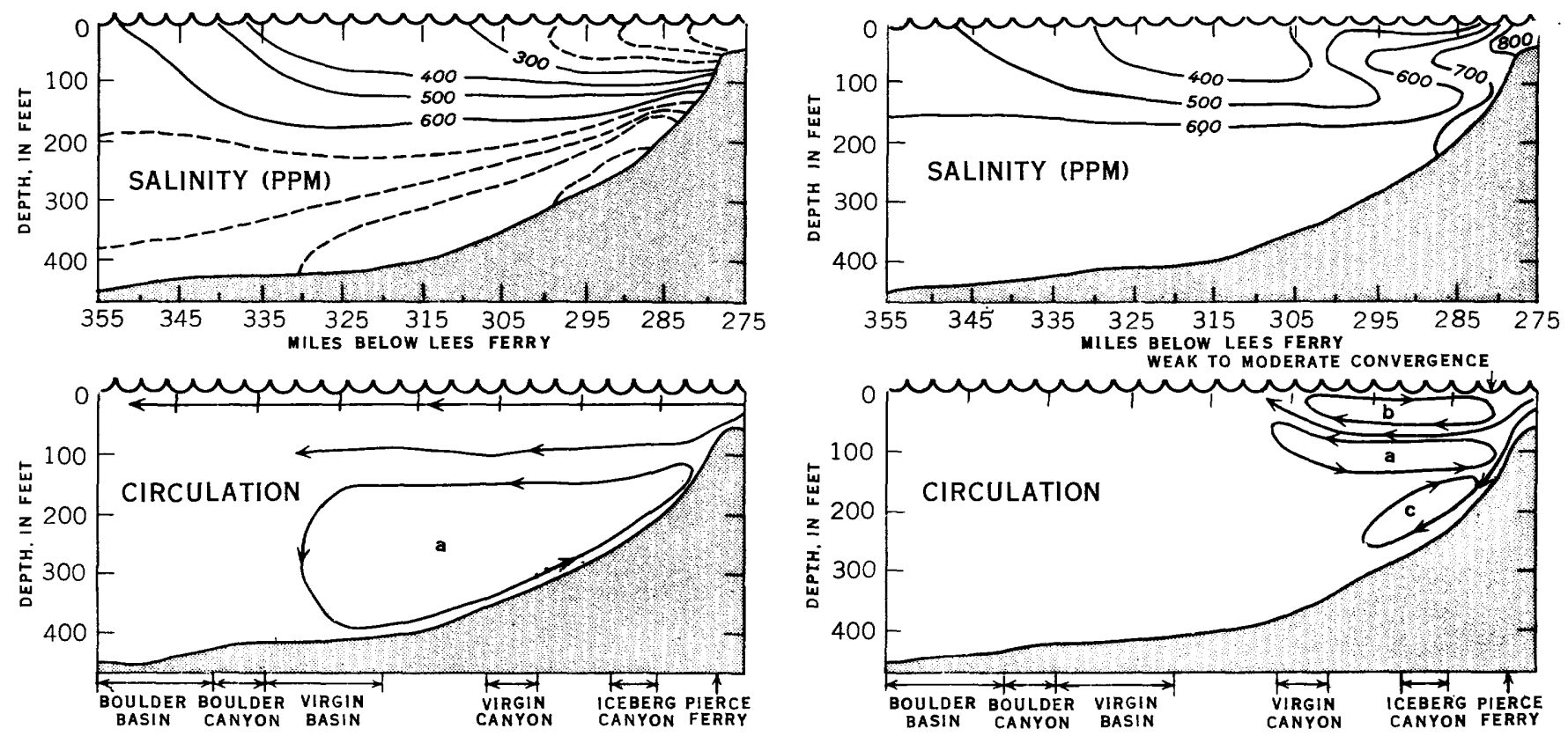

SPRING

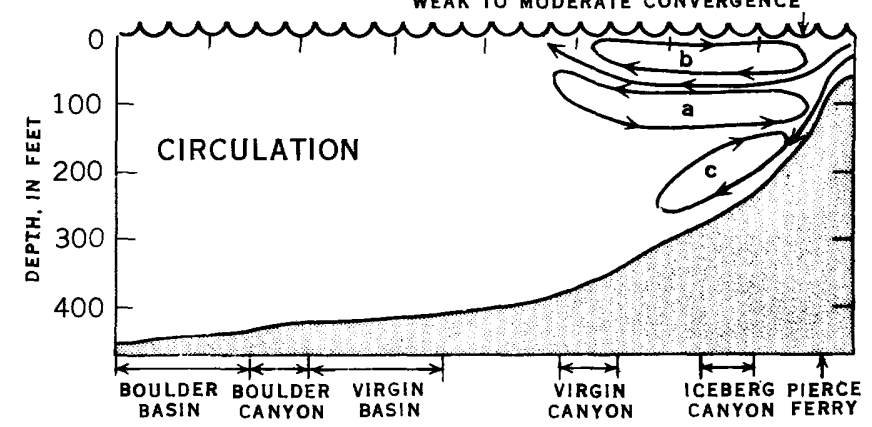

SUMMER
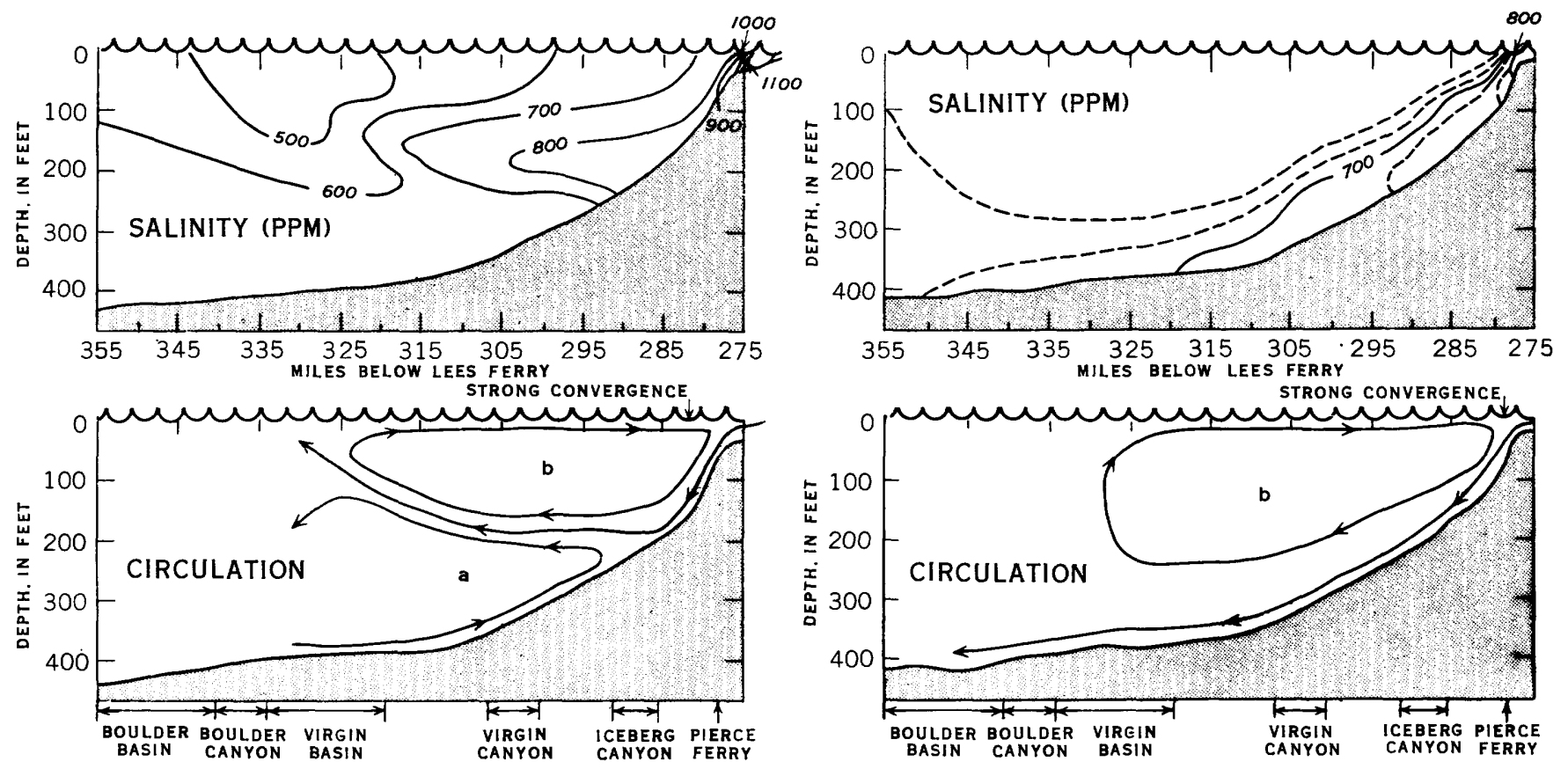

FALL

WINTER

FIGURn 28.-Typical seasonal salinity distribution and circulation patterns in Lake Mead.

Characteristic of all seasons is the relatively uniform character of Boulder Basin salinity, indicating that Virgin Basin acts as a large "mixing bowl," in and above which the large seasonal variations in salinity of the inflowing waters are smoothed to nearly their mean value. Near Hoover Dam, at the lower end of Boulder
Basin, the vertical salinity varies only from about 600 ppm to $640 \mathrm{ppm}$ during the spring season.

Vertical curves of temperature and salinity characteristic of the spring season are plotted in figure $29 \mathrm{~A}$ for stations located near Pierce Ferry, in Iceberg Canyon, Salt Springs Wash, Virgin Basin, Boulder Basin, 

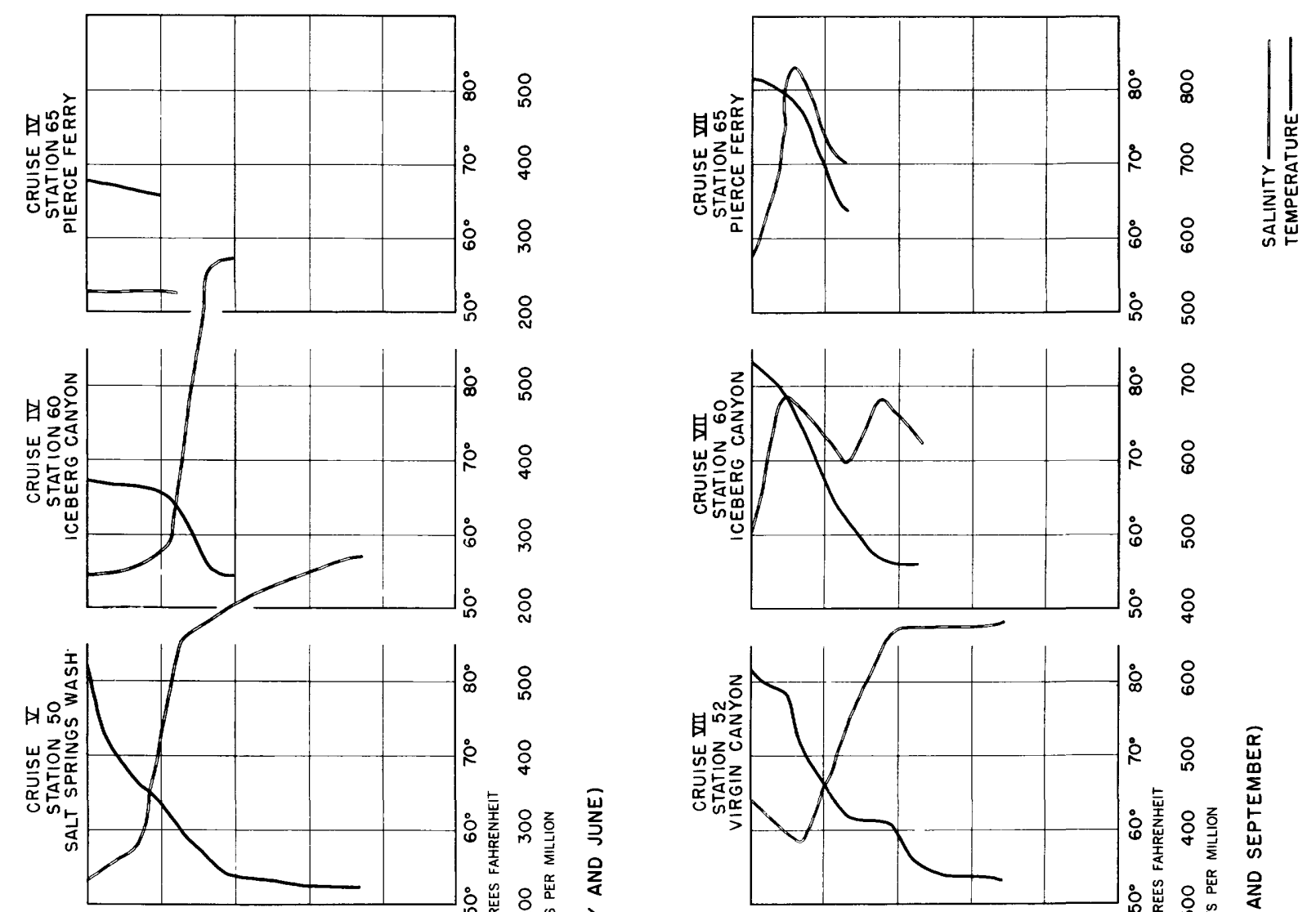

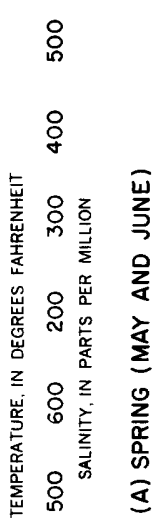
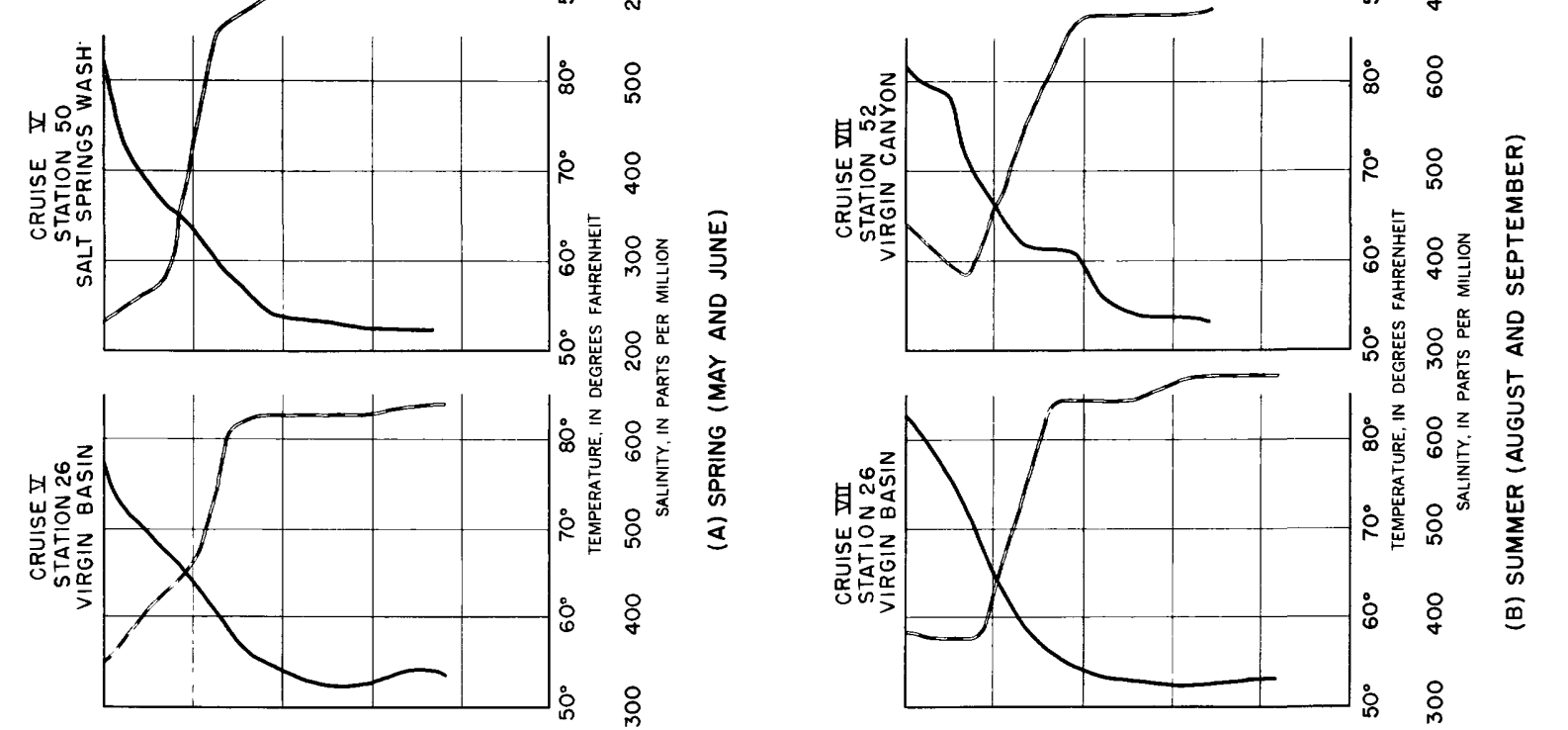

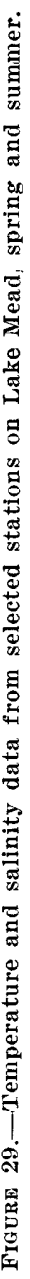
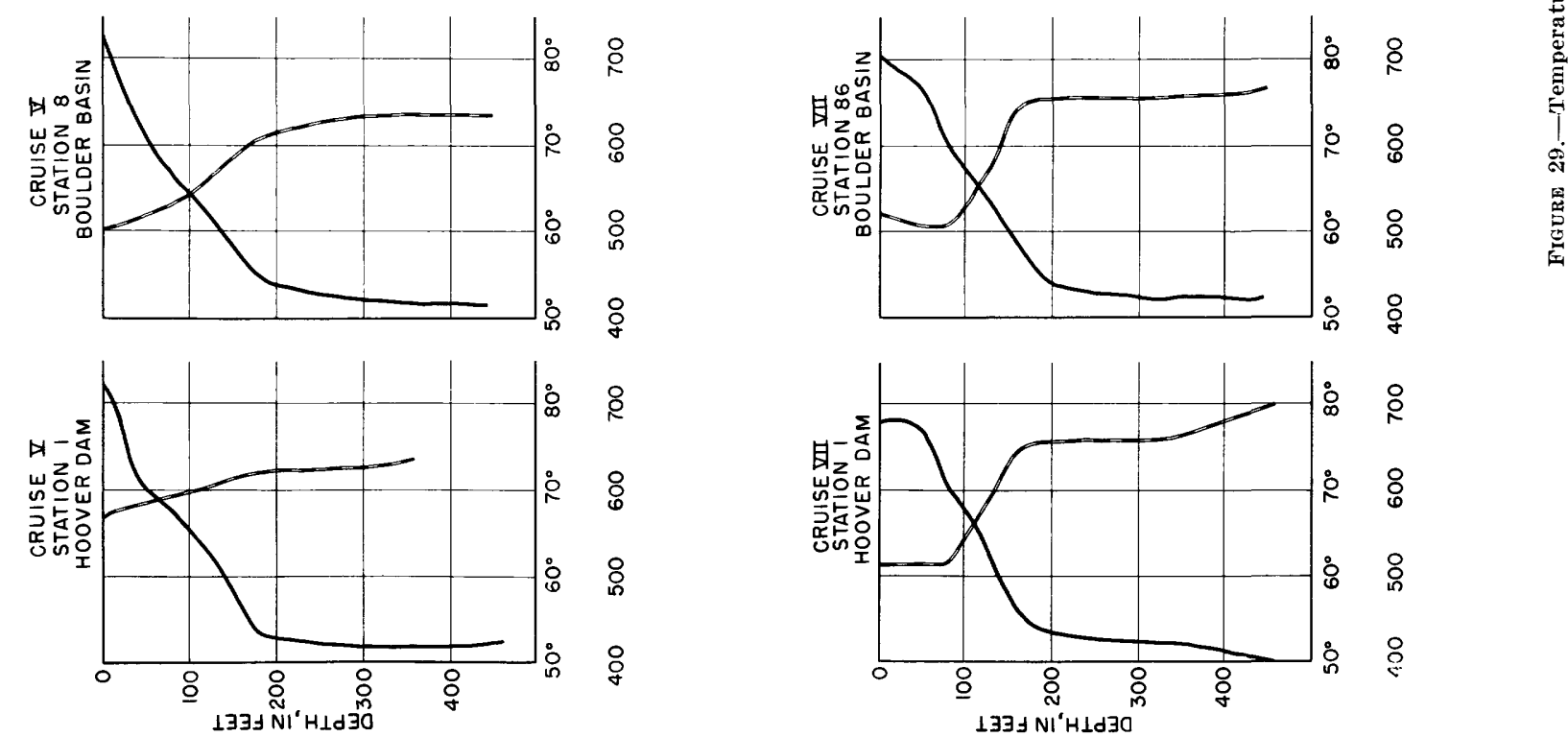
and in Black Canyon near Hoover Dam. These are actual observations and differ slightly from the somewhat smoothed picture presented in vertical section in figure 28.

Other diagrams on figure 28 offer a schematic presentation of the circulation along the old Colorado River channel. The major features during spring are the flow of fresher water downlake in the surface layer, and a counterclockwise cell below 100 feet. This cellular circulation results in flow uplake along the bottom in most of the section.

The lower boundary of the surface water flowing downlake is apparently indicated in May by the very sharp salinity and temperature gradient that occurs at a depth of about 140 feet in Iceberg Canyon. From the peak inflow of $88,000 \mathrm{cfs}$ moving through the cross section of Iceberg Canyon, the velocity due to this inflow was computed to be 0.42 foot per second, or about 7.0 miles per day. The velocity of the inflow can also be computed from the movement of the isohalines. Between cruise III on April 22-29, and cruise IV on May 25-31, the 500-ppm isohaline moved downlake some 34 miles from its middepth position in Iceberg Canyon to a surface position in the Virgin Canyon. This movement corresponds to an average displacement of 1.2 miles per day. During the same period, the $600-\mathrm{ppm}$ isohaline moved along the surface about 40 miles downstream, appearing in Boulder Canyon on cruise IV, which indicates a displacement of 1.4 miles per day. Along the bottom between Virgin Canyon and Iceberg Canyon, however, the $600 \mathrm{ppm}$ isohaline had moved uplake about 13 miles, giving an average uplake displacement of about 0.5 mile per day. In comparing these figures, it should be remembered that the salinity distribution is a result of both advective flow and mixing, and that the displacement indicated by movement of isohalines is indicative of both processes and should not be interpreted as advective flow only. The figures obtained from the movement of the isohalines are, therefore, minimum figures, and the true downstream flow is probably between 1.2 and 7.0 miles per day.

The peak runoff from the Virgin River occurred in April, a month earlier than from the Colorado River. The average inflow from the Virgin River during the last half of April was about $400 \mathrm{cfs}$, but the peak was slightly over $600 \mathrm{cfs}$. By the time of the peak inflow from the Colorado River in May, the inflow from the Virgin River had decreased to less than $100 \mathrm{cfs}$, and it was less than 200 efs during most of the other months studied. The peak flow of the Virgin River is much less than the minimum flow from the ('olorado, and the salinity distribution indicates that the conditions in Overton Arm are affected more by conditions along the old Colorado River channel than by inflow from the Virgin River. Only during May does the inflow from the Virgin River appear to affect the salinity distribution much below Overton Landing, and even then the effect does not extend down to the Lower Narrows. During May and June the low-salinity water from the Colorado River spreads along the surface into Overton Arm, affecting the salinity distribution as far north as Overton Landing. Below the Lower Narrows the salinity distribution at all depths parallels closely the conditions in Virgin Basin. Figure 30 gives the salinity distribution along the channel in Overton Arm during the spring.

The spreading of the Colorado River water up into Overton Arm is clearly shown from the horizontal plot of the Secchi-disc readings for May. The sharp demarkation between the clear lake water and the turbid river water flowing downlake on the surface occurs along a line that runs up the center of Overton Arm as far as the lower Narrows (fig. 31).

The horizontal distributions of surface salinity and temperature for the May survey are shown in figures 32 and 33. The values of temperature shown are actually for 10-foot depths, since the surface temperatures are greatly affected by diurnal processes. Note that the spread of water from the head of Virgin Basin upward into Overton Arm is shown on the horizontal salinity distribution in figure 32 .
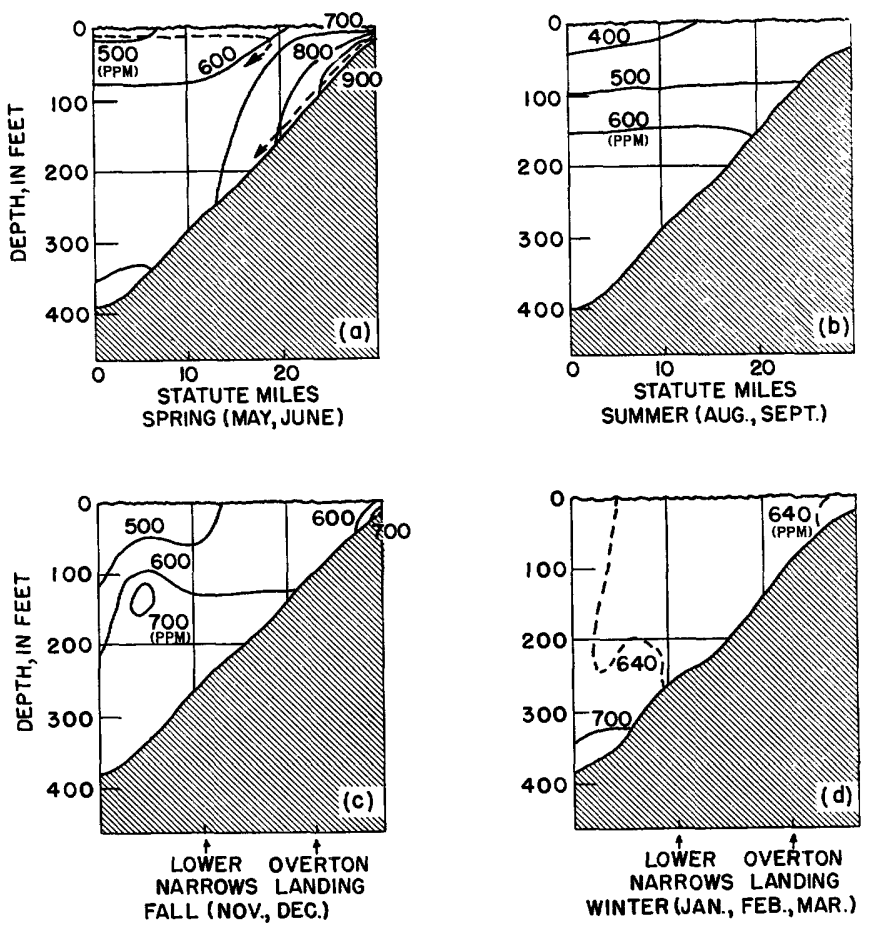

Figure 30.-Typical seasonal salinity distribution and indicated circulation in Overton Arm, Lake Mead. 


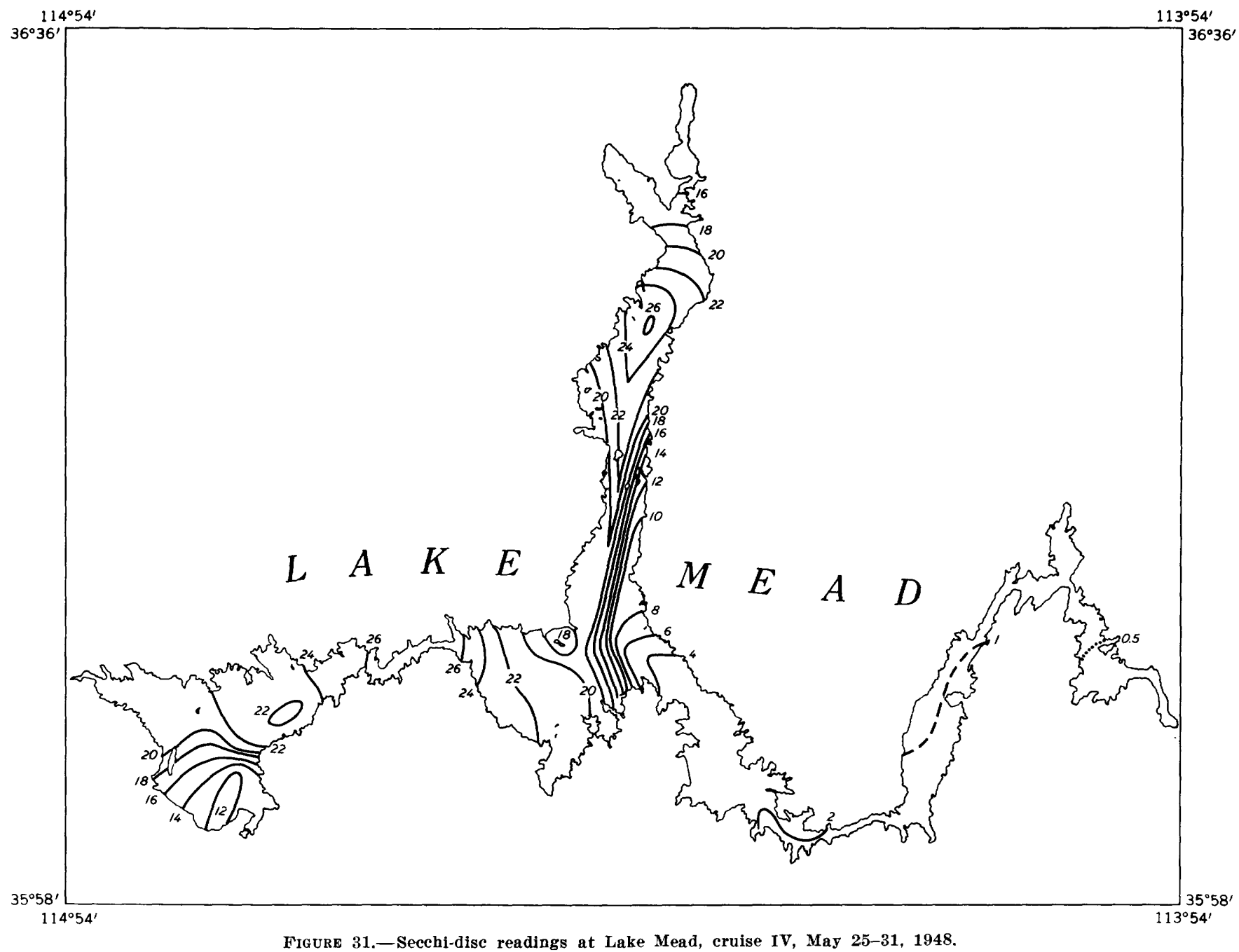

SUMMER

The inflow from the Colorado River decreases rapidly after its peak in late May and early June; in 1948 it had declined to $9,500 \mathrm{cfs}$ at the time of the August cruise and the extreme low for the year, about 3,000 cfs, occurred during mid-September. This decrease in volume is associated with increasing salinity. The inflowing water had a salinity of $875 \mathrm{ppm}$ in August and $1,033 \mathrm{ppm}$ in late September.

Inasmuch as the temperatures of the river and lake water are still nearly the same, the higher salinity results in a higher density, causing the inflowing water to sink to a depth of 80 feet beyond the edge of the delta. At this depth it spreads out over the more dilute but colder water, of still higher density, that remains from the spring inflow.

Figure 28 includes a cross section of the salinity distribution that is characteristic of summer along the old Colorado River channel. In the lake above Virgin Basin a tongue of high-salinity water extends downlake at a depth of about 80 feet, between layers of lower salinities. At 150 feet occurs a minimum-salinity layer that corresponds to the low-salinity water brought in during the high spring inflow. The high-salinity tongue extends downlake as far as the lower part of Virgin Canyon. Beyond this point the minimum-salinity layer is at the surface; there is a large region in the center of the lake with surface salinities of less than $400 \mathrm{ppm}$.

The surface water in Virgin Basin is a part of this low-salinity layer with salinities of $400 \mathrm{ppm}$ or less down to about 100 feet. At a depth of 160 feet the salinity is $600 \mathrm{ppm}$; below 160 feet the salinity is very uniform but increases gradually with depth. In Boulder Basin the salinity gradients are very weak, with values of about $500 \mathrm{ppm}$ at the surface and of $600 \mathrm{ppm}$ to $670 \mathrm{ppm}$ below 150 feet.

Vertical distributions of temperature and salinity found during this summer season are plotted in figure $29 B$, for stations located near Pierce Ferry, in Iceberg 


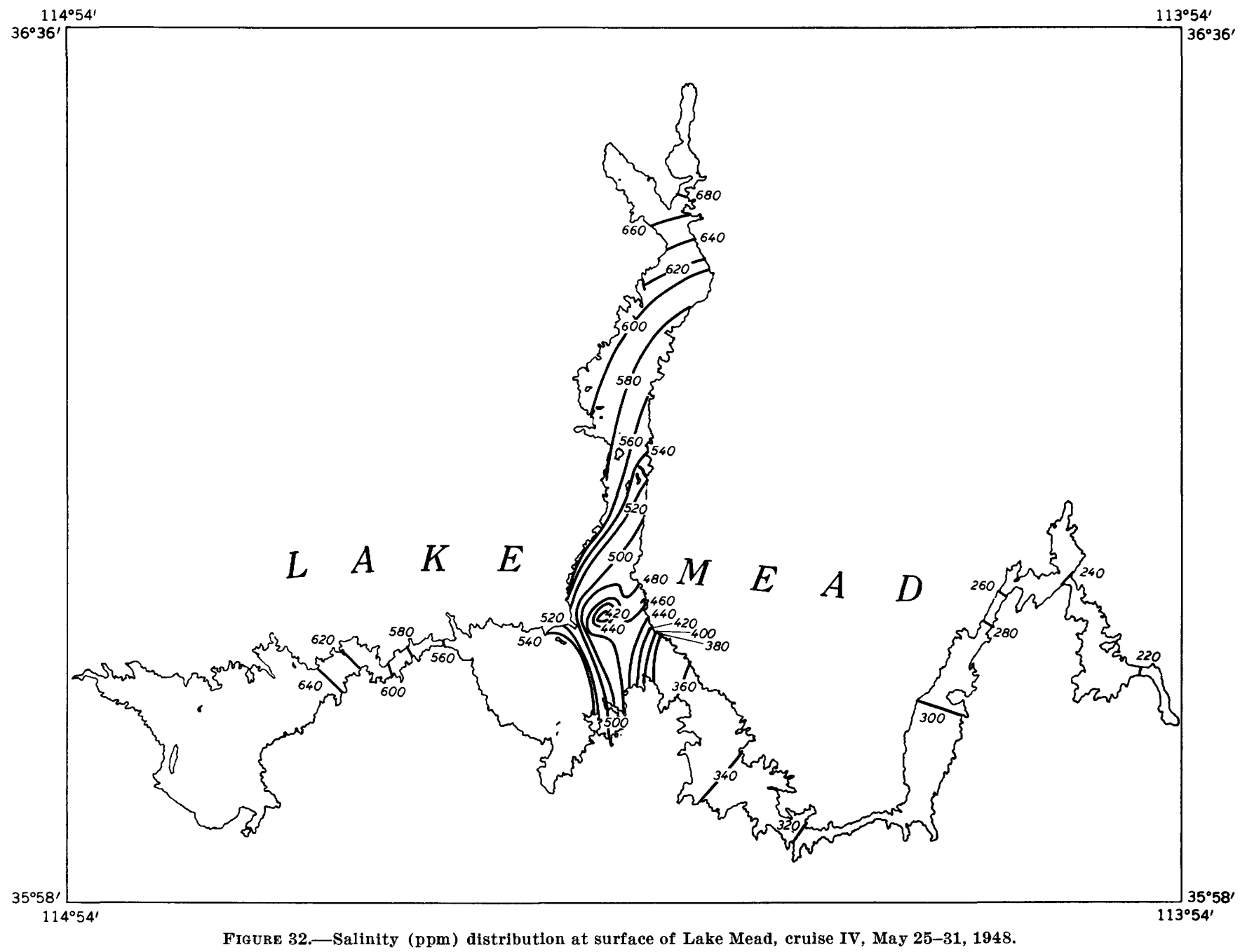

Canyon, Virgin Canyon, Virgin Basin, Boulder Basin, and Black Canyon near Hoover Dam. These observed distributions bear out the characteristics of the salinity pattern presented in the longitudinal section in figure 28. Note the similarity between all the temperature traces in figure $29 \mathrm{~B}$. This uniformity in temperature structure is found throughout most of the lake, resulting in nearly horizontal isotherms.

The indicated circulation, based upon changes in the salinity distribution in the section along the old Colorado River channel, is also shown in figure 28. The cell designated as " $a$ " on the graph for spring appears considerably smaller during the summer. The inflowing Colorado River water, being higher in salinity than the lake water, sinks to about 80 feet and spreads downlake at this level, thus giving rise to a new cellular circulation at the surface. This cell carries surface water uplake, causing a weak to moderate convergence to develop at the edge of the delta where the inflowing river water sinks.
There is evidence that some of the inflowing water continues to sink along the bottom past the 80 -foot depth and helps to establish a clockwise circulation near the bottom above Virgin Canyon. This cell, designated on figure 28 as "c", appears only during the summer.

Between the July and August cruises the 400-ppm isohaline moved downstream some 18 miles, indicating a minimum displacement of approximately 0.6 mile per day in the region between Iceberg and Virgin Canyons. During the same period the movement of the $500 \mathrm{ppm}$ isohaline gives a minimum daily displacement of 0.7 mile per day. In Iceberg Canyon during August the water flowing downlake appears to be confined to a layer about 100 feet thick, centered at about the 70 -foot depth. Computing the current in this layer in Iceberg Canyon, whose width is about 1,500 feet, and a verage inflow is about $7,500 \mathrm{cfs}$, gives a velocity of 0.8 mile per day. Like the computations for the spring season, these figures must be conservative estimates of the actual velocity, because the salinity 


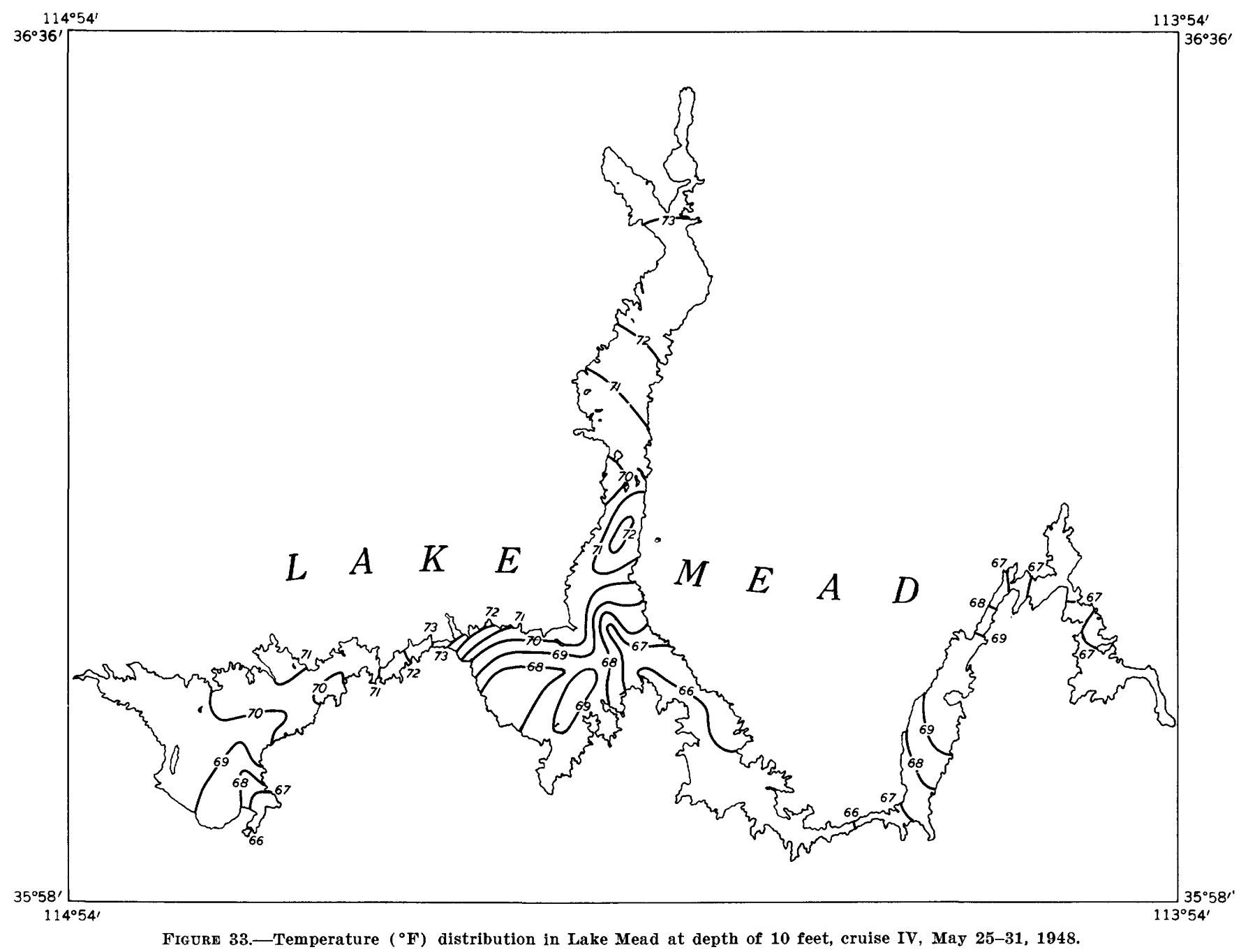

distribution reflects both advective and diffusive processes, and because more water is flowing downlake through Iceberg Canyon than comes in at the head of the lake, due to the effect of the cellular circulation above and below the downlake flow.

The inflow from the Virgin River into Overton Arm remains very low (about $100 \mathrm{cfs}$ ) during this season; in fact, from June through October. During the entire 5 -month period the distribution of salinity in Overton Arm remains about the same, which reflects the spread of low-salinity water along the surface up into Overton Arm from Virgin Basin.

Figure 30 gives this salinity distribution along the channel in Overton Arm in summer. At depths less than 100 feet the salinity is less than 500 ppm; early in the season it is less than $400 \mathrm{ppm}$ near the surface. The $600-\mathrm{ppm}$ isohaline is found at about 150 feet during these 5 months; below this level the salinity increases slowly with depth. There is very little evidence that inflow from the Virgin River affects the salinity pattern.
The dominant features in Overton Arm parallel conditions along the Colorado River channel in Virgin Basin.

The horizontal distribution of salinity and of tempperature at the 10 -foot depth during the August cruise are given in figures 34 and 35 respectively.

FALL

The inflow from the Colorado River remained low during the fall of 1948 , averaging about 6,000 cfs during October, November, and December. The inflowing water had a fairly constant salinity of about $1,000 \mathrm{ppm}$, but its temperature steadily dropped as the season progressed, from $64^{\circ} \mathrm{F}$ in late October to $43^{\circ} \mathrm{F}$ in late November. Because of this decrease in temperature, the river water had a considerably higher density than the surface lake water.

The distribution of salinity along the old Colorado River channel in the fall is shown in figure 28. The tongue of high salinity and density, evident at about 80 feet during the summer, now extends down the face 


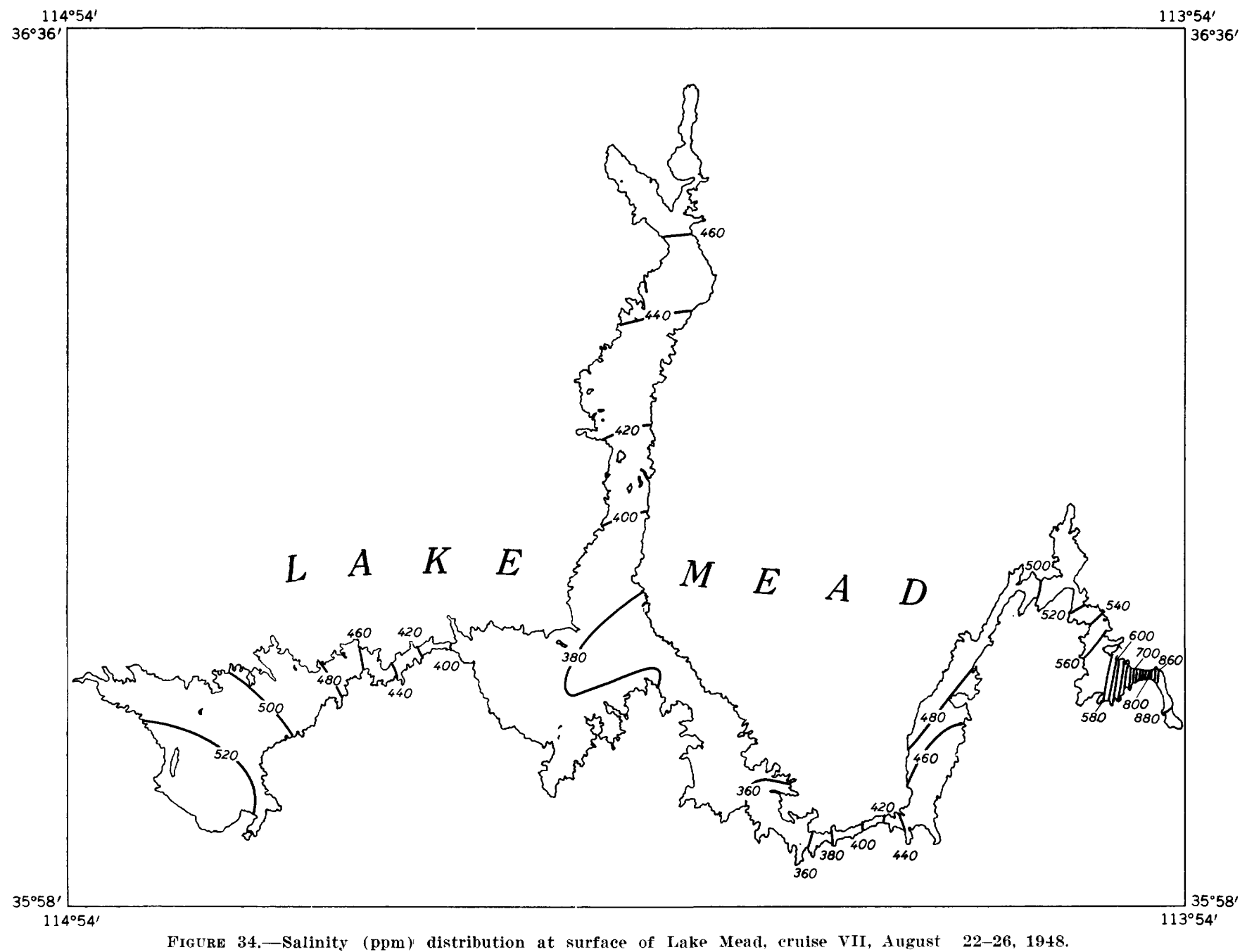

of the delta and spreads out at about the 170 -foot depth. It slopes slightly toward the surface and appears as a bulge in the $500-\mathrm{ppm}$ isohaline at a depth of about 100 feet in Virgin Basin.

A very sharp salinity and temperature gradient occurs at the head of the lake; within a distance of a few hundred yards, during the November cruise, the surface values of salinity ranged from $1,070 \mathrm{ppm}$ in the river to $730 \mathrm{ppm}$ in the lake, and the temperature from about $43^{\circ} \mathrm{F}$ in the river to about $62^{\circ} \mathrm{F}$ in the lake. This is the area of "convergence," and it is sharply marked at the surface just below Lower Granite Gorge by a line of accumulated floating debris. Upstream from this line the surface water is flowing downriver, and downstream from it the surface lake water has a definite uplake movement. This feature was observed to be particularly strong during the period from October through March, appearing in moderate intensity in September; from June through August the convergence completely disappears.
This convergence phenomenon is always associated with flow of the river water below the lake water. Figure 28 includes the pattern of circulation deduced from the salinity distribution along the old Colorado River channel during the fall. The river water flows downward over the edge of the delta as in summer but, because of the decrease in temperature, it continues to flow down along the bottom to nearly the 200-foot depth before spreading horizontally downlake. The flow appears to slope upward as it progresses downlake, appearing near the surface in Virgin Basin. The two major cellular circulations that occur in the summer remain throughout the fall, cell "a" appearing deeper and farther downlake, and cell "b" becoming considerably larger.

Figure 36 gives the vertical plots of temperature and salinity found during the fall, at stations near Pierce Ferry, in Iceberg Canyon, Virgin Canyon, Virgin Basin, and Boulder Basin, and in Black Canyon near Hoover Dam. The uniformity in the temperature 


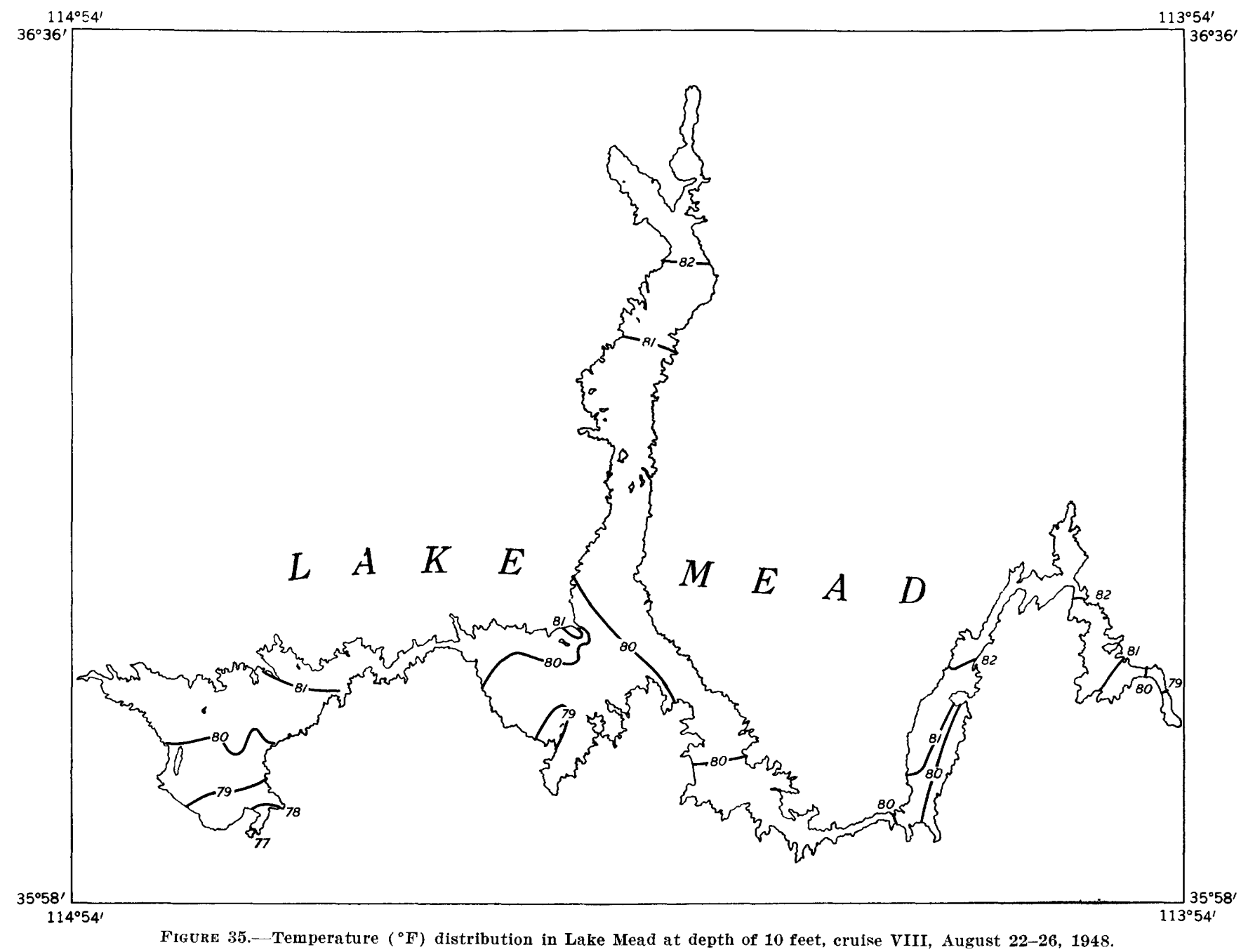

structure as far uplake as Virgin Canyon is evident in these plots.

Between the October and November surveys the 700ppm isohaline moved downlake at middepths for about 23 miles, corresponding to an average daily displacement of 0.66 mile. In Iceberg Canyon the downlake flow appears to be confined to a layer about 100 feet thick. The average inflow of $6,000 \mathrm{cfs}$ would produce a flow of 0.65 mile per day in this layer in Iceberg Canyon.

The Virgin River flow incleased slightly during the fall, having an average value of about $160 \mathrm{cfs}$. Evidence of relatively high-salinity flow from this river appears in the salinity distribution of Virgin Arm as far down as Overton Landing (fig. 30). At the lower end of Overton Arm the high-salinity inflow from the Colorado River probably causes the maximum of about. $700 \mathrm{ppm}$ at depth of 150 feet in the salinity distribution. It appears that the high-salinity water flowing down the Colorado River channel cuts northwestward across the head of Virgin Basin into Overton Arm. A low-salinity layer of less than $500 \mathrm{ppm}$ remains near the surface below the Lower Narrows.

The horizontal distribution of surface salinity and 10 -foot temperature for the November cruise is shown in figures 37 and 38 .

\section{WINTER}

The observational program actually began in the winter, the first cruise having been made in February 1948. The last cruise was also made in February, 1 year later. The second winter was considerably colder than the first; in fact, the winter of 1948-49 was the coldest in more than 30 years, and this abnormal condition is reflected in both low temperatures and low inflows. Conditions corresponding to the first winter are discussed here with some modifications, as required by information gained from the January conditions observed in the second winter. Differences between the two February cruises are discussed at the end of this section. 
CIRCULATION AND EVAPORATION
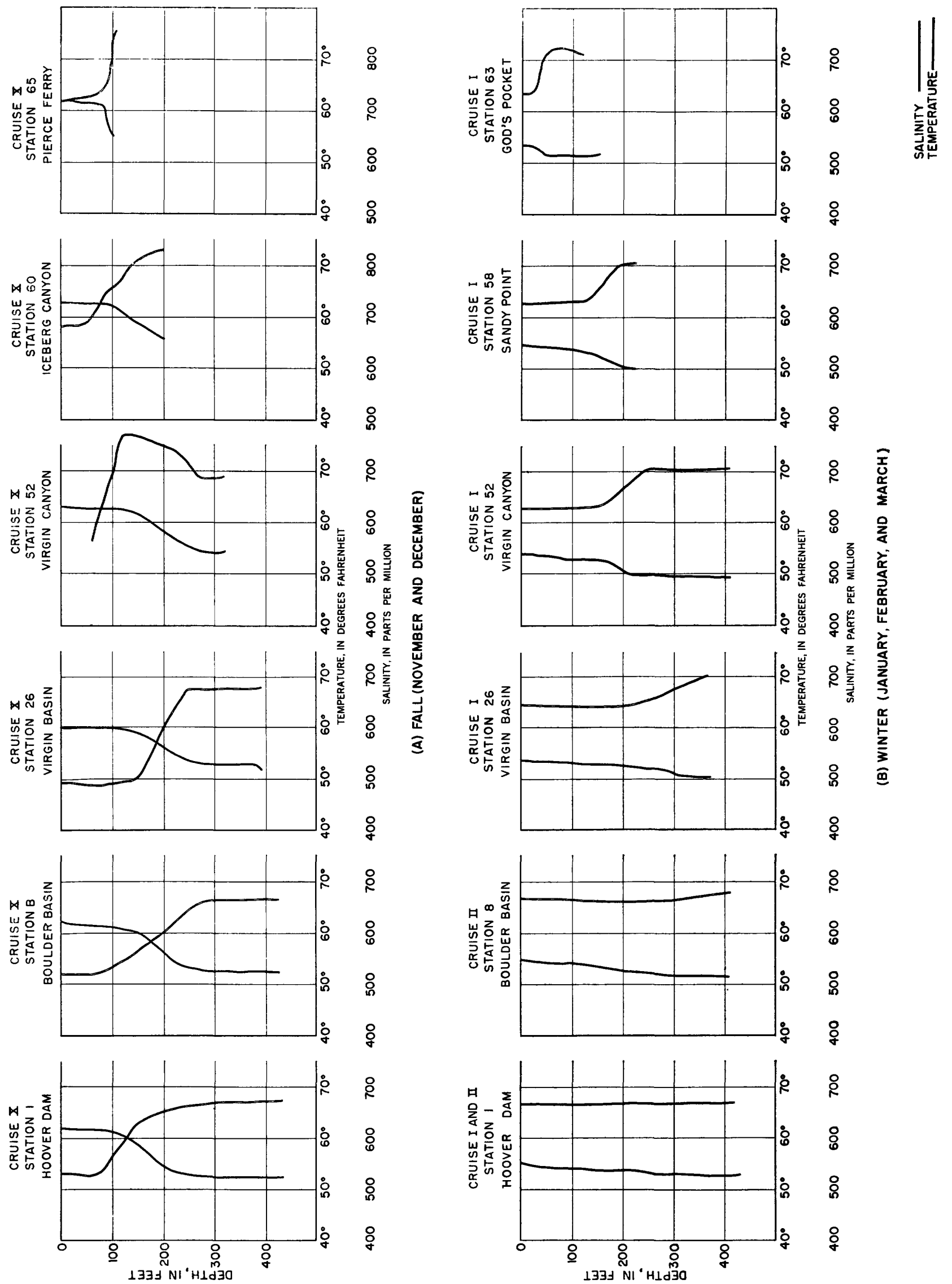


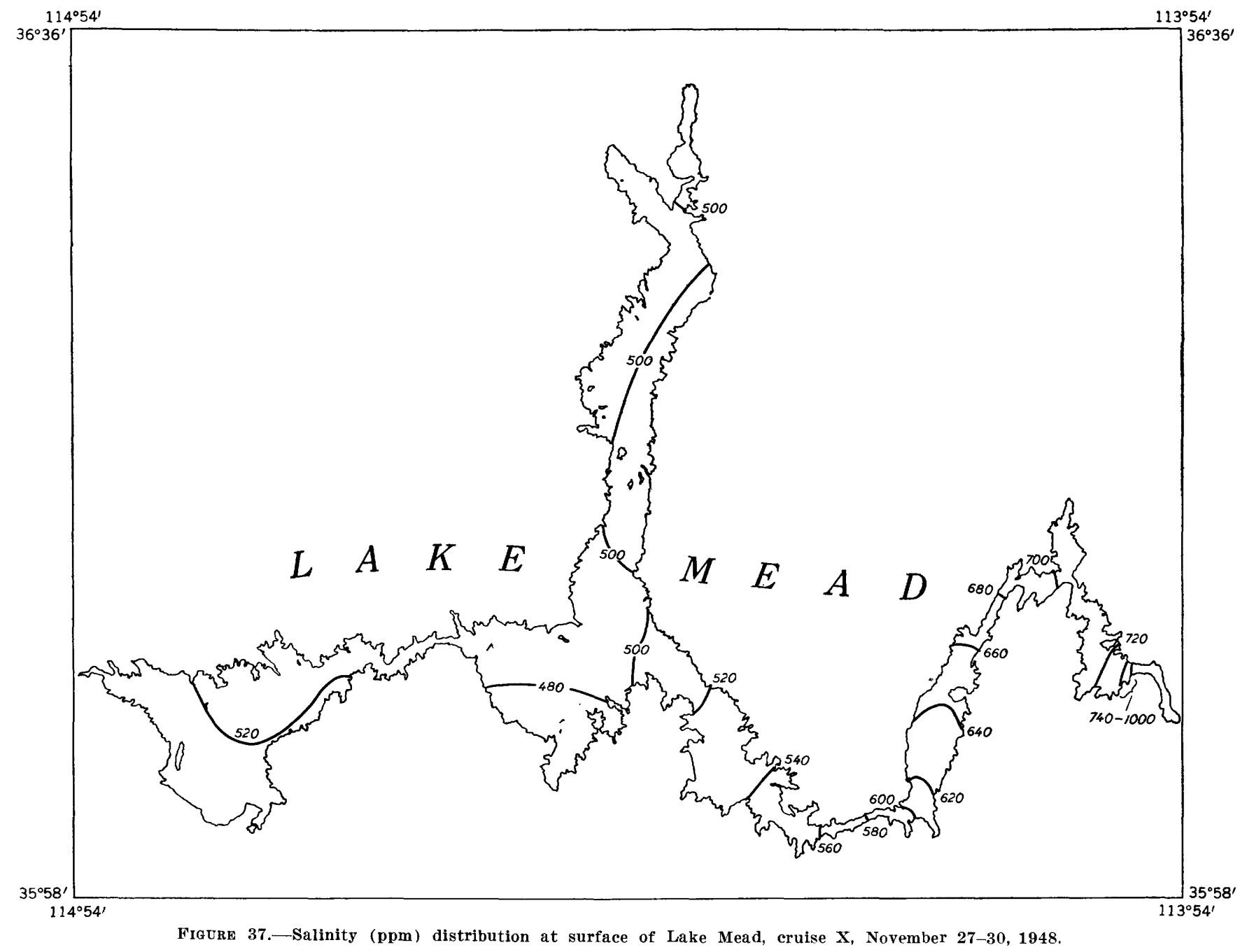

The inflowing water from the Colorado River continues to become colder, hence it sinks farther along the bottom until in midwinter the maximum salinity occurs along the very bottom and the high-salinity tongue extends into Boulder Basin. Figure 28 gives the salinity distribution along the old Colorado River channel for the first winter. Extremely uniform conditions exist throughout a large layer, extending from the surface downward for about two-thirds of the area of the section.

The circulation for this season along the Colorado River channel is also shown in figure 28. Cell "a", which dominated the spring pattern and was evident in summer and fall, has now disappeared. The river water flows down over the edge of the delta, where a marked surface convergence occurs, and spreads downlake along the bottom. Above this flow there is a celIular circulation, and the surface water moves uplake to the head and then sinks parallel to the river inflow.

Between the February and March cruises the 720- ppm isohaline moved downlake approximately 19.5 miles along the bottom from upper Iceberg Canyon to the lower part of Virgin Canyon. During the same period the $700-\mathrm{ppm}$ isohaline had moved 17.5 miles from lower Virgin Canyon to the center of Virgin Basin, and the 680-ppm isohaline had moved 11.5 miles from the upper part of Boulder Basin into Black Canyon. These three cases give displacements of 0.6 mile per day near the head of the lake, 0.5 mile per day in the midpart of the section, and 0.3 mile per day in Boulder Basin.

In Iceberg Canyon the water flowing downlake appears to have been confined to the lower 100 feet. With an inflow of 13,000 cfs, as in February 1948, the flow in this layer in Iceberg Canyon would correspond to 1.4 miles per day. The canyon, of course, is a constricted section and would give velocities greater than those occurring in other areas.

Figure $36 B$ shows the temperature and salinity curves for stations located along the old Colorado River 


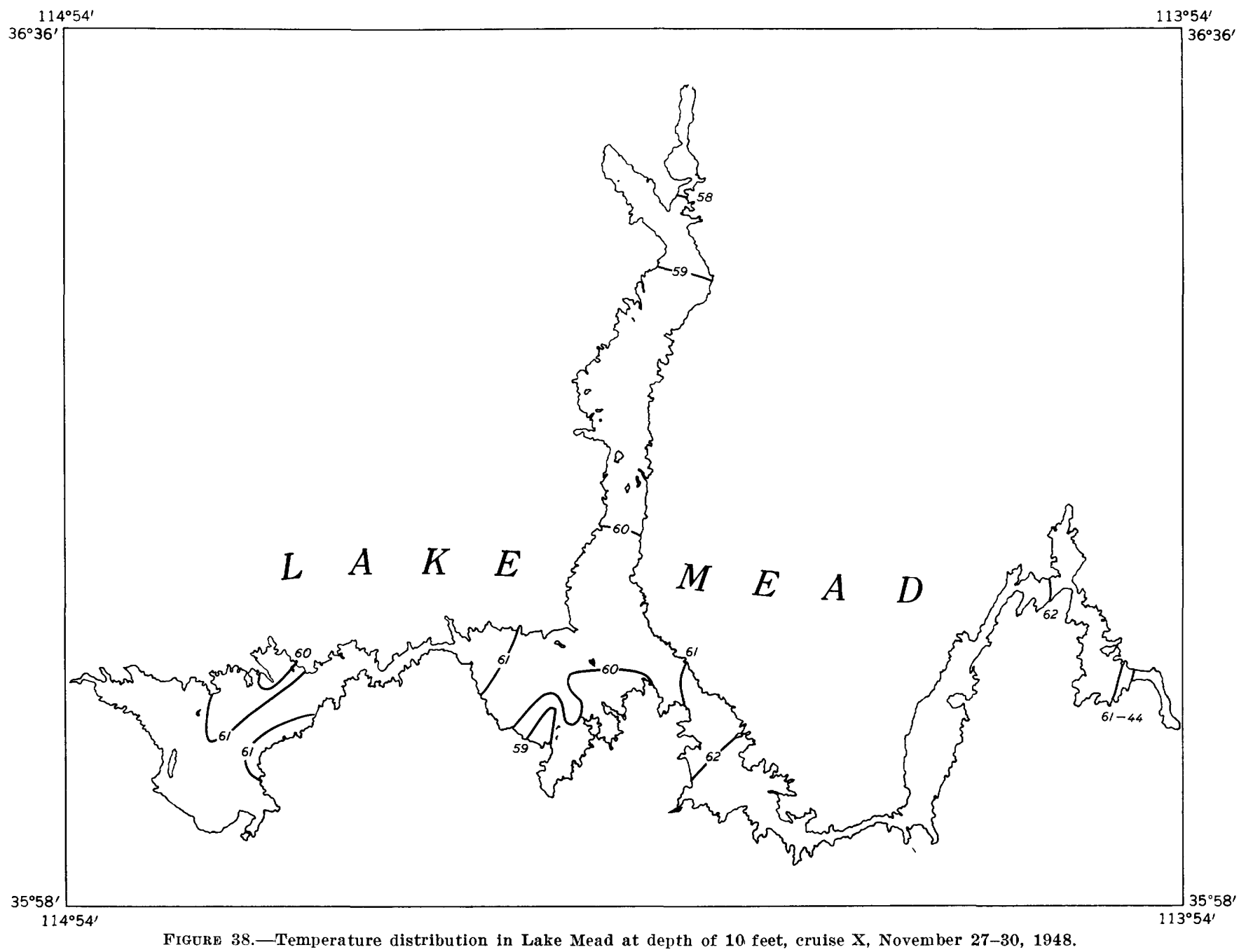

channel. These traces show the extremely uniform conditions in both temperature and salinity that prevail over much of the section.

The uniform conditions prevailing along the Colorado River channel extend also into Overton Arm. The effect of the higher salinity flow of Colorado River water along the bottom appears at the lower end of the section along the channel in Overton Arm. The salinity distribution along this section for winter is shown in figure 30.

The horizontal distribution of surface salinity and 10-foot temperature is given in figures 39 and 40 respectively for the cruise of February 1948. The extremely uniform horizontal field is evident from these charts.

That conditions differ from year to year is evident from the differences found between cruise I in February 1948 and cruise XII in February 1949. The second winter was abnormally cold; the temperature of inflow in February 1949 was some $8^{\circ} \mathrm{F}$ less than in February
1948 , and the temperatures in the lake were $3^{\circ} \mathbf{F}-5^{\circ} \mathbf{F}$ less at all levels. The inflow during cruise XII was only 4,500 cfs as compared with 13,000 cfs during cruise I.

Despite these differences the major character of the salinity pattern and the indicated circulation did not differ materially between the two winters. It is believed that the important features of the circulation for all seasons as presented above is repeated from year to year.

\section{SUMMARY OF THE CIRCULATION PATTERNS}

In winter the salinities in the lake are uniform, ranging from 600 to $700 \mathrm{ppm}$. The inflowing Colorado River water, with higher salinities, flows down over the edge of the delta and along the bottom in the old river chamnel, where it seems to influence bottom salinities well into Boulder Basin. A single cellular circulation exists, resulting in an uplake flow of surface waters from Virgin Basin.

The spring runoff results in high inflow from the 


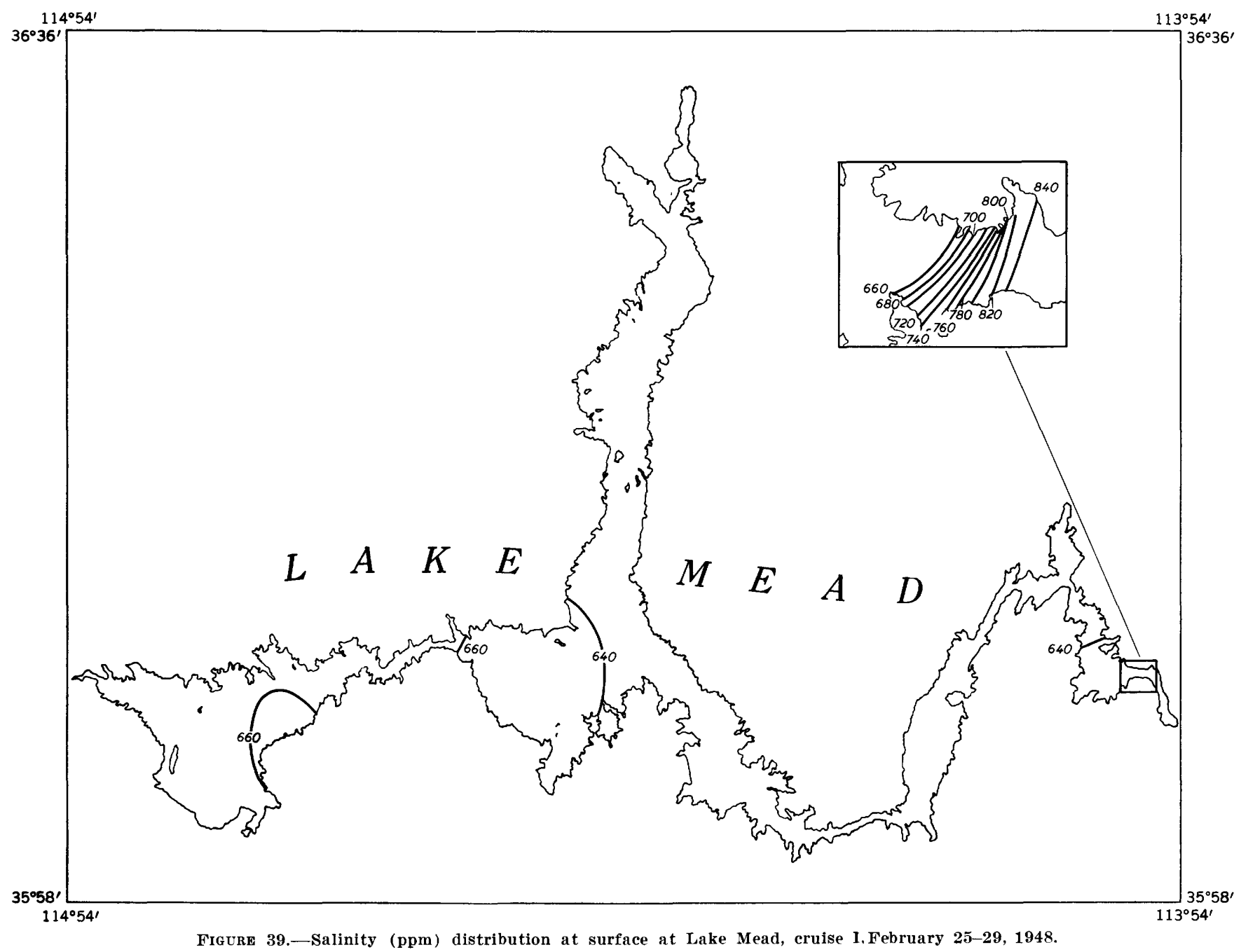

Colorado River, which, because of its low salinity of 200 to $300 \mathrm{ppm}$, flows out over the lake water, producing a layer of low salinity over most of the lake. The flow along the surface sets up a cellular circulation below the depth of 150 feet which gives rise to flow uplake along the bottom.

In summer, with decreasing inflow and increasing salinity of inflow, the downlake spread of Colorado River water occurs at about 80 feet below the surface. Above Virgin Canyon two distinct cellular circulations occur, one in the surface flow and the other below 80 feet, resulting in an uplake flow in deeper waters. There is some evidence of a third cell, which produces downlake flow along the bottom, caused by the sinking of some sediment-laden inflow water along the bottom.

In the fall the decrease in temperature of inflow from the Colorado River is associated with a further sinking of the inflowing river water. During this season there is downlake flow along the bottom until, at a depth of about 170 feet, the flow spreads horizontally downlake and then slopes slowly up toward the surface. Two large cellular circulations, one producing uplake movement of surface water and the other uplake movement of bottom water, exist above the Virgin Basin.

The seasonal cycle is completed when, with further increase in density, the inflowing waters flow all the way down the slope of the delta along the bottom. The deep cellular circulation is eliminated and the single cell of the winter season remains.

Overton Arm appears to reflect primarily the water conditions found in Virgin Basin. The influence of flow from the Virgin River is seen only in the upper few miles of the arm. Sedimentation below Lower Narrows in Overton Arm would appear from this analysis to result from the flow into Overton Arm of water of Colorado River origin. That turbid water from this source does extend into Overton Arm is evident from the Secchi-disc readings made during the May survey. 


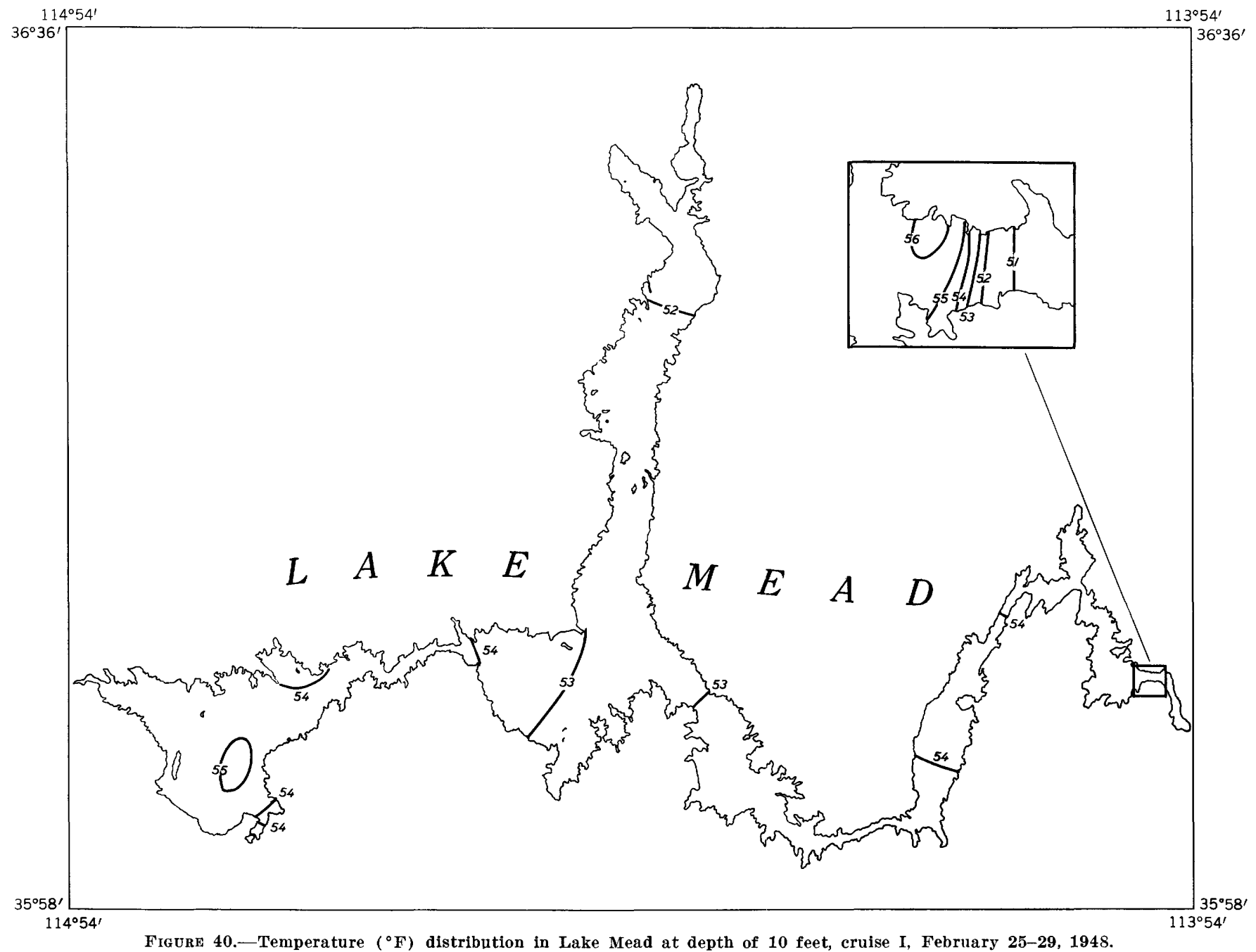

\section{EVAPORATION}

\section{TECHNIQUES FOR DETERMINING EVAPORATION}

At present there are four methods of estimating evaporation from a body of water: (a) water budget, (b) evaporation pan, (c) mass transfer, and (d) energy budget. The nature of the observational program developed for this study made it possible to gather enough information on the pertinent parameters to establish a preliminary energy budget.

Since Schmidt (1915) first estimated evaporation from the oceans by means of the energy budget, numerous attempts have been made to apply it to the determination of evaporation from small bodies of water. For example, Ångström (1920) and Cummings (1940), respectively, computed evaporation from a lake in Sweden and from Bear Lake, Utah, using an evaporation pan together with equations based on the energy concept. These and other attempts to compute evaporation from energy concepts have been beset with diffculty in evalu- ating the various parameters, especially energy storage. The application of the bathythermograph (Spilhaus, 1938), an instrument that makes a vertical temperature profile at a given place, and of the echo sounder, which provides the data for obtaining accurate lake volumes, has made it possible to evaluate the energy-storage factor.

ENERGY BUDGET

The energy budget for a body of water may be written

$$
Q_{s}-Q_{r}-Q_{b}-Q_{h}-Q_{c}+Q_{v}=Q_{\theta}
$$

in which $Q_{s}$ is the solar radiation incident to the water surface; $Q_{r}$, the reflected solar radiation; $Q_{b}$, the net energy lost by the body of water through the exchange of long wave radiation between the atmosphere and the body of water; $Q_{h}$, the energy conducted from the body of water to the atmosphere as sensible heat; $Q_{e}$, the energy utilized by evaporation; $Q_{r}$, the net energy advected into the body of water; and $Q_{\theta}$, the change in energy stored in the body of water. $Q_{r}, Q_{b}, Q_{h}$, and $Q_{e}$ 
have negative signs because normally they represent a loss of energy in the body of water.

This equation has been applied to the problem of obtaining a preliminary value of evaporation from Lake Mead. ${ }^{13}$

The energy budget equation 1 may be solved for evaporation to obtain the following

$$
E=\frac{Q_{s}-Q_{r}-Q_{b}+Q_{v}-Q_{\theta}}{\rho L(1+R)}
$$

in which $E$ is the amount of evaporation, $L$ is the latent heat of vaporization, $\rho$ the density of the water, and $R$ is the Bowen ratio (Bowen, 1926) or the ratio of the energy used to conduct sensible heat to or from the water surface to that used by evaporation.

It can be shown (Anderson, 1953) that equation 2 is an approximation, inasmuch as the energy advected from the lake by the volume of evaporated water is not considered in its development. If this process is taken into consideration, slightly lower values than those given by equation 2 result. The corrective term was not applied to the computations herein reported because of uncertainties of greater magnitude that are introduced inevaluating some of the other terms.

In applying this equation to Lake Mead it is necessary to evaluate each of the terms on the right side of the equation. The terms $Q_{s}, Q_{v}, Q_{b}, Q_{e}$, and $Q_{h}-$ the latter two being obtained through the use of the Bowen ratio - contribute directly to the energy budget, whereas $Q_{\theta}$, the change in energy storage, is a balancing term and $Q_{r}$, the reflected energy, is a corrective term.

\section{RADIATION FROM SUN AND SKY}

The value $Q_{s}$ was obtained by utilizing a method presented by Kennedy (1949) for computing insolation for either a day or a half-day. His method may be used when it is desired to obtain the insolation at a station that is located at the same latitude and elevation as a weather station and a pyrheliometer station where the insolation is known. Basically, the method is an extrapolation of the measured data at the pyrheliometer station to the station in question.

\section{REFLECTED SUN AND SKY RADIATION}

Part of the incoming solar radiation is lost, as far as the body of water is concemed, by reflection at the surface $\left(Q_{r}\right)$. The amount lost is probably dependent upon the altitude of the sun, amount of cloudiness, turbidity of the atmosphere, and the hydrodynamic char-

\footnotetext{
13 This study of the energy budget of Lake Mead and the estimate of evaporation derived therefrom represent a preliminary study made in connection with the comprehensive survey of 1948-49. The descriptions and results presented here show the stage of development of the method at that time. For a more recent and comprehensive treatment of the energy-budget method as applied to Lake Mead, see the report by Koberg (1958).
}

acter of the water surface. The average altitude of the sun was computed for each month. Using the value for the sun's altitude and the percentage of incoming solar radiation reflected from a horizontal water surface at different altitudes of the sun in clear weather-obtained from a table prepared by Sverdrup and others (1946) - an average monthly value for reflection was obtained. Considerable controversy exists over the reflectivity of a water surface; but it was believed that the above method gave the best estimate of reflection that was possible at that time.

\section{EFFECTIVE BACK RADIATION}

The difference between the long-wave radiation emitted from the water surface and that received from the atmosphere is the effective back radiation $\left(Q_{b}\right)$. It is difficult to evaluate, owing to a lack of pertinent observations. The effective back radiation is a function of the surface-water temperature, vapor pressure or relative humidity a short distance above the water surface, emissivity of the water surface, and cloudiness. The nature of the observational program made it impossible to obtain representative monthly averages of these variables, and they were therefore evaluated from Boulder City weather observations, corrected or modified as necessary by the observations taken during the monthly cruises. After obtaining the best representative values of the above variables, the effective back radiation was obtained by using empirical relationships established by Ångström (1920) and developed in graphs by Sverdrup and others (1946). This procedure may result in inaccuracies of 10 to 20 percent.

\section{ADVECTED ENERGY}

The advected energy $\left(Q_{v}\right)$ is the sum of all inflows and outflows of energy. The net amount of energy advected into and out of Lake Mead has been computed on a monthly basis, largely from daily inflow and outflow information supplied by the Geological Survey and the Bureau of Reclamation. The inflow measurements were made at Grand Canyon, Ariz., for the Colorado River, and at Littlefield, Ariz., for the Virgin River, both being a considerable distance from Lake Mead. The volume of outflow, as well as its temperature, was measured at Hoover Dam.

The temperature of the inflowing Colorado River water and Virgin River water was determined from bathythermograms made near the points of inflow into the lake during the monthly cruises. Daily values of the difference of the quantity of energy flowing into and out of the lake were computed and summed to give the monthly values.

No attempt was made to evaluate seepage, bank storage, or local runoff, and any possible gain or loss of 
energy from these sources. Two additional sources of inaccuracy are possible in the computation of the advective term: (1) in the determination of the temperature of the inflowing and outflowing water and (2) in the use of the flow figures from the Grand Canyon station to give inflow data. The values of the temperature of inflow and outflow are believed to have a maximum error of $\pm 1.0^{\circ} \mathrm{F}$. The maximum error would result in an error in computed evaporation of less than 4 percent from July through February and about 10 percent from March through June; the latter figure would be larger primarily because of the great increase in river flow during these months. This estimate of error in the evaporation figures assumes that the error in the temperature of inflowing water was opposite in sign to the error in temperature of the outflowing water, and therefore the temperature error is cumulative. The actual error in evaporation estimates from this source may therefore be less than the above values.

The actual inflow to Lake Mead may be substantially greater or less than the flow measured at Grand Canyon, 190 miles upstream from Pierce Basin. From July through March a 10-percent error in quantity of inflow would result in an error of less than 3 percent in evaporation; but in April, May, and June the error in calculated evaporation would be 6,14 , and 15 percent, respectively.

\section{ENERGY STORAGE}

Energy storage $\left(Q_{\theta}\right)$ was computed from about 60 temperature profiles taken in all parts of the lake during the monthly cruises. As far as is known, this represents the first attempt to evaluate the term accurately. The energy storage was computed by layers for each temperature profile. Comparison of the various values indicates that storage is relatively constant as between one part of Lake Mead and another, and that possibly it can be evaluated from one or two profiles or at most one profile taken in each major basin.

\section{BOWEN RATIO}

The Bowen ratio $(R)$ is the ratio of the energy conducted from the lake as sensible heat $\left(Q_{h}\right)$ to the energy utilized by evaporation $\left(Q_{e}\right)$. Its computation requires average monthly values of the temperature of the lake surface and the temperature and humidity of the air over the lake. Information on the lake-surface temperature was available from the monthly cruises, but information on the air temperature and humidity at the lake was quite inadequate. However, the information was available for Boulder City, in the records of the U.S. Weather Bureau. By using this information and comparing it with such data as were available at Lake Mead, an approximate Bowen ratio was deter- mined. Inasmuch as the ratio appears only as a corrective term in the equation, the effects of errors in the ratio are small. Thus a 25 percent error in $R$ results in a maximum error in monthly values of evaporation of only 9 percent, and an average error in the monthly calculated evaporation of 6 percent.

\section{SUMMARY}

From this discussion of the various terms in the evaporation equation, it may be concluded that the computed evaporation probably was not in error by more than 20 per cent. Figure 41 indicates the average monthly values of the various parameters in the energy budget equation as computed for Lake Mead, using the techniques outlined above.

The solar radiation $\left(Q_{s}\right)$ varies as expected, the maximum radiation occurring in June and the minimum in January, while the reflected radiation $\left(Q_{r}\right)$ is nearly constant from one month to the next. From April to August, energy $\left(Q_{v}\right)$ is advected into the lake as a result of the high inflow from the Colorado River, and from September to March, a small amount of energy is advected from the lake. On an annual basis, more energy is brought into the lake by advection than is taken out. The effective back radiation $\left(Q_{b}\right)$, which so far as the lake is concerned represents a loss of energy, is nearly constant from month to month. During the summer less than one-fourth of the total energy supplied by solar radiation and advection is dissipated by this process, but in January the back radiation is nearly equal to solar radiation. The curve for energy storage $\left(Q_{\theta}\right)$ follows in general the solar radiation curve, the maximum occurring in June and the minimum in November. The sum of energy used for evaporation and that used for conduction of sensible heat. $\left(Q_{e}+Q_{h}\right)$ is the algebraic sum of the above quantities. This sum has a primary minimum in April and primary maximum in November. During November the energy utilized by these two processes is slightly greater than the energy supplied to the lake by solar radiation.

\section{CALCULATION OF RATES OF EVAPORATION}

In order to obtain the relative amounts of energy consumed by evaporative and conductive processes, the Bowen ratio $(R)$ must be evaluated. The calculated monthly values of this quantity are as follows:

Bowen ratio for Lake Mead

\begin{tabular}{|c|c|c|c|}
\hline 1948 & & 1948 & \\
\hline February . . . & +0.410 & October & -0.123 \\
\hline $\begin{array}{l}\text { March } \\
\text { April }\end{array}$ & $\begin{array}{r}+.204 \\
-.263\end{array}$ & $\begin{array}{l}\text { November- } \\
\text { December }\end{array}$ & $\begin{array}{l}+.448 \\
+.539\end{array}$ \\
\hline May- & -.122 & & \\
\hline June. & -.043 & 1949 & \\
\hline $\begin{array}{l}\text { July } \\
\text { August }\end{array}$ & $\begin{array}{l}-.153 \\
-.115\end{array}$ & January...-- & $\begin{array}{l}+.412 \\
+.309\end{array}$ \\
\hline September.... & -.068 & & \\
\hline
\end{tabular}




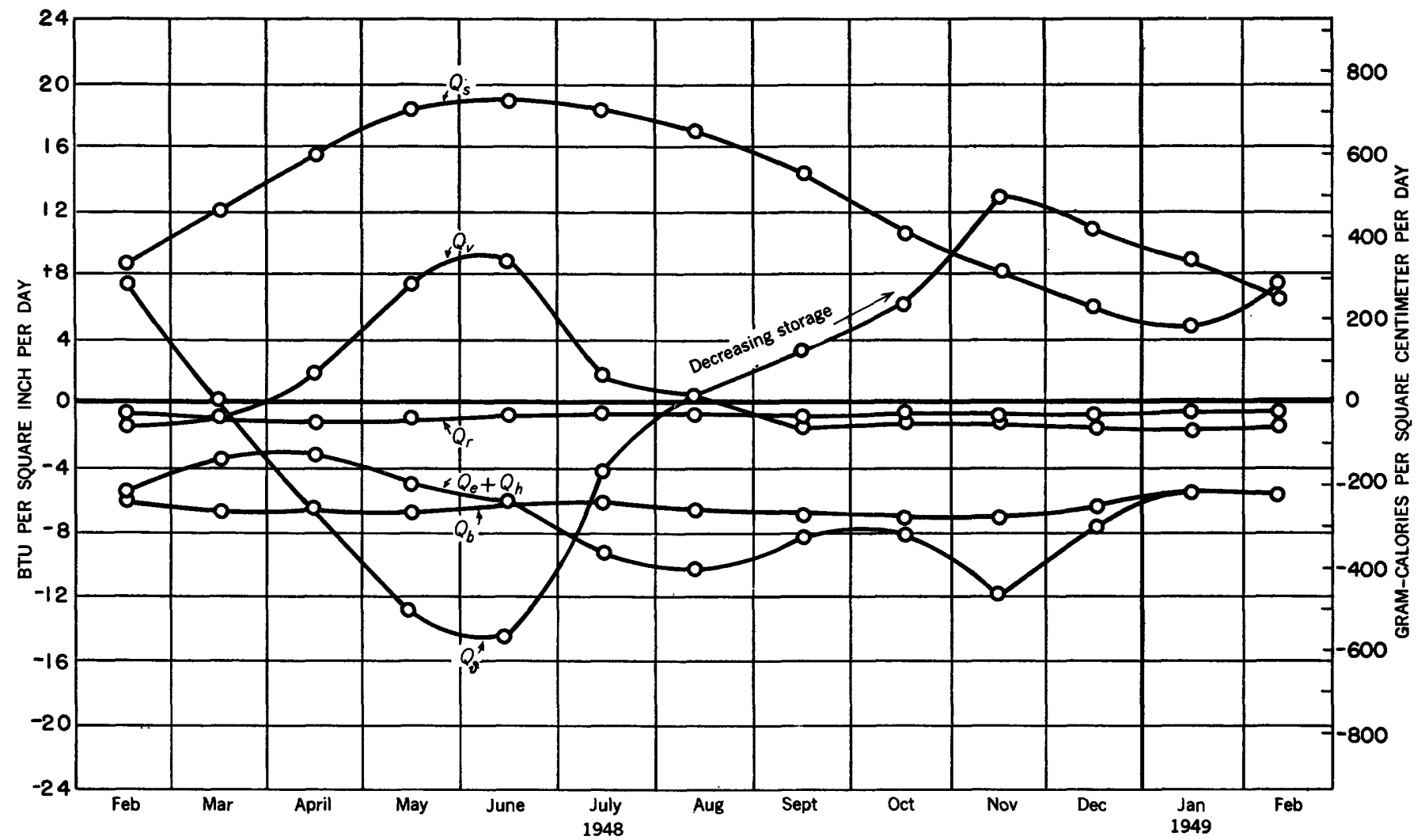

EIGURn 41.-Average monthly values of energy budget parameters as computed for Lake Mead, $1948-49$.

Positive values of the Bowen ratio indicate that heat is being conducted away from the lake-that is, the air is colder than the water; negative values indicate the opposite effect. Inspection of the data shows that heat is conducted to the lake from April to October and away from the lake from November to March. By using these monthly average values of the Bowen ratio, the sum of energy utilized by evaporation and that utilized by conduction, shown in figure 41 as $\left(Q_{e}+Q_{h}\right)$, can be broken down into its component parts. The results are graphically presented in figure 42 . Evaporative processes use a minimum amount of energy in March and a maximum amount in August.

Table 15 shows the monthly values of the amounts

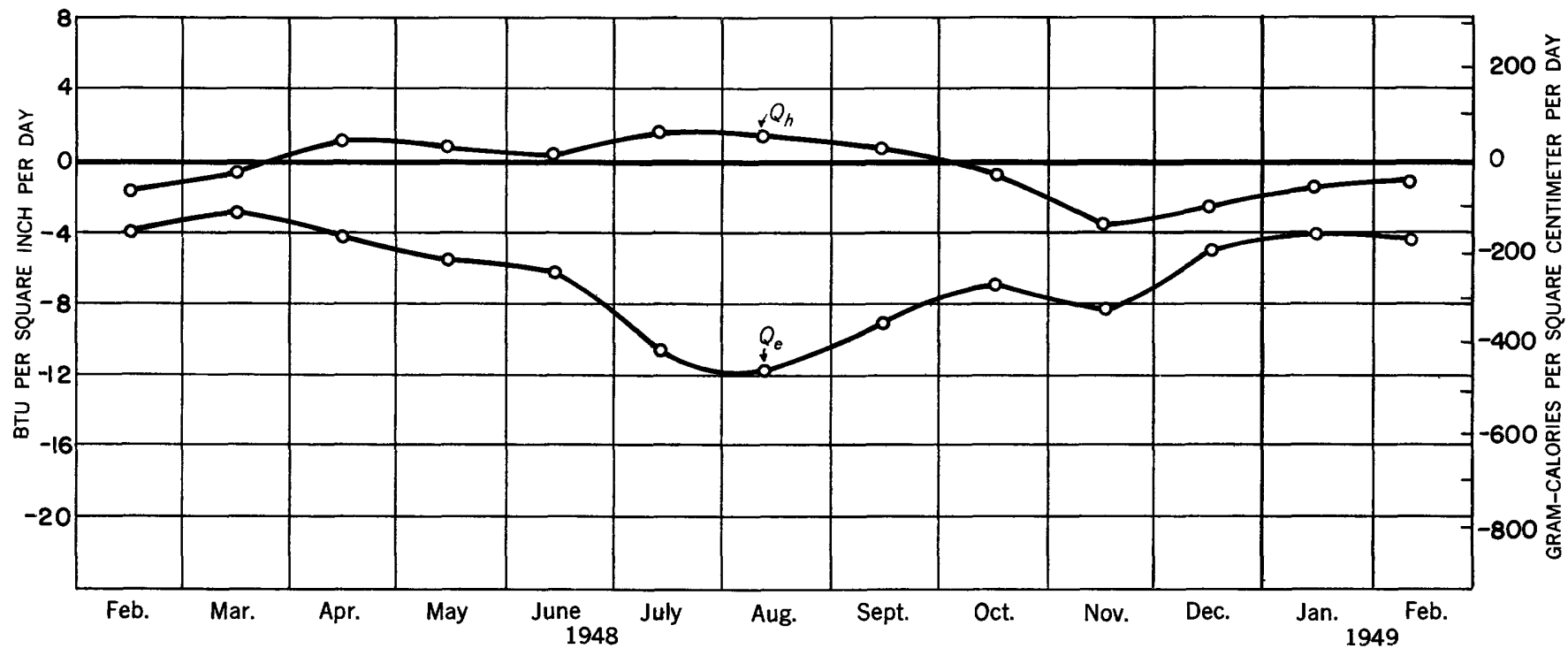

FIGURW 42.-A A verage monthly values of $Q_{e}$ and $Q_{h}$. 
TABLE 15.-Preliminary energy budget for Lake Mead

[All units are $10^{14} \mathrm{Btu}$. The convention regarding signs is the same as used in equation 1, p. 141]

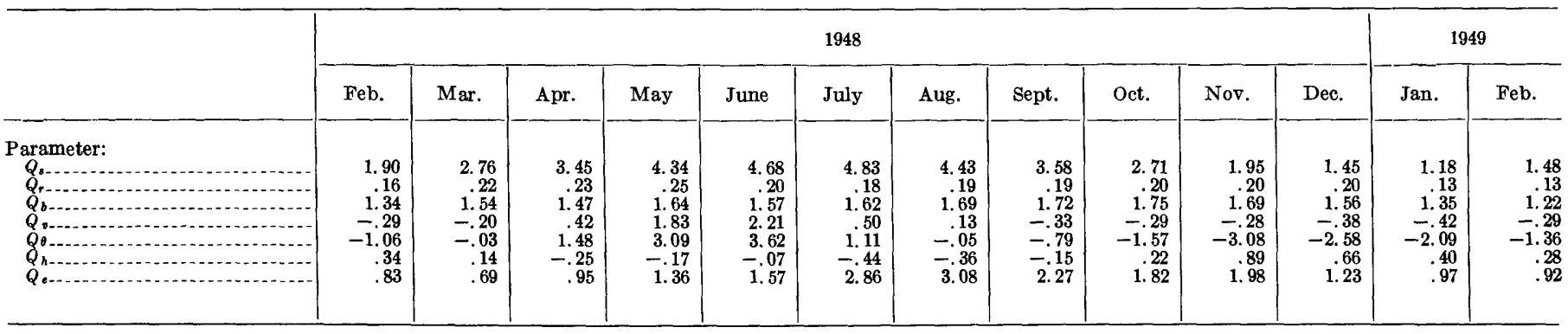

TABLE 16.-Monthly evaporation as determined from energy budget

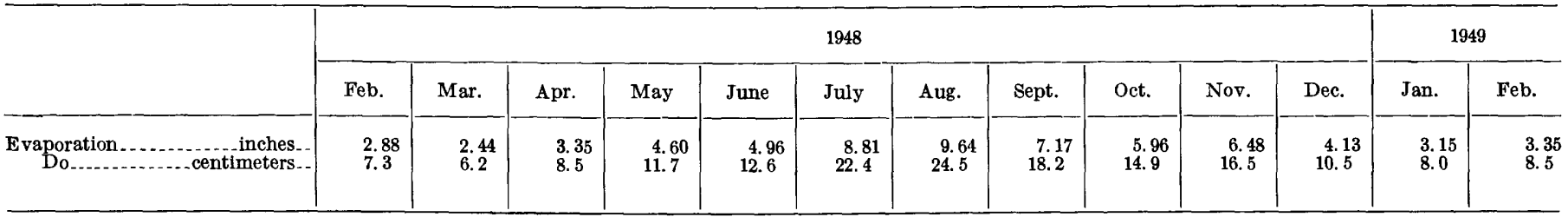

of energy utilized or supplied by the various processes entering into the energy budget for Lake Mead. The values given are totals for the month in British thermal units. An inspection of the table reveals that tremendous quantities of energy are represented in the various parameters. The energy utilized by evaporation in August is approximately three-fourths of that which was made available to the lake by solar radiation; in March it is about one-fourth of that which was supplied by solar radiation.

The volume of monthly evaporation, in centimeters and inches, as computed for the 13 months of this investigation is shown in table 16 . The greatest evaporation occurred in August, when approximately 9.6 inches of water was evaporated, and the minimum was 2.4 inches in March. In February 1948 the evaporation was about one-half inch less than in February 1949, indicating that year-to-year variations occur. The computed total evaporation was 67.1 inches (169.8 centimeters) for the 13 months covered by the investigation; by averaging the February evaporation, the annual rate of evaporation was about 64 inches. The monthly average of 5.2 inches (13.1 centimeters) may be compared with a monthly average of 3.3 inches (8.4 centimeters) for the oceans of the world.

In table 17 the computed monthly volume of evaporation is compared with the monthly volumes of Lake Mead and the monthly outflow of the lake. The percentage of the volume of lake that is evaporated is at a maximum in August, when its value is 0.4 percent, and at a minimum in March, when it is 0.1 percent. The estimates indicate that during August a quantity of water equal to 11 percent of the outflow is evaporated. Over the 13-month period, an average of 0.24
TABLE 17.-Comparison of evaporation with other pertinent factors

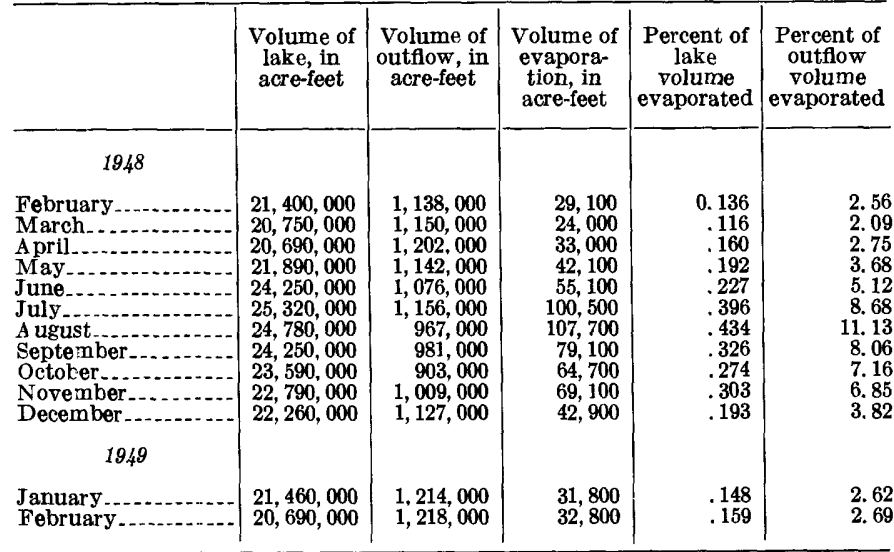

Annual evaporation:

Year keginning February 1, 1948: 679,000 acre-feet

Year beginning March 1, 1948: 683,000 acre-feet

percent of the average monthly volume of the lake, and 5.2 percent of the average monthly outflow was utilized by evaporative processes.

\section{COMPARISON WITH RATES OF PAN EVAPORATION}

Previous estimates of evaporation have been obtained by utilizing evaporation pans located on the shores of the lake and others floating in the body of water. It is recognized that pan measurements are an index of the lake's evaporation, but the nature of the correction to be applied is poorly understood. As a result, the general practice is to apply some arbitrary index correction to the pan-evaporation data to obtain a lake-evaporation estimate. Figure 43 represents a comparison of the evaporation as computed by this study with evaporation as measured at a land pan at Boulder City, 


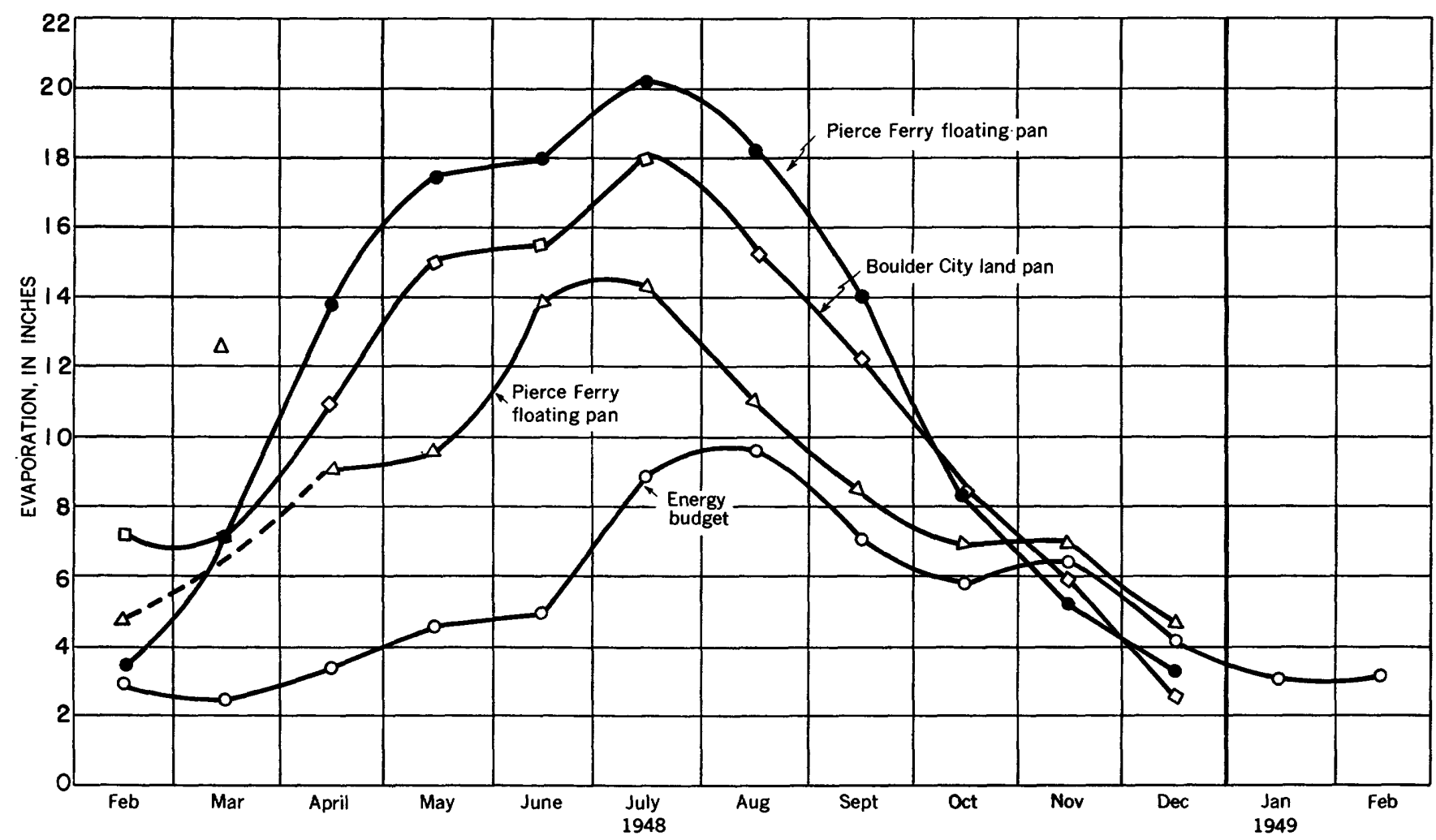

FIGURE 43.-Comparison of evaporation as computed from energy budget with pan evaporation.

Nev., and a land pan and a floating pan located at Pierce Ferry. It is evident from the figure that during most of the year all the evaporation pans give values considerably higher than those computed from the energy budget. The maximum evaporation from the pans occurred during July, but the maximum value computed from the energy budget occurred during August. This was probably caused primarily by the seasonal temperature lag of the lake. The curves show a marked seasonal variation in the ratio between evaporation as measured by land pans and as computed by the energy budget. The evaporation from the Pierce Ferry land pan during the months of high evaporation was nearly double that obtained by the energy budget, but during the months of October, November, and December the pans and the energy budget were in close agreement. The primary cause of these variations is again the seasonal temperature lag of the water body as compared to the air, which would result in both the lake and the pans having similar temperature structures during the fall, and the closer agreement of computed values. It is interesting to note the similarity in shape of the energy-budget evaporation curve and that for the floating pan located at Pierce Ferry. (Only one point, that for March, shows major disagreement. Since the disparity is so large, the pan evaporation for this month was assumed to be in error.) The pan obtained its maximum temperature in July and the lake in August; thus the evaporation maximum was displaced by a time interval of 1 month.

Finally, it may be concluded that the index correction for the pans varies from month to month, having a maximum value for the summer and a minimum for the fall and early winter transition season. It seems almost certain that the use of a constant pan index will lead to erroneous monthly results.

\section{REFERENCES CITED}

Anderson, E. R., Anderson, L. J. and Marciano, J. J., 1950, A review of evaporation theory and development of instrumentation (Lake Mead water loss investigations interim report) : Navy Electronics Laboratory Rept. 159, 62 p.

Anderson, E. R. and Pritchard, D. W., 1951, Physical limnology of Lake Mead: Navy Electronics Laboratory Rept. 258, $152 \mathrm{p}$.

Ångström, A., 1920, Applications of heat radiation measurements to the problem of the evaporation from lakes and the heat convection of their surfaces: Geog. Annaler, v. 2, p. 237.

Bowen, I. S., 1926, The ratio of heat losses by conduction and by evaporation from any water surface: Phys. Rev., 2d ser., v. 27, p. 779-787.

Cummings, N. W., 1940, The evaporation-energy equations and their practical application: Am. Geophys. Union Trans. v. 21, p. 512-522.

Defant, A., 1929, Stabile Lagerung ozeanischer Wasserkörper und dazu gehörige Stromsysteme: Berlin Univ. Inst. Meereskunde Veröff., A. Geog.-naturwiss. Reihe, v. 19. 
Helland-Hansen, B., 1916, Nogen hydrografiske metoder: Skandinaviske Naturforskeres Möte.

Kennedy, R. E., 1949, Computation of daily insolation energy : Amer. Meteorol. Soc. Bull., v. 30, p. 208-213.

Koberg, G. E., 1958, Energy-budget studies, in. Harbeck, G. E. Jr., Kohler, Max, Koberg, G. E., and others, Water-loss investigations-Lake Mead studies: U.S. Geol. Survey Prof. Paper 298, p. 20-29.

Schmidt, W., 1915, Strahlung und Verdunstung an freien Wasserfiächen; ein Beitrag sum Wärmehaushalt des Weltmeers und zum Wasserhaushalt der Erde: Annalen der Hydrographie und maritimen Meteorologie, v. 43, p. 111.

Spilhaus, A. F., 1937-38, A bathythermograph: Jour. Marine Research, v. 1, p. 95-100.

Sverdrup, H. U., Johnson, M. W. and Fleming, R. H., 1946, The oceans, their physics, chemistry, and general biology: New York, Prentice-Hall, p. 98-152.

Thorade, H., 1931, Strömung und zugenförmige Ausbreitung des Wassers: Beitr. angew. Geophysik, v. 34, p. 57.

Wüst, G. 1935, Die Stratosphäre: Deutsche atlantische Expedition Meteor, 1925-27, v. 6, pt. 2. 


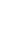




\title{
N. GHARAGTER OF THE ACGUMULATED SEDIMENT
}

\author{
By H. R. Gould, U.S. Geological Survey
}

\section{METHODS OF INVESTIGATION}

The field investigation of the accumulated sediment in Lake Mead was made between December 1947 and April 1949, using modern oceanographic equipment and techniques. A plane-personnel boat, furnished by the Navy and equipped for light hydrographic work, was used extensively in the collection of samples from the upper layers of the deposited sediment and of the suspended sediment in the overlying water. Profiles obtained by echo sounding (chap. G), supplemented by many line soundings and bottom samples, constitute the basic data used in determining the areal distribution and surface features of the accumulated sediment. The pontoon barge, equipped with powerful winches and a boom capable of handling heavy coring devices, was used in obtaining cores from the accumulated sediment.

Samples and soundings of the bottom in the shallow water of Lower Granite Gorge were obtained from a sea sled or air boat, a fast, shallow-draft vessel powered by an airplane engine and propeller mounted at the stern of the boat. The sea sled proved highly successful in traversing the shallow river bars and fast water in Lower Granite Gorge, where boats of more conventional design could not be operated.

Preliminary soundings and samples from the bottom of Lake Mead, together with data collected during density-current studies prior to 1947 (National Research Council, 1949), showed that most of the sediment in the lake had accumulated in the area of the submerged Colorado River channel and in the northern part of the inundated Virgin River valley (Overton Arm).

In order to obtain a representative picture of the accumulated sediment, 46 cores and more than 300 samples were collected. The cores were cut into segments 6 to 12 inches long and stored in airtight containers. Counting these core segments, more than 1,800 samples were studied. The number of cores and samples of various types and their distribution throughout the lake are summarized in table 18, and the location of all coring and sampling positions are shown in plate 19. Characteristics of the samples and associated hydrographic data are summarized in a supplemental report (U.S. Geol. Survey, 1954).

Of the 46 cores, 43 were collected in the vicinity of the inundated Colorado River channel between the mouth of Lower Granite Gorge and Hoover Dam, and 3 were obtained near the mouth of the Virgin River in the northern part of Overton Arm. No cores were collected from the sediment deposits in Lower Granite Gorge, because that part of the deposit consists chiefly of compact sand that could not be sampled at depth by conventional coring methods.

The sediment deposit between Pierce Basin and Hoover Dam is chiefly soft mud, which could readily be sampled at depth. At most stations in Boulder Basin and Virgin Basin, cores were collected from the total thickness of the accumulated sediment, but the lower part of the deposit was penetrated in only a few places farther east. Compact layers of silt and sand,

TABLE 18.-Distribution of cores and samples from the sediment accumulated in Lake Mead

[Figures in parentheses indicate number of cores. Cores were cut into segments 6-10 inches long, each of which constituted one sample]

\begin{tabular}{|c|c|c|c|c|c|c|c|c|c|c|c|}
\hline Coring or sampling instrument & \multicolumn{11}{|c|}{ Sampling areas and number of cores and samples } \\
\hline $\begin{array}{l}\text { Gravity corer } \\
\text { Piston corer } \\
\text { Foerst sampler-ar } \\
\text { Snapper sampler } \\
\text { Dipper } \\
\text { Pick }\end{array}$ & $\begin{array}{r}15(1) \\
0 \\
44 \\
1 \\
0 \\
0\end{array}$ & $\begin{array}{r}148(5) \\
153(2) \\
41 \\
0 \\
0 \\
0\end{array}$ & $\begin{array}{r}59(2) \\
78(1) \\
26 \\
1 \\
0 \\
0\end{array}$ & $\begin{array}{r}184(10) \\
68(1) \\
41 \\
2 \\
0 \\
0\end{array}$ & $\begin{array}{r}68(3) \\
75(1) \\
16 \\
0 \\
0 \\
0\end{array}$ & $\begin{array}{r}68(2) \\
0 \\
23 \\
0 \\
0 \\
0\end{array}$ & $\begin{array}{r}114(5) \\
0 \\
31 \\
0 \\
0 \\
0\end{array}$ & \begin{tabular}{r|}
$213(7)$ \\
$243(3)$ \\
48 \\
3 \\
0 \\
0
\end{tabular} & $\begin{array}{l}0 \\
0 \\
0 \\
0 \\
9 \\
4\end{array}$ & $\begin{array}{r}12(3) \\
0 \\
0 \\
18 \\
0 \\
0\end{array}$ & $\begin{array}{r}881(38) \\
617(8) \\
270 \\
25 \\
9 \\
4\end{array}$ \\
\hline Total. . & $60(1)$ & $342(7)$ & $164(3)$ & $295(11)$ & $159(4)$ & $91(2)$ & $145(5)$ & $507(10)$ & 13 & $30(3)$ & $1,806(46)$ \\
\hline
\end{tabular}

$4969180-60-11$ 
which had been contributed by slumping of the reservoir walls or deposited by the Colorado River during the initial filling of the reservoir, limited the depth of penetration in some areas; but in others, notably between Iceberg Canyon and Pierce Basin, the length of the core tube was the limiting factor. A maximum depth penetration of 95.5 feet (core 63) was reached by the coring equipment at mile $283.64,{ }^{14}$ in the lower part of Pierce Basin.

Most of the cores were obtained with a gravity corer, similar in design to the coring instrument described by Emery and Dietz (1941) but modified to accommodate the great thickness of the sediment accumulated in Lake Mead. The purpose of this device is to obtain a continuous core of the strata penetrated. As the name implies, the gravity corer is forced into the bottom by the gravitational pull exerted on the tube and the attached weights. Altogether, 38 gravity cores were obtained. Penetration depths ranged from 2.0 to 95.5 feet, and the cores ranged in length from 1.0 to 31.0 feet. The recovery ratios ranged from 24.6 to 57.7 percent and averaged 35.5 percent, as shown in table 19.

The gravity corer commonly yields a shortened or compressed core because of sidewall friction and resistance of the material to pentration. Emery and Dietz have demonstrated that, in a deposit whose density increases with depth, the sidewall friction and resistance to penetration balance each other in such a way that equal increments of each layer are obtained. These observations are substantiated in the most part by cores taken from the sediment accumulated in Lake Mead. Laminae ranging in thickness from a fraction of an inch to several feet are preserved in the cores with little deformation. The ratios of core length to penetration depth are plotted in figure 44. A best-fit visual line drawn through these points shows that the relation between core length and penetration depth is approximately linear. This relation has been used in adjusting the positions of samples from the cores to their estimated depths in the place of occurrence.

Toward the end of the field period, a new type of coring device was constructed by the Geological Survey and used at Lake Mead. This instrument, known as a piston corer, was adapted by W. O. Smith from the device designed by Kullenberg (1947). The piston corer is essentially a gravity corer that utilizes the hydrostatic pressure at the bottom to force the sediment into the tube. The same drawbacks that were discussed in connection with the gravity corer-namely, the internal sidewall friction and the resistance of the

\footnotetext{
${ }^{14}$ Distances are measured downstream from the Geological Survey marker opposite the mouth of the Paria River, along the pre-Lake Mead channel of the Colorado River.
}

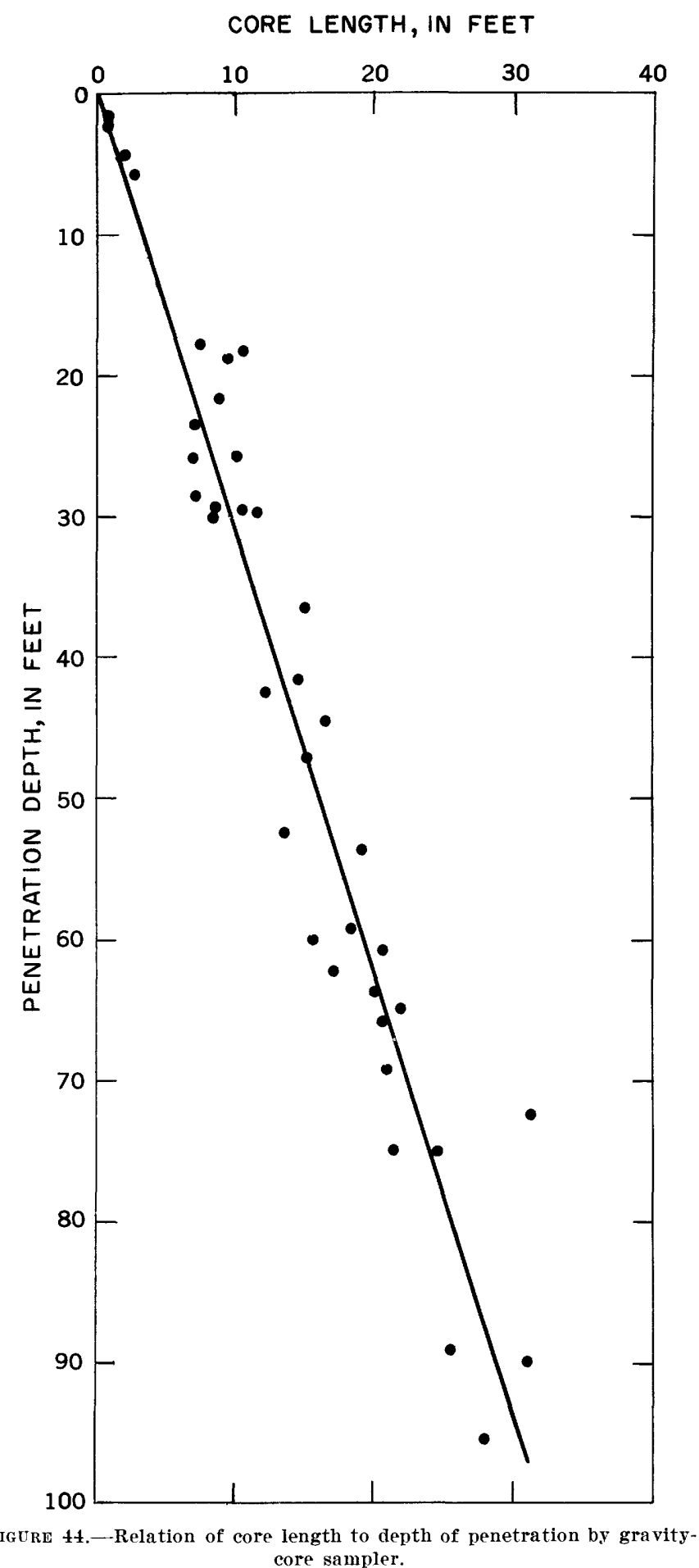

sediment against being pushed aside or downwarped at the bottom of the tube-apply also to the piston corer, but to a lesser degree. The piston corer, by utilization of hydrostatic pressure, effectively increases the resistance of the sediment against being pushed aside or downwarped. As a result, the cores are considerably longer than those taken by the gravity de- 
TABLE 19.-Penetration depths and core lengths obtained by gravity core sampler

[Location of cores is shown on pl. 19]

\begin{tabular}{|c|c|c|c|}
\hline Core & $\begin{array}{l}\text { Penetration } \\
\text { depth, } \\
\text { in feet }\end{array}$ & $\begin{array}{c}\text { Core length, } \\
\text { in feet }\end{array}$ & $\begin{array}{c}\text { Recovery, in } \\
\text { percent }\end{array}$ \\
\hline $\begin{array}{l}\mathbf{3}_{1} \\
\mathbf{8} \\
16\end{array}$ & $\begin{array}{l}72.0 \\
90.0 \\
18.2 \\
53.7 \\
65.0\end{array}$ & $\begin{array}{l}31.0 \\
31.0 \\
10.5 \\
19.0 \\
22.0\end{array}$ & $\begin{array}{l}43.1 \\
34.4 \\
57.7 \\
35.4 \\
33.8\end{array}$ \\
\hline 18 & $\begin{array}{l}60.7 \\
52.7 \\
46.5 \\
28.5 \\
23.5\end{array}$ & \begin{tabular}{r|}
20.5 \\
13.5 \\
14.5 \\
7.0 \\
7.0
\end{tabular} & $\begin{array}{l}33.8 \\
25.6 \\
31.2 \\
24.6 \\
29.8\end{array}$ \\
\hline 2425 & $\begin{array}{r}42.5 \\
36.7 \\
29.7 \\
5.8 \\
18.8\end{array}$ & $\begin{array}{r}12.1 \\
15.0 \\
11.5 \\
2.0 \\
9.5\end{array}$ & $\begin{array}{l}28.5 \\
40.9 \\
38.7 \\
34.5 \\
50.5\end{array}$ \\
\hline $\begin{array}{l}35 \\
36 \\
36 \\
38 \\
39\end{array}$ & $\begin{array}{r}4.5 \\
5.7 \\
2.1 \\
41.8 \\
21.2\end{array}$ & $\begin{array}{r}2.1 \\
2.9 \\
1.0 \\
14.5 \\
8.8\end{array}$ & $\begin{array}{l}46.7 \\
50.9 \\
47.6 \\
34.7 \\
41.5\end{array}$ \\
\hline (2n & $\begin{array}{l}26.0 \\
43.5 \\
59.1 \\
29.7 \\
29.5\end{array}$ & $\begin{array}{r}10.0 \\
17.7 \\
18.2 \\
10.5 \\
8.5\end{array}$ & $\begin{array}{l}38.5 \\
40.7 \\
30.8 \\
35.4 \\
28.8\end{array}$ \\
\hline $\begin{array}{l}45 \\
46 \\
46\end{array}$ & $\begin{array}{l}30.0 \\
17.8 \\
65.8 \\
63.8 \\
89.1\end{array}$ & $\begin{array}{r}8.2 \\
7.5 \\
20.5 \\
20.0 \\
25.5\end{array}$ & $\begin{array}{l}27.3 \\
42.1 \\
31.2 \\
31.3 \\
28.6\end{array}$ \\
\hline 63 & $\begin{array}{r}95.5 \\
26.0 \\
2.0 \\
75.0 \\
69.3\end{array}$ & $\begin{array}{r}28.0 \\
6.8 \\
1.0 \\
24.5 \\
21.0\end{array}$ & $\begin{array}{l}29.3 \\
26.2 \\
50.0 \\
32.7 \\
30.3\end{array}$ \\
\hline $\begin{array}{l}73 \\
74 \\
76\end{array}$ & $\begin{array}{l}60.0 \\
62.5 \\
75.0\end{array}$ & $\begin{array}{l}15.5 \\
16.0 \\
21.5\end{array}$ & $\begin{array}{l}25.8 \\
25.6 \\
28.7\end{array}$ \\
\hline A ver & . & 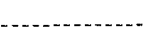 & 35.5 \\
\hline
\end{tabular}

vice. If the hydrostatic pressure is great enough, cores equal in length to the depth of penetration can be obtained. The eight cores obtained with this instrument were extremely useful in evaluating the accuracy of depth corrections applied to gravity core samples, and in providing relatively undisturbed samples for laboratory analyses.

As shown in table 20, the piston cores ranged in length from 36.5 to 75.0 feet and the depths of penetration ranged from 25.5 to 79.0 feet, thus representing a range in recovery ratios of 70.2 to 143 percent. The low recovery ratios of cores $\mathrm{K} 1$ and $\mathrm{K} 2$ were caused by loss of sediment from the bottom of the tube and by operational errors, resulting in the failure of the tube to sample the upper few feet of sediment. Core shortening also occurred in shallow-water areas where hydrostatic pressure was probably insufficient to overcome the internal sidewall friction between the sediment and the coring tube, as for example, cores $\mathrm{K} 5$ and $\mathrm{K} 6$. The high recovery ratios of cores $\mathrm{K} 1 \mathrm{c}$ and $\mathrm{K} 7$ resulted from failure of the tube to penetrate the sediment deposit to its full length. Under such
TABLE 20.-Penetration depths and core lengths obtained by piston core sampler

[Location of cores is shown on pl. 19]

\begin{tabular}{|c|c|c|c|}
\hline Core & $\begin{array}{l}\text { Penetration } \\
\text { depth, in } \\
\text { feet }\end{array}$ & $\begin{array}{c}\text { Core length, } \\
\text { in feet }\end{array}$ & $\begin{array}{c}\text { Recovery, in } \\
\text { percent }\end{array}$ \\
\hline $\begin{array}{l}\mathrm{K} 1 \mathrm{~K} \\
\mathrm{~K} 1 \mathrm{c} 2 \\
\mathrm{~K} 3 \mathrm{~K} \\
\mathrm{~K} 5 \mathrm{~K} \\
\mathrm{~K} 6 \mathrm{M}\end{array}$ & $\begin{array}{l}70.5 \\
70.0 \\
68.0 \\
43.5 \\
43.5 \\
76.5 \\
79.0 \\
25.5\end{array}$ & $\begin{array}{l}49.5 \\
75.0 \\
51.0 \\
43.5 \\
43.5 \\
69.0 \\
70.5 \\
36.5\end{array}$ & $\begin{array}{r}70.2 \\
107.0 \\
7.0 \\
100.0 \\
100.0 \\
90.2 \\
89.2 \\
143.0\end{array}$ \\
\hline
\end{tabular}

conditions, withdrawal of the instrument created an initial upward movement of the piston while the tube was still stationary, creating a vacuum in the tube and thus inward movement of extra sediment under hydrostatic pressure.

Except for cores $\mathbf{K} 5$ and $\mathbf{K} 6$, only minor adjustments in the positions of the samples in the core tube were required to obtain their approximate depths in place. Physical properties of gravity core samples, corrected for depth in place, correlate closely with the physical properties of the piston core samples taken at the same locations.

Samples of sediment in suspension and in the soft upper layers of the accumulated material west of mile 279.3 were obtained with a Foerst sampling bottle, modified for sampling of the soft mud in Lake Mead. The modified Foerst sampler is essentially an open lucite cylinder with rubber stoppers mounted at both ends, with a heavy brass weight, attached to the top stopper and suspended below the cylinder, to pull the instrument through mud and to insure positive closing action at depth. The device is lowered to the selected sampling depth in an open position, which allows a free flow of material through it. When the sampling depth is reached, a messenger is sent down the cable to trip the stopper release mechanism and hold the sample within the cylinder. Samples taken with the Foerst bottle measure about 18 inches in length. of which the lowest part appears to consist of material that entered the tube from the depth of maximum penetration and is probably uncontaminated by sediment from higher levels. Only the bottom 4 inches of each sample was saved for laboratory analysis.

Foerst samples were collected at 35 stations, 32 of which have the same field locations as the gravity cores (pl. 19). Because depths of the Foerst samples could be measured accurately, they were extremely useful in checking the corrected depths of gravity core samples obtained at identical positions. Throughout their range of overlap there was good correspondence between the physical properties of Foerst samples and gravity core samples. 
In the area immediately above Hoover Dam and below the location of the cofferdam (p. 113), the accumulated material was too fluid to be retained by either the gravity corer or the piston corer. No difficulty was encountered, however, in sampling this part of the deposit to a maximum depth of 99 feet with the weighted Foerst sampling bottle. Descriptions of the Foerst samples are given in a supplemental report (U.S. Geol. Survey, 1954).

The Foerst sampler was also used extensively for measuring the depth to the interface between the lake water and the accumulated sediment, and for providing information on the nature of that interface. Measurements to the level of the surface of the deposit by this method were accurate to within a few tenths of a foot, whereas the limit of accuracy of echo-sounding measurements in most areas was from 1 to 3 feet. Except for a few periods when the bottom of the eastern part of the lake was masked by turbidity currents (p. 165), the interface between the water and the accumulated sediment was sharp and distinct.

Samples from the surface of the sediment deposit in Overton Arm and a few samples of the original lake bottom in areas of nondeposition were obtained with a snapper-type bottom sampler designed by LaFond and Dietz (1948). In Lower Granite Gorge samples from the subaqueous part of the deposit were collected with a dipper, and the subaerial part of the deposit was channel-sampled with a geologist's pick. The various types of surface samples are listed separately in table 18, but all are grouped as "grab samples" in plate 19 (in pocket).

\section{MISCELLANEOUS OBSERVATIONS}

Although the collection of cores and samples from the accumulated sediment received the greatest emphasis, a number of other studies were undertaken. These studies included the measurement of vertical temperature gradients in the sediment deposits and photography of the lake bottom in a few areas of critical interest. In areas where there was only a thin layer of sediment, penetration measurements were made to determine its thickness. A large number of water samples collected in conjunction with studies of the water of the lake (chaps. $\mathbf{K}-\mathbf{M}$ ) were analyzed for their suspended sediment. The measurements, together with the results of the circulation studies, provided considerable information on the effectiveness of turbidity currents as agents of sediment transportation.

\section{LABORATORY STUDIES}

Laboratory studies of samples and cores began in the spring of 1948 , in space provided by the Bureau of Reclamation in the Hoover Dam powerhouse, and continued concurrently with the field work until April 1949. Routine analyses of all cores and samples included more than 1,400 water-content measurements, about 300 particle-size analyses, 117 specific-gravity determinations, and a comparison of the color of all cores and samples with the standard Munsell soil-color chart. In addition, the specific weights (p. 153) of 74 piston-core samples were determined directly in the field, primarily to check the accuracy of computed specific-weight values obtained from water-content and specific-gravity measurements, and also to measure directly the volume of gas (mostly methane) in the cores.

Since April 1949 several other types of analyses requiring specialized equipment and techniques have been made. Among these are the determinations by the writer of the organic content and calcium carbonate content of several selected samples, the bacteriological and biochemical studies by F. D. Sisler (p. 187-193), and analyses by the U.S. Bureau of Mines of the gas occurring in the deposits. The Bureau of Mines also investigated the sediment for its ceramic qualities and other commercial uses; the geochemical laboratories of the Geological Survey at Washington, D.C., made chemical, X-ray, and spectrographic analyses of a number of samples; and George Tchillingarian of the University of Southern California investigated the suitability of the sediment for use in a drilling fluid. The results of these various special analyses are presented in the discussion of the characteristics of the accumulated sediment.

Most of the laboratory methods used in measuring the physical properties of the Lake Mead sediments do not differ markedly from standard procedures outlined in most textbooks on sedimentary petrology and soil mechanics. However, because of their critical bearing on the results of the sedimentation studies as a whole, a brief discussion of them is given here.

\section{WATER CONTENT AND AIR-DRY MOISTURE CONTENT}

The method of measuring the water content and airdry moisture content consists of weighing out about 25 grams of the wet sample, exposing it to the air for several days until dry, and weighing again (Sherman, 1951). The sample is then allowed to dry in an oven at a temperature of $105^{\circ} \mathrm{C}$ for 24 hours, after which it is weighed a third time. The difference between the wet weight and the oven-dry weight is a measure of the water content and may be computed from the formula:

$$
W . C .=100 \frac{W_{w}-W_{d}}{W_{w}},
$$


where $W . C$. is the water content in percent, $W_{w}$ is the weight of the wet sample in grams, and $W_{d}$ is the weight of the oven-dry sediment in grams.

The air-dry moisture content is obtained from a similar formula:

$$
\text { M. C. }=100 \frac{W_{a}-W_{d}}{W_{a}},
$$

where $M . C$. is the air-dry moisture content in percent, $W_{a}$ is the weight of the air-dry sample in grams, and $W_{d}$ is the weight of the oven-dry sediment in grams. Variations in the air-dry moisture content have proved useful in the selection of samples with significant differences in texture for particle-size analyses (Sherman, 1951). Terzaghi and Peck (1948) have shown that the air-dry moisture content is inversely related to the average particle size, ranging from a fraction of 1 percent for sand to 6 or 7 percent for clay. These observations were verified by the Lake Mead measurements where the air-dry moisture content ranges from 0.1 percent for medium sand to about 6 percent for clay having a median particle diameter less than 1 micron.

\section{SPECIFIC GRAVITY OF SEDIMENT PARTICLES}

The specific gravity of the sediment particles was determined by the conventional pycnometer method described by Krumbein and Pettijohn (1938). Relatively large samples weighing 5 to 6 grams, were used in order to avoid errors introduced by working with small differences in weights. Care was taken to remove all air bubbles from the pycnometers by applying suction to them for about 12 hours before the final weighings were made. On 72 samples, selected from widely separated positions, 117 specific-gravity measurements were made. Duplicate analyses of 45 of the samples show that the variation of measurement by this method is not greater than 0.5 percent.

The specific gravities of silt and clay samples range from 2.640 to 2.760, and of sand samples from 2.630 to 2.660. The mean specific gravity of silt and clay samples is 2.705 and of sand samples is 2.645 . These mean values have been used in the indirect determination of cerain other physical properties of the sediment deposits, which are described in the following pages.

\section{DENSITY, POROSITY, AND SPECIFIO WEIGHT}

The density of a sediment deposit is the ratio of the weight of the sediment plus its included water (or, in the more fluid samples, of the water and its included sediment) to the weight of an equivalent volume of water alone. It is recognized that the density of water changes with temperature, and these changes are significant factors-for instance, in the development of turbidity currents (chap. Q). However, these are small in comparison with the changes that result when appreciable quantities of mineral particles are added to the water. In the determinations of density of sediment deposits, therefore, it is assumed that the weight-volume ratio of water remains constant.

In 74 piston-core samples the density was determined as the weight of the water-saturated sample divided by its volume, both expressed in metric units. The densities of these samples ranged from 1.275 to 1.971. In other samples the original volume could not be determined, because of changes occurring during collection. For these samples the density was determined indirectly by the formula

$$
D=\frac{W_{w}}{V_{w a}+\frac{W_{d}}{s g}}
$$

in which $W_{w}$ is the weight of the water-saturated sample; $V_{w a}$ the volume of interstitial water; $W_{d}$ the weight of the oven-dried sample; and $s g$ is the specific gravity of grains (as mentioned above).

Porosity, the ratio of the volume occupied by water to the total sample volume, is expressed as a percentage. In the 74 piston-core samples the volume of water was determined by weighing the sample before and after ovendrying at $105^{\circ} \mathrm{C}$, assuming a constant weightvolume ratio for the water. In the other samples the porosity was computed from the formula

$$
P=\frac{100 V_{w a}}{V_{w a}+\frac{W_{d}}{s g}}
$$

where $V_{w a}$ is the volume of interstitial water as determined by oven-drying, $W_{d}$ is the weight of the dried sample, and $s g$ is the specific gravity of the mineral grains.

Specific weight, the ratio of the weight of the solid mineral particles to the volume of the sample, is expressed in pounds per cubic foot. In the 74 piston-core samples the specific weight was determined directly as the weight of the oven-dried sample divided by the original volume of the sample and multiplied by 62.43 . For other samples the specific weight was computed by the formula

$$
S_{w}=\frac{62.43 W_{d}}{V_{w a}+\frac{W_{d}}{s g}}
$$

where $S_{w}$ is the specific weight in pounds per cubic foot and other factors have been identified above. No corrections have been made for the volume of gas in place, but the maximum error in these indirect determinations is estimated at less than 1 percent, based on measurements of the quantity of gas in 74 samples from widely separated positions. 
Because of its limited application in most geological studies, specific weight is commonly not included among the physical properties of sediments. However, it finds wide application in reservoir engineering practice. In the Lake Mead investigations the specific weight is particularly useful because it provides a relatively simple method of obtaining the total weight of the solid mineral particles deposited in the reservoir.

\section{GAS VOLUME IN PLACE}

The direct method of analysis of the piston-core samples measures the volume of gas as well as the volume of the solid mineral particles and interstitial water, but the gas in the sample occupies a much larger volume at the surface than at its true depth in place. When samples from the accumulated sediment are raised to the surface, they experience a pressure change that is equal to the difference between the pressure in place and atmospheric pressure at the surface. If no gas is present in the sediment, the sample is unaffected by this pressure change, but if gas is present, it expands to several times its volume in place. The volume of gas in samples at the surface reached a maximum of about 12 percent, but when corrected for changes in hydrostatic pressure, the maximum volume of gas in place was about 2 percent. Because of this gas expansion, direct measurements of specific weight, density, and porosity have maximum errors of approximately 5,9 , and 10 percent, respectively.

The percentage volume of gas contained in the sediment in place is obtained by the following formula :

$$
G=\frac{V_{w}-\left(V_{w a}+V_{d}\right)}{V_{w}} \times \frac{100}{P_{a}}
$$

where $G$ is the percent gas volume in place, $V_{w}$ is the volume of the sample in cubic centimeters at atmospheric pressure, $V_{w a}$ is the volume of interstitial water in cubic centimeters, $V_{d}$ is the volume of the solid mineral grains (equivalent to the weight of the dry sediment in grams divided by the specific gravity of the grains), and $P_{a}$ is the ratio between the pressure at the depth from which the sample was obtained and atmospheric pressure. The effect of temperature changes on the relative gas volumes is considered negligible and has been omitted from the formula.

\section{PARTICLE SIZE}

Determinations of particle size were made of 300 samples of fine-grained sediments, selected from widely distributed positions, both geographically and in depth, and considered, therefore, to be representative of the accumulated sediment as a whole. Sand and gravel samples from the sediment accumulated in the Lower Granite Gorge were analyzed by sieving, whereas the samples containing silt and clay were analyzed by a combination of sieving and pipetting. The methods of size analysis follow closely the general procedures outlined by Krumbein and Pettijohn (1938). However, the pretreatment of silt and clay samples differs in some significant details from most standard procedures. Since the pretreatment has a particularly critical bearing on the results of the analyses, a fairly complete description of the method used in determining the particle-size distribution of silt and clay samples is given here.

The method consisted of weighing a sufficient amount of the sample to provide about 10 grams of solid mineral particles for pipette analysis. The exact weight of the solid mineral particles was then computed from previous determinations of the water content. This procedure was followed in order to avoid drying the sample, and especially to avoid the arduous task of disaggregating the sample mechanically after it had been dried. All organic matter in the material was then removed by treating the sample with $100 \mathrm{cc}$ of a 6-percent solution of hydrogen peroxide, and placing it in a boiling bath for about 14 hours. The dissolved solids were then removed from the material by five complete washings and filtrations with a porcelain filter, after which the sample was transferred to a soil dispersion cup. A dispersing agent consisting of $75 \mathrm{cc}$ of 0.1 -normal sodium hexametaphosphate $\left(\mathrm{NaPO}_{3}\right)_{6}$, buffered to a $\mathrm{pH}$ of 9 as suggested by Tyner (1939) and diluted with $200 \mathrm{cc}$ of distilled water, was added to the sample, which was allowed to soak overnight. The material was then mixed in the dispersion cup for 10 minutes, washed through a 62-micron sieve into a 1-liter graduate cylinder, and brought up to a volume of $1,000 \mathrm{cc}$ by the addition of distilled water.

If the material retained on the 62-micron sieve amounted to more than 2 percent of the total weight of the sample, it was dry-sieved through a nest of Tyler standard screen sieves, the nominal openings of which increase uniformly from 62 microns to 4,000 microns according to the Udden (1914) and Wentworth (1922) scales, combined as shown in table 21 . The individual fractions of each grade scale were weighed and recorded. This part of the procedure was omitted for samples containing less than 2 percent of sand, and the material retained on the 62-micron mesh was recorded as the weight of the particles with diameters greater than 62 microns.

The dispersed sediment in the liter graduate was agitated for 1 minute, after which the suspended particles were allowed to settle. According to Stokes' law, a small spherical particle in liquid settles at a constant velocity that is a function of the size, shape, and density 
of the particle and of the density and absolute viscosity of the settling medium. From this relation the depths to which limiting particle sizes will travel during a given time may be computed. Samples of the suspended sediment, 25 cc in size, were withdrawn from these selected depths at measured time intervals. The limiting diameters chosen for the analyses of the Lake Mead samples correspond to the diameters smaller than 62 microns shown in table 21. Withdrawals at the limiting diameter of 0.5 micron were made, however, only for samples having an exceptionally large proportion of fine-grained material.

After the sample fractions had been dried, the residues were weighed with an accuracy of $1 \mathrm{mg}$, corrected for the weight of the dispersing agent, and converted into terms of the original weight of the total amount of suspended material. The differences between the converted weights of successive sample fractions represent the amount of material contained in the individual size grades. For example, the difference between the converted weights of the first and second fractions represent the amount of sediment contained in the coarse silt grade, $62-31$ microns.

TABLE 21.-Combined Udden and Wentworth size classification

[Grade-size divisions smaller than 62 microns follow Udden's (1914) classification; those larger than 62 microns follow Wentworth's (1922) classification. 1 micron= 0.001 millimeter]

\begin{tabular}{|c|c|c|}
\hline $\begin{array}{l}\text { Grade-size limits, diam- } \\
\text { eters in microns }\end{array}$ & Name & Grouping used in this report \\
\hline $\begin{array}{l}\text { Larger than } 256,000 \\
256,000 \text { to } 64,000 \\
64,000 \text { to } 4,000 \\
4,000 \text { to } 2,000 \\
2,000 \text { to } 1,000 \\
1,000 \text { to } 500 \\
500 \text { to } 250 \\
250 \text { to } 125 \\
125 \text { to } 62 \\
62 \text { to } 31 \\
16 \text { to } 16 \\
8 \text { to } 8 \\
4 \text { to } 2 \\
2 \text { to } 1 \\
1 \text { to } 5\end{array}$ & 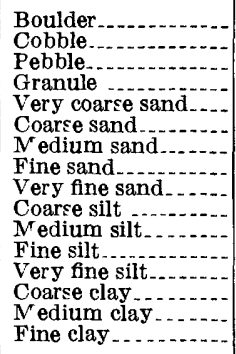 & $\left\{\begin{array}{l}\text { Gravel. } \\
\text { Very coarse sand and granules. } \\
\text { Medium and coarse sand. } \\
\text { Fine and very fine sånd. } \\
\text { Silt. } \\
\text { Medium and coarse clay. } \\
\text { Fine clay. }\end{array}\right.$ \\
\hline
\end{tabular}

The true limiting diameters differ slightly from those shown in table 21 because of small variations in the densities and shapes of particles and because of slight variations in the density and viscosity of the settling medium. The density and viscosity of the settling medium are mainly functions of its temperature, and therefore can be evaluated readily from temperature measurements. In the final computations these limiting diameters have been corrected both for temperature of the settling medium and for density of the particles, but no correction has been applied for the variation of particle shape from that of a true sphere.

The use of a dispersing agent in the laboratory analysis of the fine-grained materials poses a dilemma: On the one hand, the individual particles of deposited silt and clay, particularly if the sediment is dried or compacted, require a dispersing agent for their separation; on the other hand, such a dispersing procedure probably has no natural counterpart in Lake Mead. In order to assess the discrepancy that might accrue from the dispersing technique, duplicate analyses were made of fine silt and clay samples, showing a considerable range in texture, using untreated lake water. The results of these analyses are compared in table 22 with those obtained by dispersing the sediment. It is evident from these analyses that the silt and clay particles have settled to the bottom as flocculated masses, not as discrete units; and as would be expected, the finest material exhibits the greatest degree of flocculation. Similar studies of suspended sediment from Lake Mead turbidity currents (Sherman, 1953) and investigations of the suspended sediment in the Colorado River (Grover and Howard, 1938) show that the smaller particles also travel in a flocculated state. Sherman points out that floccule structure is at least partly a function of salinity ; however, particles larger than approximately 24 microns in diameter do not enter into floccule formation, regardless of salinity, but act independently in suspension.

TABLE 22.-Median particle diameters of samples from bottomset beds of the Colorado delta, as determined by analyses in a dispersed medium and in untreated lake water

\begin{tabular}{|c|c|c|c|c|}
\hline \multirow[b]{2}{*}{ Sample } & & & $\begin{array}{l}\text { Dispersed } 1 \\
\text { medium }\end{array}$ & $\begin{array}{l}\text { Untreated } 2 \\
\text { lake water }\end{array}$ \\
\hline & $\begin{array}{l}\text { Position, } \\
\text { as mile- }\end{array}$ & $\begin{array}{l}\text { Sediment } \\
\text { depth, in } \\
\text { feet }\end{array}$ & $\begin{array}{c}\text { Median } \\
\text { diameter, } \\
\text { in microns }\end{array}$ & $\begin{array}{l}\text { Effective } \\
\text { median } \\
\text { diameter, } \\
\text { in microns }\end{array}$ \\
\hline $\begin{array}{l}14 \\
167 \\
19\end{array}$ & $\begin{array}{l}282.3 \\
287.5 \\
350.1 \\
354.5\end{array}$ & $\begin{array}{c}0 \\
0 \\
71.6 \\
0\end{array}$ & $\begin{array}{r}5.0 \\
7.0 \\
.5 \\
.9\end{array}$ & $\begin{array}{l}13.0 \\
11.5 \\
10.0 \\
11.0\end{array}$ \\
\hline
\end{tabular}

1 Sediment dispersed with 0.896 gram of sodium hexametaphosphate $\left(\mathrm{NaPO}_{3}\right)_{6}$, per 2 Salinity of untreat

The data obtained from the sieve and pipette analyses were plotted as cumulative curves, an example of which is shown in figure 45. Attempts were made to measure the diameters of particles as fine as 0.25 micron, but the results were erratic and undependable. It was concluded that the dimensions of clay particles less than about 0.4 micron in diameter (corrected for particle density and temperature of the settling medium) could not be measured accurately by the pipette method. Krumbein and Pettijohn (1938) and others have also concluded that particles finer than approximately 0.5 micron in diameter do not obey Stokes' law, but behave rather as a colloidal suspension. This explanation accounts for the incompleteness of the curve 


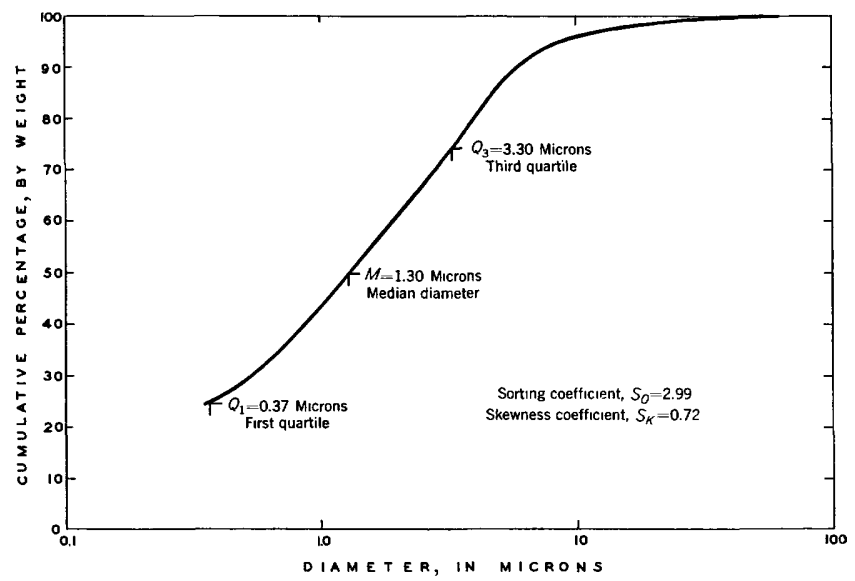

Figure 45.-Typical cumulative size-frequency curve for silt and clay samples from the sediment accumulated in Lake Mead. (Sample 266 from gravity core 16 in Boulder Canyon.)

shown in figure 45, which is typical of most of the cumulative curves for silt and clay samples from Lake Mead. From these curves, interpolated percentages of the amount of sediment in the various size grades were computed. Because of the extremely fine texture of most samples, it has been desirable in the presentation of results to group together some of the UddenWentworth grade scales (table 21).

Values of the statistical constants employed by Trask (1932)-namely, the median diameter and the coefficients of skewness and sorting-have also been determined and tabulated. The median diameter indicates the midpoint by weight of the size distribution, as determined from the cumulative curve. The coefficient of sorting is a statistical measure of the uniformity in size of the sediment particles, and is defined as

$$
S_{o}=\sqrt{\frac{\overline{Q_{3}}}{Q_{1}}},
$$

where $S_{0}$ is the coefficient of sorting, $Q_{1}$ is the lower quartile and $Q_{3}$ is the upper quartile when the frequency of sizes is cumulated in order of increasing size. For spheres of uniform size the coefficient of sorting would be 1.0 ; increase in this coefficient indicates a poorer degree of sorting. Trask has called samples well sorted if they have a coefficient of sorting less than 2.5, and poorly sorted if their coefficient of sorting is greater than 4.5 .

The asymmetry of the size-distribution curve, as shown by the position of the mode or peak of the distribution and its distance from the median, is measured by the coefficient of skewness, $S_{k}$, and may be computed from the formula,

$$
S_{k}=\frac{Q_{1} \times Q_{3}}{M^{2}}
$$

where $Q_{1}$ and $Q_{3}$ are the same quartile diameters used in the equation for the coefficient of sorting, and $M$ is the median diameter. If the modal diameter is smaller than the median diameter, $S_{k}$ is greater than 1 ; but if it is greater, $S_{k}$ is less than 1 .

The median diameter, coefficient of sorting, and coefficient of skewness for gravity-core sample 266 (fig. 45) are fairly characteristic of other silt and clay samples from Lake Mead. However, many of the samples are finer grained; so fine, in fact, that as much as 50 percent of the sample consists of particles smaller than 0.5 micron. The quartiles making up less than 25 percent of these samples could not be obtained from the cumulative curves, and it is impossible to determine sorting and skewness coefficients.

\section{DISTRIBUTION OF SEDIMENT}

The sediment that has accumulated in Lake Mead has formed two deltas, one of which extends from Bridge Canyon to Hoover Dam along the submerged channel, or thalweg, of the Colorado River, and another of much smaller size along the inundated Virgin River channel. They are referred to in this report as the Colorado delta and the Virgin delta respectively. Plate 20 shows the areal distribution of the deltas and their relations to the submerged river channels, and also shows the vertical distribution and surface features at 18 sections across the deltas and at selected positions throughout the reservoir.

\section{COLORADO DELTA}

Most of the sediment brought into Lake Mead is supplied by the Colorado River; it accumulates in the Colorado delta. The coarser particles are dropped at or near the entrance of the river into the quiet lake water, whereas the finer particles are transported into the deeper parts of the reservoir. Turbidity currents, developed at the mouth of the Colorado River (chap. $Q$ ), have been active in delta development since the inception of Lake Mead. During most seasons of the year these currents travel along the submerged channel of the Colorado River and deposit sediment continuously along its course. Several turbidity currents have traversed the entire length of the reservoir (p. 203), but others have probably traveled only short distances into the lake. These currents and the through-going inundated Colorado River channel along which they travel account for the exceptional length and extreme narrowness of the Colorado delta. As shown in plate 20, the Colorado delta is confined almost entirely to the area of the submerged Colorado River channel extending from Bridge Canyon to Hoover Dam, a distance 
of about 120 miles as measured along the course of the old channel.

The eastern 43 miles of the lake, occupying the narrow Lower Granite Gorge of the Grand Canyon and the eastern part of Pierce Basin, have been filled with sediment to a level higher than the average lake level (about 1,170 feet altitude). As shown by sections $A$ $A^{\prime}$ to $E-E^{\prime}$ (pl. 20), the Colorado delta progressively increases in thickness from Bridge Canyon to mile 277.8 , where it attains a maximum thickness of 270 feet. Topset beds make up the surface of this part of the delta, and the Colorado River now flows over them to its position of discharge in Pierce Basin (fig. 16). This part of the lake has reverted to fluviatile conditions except at high reservoir levels, when the lake extends into Lower Granite Gorge. Although some of the topset beds in the Lower Granite Gorge are above the average operating level of the reservoir (about 1,170 feet altitude), and in some places above the level of the permanent spillway crest $(1,205.4$ feet elevation), the delta in its present stage of development does not extend upstream from the original eastern end of the reservoir at mile 235 .

West of mile 277.8 , the delta lies entirely beneath the average lake surface (about 1,170 feet elevation) and is confined to the region of the submerged Colorado River channel. Foreset beds make up the surface of the delta east of mile 279.3 ; but from that point to Hoover Dam, a distance of about 75 miles, the delta is composed of bottomset beds.

In Iceberg, Virgin, Boulder, and Black Canyons steep walls bound the sediment on both sides, but in the intervening basins the delta spreads out over the terraces that flanked the inundated Colorado River channel. It is still confined, however, to the general area of the thalweg.

The valleys of tributaries to the Colorado River west of Iceberg Canyon are filled to the level of the sediment in the thalweg, but east of that canyon the sediment from the Colorado River has accumulated in the tributary valleys to somewhat higher levels. The most striking example of tributary filling occurs in Virgin Basin, where the bottomset beds of the Colorado delta fill the lower $21 / 2$ miles of the inundated Virgin River valley to the same level as the sediment in the central part of the Virgin Basin (pl. 20). The best examples of tributary filling east of Iceberg Canyon are afforded by Grapevine Bay and Grand Bay. The sediment in Grapevine Bay, about a mile south of the Colorado River channel at mile 279.2, is as much as 25 feet above the level of the sediment in the channel. Similarly, some of the sediment accumulated in Grand Bay, about 11/2 miles north of the thalweg at mile 284.6 , is almost 50 feet above the level of the sediment in the thalweg.

Sections $F-F^{\prime}$ to $N-N^{\prime}$ (pl. 20) show the range in sediment thickness from the foot of the delta front to Hoover Dam. The sediment accumulated in this region has a minimum thickness of 45 feet at mile 314.1 (section $J-J^{\prime}$ ), midway between the mouth of Virgin Canyon and Virgin Basin. From this position the delta thickens in both directions along the length of the submerged Colorado River channel. At the foot of the delta front (section $F-F^{\prime}$ ) this part of the deposit attains a maximum thickness of 155 feet. Immediately behind Hoover Dam at section $N-N^{\prime}$ the accumulated sediment is $\mathbf{1 0 6}$ feet thick.

\section{VIRGIN DELTA}

The Virgin River has supplied only about 2.4 percent of the total volume of sediment accumulated in Lake Mead; the Virgin delta is, of course, very much smaller than the Colorado delta. As shown in plate 20 , the Virgin delta occupies only the upper 14 miles of Overton Arm, and there it is restricted chiefly to the inundated channel and flood plain of the Virgin River.

Although the structure of the Virgin delta is not as clearly defined as the structure of the Colorado delta, it also probably consists of topset, foreset, and bottomset beds. At its northern end at mile 35.8, ${ }^{15}$ the delta has a thickness of less than 1 foot; the thickness increases to a maximum of 22 feet at mile 27.4 (section $Q-Q^{\prime}$, pl. 20), and then decreases in thickness to less than 1 foot at its lower end at mile 21.4.

Between the toe of the Virgin delta and Lower Narrows of Overton Arm (mile 9.3), a very thin layer of sediment has accumulated in the bottom of the former Virgin River channel. This layer is so thin that it could not be detected by echo sounding, but penetration measurements and bottom samples show that a layer of silt and clay with a maximum thickness of about 2 feet overlies the original sandy bottom of the Virgin River channel in this area. Because of the sparseness of observations, it is not known whether this layer is continuous or present only in isolated patches. Apparently, most of this material has been supplied by turbidity currents that were developed by the Virgin River.

\section{DEPOSITS FROM SMALL TRIBUTARIES}

Muddy Creek and other small tributaries to Lake Mead have undoubtedly supplied some sediment, but

15 Distances on the Virgin River are measured along the pre-Lake Mead channel, upstream from its junction with the Colorado River. 
the total quantity has been too small to be detected on the lake bottom. Numerous soundings at the mouths of Muddy Creek, Las Vegas Wash, and Hualpai Wash show no evidence of sediment accumulation in these areas. Samples from the inundated Muddy Creek channel (G528-G530, pl. 19) and penetration measurements at these sampling locations likewise suggest that no sediment has accumulated at the mouth of Muddy Creek

Some of the cores obtained from the lake bottom contain material that was probably brought in by minor tributaries, or by slumping directly into the lake. Examples are described of sediment that is probably of local origin near Detrital Wash (p. 171) and The Temple (p. 171). The total quantity of these contributions to the delta is negligible in comparison with the amount that has come from the Colorado and Virgin Rivers.

The accumulation of sediment along the thalwegs of the Colorado and Virgin Rivers and its absence in other parts of the lake are indicated by many lines of evidence. Both the acoustical sounding records (fig. 46) and numerous line soundings in all parts of the lake outside the thalweg areas agree with the topography of the original lake bottom, except in a few areas affected by landslides and wave action (p. 209, 212). Sounding weights and various oceanographic instruments that were lowered to the bottom encountered no sediment beyond the limits of the channels and their associated flood plains and terraces, although in the thalweg areas these instruments were generally covered with a thick coating of mud. Furthermore, underwater photographs of the bottom outside of the channel areas show that the vegetation growing on the reservoir floor prior to inundation has not been covered by sediment. Temperature measurements obtained by bathythermograph also denote the areal distribution of the accumulated sediment along the thalwag of the Colorado River. The temperature of the bottom in areas of sediment accumulation is higher than the temperature of the bottom in areas of nondeposition (p. 181).

\section{PHYSIOGRAPHY OF THE DELTAS

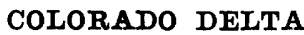 \\ TOPSET BEDS}

The topset beds that make up the surface of the Colorado delta in Lower Granite Gorge have an average slope of 1.2 to 1.3 feet per mile, over which the Colorado River flows to its position of discharge in Pierce Basin (fig. 16). Because of extreme fluctuations in river discharge and changes in lake level, the topset beds are reworked extensively. During late spring and summer, when the lake is at its highest stage, a considerable thickness of sediment is added to the topset beds in the region covered by backwater. In fall and winter, however, the lake level declines, the river cuts a channel into the deposit as it flows toward the receding lake, and the topset beds become deeply dissected. Although the actual level of the topset beds varies considerably as a function of lake stage and river discharge, observations taken by the Lower Granite Gorge field party from the fall of 1948 to the spring of 1949 show that the average gradient of 1.25 feet per mile is virtually unchanged throughout the year.

As shown by annual profiles of the Colorado delta surface (pl. 13), the average gradient of the Colorado River chamnel in Lower Granite Gorge has decreased from 7 feet per mile before the inception of Lake Mead to 1.25 feet per mile in 1948. Profiles from 1937 to 1947 are based on data collected during densitycurrent investigations (National Research Council, 1949, and U.S. Bur. Reclamation, 1949), whereas the 1948 profile, which shows considerable detail, is based on soundings during the 1948-49 survey.

The profiles represent the approximate position of the delta surface at the end of each calendar year. In constructing them, an attempt was made to distinguish between sediment that had been deposited and that which was still in suspension above the delta surface. As a result the profiles in plate 13 differ slightly in some places from the altitudes of the water-sediment interface as initially recorded. Because of inadequate data, the profiles in Lower Granite Gorge required considerable extrapolation for years prior to 1948, but they are sufficiently accurate to show that the declivity of the topset beds during this period has been markedly less than the slope of the buried Colorado River channel.

The filling of the narrow V-shaped bottom of Lower Granite Gorge has produced other notable changes in the characteristics of the Colorado River. Prior to the flooding of the reservoir, the Colorado River in this region was confined to a narrow, sinuous canyon, ranging in width from less than 100 feet near Bridge Canyon (section $\mathbf{A}-\mathbf{A}^{\prime}$, pl. 20) to about 250 feet near the Grand Wash Cliffs (section $E-E^{\prime}$ ). By 1948, however, the Colorado River had been elevated to a considerably wider part of the canyon. The width of Lower Granite Gorge at the surface of the topset beds then ranged from 200 feet at Bridge Canyon to 2,000 feet near the Grand Wash Cliffs. Although the Colorado River channel in 1948 did not occupy the full width of the gorge, except during extreme floods and at high lake stages, it was a great deal wider than the former channel at the bottom of the canyon. As shown by sections 

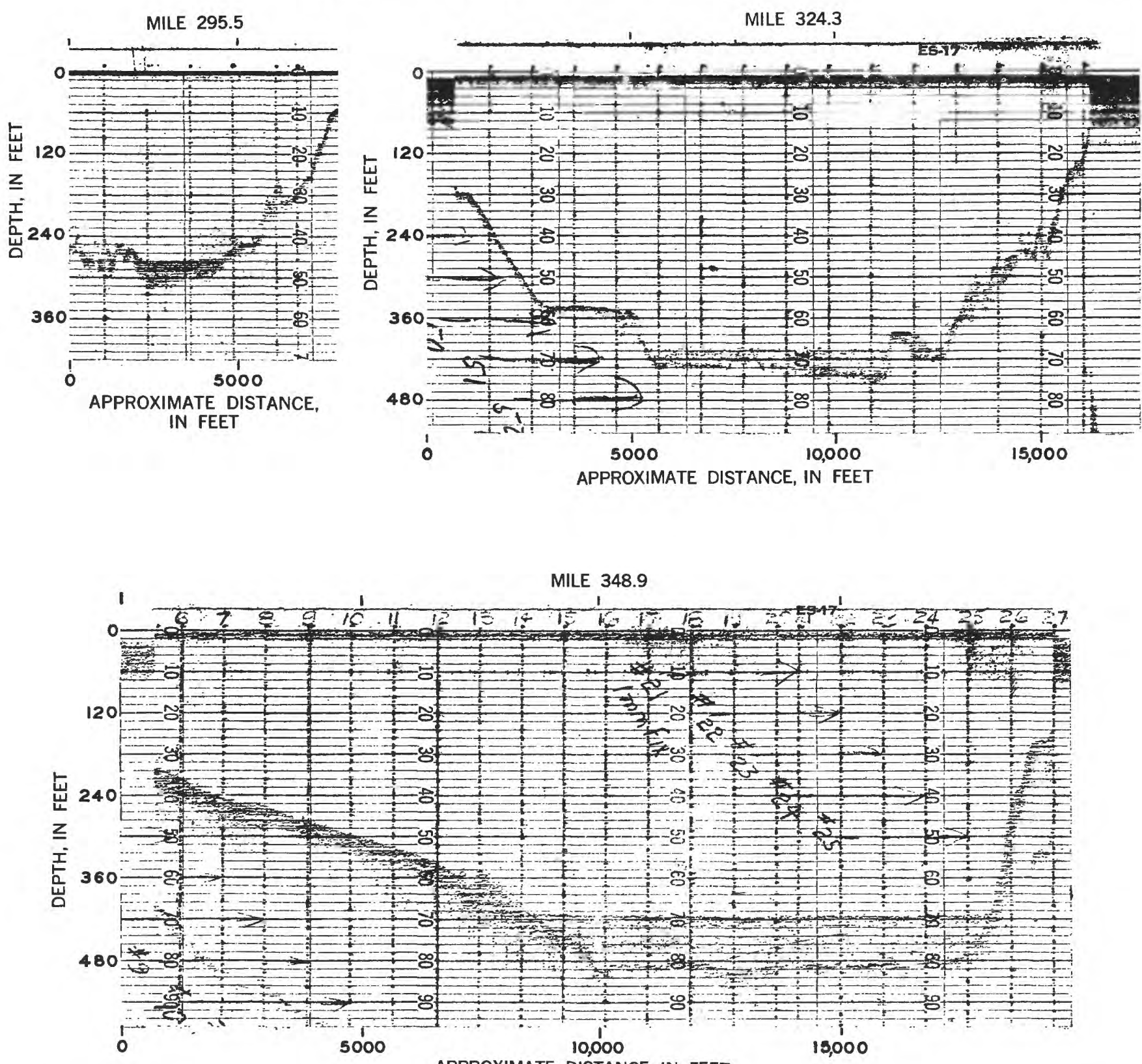

FigURE 46.-Fathograms obtained by low-frequency echo-sounding equipment in Gregg, Virgin, and Boulder Basins. Upper horizontal trace shows the sediment surface, and lower trace delineates the pre-Lake Mead topography.

$\mathrm{A}-\mathrm{A}^{\prime}$ to $\mathrm{E}-\mathrm{E}^{\prime}$, the width of the 1948 channel ranged from 200 to 600 feet, two to three times as wide as the former channel in the bottom of the canyon.

With its lesser slope and greater width, the Colorado River in Lower Granite Gorge had assumed by 1948 the characteristics of a mature stream, in contrast to the vigorous young stream that formerly flowed in the narrow V-shaped notch at the bottom of the gorge. In 1948 the Colorado River channel throughout most of its length followed a meandering course, which conformed in general to the winding plan of Lower
Granite Gorge. The convex sides of its meanders extended several feet above the water surface, whereas the concave sides stood at considerably lower levels and in some places were cut back to the bare rock walls of Lower Granite Gorge. Large eddies formed where the river changed its course abruptly and cut deep holes in the channel. As shown in plate 13, the 1948 channel was characterized by numerous bars and holes, similar to those recorded in the buried Colorado River channel (U.S. Soil Conservation Service, 1935). In Lower Granite Gorge the Colorado River, like other meander- 


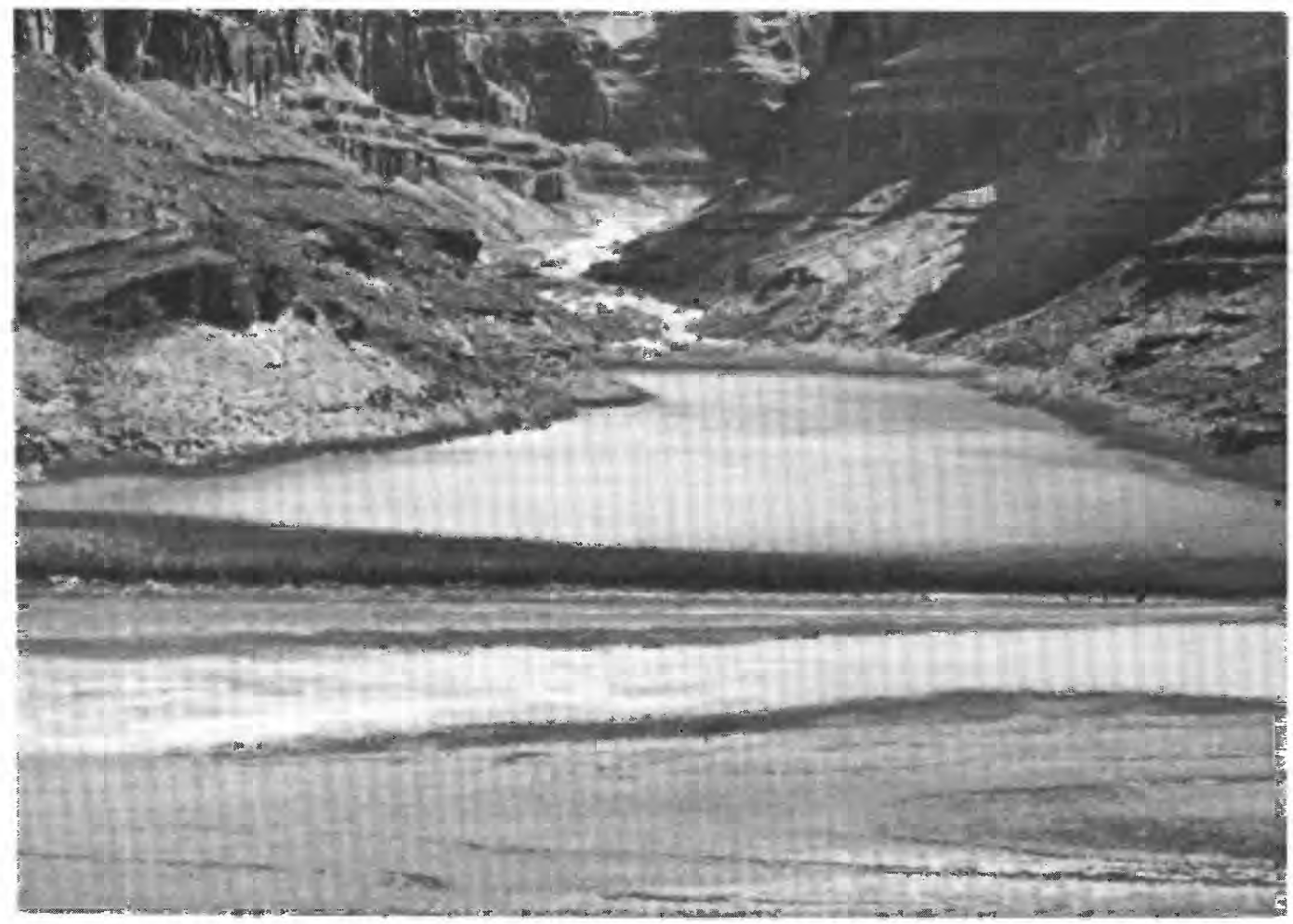

A. VIEW OF ONE OF THE MANY TRIBUTARIES SEALED OFF BY A NATURAL LEVEE, BEHIND WHICH A NARROW LAKE HAS FORMED

Higher terrace and natural levee covered by vegetation were probably formed during 1941 . The 1948 terrace appears in foreground.

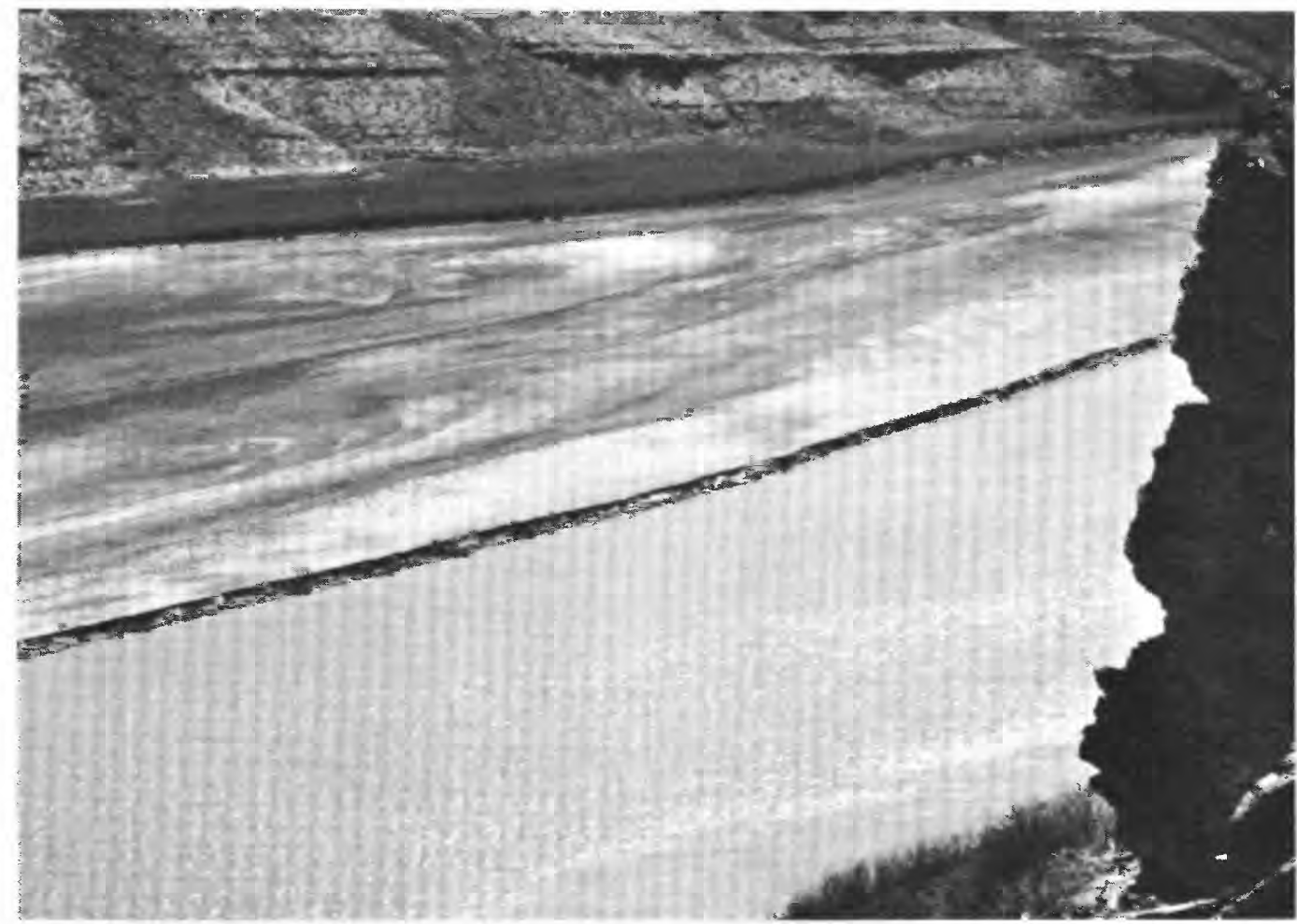

B. UPSTREAM VIEW OF THE 1948 TERRACE, IN WHICH THE COLORADO RIVER HAS ENTRENCHED ITSELF The higher, vegetation-covered terrace in background was probably formed in 1941. 


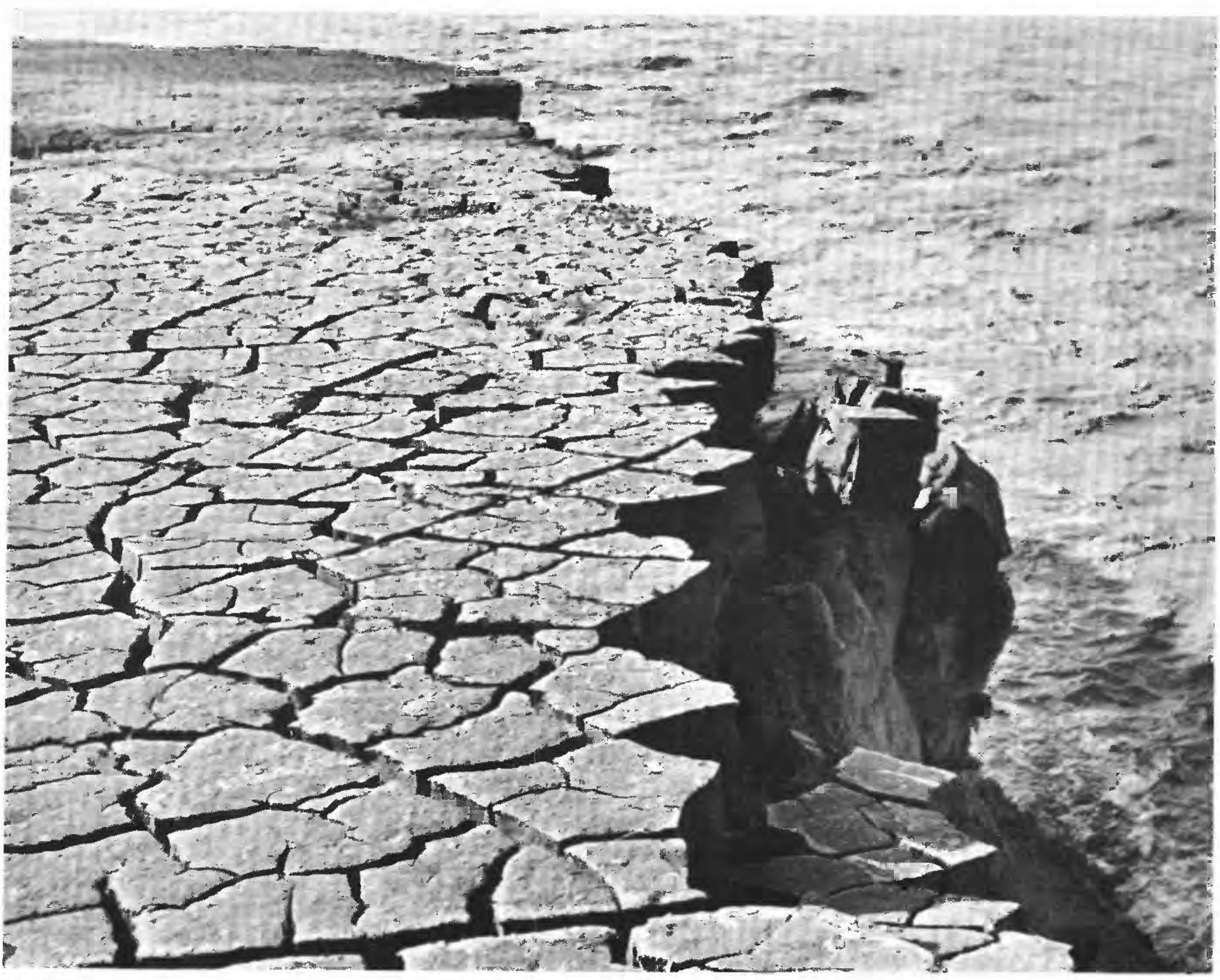

CLOSEUP VIEW OF THE 1948 TERRACE BEING CUT BACK BY THE COLORADO RIVER IN PIERCE BASIN

Columns of cross-bedded sand capped by mud-cracked layer of clayey silt are plunging into the turbulent river below. 


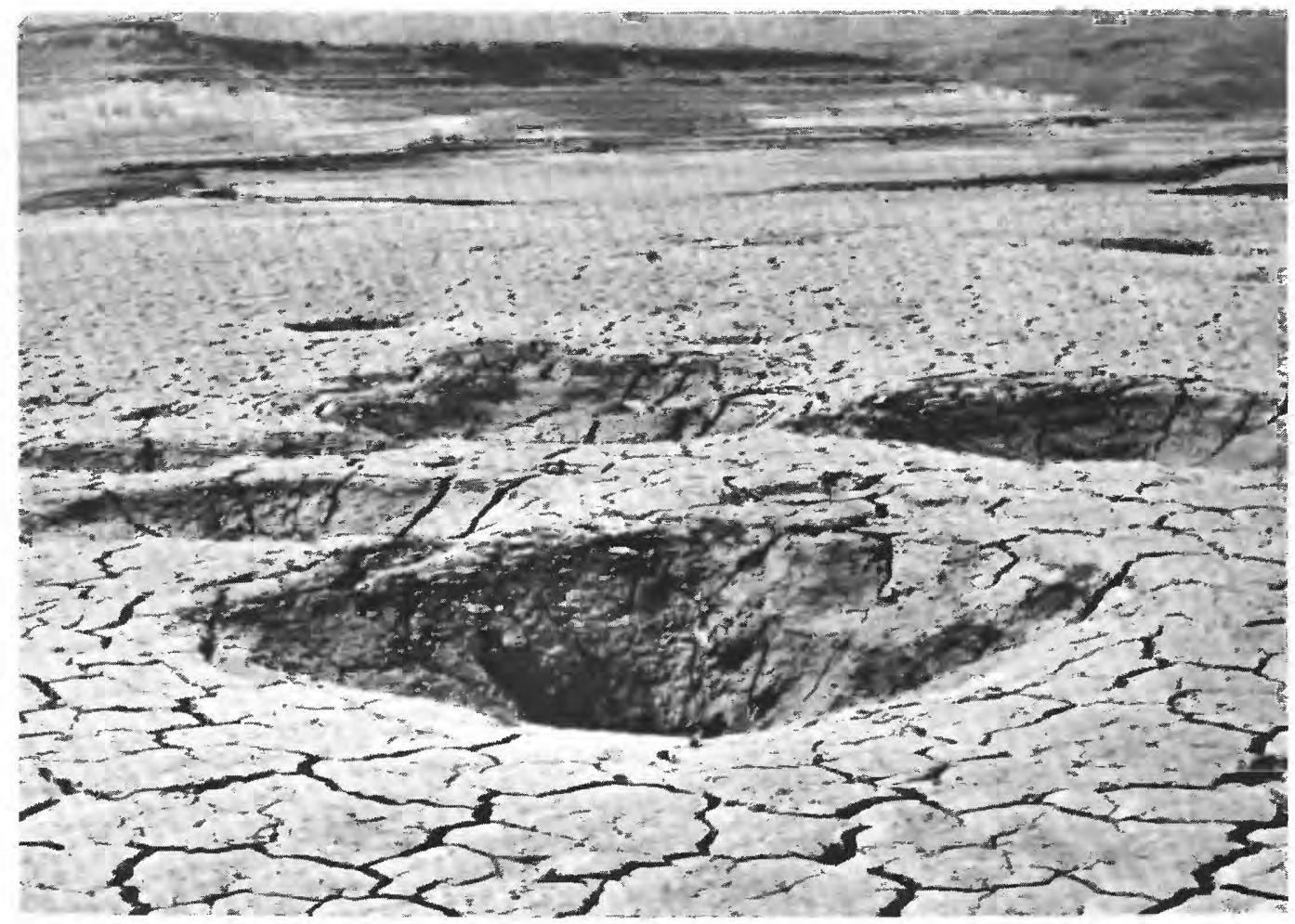

A. GENERAL VIEW

Large pit in foreground is about 7 feet in diameter.

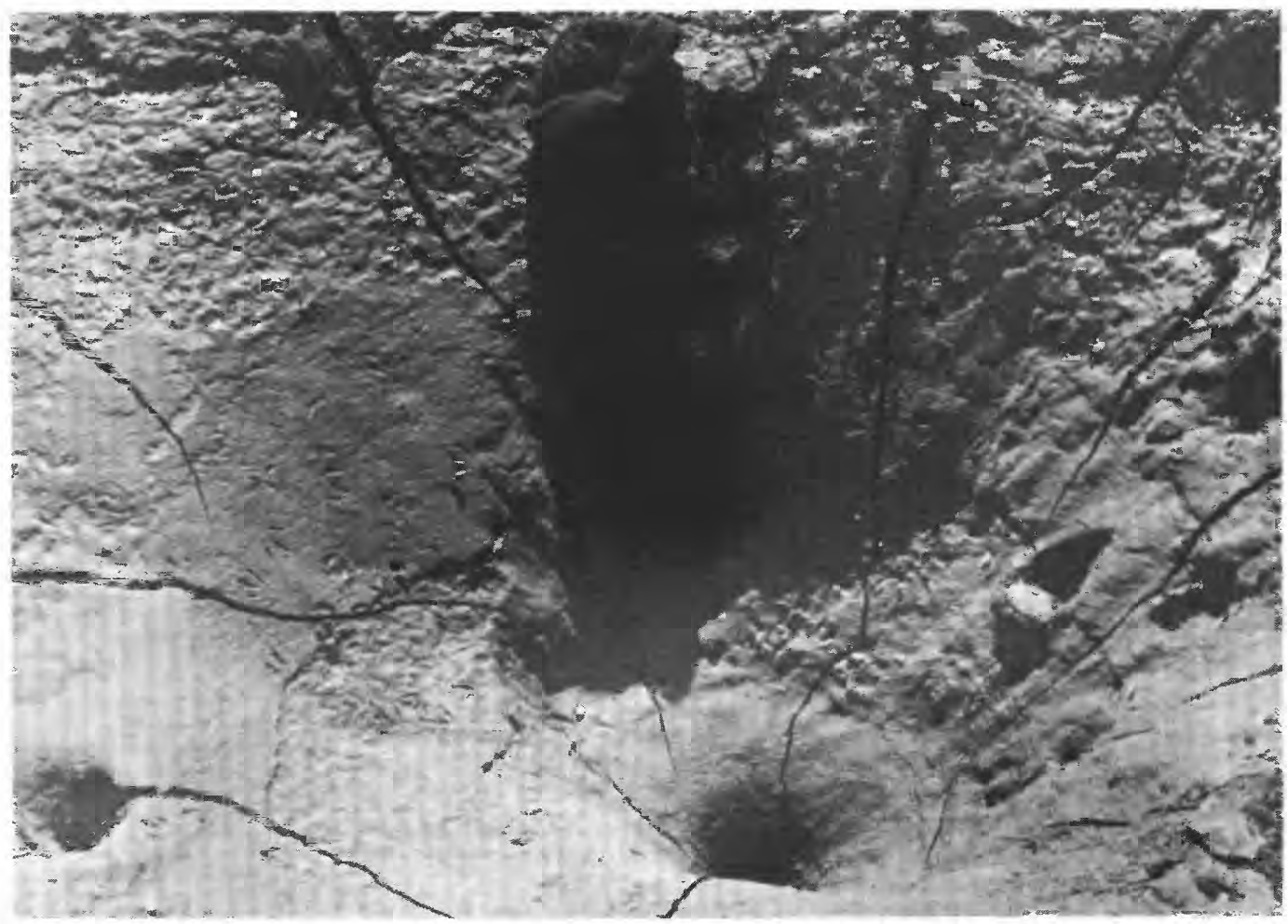

B. CLOSEUP VIEW OF ONE OF THE LARGE GAS PITS

Note circular orifice at the bottom of the pit, through which gas escapes to the surface.

GAS PITS IN THE 1948 TERRACE NEAR THE DELTA FRONT 
ing streams, is continuously changing its course in response to variations in river current, sediment load, and water discharge.

In the latter part of 1948 the river channel was flanked along most of its length by river terraces and natural levees. In the western part of the gorge the terraces commonly occupied half of the canyon width, but in the narrow eastern section they had been removed by undercutting or reduced to thin remnants against the canyon walls. Tributary canyons of Lower Granite Gorge were dammed by these natural sediment barriers, behind which shallow depressions have formed at the margins of the delta surface. Water discharged by several of the tributaries was captured in the depressions, thus forming lakes or ponds of clear water effectively isolated from the turbid water of the Colorado River (pl. 21A).

The sediment embankments across the mouths of some of the larger side canyons had been subsequently breached by water discharged from their tributaries, probably during flash floods. Most prominent among these were Spencer Canyon, Surprise Canyon, and Reference Point Canyon. However, the embankments were still intact across the mouths of other large tributary canyons, notably Separation Canyon, Helldiver Canyon, and Salt Creek Canyon.

At the time of the 1948-49 survey the terrace that was most extensive, most nearly continuous, and most prominent as seen from the river was the delta surface that had been developed at the time of high lake stage in the summer of 1948. The river entrenched its channel into this surface as the lake level receded from 1,193 feet in July to 1,165 feet in December and 1,150 feet in March 1949. The resulting terrace was continuous from Bridge Canyon to the mouth of the Colorado River in Pierce Basin. As shown in plate 20, the 1948 terrace ranged in altitude from 1,213 feet at mile 239.5 (section $B-B^{\prime}$ ) to 1,170 feet in Pierce Basin (section $E-E^{\prime}$ ).

Along most of its length the 1948 terrace had extremely little relief ( $\mathrm{pl} .21 B$ ). Natural levees generally rose less than 2 feet above the terrace level, although locally they were $4-5$ feet high. In the narrow eastern end of Lower Granite Gorge the levees commonly abutted abruptly against the canyon walls, but in the western part of the gorge and in the eastern end of Pierce Basin the levees were parallel to the channel and as much as 200 feet from the canyon walls.

Between the levees and the canyon walls numerous small depressions ranged in depth from a few inches to about 7 feet. As the lake receded these depressions became isolated ponds, several of which were subsequently drained as the Colorado River cut into the
1948 terrace en route to the lake. This drainage resulted in the cutting of deep, narrow clefts tributary to the incised channel of the Colorado River. These were particularly prominent in the eastern part of Pierce Basin near the delta front, where they provided excellent exposures of the crossbedded structure of the topset beds.

In the eastern part of Lower Granite Gorge the 1948 terrace deposit was composed almost entirely of crossbedded sand. However, in the wider western part of the gorge and in the eastern end of Pierce Basin, a layer of clayey silt about 1.5 feet thick covered the crossbedded sand of the 1948 terrace deposit. This material was deposited in the slack lake water that flooded the western part of the gorge in the summer of 1948. During a short period of observation in March 1949 , the 1948 terrace was about 20 feet above river level and was being cut back at a rate of 5 to 10 feet per hour in the vicinity of the delta front (pl. 22).

Well-developed mud cracks and gas pits characterized the surface of the 1948 terrace near the delt a front. The gas pits, first described by Maxon (1940), were conical in shape, with openings at the bottom through which gas escaped to the surface (pl. 23). The pits were 2 to 10 feet in diameter at the surface and 1 to 4 feet deep. The diameter of the gas vent at the bottom of each pit ranged from $1 / 2$ to about 2 inches.

The occurrence of gas pits on the exposed terrace near the delta front and the emanation of gas from the submerged deposit in Pierce Basin clearly indicate that gas is being squeezed out of the bottomset beds by the tremendous weight of the rapidly advancing foreset and topset members. The gas is principally methane resulting from the decay of organic matter in the bottomset beds (see analysis, table 23).

In Lower Granite Gorge east of mile 267.5, a terrace about 25 feet above the 1948 terrace could be clearly identified. This higher terrace was discontinuous and ranged in altitude from 1,226 feet at mile 242 to 1,196 feet at mile 267.5 (fig. 16). It was probably formed during the summer of 1941 when the lake surface reached an altitude of $1,220.4$ feet, the highest water level in the reservoir's history. A small remnant of this higher terrace may be seen at the right of section $D-D^{\prime}$ (pl. 20). Upstream from mile 242, the higher terrace has been removed in most places during subsequent periods of flcod.

Well-developed natural levees rise 2 to 10 feet above the higher terrace along its outer margins. These are best preserved where they cross the mouths of tributary canyons, as shown in sections $B-B^{\prime}$ and $D-D^{\prime}$ (pl. 20). Like the terrace upon which they rest, the levees were probably formed during the high lake stage of 1941 . 
This dating is supported by the annual profiles of the delta surface. As shown in plate 13, the topset beds in 1941 extended only as far west as mile 266 , which corresponds closely with the western terminus of the higher terrace and its superimposed levees. The higher terrace and levees are absent farther west because the topset beds in the western part of Lower Granite Gorge were not formed until after 1941.

Extending downstream from the western terminus of the 1941 terrace (mile 267.5) to mile 270.5 are isolated remnants of another terrace that is about 10 feet above the 1948 terrace. Spotty remnants of this and possibly other terraces are also visible upstream from mile 267.5, but they are not continuous enough to allow definite correlation with lake stage. It seems probable, however, that they are remnants of formerly continuous terraces developed during 1942 when the lake level rose to 1,213 feet, and perhaps during the somewhat lower stages in 1943 and 1944 . The absence of terraces corresponding to the high lake stages of other years is readily explained by the fluctuations in lake stage (fig. 18). All terraces developed prior to 1941 have evidently been buried by the 1941 terrace deposit. Similarly, the terraces developed during 1945, 1946 and 1947 have been buried by the 1948 terrace deposit.

The progressive upbuilding of the delta in the eastern part of Lake Mead insures that terraces will continue to be only temporary features of the physiography. Generally the only prominent terrace will be formed by the delta surface that developed at the time of the high lake stage each year, and was subsequently entrenched. The delta deposits during years of exceptionally high lake stage, such as 1941 or 1942, may persist as terraces for several years; but they too will eventually be buried.

\section{FORESET BEDS}

The foreset beds that made up the delta front in Pierce Basin in 1948 dipped sharply beneath the lake surface for a distance of about $11 / 2$ miles (miles 277.8 to 279.3 ) measured along the course of the submerged Colorado River channel (pl. 24). Near its southern margin the delta front ranged in slope from about 300 feet per mile near the top to less than 25 feet per mile near the foot, and averaged about 100 feet per mile.

In contrast, the surface slope of the delta front in its central and northern portions had been greatly modified by turbidity currents flowing over its surface. As shown in plate 24 , this part of the delta front was traversed by a narrow valley, the axis of which extended into the mouth of the Colorado River. At the foot of the delta front the valley broadened out onto the gently sloping surface of the bottomset beds. The average surface slope of the delta front measured along the valley axis was about 55 feet per mile. It is not known whether this valley represented active erosion by turbidity currents or merely a lower rate of deposition along the axis of the currents where velocities are higher (p. 213). However, in either case it is only a temporary feature, for the chief sedimentary process is deposition, as shown by the 43-mile advance of the delta front from 1935 to 1948.

\section{BOTTOMSET BEDS}

From the foot of the delta front to Hoover Dam, the average declivity of the bottomset beds in 1948 was about 4 feet per mile, ranging from an average of 9 feet per mile between the delta front and the mouth of Iceberg Canyon to less than 1 foot per mile in the southern part of Boulder Basin. As shown in plate 13 , there was a marked reduction in slope of the bottomset beds beginning in the vicinity of Virgin Canyon and extending westward to the dam. This reduced slope is adjusted in part to the size of the sediment particles, the velocities of turbidity currents carrying these particles, and in part to compaction, but the chief controlling factor appears to be the basining effect of Hoover Dam. As noted on page 15'7, the bottomset beds in 1948 had a minimum thickness of 45 feet at mile 314 and increased to 106 feet at the dam. If Hoover Dam had been constructed several hundred miles downstream, the thickness of the bottomset beds west of mile 314 should have continued to decrease, which would have resulted in a somewhat greater slope of these beds. Above mile 314, it may be postulated that the declivity is approximately equivalent to that of a delta built into a lake of "infinite extent". Below this point, the increased thickness and reduced slope are a resultant of two factors: (1) The progressively declining thickness of the delta if the dam were not there and (2) the accumulation of sediment trapped by the dam. The most notable example of basining effect is, of course, in Boulder Basin, where the slope of the bottomset beds averaged only 1.2 feet per mile in 1948.

Plate 13 also shows that the position of minimum sediment thickness, which denotes the eastern limit of basining effect, has migrated progressively farther uplake. In 1937 the position of minimum thickness was at mile 334 near the head of Boulder Canyon, and in 1938 it regressed to mile 308 near the mouth of Virgin Canyon. Since 1938 the position of minimum thickness has remained essentially stationary in the eastern part of the Temple Bar area and the western part of Virgin Canyon (miles 306 to 314).

In transverse section the surface of the sediment deposit was essentially level along most of its length, the deposit at the sides extending only a few feet above 
the center elevation (pl. 20). However, within 5 miles of the delta front the margins of the sediment were as much as 25 feet above the sediment surface along the thalweg, as illustrated in section $\mathbf{F}-\mathbf{F}^{\prime}$, plate 20 .

One of the most striking features in the northern part of Pierce Basin was the continuation of the channel that traversed the delta front (pl. 24). The channel was bordered on both sides by underwater ridges which in section $\mathbf{F}-\mathbf{F}^{\prime}$, (pl. 20) rise about 5 feet above the center of the channel. The ridges were, in turn, bordered by slight depressions in the sediment surface. These features have a marked resemblance to the natural levees and delta-flank depressions in Lower Granite Gorge.

West of mile 283 the difference between side and center elevations was generally less than 2 feet, but even in this region marginal ridges could be identified across the mouths of some of the larger tributaries entering the submerged Colorado River channel. A ridge rising about 2 feet above the average sediment level had formed across the mouth of Grand Bay at its intersection with the submerged Colorado River channel. Although field evidence was inconclusive, there was a suggestion of a similar bar across the mouth of the Overton Arm near the former junction of the Virgin and Colorado Rivers.

At the great bend of the inundated Colorado River channel, where it turns abruptly south from a general west-trending course, the accumulated sediment on the inside of the curve (mile 345 to 347 ) stood in 1948 about 5 feet higher than the general sediment level at the outside of the curve. This feature bears a marked resemblance to the sediment accumulations on the convex sides of meanders of the Colorado River as it flows across the subaerial part of the delta in Lower Granite Gorge. Like the underwater "levees" and marginal depressions bordering them, the building-up of sediment on the convex side of the great bend of the inundated Colorado River channel suggests that turbidity currents flowing along the lake bottom conform to the same mechanical principles as streamflow, an observation that has been reached independently by Menard and Ludwick (1951).

Except in the vicinity of the delta front, the interface between the surface of the bottomset beds and the overlying lake water was very clearly defined during most of the observation period; there was no mixing of the soft accumulated sediment with the lake water. For a short period in April 1948, however, and for a slightly longer period in November and December 1948, the water-sediment interface in the eastern part of the lake was obscured by turbidity currents that flowed in a thin layer along the lake bottom. In April the flow of turbid water extended only to the western end of Iceberg Canyon, but in November and December suspended sediment was encountered immediately over the bottom as far west as mile 318 , or nearly to the eastern end of Virgin Basin.

\section{VIRGIN DELTA}

Except for their subdued relief, the surface features of the Virgin delta in 1948 were generally similar to those of the Colorado delta. The topset beds made up the surface of the upper 8 miles (Virgin River, mile 35.8 to mile 27.4) of the Virgin delta. They had an average surface slope of 10.7 feet per mile, which is a reduction of 2.6 feet per mile from the average gradient of the Virgin River channel (13.3 feet per mile) in this region before the inception of Lake Mead. North of mile 30.2 the surface of the topset beds was above the mean lake level of approximately 1,170 feet, but between miles 30.2 and 27.4 the topset beds were exposed only at low lake stages. A break in slope at altitude 1,140 feet marked the delta front, where the topset beds grade into the foreset beds.

In contrast to the buried Virgin River channel, which has an average width of about 800 feet, the channel traversing the topset beds in 1948 averaged only about 350 feet in width. The topset beds of the Virgin delta, like those of the Colorado delta, are being reworked continuously in response to changes in lake stage and river discharge. In 1948 the Virgin River channel was flanked along most of its length by a welldefined terrace, which was 3 to 7 feet above the river channel (sections $O-O^{\prime}$ and $P-P^{\prime}$, pl. 20). Bordering the channel and superimposed on the terrace were broad natural levees that stood only 1 to 2 feet above the terrace level. The levees, in turn, were flanked by slight depressions in the delta surface which generally were less than 5 feet deep.

At the surface, this part of the Virgin delta was composed chiefly of cross-bedded sand, but between mile 30.2 and the delta front at mile 27.4 the sand was overlain by a layer of soft clayey silt that was only a few inches thick. This material was probably deposited in the slack water that flooded the lower part of the topset beds during the highest lake stages of 1948.

Foreset beds formed the delta surface between miles 27.4 and 26.7. These had an average downstream slope of 29 feet per mile. South of mile 26.7 the surface was composed of bottomset beds with an average declivity of 14 feet per mile. At the toe of the delta (mile 21.4) the bottomset beds graded into the profile of the former Virgin River channel. As noted previously, however, a layer of silt and clay ranging from 
a few tenths of a foot to about 2 feet in thickness had accumulated, at least in isolated patches, between the toe of the Virgin delta and Lower Narrows (mile 9.3) of Overton Arm. This layer, like the bottomset beds of the Colorado delta, was undoubtedly deposited by turbidity currents and is regarded, therefore, as an incipient extension of the bottomset beds of the Virgin delta into the deeper parts of Overton Arm.

As shown by sections $Q-Q^{\prime}$ and $R-R^{\prime}$ (pl. 20), the bottomset beds were essentially level in cross section, the sediment at the sides rising only a few feet above the center elevations. Submerged tributaries to the inundated Virgin River channel had been filled to the level of the sediment in the channel. The most prominent example of tributary filling was at mile 25.0, where the bottomset beds of the Virgin delta extended almost one-half mile into the lower part of the Muddy Creek valley (pl. 20). Submerged ridges, such as those observed at the margins of the bottomset beds of the Colorado delta, are not present or are too inconspicuous to be detected by underwater soundings.

\section{GROWTH AND STRUCTURE OF THE DELTAS}

Deltas are characteristically formed by sedimentladen streams where they enter the ocean or other bodies of still water. The growth of the delta may be analyzed conveniently with reference to the point at which the flowing water meets the still water: Sediment is dropped in the river bed as water velocities are reduced; additional sediment is carried to the edge of this graded slope and dropped into the deeper stillwater body to form foreset beds; finer material is carried farther out into the stillwater body and there forms the bottomset beds. As deposition continues the foreset beds are built out progressively farther over the bottomset beds, and in turn are covered by topset beds; also the gradient of the stream is modified and sediment is deposited upstream from the original mouth. Thus the delta grows outward in the stillwater body by deposition of foreset and bottomset beds, and by its deposition of topset beds it grows upward. It also projects backward into the original channel of the stream that provides the source material.

The growth of deltas in Lake Mead is necessarily more complex than in streams debouching into an ocean or into a lake that has a relatively constant level. During the first $61 / 2$ years of the lake history, the point at which the river entered still water migrated from Boulder Basin to Bridge Canyon in Lower Granite Gorge (a distance of more than a hundred river-miles), with variations each year corresponding to the fluctuations in lake stage. In July 1941 the lake reached a maximum level of 1,220 feet, and since then it has generally been at altitudes ranging from 1,150 to 1,200 feet, reaching a minimum level of 1,134 feet in April 1947. Since 1941 the river has entered the lake either in Pierce Basin or in the western part of Lower Granite Gorge.

A general idea of the growth of the Colorado delta from 1937 to 1948 may be obtained from the profiles of plate 13 , but there is no similar information concerning the development of the Colorado delta during its earlier stages. Prior to the 1948-49 survey there had been no investigation of the Virgin delta, and so we have little knowledge of its growth. The numerous samples and cores collected during the 1948-49 survey do not furmish much additional information on the growth of the deltas, but they do provide a fairly complete picture of the structure of the Colorado delta and a more general picture of the structure of the Virgin delta.

\section{COLORADO DELTA}

The initial stages of development of the Colorado delta must be described largely on the basis of indirect evidence obtained by analysis of records of lake level, and of the sediment suspended in the river water as it passed the Grand Canyon gagin station (p. 103). Some of the cores obtained during the 1948-49 survey have included the entire thickness of the delta material, and these indicate the characteristics of the earliest deposits; however, the earliest delta sediments may be indistinguishable from river sediments deposited prior to 1935 .

In many places, the age of sediments in the bottoms of these cores may be determined by reference to elevations shown on the 1935 topographic maps (U.S. Soil Conservation Service, 1935), because these maps generally depict the reservoir floor prior to sedimentation. The topography of Black Canyon and Boulder Basin, as portrayed by the maps of 1935 , was taken from the Brock and Weymouth survey of 1930 (Brown, 1941), and except for possible changes in the topography of the Colorado River channel between 1930 and 1935, the maps give an accurate representation of the pre-Lake Mead topography in this area. Upstream from Boulder Basin the 1935 maps were constructed from aerial photographs, supplemented with planetable data in the Virgin River valley and with cross sections across the Colorado River channel. The photographs, planetable survey of the Virgin River valley, and Colorado River cross sections upstream from Pierce Basin were all obtained prior to inundation.

However, flooding and delta deposition began in some areas prior to the surveys for these maps. Sections across the Colorado River channel between Boulder Basin and Pierce Basin were not obtained until it had 
been covered by the rising lake water; but they were made within a period of a few days to 3 weeks after inundation. Accumulation of sediment between the time of inundation and the time of survey was enough in some areas to cause appreciable discrepancies between the aerial photographs and the cross-section data, and in the compilation of the 1935 topographic maps, corrections were applied so as to reproduce the approximate topography of the area prior to inundation (Brown, 1941). In other areas the sediment that accumulated in the channel along much of its length was evidently too thin to be detected by this means, and it has probably been included as part of the pre-Lake Mead topography.

\section{GROWTH IN FEBRUARX AND MARCH 1935}

In the first 2 weeks after Hoover Dam was closed on February 1, 1935, the impounded water rose to an altitude of 700 feet. This water carried about 1 million tons of suspended sediment as it passed through Grand Canyon. It seems likely that sand was deposited at the mouth of the Colorado River as it migrated upstream with the rising lake level, and this resulted undoubtedly in the accumulation of a thin deposit of sand along the bottom of the channel between Hoover Dam and the western end of Boulder Canyon. Owing to the rapid flooding of this area, the sand layer is probably not more than a few inches thick.

The lake level remained at about 700 feet altitude from February 15 to April 1. At that time the mouth of the Colorado River was located near the head of Boulder Canyon (mile 334), about 20 miles upstream from Hoover Dam. A considerable thickness of sand must have accumulated in the bottom of the channel near the head of Boulder Canyon, for the river carried more than 4 million tons of sediment at Grand Canyon during this interval. These deposits of sand, in the form of incipiently developed topset and foreset beds, would constitute the initial development of the Colorado delta.

Even at this early stage, the role of turbidity currents in transporting silt and clay particles into the deeper parts of the lake had become firmly established (p. 109). Apparently sediment was transported from the mouth of the Colorado River along the lake bottom and through Hoover Dam. Other material was undoubtedly deposited as bottomset beds between the head of Boulder Canyon and the dam, but in cores from the accumulated sediment these cannot be distinguished from the overlying bottomset beds deposited in later years.

Of the 10 cores obtained from the channel area between Hoover Dam and the head of Boulder Canyon, only 3 (cores 7, 17, and K2, pl. 19) extended through the thick accumulation of fine-grained bottomset beds into an underlying layer of sand. Since the coring devices cannot penetrate sand to any great depth, only the upper part of the sand layer was sampled. Very likely the sand at the bottom of the cores was obtained from a thin layer laid down during the early stage of reservoir filling, but we cannot be certain of this because of its probable similarity to the sand of the Colorado River channel prior to inundation. In core 7, taken near the head of Black Canyon, sand was encountered at a depth of 88 feet underlying the fine-grained bottomset beds; this corresponds closely with the thickness of accumulated sediment as computed by difference between the 1948 topography and the pre-Lake Mead topography. Assuming that there was no change in channel topography between 1930 and 1935, the sand may be interpreted as coming from the pre-Lake Mead channel or from a very thin sand layer deposited in the channel during its flooding in February 1935.

At the head of Boulder Canyon (cores 17 and K2), sand was encountered at depths of 55 to 60 feet below the 1948 sediment surface, and 5 to 10 feet above the buried Colorado River channel as portrayed by the 1935 topographic maps. Although the pre-Lake Mead channel topography in this area was not mapped until after its inundation, the aerial photographs may well have indicated the approximate topography of the channel before flooding. If this supposition is correct, the 5 to 10 feet of sand in the bottom of the channel probably is made up of topset and foreset beds deposited during the interval from February 15 to April 1 , 1935, when the mouth of the Colorado River remained stationary near the head of Boulder Canyon.

Although only fragmentary data are available from this earliest stage of reservoir filling, it seems reasonable to conclude from the analysis above that a layer of sand, ranging from only a few inches in thickness in Black Canyon to 5 or 10 feet at the head of Boulder Canyon, accumulated in the bottom of the Colorado River channel during February and March 1935. This layer probably consists of incipiently developed topset and foreset beds deposited at the mouth of the Colorado River as it receded upstream with the rise in lake level. The silt and clay particles supplied by the Colorado River during this period were transported into the deeper parts of the lake and laid down on top of these topset and foreset beds, or carried through the tumnels at Hoover Dam (p. 109). As the lake continued to rise and after it reached a fairly stable level, silt and clay were added to the earlier bottomset beds. Slumping of adjacent canyon walls may account for 
some of the thin layers of sand (p. 171 (interstratified locally with the silt and clay of the bottomset beds.

\section{GROWTH FROM APRIL 1935 TO MARCH 1936}

As a result of the spring floods in 1935 the lake surface rose rapidly from its altitude of 700 feet on April 1 to 925 feet in July, and then remained relatively constant until April 1936. Between July 1935 and April 1936 the Colorado River entered the lake in Pierce Basin near mile 276, about 80 miles upstream from Hoover Dam. The river mouth at that time was about 2 miles east of the river entrance in 1948, but the channel was more than 200 feet below the 1948 channel. A considerable thickness of sand must have been deposited as topset and foreset beds near the mouth of the Colorado River during the 9-month interval from July 1935 to April 1936, but they are now deeply buried and we have no record of them.

Also, a layer of sand probably overlies the buried Colorado River channel between the head of Boulder Canyon and Pierce Basin, deposited at the mouth of the Colorado River as it receded upstream between April and July 1935. However, the channel in this area was not mapped until after its inundation, and therefore subsequent to the accumulation of sand at the mouth of the Colorado River as it receded upstream. Except in areas of exceptionally thick deposits where corrections have been applied (Brown, 1941, p. 402), this sand layer has evidently been mapped by the Soil Conservation Service as part of the pre-Lake Mead topography. Consequently, its thickness cannot be obtained by measuring the difference between the depth at which sand was encountered and the thickness of the accumulated sediment as determined by topographic changes from 1935 to 1948.

Brown estimates that the accumulation of sediment in the channel during the 1935 survey has resulted in a probable volumetric error in reservoir capacity of only about 1 percent of 1 year's sediment accumulation, or about 1,000 acre-feet. If this material were distributed evenly over the channel bottom between the head of Boulder Canyon and Pierce Basin, it would form a layer about 3 inches thick.

In view of the considerable quantity of sediment carried into the reservoir by the Colorado River during the flooding of the channel between the head of Boulder Canyon and Pierce Basin (April-June 1935) this estimate seems somewhat low. According to Howard (1947), a total of $871 / 2$ million tons of sediment was carried in suspension by the Colorado River past the Grand Canyon gaging station during this period, of which about $11 / 2$ million tons was carried on through the reservoir and dam by turbidity currents (Grover and Howard, 1938). From studies of the texture and specific weight of the accumulated sediment (p. 195) it seems reasonable to assume that at least 50 percent (43 million tons) of the load is made up of sand, which, when accumulated in the reservoir, has an average specific weight of about 93.8 pounds per cubic foot. In confirmation, mechanical analyses of the suspended sediment at Grand Canyon in April to June 1935 (Howard, 1947) show that sand-size particles exceeded 50 percent of the total on most days, particularly on the days when the river was carrying the greatest sediment load.

Computations based on these values suggest that a total volume of 20,000 acre-feet of sand accumulated in the reservoir during this interval. Supposedly, this material was dropped near the river mouth as it regressed upstream from the head of Boulder Canyon to Pierce Basin prior to the 1935 channel survey. If this material were evenly distributed over the bottom of the Colorado River channel between the head of Boulder Canyon and Pierce Basin, it would form a layer about 5 feet thick. Like the sand underlying the bottomset beds in the western part of the lake, this deposit is interpreted as topset and foreset beds laid down during the early stage of delta development. Cores from the sediment accumulated between the head of Boulder Canyon and Pierce Basin provide little information on the characteristics of the sand accumulated at the bottom of the buried Colorado River channel.

\section{GROWTH FROM APRIL 1936 TO JULY 1937}

During this period the lake rose in two stages from altitude 910 feet to 1,100 feet. During the period April to July 1936 the water surface rose to 1,020 feet, where it remained essentially stationary until March 1937. With the second rise (March-July 1937) the water surface attained an altitude of 1,100 feet. In response to these changes the mouth of the Colorado River receded eastward from Pierce Basin about 34 miles into the Lower Granite Gorge. From July 1936 to March 1937 the mouth of the Colorado River was in the vicinity of mile 255, and in July 1937 the river entered the lake near mile 244, about 110 miles upstream from Hoover Dam.

There is no record of sedimentation in the reservoir from April 1936 to July 1937, but it is assumed that the previously established pattern continued essentially unchanged. Sand, dropped near the river mouth as it regresed upstream, probably accumulated in topset and foreset beds along the bottom of the channel in the western part of the Lower Granite Gorge. The thickness of these beds is unknown, but presumably they are thickest in the vicinity of mile 255 , where the 


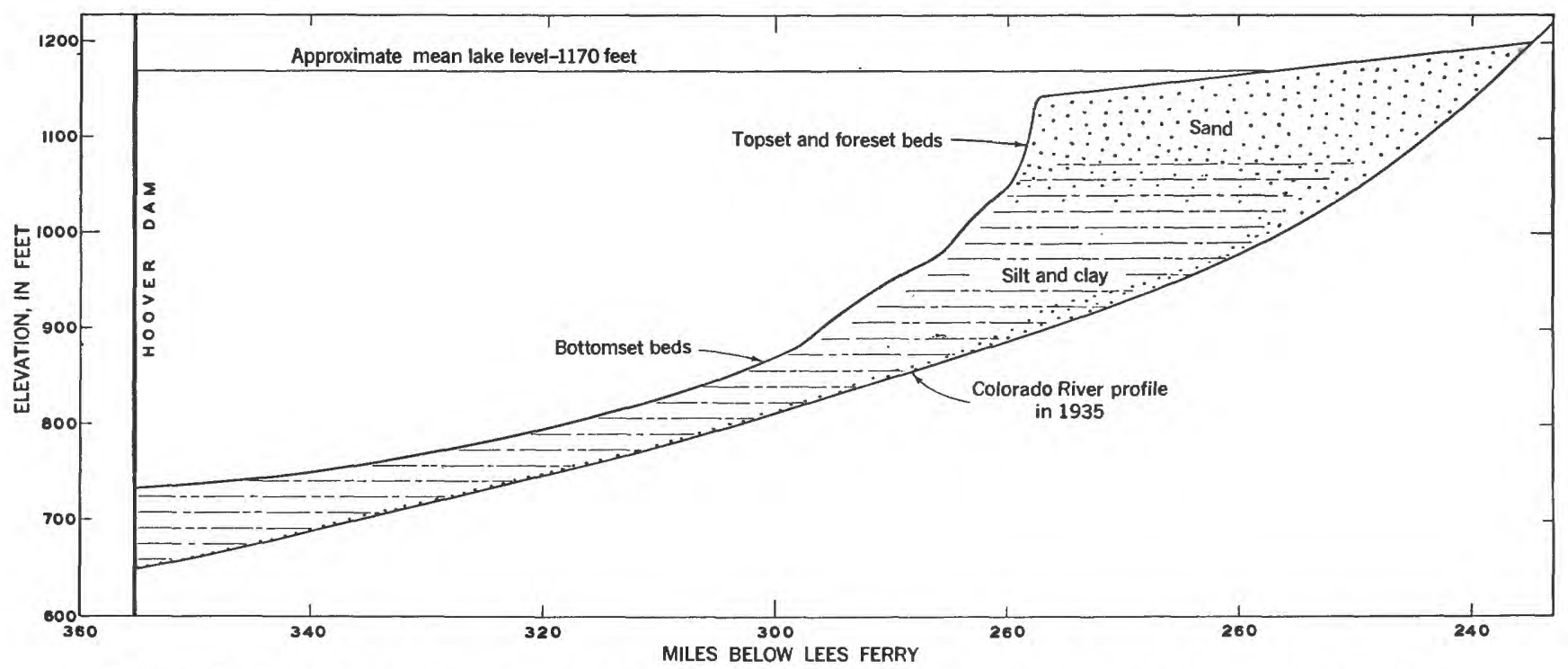

FIGURE 47.-Longitudinal section through the Colorado delta, showing relation of bottomset beds to topset and foreset beds.

mouth of the river remained essentially stationary from July 1936 to March 1937. During this period the finer particles-silt and clay-were carried into the deeper parts of the lake and deposited in the bottomset beds.

\section{GROWTH FROM JULY 1937 TO DECEMBER 1948}

The surfaces of the topset beds in Lower Granite Gorge and of the foreset beds in Pierce Basin are made up principally of hard, compact sand. In contrast, the surface of the bottomset beds to the west consists of extremely soft mud, the solid particles of which are composed of silt and clay. This marked change in sediment texture and consistency occurs at the foot of the delta front (mile 279.3) where the slope decreases abruptly from about 55 feet per mile to 15 feet per mile. The break in slope between the foreset beds and the bottomset beds is thus related to the change in texture, the coarser sediment making up the steeper slope. By extending this relation to the successive advances of the delta front ( $\mathrm{pl} .13$ ), the contact between the bottomset beds and the overlying foreset and topset beds that accumulated in the eastern part of the lake from 1937 to 1948 may be projected as illustrated in figure 47. The lower topset and foreset beds shown in this diagram accumulated during the filling of the reservoir, whereas the upper topset and foreset beds were deposited after the lake reached a relatively stable stage. The bottomset beds were deposited both during the filling of the reservoir and during the period of stable lake level.

No cores were obtained during the 1948 survey from the sediment accumulated in Lower Granite Gorge, and it is impossible to verify the accuracy of this di- vision. However, a number of drill cores, extending to maximum sediment depths of 75 feet, were taken in the eastern part of Lower Granite Gorge (mile 236:3 to mile 240.1) by the Bureau of Reclamation in 1941 and 1942. Logs of these cores, as recorded by Murdock $^{16}$ (1942), show that the sediment in this region consists of sand and silt, with a small amount of gravel near the bottom of the buried Colorado River channel. This suggests that the delta in the eastern part of Lower Granite Gorge is composed wholly of topset and foreset beds, confirming the interpretation shown in figure 47.

The Lower Granite Gorge part of the Colorado delta did not begin its development until the water level of the reservoir reached an altitude of about 1,100 feet in July 1937. Following that date the lake surface remained fairly stable, oscillating between a minimum altitude of 1,095 feet in February 1938 and a maximum of 1,220 feet in July 1941. By 1948 this part of the delta occupied the entire Lower Granite Gorge from Bridge Canyon to the delta front in Pierce Basin. In the same period many tens of feet of silt and clay accumulated in the bottomset beds that extend to Hoover Dam. These beds in the western part of the lake provide a thick cover over the part of the Colorado delta that was formed during the early stages of reservoir filling from February 1935 to July 1937.

\section{STRUCTURE IN 1948}

The structure of the Colorado delta along the thalweg in 1948 is indicated by figure 47. Because of inadequate data it is impossible to make an accurate di-

16 Murdock, J. N., 1942, Unpublished reports in the files of the U.S. Bureau of Reclamation, Salt Lake City, Utah. 


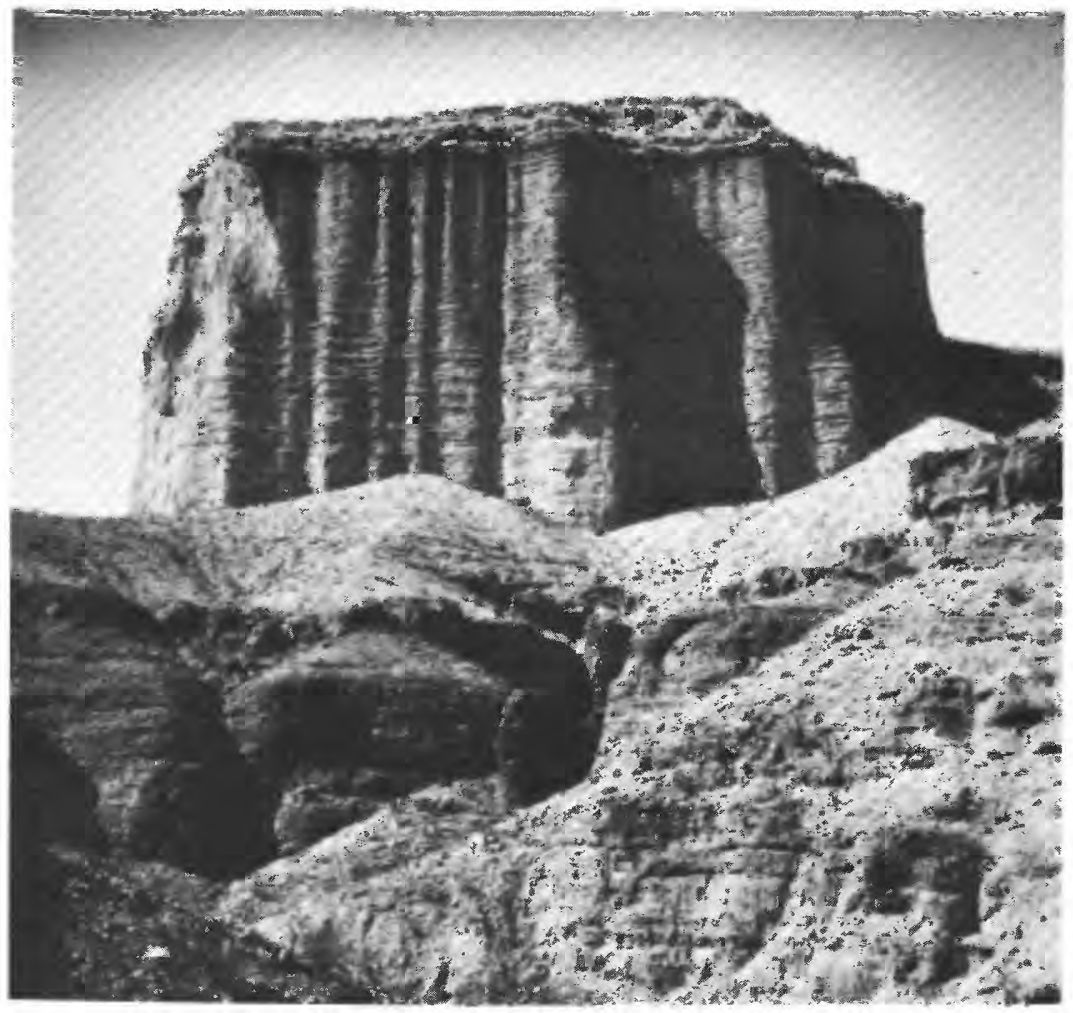

A. VIEW OF THE TEMPLE, ARIZ., IN 1934

The talus cone and underlying cliff were subsequently covered by Lake Mead. Photograph by C. R. Longwell.

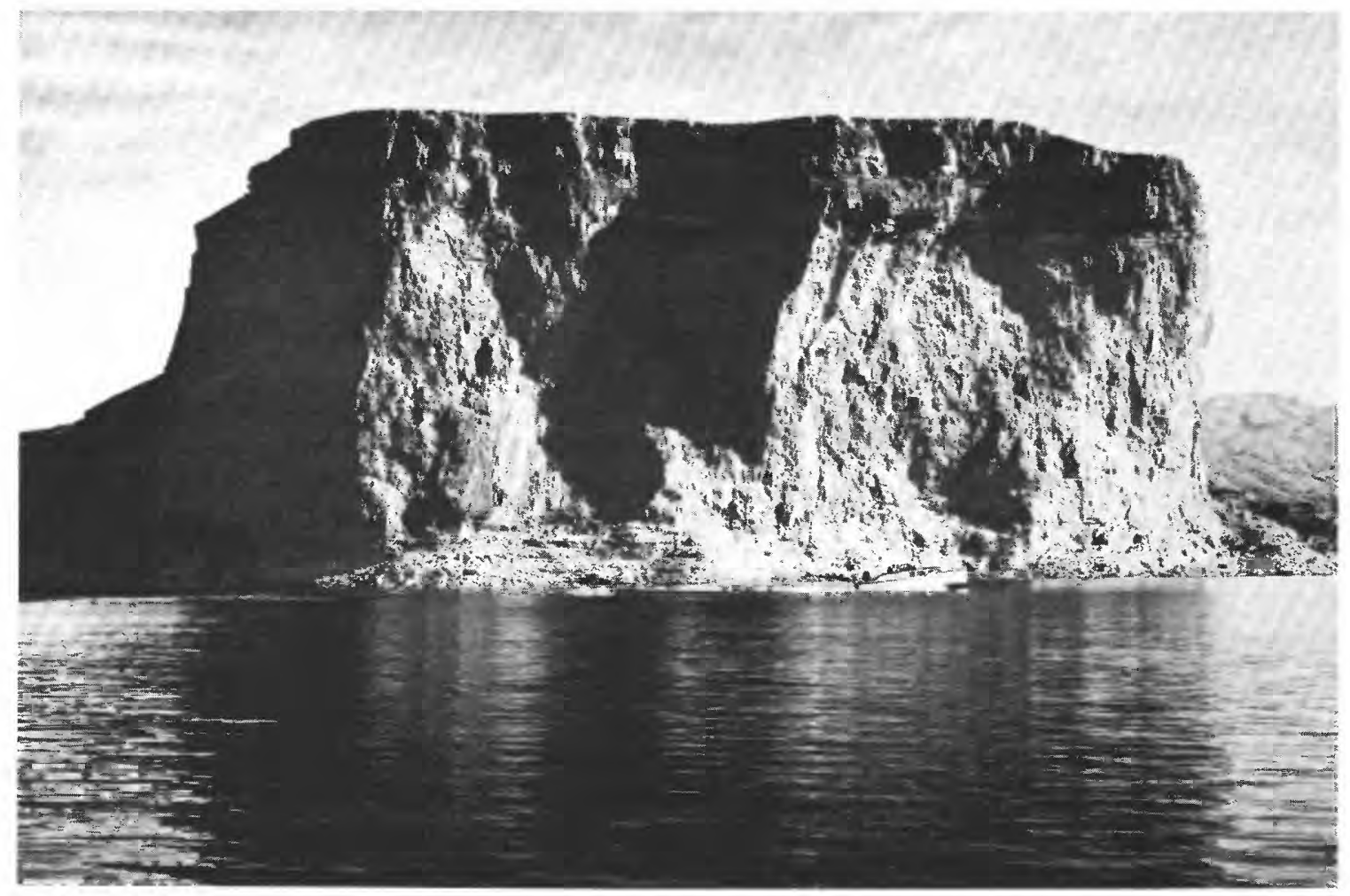

B. VIEW IN 1948, SHOWING FRESH LANDSLIDE SCARS ON THE FACE OF THE TEMPLE

Photograph by Bureau of Reclamation. 
vision between the topset and foreset beds at the bottom of the channel and the overlying bottomset beds, and the contact shown in figure 47 is therefore diagrammatic. In the eastern part of Lower Granite Gorge, the delta is made up entirely of topset and foreset beds that accumulated after the lake reached a relatively stable stage in July 1937 . In the western part of the gorge and the eastern part of Pierce Basin, bottomset beds are shown as sandwiched between the older topset and foreset beds at the bottom of the channel and the younger topset and foreset beds exposed at the delta surface. The older topset and foreset beds accumulated during the filling of the reservoir, whereas the overlying topset and foreset beds were deposited after the water level reached a relatively stable stage. West of the delta front a thick section of bottomset beds overlies a very thin section of topset and foreset beds; the bottomset beds there have been accumulating continuously since the area was first inundated by the lake in July 1935. In contrast, the topset and foreset beds were deposited during the first 5 months (February-June 1935) of reservoir filling.

The bottomset beds in Boulder Basin and Boulder Canyon range in thickness from 60 to 106 feet, and are generally thickest near the dam. Of the five deep cores from the thalweg area, three (cores 3, 16, and 76 , pl. 19) terminated in compact silt and clay at points 3 to 10 feet above the buried Colorado River channel, but cores 73 and 74 bottomed in layers of silt and clay interbedded with thin laminae of sand. In core 73 the sand laminae are prominent throughout the lower 25 feet of the section, but in core 74 they are present only in the lower 5 feet. These cores are located along the margin of a prominent underwater landslide (p. 209) and it is likely that the sand was contributed by this source. The presence of sand also accounts for the limited penetration by coring devices in this area. However, sediment from local sources constitutes a negligible proportion of the total deposit in Boulder Basin.

In Virgin Basin, 10 cores $(15,18-23,25-26$, and $\mathrm{K} 3$, pl. 19) extended to within 5 feet of the pre-Lake Mead bottom as portrayed by the 1935 topographic maps. Core 24 falls about 18 feet short of the bottom owing to the slumping of sand and coarse silt from adjacent reservoir walls into the buried Colorado River channel. Cores 20,21, 25, and 26 (at the margin of the delta near the former junction of the Colorado and Virgin Rivers) extended through the total thickness of accumulated sediment. Sand from the bottoms of cores 20,25, and 26, and small twigs and humus layers from the bottom of core 21 were probably obtained from the surface of the original reservoir floor.
Of the seven cores from the thalweg area, core 18 is the only one that terminated in sand at the bottom of the channel. All other cores bottomed in compact layers of silt and clay a few feet above the buried channel.

Locally the bottomset beds in the Virgin Basin are interstratified with thin layers of sand, most of which were probably contributed by slumping of adjacent reservoir walls. However, near the intersection of Detrital Wash and the Colorado River channel there are two layers of gypsiferous sand interbedded with the silt and clay of the bottomset beds that cannot be easily attributed to slumping. These layers are 10 to 20 feet above the channel bottom and average about 1 to 2 inches in thickness. The upper layer is at an altitude of about 763 feet, corresponding to the 1939 sediment level near the intersection of Detrital Wash with the Colorado River channel (miles 323 to 325 , pl. 13), and may have been derived from the scour of Detrital Wash near its entrance into Lake Mead, probably during the exceptional floods of 1939 (Gatewood, 1945). The lower gypsiferous layer is at altitude 755 feet and may have been deposited in 1938; like the upper layer, it was probably derived from the scour of Detrital Wash, in which there are outcrops of gypsum. As in Boulder Basin, the sediment in the Virgin Basin that has been derived from local sources is negligible in quantity. Practically all the accumulated sediment has come from the Colorado River and has been deposited in bottomset beds of the Colorado delta.

Between the eastern end of Virgin Basin (mile 320 ) and the foot of the delta front in Pierce Basin (mile 279.3) only a few cores were obtained from the deepest layers of the accumulated sediment. Along the thalweg between the mouth of Virgin Canyon and the east side of Virgin Basin, only one of five cores extended through the full thickness of sediment; this core (K4) was made up entirely of silt and clay from the bottomset beds. The other four cores (38 to 41) fell short of the original lake bottom by distances ranging from 5 to 18 feet. The deeper layers could not be penetrated, probably because of the presence of sand and coarse silt that had slumped from adjacent reservoir walls into the bottom of the channel.

Core 40, with its several thin layers of sand and coarse silt interbedded with fine silt and clay of the bottomset beds, is an excellent example of the sort of stratification that results from periodic slumping of adjacent canyon walls. In this area the layers of coarser material were probably derived from The Temple, a limestone-capped butte that rises vertically almost 500 feet above the lake surface (pl. $25 A, B)$. 
In Virgin Canyon and Gregg Basin, only two of eight cores (cores 45 and 46) penetrated the entire accumulation of bottomset beds, and these were from the margins of the delta where the sediment is less than 30 feet thick. The other cores $(42,43,44,47,59$, and $\mathrm{K} 5)$ fell short of the original lake bottom by distances ranging from 7 to 26 feet. Since none of these cores bottomed in sand, it is apparent that the limited penetration resulted from the greater consolidation of the deeper layers of the bottomset beds.

Between the mouth of Iceberg Canyon and the foot of the delta front, complete sections of the accumulated sediment were obtained only along its thin margins in Grapevine Bay and Grand Bay. As shown by cores 69 and 71 the delta in these areas is about 70 feet thick and is made up entirely of layers of silt and clay. Along the thalweg, the delta ranged in thickness from about 100 to 150 feet and the depth of penetration was limited by the lengths of the core tubes and not by compact sand or consolidated layers of silt and clay in the lower part of the channel. The maximum sampled depth, core 63 , was 95 feet. The cores in the thalweg area, like those from the delta margins, are made up wholly of bottomset beds.

At the foot of the delta front the soft mud of the gently inclined bottomset beds grades abruptly into the hard compact sand of the foreset beds that make up the delta surface in the central part of Pierce Basin. Owing to the compactness of the foreset beds, cores of the delta in Pierce Basin were limited to very shallow depths: Core 68, taken near the head of the delt a front, extended only 2.0 feet into the hard sand of the foreset beds. Core 65 and core $\mathrm{K} 7$, taken near the foot of the delta front, reached depths of about 26 feet and penetrated 21 feet of poorly consolidated silt and clay underlain by about 2 feet of compact sand and silt. Since the sand and silt could not be penetrated farther, its thickness is not known, but it suggests an interfingering of the foreset beds with bottomset beds near their contact at the foot of the delta front.

The foreset beds making up the delta front in Pierce Basin and the overlying topset beds to the east are not to be confused with the thin accumulation of topset and foreset beds deposited along the bottom of the Colorado River channel during the filling of the reservoir. The foreset and topset beds exposed in Pierce Basin and Lower Granite Gorge are building out over the thick accumulation of bottomset beds deposited in previous years. As the delta continues to grow, the bottomset beds in the western part of the lake will eventually be overridden also by the advancing foreset and topset beds.

\section{VIRGIN DELTA}

The Virgin delta began its development in the early part of May 1935, when the rising water of Lake Mead reached the junction of the Virgin and Colorado Rivers. Before that time the Virgin River discharged its sediment into the Colorado River, which, in turn, carried the sediment downstream and deposited it in the embryonic Colorado delta that was forming in the western part of the lake.

From May to July 1935, the lake flooded the lower 12 miles of the Virgin River valley (Overton Arm), and the mouth of the Virgin River receded rapidly upstream to its intersection with Bitter Wash, about 3 miles north of Lower Narrows, where it remained essentially stationary until April 1936. With the second rise in lake stage (April-July 1936) the mouth of the Virgin River receded northward to mile 19.5, where it again became stationary until March 1937 . After the third rise in level (March-July 1937) the Virgin River entered the lake near its intersection with Muddy Creek, 26 miles upstream from the former junction of the Virgin River with the Colorado River.

Sedimentation in the Virgin River channel during this early period of reservoir filling probably progressed in much the same fashion as in the Colorado River channel, the coarser particles dropping near the river mouth and the finer particles being carried into the deeper parts of the lake. However, the volume of sediment accumulated along the Virgin River channel evidently was very small. The 1948 topography of the lower 21 miles of the Virgin River valley showed no change from the pre-Lake Mead topography except near the former junction of the Virgin River with the Colorado River, where the bottomset beds of the Colorado delta transgressed the lower $21 / 2$ miles of the Virgin River valley. On the other hand, bottom samples G532, G533, G534, and G1250, and penetration measurements between miles 21.4 and 9.3 show that a thin layer of silt and clay overlies the sandy bottom of the Virgin River channel. Some of this material was evidently laid down during the flooding of Overton Arm (May 1935July 1937), but, as previously noted, there is evidence that part of it was deposited from turbidity currents after the lake reached a relatively stable level in July 1937. Possibly the sand underlying the layer of silt and clay in the bottom of the Virgin River channel was deposited at the river mouth as it regressed upstream, but we cannot be certain of this because of its probable similarity to sand accumulated in the channel before the inception of Lake Mead.

Since there are no records of sedimentation in the upper part of Overton Arm prior to the 1948 survey, it 
is impossible to trace the growth of the Virgin delta after the lake reached a relatively stable stage in July 1937. However, a very general idea of its structure may be obtained from samples and cores taken during the 1948 survey. Of three cores obtained between the toe of the Virgin delta (mile 21.4) and the foot of the delta front (mile 26.7), core 35 at mile 23.7 is the only one that penetrated the full thickness of the accumulated sediment, which included 3.5 feet of silt and clay overlying 1.5 feet of sand interbedded with thin layers of humus. Probably the sand and humus layers were obtained from the original prelake surface, although it is possible that some of the sand may have accumulated in the Virgin River channel during the filling of the reservoir.

At miles 24.5 and 26.1 the Virgin delta is about 10 feet thick, but only the upper few feet could be penetrated. Core 37 at mile 24.50 reached a depth of only 2.1 feet, and core 36 at mile 26.15 extended 5.7 feet into the delta. These cores show that the upper part of the delta was made up of layers of silt and clay; the lower part of the delta could not be penetrated, and its hard compact character suggests that it consisted chiefly of layers of sand. The sand layers are interpreted as topset and foreset beds that accumulated near the mouth of the Virgin River from July 1937 to April 1938, when it remained essentially stationary in the vicinity of mile 26.0. The overlying layers of silt and clay are interpreted as bottomset beds that were deposited in subsequent years when the Virgin River entered the lake several miles to the north.

Little is known about the structure of the Virgin delta north of the foot of the delta front at mile 26.7. The surface or near-surface layers of this part of the delta were made up chiefly of hard sand that could not be penetrated by the coring device. Between miles 26.7 and 30.2 , samples G518 to G525, and penetration measurements show that the upper fow inches of the delta was made up of soft clayey silt which, as previously noted, was probably deposited in slack water that flooded this part of the delta during the high lake stage of 1948. Immediately below the soft surface layer are layers of hard sand, which, as observed by F. C. Ames, were exposed at the delta surface north of mile 30.2. These sand layers are regarded as topset and foreset beds, the division being made at mile 27.4 where the delta profile steepens from 10.7 feet per mile to 29 feet per mile. Although no cores could be obtained from this part of the delta, it seems probable that the topset and foreset beds exposed at the delta surface are advancing over the bottomset beds that make up the delta sur face south of mile 26.7 .

\section{PHYSICAL PROPERTIES}

The Lake Mead deltas are made up almost entirely of particles of sand, silt, and clay. The sand was deposited at or near the mouths of the Colorado and Virgin Rivers and is confined, therefore, to the foreset and topset beds of the deltas. The silt and clay particles, on the other hand, have been carried into the deeper parts of the lake and deposited in the bottomset beds. As a result, the Lake Mead deltas are geographically graded, the coarsest particles accumulating at the heads of the deltas and the finest particles at the greatest distance from the source. This gradation in particle size has produced a gradátional change in most other physical properties of the deltas. For example, the sand of the topset and foreset beds, because of its small volume of interstitial water, is hard and firmly packed. In contrast, the silt and clay of the bottomset beds have an extremely high water content, which has given them the consistency of a soft ooze.

Because the Virgin delta is of relatively minor significance, and because it has not been studied as intensively as the Colorado delta, the following discussion deals chiefly with the physical properties of the materials in the Colorado delta.

\section{TEXTURE AND STRATIFICATION}

Investigations of the topset beds of the Colorado delta were confined to the surficial material in the channel and to the exposed terraces, natural levees, and shallow depressions behind the levees. In the eastern part of Lower Granite Gorge the channel deposits are chiefly medium and coarse sand and small amounts of gravel, whereas the levees and terraces consist of crossbedded fine sand. Locally the upper layers of the terraces and levees have been reworked by the wind, which produced a veneer of well-rounded, frosted sand grains upon the river embankments in many places. Surface material in the depressions behind the natural levees consists of poorly sorted clay, silt, and fine sand that has been deposited beyond the reach of the main current in the channel.

The detrital particles in the western part of Lower Granite Gorge and in the eastern part of Pierce Basin are considerably finer than those in the eastern part of the gorge. As noted previously, the 1948 terrace in these areas is capped by a layer of poorly sorted silt and clay, which accumulated in the slack water that covered the area during the high lake stage of 1948. However, the sediment immediately beneath this layer, as well as the sediment in the channel, is chiefly fine sand. The detrital material in the delta depressions is clayey silt similar to that of the depressions upstream. In the central part of Pierce Basin the steep foreset 


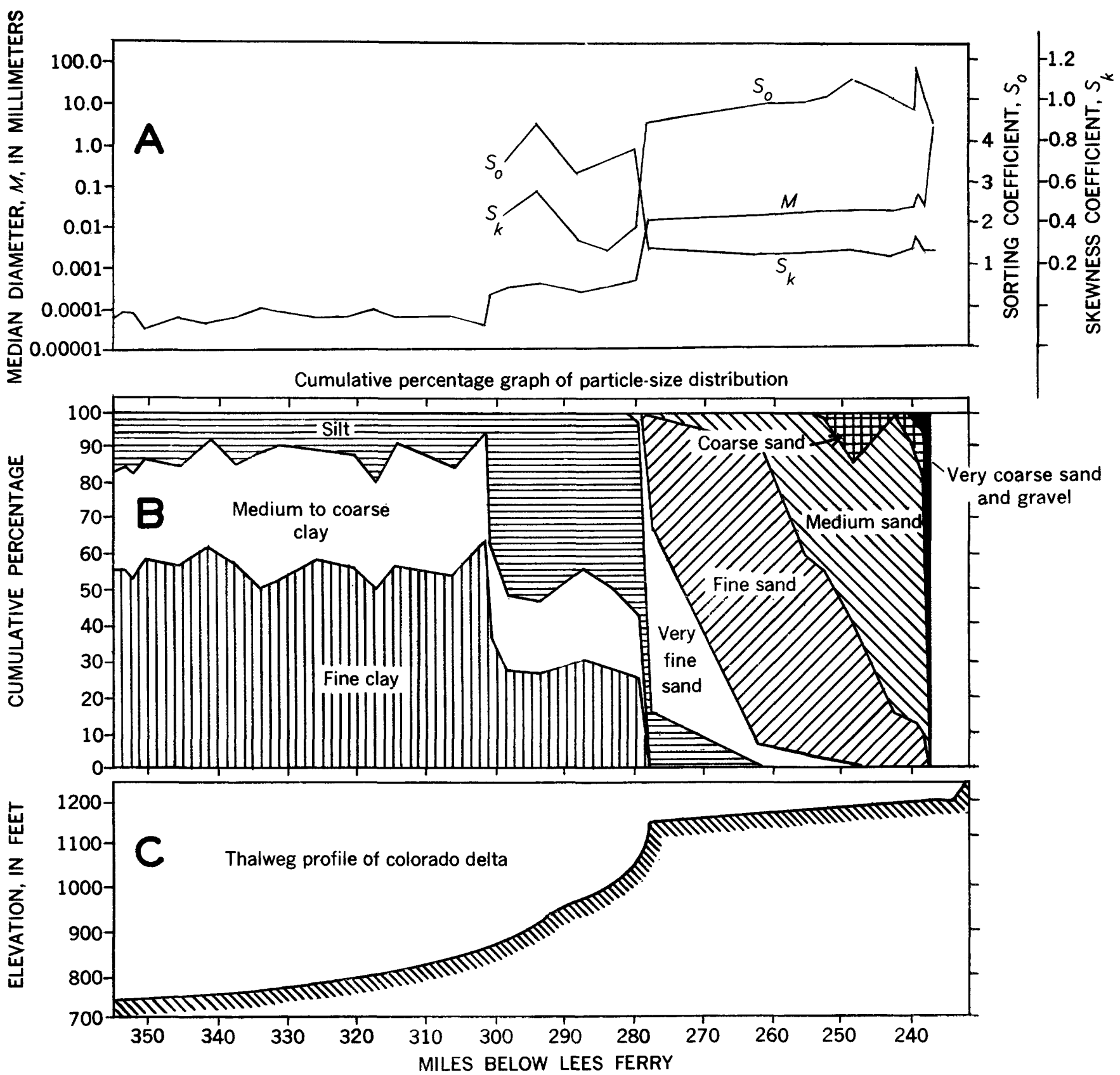

Figure 48.-Textural characteristics of the surficialdeposits of the Colorado delta along the thalweg.

beds exposed at the delta surface also consist of fine sand.

The most striking feature of the topset beds is the virtual absence of coarse gravel, in both the active channel and the natural levees. Samples from the topset beds show that gravel is present only in the easternmost 2 miles of the reservoir (miles 235 to 237 ), and that it is confined to the center of the chamnel. No cores were obtained from this part of the delta during the 1948 survey, but cores taken in 1941 and $1942^{17}$

${ }_{17}$ Murdock, J. N., 1942, Unpublished reports in the files of the U.S. Bureau of Reclamation, Salt Lake City, Utah. indicated that sand and silt constituted practically the entire thickness of the delta east of mile 240 and that only small amounts of gravel were present near the bottom of the buried Colorado River channel. On the basis of these observations it appears that only a very small part of the detrital load carried into the lake by the Colorado River is gravel.

The horizontal grading of the delta materials is shown clearly in a longitudinal section (fig. 48). The sediment particles at the surface range in median diameter from 22.5 millimeters at mile 237.3 to less than 0.001 millimeter (1 micron) at mile 354.6 . It is inter- 
esting to note also that the texture of the surficial sediment is intimately related to the slope of the delta profile. As shown by the cumulative percentage graph and the plot of median diameter, there is an abrupt decrease in grain size at the foot of the delta front. The material making up the steep foreset beds is chiefly fine and very fine sand, whereas the sediment at the surface of the gently sloping bottomset beds west of the delta front consists entirely of silt and clay. It is this relationship that has been used on page 169 to estimate the contact between the bottomset beds and the overlying topset and foreset beds in Lower Granite Gorge. The contact shown on figure 47 does not indicate subsequent compaction of the underlying bottomset beds caused by the weight of the foreset and topset members, but it does give some suggestion of the major textural changes in vertical section.

An interesting feature shown by figure 48 is the relation of the median particle diameter to the coefficients of sorting and skewness. The sorting of the sand of the topset and foreset beds is nearly perfect, and the size-frequency distribution is skewed only slightly toward the finer sizes as the median diameter decreases. In contrast, the silt and clay of the bottomset beds are poorly sorted, and the size-frequency distribution is skewed markedly toward the finer sizes. These relations suggest that the velocities of the Colorado River turbidity currents (p. 204) have been great enough to transport particles of all sizes in the silt and clay size range, but that the velocities have generally not been sufficient to transport sand. Values for sorting and skewness could not be computed for samples west of mile 302 (in Virgin Canyon) because of the large percentage of colloidal particles whose diameters could not be measured by conventional laboratory techniques.

Little is known about the texture of the incipiently developed topset and foreset beds that probably accumulated along the bottom of the Colorado River channel during the early stages of reservoir filling. Visual inspection of thin sand layers obtained locally near the bottom of the channel in the western part of the lake suggests, however, that they are similar in texture to the topset and foreset beds exposed at the surface in the eastern part of Pierce Basin and in the Lower Granite Gorge.

The topset and foreset beds of the Virgin delta have not been studied intensively, but from the limited data available they appear to be similar in texture to the topset and foreset beds of the Colorado delta. As previously mentioned, (p. 172), the topset and foreset beds south of mile 30.2 are covered by a thin layer of silt and clay, and samples from this part of the delta are confined largely to the upper silt and clay layer. The small quantity of sand in most of these samples was obtained from the surface of the underlying topset and foreset beds. A composite analysis of sample G520 shows that the sand component consists of 84 percent fine and very fine sand (62-250 microns) and 16 percent medium sand (250-500 microns); it has a median diameter of 100 microns and a sorting coefficient of 1.32. As determined by this analysis, the topset and foreset beds of the Virgin delta are markedly similar in texture to the topset and foreset beds of the Colorado delta. No samples were obtained from the topset beds exposed at the surface of the Virgin delta north of mile 30.2 , but according to F. C. Ames, who investigated this part of the delta, they are made up predominantly of sand with a minor amount of silt.

The bottomset beds of the Colorado delta are composed of stratified silt and clay; because of their high water content they are exceedingly soft and jellylike. ${ }^{18}$ Only samples from the most deeply buried layers are sufficiently solid not to flow under their own weight. Probably the most striking characteristic of the bottomset beds is the presence of numerous gas cavities, which in some zones give the beds a spongelike appearance.

Textural variations in the bottomset beds are small in transverse section as compared to those in longitudinal and vertical sections, especially west of mile 285.0. Between miles 279.2 and 285.0 the sediment accumulated in the tributaries of the submerged Colorado River channel has a noticeably larger clay fraction than the sediment along the thalweg, doubtless because the finer sediment in the submerged tributaries-like that in the delta flank depressions of the topset bedshas been deposited beyond the reach of the currents in the main channel.

Variations in particle size in longitudinal section are well illustrated by figure 48 . The median particle diameter grades from 6 microns at mile 279.3 to less than 1 micron at Hoover Dam. The relation between particle size and bottom slope is also clearly discernible in this diagram, the coarsest particles forming the steepest slope.

Vertical sections through the bottomset beds at any point show a considerable range in texture, as illustrated in figure 49. The comparatively large vertical variations in median diameter above Virgin Canyon (miles 301.9 to 279.3) suggest that the velocities and perhaps the courses of turbidity currents in this part of the reservoir have varied considerably. West of mile

\footnotetext{
18 The method of analysis of these materials is such as to indicate the size distribution of individual particles, rather than the sizes of the floccules or aggregates that settled from the lake water (p. 154).
} 

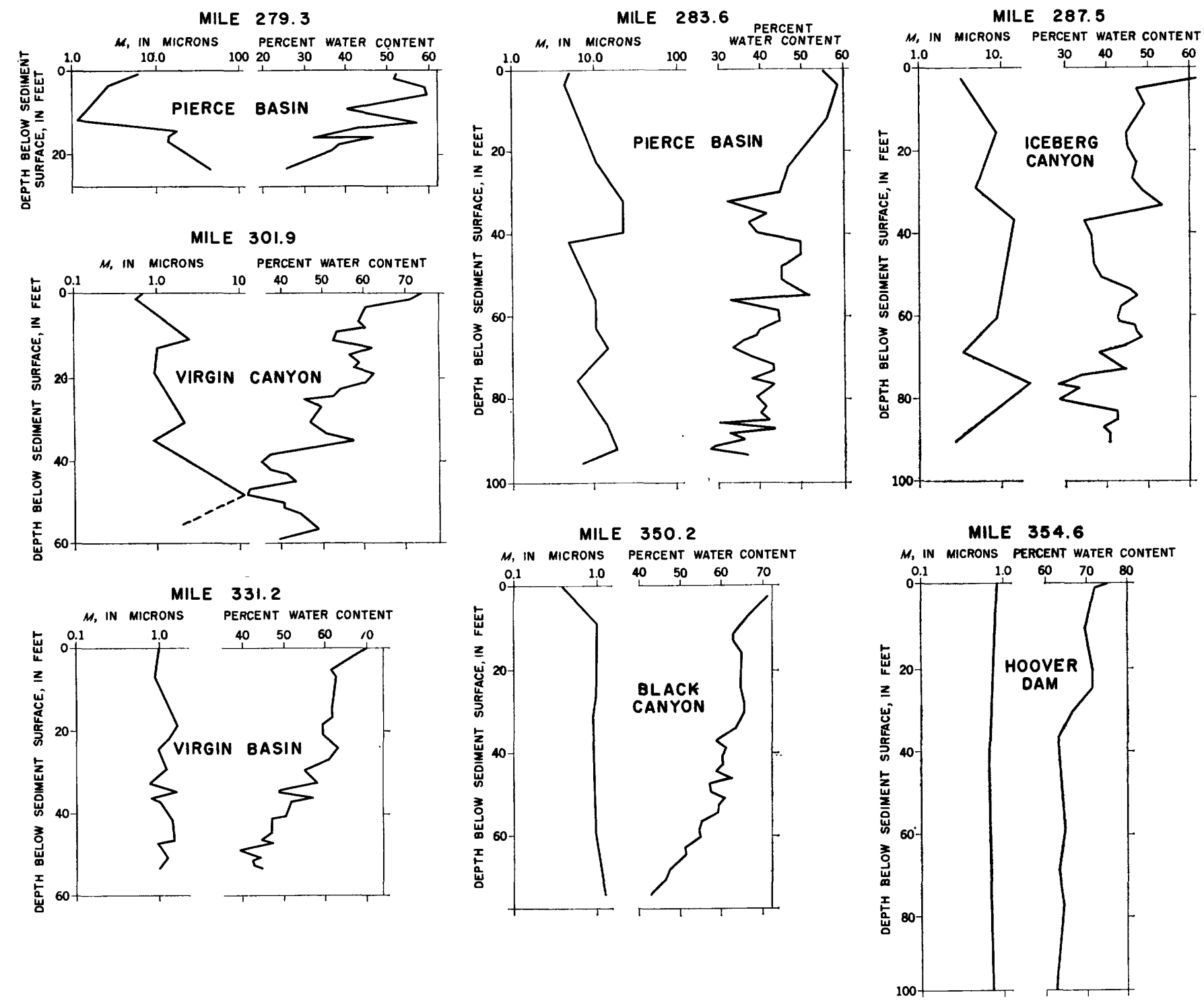

FIGURE 49.-Typical vertical sections of the bottomset beds of the Colorado delta showing the variations in water content and median particle size $(M)$. Particle-size analyses made only of samples showing significant textural changes.

301.9 the size variations in vertical section become progressively smaller, except locally where sand and coarse silt from the reservoir walls have been added to the bottomset beds. However, the total volume of sediment deposited in this manner has evidently been quite small.

The bottomset beds have a distinct stratification, even where the textural variations are not large. Individual layers range in thickness from a fraction of an inch to several feet, and are thinner and more distinct above Virgin Canyon than they are in the western part of the lake. In a few places the separate layers are marked by abrupt changes in texture, but in most places they are differentiated only by slight variations in color, from grayish-brown to reddish-brown; by thin, black organic layers; or by an unusually high percentage of gas cavities. In a few places the strata between adjacent cores could be correlated on the basis of color, texture, thickness, or sequence of beds, but such correlations were not generally possible. The horizontal grading of the bottomset beds and the probable variations in the turbidity currents that have traveled through the lake (p. 202) may account for our inability to trace the individual layers of the bottomset beds for any great distance.

The bottomset beds of the Virgin delta, like those of the Colorado delta, are made up entirely of stratified silt and clay, the individual layers of which range in thickness from less than 1 inch to about 6 inches. In most places the layers are distinguished only by 
changes in color, from reddish brown to gray, or by thin black layers of organic detritus. Porous gaseous layers are not prominent in the bottomset beds of the Virgin delta.

As shown by samples from cores and from the surface of the Virgin delta, the median particle diameter of the bottomset beds ranges from 8.2 microns, near the foot of the delta front (mile 26.7), to about 2.5 microns, near the southern end of the delta (mile 21.4). Farther south the median particle diameter of the thin layer of silt and clay in the bottom of the Virgin River channel decreases to about 1.6 microns at mile 15.1. The downlake decrease in median particle diameter of this thin layer suggests that it is an incipient extension of the bottomset beds of the Virgin delta into the deeper parts of Overton Arm.

Data on the textural variations in vertical section are available only in the vicinity of the delta front, where the bottomset beds range from 4 to 6 feet in thickness. To the north the bottomset beds are overlain by topset and foreset beds that could not be penetrated, and to the south they are in most places less than 2 feet thick. As shown by cores 35 and 36, the texture of the bottomset beds between miles 26.7 and 23.7 of the Virgin River ranges in vertical section from 3 to 30 microns. This corresponds closely to the vertical range in texture of the Colorado delta bottomset beds immediately west of the delta front at mile 279.3 of the Colorado River.

Taken as a whole, the bottomset beds of the Virgin delta are notably coarser than the bottomset beds of the Colorado delta. This may indicate that the sediment load of the Virgin River is lower in fine constituents than the sediment load of the Colorado River. On the other hand, the finer particles in the Virgin River may have been transported by turbidity currents down the relatively steep gradient of Overton Arm and deposited in the bottomset beds of the Colorado delta near the former junction of the Virgin River with the Colorado River.

\section{WATER CONTENT AND POROSITY}

The water content and porosity are of particular interest because they provide the best data as to the amount of compaction that has taken place in the accumulated sediment. When the silt and clay of the bottomset beds are deposited, the water content is commonly as much as 75 percent of the wet weight of the accumulated deposit, and the porosity is as much as 89 percent. As additional layers are deposited on top of those in place, the solid particles of the buried material are packed together more tightly and part of the interstitial water is driven out. The water content and porosity of the accumulated deposits are also related to the size, shape, and sorting of the constituent particles: Coarse, well-sorted, sandy materials have a lower water content than fine, poorly sorted silt and clay. This relation is illustrated abundantly in the Colorado delta where the water content ranges from 16 percent in the well sorted sand of the topset beds to 75 percent in the poorly sorted silt and clay of the bottomset beds, and the porosity ranges from 34 percent to 89 percent.

Because of insufficient data from the deeply buried sediment in the Lower Granite Gorge, the discussion of variations in water content must be confined to the bottomset beds west of the delta front, as represented by the typical sections of figure 49 . The water content in all sections tends to decrease with increasing depth, but there are many inversions where the texture changes, as the water content is inversely related to the median diameter. The sections at miles $279.3,283.6$, 287.5 , and 301.9 show many such inversions, owing to abundant textural changes in this portion of the delta. The correlation would doubtless be more evident if all samples had been analyzed for both particle size and water content; size analyses require so much time, however, that they were made only of samples showing the most significant textural changes. At miles 331.2 and 350.2, textural changes are fewer and smaller, and the water-content inversions are less pronounced. Immediately above Hoover Dam (mile 354.6) the texture of the material in vertical section is almost uniform and the decrease in water content with increasing depth is approximately linear. These diagrams also show that the lateral range in water content is closely related to textural variations in longitudinal section. At mile 279.3 , where the average median diameter of the particles is about 10 microns, the water content ranges from 51 percent at the surface to about 30 percent at a depth of 21 feet. In contrast, the water content of sediment at the dam, where the average median diameter is less than 1 micron, ranges from 71 percent at the surface to 62 percent at a depth of 99 feet.

Probably a better picture of the lateral range in water content and consolidation of the bottomset beds of the Colorado delta can be obtained from the fathograms shown in figure 85. At mile 348.9 in Boulder Basin, where the bottomset beds have much interstitial water and are only slightly compacted, recorded sound reflected from both the surface of the bottomset beds and the underlying topography of the pre-Lake Mead bottom are clearly visible. The surface of the bottomset beds and the underlying topography at miles 324.3 in Virgin Basin and 295.5 in Gregg Basin can also be distinguished, but with greater difficulty. The dense- 
ness of the record between the upper and lower traces at miles 324.3 and 295.5 results from the greater compaction and lower water content of the bottomset beds in these areas. Owing to the still greater compaction of the bottomset beds east of mile 295.5, the sound was completely absorbed before it reached the bottom of the buried Colorado River channel. Consequently, fathograms east of mile 295.5 show only the surface of the bottomset beds. A comparison of sediment compaction data with the fathograms suggests that the sediment becomes opaque to sound at 14.25 kilocycles when the water content reaches about 34 percent and when the specific weight approaches 70 pounds per cubic foot.

There are no data on the water content and porosity of the topset and foreset beds of the Virgin delta, but their general similarity in texture to the topset and foreset beds of the Colorado delta suggests that their water content and porosity are also similar. On the other hand, the bottomset beds of the Virgin delta at any given depth have a notably lower water content and porosity than the bottomset beds of the Colorado delta. For example, the water content of the surface layers of the Virgin delta bottomset beds ranges from 39 to 62 percent, and the porosity from 63 to 82 percent. In contrast, the water content of the surface layers of the Colorado delta bottomset beds ranges from 47 to 75 percent, and the porosity from 71 to 89 percent. The lower water content and porosity of the Virgin delta bottomset beds result apparently from their coarser texture.

In vertical section the water content and porosity of the Virgin delta bottomset beds decrease with increasing depth of burial. As shown by core 36 taken at mile 26.15 , the water content ranges from 52.9 percent at the surface to 35.0 percent at a depth of 5 feet. The porosity in this same depth interval ranges from 75.3 to 59.3 percent.

\section{SPECIFIC WEIGHT}

The specific weight of the sediment deposit is related to the same physical properties that were outlined in the discussion of water content and porosity; namely, the size and sorting of the constituent particles and the depth of sediment burial. Coarse sediments (sand and gravel) have a high specific weight when they are first deposited, because of the dense packing of the constituent particles. On the other hand, fine sediments (silt and clay) have a very low specific weight when they are initially laid down, because of the loose arrangement of the solid grains. This relation is well illustrated in the Colorado delta, where the specific weight ranges from 108 pounds per cubic foot for coarse sand to as little as 18 pounds per cubic foot for silt and clay.

If the accumulated material is very fine grained, the specific weight increases with the depth of sediment burial. The rate of increase in the specific weight of sand with depth of burial is small, owing to its initially dense packing. On the other hand, the loose arrangement of silt and clay particles is readily changed to a denser state as the depth of burial increases. This causes a marked increase in the compaction of silt and clay sediments, the deepest layers having the highest specific weight.

Both the horizontal and vertical variations in the specific weight of the Colorado delta are illustrated in figure 50. This diagram shows clearly that the specific weight of the topset and foreset beds exposed at the delta surface above mile 279.3 is greater than that of the most deeply buried bottomset beds west of the delta front, and that the specific weight of the bottomset beds increases with increasing depth. It is interesting to note, also, that the specific weight of the bottomset beds at any given depth decreases progressively from the foot of the delta front to Hoover Dam. This decrease is related primarily to the decrease in size of the constituent particles, as shown by comparison of the physical characteristics of two samples, one from a depth of 38.9 feet at mile 283.64 and the other from the same depth at mile 350.08 . The sample at mile 283.64 had a median particle diameter of 22.0 microns and a specific weight of 62.1 pounds per cubic foot. In contrast, the sample at mile 350.08 had a median diameter of 0.73 micron and a specific weight of 32.5 pounds per cubic foot. In the deeper, unsampled layers of the bottomset beds, the specific weight has been obtained by linear extrapolation of specific weight data from higher levels. These extrapolations are denoted in figure 50 by dashed lines.

From the previous discussion of delta structure, it seems probable that a very thin layer of incipiently developed topset and foreset beds, formed during the early stages of reservoir filling, underlies the bottomset beds west of the delta front. Since there are no data on the specific weight of these beds, they have been included with the bottomset beds in this extrapolation. If the topset and foreset beds at the bottom of the channel are similar in specific weight to the topset and foreset beds exposed at the delta surface in Lower Granite Gorge, the extrapolated specific weight of the sediment along the bottom of the Colorado River channel west of the delta front is probably too low. The average specific weight of the topset and foreset beds in Lower Granite Gorge is estimated at 93.8 pounds per cubic foot, wheras the average extrapolated 
CHARACTER OF THE ACCUMULATED SEDIMENT

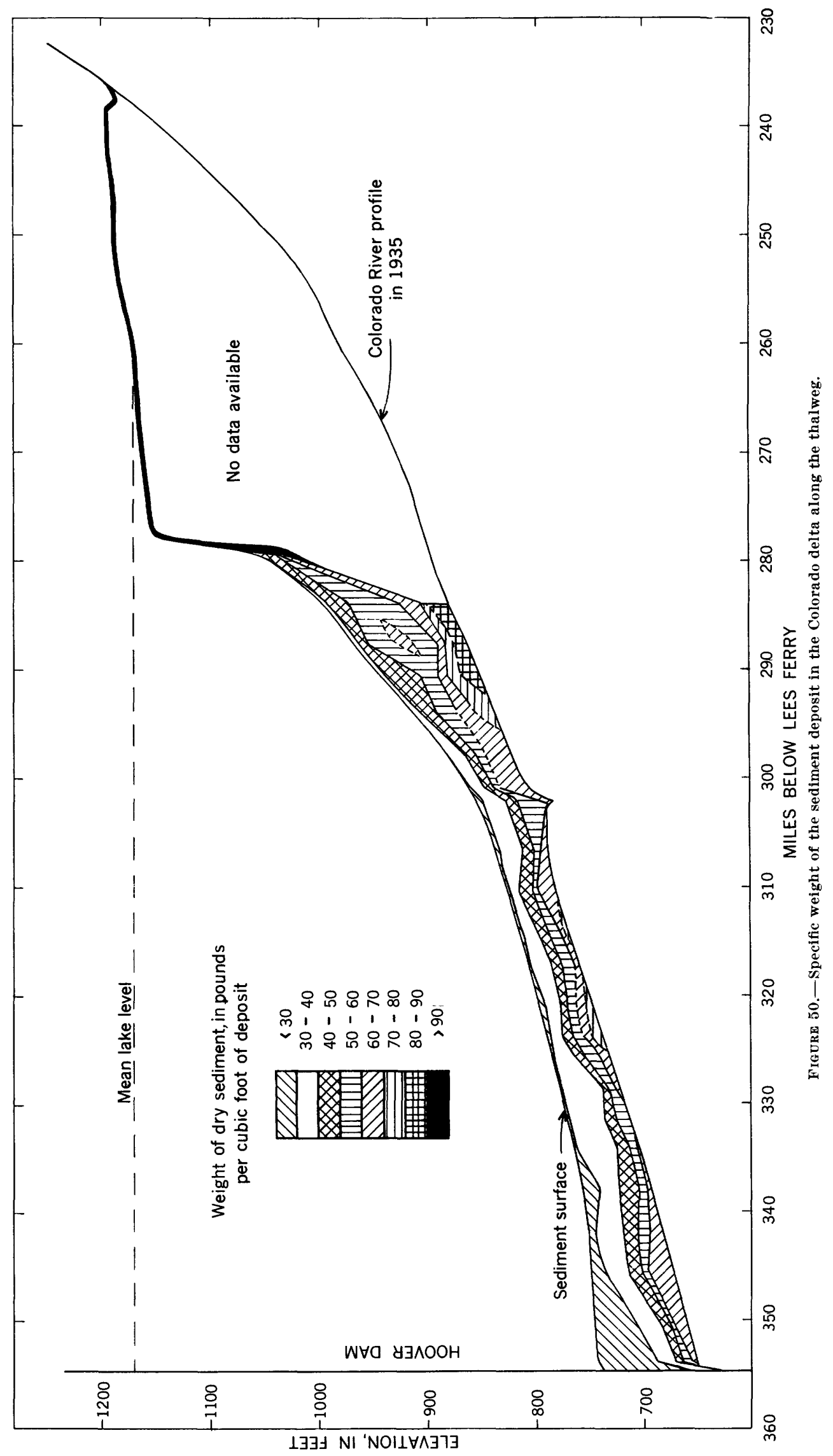


specific weight of the sediment at the bottom of the channel west of the delta front is about 75 pounds per cubic foot. Since the volume of the layer of topset and foreset beds at the bottom of the channel is probably very small, it seems likely that use of the average extrapolated specific weight of 75 pounds per cubic foot has introduced no serious error in computations of the total weight of sediment accumulated in the Colorado delta.

No quantitative data are available on the vertical variations in specific weight of the sediment accumulated east of the Colorado delta front. Computations based on delta structure (fig. 47) and the volume of sediment suggest, however, that the sandy topset and foreset beds make up about 83 percent of the total volume of this part of the delta and that bottomset beds of silt and clay constitute only 17 percent.

According to laboratory experiments by Terzaghi (1925), the compaction and increase in specific weight of sand are insignificant when subjected to pressures less than about 100 pounds per square inch. Since the weight of the superposed load reaches this value only in the most deeply buried sand layers east of the delta front, the specific weight of the topset and foreset beds probably does not increase appreciably with increasing depth, and the specific weight of the surface material is presumed to be characteristic of all depths.

This conclusion is supported by specific-weight measurements of several sand samples from deep levels in the bottomset beds. This material, probably derived by slumping of the reservoir walls, has about the same specific weight at depths of 37 to 55 feet as the sand at the surface of the delta in Lower Granite Gorge. Consequently the specific weight of all the sand in the topset and foreset beds east of the delta front is estimated at 93.8 pounds per cubic foot, which is the average specific weight of 12 samples collected from the surface of the topset and foreset beds. Two other samples are not considered representative of the topset and foreset beds as a whole because of their coarseness and high specific weight; they have not been included in this average.

It has been assumed that the deeply buried bottomset beds east of the Colorado delta front are similar in texture to the bottomset beds immediately west of the delta front. Then the sediment in the two areas should have the same compaction properties, and the specific weight at any given level would be related to the depth of burial. The bottomset beds east of the delta front range in depth from 150 feet to about 250 feet. Data from the bottomset beds immediately west of the delta front are available, however, only to a sediment depth of 95 feet. By linear extrapolation of these data to greater depths, we obtain an estimated mean specific weight of 100 pounds per cubic foot for the deeply buried bottomset beds in the vicinity of the delta front.

No data are available on the specific weight of the Virgin delta topset and foreset beds. Their general textural correspondence to the topset and foreset beds of the Colorado delta suggests, however, that they are also similar in specific weight. It is assumed, therefore, that the Virgin delta topset and foreset beds have about the same average specific weight ( 93.8 pounds per cubic foot) as the topset and foreset beds of the Colorado delta.

Because of their coarser texture, the specific weight of the Virgin delta bottomset beds at any given depth is notably higher than the specific weight of the Colorado delta bottomset beds. The specific weight of the uppermost bottomset beds ranges from 62.0 pounds per cubic foot near the delta front to 30.6 pounds per cubic foot at the lower end of the delta. As shown by core 36 , where the Virgin delta bottomset beds are thickest the specific weight ranges from 41.7 pounds per cubic foot at the surface to 68.7 pounds per cubic foot at a depth of about 5 feet.

\section{GAS CONTENT}

The occurrence of a considerable amount of gas in the sediments of the Colorado delta is indicated by abundant gas pits on the exposed terrace near the delta front and by a great number of unconnected gas cavities in the cores from the bottomset beds. Gas bubbles emanating from the subaqueous bottomset beds in Pierce Basin were sampled, and an analysis of the gas composition made by the U.S. Bureau of Mines Petroleum and Oil-Shale Experiment Station in Laramie, Wyo., showed the following constituents:

\section{Constituents of gas from the Colorado delta in Pierce Basin}

[Analysis by Petroleum and Oil-Shale Experiment Station, U.S. Bureau of Mines, Laramie, Wyo.]

Percent

Methane, $\mathrm{CH}_{4}-18.0$
Nitrogen, $\mathrm{N}_{2^{-}}-16.3$

Oxygen, $\mathrm{O}_{2-1}$

Argon, $\mathrm{A}$

Carbon dioxide, $\mathrm{CO}_{2}$

100.0

According to this analysis, the gas is composed principally of methane, some nitrogen and oxygen, and small amounts of argon and carbon dioxide. The nitrogen, oxygen, and argon are in roughly the same proportion as they are in air. The dissolved gases in the lake water overlying the bottomset beds are presumed to have been in equilibrium with the atmosphere, so that the proportions of nitrogen, oxygen, 
and argon should be about the same in the water as in the air. It seems a reasonable conclusion, therefore, that most if not all of the nitrogen, oxygen, and argon were introduced from the water into the gas bubbles as they ascended from the bottomset beds to the lake surface. The methane and carbon dioxide, on the other hand, must have been produced by the biochemical decomposition of organic matter in the bottomset beds.

Except for the small amount of argon, the gas contained in the bottomset beds of the Colorado delta has about the same composition as that reported by Shaw $(1913,1914)$ of gas samples from the Mississippi delta.

Gas cavities occur at practically all depths in the bottomset beds of the Colorado delta west of the delta front; they are extremely numerous in some layers. Deeper cavities are elongated in planes parallel to the bedding, suggesting that the lateral expansion of the gas has been greater than the vertical expansion as the cores were brought to the surface.

When cores from the bottomset beds were raised to the surface, it was found that the gas contained in them expanded to several times its volume at depth, and formed cavities ranging in diameter from less than 1 millimeter to about 15 millimeters at atmospheric pressure. To obtain an estimate of the average gas content in place, 74 samples of measured volume were collected from the bottomset beds of the Colorado delta. These samples were obtained from localities widely distributed, both laterally and vertically, and are considered, therefore, to be representative of the Colorado delta bottomset beds as a whole. The volume of gas in the sediment in place was calculated as outlined on page 154 .

At atmospheric pressure the gas volume may be as much as 12 percent of the volume of the water-saturated sediment, but the maximum gas content in place is about 2 percent. In vertical section the gas content does not vary systematically, but in longitudinal section there is a general decrease in gas content downlake from the delta front. The gas content, as determined by averaging the individual measurements in each of the six vertical sections of cores $\mathrm{K} 1$ to $\mathrm{K} 6$, ranges from 1.1 percent at mile 283.5 to 0.3 percent at mile 351.8 (fig. 51). The average of all determinations is 0.6 percent, which is probably representative of the average gas content of the bottomset beds west of the Colorado delta front.

The gas issuing from the pits in the surface of the 1948 terrace was doubtless being squeezed out of the underlying bottomset beds by the weight of the topset and foreset beds, and passed through those beds on its way to the surface. No evidence was found of gas originating in the topset or foreset beds.

$$
4969180-60-13
$$

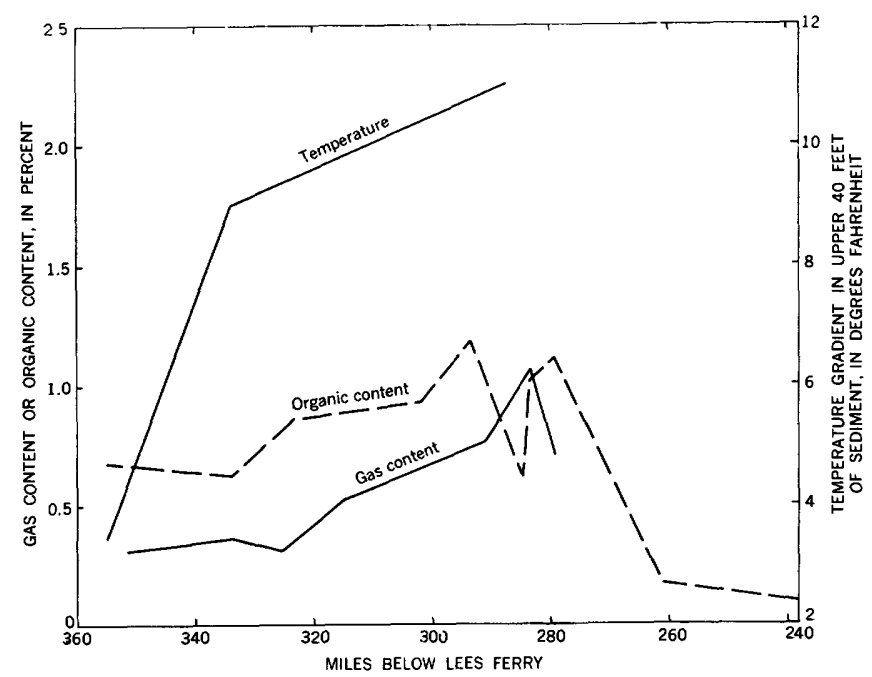

Figure 51.-Relations of gas content, organic content, and temperature gradient in longitudinal section through the Colorado delta. Values of organic content and gas content are averages of samples from each of several vertical sections. Teniperature gradient represents temperature increase in the upper 40 feet of the accumulated sediment.

No measurements were made of the gas content of the Virgin delta bottomset beds, but, from visual inspection of cores, gas cavities are not nearly so prominent as they are in the bottomset beds of the Colorado delta (see pl. 23).

\section{SEDIMENT TEMPERATURE}

The temperature of the bottomset beds of the Colorado delta is higher than that of the water in the reservoir immediately above them, and higher than would be expected from the regional geothermal gradient. Measurements since the summer of 1937 (National Research Council, 1949) show that the surficial layers of the bottomset beds everywhere are more than $5^{\circ} \mathrm{F}$, and in places as much as $9^{\circ} \mathrm{F}$, warmer than the overlying lake water with which they are in contact.

In the cruises described by Anderson and Pritchard $(1951$, p. 52$)$ it was the practice to lower the bathythermograph until it rested on the bottom at each station. The weight of the bathythermograph commonly caused the instrument to sink as much as 20 feet in the soft mud before coming to rest. Temperature traces generally showed a considerable increase in temperature just at the surface of the mud, but no increase in the water immediately above the bottom.

In order to measure the temperatures of the deeper sediments, a mud bathythermograph, especially designed and constructed by the Navy Electronics Laboratory, was lowered into the bottomset beds at three localities between the foot of the delta front and Hoover Dam. The mud bathythermograph is a modification of the conventional bathythermograph which 
provides a continuous graphic record of the temperature as a function of depth. The chief modifications include the addition of a pointed nose, weighted so as to penetrate the sediment to considerable depth, and relocation of the temperature-measuring capillary tubing to reduce the hysteresis caused by mud clinging to the instrument. By lowering this instrument at a rate of less than 3 feet per minute, hysteresis was reduced enough that reasonably accurate records of temperature were obtained.

A record of temperature throughout the total thickness of bottomset beds was obtained immediately upstream from Hoover Dam. At localities in Boulder Canyon (mile 333.9) and Iceberg Canyon (mile 287.5) the bathythermograph was stopped by compact sediment at depths of 42 feet and 45 feet respectively. These measurements (fig. 52) show that the temperature of the bottomset beds increases with increasing depth and that the temperature gradient is much steeper near the foot of the delta front than it is near Hoover Dam.
The average temperature gradient ranges from $0.28^{\circ} \mathrm{F}$ per foot at mile 287.5 to $0.07^{\circ} \mathrm{F}$ per foot at mile 354.6. The traces at miles 287.5 and 354.6 show a distinct temperature stratification. The change in temperature at the water-sediment interface is abrupt in all records.

Several factors have contributed to the heating of the bottomset beds of the Colorado delta, but they have not been evaluated quantitatively. F. D. Sisler discusses several of the possible causes of this heating on pages 190-191, and concludes that biochemical processes probably account for most of the observed heating.

It is possible also that part of the heat may result from an initially higher temperature of the sediment when it was deposited in the bottomset beds. Densitycurrent records prior to 1948 (U.S. Bur. Reclamation, 1941, 1947) show that the temperature of turbidity currents flowing along the bottom of the reservoir has generally been lower than the temperature of the overlying lake water. However, on March 28, 1939, a flow of
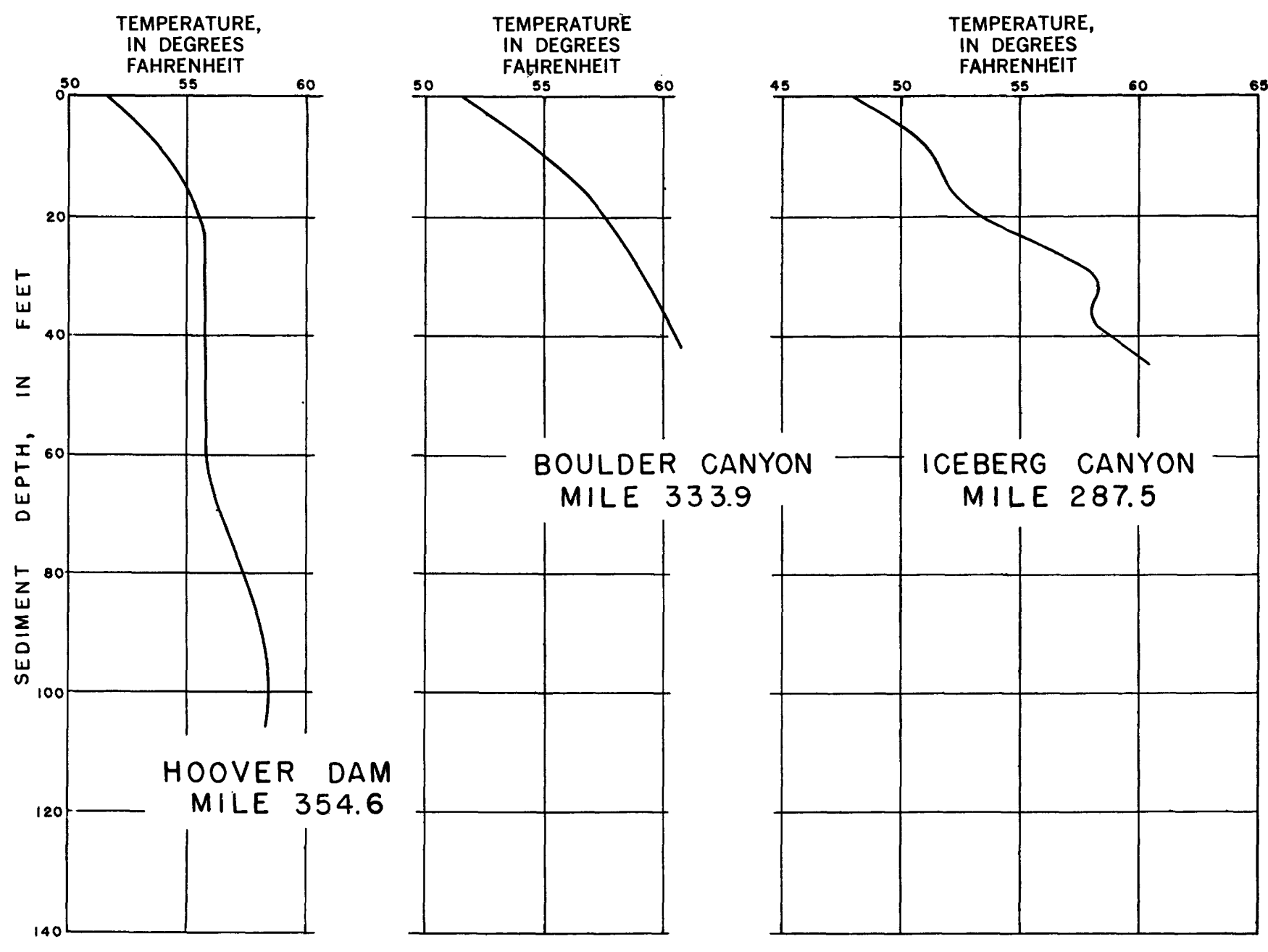

Figure 52.-Vertical distribution of temperature th the bottomset beds of the Colorado delta. 
turbid water about $4^{\circ} \mathrm{F}$ warmer than the overlying water was detected at the bottom of the reservoir as far west as Boulder Canyon. The temperatures of some other flows may have been correspondingly high, but there are no records of them. A similar occurrence of warm turbidity currents flowing along the bottom of Elephant Butte Reservoir has been noted by Fiock (1934).

The geothermal gradient near Hoover Dam has been estimated at about $0.013^{\circ} \mathbf{F}$ per foot (U.S. Bur. Reclamation, 1950, p. 177). If the vertical flow of heat through the bottomset beds were the same as that through the underlying and bordering rocks, heat of deep-seated origin would account for only a very small part of the heating observed in the sediments, The only hot springs known in the Lake Mead area are those discovered at the site of Hoover Dam during the construction period (U.S. Bur. Reclamation, 1950, p. 179). Possibly these springs have contributed a small amount of heat to the overlying bottomset beds in the vicinity of Hoover Dam, but they could not account for the general heating of the bottom sediments.

\section{CHEMICAL PROPERTIES}

Chemical, spectrographic, and clay-mineral analyses have been made of a relatively few samples, selected so as to provide a reasonably accurate picture of the general chemical composition of the accumulated sediment as a whole. Evidence of precipitation of calcium carbonate from the lake water led to a more intensive investigation of the content and distribution of calcium carbonate in the accumulated sediment. The organic matter in the sediment, because of its possible relation to the heating of the bottomset beds and to the evolution of methane, was investigated more thoroughly than most other constituents.
CHEMICAL ANALYSES

Eight samples from widely distributed localities were analyzed in the geochemical laboratories of the Geological Survey. Of these, seven samples from the Colorado delta include representative material from the topset, foreset, and bottomset beds; and one sample from the Virgin delta is representative of the bottomset beds.

The results of these analyses (table 23) show that the composition of the topset beds of the Colorado delta differs markedly from the composition of the bottomset beds. The bottomset beds of the Colorado and Virgin deltas are notably similar in composition. The topset beds of the Colorado delta are made up almost entirely of $\mathrm{SiO}_{2}$, whereas the bottomset beds have an average $\mathrm{SiO}_{2}$ content of only about 50 percent. Of the major constituents, $\mathrm{Al}_{2} \mathrm{O}_{3}, \mathrm{Fe}_{2} \mathrm{O}_{3}, \mathrm{MgO}, \mathrm{CaO}$, and $\mathrm{K}_{2} \mathrm{O}$ are much more abundant in the bottomset beds. Likewise, the minor constituents $\mathrm{Na}_{2} \mathrm{O}, \mathrm{TiO}_{2}$, $\mathrm{P}_{2} \mathrm{O}_{5}$, and $\mathrm{MnO}$, are appreciably higher in the bottomset beds than in the topset beds. The foreset beds of the Colorado delta are intermediate in composition between that of the topset and bottomset beds, but more like the topset beds.

Judging from its high silica content, the sand of the topset beds is made up chiefly of detrital fragments of quartz. The silt and clay samples from the bottomset beds are made up chiefly of hydrous aluminum silicates and hydroxides of iron and aluminum, as shown by lower silica content, by appreciable quantities of $\mathrm{Al}_{2} \mathrm{O}_{3}$, $\mathrm{Fe}_{2} \mathrm{O}_{3}, \mathrm{MgO}$, and $\mathrm{K}_{2} \mathrm{O}$, and by high ignition loss. The foreset beds, chiefly sand with small amounts of silt and clay, are made up of quartz fragments and a minor proportion of hydroxides and hydrous aluminum silicates.

TABLE 23.-Chemical analyses of samples from the sediment deposits in Lake Mead, in percent

\begin{tabular}{|c|c|c|c|c|c|c|c|c|}
\hline \multirow[b]{3}{*}{$\begin{array}{l}\text { Location of sample, mile } \\
\text { Sample } \\
\text { Depth below sediment surface }\end{array}$} & \multicolumn{7}{|c|}{ Colorado delta } & \multirow{3}{*}{$\begin{array}{c}\begin{array}{c}\text { Virgin } \\
\text { delta }\end{array} \\
\begin{array}{c}\text { Bottomset } \\
\text { beds }\end{array} \\
\begin{array}{c}15.8 \\
\text { G533 } \\
0\end{array} \\
\end{array}$} \\
\hline & Topset beds & Foreset & & & mset be & & & \\
\hline & $\begin{array}{c}255.5 \\
\mathrm{G} 1270 \\
0 \\
\end{array}$ & $\begin{array}{r}277.9 \\
1037 \\
\end{array}$ & $\begin{array}{l}287.5 \\
937 \\
58 \\
\end{array}$ & $\begin{array}{c}297.7 \\
698 \\
13\end{array}$ & $\begin{array}{l}306.2 \\
634 \\
42\end{array}$ & $\begin{array}{c}325.3 \\
332 \\
18\end{array}$ & $\begin{array}{r}345.4 \\
1176 \\
30\end{array}$ & \\
\hline 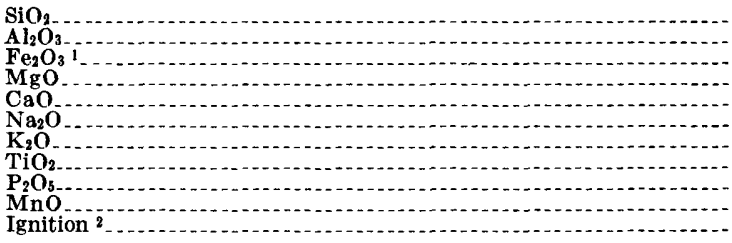 & $\begin{array}{l}91.7 \\
1.6 \\
1.8 \\
.22 \\
1.4 \\
.46 \\
.79 \\
.32 \\
.05 \\
.02 \\
1.1\end{array}$ & $\begin{array}{l}80.4 \\
5.2 \\
1.0 \\
.75 \\
3.6 \\
.75 \\
2.0 \\
.24 \\
.07 \\
.02 \\
5.1\end{array}$ & $\begin{array}{r}55.7 \\
12.2 \\
4.0 \\
2.8 \\
7.4 \\
.90 \\
2.4 \\
.59 \\
.18 \\
.08 \\
13.0\end{array}$ & \begin{tabular}{c|}
55.2 \\
13.0 \\
4.0 \\
3. \\
7.6 \\
.76 \\
2.4 \\
.72 \\
.17 \\
.06 \\
13.2
\end{tabular} & $\begin{array}{r}56.4 \\
15.4 \\
4.9 \\
2.6 \\
5.1 \\
.69 \\
2.6 \\
.70 \\
.17 \\
.08 \\
12.2\end{array}$ & $\begin{array}{r}52.1 \\
17.2 \\
5.2 \\
3.0 \\
5.0 \\
.48 \\
2.6 \\
.64 \\
.16 \\
.06 \\
14.0\end{array}$ & $\begin{array}{r}47.0 \\
14.8 \\
4.6 \\
3.7 \\
9.2 \\
.48 \\
2.6 \\
.58 \\
.18 \\
.08 \\
16.6\end{array}$ & $\begin{array}{r}45.4 \\
14.2 \\
4.8 \\
4.3 \\
9.8 \\
.66 \\
2.8 \\
.58 \\
.20 \\
17.3 \\
17.3\end{array}$ \\
\hline Total ... & 99.5 & 99.1 & 99.2 & 100.1 & 100.8 & 100.4 & 99.8 & 100.1 \\
\hline
\end{tabular}

1 Total Fe expressed as $\mathrm{Fe}_{2} \mathrm{O}_{3}$

2 Includes loss due to oxidation of $\mathrm{FeO}$. 
The composition of the sand in the topset beds of the Colorado delta is remarkably similar to the average composition of river sands listed by Clarke (1924, p. 507), except that it contains one-fourth the aluminum and about twice the calcium concentration shown in Clarke's average. Likewise, the composition of the bottomset beds of both the Colorado delta and Virgin delta corresponds very closely with the average composition of shales (Clarke, 1924, p. 30). The only notable differences are that the bottomset beds of the Lake Mead deltas contain about twice the calcium and only one-half the sodium concentration of the average shale.

\section{SPECTROGRAPHIC ANALYSES}

Six samples from the bottomset beds of the Colorado delta were analyzed spectrographically in the geochemical laboratories of the Geological Survey in Washington, D.C., using prepared soil samples and a sample of Mississippi River silt as comparison standards. Owing to their general similarity the analyses have been averaged for presentation. A. T. Myers, the analyst, states that the element composition of the silt and clay from the Colorado delta is of the same order as that of the Mississippi River silt, except that the Colorado delta samples contain only one-half the sodium and one-fourth the copper concentration found in the Mississippi River silt.

$$
\begin{gathered}
\text { Spectrographic analysis of samples from the bottomset beds } \\
\text { of the Colorado delta }
\end{gathered}
$$

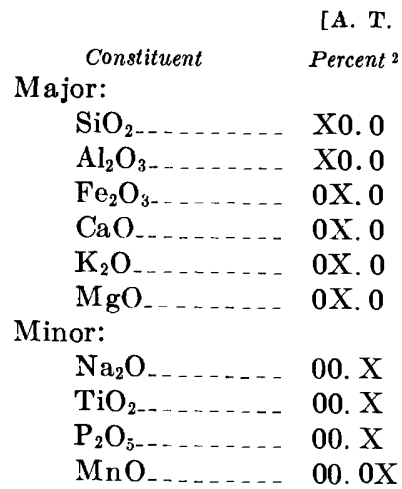

Constituent
Minor-Continued
$\mathrm{ZrO}_{2} \ldots$
$\mathrm{BaO} \ldots \ldots$
$\mathrm{NiO}_{2} \ldots \ldots$
$\mathrm{CuO}_{\mathrm{Cr}_{2} \mathrm{O}_{3}} \ldots \ldots$
$\mathrm{V}_{2} \mathrm{O}_{5} \ldots \ldots$
$\mathrm{PbO}$
Trace:
$\mathrm{Sr}$
$\mathrm{Y}$

Percent ${ }^{2}$

$00.0 \mathrm{X}$

$00.0 \mathrm{X}$

$00.00 \mathrm{X}$

$0000 \mathrm{X}$

$00.00 \mathrm{X}$

$00.00 \mathrm{X}$ $00.000 X$

1 Average for samples G3, G13, 27, 30, 42, and 62 .

${ }^{2}$ The first slgnificant digit in the percentage composition is denoted by $\mathbf{X}$. For example, the percentage of $\mathrm{SiO}_{2}$, shown as X0.0 percent, in dicates that the material contains between 10 and 90 percent $\mathrm{SiO}_{2}$. Additional elements, Ag, As, $\mathrm{Au}, \mathrm{Be}, \mathrm{B1}, \mathrm{Cd}, \mathrm{Co}, \mathrm{Ge}, \mathrm{In}, \mathrm{La}, \mathrm{Mo}$. and, $\mathrm{Zn}$ were looked for but not found.

\section{CLAY MINERALS}

Clay-mineral analyses were made of four samples from the bottomset beds of the Colorado delta by George Tchillingarian of the University of Southern California. He reports that montmorillonite is slightly more abundant than illite and kaolinite, and that kaolinite is more prominent in the particles larger than 1 micron than in the smaller particles. This is in close accord with the earlier findings of Grim, Dietz, and Bradley (1949), which show approximately equal proportions of illite, montmorillonite, and kaolinite in the bottomset beds of the Colorado delta.

\section{CALCIUM CARBONATE}

To obtain an estimate of the quantity and distribution of calcium carbonate in the sediments of the Colorado delta, 34 samples from widely distributed positions were analyzed by the alkalimeter method outlined by Trask (1932, p. 97). These analyses (table 24) show that the sand of the topset and foreset beds contains much less calcium carbonate than do the silt and clay of the bottomset beds. The calcium carbonate content of the topset and foreset beds ranges from 2.3 to 6.4 percent and averages 4.6 percent. In contrast, the calcium carbonate content of the bottomset beds ranges from 10.2 to 19.7 percent and averages 16.1 percent. A marked increase in calcium carbonate is correlative with the abrupt decrease in grain size at the foot of the delta front at mile 279.3.

TABLE 24.-Characteristics of calcium carbonate and organic matter in selected samples from the Colorado delta

\begin{tabular}{l|r|r|r|r|r}
\hline Location, mile-- & Sample & $\begin{array}{c}\text { Sediment } \\
\text { depth, in } \\
\text { feet }\end{array}$ & $\begin{array}{c}\text { Median } \\
\text { diameter, } \\
\text { in microns }\end{array}$ & $\begin{array}{c}\mathrm{CaCO}_{3} \\
\text { in percent }\end{array}$ & $\begin{array}{c}\text { Organic } \\
\text { matter, in } \\
\text { percent } 1\end{array}$ \\
\hline & \multicolumn{7}{|c|}{ Topset beds } \\
\hline
\end{tabular}

1 Organic carbon determined by chromic acid reduction, multiplied by 1.7 . 
Although the high calcium carbonate content of the bottomset beds is related to their fine texture, the percentage of calcium carbonate in individual samples does not vary systematically as a function of particle size. For example, sample SIO-1C, which has a median diameter of 0.8 micron, has about the same calcium carbonate content as sample 1029 , which has a median diameter of 45 microns. Likewise there are no systematic lateral or vertical variations in the calcium carbonate content of the bottomset beds.

Similarly, the low calcium carbonate content of the topset and foreset beds is related to their coarse texture, but calcium carbonate determinations of individual samples do not vary systematically as a function of grain size.

No analyses have been made of calcium carbonate in samples from the Virgin delta. However, the calcium concentration in the Virgin delta bottomset beds (table 23) suggests that the calcium carbonate content of the Virgin delta is of the same order of magnitude as that of the Colorado delta.

The total weight of sediment in the topset and foreset beds of the Colorado delta is estimated (p. 195) to be approximately equal to that in the bottomset beds. From the average calcium carbonate content of the topset and foreset beds ( 4.7 percent) and of the bottomset beds (16.1 percent) it is estimated that the Colorado delta has an average calcium carbonate content of 10.3 percent. This estimate is considered to be applicable to all the sediment accumulated in Lake Mead because the contributions from the Virgin River and other sources are generally similar to those from the Colorado River and, in any event, constitute a very small proportion of the total.

Some calcium carbonate is precipitated from the lake water, as shown by thin calcareous incrustations on the reservoir walls and by deposits of calcium carbonate in the drainage tummels of Hoover Dam. An analysis of the incrusting material by Wilson Orr of the University of Southern Califormia shows that calcium carbonate constitutes approximately 90 percent of these precipitates. The remaining 10 percent consists of dead green algae which have been identified as the genus Spyrogira by E. Yale Dawson of the Allan Hancock Foundation at the University of Southern California.

The quantity of calcium carbonate in the accumulated sediment, however, is far greater than can be accounted for by precipitation from the lake. C. S. Howard states (p. 123) that about 9 million tons of calcium carbonate and 1 million tons of silica were precipitated from the lake water during the 14-year interval 1935-48. In terms of the 2,000 million tons (dry weight) of sediment that has accumulated in Lake Mead during the same period, the amount of precipitated calcium carbonate is 0.45 percent, and of silica, 0.05 percent.

From the great difference between the amount of calcium carbonate precipitated from the lake water ( 0.45 percent) and that contained in the accumulated sediment ( 10.3 percent $)$, it is evident that large quantities of calcium carbonate are carried into the lake as part of the suspended load of the Colorado River. This conclusion is confirmed by analyses by Sykes (1937) of the suspended load of the Colorado River in the delta at the head of the Gulf of Califormia. According to his average analysis, the suspended load has an average calcium carbonate content of 10 percent.

\section{ORGANIC CONTENT}

The organic matter in the accumulated sediment determines to a large extent the intensity of biochemical processes. Most of the organic matter is finely divided plant fragments, transported into the lake by the inflowing streams and deposited with the inorganic particles in the Lake Mead deltas. Some orgamic matter is also contributed to the sediment by fresh-water algae and subaerial vegetation growing in and about the lake. The luxuriant growth of green algae on the walls of the reservoir and the numerous saltcedar plants bordering the lake are destroyed periodically by rising water as the lake level fluctuates, thus providing an intermittent supply of organic detritus to the accumulated sediment. The thin organic layers distributed throughout most cores indicate periods of greater than normal contribution of organic detritus, either from lake sources or from the inflowing water.

To obtain an estimate of the quantity and distribution of organic matter, the organic carbon contents of 33 samples from the Colorado delta were measured by the chromic acid method (Allison, 1935). Organic matter is of course composed of oxygen, hydrogen, nitrogen, and other constituents in addition to carbon, but Trask (1932, p. 18) has found a fairly constant relation between organic carbon and total organic content. On the basis of this relation the organic content of the samples shown in table 24 was calculated by applying a factor of 1.7 to the organic carbon values, as recommended by Trask.

The silt and clay of the bottomset beds contain much more organic matter than does the sand of the topset and foreset beds. The average organic content of samples from the bottomset beds is 0.93 percent, and of samples from the topset and foreset beds, 0.14 percent. The concentration of organic particles in the bottomset beds is to be expected because they are low in density 
and would logically be deposited with finer inorganic particles. However, within the bottomset beds themselves there appears to be no clear relation between organic content and grain size, nor is there systematic variation in organic content in vertical section.

The organic content is notably higher near the foot of the delta front than in the western part of the lake. As determined by averaging the individual measurements in each of nine vertical sections, the organic content in longitudinal section shows a general but somewhat irregular decrease from 1.12 percent at mile 279.3 in Pierce Basin to 0.68 percent at Hoover Dam (fig. 51).

The gas content and temperature gradient of the bottomset beds have been plotted on the same graph as the organic content. The general similarity of the three curves suggests that the organic content, gas content, and temperature gradient are directly related. Where the organic content is high, the temperature gradient and gas content are also high; conversely, where the organic content is low, the temperature gradient and gas content are, in general, low.

Since organic material controls to a large extent the number of bacteria in sediments (ZoBell, 1939), we should expect the largest bacterial population to be concentrated where the organic material is most abundant. This relation of organic content, gas content and temperature gradient is in accord with F. D. Sisler's findings (p. 190, 193) that bacteria and biochemical processes within the sediment are chiefly responsible for the production of gas and heating of the bottomset beds.

\section{REFERENCES CITED}

Allison, L. E., 1935, Organic soil carbon by reduction of chromic acid: Soil Sci., v. 40, p. 311-320.

Anderson, E. R., and Pritchard, D. W., 1951, Physical limnology of Lake Mead: Navy Electronics Lab. Rept. 258, 152 p.

Brown, C. B., 1941, Mapping Lake Mead: Geog. Rev., v. 31, p. 387.

Clarke, F. W., 1924, The data of geochemistry : U.S. Geol. Survey Bull. 770, p. 30, 507-509.

Einery, K. O., and Dietz, R. S., 1941, Gravity coring instrument and the mechanics of sediment coring: Geol. Soc. America Bull., v. 52, p. 1685-1714.

Fiock, L. R., 1934, Records of silt carried by the Rio Grande and its accumulation in Elephant Butte Reservoir: Am. Geophys. Union Trans., v. 15, p. 468-473.

Gatewood, J. S., 1945, Floods of September 1939 in Colorado River basin below Boulder Dam: U.S. Geol. Survey WaterSupply Paper 967A, p. 9-11, 32, and pl. 5.

Grim, R. W., Dietz, R. S., and Bradley, W. F., 1949, Clay mineral composition of some sediments from the Pacific Ocean off the California coast and the Gulf of California: Geol. Soc. America Bull., v. 60, p. 1805-1806.
Grover, N. C., and Howard, C. S., 1938, The passage of turbid water through Lake Mead: Am. Soc. Civil Engineers Trans., v. 103, p. 720-732.

Howard, C. S., 1947, Suspended sediment in the Colorado River, 1925-41: U.S. Geol. Survey Water-Supply Paper 998, p. 41.

Krumbein, W. C., and Pettijohn, F. J., 1938, Manual of sedimentary petrography: New York and London, D. Appleton Century Co., p. 501-502.

Kullenberg, 1947, The piston core sampler: Svenska Hydrog.Biol. Komm. Skr., 3e ser., Hydrografi, band 2, häfte 2, p. 1-46.

LaFond, E. C., and Dietz, R. S., 1948, New snapper-type sediment sampler: Jour. Sed. Petrology, v. 18, p. 34-37.

Maxon, J. H., 1940, Gas pits in nonmarine sediments: Jour. Sed. Petrology, v. 10, p. 142-145.

Menard, H. W., and Ludwick, J. C., 1951, Applications of hydraulics to the study of marine turbidity currents: Soc. Econ. Paleontologists and Mineralogists Spec. Pub. 2, p. 2-13.

National Research Council, Interdivisional Committee on Density Currents, Subcommittee on Lake Mead, 1949, Lake Mead density current investigations, $1937-40$, v. 1,2 ; $1940-46$, v. 3: Washington, U.S. Bur. Reclamation, 3 v., $904 \mathrm{p}$.

Shaw, E. W., 1913, The mud lumps at the mouths of the Mississippi : U.S. Geol. Survey Prof. Paper 85B, p. 26.

- 1914, Gas from mud lumps at the mouths of the Mississippi : U.S. Geol. Survey Bull. 541A, p. 21.

Sherman, Irving, 1951, A rapid substitute for textural analysis: Jour. Sed. Petrology, v. 21, p. 173-177.

1953, Flocculent structure of sediment suspended in Lake Mead: Am. Geophys, Union Trans., v. 34, p. 394-406.

Sykes, Godfrey, 1937, The Colorado delta: Am. Geog. Soc. Spec. Pub. 19, p. 132-133.

Terzaghi, Karl, 1925, Principles of soil mechanics, elastic behavior of sand and clay: Eng. News Rec., v. 95, p. 989990.

- and Peck, R. B., 1948, Soil mechanics in engineering practice: New York, John Wiley and Sons, p. 124-125.

Trask, P. D., 1932, Origin and environment of source sediments of petroleum : Houston, Gulf Publishing Co., p. 18-19, 67$76,97$.

Tyner, E. H., 1939, The use of sodium metaphosphate for dispersion of soils for mechanical analysis: Soil Sei. Soc. America Proc., v. 4, p. 106-113.

Udden, J. A., 1914, Mechnical composition of clastic sediments : Geol. Soc. America Bull., v. 25, p. 655-744.

U.S. Bur. Reclamation, 1949, Report of river control work and investigations in 1948 and 1949 : Boulder City, Nev., Office of River Control, p. 43-124, figs. 44-46.

1950, Boulder Canyon project final reports, Pt. III, Bull. 1.

U.S. Geological Survey, 1954 supplemental base data for Lake Mead comprehensive survey of 1948-49: U.S. Geol. Survey open-file report.

U.S. Soil Conservation Service, 1935, Topographic maps of Lake Mead area: sheets 1-52, scale 1: 12,000.

Wentworth, C. K., 1922, A scale of grade and class terms for clastic sediments: Jour. Geology, v. 30, p. 377-392.

ZoBell, C. E., 1939, Bacteria in marine sediments in Trask, P. D., ed., Recent marine sediments: Tulsa, Okla., Am. Assoc. Petroleum Geologists, p. 416-427. 


\title{
O. BAGTERIOLOGY AND BIOCHEMISTRY OF THE SEDIMENTS
}

\author{
By F. D. Sisler, Scripps Institution of Oceanography
}

\section{PHYSICAL AND CHEMICAL CHARACTER}

A bacteriological investigation of the Lake Mead sediments was undertaken as a result of discussions of the Lake Mead sedimentation problem by H. R. Gould, of the Geological Survey; E. C. LaFond and R. D. Russell of the Navy Electronics Laboratory; and C. H. Oppenheimer, F. D. Sisler, and C. E. ZoBell of the Scripps Institution of Oceanography.

On January 25, 1949, Oppenheimer and the writer joined Gould at Lake Mead and established a small boat station within 50 yards of Hoover Dam and midway between the intake towers. On that date the elevation of Lake Mead was 1,159.8 feet above sea level, and the surface water temperature was $51.9^{\circ} \mathrm{F}$. Gould used a specially designed mud bathythermograph that penetrated the deep, soft sediment to a depth of about a hundred feet and obtained a trace of the temperature as a function of depth. The temperature of the mud near the mud-water interface was higher by several degrees Fahrenheit than that of the water immediately above it.

To obtain samples of the sediment at various depths for bacteriological examination, a modified Foerst sampler was fastened above the mud bathythermograph. . The sampler consisted essentially of a plastic tube that could be closed at both ends simultaneously by means of rubber stoppers activated by a system of levers and the force of a heavy messenger. The bathythermograph, with sampler attached in the open position, was lowered into the mud with cable and winch. After the desired depth was reached, a messenger was dropped down the supporting cable to close the sampler. It was assumed that most of the fluid mud passed through the cylinder during the lowering procedure, and that the mud which collected in this apparatus was representative of the depth reached by the apparatus when the messenger was sent down. Mud samples were taken from depths of about $0.4,49$, and 99 feet below the mud surface. The physical and chemical characteristics of the sampled materials, as reported by Gould, are shown in table 25.

In order to reduce the effect of contamination of the mud samples from the stated depths with mud from
TABLE 25.-Characteristics of sediment between intake towers at Hoover Dam

\begin{tabular}{|c|c|c|c|c|c|}
\hline \multicolumn{6}{|c|}{ Physical characteristics } \\
\hline \multirow{2}{*}{ Sample } & \multirow{2}{*}{ A ppearance } & \multirow{2}{*}{$\begin{array}{c}\text { Depth } 1 \\
\text { (feet) }\end{array}$} & \multicolumn{2}{|c|}{ Temperature $\left({ }^{\circ} \mathrm{F}\right)$} & \multirow{2}{*}{$\begin{array}{c}\text { Water } \\
\text { content } \\
\text { (percent) }\end{array}$} \\
\hline & & & $\begin{array}{c}\text { Immedi- } \\
\text { ately after } \\
\text { recovery }\end{array}$ & In place & \\
\hline S10-1C. & $\begin{array}{l}\text { Light brown with thin } \\
\text { black organic layer at } \\
\text { surface }\end{array}$ & 0.4 & 54.1 & 52.0 & 71.1 \\
\hline $\mathrm{S} 10-2 \mathrm{C}$ & Medium brown viscous & 44.4 & 54.4 & 55.8 & 65.8 \\
\hline S10-3C & $\begin{array}{l}\text { Medium brown viscous } \\
\text { mud with } \mathrm{H}_{2} \mathrm{~S} \text { odor. }\end{array}$ & 99.2 & 54.9 & 58.4 & 62.3 \\
\hline
\end{tabular}

Particle-size analysis of sample obtained 95 feet below sediment surface

\begin{tabular}{|c|c|c|c|}
\hline \multirow{2}{*}{ Classification } & \multirow{2}{*}{$\begin{array}{c}\text { Particle } \\
\text { dímeter }{ }^{2} \\
\text { (microns) }\end{array}$} & \multicolumn{2}{|c|}{ Percent by wetght } \\
\hline & & Grade size & Cumulative \\
\hline $\begin{array}{l}\text { Coarse silt } \\
\text { Medium silt } \\
\text { Fine silt } \\
\text { Very fine silt } \\
\text { Coarse clay } \\
\text { Medium clay } \\
\text { Fine clay }\end{array}$ & $\begin{array}{l}31 \text { to } 62 \\
16 \text { to } 31 \\
8 \text { to } 16 \\
4 \text { to } 8 \\
2 \text { to } 4 \\
1 \text { to } 2 \\
.5 \text { to } 1\end{array}$ & $\begin{array}{r}0.5 \\
.5 \\
2.1 \\
10.4 \\
10.9 \\
16.1 \\
59.5\end{array}$ & $\begin{array}{l}100 \\
99.5 \\
99.0 \\
96.9 \\
86.5 \\
75.6 \\
59.5\end{array}$ \\
\hline
\end{tabular}

Chemical analyses

[By U.S. Department of Agriculture]

\begin{tabular}{|c|c|c|c|c|c|c|}
\hline $\begin{array}{l}\text { Depth of } \\
\text { sample } 1 \\
\text { (feet) }\end{array}$ & $\underset{\text { (percent) }}{\mathrm{CaCO}_{3}}$ & $\begin{array}{c}\text { Carbon } \\
\text { (percent) }\end{array}$ & $\begin{array}{c}\text { Organic } \\
\text { matter } 3 \\
\text { (percent) }\end{array}$ & $\begin{array}{l}\mathrm{SO}_{4} \text { (per- } \\
\text { cent) }\end{array}$ & $\begin{array}{c}\mathrm{Cl} \text { (per- } \\
\text { cent) }\end{array}$ & $\begin{array}{c}\text { Ratio } \\
\mathrm{SO}_{4}: \mathrm{Cl}\end{array}$ \\
\hline $\begin{array}{l}0.3 \\
46 \\
99\end{array}$ & $\begin{array}{l}13.7 \\
16.2 \\
15.7\end{array}$ & $\begin{array}{r}0.39 \\
.47 \\
.34\end{array}$ & $\begin{array}{r}0.66 \\
.80 \\
.58\end{array}$ & $\begin{array}{r}0.035 \\
.056 \\
.056\end{array}$ & $\begin{array}{r}0.011 \\
.019 \\
.025\end{array}$ & $\begin{array}{l}3.18 \\
2.94 \\
2.24\end{array}$ \\
\hline
\end{tabular}

1 Depths are below sediment surface.

3 Computed from percentage of carbon, using factor of 1.7 .

other depths, a situation that was unavoidable with the sampling technique employed, the samples were placed in sterile containers and serial dilutions were prepared immediately afterwards in a laboratory within Hoover Dam. Various media were then inoculated from the serial dilutions. The purpose of this technique, performed immediately after the mud samples were obtained, was to dilute out and thereby eliminate the contaminating bacteria before they could multiply. The inoculated media, mud, and water samples were taken to the Scripps Institution laboratories, where 
bacteriological and biochemical analyses continued the following day.

The laboratory analyses included tests to determine the bacterial populations, both total and by physiological groups, at each sampled depth. Determinations of the biochemical oxygen demand gave confirmatory evidence of bacterial activity and fermentation, and the rate of migration provided a basis for judging the capabilities for dissemination throughout the mass of sediment. Other tests provided qualitative data as to the effect of biochemical activity upon the characteristics of the sediment-notably the evolution of gas and the heating and compaction of sediments--as described on pages $177-183$.

\section{BACTERIAL POPULATIONS}

Several media were employed for the estimation of bacterial populations. These media were selective for various types of organisms according to their principal metabolic characteristic.

For total population, a nutrient medium was prepared with a semisolid base of agar. This medium, as well as other media employed in this study, was placed in screw-cap test tubes which served as culture receptacles. The semisolid agar base provided for the growth of aerobes and microaerophiles, as well as anaerobes. Peptone, yeast extract, and a carbohydrate (dextrose) were incorporated in the medium to favor the growth of most of the organisms expected to be present in the mud.

For the estimation of proteolytic bacteria, those organisms attacking protein substances, a gelatin-base medium was used. The liquefaction of gelatin, a simple protein, by bacteria is evidence of proteolytic action. Gelatin-liquefying bacteria, therefore, may be considered as proteolytic organisms. The presence of large numbers of proteolytic bacteria may be indicative of a high protein content in the source area.

For saccharolytic bacteria, which utilize carbohydrates as a principal energy source, a soluble starch medium was employed. The destruction of the starch in an inoculated medium, as determined by the iodine test, is indicative of the presence of saccharolytic bacteria. The presence of large numbers of these bacteria in the place of occurrence is possible evidence of a high carbohydrate supply.

Simple carbohydrates are quickly consumed by bacteria, however, and are not likely to be found in high concentrations in humus or sedimentary materials. The destruction of the more complex polysaccharides such as cellulose occurs at a much slower rate. Cel- lulose is often the principal organic energy donor in lake- and river-bottom sediments and has been held responsible for the vigorous methane evolution that sometimes occurs in these places. Since methane evolution had been previously observed at Lake Mead, a medium was used for the estimation of cellulose-decomposing bacteria. The destruction of strips of lens paper inserted in tubes of nutrient medium inoculated with dilutions of Lake Mead sediment was taken as evidence of the presence of cellulose-decomposing bacteria.

For bacteria that reduce nitrate to nitrite, ammonia, or free nitrogen, a nutrient medium containing nitrate was employed. The appearance of nitrite or nitrogen, or the disappearance of nitrate from the inoculated medium after incubation, was considered a positive test for the presence of nitrate reducers. Qualitative tests for nitrate were made by using reagents of diphenylamine and hydrochloric acid, and for nitrite by using reagents of dimethyl alpha-naphthylamine and sulfanilic acid. The significance of nitrate reducers in sediments is somewhat obscure. In general the presence of appreciable numbers of these organisms in the source area is suggestive of a high content of organic matter, but it is not indicative of a high nitrate concentration because nitrate reducers are often found in sediments that are relatively free of nitrate. Sewage usually contains large numbers of nitrate-reducing bacteria but seldom contains a high nitrate concentration unless it is in an advanced stage of purification.

Sulfate-reducing bacteria are often responsible for the foul hydrogen sulfide odor in the vicinity of sluggish streams, swamps, and tidelands. Since these organisms are strict anaerobes, their activity or relative abundance is indicative of the reducing conditions of stagnant or poorly oxygenated basins. Sulfate reducers bring about the reduction of sulfate at the expense either of organic matter serving as hydrogen donor or of molecular hydrogen. The former process is termed heterotrophic, and the latter autotrophic, metabolism. The medium used for the detection of sulfate reducers was prepared with a semisolid base of agar. In addition to other nutrients, sulfate and a trace of iron salt were added to the medium. The organisms reduce sulfate to hydrogen sulfide, which in turn reacts with iron to form black iron sulfide; the appearance of blackening in the inocnlated medium after incubation was therefore the criterion used for the detection of sulfate-reducing bacteria. The disappearance of hydrogen gas trapped under inverted vials in the medium was considered a positive test for the presence of hydrogen utilizers. 
The compositions of the various selective media under consideration are as given below.

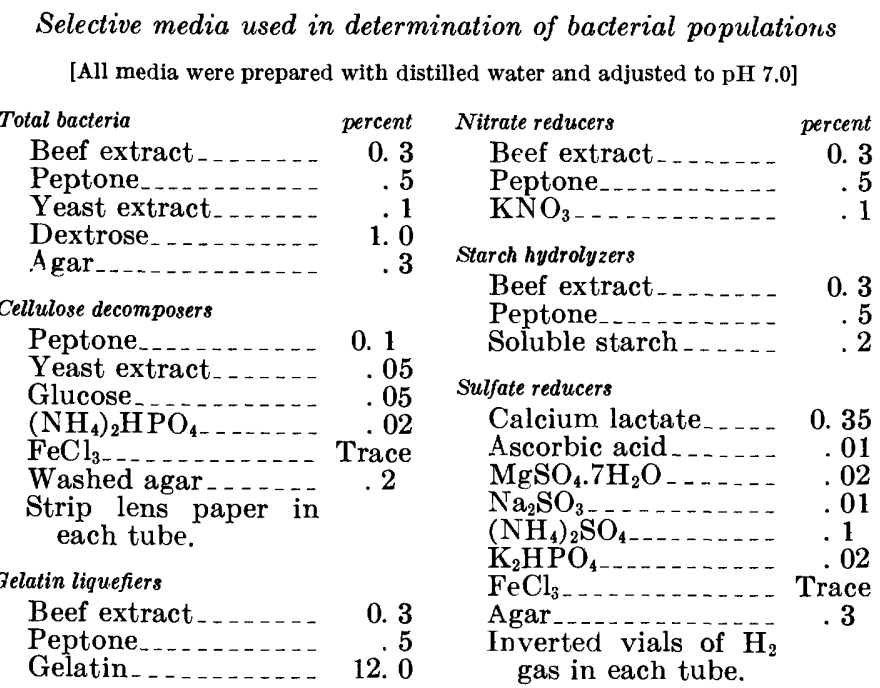

As mentioned previously, serial dilutions of mud samples taken from three different depths and a water sample near the mud-water interface were inoculated into selective media immediately after the samples were obtained. The relative abundance of the various types of bacteria inhabiting the mud was determined from the highest dilution that afforded growth in the selective medium observed. This method for estimating bacterial populations is commonly referred to as the "minimum dilution" method. Inoculated media were incubated at $28^{\circ} \mathrm{C}$ for a minimum period of 30 days, to insure growth of dormant bacteria. In general, the procedures and media employed for these examinations are the ones recommended by the Society of American Bacteriologists (1947), with the exception of those used for hydrogen utilizers and cellulose decomposers. The latter techniques originated in the Scripps Institution laboratory.

\section{TOTAL POPULATION}

The following observations were made of duplicate tubes of medium, inoculated with samples of mud or water and incubated for 30 days at $28^{\circ} \mathrm{C}$ :

Total bacterial population

\begin{tabular}{|c|c|c|c|c|c|c|c|}
\hline \multicolumn{2}{|l|}{ Sample } & \multicolumn{6}{|c|}{ Growth in dilutions of - } \\
\hline Material & $\begin{array}{l}\text { Depth, } \\
\text { in feet }\end{array}$ & $10^{2}$ & $10^{3}$ & $10^{4}$ & $10^{5}$ & $10^{6}$ & $10^{7}$ \\
\hline Water. & -1.0 & + & & & & & \\
\hline $\begin{array}{r}\text { Mud................ } \\
\text { Do }\end{array}$ & $\begin{array}{l}46^{.5} \\
99\end{array}$ & $\stackrel{+}{+}$ & + & \pm & + & $\begin{array}{l}+ \\
+ \\
+\end{array}$ & + \\
\hline
\end{tabular}

1 Below sediment surface
These data are interpreted as meaning that at least $1,000,000$ bacteria per gram (wet weight) are contained in the mud columns at all depths. The most abundant flora appear near the mud surface, showing a minimum of 10 million bacteria per milliliter. The total counts in the mud are like those found in raw sewage, whereas the water a few feet above the mud appeared to be practically free from bacteria.

The abundance of bacteria in the Lake Mead sediments agrees well with that commonly found in the surficial sediment layers beneath both marine and fresh-water bodies, but is quite different in the vertical distribution of the organisms. In marine and natural lake muds the number of bacteria diminishes rapidly with depth. Listed for comparison are the totals of bacterial populations as a function of mud depth in three fresh-water lakes (Henrici and McCoy, 1938) and the total of the populations found in the Lake Mead muds. The Lake Mead sediments appear to be unique insofar as they contain a high bacterial population distributed rather uniformly throughout a relatively deep and loosely packed layer.

Total bacterial populations in sediments underlying fresh-water lakes

[Minimum number per gram wet weight]

\begin{tabular}{|c|c|c|c|c|}
\hline Core depth, 1 in feet & $\begin{array}{c}\text { Lake } \\
\text { Alexander }\end{array}$ & $\begin{array}{c}\text { Lake } \\
\text { Mendota }\end{array}$ & $\begin{array}{c}\text { Brazelle } \\
\text { Lake }\end{array}$ & Lake Mead \\
\hline 0 & $\begin{array}{r}100,000 \\
1,000 \\
100\end{array}$ & $\begin{array}{r}100,000 \\
10,000 \\
1,000\end{array}$ & $\begin{array}{r}100,000 \\
1,000\end{array}$ & $\begin{array}{l}10,000,000 \\
10,000,000 \\
1,000,000 \\
1,000,000\end{array}$ \\
\hline
\end{tabular}

1 Below sediment surface.

\section{PHYSIOLOGICAL GROUPS}

The results of the examination of the various selective media for the isolation of physiological types of bacteria are condensed and included with the total counts as follows:

Bacterial populctions by physiological group

[Minimum number per gram, wet weight]

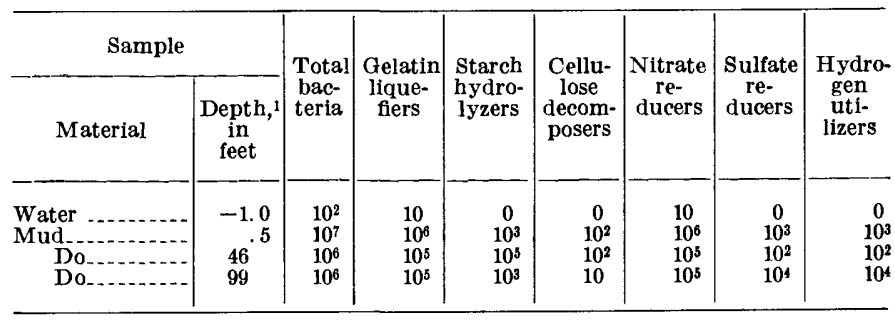

1 Below sediment surface.

These data show a rather uniform distribution throughout the mud column of the various physiological groups of bacteria for which tests were made. The 
anaerobic sulfate reducers and hydrogen utilizers are most numerous at the greatest depth, which is to be expected because reducing conditions increase with depth in most sediments. The activity of sulfate-reducing bacteria is indicated also by the ratio of sulfate to chloride at the various depths (see chemical analyses in table 27). Chloride may be considered a biochemically stable ion, whereas sulfate is subject to reduction by biochemical processes. Thus the ratios are easier to interpret than absolute values, inasmuch as the latter are affected by physical processes that vary with depth.

\section{BIOCHEMICAL OXYGEN DEMAND}

A conventional method of determining fermentable organic content is by biochemical oxygen demand (BOD). These determinations were made on the samples taken from the three different depths by the alum flocculation modification procedure outlined by the American Public Health Association (1946). Three dilutions were employed, representing approximately 10-, 1-, and 0.1-percent inocula of which the 1-percent dilutions appeared to give the most consistent results. The BOD values obtained from these dilutions are as follows:

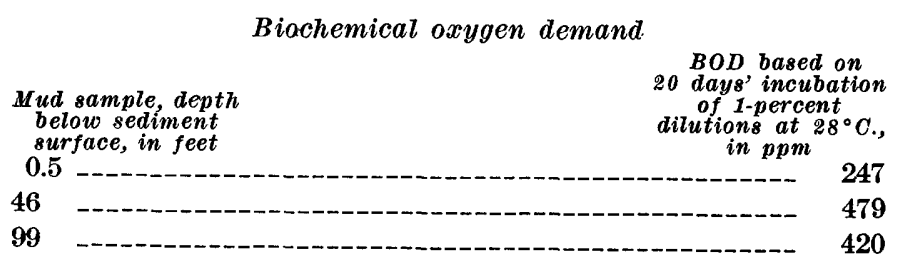

The biochemical oxygen demand is directly proportional to the concentration of fermentable substances; for average sewage it is between 300 and $600 \mathrm{ppm}$. The highest concentration of oxidizable material at Lake Mead is contained in the sediments from intermediate depths. Also, the chemical analyses of 3 samples in table 25 indicate that the organic matter is more concentrated at intermediate depths.

\section{MIGRATION OF BACTERIA}

It is desirable to know the rate of migration of the natural flora through the medium in order to evaluate their activities and, influence as geomicrobiological agents. The physical, chemical, and biochemical nature of the medium may determine to a large extent the migration rate of the natural flora. Other factors, such as density, viscosity, temperature, chemical and physical composition, available nutrients, moisture, and convection currents, may act to promote or retard the natural movement of the micro-organisms through a stratum of mud.
To obtain an approximation of the migrations of natural flora through the sediment deposits in Lake Mead, measurements were made of the time required for bacteria to travel through a column of sterilized mud. Cotton-plugged, glass U-tubes containing autoclaved sediment from Lake Mead were inoculated at one end with a bit of raw mud. Other tubes filled with sterile mud were left uninoculated to serve as controls. The $\mathrm{U}$-tubes were incubated at $5^{\circ} \mathrm{C}$ and $28^{\circ} \mathrm{C}$. Periodically, some of the material from the uninoculated end of the tubes was placed in nutrient broth and streaked on agar slants. The broth tubes and agar slants were observed for growth after incubation for 3 days at $28^{\circ} \mathrm{C}$. The results from duplicate tubes are as follows:

\begin{tabular}{c|r|r|r}
\hline $\begin{array}{c}\text { Length of mud solumn, in } \\
\text { centimeters }\end{array}$ & $\begin{array}{c}\text { Temperature } \\
\text { of incuba- } \\
\text { tion, in }{ }^{\circ} \mathrm{C}\end{array}$ & $\begin{array}{c}\text { Days re- } \\
\text { quired for } \\
\text { growth to } \\
\text { appear } \\
\text { migration }\end{array}$ & $\begin{array}{c}\text { Average mi- } \\
\text { gration rate, } \\
\text { in cm per } \\
\text { day }\end{array}$ \\
\hline 18 & 28 & $5-9$ & 2.5 \\
\hline
\end{tabular}

EFFECTS OF BIOCHEMICAL ACTION

HEATING OF SEDIMENTS

Mud collected at a depth of approximately 40 feet was used to demonstrate the effect of microbial activity on heating of the sediments-specifically, to determine whether the normal flora in the mud could actually produce a measurable increase in temperature while growing in the untreated mud. Several gallons of mud were sterilized by autoclaving for 2 hours at $120^{\circ} \mathrm{C}$. One-quart samples were placed in sterile, cottonplugged Erlenmeyer flasks. Some of the flasks containing sterilized mud were inoculated with 1-percent raw mud. These flasks of sterile and inoculated mud, and flasks of raw mud, were placed in water baths of constant temperatures. Thermos bottles without stoppers also were immersed in the water baths. When the temperature of the muds and the thermos bottles had come to equilibrium with the water baths, the thermos bottles were filled with the mud from the flasks, tightly stoppered, and returned to the water bath.

After incubation for 3 to 4 weeks, the temperatures of the muds were taken by submerging a long-stemmed thermometer in the mud to a depth midway in the thermos bottle. All temperature readings were taken at the same depth from the surface. This procedure was followed several times, and after each test the thermos bottles were rotated-that is, the test and control thermos bottles were exchanged to neutralize differences in conductivity existing between the thermos 
TABLE 26.-Increase in temperature by bacterial action [In degrees centigrade]

\begin{tabular}{l|r|r}
\hline & $\begin{array}{c}\text { Tempera- } \\
\text { ture }\end{array}$ & $\begin{array}{l}\text { Increase above } \\
\text { control sample }\end{array}$ \\
\hline Test 1: After 3 weeks incubation \\
\hline Water bath temperature & $6 \pm 1$ & 6.4 \\
Sterile mud (control) & 6.9 & 0.5 \\
Inoculated mud. & \\
Raw mud... & \\
\hline
\end{tabular}

Test 2: After 3 weeks incubation

\begin{tabular}{lr|r|r}
\hline Water bath temperature & \\
Sterile mud (control) & $20 \pm 1$ & \\
Inoculated mud & 20.8 & \\
Raw mud. & 21.5 & \\
\hline
\end{tabular}

Test 3: After 3 weeks incubation

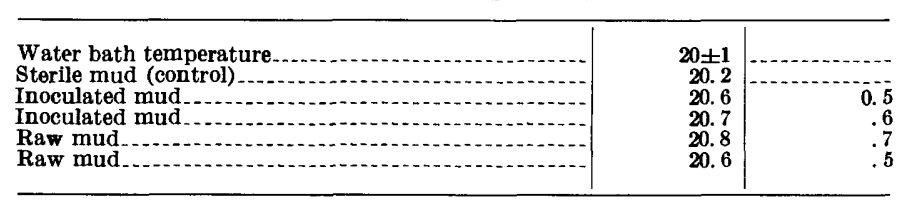

Test 4: After 4 weeks incubation

\begin{tabular}{|c|c|c|}
\hline $\begin{array}{l}\text { Water bath temperature } \\
\text { Sterile mud (control) } \\
\text { Sterile mud (control) } \\
\text { Inoculated mud } \\
\text { Inoculated mud }\end{array}$ & $\begin{array}{r}22 \pm 1 \\
22.2 \\
22.5 \\
23.0 \\
22.8\end{array}$ & $\begin{array}{l}0.5 \text { to } 0.8 \\
0.3 \text { to } 0.6\end{array}$ \\
\hline
\end{tabular}

bottles used in the tests. The results are summarized in table 26.

In all tests, the temperatures of the inoculated and raw mud samples were higher than those of the sterile controls. Because the thermos bottles were not perfect insulators, the amount of the heating observed under the conditions of this experiment may well represent only a fraction of the potential. The test data suggest that the mud still contains appreciable fermentable substances and that thermogenic bacteria are undoubtedly quite active at the depth of occurrence. It is estimated that the heat obtained from the biochemical oxidation of oxidizable material in Lake Mead mud is approximately $10^{-6}$ calories per hour per gram.

Heat generated from radioactive materials has been suggested as a possible cause for the anomalous heating of the Lake Mead sediments. In order to estimate the amount of radioactivity in the sediments near Hoover Dam, sample material was tested by several types of radiation counters. The most sensitive instrument used was the Radiation Counter Laboratories scalartype Mark 9 Model 3 nucleometer, which is capable of detecting alpha, beta, and gamma radiations. A 106-mg sample, composite of all depths, gave 10 counts per minute above background when examined with this instrument. Assuming 10 percent of efficiency for the instrument and no absorption in the sample, it is estimated that the maximum amount of energy liberated as heat from radioactivity is less than $10^{-10}$ calories per hour per gram. The probable energy would be a hundred or a thousand times less than this maximum estimate. By contrast, the estimated energy potential from biochemical action is at least 10,000 times as great as that estimated from radioactivity.

\section{EVOLUTION OF GAS}

During the laboratory experiments, it was observed that both the inoculated and raw muds underwent fermentation with the evolution of gas during incubation. To determine the nature of the gas evolved from the raw mud, 10-milliliter samples of raw mud from three different depths were placed in Thunberg tubes of $30 \mathrm{ml}$ capacity. The tubes, containing $10 \mathrm{ml}$ of mud and $20 \mathrm{ml}$ of air, were sealed and incubated at $20^{\circ} \mathrm{C}$ for 6 days. At the completion of the incubation period, the gas phase remaining over the mud in each sample was analyzed by mass spectrometer. The analyses are listed as follows, together with the average composition of atmospheric gases:

\begin{tabular}{l} 
Percent composition of gas developed during 6-day incubation \\
period \\
\hline \multirow{2}{*}{ Gas } \\
\end{tabular}

These data show evidence of an oxygen demand at all depths. The relative oxygen depletions correlate well with the BOD's for the same samples, for both indicate the greatest oxygen demand at the intermediate depth of 46 feet, almost as great a demand at 99 feet, and considerably less at the surface. All components of the gas mixture may be considered as biologically unstable, except argon. which is an inert gas and is therefore used here as a reference gas. The nitrogen : argon ratios suggest a tendency of the mud to bind nitrogen gas at shallower depths, indicative of activity of nitrogen-fixing bacteria.

Although traces of methane appeared in the gas phase over the 46-foot mud sample, the principal gas evolved appeared to be carbon dioxide. When a larger sample was incubated for a shorter period of time, considerable methane gas was detected. Since methaneconsuming bacteria were undoubtedly present also, some of the trapped methane may have been consumed during prolonged incubation. To test this possibility, 1 quart of raw mud and 1 quart of mud sterilized by 
autoclaving were placed in sealed containers, each of which had an air space of approximateiy $25 \mathrm{ml}$, and incubated at $22^{\circ} \mathrm{C}$ for 2 days. At the end of the incubation period the gas phase over the samples was analyzed by mass spectrometer. Examination of gas analyses and change in pressure of gas phase showed that approximately 50 percent of the gas was methane. Twenty-five $\mathrm{ml}$ of methane was produced in 2 days by 1 quart of raw mud at $22^{\circ} \mathrm{C}$.

Percent composition of gas developed during 2-day incubation period

\begin{tabular}{|c|c|c|}
\hline Gas & Raw mud & Sterile mud \\
\hline $\mathrm{O}_{2 \ldots}$ & $\begin{array}{r}8.09 \\
.46\end{array}$ & $\begin{array}{r}19.10 \\
.50\end{array}$ \\
\hline $\begin{array}{l}\mathrm{N}_{2} \\
\mathrm{~N}_{2}\end{array}$ & $\begin{array}{r}54.77 \\
36.18 \\
.50\end{array}$ & $\begin{array}{r}.00 \\
79.38 \\
1.02\end{array}$ \\
\hline Terminal pressure in atmospheres 1 & 2.1 & 1.2 \\
\hline
\end{tabular}

1 Original gas pressure adjusted to 1 atmosphere.

It is therefore doubtful that methane is escaping from the Lake Mead sediments as fast as it is being produced, because methane oxidizers near the surface would probably consume part of the methane. In the first experiment, where the muds were incubated for 6 days, methane was detected in only one of the samples and that was only a trace. When the same sample was incubated for only 2 days, much more methane was found, indicating that after the methane concentration increased, methane-oxidizing bacteria removed the methane again according to the reaction :

$$
\mathrm{CH}_{4}+2 \mathrm{O}_{2} \rightarrow \mathrm{CO}_{2}+2 \mathrm{H}_{2} \mathrm{O}
$$

In the absence of oxygen this reaction could not occur. Thus, more vigorous evolution of methane would be expected when the oxygen concentration in the surficial mud layer is at a minimum.

\section{COMPACTION OF SEDIMENTS}

Mechanical analyses of the sediments near Hoover Dam, reported by H. R. Gould, show a median particle diameter of less than 1 micron (p. 175). Such small particles approach the colloidal realm and hence should be affected by electrolytes or ionic charges. Lyophilic colloids owe their stability to two factors, electric charge and solvation, and hence are more stable than lyophobic colloids, which depend on charge alone. The sediments collected near Hoover Dam appear to be characteristically lyophilic, or, since water is the dispersion medium, hydrophilic in nature. Ordinarily small changes in $\mathrm{pH}$ or electrolyte concentrations have little effect on pure hydrophilic colloid systems because of their stability. However, since we are dealing with a colloid mixture in the case of these sediments, a shift in the $\mathrm{pH}$ may ac- celerate the mutual precipitation of hydrophilic colloids having different isoelectric points. Such a phenomenon is called coacervation. Coacervation may result in the liberation of much of the water of hydration from hydrophilic colloidal systems.

Measurements of the hydrogen-ion concentration $(\mathrm{pH})$ and oxidation-reduction potential ( $\mathrm{Eh})$ were made on the samples obtained at mud depths of $0.3,46$, and 99 feet and on a water sample taken a few feet above the mud-water interface. The measurements were made electrometrically with the Beckman meter using glass electrodes for $\mathrm{pH}$ determinations, and platinum electrodes for Eh determinations. The samples were 3 days old, but had been stored in completely filled glass jars tightly capped to prevent the introduction of air. The results of these measurements should be considered as comparative values only, since the measurements were not taken in the place of occurrence.

$p H$ and Eh of sediment and of water at lake bottom

\begin{tabular}{|c|c|c|c|}
\hline \multicolumn{2}{|l|}{ Samples } & \multirow{2}{*}{$\mathrm{pH}$ at $23^{\circ} \mathrm{C}$. } & \multirow{2}{*}{$\begin{array}{l}\mathrm{Eh} \text {, in volts } \\
\text { at } 23^{\circ} \mathrm{C} \text { and } \\
\text { pH as shown }\end{array}$} \\
\hline Material & $\begin{array}{l}\text { Depth, } 1 \\
\text { in feet }\end{array}$ & & \\
\hline $\begin{array}{l}\text { Water } \\
\text { Mud } \\
\text { Do } \\
\text { Do }\end{array}$ & $\begin{array}{r}(2) \\
0.3 \\
46 \\
99\end{array}$ & \begin{tabular}{l|}
8.1 \\
7.15 \\
7.22 \\
7.28
\end{tabular} & $\begin{array}{r}0.471 \\
.170 \\
.111 \\
.099\end{array}$ \\
\hline
\end{tabular}

${ }^{1}$ Below sediment surface. ${ }^{2} \mathrm{~A}$ few feet above sediment surface.

In order to determine the possible effect of hydrogenion concentration upon sediment compaction, samples of mud collected near Hoover Dam were treated with $\mathrm{HCl}$ or $\mathrm{NaOH}$, and the effects of change in $\mathrm{pH}$ were observed. The acid or base was added in equal volumes to samples of mud to give a range from $\mathrm{pH}_{2}$ to $\mathrm{pH} 12$. Control tubes contained an equal volume of distilled water in place of $\mathrm{HCl}$ or $\mathrm{NaOH}$ solutions. After the acid, base, or water was added to tubes of the mud, they were shaken and left to settle. The ratio of the settled mud to the total mud plus supernate was determined daily using vernier calipers. After 18 days, no further change was observed in any of the tubes.

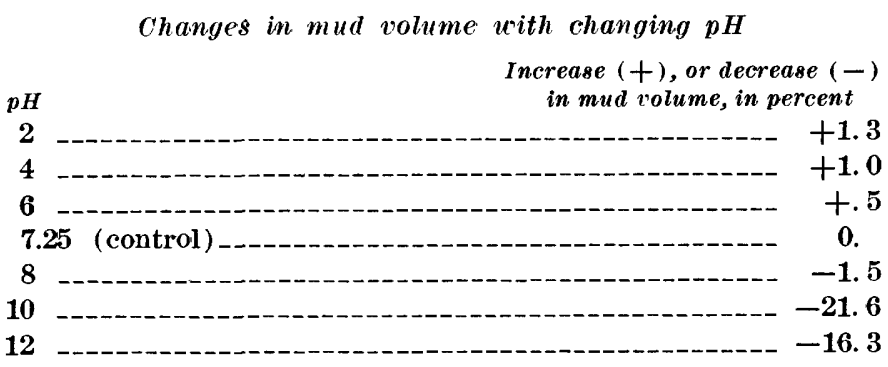

The isoelectric point appears to lie around $\mathrm{pH} 10$. Since the natural mud has a lower reaction than $\mathrm{pH}$ 
10 , an increase in $\mathrm{pH}$ should result in greater compaction.

Bacteria and other micro-organisms affect the $\mathrm{pH}$ of bottom sediments by various processes. They may remove or produce organic acids directly, or they may bring about the solution or precipitation of natural buffer systems such as carbonates. Bacteria which reduce sulfate or carbonate may raise the $\mathrm{pH}$ of bottom sediments by several units. On the other hand, bacteria which oxidize sulfur compounds to sulfate may lower the reaction to $\mathrm{pH} 2$ or 3 . It is generally recognized that wherever bacteria or allied microorganisms are present and active, changes in $\mathrm{pH}$ usually occur.

From the tests described above, it appears that as of January 1949 the net effect of biochemical activity at the intake towers was to reduce the $\mathrm{pH}$ slightly (in comparison with that of the lake water), and therefore to reduce the rate of compaction of the sediment. But since the $\mathrm{pH}$ of the sediment appears to increase with depth (hence with age) a reversal of the above phenomenon may be taking place-that is, a tendency towards increase in compaction rate. However, the limited data above do not permit confident extrapolations as to the direction and rate of $\mathrm{pH}$ changes of the sediment.

\section{SUMMARY AND DISCUSSION}

Biochemical and bacteriological analyses have been made of samples taken from a 100 -foot vertical section of the Lake Mead sediments near Hoover Dam. A unique condition from a bacteriological standpoint was found in the high bacterial populations that existed at all depths in the 100-foot column. Laboratory tests indicate that the abundance and activity of the microflora have contributed to the heating of the fresh sediment layer in Lake Mead, but radioactivity was found to be negligible as a possible source for the heating of the sediment in Lake Mead. It is estimated that the amount of heat from radioactivity is less than $10^{-10}$ calories per hour per gram, whereas the heat obtained from the biochemical oxidation of oxidizable material in Lake Mead mud is approximately $10^{-6}$ calories per hour per gram.

The fermentable organic matter of the mud, as determined by BOD test, is as high as that found in some raw sewage. The water above the mud, on the other hand, was found to be as pure as good well water. The evolution of methane from the mud was demonstrated in the laboratory. Methane production is a common occurrence in swamps and some lakes where conditions are anaerobic and where abundant organic matter such as cellulose is present. Although the mud appeared to be a stable colloidal mixture, a shift in reaction from $\mathrm{pH} 7.25$ to $\mathrm{pH} 10$ brought about a 22-percent volume reduction or compaction.

Much of the biochemical change taking place in the sediments can be determined only by observations over a period of time. It would be interesting to know, for example, whether the $\mathrm{pH}$ of the sediments is becoming higher or lower. It would also be worth while knowing the extent to which bacteria are increasing or decreasing the bulk of the sediments.

There are many ways in which bacteria may influence the bulk or mass of the sedimentary material they inhabit. They may produce or destroy colloidal systems according to the nature of the organisms and their environment. They may alter the reaction of the sediments, which may increase or decrease the bulk. The mechanisms responsible for the change in bulk of the sediments as influenced by $\mathrm{pH}$ are probably diverse. The hydrogen-ion concentration affects the charge on the particles. An alteration of the charge may increase or decrease the stability of a colloidal mixture, depending on the type of colloid. The reaction may bring about the solution of carbonates or may even result in the evolution of gaseous carbon dioxide. The solution of biochemically unstable substances, such as organic matter, carbonates, sulfates, nitrates, iron, and other metal compounds, may materially reduce bulk. On the other hand, these same substances may be produced, directly or indirectly, through the influence of micro-organisms.

A more critical analysis of the information presented herein might be made in a roundtable discussion with geologists, hydrologists, and other interested parties who have participated in this sedimentation program. Comments on the significance of some of the data mentioned have not been made, primarily because the picture is incomplete. The extent to which biochemical activities may have contributed to the heating of the sediments in Lake Mead, for example, cannot be estimated accurately until all the factors which influence the heat budget have been evaluated. Continued observations over a period of time should be made if it is desired to predict with any measure of success the directions and ultimate equilibria of the diversified biochemical reactions now taking place.

\section{REFERENCES CITED}

American Public Health Association, 1946, Standard methods for the examination of water and sewage: 9th ed., p. 124-144. Henrici, A. F., and MeCoy, E., 1938, The distribution of heterotrophic bacteria in the bottom deposits of some lakes: Wis. Acad. Sci. Trans., v. 31, p. 323-361.

Soc. Am. Bacteriologists, 1947, Manual of methods for pure culture study of bacteria: v. 2 , p. $3-15 ;$ v. 5 , p. $2-15 ;$ v. 6 , p. 3-15. 



\title{
P. AMOUNT OF SEDIMENT
}

\author{
By H. R. Gould, U.S. Geological Survey
}

The amount of sediment accumulated in Lake Mead may be expressed in terms of either volume or weight. The sediment volume is the space occupied by the accumulated material, which includes both the solid constituents and the interstitial water. The sediment weight, however, includes only the solid particles.

\section{VOLUME}

The volume of sediment accumulated in Lake Mead has been computed by Speert, Ames, and Kennon (p. 84-87). In December 1948, the sediment that had accumulated in Lake Mead had a total volume of $1,426,000$ acre-feet, of which $1,418,000$ acre-feet was stored below the level of the permanent spillway crest. $^{19}$ If this volume were confined to an area of 1 square mile it would form a block some 2,220 feet, or almost one-half mile, in height. As compared with the capacity of Lake Mead, however, the total volume of sediment is less impressive. It has reduced the usable water storage capacity of the reservoir below the level of the permanent spillway crest from $25,571,000$ to $24,756,000$ acre-feet, a reduction of about 3.2 percent.

To determine the areal distribution of sediment volume, the lake was divided into eight areas (fig. 17), and the volume of sediment in each area was computed separately (table 6). These areas conform in general to the major geographic divisions of the lake, and divide the accumulated sediment insofar as practicable into similar sedimentary units. For example, area 1 is Boulder Basin, where the finest grained and least compacted material has accumulated; and area 7 is Lower Granite Gorge, where the sediment is made up predominantly of firmly packed sand.

The Colorado delta (areas 1-7) contains 97.6 percent of the total volume of sediment; the Virgin delta (area 8) contains only 2.4 percent. The greatest volume of sediment in the Colorado delta has accumulated in Lower Granite Gorge (area 7), but Boulder Basin (area 1), at the other end of the reservoir, contains more than twice as much sediment as Virgin Basin (area 2.)

19 These totals do not inciude the sediment, estimated about 20,000 acre-feet, which was deposited after the closure of Hoover Dam but before the completion of the reservoir survey in 1935 . (See p. 167.)

\section{WEIGHT}

To obtain the total weight of the solid mineral particles, the volume of sediment in each 10-foot increment of elevation was multiplied by its average specific weight. These weight increments were then added together to obtain the total weight of solid mineral particles in each of the eight selected areas. As mentioned previously (p. 180), the specific weight of the sediment accumulated in Lower Granite Gorge and the eastern part of Pierce Basin (area 7 and part of area 6) was obtained largely by extrapolation of specific weight data from surface layers of this part of the deposit and from the bottomset beds west of the Colorado delta front. Owing to insufficient sediment data from the topset and foreset beds of the Virgin delta, the specific weight of the sediment accumulated in area 8 also was derived in part by extrapolation. However, in areas 1-5 little extrapolation was required.

These computations (table 27) show that slightly more than 2 billion tons of sediment has accumulated in Lake Mead during the 14-year interval 1935-48. Of this total, 97.2 percent is contained in the Colorado delta (areas 1-7) and 2.8 percent in the Virgin delta (area 8). The greatest weight of material was deposited in Lower Granite Gorge (area 7) where 55.3 percent of the total has accumulated. A further estimate based on delta structure reveals that about 50 percent of the total weight of sediment in the Colorado delta (areas 1-7) is contained in the topset and foreset beds and about 50 percent is accumulated in the bottomset beds. Because of inadequate data, no attempt was made to estimate the relative quantities of material in the topset, foreset, and bottomset members of the Virgin delta.

A comparison between the weight and volume of sediment in each of the selected areas is also presented in table 27. More than 55 percent of the total weight of sediment was deposited in Lower Granite Gorge (area 7), but its volume is only 37.9 percent of the total volume of accumulated sediment. In contrast, only 10.9 percent of the total weight of sediment has been deposited in Boulder Basin (area 1), but it has a volume of almost 21 percent of the total. This 
TABLE 27.-Volume, weight, and particle size of sediment in individual basins, Lake Mead

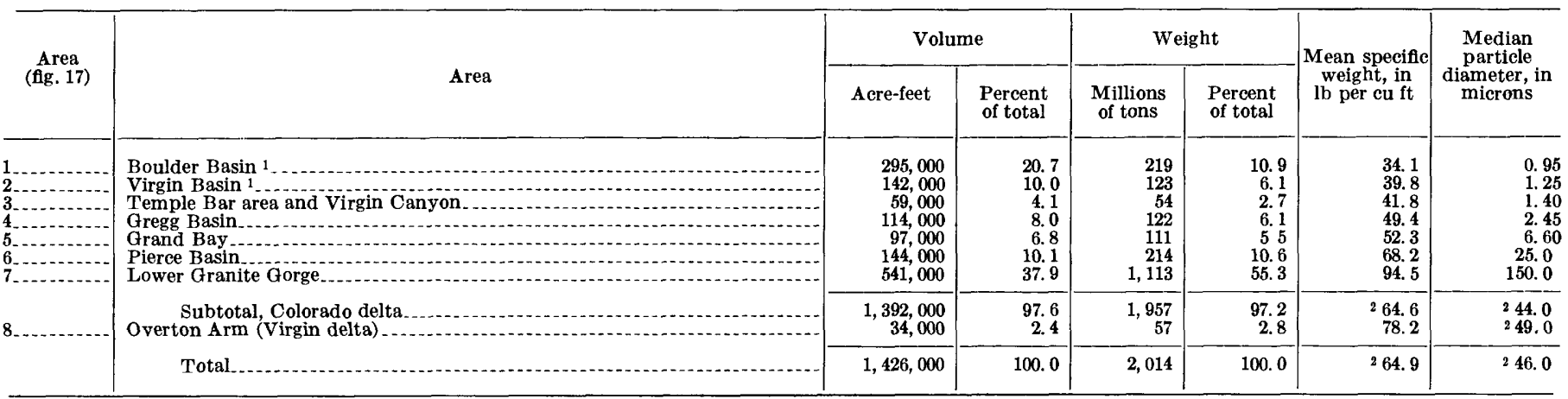

1. Includes part of Boulder Canyon (fig. 17).

2 Weighted average.

comparison further illustrates the variations in compaction of the sediment deposit, which are due to differences in the physical properties of the solid particles and to the depth of sediment burial.

The mean specific weight of the sediment in each of the eight selected areas is also given in table 27 , based on the volume and weight computations. According to these calculations, the average specific weight of all the sediment accumulated in Lake Mead is 64.9 pounds per cubic foot. The mean specific weight of the sand comprising the topset and foreset beds is 93.8 pounds per cubic foot, and the mean specific weight of the silt and clay making up the bottomset beds is 51.8 pounds per cubic foot. The sediment in the Virgin delta (area 8) averages 78.2 pounds per cubic foot, whereas the material in the Colorado delta (areas 1-7) averages only 64.6 pounds per cubic foot. The higher average specific weight of the Virgin delta may be related, at least in part, to its smaller percentage of fine constituents. As noted previously, the bottomset beds of the Virgin delta are considerably coarser than the bottomset beds of the Colorado delta. This has given them a lower porosity and higher specific weight than the bottomset beds of the Colorado delta. The considerable extrapolation required in estimating the weight and volume of the topset and foreset beds of the Virgin delta may also have contributed to the difference in the average specific weights.

\section{RATE OF SEDIMENTATION}

An estimate of the rate of sedimentation is readily obtained. About 2,014 million tons of sediment was deposited in Lake Mead during the 14-year period $1935-48$; thus, the average annual rate of sedimentation is estimated at 144 million tons. As indicated earlier, most of the material in the Colorado delta and the Virgin delta was supplied by the Colorado and Virgin Rivers, respectively. Consequently, a further estimate may be made of the mean annual load of detrital material carried into the lake by each of these rivers. According to this estimate, the mean annual load of the Colorado River is 140 million tons, whereas that of the Virgin River is only 4 million tons.

It is interesting to compare the above estimate of the mean annual load of sediment. supplied by the Colorado River with suspended-load measurements obtained by the Geological Survey at the Grand Canyon gaging station. According to Howard (p. 103), about 1,990 million tons of suspended sediment was carried past the Grand Canyon station during the period 1935-48, of which less than 10 million tons was carried out of the reservoir. This is equivalent to a mean annual load of about 142 million tons, or about 2 million tons more than the estimated average annual deposition of sediment from the Colorado River in Lake Mead in the same period. No estimate is made of the average annual suspended load of the Virgin River, because of the short period of record.

Such close agreement between the mean annual suspended load of the Colorado River and the average annual rate of sedimentation in the Colorado delta is indeed striking. However, the material carried as bed load was not included in the measurement of sediment passing the Grand Canyon station, whereas it is included in the estimate of the amount of sediment accumulated in the Colorado delta. If the quantity of sediment carried in the bed load is appreciable, we would expect the total amount of sediment in the Colorado delta to be somewhat greater than the total suspended load passing the Grand Canyon station. Since this is not the case, it appears that the bed load of the Colorado River is extremely small, and that practically all of the sediment supplied by the Colorado River is carried in suspension. Thomas (p. 29) has cited evidence that the bed load of the Colorado River upstream from Lake Mead is not great. The absence of significant quantities of coarse constituents in the Colorado delta also suggests a small bed load. 
The relative accuracy of the estimated sedimentation rates based on the amount of sediment in the Colorado delta and on suspended-load measurements cannot be evaluated quantitatively. It is noted (p. 233) that there are several possible sources of error in the determination of suspended-sediment load. Also, satisfactory techniques have not yet been developed for measurement of bed load in a stream.

The rate of sedimentation estimated from the total weight of sediment accumulated in the Colorado delta is also subject to error. Small errors have undoubtedly been introduced by assuming that cores obtained along the central part of the delta are representative of the entire cross sections. However, the chief source of error probably lies in the considerable extrapolation required in estimating the total weight of sediment in the thick part of the Colorado delta east of the delta front.

Although none of these possible errors can be evaluated quantitatively, the close correspondence of estimates of the rate of sedimentation obtained by such widely differing methods suggests that the estimates are reasonably correct.

\section{MEDIAN PARTICLE SIZE}

To obtain a quantitative estimate of the average size distribution of the constituent particles, size data for samples from each of the eight selected areas were averaged separately. In Lower Granite Gorge and the eastern part of Pierce Basin, where data are inadequate, it was assumed that the deeply buried topset and foreset beds were about the same in texture as the surface layers and that the bottomset beds were similar in texture to the bottemset beds that were sampled in Pierce Basin. Likewise, in the absence of adequate data, the texture of sediment accumulated in the Virgin delta topset and foreset beds was determined by extrapolation largely from size analyses from the topset and foreset beds of the Colorado delta. Owing to the general textural similarity of the topset and foreset beds of the Virgin and Colorado deltas, it seems probable that no great error has resulted from this extrapolation.

The results of these computations (fig. 53) show that the median particle diameter of the sediment in the Colorado delta decreases progressively from the easterm end of the lake (area 7) to Boulder Basin (area 1) and that the median particle diameter of the Virgin delta (area 8 ) is about twice that of the sediment accumulated in Pierce Basin (area 6).

Table 27 shows the median particle diameter of the sediment in each of the eight selected areas. The mean specific weight increases as the median particle size in496918 o- $60-14$ creases, but casual comparison suggests that the relation in areas $1-5$, where the median diameter is less than 62 microns, may be different from that in the other areas, where the particles are predominantly of sand size.

In figure 54 the average textural characteristics of the material in several of the areas have been combined and weighted so as to provide an estimate of the average size distribution of various parts of the accumulated sediment. The curve for areas 1-8 shows that the median particle diameter of all the sediment accumulated in Lake Mead is about 46 microns, and the curve for areas 1-7 shows a median particle diameter of 44 microns for the material of the Colorado delta. The median diameter of the silt and clay particles of the Colorado delta bottomset beds (areas 1-5) is, in contrast, only 1.65 microns.

Except for small amounts of material contributed by ephemeral tributaries and by slumping of the reservoir walls, practically all the material in the Colorado delta (areas 1-7) was carried into the lake by the Colorado River. The cumulative curve for areas 1-7 is, therefore, an estimate of the average size distribution of the total load of sediment carried into Lake Mead by the Colorado River during the 14-year interval 1935-48. This curve shows that the average sediment load of the Colorado River during this period was made up of approximately 45 percent sand (greater than 62 microns), 27 percent silt (4-62 microns), and 28 percent clay (less than 4 microns). The most striking feature of this distribution is the virtual absence of coarse components. Only 1 percent of the material consists of particles greater than 500 microns in diameter-that is, coarse sand or larger grains.

\section{AVERAGE CHEMICAL COMPOSITION}

From the sediment weight and chemical data presented in the preceding pages, a further estimate can be made of the mass chemical composition of the sediment accumulated in the Colorado delta. The method used in estimating the average composition of the Colorado delta corresponds closely to the method of estimating the average particle-size distribution. Because of inadequate chemical data from the sediment of the Virgin delta, no attempt is made to estimate its average composition.

One sample from each of the seven delta subdivisions (areas 1-7, fig. 53) was chemically analyzed, with results as reported in table 23 . In areas $1-5$, where the Colorado delta is made up almost entirely of bottomset beds, it is assumed that the chemical composition of each sample is representative of the total weight of sediment in the area from which it was obtained. How- 


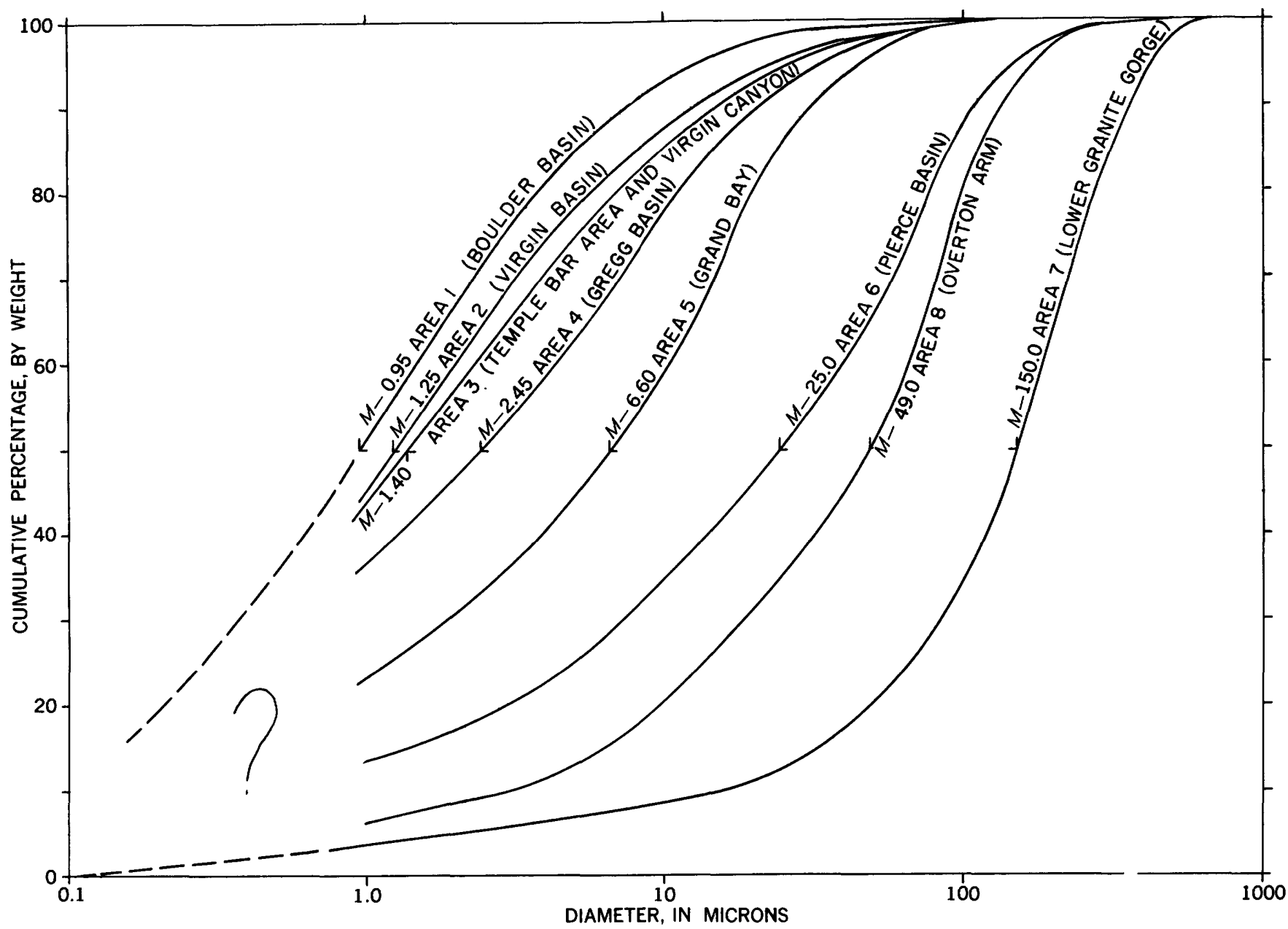

FIgURE 53.-Cumulative curves showing the estimated average size distribution of the accumulated sediment in each of the elght selected lake areas. The median particle diameter $(M)$ for each curve is shown in microns.

ever, in areas 6 and 7, where the delta is made up of topset, foreset, and bottomset beds, this assumption is not valid. Chemical data in these areas are available only for samples (1037 and G1270, table 23) from the topset and foreset beds, but it is assumed that the bottomset beds in areas 6 and 7 are similar in composition to the bottomset beds in area 5 (sample 937, table 23). On the basis of this assumption an estimate has been made of the average chemical composition of the total sediment in areas 6 and 7 . The average chemical analyses of the sediment in the seven lake areas were then combined and weighted in order to obtain an estimate of the average chemical composition of all of the sediment in the Colorado delta. The results of these computations presented in table 28 represent an estimate of the average chemical composition of the total load of sediment carried into Lake Mead by the Colorado River during the 14-year period, 1935-48.

A comparison of this analysis with Clarke's composite analysis of 235 samples from the Mississippi delta shows a marked similarity in the composition of the Colorado and Mississippi deltas. The only notable differences are in the concentrations of calcium, sodium, and potassium. The Colorado delta contains about twice the calcium, one-half the sodium, and about threefourths the potassium concentration of the Mississippi delta.

TARLE 28.-Estimated average chemical composition of the sediment accumulated in the Colorado delta, 1935-48

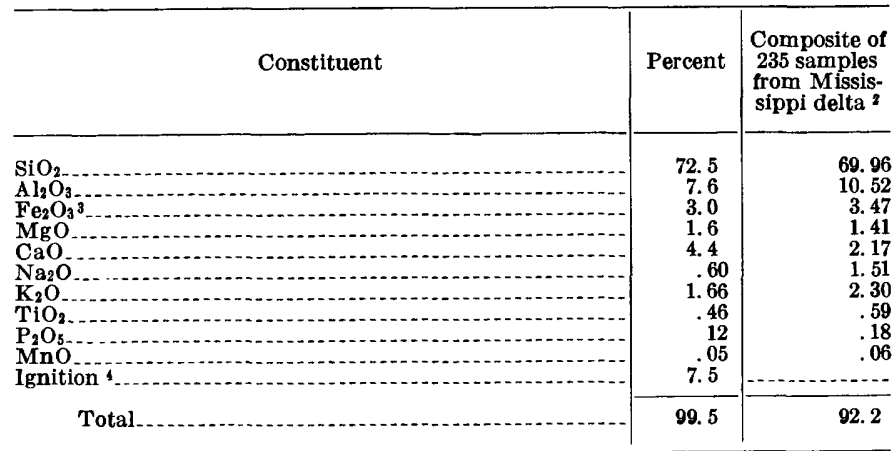

1 Weighted average of samples $332,634,698,937,1037,1176$, and $\mathrm{G} 1270$ 2 See Clarke, 1924, p. 509.

- Includes loss due to oxidation of $\mathrm{FeO}$. 


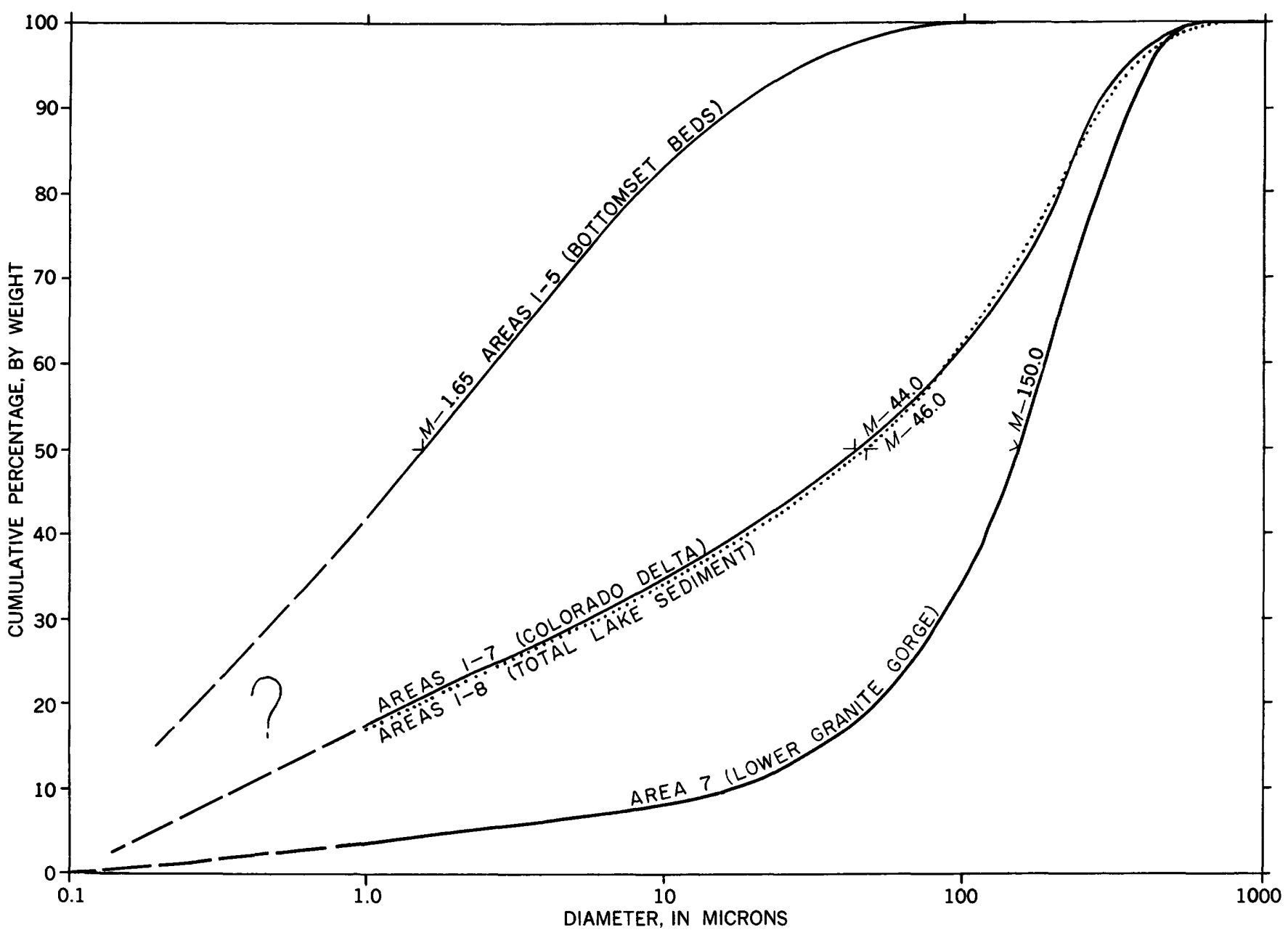

Figure 54.-Cumulative curves showing the estimated average size distribution of the accumulated sediment in several of the lake areas combined. The median particle diameter for each curve is shown in microns.

POTENTIAL ECONOMIC USE

With the thought that the sediment accumulated in Lake Mead might be a resource instead of a liability, the exceedingly fine grained material in the bottomset beds of the Colorado delta was investigated for its possible uses in the ceramic and petroleum industries.

Tests of the ceramic properties of the sediment were made by T. A. Klinefelter of the U.S. Bureau of Mines, who states that the clay of the bottomset beds is of the montmorillonite (nonswelling bentonite) type, as determined by $\mathrm{X}$-ray patterns and physical properties. The ceramic tests were confined, therefore, to oil bleaching and heat treatment. The results of these analyses show that there is some possibility of using the Lake Mead clay in decolorizing or clarifying fats and oils. However, the clay would require activation by leaching in acid before it could be used for this purpose. There is also a possibility that the clay could be used as a catalyzer for oil cracking, but no test for this property has yet been made.
The chief potentiality of the Lake Mead sediment may be as a bloating clay for use in the manufacture of light-weight cements, building brick, and other construction materials. When flash heated to a temperature of $2,100^{\circ} \mathrm{F}$, the Lake Mead clay increases from 3 to 4 times in volume, forming a fine bloat with small though somewhat uneven vesicles or blebs. The specific weight of the bloat ranges from 19 to 24 pounds per cubic foot, which is well within the commercial range of bloating clays. At lower temperatures the product would be somewhat heavier and stronger. Most of the commercial products range in weight from 45 to 55 pounds per cubic foot, chiefly because lighter bloats cannot be produced at temperatures of $1,800^{\circ} \mathrm{F}$ to $2,200^{\circ} \mathrm{F}$ from most clays used for this purpose. Hence, the Lake Mead material would be unusually good as bloating clay, although it would require care in handling in the kilns because of its narrow bloating range. As determined by slow heating $\left(100^{\circ} \mathrm{F}\right.$ per hour), bloating of the Lake Mead clay occurs at temperatures between $2,000^{\circ} \mathrm{F}$ and $2,200^{\circ} \mathrm{F}$. 
The suitability of the material as a drilling fluid was investigated by George Tchillingarian of the University of Southern California, who found that it fails to meet the specifications of the petroleum industry.
The viscosity and filtration loss of drilling muds prepared with the Lake Mead clay are too high for it to compete with fresh-water clays currently used for this purpose. 


\section{Q. TURBIDITY GURRENTS}

By H. R. Gould, U.S. Geological Survey

A turbidity current can be simply defined as a current that carries fine-grained sediment in suspension. Johnson (1939) first introduced the name as a synonym for density current (Daly, 1936) and suspension current (Stetson and Smith, 1938). Water charged with fine suspended particles is denser than clear water of the same temperature and salinity, and, because of its greater density, the water that carries suspended sediment can flow beneath less dense clear water. If, for example, a river carrying an appreciable amount of suspended sediment enters a quiet body of clear water of the same temperature and salinity, the turbid water will plunge beneath the mass of clear water and travel by gravity along the floor of the standing body of water. Bell (1942a) has referred to this type of turbidity current as an underflow.

In nature, however, the temperature and salinity of a standing body of water are seldom the same from top to bottom. The oceans as well as most lakes have a distinct stratification in both temperature and salinity, the lower layers commonly being colder and more saline than the upper layers. Since water increases in density with decrease in temperature (to $39^{\circ} \mathrm{F}$ ) and increase in salinity, the lower strata are denser than the upper strata. In some cases the density of turbid river water entering a lake is greater than the density of the upper lake layers but not as great as the density of the lower strata. Under these conditions the turbid river water sinks beneath the lake surface and flows on one of the lower water layers of higher density. This type of turbidity current has been termed an interflow by Bell (1942a).

Still another type of turbidity current, recognized by Bell but not included in the definitions of other investigators, is called an overflow. Overflows occur when the muddy rixer water is less dense than the water at the surface of the lake, and, as the name implies, the muddy river water flows over the lake surface. In order for this type of flow to take place, the sediment-laden river water must be warmer or less saline, or both, than the underlying lake water.

Most definitions of density currents (Daly, 1936; Stetson and Smith, 1938; Johnson, 1939; Kuenen and
Migliorini, 1950) require that they have a higher density than the water at the surface of the lake, and consequently do not include the type of current referred to as an overflow. Bell (1942b), however, broadly defines a density current as a gravity flow of liquid or gas through, under, or over a fluid of approximately equal density. He uses the phrase, "of approximately equal density," to exclude specific types of gravity flows that are not truly density currents. A river flowing beneath air has been cited by Bell as an example of a gravity flow that does not meet the requirements of a density current because of the very great difference between the density of water and air. When referring solely to movement of water masses in relation to each other, however, there is no need for including Bell's concept "of approximately equal density."

Bell's definition of a density current, when applied to water masses, includes all currents that are produced by differences in density. Some of them are produced solely by differences in temperature or salinity, whereas others may originate, at least in part, from differences in the amount of suspended sediment. The type of density current in which suspended sediment accounts for part of the difference in density is referred to in this paper as a turbidity current. Thus, a turbidity current can be defined as a gravity flow of turbid water through, under, or over water of different density. Part of the difference in density is produced by the suspended sediment, but suspended sediment is not always the dominant factor. In the overflow type of turbidity current, the lower density is due to higher temperature or lower salinity or both. Similarly, in the interflow or underflow type of current, suspended sediment may not account in some cases for as great a part of the higher density as does lower temperature or higher salinity.

Our knowledge of density currents in general, and of turbidity currents in particular, is still fragmentary, and there are many unsolved problems. Some of these unanswered questions occur even in the matter of definition. The reader may well ask how a density current is to be distinguished from other movements of water that result from differences in density, from the circula- 
tion patterns described by Anderson and Pritchard (p. 139) for instance, or even from the seasonal turnover of lake water in temperate regions. The answer may be in the mixing of waters: a density current moves through still water with very little mixing, (p. 109) and remains identifiable because of the lack of mixing. Density currents degenerate by mixing with the surrounding water and pass into anonymity.

This factor of mixing may account for the very small number of density currents that have been identified in the density-current investigations beginning in 1937, chiefly in Boulder Basin. The inflowing river water is always somewhat turbid, and is commonly different from the lake water also in temperature and salinity. Thus, at the entrance of the river into the lake, conditions should generally be favorable for density currents, and particularly for turbidity currents. But, as pointed out by Anderson and Pritchard (1951, p. 53)-

Virgin Basin acts as a large "mixing bowl" in which the large seasonal variations in salinity of the inflowing Colorado River waters are smoothed to nearly their mean value. Below Virgin Basin the water is nearly uniform with respect to salinity.

Mixing in Virgin Basin may also account for the general clarity and fairly uniform temperature of the water downlake in Boulder Basin. However, the earliest observed turbidity currents passed through Boulder Basin and Hoover Dam with suspended load and dissolved solids correlative with those measured at Grand Canyon (p. 109).

\section{RELATION TO RIVER DISCHARGE AND LAKE STRATIFICATION}

Turbidity currents are developed at the mouths of both the Colorado and Virgin Rivers, and they have transported a tremendous quantity of silt and clay to the deeper parts of the lake. The Virgin River turbidity currents are of relatively minor significance and they have not been studied intensively. Turbidity currents are always present near the mouth of the Colorado River, but only rarely do they flow the entire length of the lake. The three types of currents designated above as overflow, interflow, and underflow all occur in Lake Mead, but underflow is by far the dominant and most important type.

\section{OVERFLOWS}

Overflows occur only during the late spring and early summer (usually from late April to early July) when the incoming river water is less dense than the water at the surface of the lake. The inflow during this period is derived principally from the rapid melting of snow in the Upper Colorado River basin and represents the maximum inflow for the year. The temperatures of the river water and the lake surface water are ap- proximately the same, but the salinity of the inflowing water is much lower than that of the lake water (p. 108). The river in this period commonly carries a higher proportion of sand grains than in other seasons (p. 106), and these coarse particles are deposited in the topset and foreset beds of the Colorado delta. Thereafter the inflowing water, even with the finer sediment remaining in suspension, may have a density lower than that of the lake. Under these conditions the turbid river water spreads out over the lake surface, rapidly at first and then progressively more slowly as the overflow continues downlake.

Owing to the decreasing velocities and to the mixing of the overflow with the denser lake water, a large part of the sediment is dropped from suspension during the first few miles of travel. The rapid settling of the suspended sediment and the mixing of the overflow with the underlying lake water is well illustrated by a series of observations made in May 1948 at mile 287.5, about 10 miles downlake from the entrance of the Colorado River into Lake Mead at that time. The proportion of sediment by weight increased progressively from 0.013 percent at the surface to 0.110 percent near the bottom of the lake.

Although a considerable amount of suspended sediment settles out of the overflows in the eastern part of the reservoir, enough may remain in suspension to give the lake surface a perceptibly turbid appearance far from the river entrance. However, the turbid overflows seldom extend west of Virgin Basin and they apparently never reach the dam (National Research Council, 1949). This conclusion is supported by the distribution of $\log _{\mathrm{s}}$ and other debris along the lake shore. During most seasons, logs carried into the lake by the Colorado River remain stationary near the river mouth, but during periods of overflow (late April to early July) they are carried downlake and eventually become stranded along the shoreline. East of Virgin Basin the coves and gently sloping beaches are littered with $\operatorname{logs}$, but to the west there are no such accumulations. The westernmost boundary of the overflow in May 1948 was detected in the center of Virgin Basin. The suspended sediment in this region ranged from 0.007 percent at the lake surface to 0.008 percent at the bottom.

Bell (1942b, p. 30) has illustrated by laboratory experiment that particles, dropped from an overflow, upon approaching the bottom may continue to travel downstream as an underflow. Because of the difficulty in distinguishing movement of a thin layer of very fluid sediment over the bottom of a lake, there is no direct evidence that this type of flow occurs in Lake Mead. However, it is evident from the distribution of the ac- 
cumulated sediment (pl.20) that small underflows must take place along the steep slopes normal to the submerged channel of the Colorado River. If minor underflows of this type were not active in Lake Mead, the sediment that is dropped from overflows would be expected to accumulate over a great part of the lake bottom. Investigations of the accumulated sediment show that essentially all the sediment brought into the lake by the Colorado River turbidity currents has accumulated in the region of the submerged Colorado River channel, and that no appreciable amount of sediment from this source has accumulated in other areas of the lake bottom. It seems probable, therefore, that the sediment dropped from the overflows in the shallow lake areas travels along the bottom until it comes to rest in the deep submerged channel of the Colorado River. There is no evidence that the material, upon reaching the submerged channel, continues to move as an underflow in a downlake direction.

Although the overflow type of turbidity current predominates in late spring and early summer, interflows and underflows may occur for short periods when the density of the inflow is sufficient to cause the river water to plunge beneath the lake surface.

\section{INTERFLOWS}

Interflows are apparently of minor significance compared to overflows and underflows. Anderson and Pritchard (p. 132,134) indicate that interflows during 1948 were most prominent in August and September, but conditions continued favorable throughout the autumn. During the summer the temperatures of the river and the lake surface water were about the same, but the salinity of the incoming water was considerably greater than the salinity of the lake surface layer. However, the density of the river water, even with its dissolved and suspended load, was not as great as that of the colder water at the bottom of the lake. Under these conditions the turbid river water sinks through the light surface layer and spreads out at intermediate depth over denser water, thus conforming to the definition of an interflow. The suspended sediment readily settles to the bottom within a few miles of the river entrance, but the high salinity of such interflows can be identified for a considerable distance downstream and thus distinguishes the interflow from the lake water above and below it.

\section{UNDERFLOWS}

Underflows are the dominant and most important currents transporting sediment within Lake Mead. Whenever the density of the inflow is greater than the density of the lower lake layers, the turbid water plunges beneath the lake surface and travels downlake along the submerged channel of the Colorado River. In late spring and summer, overflows and interflows are periodically replaced by underflows, and during fall and winter there is a continuous movement of turbid water along the lake bottom. Water discharged by the Colorado River from October to April is colder and more saline than the deep water in the eastern part of the lake. Owing to these factors and to its suspended sediment, the muddy river water sinks rapidly beneath the clear lake water and travels along the submerged Colorado River channel. During this period the division between the turbid river water and the clear lake surface is sharp and distinct as shown in plate 17 and is commonly marked by a collection of logs. This line of demarkation, known as a convergence (p. 135), denotes a downlake movement of water at the bottom and an uplake movement at the surface. The debris collects at the line where the opposing surface currents meet.

Most underflows do not reach the western part of the lake, but at least 12 conspicuous underflows have traveled along the old Colorado River channel from the river mouth to Hoover Dam. Most of these occurred during the first 7 years of reservoir operation (19351941), when the lake was 70 to 120 miles long (fig. 24). The only major flow of turbid water to reach the dam since 1941 arrived in the fall of 1947 , when the distance between the river mouth and the dam was about 78 miles. Although these extensive currents are comparatively rare, they have transported a tremendous quantity of sediment great distances from the head of the lake.

The first three major underflows arrived at Hoover Dam during 1935, when the lake was 70 to 90 miles long. As pointed out by Howard (p. 109), these underflows were related to large increases in the quantity of suspended sediment carried by the Colorado River past the Grand Canyon gaging station. There is no record of underflows reaching the dam during the latter part of 1936 and the early part of 1937 , but the density-current records of the Bureau of Reclamation (National Research Council, 1949, p. 20) indicate that by June 1937 the diversion tunnel, through which water had previously been discharged, was covered by about 10 feet of sediment. Thus it appears that the flow of turbid water through the lake was as prominent in 1936 and 1937 as in 1935.

Since June 1937, monthly measurements of the sediment level at the intake towers (National Research Council, 1949, and Bur. Reclamation, 1949 and 1953) reveal the periods during which conspicuous flows of turbid water have reached Hoover Dam. The periods of underflow are marked by a rapid rise in the top 
of the sediment accumulation behind the dam, whereas the intervals between periods of underflow are marked by a gradual but progressive lowering of the sediment surface due to compaction.

The fluctuations in sediment level at the dam are shown in the graphs of plate 26 , which also show the approximate daily densities of the incoming river water during the 14-year period from 1935 to 1948 . These densities were computed from measurements of temperature, salinity, and suspended sediment of the Colorado River as recorded at the Grand Canyon gaging station (p. 103), using the method outlined by Rubey (1938), who states that densities computed by his method probably have an average error of about 0.0003 gram per cubic centimeter. In the computations, the density of the suspended solids was taken as 2.67 , as determined by direct measurement, rather than the assumed value of 2.60 used by Rubey. In the absence of temperature data for the period February 1, 1935, to September 30, 1936 , it is assumed that the temperature in that period varied in about the same manner as in 1939.

The density of the water entering the main body of Lake Mead, after the coarser sediment particles have been deposited in the Lower Granite Gorge and Pierce Basin, is undoubtedly somewhat lower than the density of the water passing the Grand Canyon gaging station. However, it seems a fair assumption that the daily variations in the amount of sediment still in suspension when the turbid river water enters the lake are roughly in the same proportion as the variations in the suspended sediment content of the Colorado River at the Grand Canyon gaging station. Of course, these variations are not synchronous, owing to the time required for water to flow from the Grand Canyon station to the head of Lake Mead. Computations by Rubey (1938) indicate that the time required for water to travel from the Grand Canyon station to the eastern end of the lake ranges from 1 to $41 / 2$ days, the shorter travel times occurring during periods of floods. Howard notes (p. 103) that the turbid flows of 1935 passed through Hoover Dam about 8 days after they were observed at Grand Canyon.

The data presented in figure 26 show clearly that the rises in the sediment level behind Hoover Dam follow the peak water densities of the Colorado River at the Grand Canyon station. Some lag may be expected between the appearance of high-density water at the Grand Canyon station and the rise in the sediment level behind the dam, because of the time required for the high-density water to travel from the Grand Canyon station to Hoover Dam. This travel time does not account, however, for the total time separation of the curves in figure 26. Observations of the sediment level behind the dam are made only once each month; it is therefore possible that the time of arrival of turbid underflows at the dam may be missed by as much as 30 days.

Even though the times of arrival of underflows at Hoover Dam since June 1937 are known less accurately than those in 1935, many of the rises in sediment level behind the dam are clearly related to peak water densities at the Grand Canyon station. Most of these periods of underflow have been associated with peak river-water densities of 1.02 or greater, although two of the underflows are associated with relatively low densities of river water. In March 1935 the maximum density of the river water prior to the arrival of the first major underflow at the dam was only 1.012, and in May 1939 a conspicuous underflow was associated with peak densities of only 1.006. On the basis of these observations alone, it is evident that other factors in addition to density determine the distance that underflows move along the bottom of Lake Mead. Variations in the size of the suspended particles, their degree of flocculation, the duration and volume of high density inflows, mixing of the inflow with the lake water, and changes in the slope and width of the channel over which underflows move may influence the distance of travel of underflows in the lake. From the records of density currents to date, however, density appears to be a dominant factor.

\section{VELOCITY, DENSITY, AND THICKNESS}

One of the most striking features of the underflows is their extremely low velocity. Bell (1942a, p. 522) estimated that the average velocity of one of the underflows reaching the dam in 1935 was approximately 0.83 foot per second. Records since 1937 (National Research Council, 1949, and U.S. Bur. Reclamation, 1949) show that the average velocities of the later currents were generally about 0.5 foot per second and might be as low as 0.3 foot per second. These records also indicate that the underflows travel much more rapidly over the steeper, upper parts of the delta than over the lower parts. Mean velocities of 1.0 foot per second are common near the river mouth where the turbid water plunges down the face of the delta front, but by the time these currents reach the flat floor of the Boulder Basin, their velocities are less than 0.25 foot per second and are commonly too low for measurement.

In most of Lake Mead, underflows are confined to the submerged channel of the Colorado River and are generally only a few feet thick. Between the entrance of the river in 1948 and the mouth of Iceberg Canyon (a distance of about 14 miles), abundant mixing of the muddy inflow and the lake water occurred several 
tens of feet above the reservoir botton, but west of Iceberg Canyon the underflow of turbid water was confined to the very deepest part of the reservoir.

In late November 1948, an underflow of muddy water extended into the eastern part of Virgin Basin. Observations of this current showed a very sharp interface between the muddy flow at the bottom of the lake and the clear water above. The average thickness of the underflow west of Iceberg Canyon was about 3 feet and its density ranged from approximately 1.001 at the top to about 1.20 at the bottom. In figure 55 the typical vertical distribution of density of the November 1948 underflow is shown in a section taken at the mouth of Virgin Canyon. The marked increase in density near the bottom of the underflow probably represents a division between material that is still in motion and that which was recently deposited, but as this contact is somewhat transitional, it is shown in figure 55 as a gradational zone.

\section{AMOUNT OF SEDIMENT AND DISTANCE OF TRAVEL}

It was estimated (p. 195) that about 50 percent of the total weight of sediment accumulated in the Colorado delta is contained in the fine-grained bottomset beds. Practically all of this material was transported by turbidity currents developed at the mouth of the Colorado River. Cores from the bottomset beds provide no information as to the relative quantities of material that were transported into the lake by the three types of turbidity currents: overflows, interflows, and underflows. It is clear, however, that most of the sediment

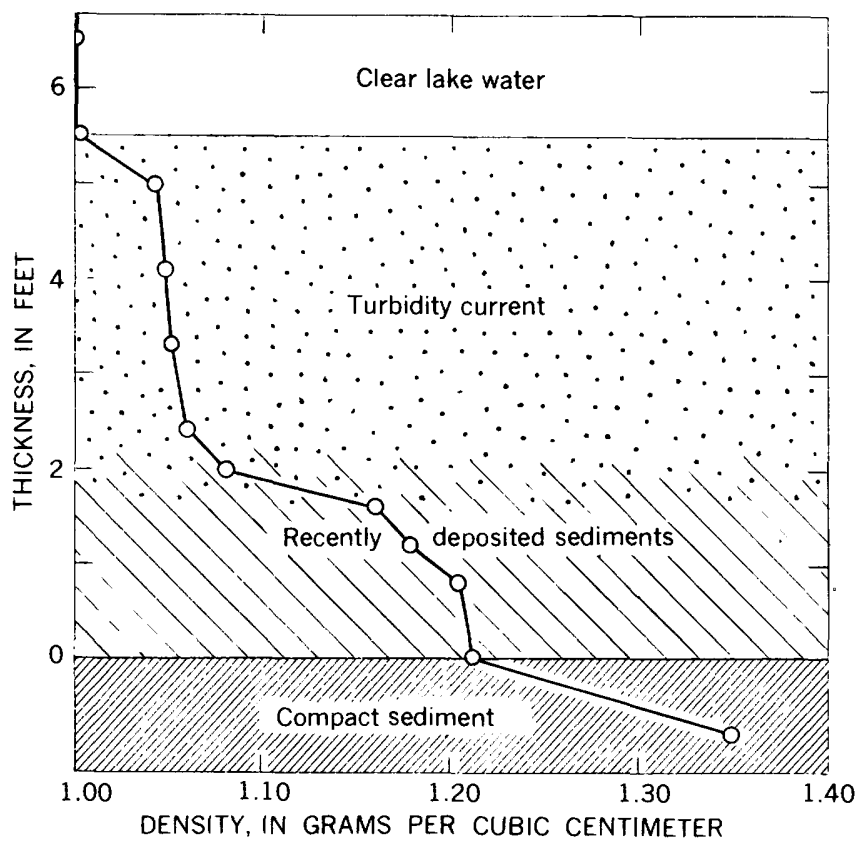

FiguRe 55.-Distribution of density during underflow of November 1948 in vertical section at mile 301.9, in Virgin Canyon.

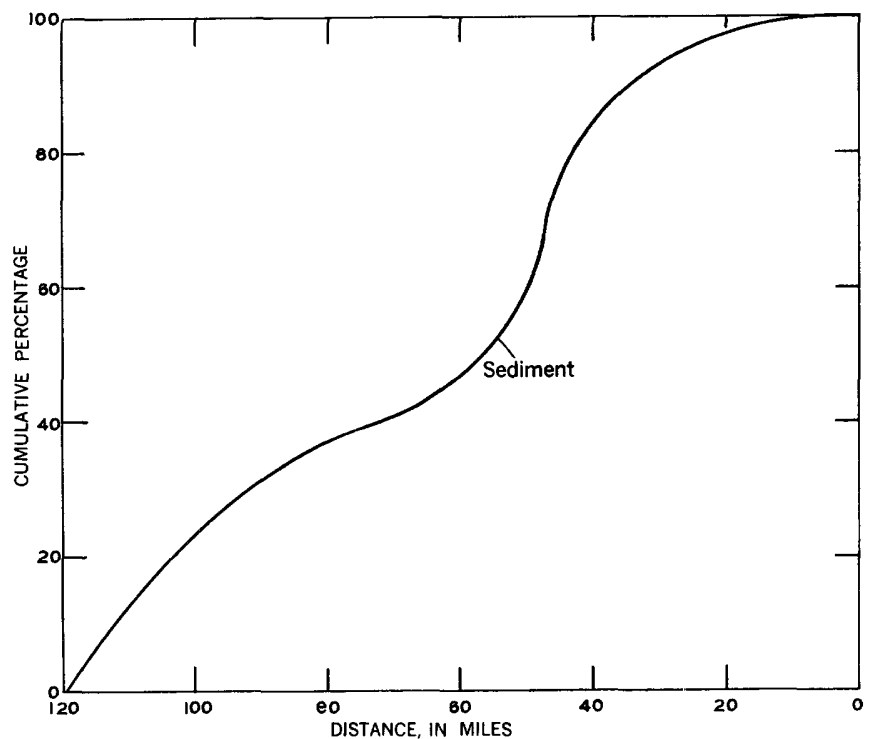

Figure 56.-Percentage distribution of sediment transported by turbidity currents in relation to distance from the east end of the lake. measured along the buried Colorado River channel. Curve shows only the percentage distribution of sedinent transported by turbidity currents, not the ratio of such sediment to total sediment.

11 Boulder Basin was transported by underflows, because interflows have never been identified in that basin and overflows rarely extend west of Virgin Basin.

In figure 56 the percentage distribution of sediment transported by the Colorado River turbidity currents is plotted against the distance from the eastern end of the reservoir at Bridge Canyon, measured along the buried Colorado River channel. This figure shows that about 80 percent of the sediment carried by turbidity currents accumulated on the reservoir floor at a distance of more than 43 miles from the head of the reservoir, and that 23 percent accumulated at a distance of more than 100 miles. Owing to the advance of the delta front into the lake, it is not known precisely how far this material was transported. It is known, however, that most of the sediment in Boulder Basin was transported at least 70 miles before finally coming to rest. These long-ranging flows of turbid water could, in all probability, have continued for many more tens of miles, if Lake Mead had been large enough.

The Colorado delta deposits along the thalweg of the river have a minimum thickness of 45 feet at mile 314.1 in the Temple Bar area, about 40 miles above Hoover Dam. The progressively increasing thickness east of this point is normal for a sediment-laden stream entering quiet water. The increasing thickness to the west may be attributed to Hoover Dam, which arrested the infrequent but farthest-traveling turbidity currents and caused deposition of their suspended loads. In 
open water, some of these currents might have continued for tens or even hundreds of miles, and the total thickness of deposition would generally decrease progressively from the point of entrance of the inflowing water, doubtless with modifications resulting from configuration of the bottom.

\section{CHANGE IN SLOPE AND WIDTH OF THE CHANNEL}

The sediment that has accumulated in the Colorado delta has reduced the average slope of the former Colorado River channel from 5 feet per mile to about 3 feet per mile. The greatest reduction in slope occurs in Boulder Basin, where the declivity of the sediment surface is less than 1 foot per mile. As shown in plate 13 , this reduction in slope occurred prior to 1942 , when Boulder Basin received most of its sediment. Because of the rapid rate of sedimentation in the first 7 years of reservoir operation, the width of the channel was also greatly increased. As the continued underflow of turbid water is controlled in part by the slope and cross-sectional area of the channel, it is possible that this early reduction in slope and the increased width of the channel may be partly responsible for the decreased flow of turbid water into the western part of the lake since 1942 (pl. 26). However, periods of high-density inflow have occurred only rarely in recent years, and they may be the chief reason for the dearth of major underflows since 1942.

\section{SIZE OF SUSPENDED PARTICLES}

Assuming that the deeply buried bottomset beds in Lower Granite Gorge are similar in texture to the bottomset beds west of the Colorado delta front, we can obtain a fair estimate of the average size distribution of the particles transported by the Colorado River turbidity currents. According to this estimate (areas 1-5, fig. 54) the suspended particles have an average median diameter of 1.65 microns (in dispersed state) and consist of 67 percent clay (smaller than $4 \mathrm{mi}$ crons), 32 percent silt (4-62 microns) and less than 1 percent sand (larger than 62 microns).

Even though the range in size of the sediment particles is small, the bottomset beds are horizontally graded, the coarsest particles being deposited near the river mouth and the finest at the greatest distance from the source. This relation is illustrated in figure 53, where the size characteristics of samples from each of the seven subdivisions of the Colorado delta are combined and averaged so as to give a composite size distribution curve for each of the divisions. Curves for areas 1 through 5 show the gradation in particle size of material transported by turbidity currents, whereas the curves for areas 6 and 7 include sand and coarse silt that has not been transported by turbidity currents.

As mentioned previously (p. 155) the sediment in the bottomset beds of the Colorado delta in its natural condition does not settle out as discrete particles, but as flocculated masses that are 2 to 20 times larger than the individual grains (table 22). Similar studies of suspended sediment in the Lake Mead underflows (Sherman, 1953) and in the Colorado River (Grover and Howard, 1938, p. 728-729) show that the material also travels in a flocculated state.

Flocculation of fine sediment has been cited by Johnson (1939) and others as a condition which probably prevents the formation of extensive turbidity currents, but the validity of this assertion is open to question. As pointed out by Bell (1942a, p. 541), flocculation causes rapid settling, but floccules, because of their large volume of entrapped water, may behave as a fluid that will flow on much gentler slopes than unflocculated material. Hence it appears that flocculation may actually assist in producing and maintaining turbid underflows.

\section{VIRGIN RIVER TURBIDITY CURRENTS}

The Virgin River turbidity currents, although of little quantitative significance, are worthy of brief mention. Essentially all of the sediment carried into the lake by the Virgin River has accumulated in the upper 14 miles of Overton Arm, and it is apparent that most of the Virgin River turbidity currents have extended only a short distance into Lake Mead. However, there is evidence that some underflows of turbid water have traveled through most, if not all, of the inundated Virgin River channel.

Our knowledge of these extensive currents is based entirely on data obtained at the Lower Narrows, 9.3 miles upstream from the former junction of the Virgin River and the Colorado River. Records obtained by the Bureau of Reclamation at this station show that suspended silt and clay particles were present in the former Virgin River channel from January to March 1938 and again from June to September 1938. From January 1939 to February 1940, the suspended sediment disappeared completely as shown by the presence of clear water in contact with the sandy bottom of the channel. It appears that essentially no sediment was permanently deposited from these early underflows as they moved through Lower Narrows.

Again in March 1940 suspended sediment appeared in the bottom of the channel at Lower Narrows, but, in contrast to the earlier underflows, some of the sediment was deposited. Samples taken by the Bureau of Rec- 


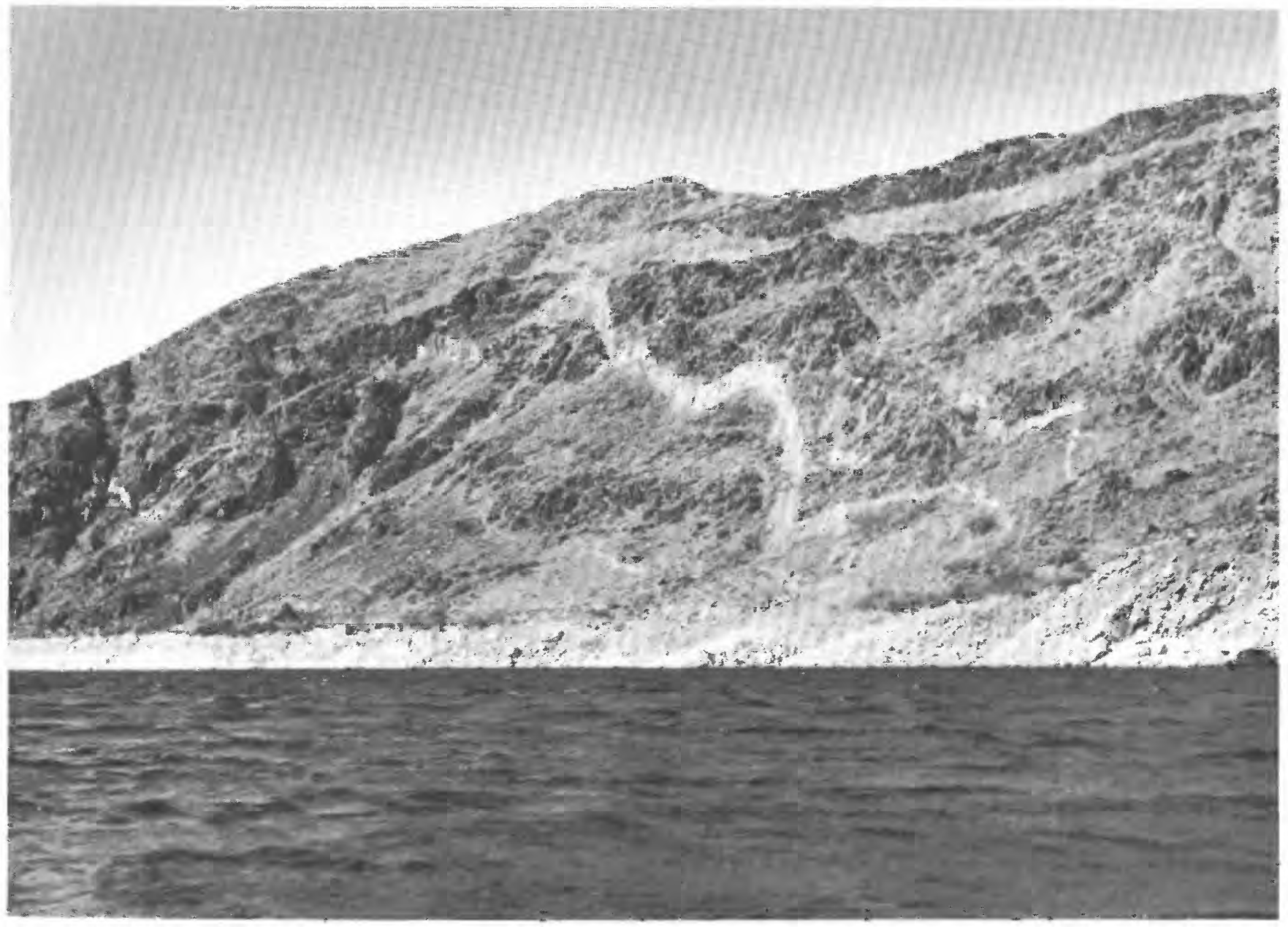

LANDSLIDE ON THE NORTH WALL OF VIRGIN CANYON, NEAR THE MOUTH

The 1941 high-water mark, which stands about 65 feet above the lake surface, has not been displaced. Photograph by Bureau of Reclamation, October 1953. 
lamation in June 1940 showed that the bottom material was composed of sand, silt, and clay, and indicated that a very thin layer of slit and clay had been deposited on top of the sand in the inundated channel. Records obtained once or twice each year since June 1940 show that suspended sediment has appeared periodically in the submerged channel between 1942 and 1947. Suspended sediment was observed in the channel at Lower Narrows in April 1948, but by January 1949 it had disappeared. The suspended sediment at Lower Narrows commonly appears prior to the period of Colorado River overflows, and the Virgin River is evidently its source.

Part of the suspended sediment that moves along the former Virgin River channel has probably been derived from the Colorado River overflows. During the late spring and summer of 1948 the overflow of turbid water from the Colorado River extended northward from Virgin Basin into Overton Arm, indicating (p. 13) that at least part of the suspended sediment that was observed in the old Virgin River channel was dropped from the Colorado River overflows.

A layer of silt and clay ranging from a few tenths of a foot to about 2 feet in thickness has accumulated in the bottom of the inundated Virgin River channel between the toe of the Virgin delta and Lower Narrows (p. 172). This is regarded as an incipient extension of the bottomset beds of the Virgin delta into the deeper parts of Overton Arm. Whether or not this thin layer of accumulated sediment represents the total amount of material carried by the extensive Virgin River turbidity currents is not known. However, it is certainly possible that some of the sediment may have been carried along the entire length of the old Virgin River channel and deposited among the bottomset beds of the Col- orado delta in the area of the former junction of the Colorado and Virgin Rivers.

\section{REFERENCES CITED}

Anderson, E. R., and Pritchard, D. W., 1951, Physical limnology of Lake Mead: Navy Electronics Lab. Rept. 258, 152 p.

Bell, H. S., 1942a, Density currents as agents for transporting sediment: Jour. Geology, v. 50, p. 512-547.

$1942 \mathrm{~b}$, Stratified flow in reservoirs and its use in the prevention of silting: U.S. Dept. Agriculture Misc. Pub. $491,46 \mathrm{p}$.

Daly, R. A., 1936, Origin of submarine canyons: Am. Jour. Sci., ser. 5 , v. 31 , p. $406-407$.

Grover, N. C., and Howard, C. S., 1938, The passage of turbid water through Lake Mead: Am. Soc. Civil Engineers Trans., v. 103, p. $720-32$.

Johnson, D. W., 1939, The origin of submarine canyons: New York, Columbia University Press, p. 27, 52.

Kuenen, P. H., and Migliorini, C. I., 1950, Turbidity currents as a cause of graded bedding: Jour. Geology, v. 58, p. 94-95.

National Research Council, Interdivisional Committee on Density Currents, Subcommittee on Lake Mead, 1949, Lake Mead density current investigations 1937-40, v. 1, 2; 1940-46, v. 3; Washington, U.S. Bur. Reclamation, 3 v. $904 \mathrm{p}$.

Rubey, W. W., 1938, Discussion of "The passage of turbid water through Lake Mead" by N. C. Grover, and C. S. Howard: Am Soc. Civil Engineers Trans., v. 108, p. 763767.

Sherman, Irving, 1953, Flocculent structure of sediment suspended in Lake Mead: Am. Geophys. Union Trans., v. 34, p. 394-406.

Stetson, H. C., and Smith, J. F., 1938, Behavior of suspension currents and mud slides in the continental slope: Am. Jour. Sci., ser. 5, v. 35, p. 1-2.

U.S. Bureau of Reclamation, 1949, Report of river control work and investigations in 1948 and 1949: Boulder City, Nev., Office of River Control, p. 43-124, figs. 44-46.

- 1953, Report of river control work and investigations in 1950 and 1951: Boulder City, Nev., Office of River Control, p. 55-94, flgs. 45-47. 


\title{
R. EROSION IN THE RESERVOIR
}

\author{
By H. R. Gould, U.S. Geological Survey
}

Although Lake Mead is predominantly a site for aggradational processes, there are also many evidences of the effects of erosion. Some of these effects are conspicuous to the casual observer, and some have a bearing on the storage capacity of the reservoir, or upon the quality of the stored water. The effects of erosion are abundantly reflected by small-scale sliding and slumping of steep-sided headlands, cutting of terraces, and solution of gypsum and other salines in the basin areas of the lake. Some erosion has resulted from the scour of Detrital Wash near its entrance into Lake Mead (p. 71, 171). The submarine channel in the delta deposits (p. 164) may also be evidence of erosion by turbidity currents.

Slumping along the lake border occurs both above and below the water surface, but in only a few places has it been sufficient to produce any notable change in the configuration of the lake (p. 70). Most of the material moved by landslides and wave action is redistributed within the reservoir itself. However, in a few localities, weakly cemented or highly jointed materials, standing many tens of feet above the water surface, have slumped into the lake, and this has resulted in a slight reduction in reservoir capacity. On the other hand, a large percentage of the salines dissolved from the reservoir floor are carried out of the lake in solution, resulting in a slight increase in storage capacity. These changes were too small, however, to be measured quantitatively in the 1948 survey.

\section{LANDSLIDES}

Small-scale landslides may be seen along the shore in practically all parts of the lake, but the largest and most prominent slides are in Virgin Canyon and the southeast part of Gregg Basin near Hualpai Wash. The most striking of these (pl. 27) is in the highly jointed gneiss and schist of Precambrian age (pl. 1) which forms the north wall of Virgin Canyon near its mouth. According to E. T. Schenk of the U.S. Bureau of Mines Experimental Station in Boulder City, Nev., this large mass of rock began its movement during the early stages of reservoir filling. Sliding evidently took place along joints filled with argilla- ceous materials that became wet as the reservoir filled. Since the high-water mark (denoted by the white precipitate on the canyon wall) is not displaced, it is apparent that all movement ceased before July 1941.

The slides in the southeastern part of Gregg Basin occur in the Hualpai limestone and its associated siltstone and clay beds of possible Pliocene age (pl. 1). As in the Virgin Canyon slide, movement probably took place along wetted clay-filled joints as the lake level rose. The greatest amount of sliding in this region occurred after 1941, as shown by the considerable displacement of the high-water mark on the reservoir wall.

According to Sharpe's classification (1938), the landslides in Virgin Canyon and Gregg Basin are of the slump variety. The largest of the Gregg Basin slumps (pl. 28) is typical of others in the region. Movement has taken place on a spoon-shaped surface concave toward the slip, and the slumped material has moved as a unit with a pronounced backward rotation. At the apex (pl. 28A) the movement is chiefly vertical, but at the sides there is a marked horizontal component. In a few of the slumps, movement has taken place on a series of closely spaced parallel surfaces, thus giving them a terraced or steplike appearance.

There is little evidence of sliding and slumping of the reservoir floor below the average lake level (about 1,170 feet altitude). Closely spaced profiles of the bottom topography reveal only three slumps of any considerable size, all in Boulder Basin (p. 70). From inspection of the geologic map of Lake Mead (pl. 1), it is clear that these slides occurred in the poorly consolidated Chemehuevi formation of Pleistocene age. The largest one extends from the shoreline on the north side of Boulder Basin to the submerged Colorado River channel between miles 341.0 and 343.5. Sand and coarse silt contributed by this slumping were detected at a depth of about 40 feet in the bottomset beds of the Colorado delta (p. 171), thus indicating that the slide occurred early in the history of the reservoir.

A smaller subaqueous slide occurred between miles 351.5 and 352.0 , where material from the Chemehuevi formation has slumped into the channel area south of 


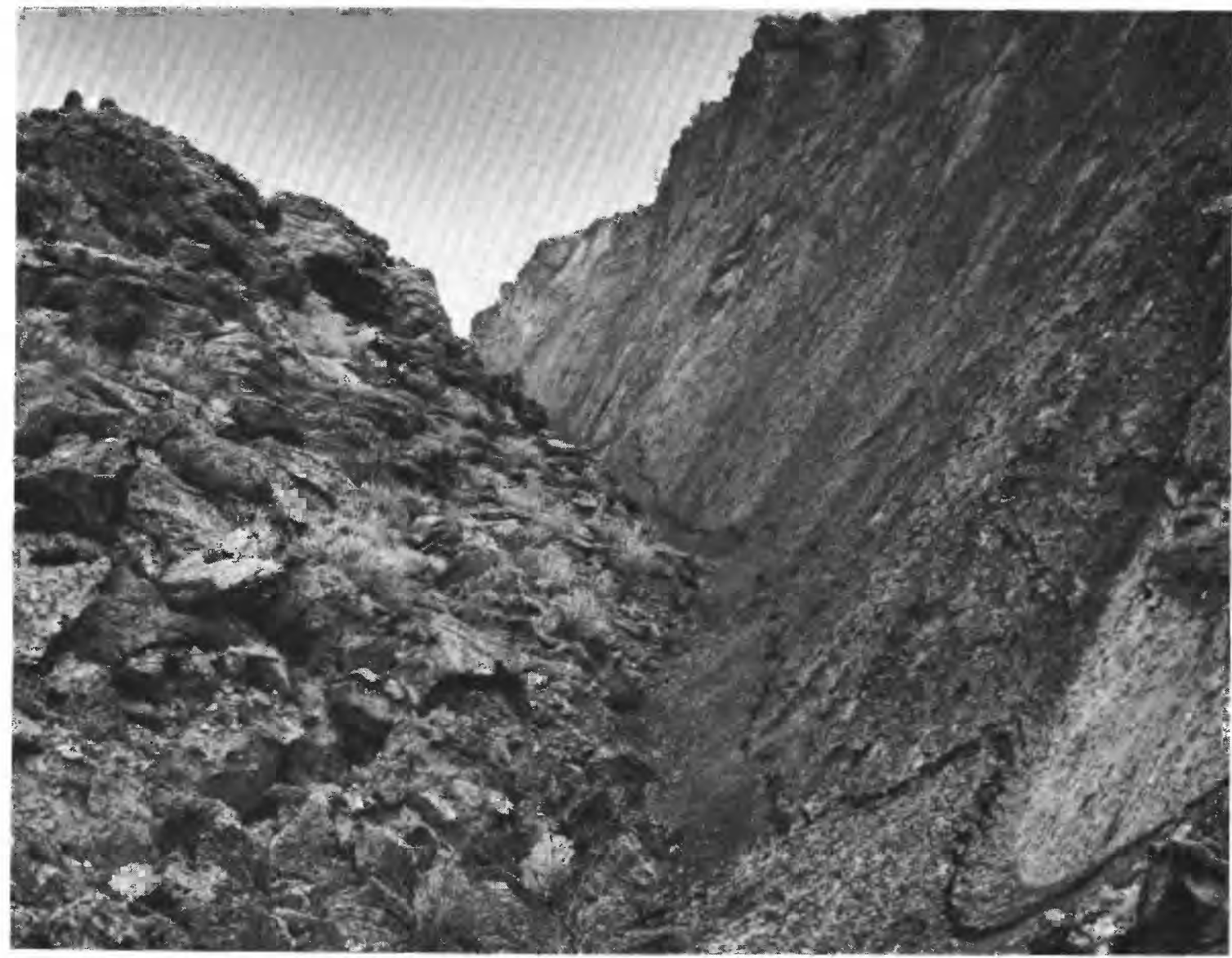

\section{A. NORTHWARD VIEW}

Note the clayey character of the material on the slip plane. The downslumped block on the left has been rotated backwards as shown by the steep dip of the bedding and the inclination of the vegetation.

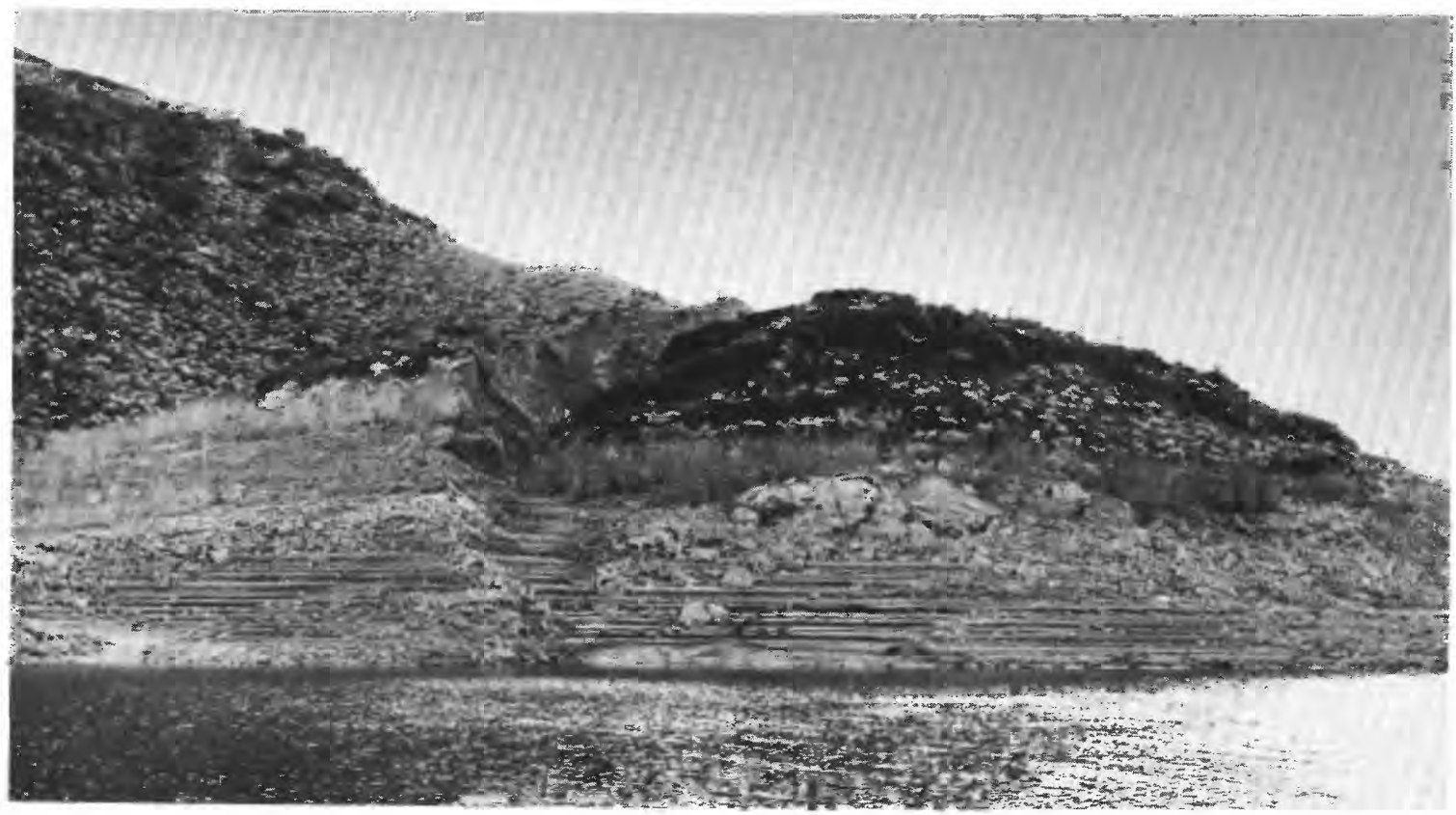

B. SOUTHWARD VIEW

The displacement of the 1941 high-water mark, denoted by a line of driftwood above the wave-cut terrace area, shows that most of the movement has taken place since 1941 .

PROMINENT LANDSLIDE ON THE EAST SIDE OF GR EGG BASIN, NEAR THE MOUTH OF HUALPAI WASH Photographs by Bureau of Reclamation. 


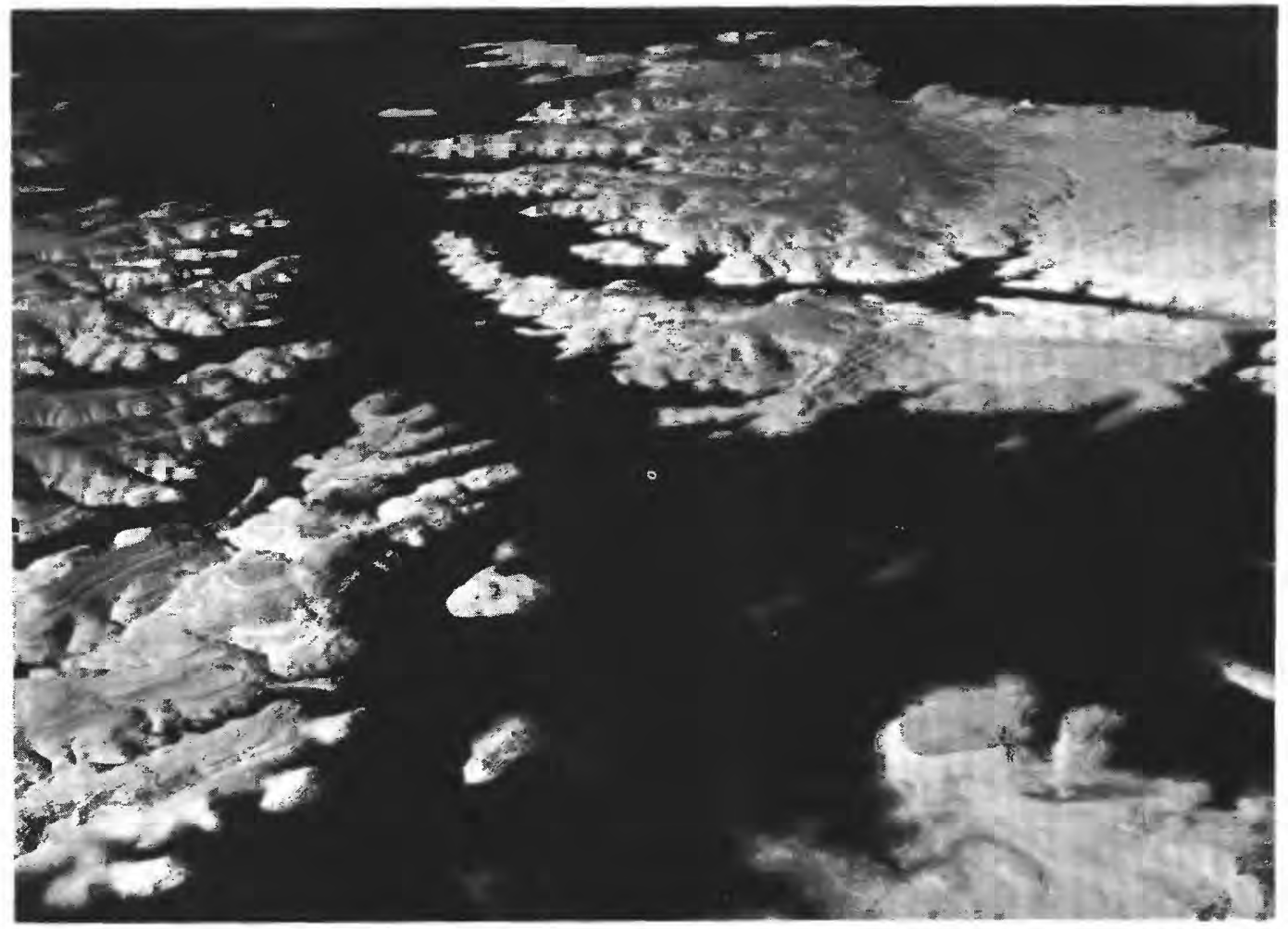

A. SOLUTION AND TERRACING OF GYPSUM REEFS NEAR THE MOUTH OF DETRITAL WASH

Photograph by Bureau of Reclamation.

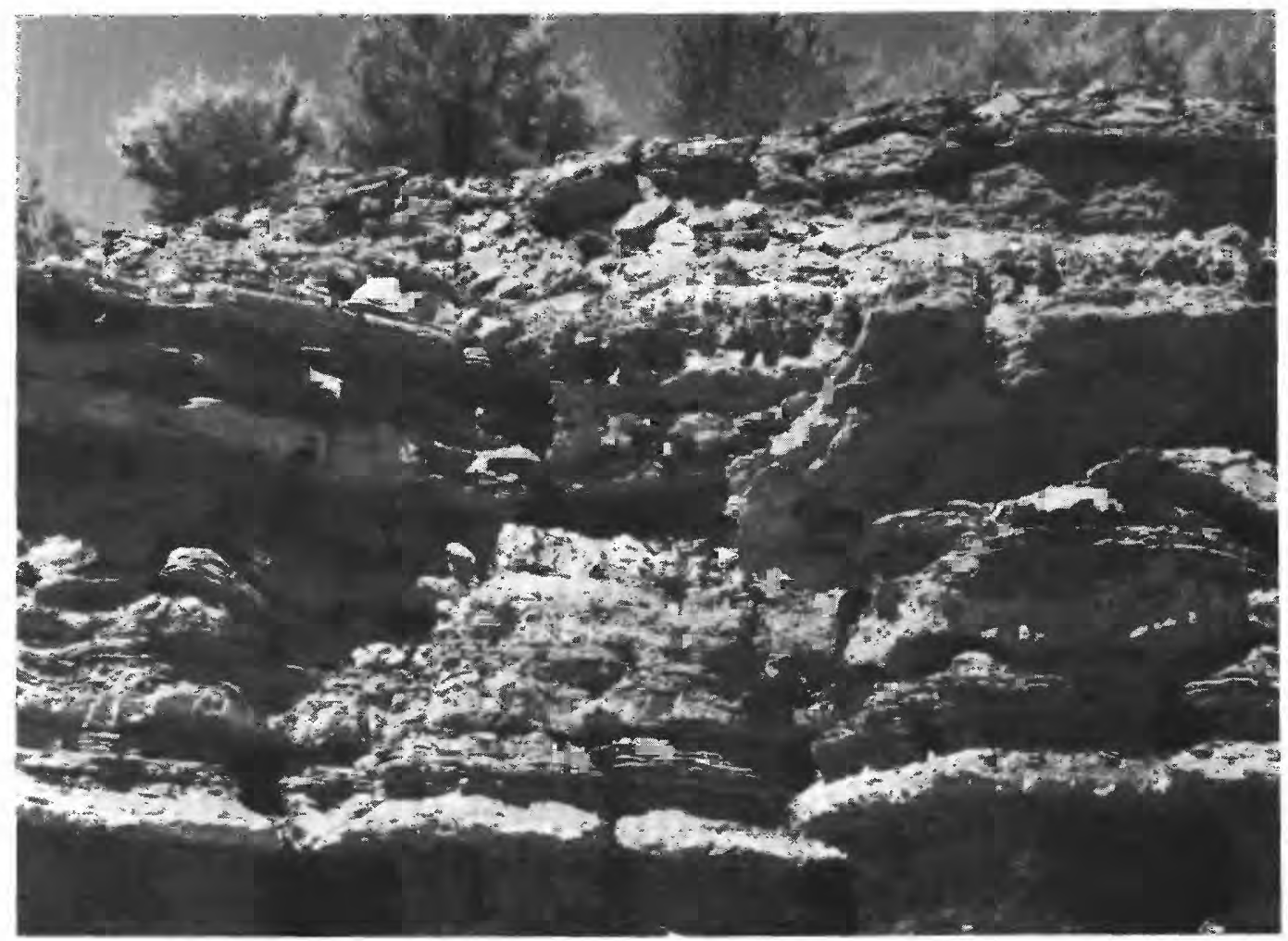

B. SOLUTION CAVITIES IN SILTSTONE AND GYPSUM OF THE MUDDY CREEK FORMATION IN LAS VEGAS BAY Photograph by Bureau of Reclamation. 
Sentinel Island. In a few other places, notably between the east side of Virgin Basin and the mouth of Virgin Canyon, sand and coarse silt slumped from the adjacent reservoir walls were detected in cores from the bottomset beds of the Colorado delta. The slumps in these areas were too small, however, to be revealed by underwater soundings.

In addition to the landslides caused by wetting, a number of small slides have resulted from wave undercutting and caving. These slides may be seen in many areas of the lake. They are best developed near the head of Las Vegas Bay, along the east side of Overton Arm, and between Virgin Canyon and the east side of Virgin Basin. In these areas undercutting and caving have been confined to weakly cemented clastics of the Muddy Creek formation of probable Miocene age, (p. 15).

At the head of Las Vegas Bay, excavation of weak silt and clay strata has allowed large blocks of the overlying breccia to give way. Similarly, in Overton Arm and near the mouth of Temple Bar Wash prominent headlands of poorly consolidated clastics of the Muddy Creek formation have been sharply truncated by wave action and caving. The level of undercutting suggests that most of the slumping in these areas occurred during the high lake stages of 1941 and 1942.

\section{WAVE-CUT TERRACES}

In most areas of the lake the shore is only moderately sloped and is not subject to serious caving or slumping. Erosion in these areas is confined to the cutting of terraces in the easily eroded basin formations. Wave-cut terraces occur at practically all altitudes between 1,150 and 1,220 feet, the approximate range in lake level from 1941 to 1948 , but they are best preserved at altitudes above 1,200 feet, which are seldom reached by the water surface. At lower altitudes, the terraces are obscured owing to modification by frequent changes in lake stage. The terraces range in width from a few inches to several feet, depending on the type of rock, the altitude and configuration of the shore, and the relation of the shore to the prevailing wind direction.

Wave action has also been effective in truncating the tops of small islands and shoals in Las Vegas Bay. These prominences, composed of weakly cemented cobbles, have been cut as much as 30 feet below their original levels, as shown by comparison of the 1948 topography with the pre-Lake Mead topography. In other areas where islands and shoals are composed of more durable materials, no such leveling was observed. In general the effects of wave action, though conspicuous, are insignificant insofar as reservoir storage is concerned, as pointed out by Ames (p. 7).

\section{SOLUTION}

Erosion of the reservoir floor by solution is of particular interest owing to the considerable quantities of gypsum and other saline materials exposed in the broad basins of the lake. Most of the gypsum occurs in the Muddy Creek formation (p. 15) which makes up a large part of the reservoir floor in Virgin Basin, Overton Arm, and the northern part of Boulder Basin (pl. 1). Longwell (1936) reported the occurrence of gypsum and anhydrite beds with a total exposed thickness of 400 to 500 feet in the southern part of Virgin Basin, and layers of pure gypsum about 25 feet thick in Las Vegas Bay. Gypsiferous clay and silt beds of the Muddy Creek formation are also prominent in these areas. The other soluble salts of the Muddy Creek formation are not nearly as extensive as the gypsum, according to Longwell; rock salt and other saline materials occur only locally in Virgin Basin and Overton Arm.

The soluble outcrops have been covered by the lake in most places, but in a few localities they are exposed along the shore or in near-shore reefs and low-lying islands. The most extensive of these are in the southern part of Virgin Basin, where the shore and offshore islands are made up almost entirely of thick beds of gypsum and anhydrite. From inspection of these beds (pl. 29) and other gypsum outcrops, it is clear that solution is locally effective in eroding the reservoir boundary. Solution appears to be confined, however, to the surface layers of the soluble material, and it has not yet produced any appreciable change in configuration of the lake either along the shore or below the water surface.

Howard's data on chemical changes of the Colorado River water as it passes through Lake Mead, (p. 121124) show that about 20 million tons of material was dissolved from the reservoir bed and banks from 1935 to 1948 . This material consisted of about 12.2 million tons of sulfate, 5.1 million tons of calcium, and $2.7 \mathrm{mil}-$ lion tons of sodium, potassium, and chloride, all of which remained in solution except 3.6 million tons of calcium, which combined with 5.6 million tons of carbonate and was precipitated from the lake. This has resulted in a corresponding loss of carbonate from the Colorado River water as it passed through Lake Mead from 1935 to 1948 . Likewise, there was a loss of about 1.0 million tons of silica during the same interval owing to its precipitation in the lake.

In summary, Howard's data show that from 1935 to 1948 about 20 million tons of soluble material was dissolved from the reservoir bed and banks and that about 10 million tons of dissolved solids was precipitated from the lake. These changes caused a net gain of 
about 10 million tons of dissolved solids in the Colorado River water as it passed through Lake Mead; hence the average salinity of the water discharged at Hoover Dam and the average salinity of the water stored in the lake are higher than the average salimity of the inflow. Solution of soluble materials from the reservoir boundary has resulted in a higher concentration of calcium, sulfate, potassium, sodium, and chloride in the lake water and outflow than in the inflow. On the other hand, precipitation from the lake has produced a lower concentration of carbonate and silica in the lake and outflow than in the inflow.

The solution of gypsum and anhydrite has been much greater than the solution of rock salt (halite, sylvite, etc.) represented by the minor amounts of sodium, potassium, and chloride. Gypsum and anhydrite have contributed about 87 percent of the dissolved solids, whereas rock salt has contributed only 13 percent. Rock salt is much more soluble than gypsum and anhydrite, and its smaller contribution to the dissolved solids probably results from its limited exposures. According to the Bureau of Reclamation (1950), the total exposed area of salt outcrops on the reservoir floor prior to inundation was only 22 acres. Subsequent covering of some of these outcrops by sediment that accumulated from 1935 to 1948 has reduced their areal dimensions still more.

Assuming an everage density of 2.5 for gypsum and anhydrite and an average density of 2.1 for rock salt, we can obtain reasonable estimates of the volumes of these constituents dissolved from the reservoir boundary, and also estimates of their average rates of solution. According to these estimates, the total volume of gypsum and anhydrite taken into solution from 1935 to 1948 is 5,200 acre-feet, and the volume of rock salt dissolved during the same interval is 900 acre-feet, making a total of 6,100 acre-feet. The average annual rate of solution is, therefore, 370 acre-feet for gypsum and anhydrite and 65 acre-feet for rock salt. If the total volume of dissolved material were confined to an area of 1 square mile, it would form a layer about 9.5 feet thick.

Earlier estimates by the Bureau of Reclamation (1950) included a prediction that a maximum of 330 acre-feet of rock salt would be dissolved from the reservoir during its first year of operation (1935) and that the anmual rate of solution in subsequent years would be reduced to about half that value. On the other hand, the predictions indicated that gypsum 496918 o-60-15 would undergo no appreciable solution. The estimates based on chemical changes in the lake water show, however, that the solution of rock salt has been far less than was predicted by the Bureau of Reclamation, and that solution of gypsum and anhydrite has been of considerably greater significance.

Unlike the material eroded by landslides and wave action, most of the salines taken into solution are permanently removed from the reservoir in the water discharged at the dam.

\section{EROSION OF THE DELTA SURFACE}

There is no evidence of erosive forces acting upon the lowest part of the delta; a feature brought out by the hydrographic survey in 1948 was the remarkable smoothness and regularity of the surface formed by the bottomset beds (pl. 6). On the other hand, the topset beds forming the uppermost part of the delta are periodically subject to erosion (p. 158).

There remains that part of the delta in the vicinity of the delta front, which is approximately the locus of maximum deposition. A channel in this area (pl. 24) has been described briefly (p. 164), but it deserves further consideration here because, with further study, it may constitute evidence of erosion by turbidity currents. This channel, as shown by the 1948 hydrographic survey, is clearly defined from mile 277.8 to mile 280 ; it is generally 300 to 1,000 feet wide and has a maximum depth of about 25 feet below the average delta front at mile 278.6.

Nothing is known of the history of this channel except that it was there in 1948. It is not known whether some such channel developed early in the history of delta deposition, and if so, whether it has shifted from side to side as the delta grew. Nor is it known whether it maintains approximately the same form at all times, or is filled during periods of peak sediment deposition, or is scoured more deeply under certain conditions of inflow.

\section{REFERENCES CITED}

Longwell, C. R., 1936, Geology of the Boulder Reservoir floor, Arizona-Nevada : Geol. Soc. America Bull., v. 47, p. 1429-1432.

Sharpe, C. F. S., 1938, Landslides and related phenomenon-a study of mass movements of soil and rock: New York, Columbia Univ. Press, 136 p.

U.S. Bur. Reclamation, 1950, Geological investigations, in Boulder Canyon project final reports, pt. 3, Bull. 1 : Washington, $231 \mathrm{p}$. 



\title{
S. SEDIMENTATION IN RELATION TO RESERVOIR UTILIZATION
}

\author{
By H. R. Gould, U.S. Geological Survey
}

One of the chief problems in the operation and maintenance of the reservoir is the loss of water storage resulting from the accumulation of sediment. As shown in table 8, the sediment accumulated in 14 years has reduced the water-storage capacity of the reservoir below the permanent spillway crest $(1,205.40$ feet elevation) from $28,794,000$ acre-feet in 1935 to $27,376,000$ acre-feet in 1948, a decrease of 4.9 percent. The usable storage below this crest, however, diminished only 815 ,000 acre-feet, or about 3.2 percent, of the 1935 usable capacity. If it could be assumed that the rate of sedimentation and storage loss would continue at the same rate in the future, and that the capacity of the reservoir for storing sediment were the same as its capacity for storing water, the maximum life expectancy of Lake Mead could be calculated quite readily : about 20 times 14, or 280 years. However, neither of these assumptions is valid. Even with a uniform rate of sediment inflow, the rate of storage depletion could not be expected to remain constant, owing to the future compaction of the accumulated sediment. Also, the reservoir's water-storage capacity is considerably different from its sediment-storage capacity, because the upper surface for water must be essentially horizontal but the sediment surface can never be. It is the purpose of this section to attempt an evaluation of these factors and to forecast the pattern of sediment accumulation in Lake Mead. The problem of the "life of the reservoir," involving analysis not only of the pattern of sedimentation but its rate, and also many pertinent natural and developmental factors, is discussed in chapter $\mathbf{T}$.

\section{SEDIMENT-STORAGE CAPACITY ABOVE THE PERMA- NENT SPILLWAY LEVEL}

It is frequently assumed that the capacity of a reservoir to store sediment is the same as its capacity to store water. Stevens (1946), for example, in estimating the life expectancy of Lake Mead assumed that the sediment-storage capacity is equal to the waterstorage capacity at the permanent spillway level. This assumption would require, as pointed out by Mackin (1948), that when the delta front reaches the dam the river must transport its detrital load from the head of the reservoir to the delta front on a surface of no slope. It is obvious that such a condition could not exist and that when the reservoir is filled, the sediment surface must slope upstream from the dam. The sediment-storage capacity of the reservoir must, therefore, be greater than its water-storage capacity. For Lake Mead, the difference between the water-storage and sediment-storage capacities is equal to the volume between the level surface at the elevation of the permanent spillway crest and the sloping sediment surface that will extend upstream from the dam when the reservoir becomes filled with sediment.

In a previous discussion of the characteristics of the Colorado delta, it was shown that the topset beds over which the Colorado River flows have an average slope of about 1.25 feet per mile and that this slope has remained essentially constant since the inception of Lake Mead. The highest topset beds near Bridge Canyon are as much as 65 feet above the average lake level (about 1,170 feet elevation), and 15 feet above the highest level yet attained by the lake; but they do not, in their present stage of development, extend upstream from the eastern end of the reservoir. Whether or not the slope of the topset beds will remain the same in the future is not known, but some idea of its possible trend may be obtained from consideration of delta development in a more advanced stage at Elephant Butte Reservoir on the Rio Grande.

According to Eakin (1939), the topset beds near the head of Elephant Butte Reservior at San Marcial, N. Mex., grew about 10 feet in thickness between 1916 and 1935. Happ (1946) noted that by 1941 the aggradation of topset beds had extended at least 15 miles upstream from the head of Elephant Butte Reservoir. Furthermore, he reported a marked increase in the rate of upvalley aggradation since 1935 . Between 1914 and 1935 only 15 percent of the total sediment load carried by the Rio Grande to Elephant Butte Reservoir was deposited in the topset beds upstream, but between 1936 and 1941 about 48 percent of the load was deposited in these beds. Happ predicted that in future years the topset beds would progress still farther upstream and that the percentage of the total load deposited in them would be greater than for the interval 1936 to 1941 . 
The net effect of this upvalley extension of the delta is to increase the gradient of the topset beds, over which the Rio Grande flows to its entrance in Elephant Butte Reservoir. This gradual steepening is in accord with Mackin's observation $(1948$, p. 496$)$ that a delta in its more advanced stages of development tends to parallel the gradient of the stream channel over which it has been deposited, provided that the original stream was at grade.

The pre-Lake Mead gradient of the Colorado River in the Lower Granite Gorge averaged 7 feet per mile, but it is likely that the river was not at grade. The average gradient of the river below Yuma, Ariz., is about 1 foot per mile, and the slope of the Colorado River delta in the Gulf of California, which contains sediment comparable to that now accumulating in Lake Mead, is of the same order. The average slope of the natural channel from Hoover Dam to the Gulf of California is about 1.5 feet per mile.

Although the observations of delta growth in Elephant Butte Reservoir furnish some qualitative information of value in considering the future development of the Colorado delta in Lake Mead, essential quantitative data are lacking. However, if we assume that the slope that will be attained when Lake Mead becomes filled with sediment will be at least as great as the slope of the topset beds in 1948 (roughly 1.2 feet per mile), a conservative estimate can be made of the sediment-storage capacity above the permanent spillway level.
In figure 57 the present slope of the Colorado delta topset beds has been projected so as to extend from the permanent spillway crest at Hoover Dam to the upstream intersection of the spillway with the Colorado River channel. By operation of the spillway gates, water can be stored in the lake to a level 16 feet above the permanent crest, and in 1948 the controlled capacity above that crest was $2,450,000$ acre-feet. But it is anticipated that the gates would be used for no more than temporary storage, and that the sediment surface would therefore become graded to the level of the permanent crest as an ultimate maximum. Of course, Lake Mead would no longer exist when that stage of sedimentation was reached.

On the basis of the above assumptions, the sloping surface in figure 57 delineates the upper limit of the accumulated sediment when the reservoir becomes filled. As shown by this diagram, the topset beds at the original eastern end of the reservoir (mile 235) would increase to an elevation of about 1,350 feet, or 145 feet above the permanent spillway level. The topset beds would then intersect the old Colorado River profile at mile 221.5 , about 13.5 miles upstream from the original head of the reservoir and at an elevation of about 1,365 feet.

Computations of the volume between the surface at spillway level and the sloping surface of the topset beds, based on planimeter measurements of the areas enclosed by contours of the two surfaces, show that the sediment-storage capacity above the permanent spill-

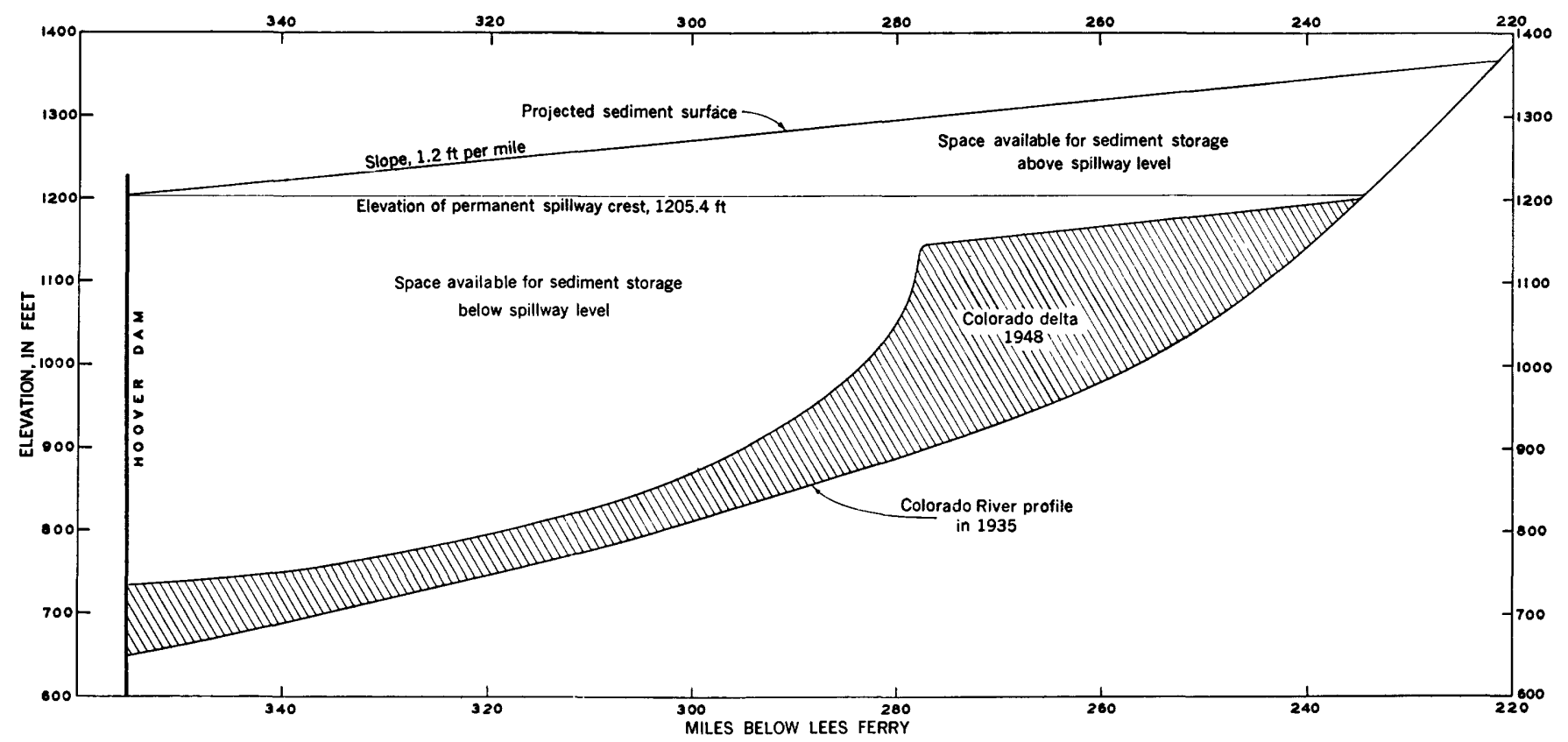

FraURE 57.-Diagrammatic representation of the surface of the sediment that would be accumulated in Lake Mead when the lake is filled to permanent spillway level. 
way level is about 6 million acre-feet, almost 25 percent of the storage capacity below the permanent spillway level. The ultimate sediment-storage capacity is estimated, therefore, at 35 million acre-feet.

This estimate of sediment-storage capacity is necessarily oversimplified owing to the lack of quantitative data on the complex interrelations of factors governing stream aggradation. It has been assumed, for example, that the long, narrow arms of the reservoir will be filled to the level of the sediment in the main body of the lake, whereas it is possible that the sediment level in these regions may be considerably lower than that of the main part of the delta. Furthermore, it has been necessary to assume that Overton Arm, which extends northward from the central part of the lake, will be filled to the level of the delta surface in Virgin Basin. A considerable quantity of detrital material must be supplied to Overton Arm from the Colorado River, because the quantity of sediment transported into Lake Mead by the Virgin River alone is not sufficient to fill this part of the reservoir during the period that will be required to fill the main body of the lake. It is quite likely, however, that unless the proportion of sediment contribution from the Colorado River is reduced by upstream developments, Overton Arm may never be completely filled with sediment. Instead it may be reduced to a lake consisting chiefly of dead storage, by reason of the upbuilding of the Colorado delta along the thalweg of the Colorado River.

\section{SEDIMENT COMPACTION}

Sediment compaction has an extremely important bearing on the rate of depletion of water-storage volume and on the life expectancy of the reservoir. The sediment accumulated in Lake Mead consists of two major types of material-namely, the sand of the topset and foreset beds, and the silt and clay of the bottomset beds. The compaction of sand is probably insignificant and consequently can be neglected, but the potential compaction of silt and clay is large.

The degree to which silt and clay sediments are compacted is related primarily to the depth of their burial and to the size of their constituent particles. In order to obtain an average empirical relation between these various factors, the relations between water content and depth for all cores from the bottomset beds of both the Colorado and Virgin deltas were plotted, and a best-fit visual curve was drawn. This curve (fig. 58) shows an approximately linear relation between decrease in water content and depth of burial of the bottomset beds.

Although this curve furnishes reasonably accurate compaction data throughout a depth interval of 95 feet, it alone does not afford an adequate basis for estimat-

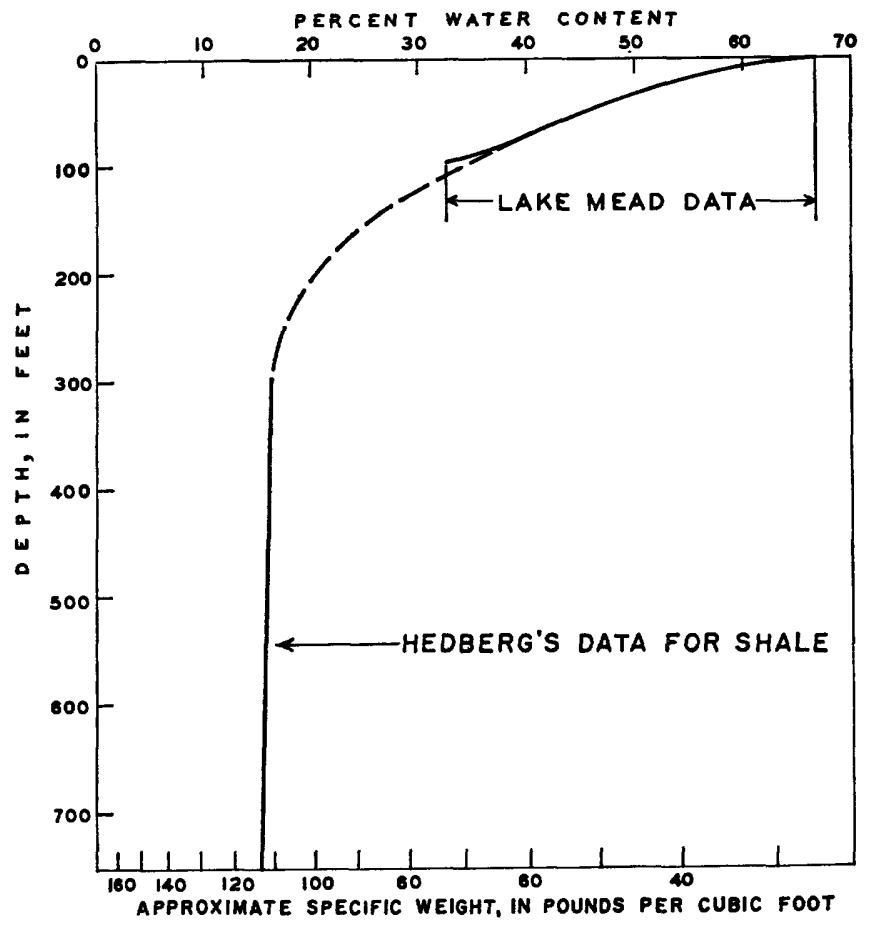

Frgure 58.-Water content and approximate specific weight of silt and clay, plotted as a function of depth. Dashed line indicates interpolation.

ing the compaction of the material at greater depths after the reservoir has become filled with sediment. However, by the use of Hedberg's porosity data (1936) for fine-grained sediments (shale), it is possible to extend the water-content curve obtained from the Lake Mead cores to considerably greater depths, as illustrated in figure 58 .

In the analysis of the individual cores it was noted that the samples near the original reservoir bottom were considerably lower in water content than samples from the same sediment depth at nearby locations, but at higher levels above the original bottom. An excellent example of this relation is afforded by samples from the bottomset beds of the Colorado delta in the southern part of the Boulder Basin: One sample (No. 150) from a sediment depth of 16 feet, and only 9 feet above the original reservoir floor, had a water content of about 47 percent, whereas another sample (No. 1207) from the same sediment depth, but about 66 feet above the original reservoir bottom, had a water content of 64 percent.

A possible explanation for the low water content of the sediment near the original reservoir floor may be found by consideration of the mechanism of compaction in a very thin layer of sediment which we will assume is located midway between the top and bottom of the accumulated material. When this thin layer is subjected to increased pressure from above, such as would result from additional sediment loading, some 
of the interstitial water is forced from the layer into the overlying strata, but the layer receives water that is driven from the interstices of underlying sediment. However, the inflow of water into this thin layer is less than the outflow; thus the water content of the layer under consideration is reduced. Let us now consider another increment of sediment, located at the same depth as in the example above but in contact with the original reservoir bottom. When subjected to increased loading, some of the interstitial water will be forced out of this sediment layer, as in the example above, but owing to the low compaction of the original reservoir bottom, there will be little if any squeezing out of water from below. As a result, the water content of this layer in contact with the original bottom is considerably less than that of a similar layer located at mid-depth. In their studies of cores of marine sediments, Emery and Rittenberg (1952, p. 760) concluded that because of this phenomenon, sediments overlying a buried hill would at first compact more rapidly than those in the surrounding area. The water content in the basal layers of sediment in a reservoir would also be reduced if the underlying reservoir floor were relatively impermeable, so that its saturation proceeded slowly and continued after the deposition of the first sediments, causing drainage from those basal layers.

Theoretically, the water content in the sediment at all levels would be reduced to some extent owing to the low compaction of the original reservoir floor. Only in a sediment accumulation of infinite thickness would this effect be entirely eliminated. In Lake Mead the marked reduction in water content appears to be appreciable only in about the lower 10 feet of the bottomset beds; but because of variable thickness, the watercontent values in figure 58 appear to be significantly lower in the bottom 30 feet of the curve. Consequently, the values are not considered representative, and this part of the curve has been disregarded in the extrapolation of the curve to greater depths.

Returning now to the portion of the water contentdepth curve based on Hedberg's data (fig. 58), one cannot be certain that his values are applicable to the silt and clay accumulated in Lake Mead. Hedberg's determinations were obtained from clay and shale strata that had been buried for a great length of time, compared to the few centuries that the earliest Lake Mead sediments will have been buried when the reservoir becomes entirely filled. Supposedly the sediments examined by Hedberg had sufficient time for the forces of compaction to reach approximate equilibrium, but we do not know whether the Lake Mead silt and clay will attain a comparable state of compaction during the life of the reservoir. Furthermore, Hedberg gives no precise information as to the size, shape, and sorting of the constituent sediment particles, and there is the possibility that the texture of the material investigated by him differs significantly from the texture of the Lake Mead silt and clay. Because of the close relation between texture and compaction, any significant difference in texture would produce a corresponding change in compaction. In applying the part of the water content-depth curve constructed from Hedberg's data to the Lake Mead sediments, therefore, it is necessary to assume that a few hundred years is sufficient for the compaction of sediments to reach a state of equilibrium with the weight of the overburden, and that the sediment investigated by Hedberg does not differ significantly in texture from the silt and clay accumulated in Lake Mead.

No compaction data are available in the critical range between depths of 95 feet (the lower limit of the Lake Mead observations) and 290 feet (the shallowest observational depth reported by Hedberg). Continued observation in Lake Mead will eventually provide specific information for this zone about which very little is yet known. For the present, the interpolated part of the water content-depth curve, together with the upper few hundred feet of the curve constructed from Hedberg's data, is considered to provide reasonably reliable compaction data for deeply buried layers of silt and clay accumulated in Lake Mead when it becomes entirely filled with sediment. The accumulated sediment at the time of reservoir filling will attain a maximum thickness of about 575 feet immediately upstream from Hoover Dam.

\section{PATTERN OF SEDIMENTATION IN THE FUTURE}

The gates through which water can be discharged from the reservoir are at three levels, the highest of which is at the spillways whose permanent crests are at elevation 1,205 feet. The gates at the two lower levels are situated in the four intake towers immediately uplake from Hoover Dam. The sills of the uppermost gates are at elevation 1,045 feet, 310 feet above the 1948 sediment surface and 415 feet above the original floor of the reservoir. The sills of the lower gates are at 895 feet, 160 feet above the 1948 sediment surface and 265 feet above the original lake bottom at the intake towers. The intake towers contain the outlets through which water for generating power and for downstream users is normally discharged.

Water stored below the 895-foot level is, of course, in dead storage. When water was first impounded behind Hoover Dam, the dead-storage space measured 3,223,000 acre-feet, but by January 1949 it had been re- 
duced by the accumulation of sediment to $2,620,000$ acre-feet; or by 18.7 percent. When the dead-storage space becomes completely filled with sediment, it will be necessary either to discharge great quantities of sediment to downstream areas or to close the lower gates and allow them to become covered. Loss of the deadstorage space thus will mark the first critical stage of reservoir filling. Similarly, the filling of the reservoir to the levels of the upper outlet sill and permanent spillway crest will denote, respectively, the second and third critical stages. The following sections present predictions as to the amount and distribution of sediment that will have accumulated in the reservoir at each of the three critical stages; they state the methods used and the assumptions made in arriving at these predictions.

\section{COMPLETE FILLING}

On the basis of foregoing considerations it is possible to obtain a reasonable estimate of the amount of sediment that will be required for the reservoir to become completely filled; that is, the stage when the sediment accumulation would intersect the dam at the elevation of the permanent spillway crest. A total of about 2,000 million tons of sediment (dry weight) was deposited in Lake Mead during the 14-year period, 1935-48 (p. 195). This quantity is taken as a convenient unit of measurement for discussion of the future accumulation of sediment in Lake Mead. It was shown (p. 197) that the composition of this material is approximately 45 percent sand and 55 percent silt and clay; the total load of sand, therefore, is 900 million tons, and the total load of silt and clay is 1,100 million tons. There is no assurance that the Colorado River will continue to carry sediments similarly proportioned in particle size. The geologic history of the Chemehuevi formation (p. 16) shows that the river has not done so in the past, but instead has carried a considerable amount of gravel. Such changes, as recorded in geologic history, may require thousands of years; for the few centuries under discussion in the following paragraphs, it is assumed that the size distribution will be similar to that in the 2,000-million-ton sample that accumulated prior to the 1948-49 survey.

Data on the physical properties of the sediment suggest that compaction of the sand is insignificant, but that the silt and clay undergo considerable compaction as their depth of burial increases (fig. 58). It is desirable, therefore, to consider the sand and fine constituents independently.

Using a mean specific weight of 93.8 pounds per cubic foot for sand, we find that the ultimate sediment-storage capacity $(35,700,000$ acre-feet) was reduced 441,000 acre-feet by the first 900 million tons of sand brought into the reservoir. Since it is assumed that the sand will experience no further compaction, the sand in each 2-billion-ton unit will reduce the total sediment-storage capacity by an equivalent amount.

The rate of sediment-storage depletion resulting from the accumulation of silt and clay is not constant, but will become progressively less because of increased compaction during the filling of the reservoir. In order to obtain the rate of this sediment-storage reduction, we must first determine the total weight of sediment that will be stored in the reservoir when it becomes entirely filled. This can be accomplished by use of the sediment-compaction data shown in figure 58 and the sediment-storage capacity curve presented in figure 59 .

In the following determinations, it is assumed that the pattern of sedimentation during the period 193548 will continue in the future - that is, the sand will be deposited in the topset and foreset beds, and the silt and clay will accumulate in the bottomset beds. When the reservoir becomes entirely filled with sediment, the sand will overlie the silt and clay. Figure 59 shows the estimate of available sediment-storage space above the permanent spillway level to be equally distributed above and below elevation 1,240 feet, the level to which the sediment compaction data in figure 58 have been referred. For example, water contents at depths of 0 feet and 200 feet in figure 58 correspond respectively to elevations of 1,240 feet and 1,040 feet in figure 59 .

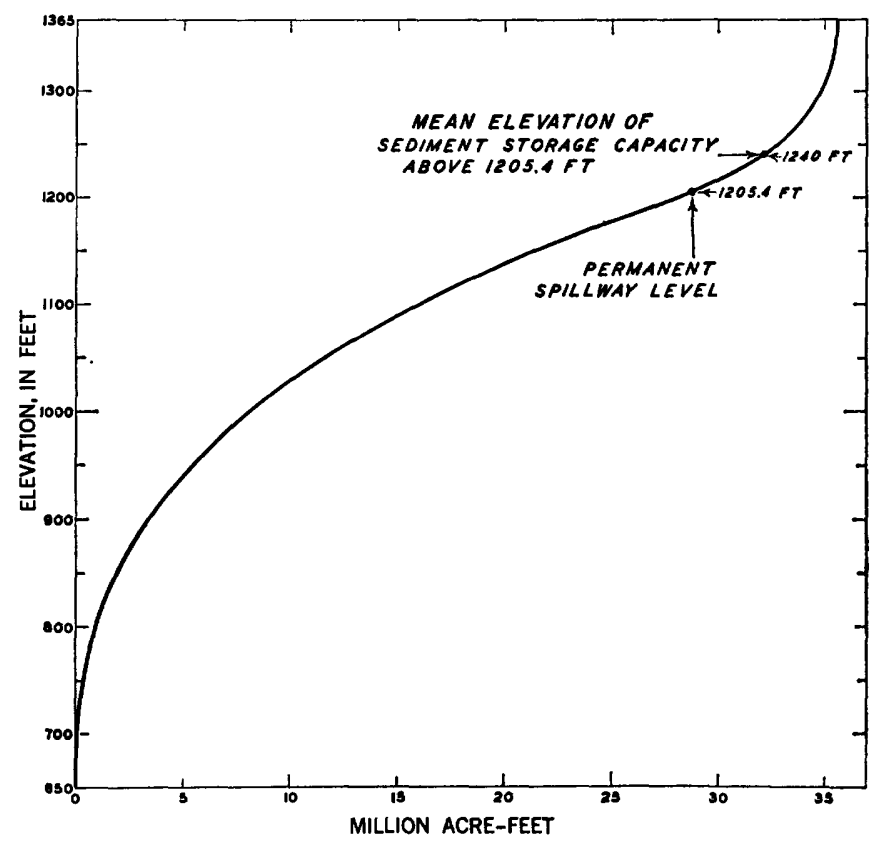

Figure 59.-Curve showing the estimated sediment-storage capacity of Lake Mead when the accumulated sediment reaches the elevation of the permanent spillway crest at Hoover Dam. 
To obtain the weight of silt and clay accumulated in the reservoir when it becomes filled with sediment, the volumes of silt and clay in successive 50-foot increments of elevation (fig. 59) were multiplied by their average specific weights (as determined from fig. 58). Because of the assumption that the silt and clay will make up the lower part of the deposit, the computations were made from the lake bottom upward. The total weight of silt and clay (table 29) was then obtained by summation of the weights of the 50 -foot increments. The results of the computations are presented in graphic form in figure 60 .

The weight of sand accumulated in the reservoir when it becomes filled with sediment can be computed in the same manner as the weight of silt and clay, except that compaction need not be considered. In making these computations, the author used a mean specific weight of 93.8 pounds per cubic foot for the accumulated sand (as determined on p. 180). Because of the assumption that the sand will be confined to the upper layers of the deposit, the weight of sand in each 50 -foot increment of depth was computed from the elevation of maximum sediment storage (fig. 59) downward. The total weight of sand (table 29) was then obtained by summation of the weights of the 50foot increments. The results of these computations

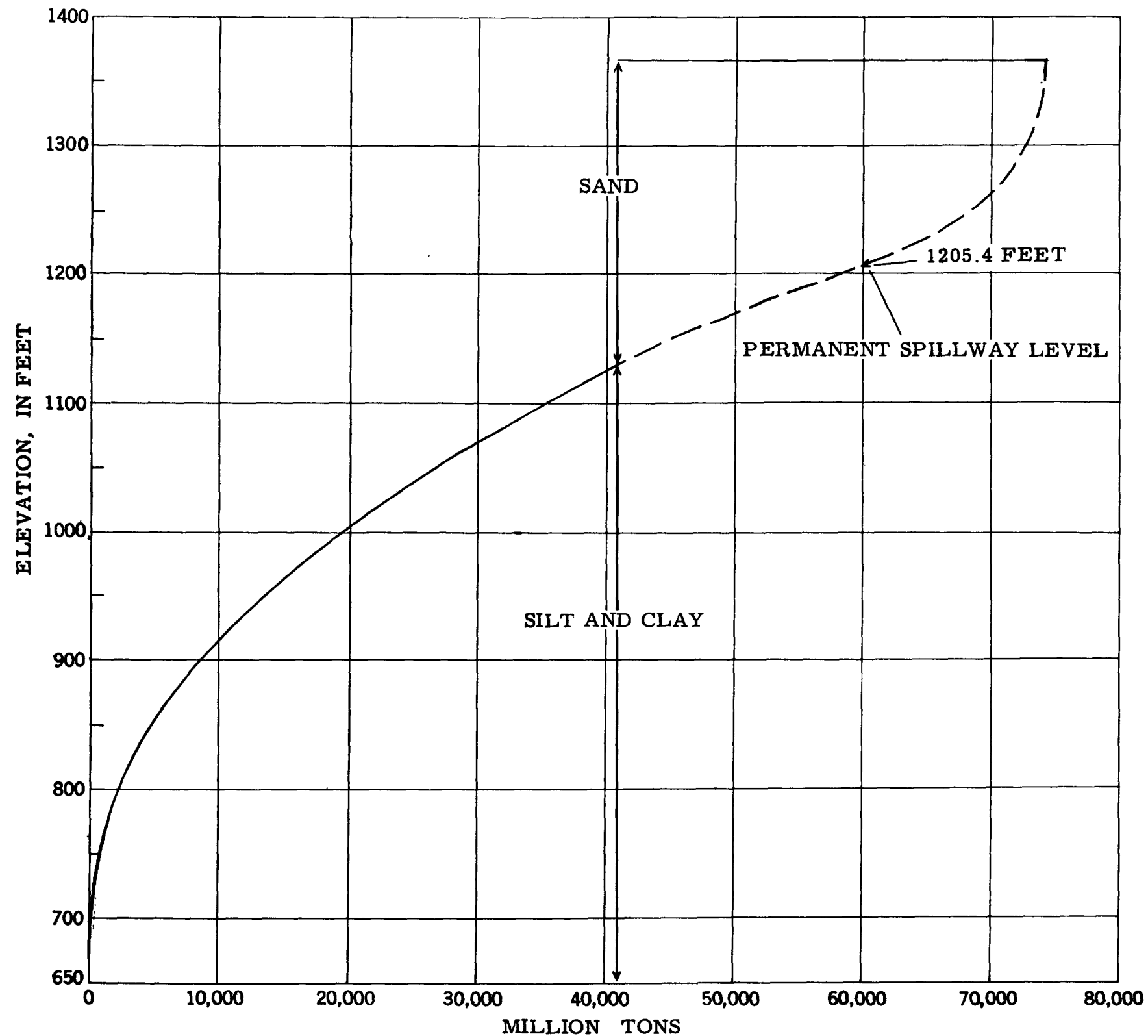

Figure 60.-Cumulative curve showing the estimated weight of sediment, and of coarse and fine components, when the reservoir becomes filled with sediment. 
are plotted on the same graph as the silt and clay data (fig. 60).

Near the level of contact between the sand and the underlying silt and clay, the increments of elevation were reduced to 10 feet, and a graphic method was employed to obtain a better balance between the total weights of the sand and the silt and clay constituents. This procedure resulted, also, in a better estimate of the elevation of contact between the silt and clay and the overlying sand. As shown in figure 60, most of the silt and clay will presumably be stored below elevation 1,130 feet, and most of the sand will be stored above this elevation. Other quantitative results of these computations are given in table 29. Further calculations based on this table show that the average rate of reduction in total sediment-storage space during the time required to fill the reservoir is 956,000 acrefeet for each 2,000-million-ton unit. Since the sand of this volume will occupy 441,000 acre-feet (p. 219), the silt and clay when fully compacted will occupy 515,000 acre-feet.

TABLE 29.-Estimated weight, volume, and specific weight of the sediment in Lake Mead when filled under conditions assumed

\begin{tabular}{|c|c|c|c|}
\hline Sediment & $\begin{array}{l}\text { Weight, in } \\
\text { millions } \\
\text { of tons }\end{array}$ & $\begin{array}{l}\text { Volume, in } \\
\text { acre-feet }\end{array}$ & $\begin{array}{l}\text { Mean specific } \\
\text { weight, in } \\
\text { lb per cu ft }\end{array}$ \\
\hline $\begin{array}{l}\text { Silt and clay } \\
\text { Sand } \\
\text { Silt, clay, and sand..... }\end{array}$ & $\begin{array}{l}41,100 \\
33,600 \\
74,700\end{array}$ & $\begin{array}{l}19,250,000 \\
16,450,000 \\
35,700,000\end{array}$ & $\begin{array}{l}98.0 \\
93.8 \\
96.1\end{array}$ \\
\hline
\end{tabular}

\section{HALFWAY POINT IN RESERVOIR FILLING}

It appears that the usefulness of the reservoir will not be materially impaired until its water-storage capacity at the level of the permanent spillway crest is reduced to about 13 million acre-feet, the average annual flow into Lake Mead from 1935 to 1948. This would be slightly less than half the original waterstorage capacity at that level.

Admittedly a major attribute of Lake Mead today is its capability for holdover storage; with a capacity more than twice the average inflow, it can accumulate water during years of high runoff and release it during subsequent years of low runoff, thus furnishing a relatively constant supply during wet and dry years. It might appear, then, that reduction in capacity to an amount equivalent to the average yearly inflow would be a serious impairment of its usefulness. However, under the terms of the Colorado River Compact of 1922 and the Treaty of November 1944 with the United States of Mexico, not more than 9,250,000 acrefeet of water annually is yet allocated to the Lower Basin, for which Lake Mead constitutes the prime regulating body. A capacity of $13,000,000$ acre-feet, therefore, would represent an amount about 40 percent greater than the annual use in the Lower Basin, including Mexico, on the basis of present allocations. Furthermore, the usable storage in the lake at that time may be considerably greater than $13,000,000$ acrefeet because of bank storage provided by alternate saturation and drainage of the delta sands as the reservoir level rises and falls (p. 99). The controlled storage in Lake Mead can also be increased substantially by raising the spillway gates at Hoover Dam.

In order to obtain an estimate of the sediment accumulation when the water-storage capacity is reduced to about 13,000,000 acre-feet, the following assumptions are made: (1) The average water level of the reservoir will be maintained at or near the elevation of the permanent spillway crest, by raising the spillway gates during months of peak inflow. (2) A proportionate amount of the total volume of sediment stored above the permanent spillway crest when the reservoir becomes filled with sediment will be deposited above spillway level each year. (3) The total weight of sediment will be made up of 45 percent sand and 55 percent silt and clay, as in 1948 . (4) The mean specific weight of sand will remain the same (93.8 pounds per cubic foot) as in 1948 . (5) The mean specific weight of silt and clay will increase, according to the relation shown in figure 58 , from 51.8 pounds per cubic foot (the mean specific weight of silt and clay accumulated in Lake Mead from 1935 to 1948) to 98.0 pounds per cubic foot (the estimated mean specific weight of silt and clay when the reservoir becomes completely filled with sediment), and this increase will be proportional to the ratio between the sediment volume in $1948(1,426,000$ acre-feet $)$ subtracted from the sediment volume at any future time, and the sediment volume in 1948 subtracted from the ultimate sediment volume $(35,700,000$ acre-feet) when the reservoir becomes entirely filled with sediment.

The volume of sediment that will be stored in the reservoir when its water-storage capacity is reduced to $13,000,000$ acre-feet can be evaluated readily from assumptions 1 and 2. The volume of sediment below spillway level is equal to the difference between the original reservoir capacity below spillway level $(28,794,000$ acre-feet) and the space still available for water storage $(13,000,000$ acre-feet). The amount of sediment stored below spillway level would therefore be $15,794,000$ acre-feet, or about 55 percent of the original reservoir volume below the permanent spillway level. According to assumption 2 the volume of sediment accumulated above the spillway level will be 55 percent of the total space $(6,900,000$ acre-feet) available for sediment storage above the spillway level, or 
$3,800,000$ acre-feet. The total volume of sediment that will be stored in the reservoir at the time the waterstorage space is reduced to $13,000,000$ acre-feet is estimated therefore at $19,600,000$ acre-feet.

With this estimate of sediment volume the mean specific weight of the silt and clay accumulation may be determined as outlined in assumption 5. According to figure 58, the mean specific weight of the silt and clay ( 51.8 pounds per cubic foot) that accumulated in Lake Mead from 1935 to 1948 is the same as the specific weight of a layer of silt and clay buried to a depth of 50 feet. Similarly, the estimated mean specific weight (98.0 pounds per cubic foot) of the silt and clay accumulation when the reservoir becomes filled with sediment is the same as the specific weight of a layer covered by 200 feet of overburden. The mean specific weight increases not only with depth of burial, but also with the volume of sediment. According to assumption 5, the increase in the mean specific weight of silt and clay resulting from increased depth of burial will be proportional to the increase in sediment volume. For example, when the mean specific weight of the silt and clay becomes the same as the specific weight (79.0 pounds per cubic foot) of a layer at a depth of 125 feet (midway between the 50-foot and the 200foot layers, fig. 58), the volume of accumulated sediment will increase by half of the difference between the volume of sediment that accumulated from 1935 to $1948(1,426,000$ acre-feet $)$ and the ultimate sediment volume $(35,700,000$ acre-feet $)$, or by $17,137,000$ acrefeet.

The 19,600,000 acre-feet of sediment that will be stored in the reservoir when its water-storage capacity is reduced to $13,000,000$ acre-feet represents an increase of $18,174,000$ acre-feet over the volume of sediment accumulated from 1935 to 1948 . Using the method outlined above, it is estimated that the silt and clay accumulated in the reservoir at the halfway point will have a mean specific weight of 80.0 pounds per cubic foot.

From assumptions (3) and (4) above, the total weight of the sediment accumulated in the reservoir when its water-storage capacity is reduced to $13,000,000$ acre-feet can be computed by the following equations:

$$
\begin{gathered}
0.45 W_{t}=21.78 S_{s}\left(V_{t}-V_{f}\right) \\
0.55 W_{t}=21.78 S_{f} V_{f}
\end{gathered}
$$

where $W_{t}$ is the total weight of the accumulated sediment in tons, $S_{s}$ is the mean specific weight of the sand fraction, $V_{t}$ is the total volume of the accumulated sediment in acre-feet, $V_{f}$ is the volume of the silt and clay fraction in acre-feet, and $S_{f}$ is the mean specific weight of the silt and clay fraction. The numerical factor
21.78 is used for converting pounds to tons and cubic feet to acre-feet; the numerical values 0.45 and 0.55 are proportions of the total weight of sediment made up by the sand fraction and the silt and clay fraction, respectively.

Solving equation 2 for $V_{f}$ in terms of $W_{t}$ and substituting this value in equation 1 , we find that $W_{t}$, the total weight of sediment accumulated in the reservoir when the water-storage capacity is reduced to $13,000,000$ acre-feet, is 36,600 million tons. Further computations show that the sand fraction will have a volume of $8,100,000$ acre-feet and a weight of 16.5 billion tons. The silt and clay fraction will occupy a volume of $11,500,000$ acre-feet and weigh 20,100 million tons. The mean specific weight of the total accumulation will be 85.7 pounds per cubic foot.

Of the $8,100,000$ acre-feet of sand, $3,800,000$ acrefeet will be deposited above the altitude of the permanent spillway crest. The $4,300,000$ acre-feet of sand to be deposited below spillway level would be enough to fill all the original water-storage space below that level in Lower Granite Gorge, Pierce Basin, Grand Bay, Iceberg Canyon, Gregg Basin, and the upper 3 miles of Virgin Canyon. Even without any accumulation of bottomset beds in these areas, the top of the delta front at the halfway point in filling of the reservoir must advance at least to mile 306, about 28 miles downlake from its position in Pierce Basin in 1948.

Assuming that the topset beds maintain an average slope of about 1.2 feet per mile as at present, the 1948 delta surface in Lower Granite Gorge and Pierce Basin would be buried under about 69 feet of additional material, of which 35 feet would result from increasing the average water level in the reservoir from 1,170 feet to 1,205 feet, and the remainder (34 feet) would be accounted for by upbuilding of the topset beds at a rate of 1.2 feet for each mile of advance of the delta front. The highest delta deposits at that time would be 8 miles upstream from Bridge Canyon rapids (which will then be covered by sediment) at altitudes as high as 1,300 feet, or about 95 feet above the altitude of the permanent spillway crest. These deposits are included in the $3,800,000$ acre-feet of accumulation above the spillway level.

The silt and clay fraction, as estimated above, will amount to $11,500,000$ acre-feet, and it will accumulate in the bottomset beds. If this material were to form a level surface in the lowest parts of the reservoir west of the delta front at mile 306 , it would rise to an altitude of 1,070 feet, or 25 feet above the altitude of the sill of the upper outlet gates. However, in order for turbidity currents to transport the detrital load to the lowest parts of the reservoir, the bottomset beds must 
have a downlake slope. To obtain a reasonable estimate of this slope, let us consider the declivity of the subaqueous delta surface in 1948 and the space available for sediment storage in the lowest parts of the reservoir west of the top of the delta front (mile 306) at the halfway point. As pointed out on page 164 there is a marked reduction in declivity of the 1948 delta surface, beginning in the vicinity of Virgin Canyon and extending to Hoover Dam, and it was shown that this decreased slope is related to a progressive thickening of the bottomset beds toward Hoover Dam. Both the decreased slope and the delta thickening are ascribed to the basining effect of the dam (p. 205).

An analysis of volume capacities (tables 5-7, p. 91-93) shows that this basining effect at the halfway point must extend approximately the same distance uplake from the dam as it did in 1948, and that the slope of this part of the delta cannot be greater than the average slope ( 1.2 feet per mile) of the bottomset beds in Boulder Basin in 1948, which is the best available example of the basining effect. Calculations based on volume capacities and an assumed slope of 1.2 feet per mile show that the bottomset beds at the halfway point would extend to mile 308 , where they would have an altitude of 1,100 feet. Assuming that the delta front maintains its 1948 slope of about 55 feet per mile, the surface of the bottomset beds would grade into the foreset beds at about the same position as in 1948; that is, 105 feet below the altitude of the top of the delta front and 2 miles downlake. The bottomset beds at the dam would then rise to an altitude of 1,044 feet, only 1 foot below the sill of the upper outlet gates. The available capacity below this assumed slope of 1.2 feet per mile is just sufficient to store the $11,500,000$ acrefeet of silt and clay accumulated in the reservoir at the halfway point.

If a slope greater than 1.2 feet per mile is assumed in these calculations, the capacity will not be sufficient to store the 11,500,000 acre-feet of silt and clay. For example, the capacity below a surface with a slope of 1.8 feet per mile extending from an altitude of 1,100 feet at the face of the delta front and intersecting the dam at an altitude of 1,010 feet is only 10,000,000 acrefeet of the $11,500,000$ acre-feet required. Likewise, the capacity below a surface with a subaqueous slope of 5.8 feet per mile, which is slightly greater than the average subaqueous slope of the delta in 1948 , is only 10,000,000 acre-feet. The inadequacy of the reservoir for storing the 11,500,000 acre-feet of silt and clay below these higher gradients is explained by the irregular distribution of available storage space west of mile 306. At the halfway point, the upper 25 percent of the subaqueous profile where the sediments are thickest will be confined to the narrow Virgin CanyonTemple Bar area (miles 306-317), which cannot possibly store a corresponding percentage of the $11,500,000$ acre-feet of silt and clay to be deposited west of the delta front. This quantity will invade considerable portions of Virgin Basin and Boulder Basin where greater storage capacity is available. The assignment of sufficient quantities of sediment to these areas requires a slope not greater than 1.2 feet per mile.

For many years the accumulation of bottomset beds will continue in the portion of the reservoir east of Virgin Canyon, in the area over which the delta front will have advanced when the reservoir is half filled with sediment. Some of the space in these upper areas will thus be preempted by bottomset beds, so that the topset beds and foreset beds must advance farther downlake than would be estimated on the basis of basin capacities alone. Assuming that 20 percent, or 860,000 acre-feet, of the capacity below spillway level in the upper basins will be occupied by bottomset beds, the top of the delta front would have to advance over the underlying bottomset beds to mile 317 at the eastern end of Virgin Basin. Using a slope of 1.2 feet per mile for the profile west of the delta front at this point, and a volume of 10,740,000 acre-feet of bottomset beds to the west, we find that the bottomset beds would intersect the intake towers at an altitude of 1,025 feet, or about 20 feet below the upper outlet sills.

In summary, it is predicted that the filling of Lake Mead will have reached the halfway point when the sediment accumulation becomes slightly more than 18 times as great as the amount brought into the lake between 1935 and 1948. At that time the topset, foreset, and underlying bottomset beds will fill all the reservoir east of Virgin Basin and extend into that basin. The bottomset beds at the dam will reach almost to the level of the upper outlet gates. The water-storage capacity (not including ground-water storage) will be about $13,000,000$ acre-feet below the permanent spillway crest, comprising about 4,500,000 acre-feet in Boulder Basin, 500,000 acre-feet in Boulder Canyon, 5,000,000 acrefeet in Virgin Basin and 3,000,000 acre-feet in Overton Arm. The total water storage can be increased to about $14,900,000$ acre-feet by raising the spillway gates.

\section{FIILING TO SILLS OF LOWER OUTLET GATES AT HOOVER DAM}

The general procedure outlined in the preceding pages is used to estimate the amount of sediment required for filling the reservoir to the altitude (895 feet) of the lower outlet sills at Hoover Dam. In this estimate it is assumed that the lower 46 miles (extending downlake from mile 308 at the mouth of Virgin 
Canyon) of the delta profile will exhibit some basining effect and that this part of the profile will have a slope of 1.2 feet per mile. With the lower end of this sloping plane intersecting the dam at the level of the lower outlet sills, the upper end will rise to an altitude of 950 feet at mile 308 . Uplake from this position it is assumed that the subaqueous profile will have the same slope as the upper part of the 1948 subaqueous profile relative to the position of the delta front. It is assumed, also, that the average slope of the subaerial part of the delta (topset beds) east of the delta front will remain at 1.2 feet per mile as in 1948 , and that the average water level in the reservoir will be maintained about at the elevation of the permanent spillway crest.

Based on these assumptions, the delta front at this stage of reservoir filling will have progressed to the mouth of Iceberg Canyon at mile 290, about 12 miles downlake from its position in Pierce Basin in 1948. The sediment accumulated in the reservoir at this stage will have a total volume of $8,400,000$ acre-feet which will comprise $3,000,000$ acre-feet of sand and 5,400,000 acre-feet of silt and clay.

The sand fraction will be deposited, of course, as foreset beds at the delta front and as topset beds farther east. Of the total volume of sand, 1,400,000 acrefeet will be deposited below altitude 1,205 feet, and $1,600,000$ acre-feet will be deposited above this altitude. Assuming that the topset beds will maintain their present slope of 1.2 feet per mile, the 1948 delta surface in Pierce Basin and Lower Granite Gorge would be buried by about 49 feet of additional material, of which 35 feet would result from increasing the average operating level of the reservoir from 1,170 to 1,205 feet, and the remainder (14 feet) would result from upbuilding of the topset beds at a rate of 1.2 feet for each mile of advance of the delta front. The topset beds at this stage would extend about 6 miles upstream from Bridge Canyon rapids and they would rise to a maximum altitude of 1,280 feet, or 75 feet above the altitude of the permanent spillway crest.

Of the 5,400,000 acre-feet of silt and clay, about 500,000 acre-feet will underlie the accumulation of sand east of the delta front. This part of the silt and clay fraction comprises the bottomset beds in the area over which the delta front will have progressed at this stage in reservoir filling. The remaining 4,900,000 acre-feet of silt and clay will make up the bottomset beds extending from the foot of the delta front to Hoover Dam.

At a mean specific weight of 93.8 pounds per cubic foot, the sand will have a total weight of 6,100 million tons. Further calculations, based on the method out- lined on pages 221-223, show that the silt and clay will have a mean specific weight of 62.6 pounds per cubic foot and a total weight of 7,400 million tons. The entire accumulation will have a mean specific weight of 73.6 pounds per cubic foot and a total weight of 13,500 million tons.

In summary, the sediment level at the dam will have reached the elevation of the lower outlet sills when the total accumulation becomes about 7 times as great as the amount brought into the lake from 1935 to 1948. At that time the reservoir east of Gregg Basin will be completely filled with sediment, but abundant storage space will still be available in the western part of the reservoir. The water-storage capacity below the permanent spillway crest will be about $22,000,000$ acrefeet, comprising 6,300,000 acre-feet in Boulder Basin, 800,000 acre-feet in Boulder Canyon, 8,000,000 acre-feet in Virgin Basin, 3,300,000 acre-feet in Overton Arm, $2,000,000$ acre-feet in the Temple Bar area, 300,000 acrefeet in Virgin Canyon, and 1,300,000 acre-feet in Gregg Basin. By raising the spillway gates, the total storage can be increased to about $24,100,000$ acre-feet.

As pointed out on page 221 , these predictions are based on certain assumptions, of which an important one depends on reservoir operations. It is assumed that the average operating level will be at spillway level, and on that assumption it is predicted that about 20 per cent of the total sediment load will be deposited above the level of the permanent spillway crest. Lower average operating levels will reduce the proportion of sediment deposited at high levels, extend the delta front downlake, reduce the area available for deposition of silt and clay, and result in a more rapid rise of the sediment level at the dam.

\section{TERMINAL SLOPE AND RESIDUAL STORAGE}

In the foregoing discussion of the various stages of reservoir filling, it has been assumed that all the sediment transported into Lake Mead will be deposited in the lake and that none will be discharged through the outlet gates or spillway tunnels of Hoover Dam. If the outlet gates are used for discharging sediment through the dam, however, it is likely that the reservoir will never become entirely filled with sediment but will eventually reach a terminal stage when all the sediment transported into the lake will be discharged through the outlet gates and spillway tunnels of Hoover Dam. Inasmuch as the intake towers are only a few hundred feet from the dam, the sediment surface at the terminal stage will intersect the dam at about the elevation of the upper sills $(1,045$ feet). At this stage the reservoir will be almost completely filled with 
sediment. There will remain, however, a very small space still available for water storage. This space is referred to in this paper as "residual storage," and the slope of the sediment surface underlying the residual storage space is referred to as the "terminal slope."

As estimated on the preceding page, the sediment surface at the dam will rise to the level of the lower outlet sills when the accumulation becomes about 7 times as great as in 1948. Even before this time, however, turbidity currents carrying an appreciable quantity of suspended sediment may be expected to override intermittently the sills of the lower gates. Use of these gates may then be abandoned, in order to avoid passing great quantities of suspended sediment into the small reservoirs (Lake Mohave and Havasu Lake) downstream from Hoover Dam, unless some method is developed for passing sediment through them also.

If the use of the lower gates is abandoned at that time, the upper gates will still be capable of discharging clear water until they, too, begin to be engulfed in sediment. According to the estimate on page 223, this stage will be reached when the reservoir becomes about half filled with sediment, or when the total accumulation becomes about 18 times as great as in 1948. At that time the delta front will be near the eastern end of Virgin Basin, about 37 miles uplake from the dam, and the sediment surface at the dam will be only a few feet below the sills of the upper gates. Probably some sediment will have to be passed through the upper gates before this stage is reached, but the following considerations indicate that the quantity will be small. As noted on page 203 , the suspended sediment entering the lake during most of the year travels downlake along the bottom of the reservoir. In consequence, the upper water strata are generally clear and uncontaminated by suspended sediment. However, when the Colorado River is in flood (usually from late April to early July), the turbid water spreads out over the lake surface and travels for a considerable distance downlake. In May 1948 turbid surface flow was observed as far west as the center of Virgin Basin, about 48 miles from the river entrance. Thus we may expect that some suspended sediment will be discharged during late spring and early summer through the upper outlet gates prior to the time the sediment level reaches the gate sills, because the distance between the dam and the Colorado River entrance will probably be much less than 48 miles.

Measurements during the high spring inflow of 1948 show that the average suspended-sediment concentration in the upper lake layers at a distance more than
20 miles from the river entrance was only about 0.008 percent. Using this value for the suspended-sediment concentration and assuming that the water discharged through the upper outlet gates will average $30,000 \mathrm{cfs}$ during a 3-month period of high spring inflow, a total of 580,000 tons of sediment will be discharged annually through the upper gates. This is only 0.4 percent of the average annual weight of sediment accumulated in Lake Mead from 1935 to 1948 . It may be concluded, therefore, that the sediment discharged through the upper outlet gates will initially be in small quantities and limited to the period of spring floods. However, as the sediment surface approaches the upper gates, some of the turbidity currents flowing along the bottom of the reservoir will overtop them, which will result in the passage of progressively larger quantities of sediment through the dam.

When that happens, consideration and evaluation of a number of factors will be required by those responsible for operation of Lake Mead and the control of the Colorado River. The passage of large amounts of sediment through the dam will destroy the usefumess of downstream reservoirs, unless some provision is made for passing sediment through them. On the other hand, if the upper outlet gates are abandoned and the reservoir is allowed to become entirely filled with sediment, all the sediment carried into the lake will ultimately be discharged downstream through the spillway tunnels. This, of course, will also result in the filling of downstream reservoirs, but at a somewhat later date.

Still another factor must be considered. If the upper outlet gates are permanently closed to avoid discharging large quantities of sediment downstream, the power output of Hoover Dam will cease. On the other hand, if the upper outlet gates are used for discharging sediment, Hoover Dam can continue indefinitely a large proportion of its average annual output of electrical energy.

The question as to whether the dam could pass large quantities of sediment requires consideration of a number of factors, the most important of which appear to be the following: (1) The maximum water-discharge capacity of the upper outlet gates when the lake surface is at an elevation of $1,205.4$ feet; (2) the maximum sediment particle size that can be physically passed by the powerplant turbines; and (3) the abrasive effects of sedimentary debris on the powerplant turbines and appurtenant structures. These factors are evaluated as follows by C. P. Vetter and J. W. Stanley :

The maximum discharge which could be passed through the upper outlet gates by power units now operating or under 
installation and outlet needle valves, with a forebay level of 1,205.4 feet, is approximately as follows :

\begin{tabular}{|c|c|}
\hline & $\begin{array}{l}\text { Cubic feet } \\
\text { per second }\end{array}$ \\
\hline Through power units & 33,500 \\
\hline Through 12 lower tunnel needle valves_....... & 41,2 \\
\hline Through 11 canyon wall needle valves & 41,800 \\
\hline
\end{tabular}

In view of the outlet capacity listed above, it is apparent that all the flood inflow, except during short peaks of extreme floods, could physically be passed without use of the spillways.

The present sediment inflow to Lake Mead could be passed through the powerplant turbines, although some increase in turbine wear would result and more frequent repairs would be necessary. Gravel, of course, would cause excessive wear, but particles of the size now entering the lake could be passed, if necessary.

On the basis of this competent appraisal there seems to be no question that most of the sediment and water delivered to Lake Mead could be passed through the upper outlet gates by the powerplant turbines and outlet needle valves. Only during short peaks of extreme floods would use of the spillways be required.

If sediment is intentionally and regularly passed through the upper outlet gates, it is of interest to speculate briefly on the possible course of sedimentation as the reservoir passes into its terminal stage, the stage when all the sediment transported into Lake Mead will be discharged through Hoover Dam. The coarser particles, principally sand, will presumably continue to accumulate in the topset and foreset beds, and part of the silt and clay will accumulate in the upper reaches of the bottomset beds. In this way the delta front will continue its advance down the lake, but at a diminishing rate owing to the passage of progressively larger quantities of sediment through the upper outlet gates. The amount of sediment discharged through the upper outlet gates must necessarily increase because of the reduced distance between the river entrance and the dam, and because of the growth downlake of the steeper parts of the delta profile. The slope of the lower, flatter part of the delta profile-produced chiefly by the basining effect of Hoover Dam-will increase, approaching the slope of a delta built into a lake of "infinite extent." These factors will result, of course, in a steeper average slope of the subaqueous delta surface, which will increase the velocity and sedimenttransporting power of turbidity currents moving along the bottom of the reservoir. In other words, the sediment that formerly accumulated on the lower and flatter part of the delta will be discharged through the upper outlet gates.

As the steeper parts of the delta grow toward the dam, the average slope of the subaqueous delta surface will become progressively greater. Eventually, an average slope will be attained that is great enough to provide a sufficient velocity for the transportation through the upper outlet gates of all the sediment delivered to Lake Mead. This slope is referred to as the "terminal slope."

Owing to the lack of quantitative data and to an incomplete understanding of the interrelations of factors governing transportation of sediment through reservoirs, it is possible to predict the nature of the terminal slope only in a very general way. It seems reasonable to assume that the terminal slope will not be less than 55 feet per mile, which was the average slope of the Colorado delta front in 1948 (measured along the axis of the valley traversing the foreset beds). That slope in 1948 was apparently in equilibrium with the bottom velocities then prevailing in its vicinity. As the reservoir nears its terminal stage, however, the velocity at the bottom may be expected to increase appreciably. Part of this increase will result from the limited capacity of the reservoir at its terminal stage, which, during times of flood at least, will require a considerable increase in the discharge of water through the upper outlet gates. A further increase in the bottom velocity may be expected in the narrow constriction of Black Canyon upstream from Hoover Dam. Presumably, this increase in velocity will provide a terminal slope somewhat steeper than that of the Colorado delta front in 1948 , but there is no reasonable basis for estimating with any precision the amount of steepening to be expected. Consequently, it is assumed that the terminal slope will be the same as the average declivity ( 55 feet per mile) of the delta front in 1948.

If the lake is maintained at the level of the permanent spillway crest (elevation 1,205.4 feet), the terminal slope will intersect the upper outlet sills at the intake towers when the Colorado River entrance is only about 3 miles uplake from Hoover Dam. Because it is assumed that all the sediment entering the reservoir in its terminal stage will be discharged through the dam, a small space, referred to as "residual storage," will still be permanently available for water storage. In order to obtain an estimate of the residual storage capacity, a terminal slope of 55 feet per mile was assumed as a basis for constructing a hypothetical topographic map of the reservoir floor at its terminal stage (fig. 61). A contour interval of 10 feet was used, the areas enclosed by the contours were measured by planimeter, and the volumes between adjacent contour surfaces were computed. According to these computations, the reservoir at its terminal stage will have a residual storage capacity of 64,700 acre-feet, or only 0.22 percent of the initial storage capacity $(28,794,000$ 


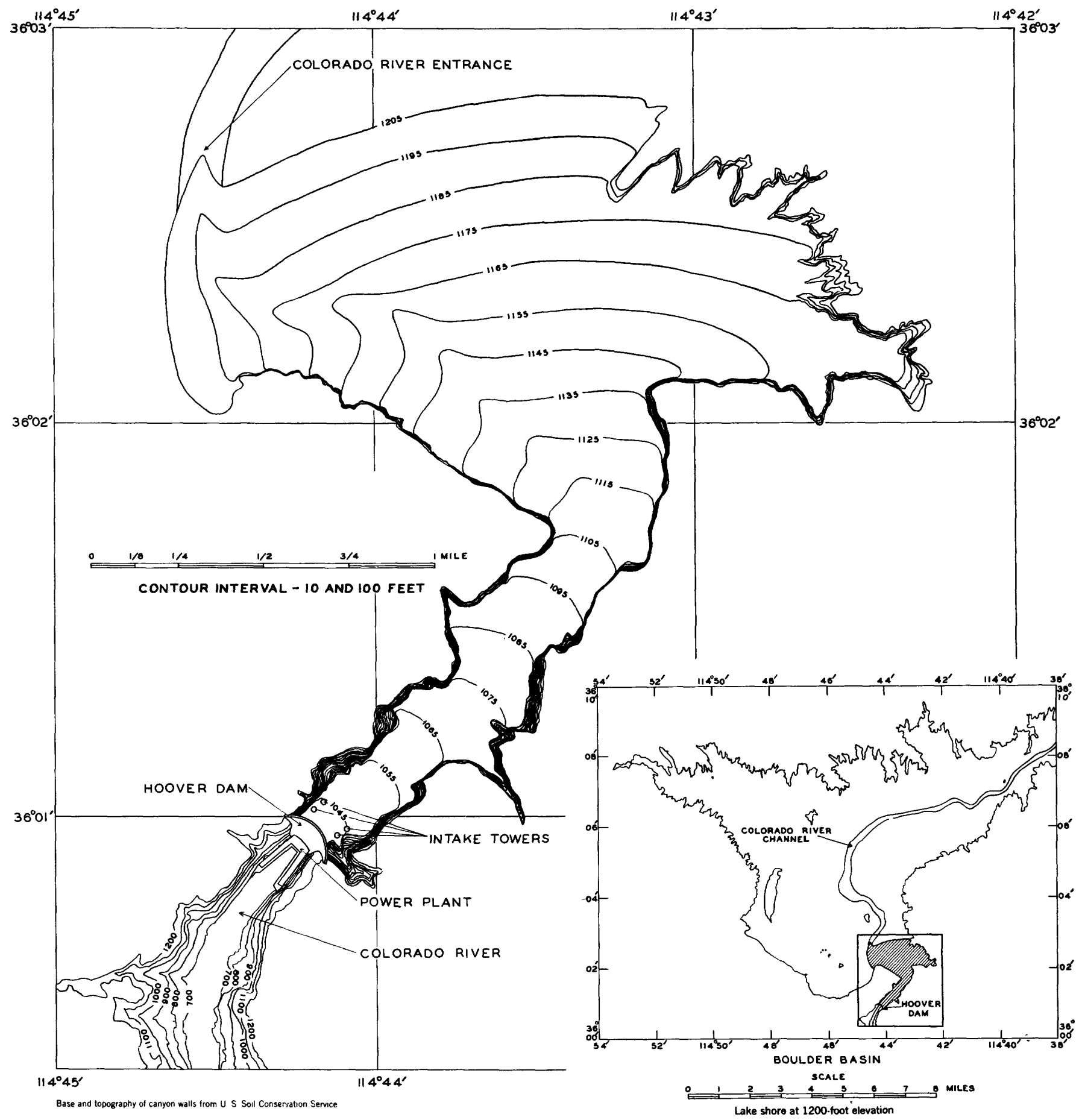

FIgURE 61.-Hypothetical bottom topography of Lake Mead at its terminal stage. The relation of the lake at its terminal stage to Boulder Basin appears in the inset.

acre-feet) of Lake Mead at the elevation of the permanent spillway crest (1,205.4 feet). Expressed in other terms, the reservoir in its terminal stage will hold only 0.48 percent of the average annual inflow to Lake Mead during the 14-year period 1935-48.

Under the conditions assumed, during December, January, and February, when the flow into the lake generally averages less than 7,000 cfs (U.S. Geological Survey, 1954, p. 551-573) the reservoir will be capable of storing the equivalent of 6 days of inflow. In May and June, however, when the flow a verages about 50,000 cfs, the holdover storage will be reduced to the quantity of water flowing into the reservoir in only 16 hours. During this period and especially at times of 
peak discharge, when the flow sometimes exceeds 100,$000 \mathrm{cfs}$, the spillway gates may be raised to provide some regulation of the river flow. At the terminal stage these gates can increase the water-storage capacity by about 280,000 acre-feet, which can be used for a small measure of flood control, but will be entirely inadequate for seasonal regulation for downstream users.

\section{AMOUNT OF EROSION REQUIRED FOR FILLING LAKE MEAD}

The quantitative measurements of the sediment accumulated in Lake Mead provide a basis for estimating with considerable accuracy the average rate of erosion from the tributary drainage basin during the 14-year period 1935-48. Most of the weathering products are carried from their source areas in the detrital load of the Colorado River and its tributaries; since the closure of Hoover Dam in 1935 this material has accumulated in Lake Mead. The 2,000 million tons deposited in Lake Mead from 1935 to 1948 is therefore a measure of the total amount of stream-transported detritus removed from the tributary drainage basin during this period.

According to C. S. Howard (p. 121), 140 million tons of dissolved solids was carried in the Colorado River as it passed through Grand Canyon from February 1935 to September 1948, and the total dissolved load brought into Lake Mead during the 14-year period $1935-48$ was probably of the order of $148,000,000$ tons. The total weight of material carried from the tributary drainage basin in solution and as stream-transported detritus during this interval is therefore estimated at about 2,150 million tons. No data are available on the amount of material removed by wind action, but the sediment transported in this fashion is probably negligible compared to the amount of material removed by other agencies.

Using the above value for the total weight of material removed and a value of 2.67 for the specific gravity of the mineral particles, we can obtain a reasonable estimate of the average rate of erosion from the basin from 1935 to 1948 .

The rate of erosion can be expressed in terms of either soil or unweathered rock. According to Lutz and Chandler (1946), the mean porosity of average soils is about 50 percent. Assuming this to be the average soil porosity in the Colorado River basin, calculations indicate that a layer of soil having an average thickness of 0.133 inch has been removed from the 168,000 square miles of the tributary drainage basin during the 14-year interval. If this rate of erosion were to continue in the future, a layer of soil having an average thickness of 1 foot would be removed every 1,260 years.

The average porosity of all types of unweathered rock in the basin is very difficult to estimate from available data. Average shale has a porosity of about 13 percent (Pettijohn, 1949), but the unconsolidated and semiconsolidated sediments, which are widely distributed in the basin, probably have porosities ranging to more than 35 percent. Even crystalline rocks have an appreciable porosity due to joints and other fractures. Solution cavities in limestones, and gas vesicles in basalt and other lava flows, give a considerable porosity to rocks of these types. For this estimate an arbitrary assignment of 15 percent for the mean porosity of unweathered rock in the Upper Colorado River Basin is probably not unreasonable. Expressed in terms of unweathered rock having an estimated porosity of 15 percent, we find that the tributary drainage basin has been reduced in elevation by an average of about 0.078 inch from 1935 to 1948 . At this rate, the average lowering of the basin by erosion would be about 1 foot every 2,150 years.

The 75,000 million tons of sediment required to fill the reservoir completely would represent the erosion products from a soil layer averaging 4.9 inches in thickness over the entire tributary basin. However, we may be sure that the rate of erosion will be far from uniform over the basin. Judging by the history of the past century, we may expect that between now and the date when the reservoir is full of sediment, the erosion in some parts of the basin will be negligible and in others will be measurable in tens of feet.

The records of suspended sediment in streams indicate these inequalities in sediment production and therefore in the rates of erosion in various part of the basin (p. 26). The network of sediment-gaging stations is enough to indicate that the drainage basin tributary to Lake Mead could be divided approximately into halves, consisting of (1) headwater areas in Colorado, Wyoming, and northern Utah, which commonly contribute more than three-fourths of the water but less than one-fourth of the sediment to Lake Mead; and (2) arid areas in New Mexico, Nevada, Arizona, and southern Utah, which produce less than one-fourth of the water but most of the sediment carried into the lake. Assuming a similar contrast in sediment production in the future, the filling of Lake Mead would be accompanied by erosion averaging nearly 8 inches in the arid areas but only slightly more than 2 inches in the headwater half of the drainage basin. 


\section{REFERENCES CITED}

Eakin, H. M., 1939, Silting of reservoirs, revised by Brown, C. B.: U.S. Dept. Agriculture Tech. Bull. 524, p. 90-99.

Emery, K. O., and Rittenberg, S. C., 1952, Early diagenesis of California basin sediments in relation to origin of oil : Am. Assoc. Petroleum Geologists Bull. v., 36, p. 735-804.

Happ, S. C., 1946, Discussion of Stevens, J. C., Future of Lake Mead and Elephant Butte Reservoir: Am. Soc. Civil Engineers Trans., v. 111, p. 1298.
Hedberg, H. D., 1936, Gravitational compaction of clays and shales: Am. Jour. Sci., ser. 5, v. 31, p. 241-287.

Mackin, J. H., 1948, Concept of the graded river: Geol. Soc. America Bull., v. 59, p. 496-498.

Sterens, J. C., 1946, Future of Lake Mead and Elephant Butte Reservoir: Am. Soc. Civil Engineers Trans., v. 111, p. 1242-1254.

U.S. Geol. Survey, 1954, Compilation of records of surface waters of the United States through September 1950; part 9-Colorado River basin: U.S. Geol. Survey Water-Supply Paper 1313, $733 \mathrm{p}$. 



\title{
T. LIFE OF THE RESERVOIR
}

\author{
By H. E. Thomas, H. R. Gould, and W. B. Langbein
}

In the preceding chapter, H. R. Gould has described the conditions that would mark the last stages of Lake Mead as a water-storage facility, and has indicated for certain assumed conditions the tonnage of sediment that would be accumulated in the reservoir area at that time. He has also discussed conditions at the time when the sediment accumulation would amount to about half the sediment-storage capacity and has pointed out that the usefulness of the reservoir will probably not be seriously impaired until that halfway point is reached. The calculated quantity of sediment-about 75 billion tons when the reservoir becomes completely filled, or 3,700 million tons at that halfway point-are essential items in the computation of the life of the reservoir.

The life, or the half-life, of the reservoir in years depends also upon the average annual rate of sediment accumulation. In the following sections the life of the reservoir is forecast first on the assumption that the average rate of accumulation in the 14-yenr period 1935-48 will continue in the future, and then on the basis of analyses of other hydrologic data for the purpose of evaluating the "normal" rate of accumulation.

\section{PROJECTION OF OBSERVED RATES OF SEDIMENT ACCUMULATION}

Some estimates of the probable life of Lake Mead have been based on projection of the observed rates of sediment accumulation at Hoover Dam. As shown by figure 24, the top of the sediment rose 100 feet in the first 3 years of operation of the dam, and then it rose another 40 feet by the fall of 1941 , less than 7 years after water was first impounded. This rapid rise of the sediment level-to a position about halfway between the original river bed and the lower gates at the intake towers - could lead to very pessimistic estimates as to the life of the reservoir. However, the rapid rise is explained by the shape of the reservoir; the volume in the lowest 100-foot layer of the reservoir (below elevation 720 feet) constitutes less than 0.5 percent of the reservoir capacity, as shown by the original capacities in table 7. Records since 1941, too, show that sediment compaction is a very important factor at the dam, for by January 1950 the sediment surface at the intake towers was 38 feet lower than the maximum in 1941. Projections of the observed rate of sediment accumulation into the future necessarily lead to erroneous estimates of the life of the reservoir, if they neglect the factor of compaction.

Other estimates of the life of Lake Mead have been based upon projection of the ratio of sediment volume to the water-storage capacity of the reservoir. This was essentially the basis for the estimate made by Stevens (1946), for he assumed that practically all the sediments carried by the inflowing streams would be deposited in the reservoir below an elevation of 1,205 feet, and he assumed an average specific weight of 65 pounds per cubic foot for the accumulated sediment, which is about the average for existing deposits as determined in the 1948-49 survey. By evaluation of the data collected prior to October 1942, Stevens deduced that the sediment would accumulate at an average annual rate of 198,000 acre-feet, and that the reservoir would therefore be completely filled with sediment in 144 years. But in the 1948-49 survey it was determined that the volume occupied by sediment was $1,426,000$ acre-feet, and thus the average annual rate of accumulation in the 14-year period was 102,000 acre-feet. By projection of this rate of accumulation, the time required for deposition of a volume of sediment equivalent to the original water-storage capacity of Lake Mead would be 280 years.

However, the maximum life of the reservoir will be considerably greater than this, because (1) the sediment-storage capacity is greater than the waterstorage capacity of the lake and (2) the current average specific weight of the sediment will be increased by compaction. From consideration of the principles of stream gradation and the history of delta building in Lake Mead to date, Gould concludes (p. 217) that the sediment-storage capacity of the reservoir may be as much as 25 percent greater than the water-storage capacity. From analysis of core samples and other data, he estimates that the average specific weight of the sediment when the reservoir is completely filled will be 50 percent greater than the average of the 
deposit in 1948. The 2,000 million tons of sediment deposited in the 14-year period (1935-48) constitutes only 2.7 percent of the calculated ultimate storage capacity of nearly 75,000 million tons. By projection of this rate of accumulation, the probable maximum life of the reservoir is computed to be about 520 years. The time required to reach the halfway point, when accumulation of 37,000 million tons of sediment will have reduced the water-storage capacity at permanent spillway crest to 13 million acre-feet, will be about 260 years.

\section{"NORMAL" RATE OF SEDIMENT ACCUMULATION}

In using the record for a 14-year period to forecast events 5 centuries in the future, we are using an exceedingly short base and projecting it for nearly 40 times its length. Any inaccuracies in that base are correspondingly magnified in the forecasts. Thus, if on the average it takes only 12 years for streams to carry additional quantities of 2,000 million tons, such as reached Lake Mead in the 14-year period of record, the probable life of the reservoir would be shortened by 75 years. The records at Grand Canyon show that there is sufficient variability in sediment load to justify a great range in forecasts as to the probable life of the reservoir. In the single year 1927 the suspended load of 480 million tons was equivalent to nearly one-fourth of the total carried in the 14-year base period; and in the 8 years $1926-33$ the river carried 2,000 million tons of sediment past the Grand Canyon station-as much as was carried in the 14-year period 1935-48.

Hydrologists are generally agreed that the period 1935-48 was not a "normal" period, for the average runoff was appreciably less than averages for longer terms, and the sediment load also was less than the average for the entire period of record. The problem is complicated by the fact that the sediment-runoff relation since 1941 has been notably different from that recorded in earlier years (p. 104).

The following sections are devoted to an analysis of (1) existing records, to determine whether some of the variation in results may stem from changes in methods of collection of basic data; (2) observed variations in runoff and sediment load, and the modifications that may result from additional water-development projects upstream from Hoover Dam; (3) the effects of allowing some sediment to flow out of the reservoir; and (4) other factors that may produce minor changes in reservoir volume and thus may shorten or lengthen the time required for filling.

In analyzing the available data, one is frequently handicapped by a paucity or complete lack of information on certain important problems, and he finds himself forced to speculate to an extent that is not con- doned in most scientific work. However, the purpose of this speculation is to qualify and limit the major speculation as to the probable life of the reservoir, and to indicate the fields in which our knowledge must be increased before the economic life of Lake Mead, or indeed of large reservoirs in general, can be evaluated accurately.

\section{EVALUATION OF EXISTING RECORDS}

The volumetric survey of 1948 provides only one point of correlation between runoff and sediment: 2 billion tons of sediment was carried into the reservoir by 176 million acre-feet of Colorado River water, plus the unmeasured flow of other tributaries. Any detailed analysis of the rate of sediment transportation in relation to stream discharge depends on records of suspended load, especially the record for the Colorado River at Grand Canyon.

\section{GAGING OF SUSPENDED SEDIMENT AT GRAND CANYON}

The sharp change in the annual sediment runoff relation at Grand Canyon since 1941 (fig. 22) may lead the curious minded to wonder whether changes in equipment or techniques used in the measurements might be partly responsible. In the past 25 years there has been progress toward greater accuracy in the measurement of suspended load in streams; the corollary to that statement must be that records for earlier years may be subject to greater error than current records.

Records of suspended sediment at Grand Canyon for the years prior to 1944 are based upon samples collected with the Colorado River sampler. The sampler was essentially a bracket, suspended from a cable, which held a pint bottle and, beneath it, a 50-pound elliptical weight. The bottle was held vertically, except of course for the angle of downstream drift, and the sample was admitted through a $5 / 16^{\text {-inch }}$ or $9 / 16^{\text {-inch orifice }}$ in the cap, sometimes with air exhaust. Sampling could extend downward as far as 1.5 feet above the stream bed, a limit set by the height of the bottle and the underslung weight.

Since A pril 1944 the D-43 depth-integrating sampler has been used at Grand Canyon. This sampler has a cast-bronze streamlined body with integral horizontal and vertical tail vanes; it weighs about 50 pounds. The bottle is inclined slightly from horizontal, and is

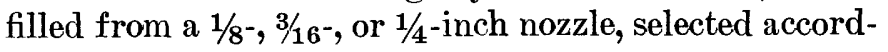
ing to discharge conditions at the time of sampling. Sampling extends downward as far as 0.3 foot above the riverbed.

A few field tests have indicated that the Colorado River sampler is erratic in comparison with the D-43 
sampler; the direction of integration, the type of bottle cap, and conditions in the stream cause marked variation in the efficiency of the Colorado River sampler. In five comparisons at Grand Canyon, at depths ranging from 19 to 29 feet the Colorado River sampler on round-trip integration indicated concentrations ranging from 99 to 103 percent of those shown by a D-43 sampler. ${ }^{20}$ Sketchy comparative tests at other places in the Colorado River Basin (Benedict, 1944) are quite inadequate for correlation of records obtained by the respective samplers; but, such as they are, they indicate that the Colorado River sampler registers less sediment than the D-43 sampler, especially in smaller and presumably shallower streams. In seven samples from streams discharging more than $10,000 \mathrm{cfs}$, the two samplers agreed within 2 to 12 percent, but in streams of lesser discharge the Colorado River sampler recorded 25 to 50 percent less sediment than the $\mathrm{D}-43$. This under-registering may result in part from the inability of the Colorado River sampler to get down close to the streambed, where the coarser particles are concentrated.

These few tests give no indication that the sediment measured by the Colorado River sampler-that is, the recorded load prior to 1944 -is excessive. If anything, the errors of this sampler would be in the other direction, so that the recorded load would be less than the actual. The change in sampling equipment cannot be held responsible for the generally lower concentration of sediment since 1942 .

The method of computation of sediment concentration during the early years of record caused a slight exaggeration of suspended load during the period prior to March 1930. The computations were based upon the assumption that the sample would have a weight equivalent to that of an equal volume of pure water. As a result the calculated sediment load would be 3 percent greater than actual for a 5-percent concentration, and 6 percent greater for a 10-percent concentration. Sediment concentrations in excess of 5 percent were common in 1927 and 1929, and correction of these errors would reduce the very high recorded sediment loads in those years (Daines, 1949). However, the errors occur only in records for years prior to the beginning of construction of Hoover Dam.

\section{UNGAGED INCREMENTS OF SFDIMENT}

Only a part, albeit a predominant part, of the sediment entering Lake Mead is measured at Grand Canyon. The gaging station on the Virgin River at Littlefield, Ariz., operated since 1947, shows that the stream

\footnotetext{
20 Federal Interagency River Basin Committee, Subcommittee on Sedi mentation, 1946, Comparative field tests on suspended sediment samplers: Progress report, unpublished.
}

contributes less than 3 percent as much sediment as is contributed by the Colorado River at Grand Canyon. Other tributaries also contribute some sediment to the reservoir. The record at Grand Canyon is of the suspended load only, and the sediment passing the station as bed load is unmeasured.

A comparison of the findings of the volumetric survey of 1948 with the record of suspended load at Grand Canyon shows that these ungaged increments must be small quantities, evidently smaller than the limits of error in the two systems of measuring the accumulated sediment. The suspended sediment measured at Grand Canyon from February 1, 1935, until the completion of the volumetric survey on February 28, 1949, totaled 1,990 million tons. Somewhat less than 10 million tons continued through the reservoir and on downstream prior to May 1936, leaving 1,980 million tons to accumulate in the Colorado delta in Lake Mead.

The total weight of sediment in Lake Mead, as calculated in the volumetric survey of $1948-49$, was 2,014 million tons, of which about 57 million tons, or less than 3 percent, was deposited by the Virgin River in the upper part of the Overton Arm. Thus the sediment in the Colorado delta totaled only 1,957 million tons. However, this determination is based on differences between the topography as shown by maps made in 1935 and the bottom topography as determined in 1948-49. The surveys for the 1935 maps were not completed in some areas until sediment deposition had already begun, and it has been estimated (p. 168) that as much as 43 million tons may have been included in the "pre-Lake Mead" topography.

Also, the sediment as calculated from the volumetric survey may be less than the total deposited in the period February 1, 1935, to February 28, 1949, because of the continuing deposition of sediment throughout the period of the hydrographic survey. About 115 million tons of suspended sediment passed the Grand Canyon station during the year of the survey, of which 100 million tons was recorded in the first 5 months (MarchJuly 1948, inclusive). These are the months of the annual freshet, when most of the suspended load is likely to be of sand size, and clay-sized particles commonly make up less than 10 percent of the total; practically all the sand and the coarser grades of silt are deposited in the eastern part of the lake, particularly in Lower Granite Gorge (p. 173). The surveys of these areas were begun after the freshet was over, and the measured sediment probably includes most of the 1948 increment. An unknown proportion of the 15 million tons of sediment carried by the river in the 7 months from August 1948 to February 1949 may have been 
deposited subsequent to the completion of the hydrographic survey in some parts of the reservoir.

It is evident that if the total as calculated by the volumetric survey is adjusted because of uncertainties as to sedimentation at the beginning and end of the base period, it might be increased by as much as 60 million tons. Thus the total in the Colorado delta may well be stated as ranging from about 1,960 million to 2,020 million tons. The calculated suspended load at Grand Canyon is near the midpoint of this range, and there is thus no indication that the bed load at Grand Canyon or ungaged sediment from other sources constitutes a significent proportion of that delta.

\section{VARIATIONS IN RATE OF SEDIMENT INFLOW}

VARIATIONS IN SEDIMENT LOAD AND RUNOFF

The record of sediment at Grand Canyon, beginning in 1926, provides information as to the suspended load and contemporaneous runoff for a quarter of a century. Records of river discharge cover a longer period, and climatic fluctuations are inferred for a still longer period, but the sediment-runoff relations in these extended periods must be extrapolated from the relatively short sediment-gaging records.

The average annual load of suspended sediment passing the Grand Canyon gaging station in the 25year period 1926-50 was 168 million tons (table 10), or about 18 percent greater than the mean annual load (142 million tons) during the 14-year period 1935-48. The mean annual runoff in the 25-year period was 12.8 million acre-feet, or 2 percent greater than the average for the period 1935-48.

Some further qualitative knowledge of the amount of sediment removed from the Upper Colorado River Basin during an earlier period may be obtained from the suspended-sediment records taken at Yuma, Ariz., from 1911 to 1934 . The mean annual suspended load that passed Yuma between 1911 and 1925 was about 38 percent greater than in the period 1926-34. The total quantity of suspended sediment discharged at Yuma during any given year has always been smaller than that which passes the Grand Canyon station, as determined by comparison of the records at these stations during the period 1926-34; the annual sediment load recorded at Yuma varied between 36 percent and 78 percent of the annual suspended load recorded at the Grand Canyon station. Nevertheless, the sediment records at the two stations show the same general trend. Both high and low sediment loads at the Grand Canyon station are reflected by corresponding high and low values at Yuma, though there is no constant relation between the total quantity of sediment discharged at the two stations during any given year. Even though these records are not directly comparable, the high sediment loads recorded at Yuma from 1911 to 1925 suggest a greater rate of sediment movement by the Colorado River in those years than in the period 1926-50.

From this brief analysis of the historical suspendedsediment data, it appears that the average annual rate of sediment transport into the Lake Mead area during the 25-year period $1926-50$ was about 18 percent greater than during the 14-year period 1935-48. If the high suspended load recorded at Yuma, Ariz., in the years 1911-25 is representative of the Upper Colorado River Basin, it appears that the rate of sediment transport into the Lake Mead area during the 40year period 1911-50 may possibly be as much as 50 percent above the $1935-48$ average.

Records of the discharge of the Colorado River have been obtained continuously since 1921 at Lees Ferry, Ariz., 87 miles upstream from the Grand Canyon station and just above the mouth of the Paria River. These records have been extended back to 1895 by estimates based on fragmentary records from downstream stations and from tributaries (U.S. Geol. Survey, 1954, p. 522). According to this record, the average annual discharge at Lees Ferry in the 56-year period 1895-1950 was 13.8 million acre-feet and in the 25-year period $1926-50$ was 12.4 million acre-feet. Thus in the 56-year period the river discharge at Lees Ferry was about 12 percent greater than in the period 1925-50. It has been estimated that diversions for irrigation, reservoir evaporation, and exports of water from the basin upstream from Lees Ferry reduced the streamflow at that point by 0.7 million acre-feet in 1897. By 1921 these stream depletions had increased to 2.6 million acre-feet, and they have exceeded 2 million acre-feet in most years since 1926. Thus the lesser flow in the period 1926-50 is attributed only in part to natural climatologic changes, and partly to increased diversions from the river. The estimated virgin flow at Lees Ferry in the period $1895-1950$ is 15.7 million acre-feet.

The tributary inflow between Lees Ferry and Grand Canyon is relatively small, and is derived chiefly from springs and from the Little Colorado River. In the period 1926-50 the average annual flow at Grand Canyon was 12.8 million acre-feet, or about 0.4 million acre-feet greater than at Lees Ferry. By analogy with Lees Ferry, it may be inferred that the mean annual discharge at Grand Canyon in the 56-year period 18951950 was about 12 percent greater than in the period 1926-50, or about 14.2 million acre-feet. Also by analogy with Lees Ferry, the estimated virgin flow at 
Grand Canyon in the 56-year period is of the order of 16 million acre-feet.

La Rue (1925, p. 121, pl. 74) extended the streamdischarge record for Lees Ferry back to 1851, by means of correlation with the historic and traditional records of the level of Great Salt Lake. According to this extended record, the virgin runoff of the Colorado River at Lees Ferry in the 72-year period 1851-1922 averaged 16 million acre-feet a year. This estimate is based on more tenuous evidence than that for the 56year period 1895-1950, but is of the same order of magnitude and suggests that the hydrologic records now available are sufficient to give a firm figure for longterm mean runoff.

By using Schulman's results (1945) from tree-ring investigations in the Upper Colorado River Basin we can obtain an estimate of the average rate of runoff of the Colorado River during the past several hundred years. According to Schulman, there is general agreement among rainfall, runoff, and tree growth in the Upper Colorado River Basin during the period for which rainfall and runoff data are available. By tree-ring dating methods he has concluded that the growth index of the Douglas fir during the years 18871945 has varied considerably from the mean for the 658-year period 1288-1945. He reports $(1945$, p. 44) that this growth index in $1887-1905$ was 18.1 percent less than the 658-year average, whereas during the interval 1906-30 it was 16.1 percent above the long-term average. From 1931 to 1940 the growth index was 19.7 percent below the average, but it was near normal during the interval 1941-45. Since there is general correspondence between the tree-growth index and runoff in 50 years of contemporaneous records, we can conclude that the runoff in past centuries also has probably experienced the same general fluctuations as the tree growth.

Extrapolation of these results, together with available runoff records, suggests that the average annual virgin streamflow (i.e., flow undepleted by artificial diversion for irrigation and other uses) at the Grand Canyon station during the past 658 years has been about 15.8 million acre-feet, which is slightly less than the estimated virgin flow in the 56 years-1895-1950. However, this long-term average is about 14 percent greater than the estimated actual flow in the 56 years, 24 percent greater than the measured flow in the period 1926-50, and 26 percent greater than the average discharge in the 14-year period 1935-48.

The depletions caused by water development in the Upper Basin, currently about 2.2 million acrefeet a year, will doubtless insure that the average flow at Grand Canyon in the future will be less than the average as derived from tree-ring records. With no increase in the amount of upstream diversions, this long-time future average should be about 13.8 million acre-feet, or about 10 percent greater than the average in the 14-year period $1935-48$.

\section{VARIATIONS IN RELATION OF SEDIMENT TO RUNOFF}

In four years since 1926 the annual runoff at Grand Canyon was close to the projected long-term mean of 13.8 million acre-feet: In 1930, 1944, 1947, and 1948 the runoff ranged from 13.4 million to 13.9 million acrefeet. These four years demonstrate the striking variation in sediment transport that is all too characteristic of the records to date. The measured sediment load was more than 235 million tons in 1930 , but less than 98 million tons in 1944. In both 1947 and 1948 the load was close to the 142-million-ton average for the 14-year period of 1935-48. These inconsistencies are apparent throughout the record, including years of high as well as low runoff. Thus in 1950 less sediment was carried in 11.2 million acre-feet of water than was transported by 6.7 million acre-feet in 1931 ; and 17.3 million acrefeet of water carried 389 million tons of sediment in 1927 , but only 230 million tons in 1942 .

The monthly sediment load at Grand Canyon has ranged from 156,000 tons in January 1944 to 134 million tons in August 1929. This variation is far more striking than is the variation in annual load, for the maximum monthly load is about 85 times the minimum, and is nearly as large as the average annual load since 1935 . Graphs of monthly sediment load and average discharge at Grand Canyon since the completion of Hoover Dam are presented in figure 62, which shows a maximum in sediment load each year corresponding to the peak discharges of May and June. In almost every year there is also a secondary maximum (shown by ruled pattern) usually in August or September but sometimes as late as October; in 1936, 1940, 1946, and 1947 these later sediment-load maxima were greater than those in the spring. The river discharge during the months of these secondary maxima is much less during May and June. The average percentage of sediment by weight also rises to a maximum in May and June, and to a second maximum in the late summer or autumn (shaded in figure 62), but the second maximum is generally higher than the first. In other words, the high sediment loads in the late summer and fall generally occur with higher concentrations of sediment than those in the spring. The months of November to February are generally months of minimum flow, minimum sediment load, and minimum concentration of sediment. 


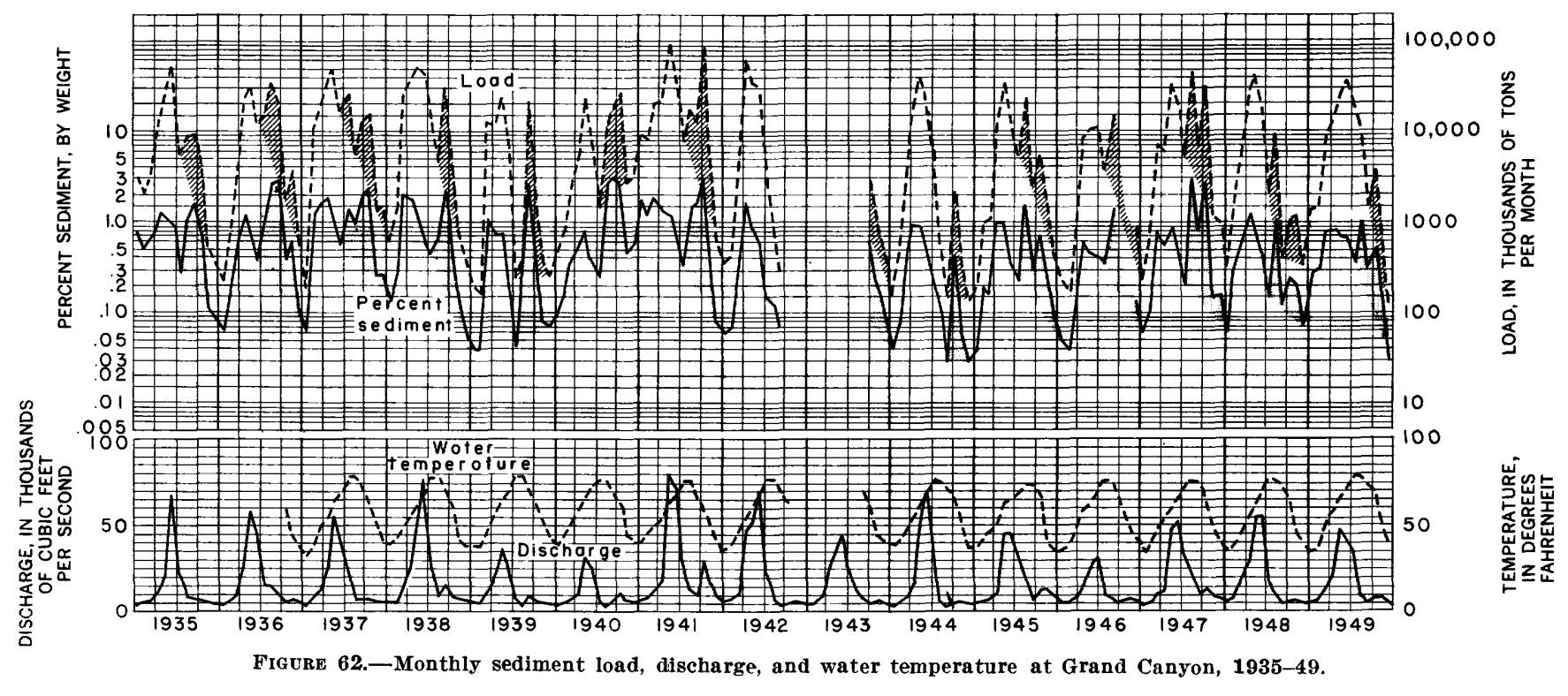

A logarithmic plot of monthly runoff against sediment load (fig. 63) shows the following relations:

1. Points representing months when runoff was less than 1 million acre-feet and sediment load less than 5 million tons form a fairly straight and well-defined band. Generally these are the months November to February. Points representing the months of March and of August to October are more widely dispersed, but most of them also fall in the straight band noted above, or in its extension.

2. Points shown by open circles, which represent the months of maximum discharge (April-July), are generally above the band defined by paragraph 1 , and form a band with different slope. Thus the sediment load is less during the annual freshet than is to be expected from the sediment-runoff relation as defined in other months of the year. After the peak discharge, notably in July, the river generally carries less sediment than it did with equivalent discharge during rising stage in April or May, and it transports only about as much sediment as it had carried with far less water in March or April.

3. Several points are below the band defined by the points mentioned in paragraph 1. All but five of these points represent months in the years 1931, 1933, 1934, $1935,1939,1940$, and 1946 , the 7 years of least runoff in the period of record, and months in those years are depicted by larger circles on figure 63. Many points within the lower part of the band also represent months in those dry years. In the months of greatest runoff during those dry years (April to July, shown by double open circles), the sediment load was commonly greater in proportion to runoff than in corresponding months of other years. Generally in these dry years the sediment load was greater than is to be expected from the sediment-runoff relation suggested by the points mentioned in paragraphs 1 and 2 .

The band in which the majority of points are located (par. 1) appears to be an expression of the fundamental relation of runoff to sediment load, when the sediment is predominantly clay and silt: The load is a power function of discharge. This relation involves the interaction of several variables, including all velocities expressible in terms of discharge. Because of this relation, the sediment load can be expected to increase with, but at a rate faster than, the runoffan increase that is apparent in annual relations. However, the divergences of many points from this general relation indicate that other factors are involved, and these factors may be such as to render valueless any projections into the future of the short period of available record.

The band formed by the points representing the months of greatest runoff (par. 2) indicates that there is a different power relation when the suspended load includes a higher proportion of fine and medium sand (125 to 500 microns in diameter). As pointed out by Leopold and Maddock (1953, p. 40), in discussing experiments with such sands, "With increasing discharge the bed may change successively through conditions described as smooth, riffles, bars, dunes, and 


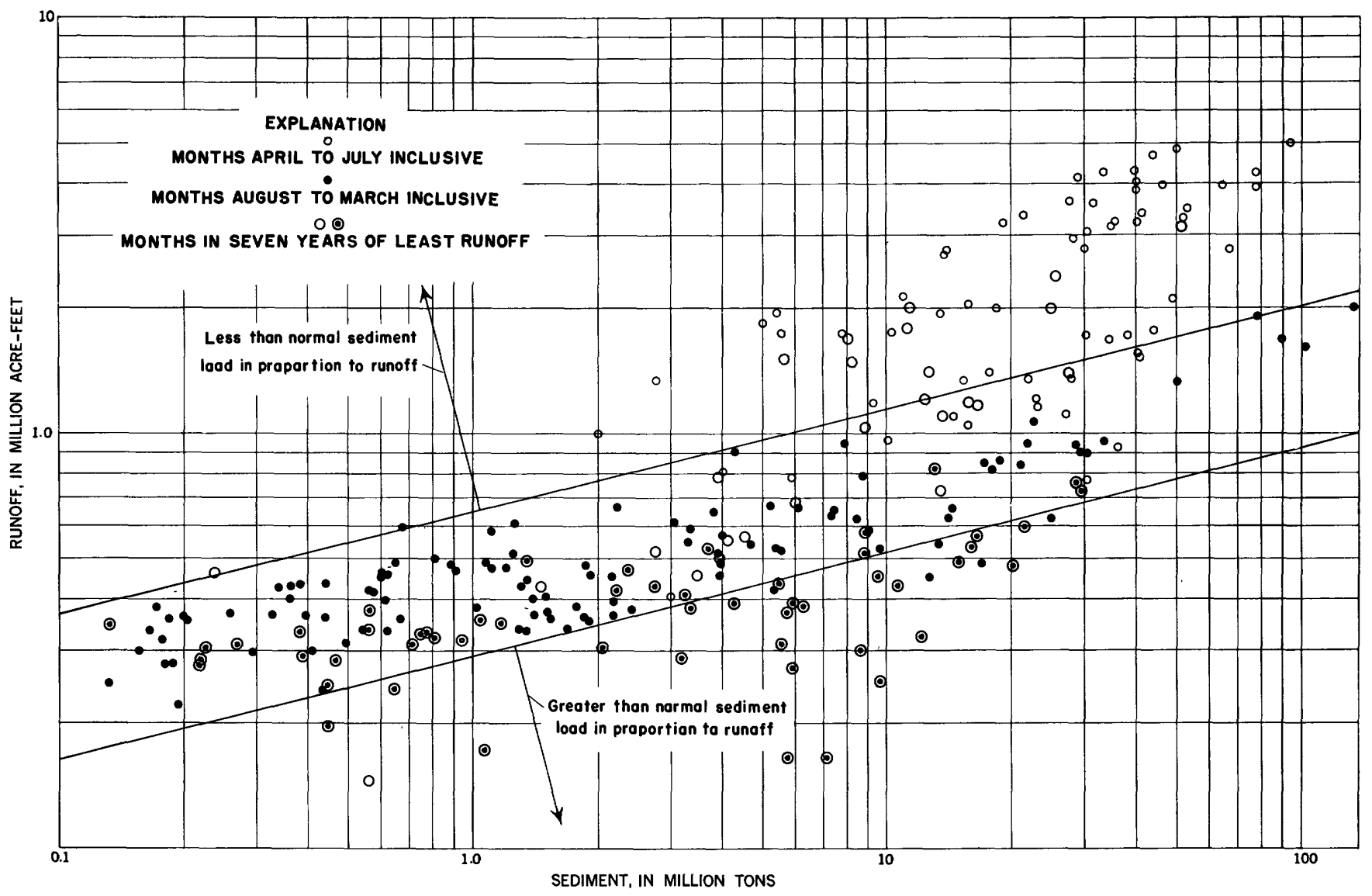

Figure 63.-Relation of monthly runoff to sediment load at Grand Canyon.

finally antidunes." Such changes in bed configuration may change the channel roughness significantly. As summarized by Leopold and Maddock, "An increase in bed roughness is one type of change that will result in the decrease of velocity with respect to depth. Because changes in the velocity-depth relation constitute a part of the adjustment of channel shape to load, variations in roughness affect capacity for load."

During periods of drought the suspended load may be substantially greater than would be expected by the usual power relations. This may be a reflection of the broad interrelations among climatology, vegetative cover, runoff, and erosion in the tributary drainage basin, and forecasts of sediment load may be considerably in error if they neglect these factors. Daines (1949), following his analysis of sediment load in relation to runoff and precipitation, concludes that:

Intensity, duration, frequency, distribution, and season of occurrence of precipitation-not total amount-effects variations in the runoff-sediment discharge relation. Occasional intense storms may flush away considerable sediment loads, while other storms of equal volume may have very little erosive effect depending upon rainfall characteristics and ground conditions. Correlation of sediment discharge with all of the rainfall characteristics would undoubtedly give better results than correlation with runoff alone; however, inadequate information precludes the possibility of direct correlation of sediment with all rainfall characteristics.

Analysis of the record by months suggests that there may be possibilities of isolating the factors which contribute to the complexity of the sediment-runoff relation. Quantitative evaluation of the effects of individual factors will require more detailed analysis, using smaller time units as well as smaller geographic units, such as records for individual storms and for gaging stations that can segregate the sources of the sediment load.

As shown by figure 22, the sediment-runoff relation in the years 1942 to 1950 is as consistent as for earlier years of record, and the curve showing that relation is approximately parallel to that drawn on the basis of records for the years 1926 to 1940 . However, in each of the later nine years the annual sediment load was 50 million to 100 million tons less than would be expected on the basis of the curve established by data for years prior to 1941 .

The analysis of monthly records indicates a greater amount of sediment in dry years than would be expected from the usual sediment-runoff relations, and 
it is noted that the period $1942-50$ includes only one (1946) of the seven years of least runoff since 1926; the other six occurred in the decade 1931-40. The analysis of monthly records also shows that during the annual freshet (generally April-July) the sediment load is commonly less than is to be expected from the relation that characterizes other months. There is no indication, however, that the annual freshets in recent years carry a significantly larger proportion of the yearly runoff than in earlier years. The April-July runoff has constituted 65 to 75 percent of the annual total in all except six of the years since 1926; those six exceptional years $(1930,1931,1934,1939,1940$, and 1946) have been years generally of minimum annual runoff, and the April-July runoff has been as little as 50 percent of the total for the year.

In general, neither the annual runoff nor the seasonal distribution of runoff since 1941 has been perceptibly different from that in earlier years, and thus neither offers an explanation for the change in sediment-runoff relations since that year. Because 1941 introduced a new and different relation that has persisted for at least 9 years, the factor or factors causing the change must have been effective for a similarly long period. It is believed that a possible explanation may lie in longterm regional trends in precipitation.

The southwestern United States in recent years has recorded a drought which is recognized as one of the eight most severe droughts in 600 years. This drought began in 1942 in Arizona and southern Utah, 1943 in New Mexico and west Texas, and 1945 in California; as of October 1951 it had not yet ended (U.S. Dept. Interior, 1951). Lake Mead is within this broad drought region, but the principal sources of its water supply are far to the north, in a region where precipitation has generally been about normal.

Records of annual statewide precipitation in percent of normal, as published by the Weather Bureau (1952), give some indication of regional variations in precipitation trends, although the averages for the Colorado River basin States are based in part on records from areas beyond the limits of the basin. These averages indicate that precipitation was approximately normal throughout the Colorado River basin and a broad surrounding area in the years 1935 to 1938 ; it was somewhat below normal in 1939, and near normal again in 1940. The following year, 1941, was a banner year for precipitation in a broad region that included the entire Colorado River basin. During the first 7 years of Lake Mead history the precipitation trends were fairly similar throughout the basin.

By contrast, the years since 1941 have been characterized by marked variations in different parts of the basin.
In 1942 the average precipitation in Arizona was less than 70 percent of normal, but precipitation in other States of the basin was approximately normal. From 1943 through 1948 there was a notable contrast between precipitation in Arizona and New Mexico and the States farther north. Thus in Colorado, Wyoming, and Utah precipitation was appreciably above normal in 1944, 1945,1946 , and 1947 , and only slightly below average in 1943 and 1948. In drought-ridden Arizona and New Mexico (and bordering areas in southern California, Nevada, Utah, and Colorado) precipitation was generally less than 85 percent of normal in $1943,1945,1947$, and 1948, and slightly below normal in 1944 and 1946 .

These contrasting precipitation patterns are of significance in the consideration of sediment-runoff relations, because the drought-affected area included most of the sediment-producing area of the Colorado River basin. Precipitation was less than 85 percent of normal in 6 or more of the 9 years $1942-50$ in the basins of the Virgin, Little Colorado, San Juan, and Dirty Devil Rivers and of smaller tributaries that enter Colorado River below the mouth of Green River. In 3 to 5 of those years similar drought conditions prevailed in the basins of the Price, Duchesne, and Dolores Rivers. However, the basins of the major water-producing tributaries-the Green, Yampa, Colorado, and Gunnison Rivers-received approximately normal precipitation throughout the 9 years.

The change in the annual sediment-runoff relation since 1941 may well be a product of drought: reduced streamflows in sediment-producing tributaries and corresponding reduction in contribution of sediment from them, in association with normal streamflow from the high headwater areas in Colorado, Wyoming, and northern Utah.

This explanation-that drought may cause sediment loads smaller than expected by the usual sediment-runoff relations-appears to conflict with the conclusion on page 237 that the sediment loads are greater than normal in drought years. It is evident that the evaluation of the effects of drought cannot be made from general information for the entire basin, but must have specific data on the subdivisions of that basin.

\section{VARIATIONS RESULTING FROM WATER DEVELOPMENT}

The existing developments of water in the drainage basin tributary to Lake Mead consist of diversions from the main stem above Grand Junction, Colo., and from tributaries. The natural distribution of flow of the river is essentially unmodified by these developments, for the aggregate storage capacity of existing reservoirs serving the Colorado River basin above Grand Canyon is less than 1 million acre-feet. 
These developments deplete the flow of the Colorado River at Grand Canyon by an amount estimated at more than 2 million acre-feet annually. The effect of this depletion upon the transportation of sediment through Grand Canyon is not known to the writers. Obviously the diverted water cannot transport sediment through the canyon, but that water may have been involved in erosion and sediment transportation prior to its diversion from the river, and thus may have had an indirect influence upon the sediment load at Grand Canyon.

Full development of the water resources of the Colorado River basin will require several large dams upstream from Hoover Dam (U.S. Bur. Reclamation, 1946, 1950). Two of the proposed dams would be on the main stem. The Bridge Canyon dam would be 120 miles upstream from Hoover Dam, in Lower Granite Gorge just above the high-water level of Lake Mead; with a height of about 700 feet, it would form a reservoir with 3.7 million acre-feet capacity. The proposed Glen Canyon dam would be 370 miles upstream from Hoover Dam, and would rise 580 feet above the present river bed; its capacity would be about 26 million acre-feet.

The proposed Bridge Canyon reservoir would intercept all the sediment flowing past the Grand Canyon gaging station and thus would reduce the sediment inflow to Lake Mead to the small quantities contributed by the Virgin River and ephemeral tributaries to the lake- a contribution that currently amounts to less than 5 percent of the total. However, the capacity of Bridge Canyon is so small that it could assume this sediment burden for only a relatively short time: its water-storage capacity is about 12 percent of that of Lake Mead, and if sediment storage and compaction in the two reservoirs are proportional, the Bridge Canyon reservoir would take about 12 billion tons for complete filling, or about 6 times as much sediment as was carried into Lake Mead in a 14-year period. To prolong the useful life of this reservoir, current plans envisage the construction of the Bridge Canyon dam after sedimentstorage facilities have been provided in Glen Canyon.

The sediment-storage capacity of Lake Mead might be reduced slightly by operation of the Bridge Canyon dam, which is planned at mile 237 below Lees Ferry. It has been predicted (p. 216) that as sediment accumulates in Lake Mead the head of the Colorado delta will migrate upstream, and will be at mile 221.5 (15 miles above the Bridge Canyon damsite) when the lake is completely filled with sediment. Experience at Hoover Dam and at Parker Dam (Stanley, 1951) shows that clear water released from a dam is likely to erode the channel below the dam and carry sediment downstream. Thus some of the sediment that would be deposited above the Hoover Dam spillway level might be washed down into Lake Mead by releases from the Bridge Canyon dam.

The proposed Glen Canyon reservoir also would intercept all the sediment that now moves toward Lake Mead, except for the quantities contributed by the Virgin and Little Colorado Rivers, and minor tributaries that contribute very little water but are likely to have high concentrations of sediment when they do flow. The record from the Lees Ferry gaging station indicates the suspended load that would be intercepted by the Glen Canyon dam 15 miles upstream; but there are no data for estimating the bedload that passes the station. In 6 years of contemporaneous records, the suspended load at Lees Ferry averaged 80 percent of that measured at Grand Canyon.

The proposed Glen Canyon reservoir (U.S. Bur. Reclamation, 1950) is comparable in magnitude with Lake Mead. It will have about 90 percent of the waterstorage capacity upon completion, and its maximum water depth and water-surface area will be almost as great as those of Lake Mead. Inactive storage in Glen Canyon (that is, storage space below the level of the lowest outlet) will be almost twice that in Lake Mead. Its probable sediment-storage capacity has not been calculated on the basis of the findings of the Lake Mead survey but is presumed also to be similar to that of Lake Mead.

Obviously the construction of Glen Canyon dam, and the interception of more than 75 percent of the sediment load that now moves into Lake Mead, would prolong the life of Lake Mead by several centuries. Lake Mead would necessarily outlive the Glen Canyon reservoir umless the Glen Canyon dam were constructed and operated so as to pass large quantities of sediment downstream. With both reservoirs in operation, any estimate of the life of each would require collection and analysis of additional data.

In addition to the Glen Canyon dam, nine other dams have beem proposed in the Colorado River storage project (U.S. Bur. Reclamation, 1950). These are all upstream from the area that yields the bulk of the sediment to the Colorado River, and according to the preliminary estimates made for the Colorado River storage project, all of them combined would intercept only about one-fourth as much sediment as Glen Canyon. So far as interception of sediment is concerned, these reservoirs will add little to the life of Glen Canyon reservoir or Lake Mead.

There remains the question as to the effect of regulation and use of water within the Upper Basin, which is the prime purpose of the Colorado River storage project. By the terms of Article III of the Colorado 
River Compact, the Lower Basin was given the right to exclusive beneficial use of waters of the Colorado River system amounting to 7.5 million acre-feet per annum, plus the right to increase its beneficial use of such waters by 1 million acre-feet per annum. The treaty with the United States of Mexico requires deliveries across the international border of 1.5 million acre-feet of water, from surplus if available, but otherwise to be supplied equally from waters previously allocated respectively to the Upper and Lower Basins. Thus the average annual deliveries to the Lower Basin as computed for the compact point at Lee Ferry may be reduced ultimately to 7.5 million plus 1 million plus 0.75 million acre-feet, a total of 9.25 million acre-feet. Compared with average annual flows of 12.4 million acre-feet at Lee Ferry in 1935-48, this is a reduction of about 25 percent.

In evaluating the effect of these upstream reservoirs and subsequent development and use of water in the Upper Basin upon sediment accumulation in Glen Canyon and Lake Mead, the following points should be noted: (1) The reduction in annual runoff will cause some reduction in sediment transportation, according to the sediment-runoff relations that have been observed. (2) Regulation by upstream reservoirs will probably insure more uniform distribution of runoff throughout the year. Because of reduction in April-July peak flows, the quantities of coarser (sand-size) particles in the suspended load in those months will probably be reduced. (3) With regulation, the minimum (AugustMarch) flows may be no less than those recorded in the past, and may be substantially greater, even though the annual runoff is reduced 25 percent. Thus the river will be capable of carrying high concentrations and high total loads of silt and clay-sized particles in some periods. (4) If the proposed Coconino and Navajo dams are constructed on the Little Colorado and San Juan Rivers, respectively, they will intercept a considerable proportion of the sediment coming from the Four Corners area; otherwise the tributaries draining that region will continue to carry large sediment loads into the main stem.

\section{VARIATIONS IN RATE OF SEDIMENT OUTFLOW}

The life of Lake Mead will be prolonged if some of the sediment is permitted to pass through the reservoir and dam and continue downstream. At the present time, of course, there is no possibility of passing sediment through the intake towers, and there is little likelihood of doing so in the near future because the water is usually clear at the lower gates of the intake towers.

The sediment surface at the dam rose to its highest recorded level in 1941, and was then 130 feet below the sills of the lower gates of the intake towers. In the following decade the recorded sediment level ranged from 140 to 175 feet below those sills (fig. 24). At some time in the future it is inevitable that the sediment surface will approach the sills, and it will then become a question of operational policy whether to cease using the lowest reservoir outlets or to draw sediment-laden water through them. It was stated (p. 226) that passage of silt and clay through the turbines will not cause undue mechanical trouble.

As estimated on page 224, the sediment surface at the intake towers will rise to the sills of the lower gates when the total weight of sediment accumulation reaches 13.5 billion tons. This is about 7 times as much as accumulated in 1935-48, and if the rate of accumulation does not change, almost a century will be required for its accumulation.

Even if passage of sediment-laden water through the lower gates is accepted as normal procedure, the outflow of sediment will be nil for several decades, while the sediment surface rises toward the 895 -foot level. Then one can expect sediment outflow, occasionally at first as a result of exceptional turbidity currents, then more frequently and with greater volumes of sediment as the sediment surface in Boulder Basin continues to rise. Ultimately the sediment surface may develop a slope which would permit a large fraction of the finer materials to flow out of the reservoir.

The problem of sediment outflow through the upper gates at 1,045 feet elevation is analogous; but it is conditioned upon the closing of the lower gates when the sediment surface approaches them, so that sediment continues to accumulate near the dam. As pointed out on page 223 , the sediment surface may still be slightly below the sills of the upper gates at the halfway point when the weight of the accumulated sediment becomes 18 times as great as the quantity deposited from $1935-$ 48 , even with no sediment outflow from the reservoir.

\section{PROBABLE RATES OF SEDIMENT ACCUMULATION IN THE FUTURE}

From the foregoing discussion, the following conclusions are believed to be warranted as to the future rates of sediment accumulation in Lake Mead:

1. The average annual rate of suspended-load transport at Grand Canyon in the 14-year period 1935-48 was 142 million tons, and this rate is well confirmed by the calculated total of sediment accumulated in Lake Mead during the period. However, the quantities calculated by both methods are probably 3 to 5 percent less than the total sediment deposited in the lake in the 14-year period. The error in suspended-load measurements results chiefly from the omission of unmeasured 
loads of the Virgin River and other minor tributaries to the lake, whereas the error in measurement of the quantity of sediment accumulated in the lake results from the omission of unmeasured amounts of sediment deposited during the 1935 and 1948 surveys. The uppermost graph of figure 64 is based on the assumption that sediment accumulation will continue at the rate of about 148 million tons a year, or 4 percent more than the average annual suspended load at Grand Canyon during 1935-48.

2. The average annual rate of suspended-load transport at Grand Canyon in the last 7 years of this 14-year period was only 104 million tons per year, but this reduced rate is attributed to exceptional climatic variations within the basin and is not considered to be indicative of future trends. Inclusion of the data for these 7 years has of course lowered the average annual rate in the 14-year period.

3. The average annual suspended-load transport at Grand Canyon in the 25-year period 1926-50 was 168 million tons, and if a 4-percent allowance is made for unmeasured contributions to the river above Black Canyon (as in 1935-48) the estimated average rate of sediment inflow to the Lake Mead area would be increased to 175 million tons a year. Most of the graphs of figure 64 are based on a projection of this rate.

4. Correlation of sediment records at Grand Canyon and at Yuma is considered to be too weak to justify conclusions as to rates in years prior to 1926 .

5 . The average annual runoff in the 25 -year period 1926-50 was only 2 percent greater than in the 14-year period 1935-48. There is evidence from tree-ring studies that the long-term average virgin flow of the Colorado River at Grand Canyon is of the order of 15.8 million acre-feet annually, which is slightly less than the average obtained from extended records of streamflow in 1895-1950, corrected for stream depletions. With current depletions, however, the estimated long-term average at Grand Canyon is about $13.6 \mathrm{mil}-$ lion acre-feet a year. The 1926-40 curve on figure 22 offers a possible sediment-runoff relation, based on 15 years of record : with average annual runoff of 13.6 million acre-feet the average annual sediment load would be of the order of 200 million tons, which, when increased 5 percent for other sources of sediment, gives a long-term average sediment inflow of 210 million tons. The basis for this estimate is weak, because of the great uncertainty as to the sediment-runoff relation.

6. The Glen Canyon reservoir, if constructed, will intercept more than 75 percent of the sediment moving toward Lake Mead; together with Bridge Canyon reservoir it will intercept about 95 percent of it, until the two reservoirs start spilling sediment. Upstream development and use of water may reduce the sediment inflow to these two reservoirs by about 25 percent.

7. After the sediment level at Hoover Dam has risen to the level of the lower outlet gates, silt and clay can be passed through the turbines until the rate of sediment outflow approaches one-half the rate of sediment inflow.

The graphs of figure 64 demonstrate the variation in estimates that have been based on various assumptions as to the future. More significantly, they show that the benefits of Lake Mead will be felt for centuries to come, and that the usefulness of the reservoir will not be seriously impaired for as long a time as is predictable in this day of rapidly advancing science.

\section{MISCELLANEOUS CHANGES IN RESERVOIR VOLUME}

In the preceding chapters, numerous minor changes since 1935 in the configuration of the bed and banks of Lake Mead have been discussed. Some of these modifications have caused increases or decreases in the water-storage volume at certain reservoir levels without changing the over-all storage capacity-for example, the erosion of some parts of the reservoir floor and redeposition elsewhere within the reservoir (p. 209), and the slumping of walls below the high-water line (p. 209). Other modifications have changed the overall storage capacity, as for example the downwarping of the earth's crust (p. 37), the compaction of loose materials forming the original floor of the reservoir (p. 36), and the dissolving of gypsum and rock salt (halite, sylvite, and other mineral salts) (p. 212). In comparison with the major changes in water-storage volume caused by sediment accumulation, all other changes to date have been insignificant (p. 70-71).

\section{DOWNWARPING OF THE RESERVOIR FLOOR}

The weight of water in Lake Mead caused enough downwarping to be measurable in 1941, when the lake held about 85 percent of its capacity. The downwarping was greatest in the crustal blocks adjacent to the Boulder and Virgin Basins but amounted at most to only a few inches, and it was concluded that the resulting net changes in reservoir volume were very small (p. 38).

As the reservoir fills with sediment, the total load upon the earth's crust will increase to almost twice the load that resulted from filling the lake to capacity with water. However, any change in reservoir volume will depend upon the differential settlement of the reservoir floor with respect to the dam, and upon the effect of differential crustal movements independent of the reservoir. 


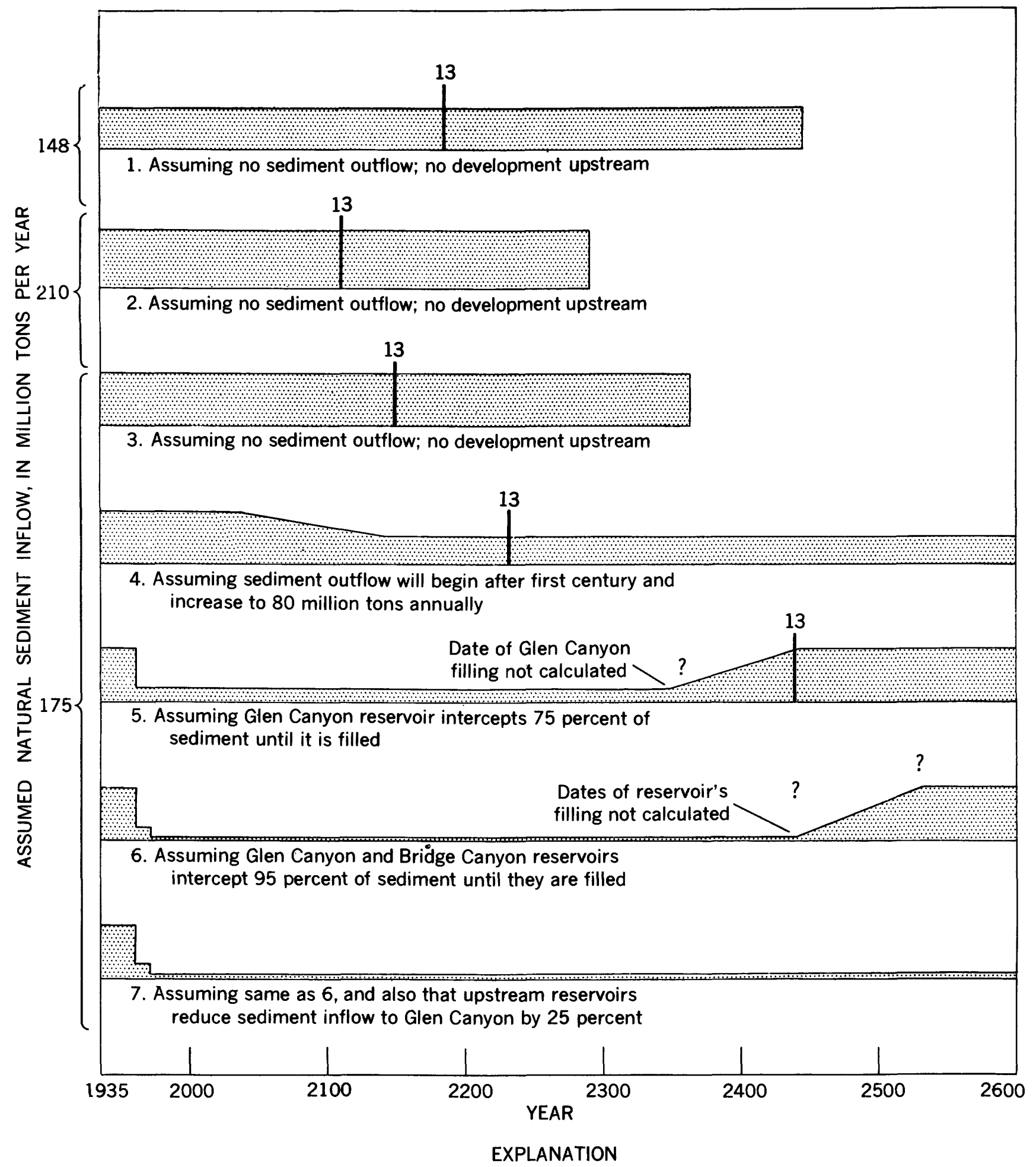

Width of bar is proportional to net rate of sediment accumulation

13

Indicates time when water-storage capacity is reduced

to 13 million acre-feet

Figure 64.-Actuarial projections for Lake Mead. showing estimated dates when it will be completely filled with sediment. 
Most of the reservoir, particularly the broad basins, is underlain by unconsolidated clay, silt, sand, and gravel. The details of the composition and thickness of these materials are unknown, and no surmises have been made as to the compaction that may result from the burden of water or of sediment in the reservoir. The methods used in the 1948 hydrographic survey were such as to measure the net change in water-storage volume since 1935 . Thus consideration of any compaction of underlying unconsolidated materials, if measurable, would result in a lesser computed volume of sediment than the actual total.

\section{DISSOLVING OF MATERIALS OF THE RESERVOIR FLOOR}

About 20 million tons of material, chiefly gypsum and some halite, was dissolved from the reservoir bed and banks by the lake water in the period $1935-48$, and it was estimated that this solution increased the volume of the reservoir by about 6,100 acre-feet (p. 213). It might be expected, however, that the rate of solution would be greatest in the early years of reservoir history, when the soluble outcrops are most accessible to the lake water, and would decrease progressively as solution progresses farther into the soluble rock, or as those rocks are covered and protected by sediment, and other inorganic and organic material.

The records of dissolved solids in the inflowing and outflowing water give some indication as to the relative rates of solution since 1935 . The weighted average salinity of the water at Grand Canyon is shown graphically in figure 65 for each year, beginning with 1935. Another graph shows the 3-year progressive average salinity - that is, each point represents the average of the preceding 3 years - on the premise that the reservoir is large enough to store and mix the water from as much as three years of inflow. The trend of this 3-year progressive average is similar to the trend in weighted average salinity of the outflow, also shown in figure 65, except in 1941 when the inflow amounted to about two-thirds of the reservoir capacity. From 1937 to 1945 the average salinity of the outflow was 15 to 25 percent greater than the 3-year average
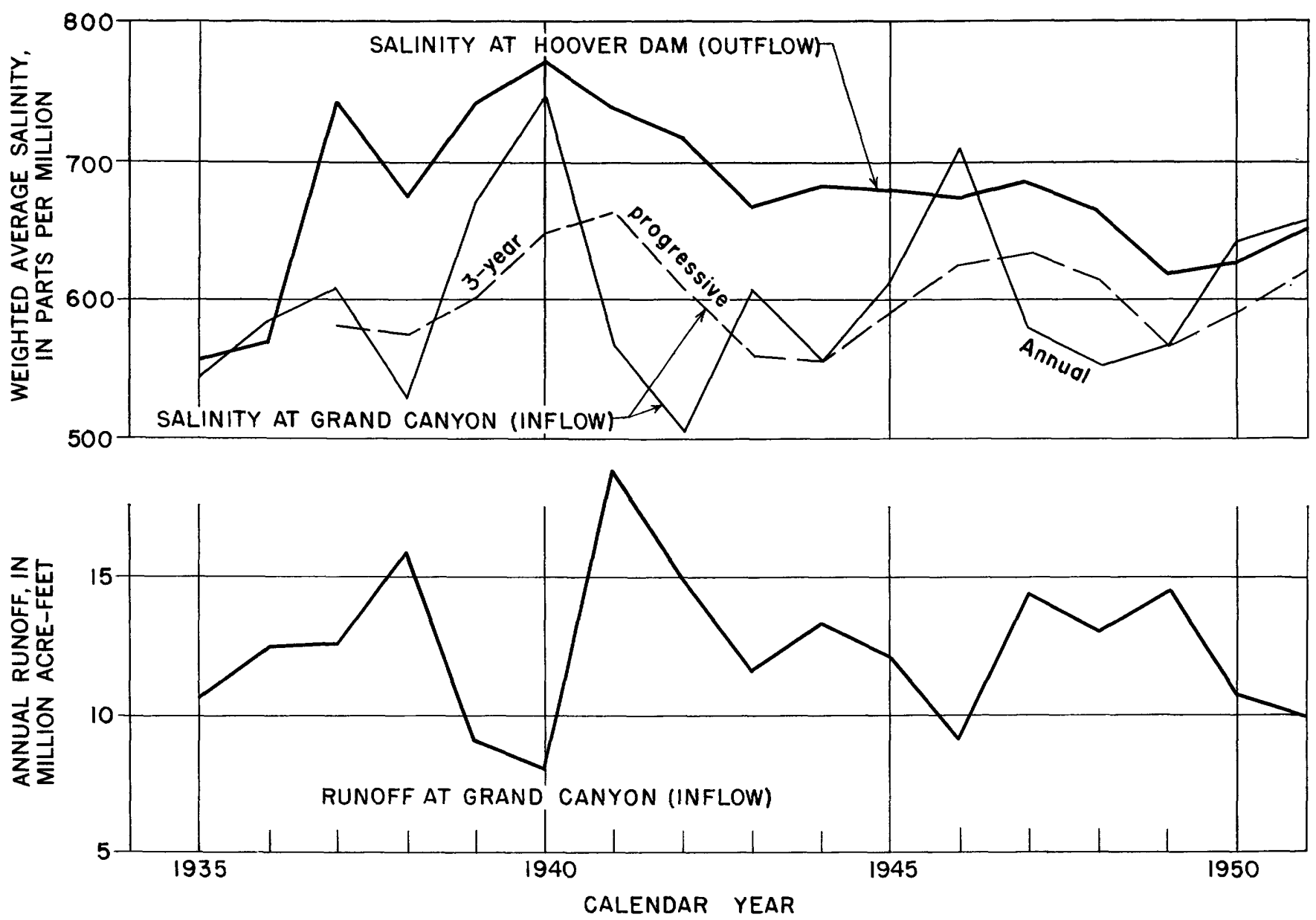

Figure 65.-Weighted average salinity of inflowing and outflowing water of Lake Mead since 1935. 
salinity of the inflow, but it has been only 7 to 9 percent greater in each year since 1946.

So far as can be discerned from these data alone, it thus appears that the rate of solution of gypsum was greatest in the first decade of reservoir history. Since 1946 the salinity of the outflowing water has been somewhat greater than the 3-year average of the inflow, but that increase can be accounted for largely by evaporation and by unmeasured inflow to the reservoir. Thus the prospects for even a slight increase in reservoir volume by such dissolving action in the future are not bright. However, the quality of the outflowing water in the future should be only slightly inferior to the 3 year average inflow, and it is possible that the salinity of the annual outflow will not again exceed about 700 ppm until and unless there is a significant and sustained increase in dissolved solids in the inflowing water.

\section{REFERENCES CITED}

Benedict, P. C., 1944, Preliminary field tests of the United States sediment-sampling equipment in the colorado River Basin: Mimeo. rept. in files of U.S. Geol. Survey, Iowa City, Iowa, $10 \mathrm{p}$.
Daines, N. H., 1949. Study of suspended sediment in the Colorado River: U.S. Bur. Reclamation, Hydrology Division, mimeo. rejt., $26 \mathrm{p}$.

La Rue, E. C., 1925, Water power and flood control of Colorado River below Green River, Utah: U.S. Geol. Survey Water-Supply Paper 556, $171 \mathrm{p}$.

Leopold, Luna, and Maddock, Thomas, Jr., 1953, The hydraulic geometry of stream channels and some physiographic implications: U.S. Geol. Survey Prof. Paper 252, 56 p.

Schulman, Edmund, 1945, Tree-ring hydrology of the Colorado River Basin: Ariz. Univ. Bull., v, 16, no. 4, 51 p.

Stanley, J. W.. 1951, Retrogression on the lower Colorado River after 1935: Am. Soc. Civil Engineers Trans., v. 116, p. 943958.

Stevens, J. C., 1946, Future of Lake Mead and Elephant Butte Reservoir : Am. Soc. Civil Engineers Trans., v. 111, p. 12421254.

U.S. Bur. Reclamation, 1946, The Colorado River: Washington, p. 279-281.

1950, Colorado River storage project and participating projects: U.S. $83 d$ Congress. House Doc. 364.

U.S. Geol. Survey, 1954, Compilation of records of surface waters of the United States through September 1950; part 9-Colorado River basin: U.S. Geol. Survey WaterSuplly Paper 1313, 733 p.

U.S. Dept. Interior, 1951, The drought in the southwestern United States as of October 1951: Washington, $65 \mathrm{p}$.

U.S. Weather Bureau, 1952, Climatological data, National summary : Annual 1951, v. 2, no. 13, p. 8, Asheville, N.C. 


\title{
U. THE SEDIMENT PROBLEM IN RESERVOIRS
}

\author{
By Thomas L. Maddock, JR., U.S. Bureau of Reclamation
}

The accumulation of sediment in reservoirs has long been recognized as one of the principal problems involved in the Western United States in providing for regulation of rivers by storage. Even the rivers in humid regions carry some sediment, and in several reservoirs in the eastern half of the country the accumulation of sediment is a significant engineering problem. More than 50 years ago F. H. Newell of the Geological Survey-later to become the first Director of the Reclamation Service (now the Bureau of Reclamation) wrote: "Thus, the upper ends of all reservoirs are rapidly filled with silt and it becomes an important question to the projectors of storage works as to how many years will elapse before the value of the reservoir is practically destroyed and whether its use can be restored in part by subsequent removal of some of this material."

To answer part of the question posed by Newell, the Geological Survey undertook, from 1904 to about 1910, what today would be called a miscellaneous sedimentsampling program on many streams in the West, particularly those whose load of sediment was obviously great. For a long time, records collected during this period formed the basis for estimates of the sediment load of western streams, and such estimates in turn provided the basis for decisions as to the amount of reservoir capacity to allocate to sediment storage and for estimates of the useful life of proposed reservoirs.

The greatest interest centered in the rate of sediment movement in the Rio Grande and Colorado River basins, perhaps the two streams most heavily laden with sediment in the country. Reports by Stabler (1911), Follett (1913), and Fortier and Blaney (1928) are the best known studies of sediment load in these two streams. The early estimates of sediment movement appear to be surprisingly good and reflect the ability and good judgment of those engaged in the early development of the water resources of the West.

In the light of more recent data, the estimates of average sediment load were generally somewhat high, and the predictions of reservoir life thus appear to be conservative. In 1899, the sediment load of the Gila River at San Carlos, Ariz., was estimated to average

$4969180-60-17$
8,440 acre-feet per year, but the observed rate of deposition in San Carlos Reservoir on the Gila River in the period 1928-47 was 3,200 acre-feet per year. In 1913, the average annual sediment load of the Rio Grande at Elephant Butte Reservoir, N. Mex., was estimated to be 19,700 acre-feet; the observed rate of accumulation in Elephant Butte Reservoir in 1915-47 was 14,400 acre-feet per year. Prior to the construction of Hoover Dam the sediment load of the Colorado River was estimated to be 137,000 acre-feet per year, but the 1948-49 survey has shown the average annual rate of accumulation to have been about 102,000 acre-feet. In nearly all cases present estimates promise a greater length of life for major western reservoirs than those made prior to 1930 .

This encouraging news does not allay the problem of sedimentation in reservoirs, but merely puts off the day of reckoning. Commonly sedimentation is a minor problem during the first years of operation of a reservoir, but as the water-storage facility is used by succeeding generations the problem becomes of progressively greater significance and concern. Sooner or later the water users ask the questions: How long will the reservoir continue to be of use to them; what can be done to increase that economic life; will there be diminution or deterioration of their water supplies (and, if so, when and how much); and what alternatives are available for meeting their continuing requirements?

These questions cannot be answered merely from an analysis of records of the rate of movement of sediment into reservoirs, even if those records were complete and accurate, which they are not. Also, detailed information is essential as to the mechanics of transportation and deposition of sediments in reservoirs, which is obtained by comprehensive surveys such as the one undertaken in Lake Mead during 1948-49. In part, the answers would depend upon an understanding of the dynamics of sedimentation, including erosion and transportation in the tributary watershed as well as deposition in the reservoir.

It is difficult to predict the useful life of a reservoir even if the rate of sediment movement into the reser- 
voir is known. This difficulty comes about partly because the rate of sediment movement in streams is measured by weight, and the weight of the sediment must be converted into space occupied. The conversion factor as found by reservoir surveys is not constant because the sediment becomes more compact as it dries and as deposits deepen. The space occupied by a given weight of sediment, therefore, will vary with the type of reservoir operation and the age of the reservoir. This is one of the reasons why successive volumetric surveys of a reservoir tend to show decreasing rates of sediment accumulation.

In the United States there is no experience to guide any estimate of how rapidly a large reservoir will fill to the last stages of its life. It is known that, as the capacity of a reservoir diminishes, more of the sediment load passes through without being deposited. It is known also that, as deposition in a reservoir proceeds, a considerable quantity of sediment is deposited upstream from the flow line of the reservoir. Here again experience is not yet a sufficient guide to a determination of the amount of sediment that will be deposited in such locations. Critical problems can result from upstream deposition, and some have been observed. However, what happens above a reservoir seems to be dependent on many factors, such as reservoir operating levels, the amount of the sediment load, the amount of water carried by the stream, and the potential for vegetal growth.

If the problem of determining the life of a reservoir is not a simple one, the value of preventing sediment accumulation in a reservoir is not easily determined either. The difficulty is complicated by the fact that reservoir storage may have different values from place to place, or from time to time. Streamflow generally must be regulated to be useful, and the degree of regulation desired is a measure of the reservoir storage required. Filling a reservoir with sediment does not destroy the value created by the falling water in power production and may even increase power production by holding a given amount of water at a higher elevation, although if regulatory space is lost the firm power production may be decreased. Loss of reservoir capacity is not of tremendous importance when ample supplies of water are available, nor is it of importance in the dry years when storage space will not be filled. But maintenance of reservoir storage is of tremendous importance in the transition from wet to dry years, and most western irrigation projects now under way contemplate holding over the surplus flows of wet years to make up the expected deficiency in dry years. Thus, irrigated acreage is directly related to reservoir capac- ity and must be decreased as the reservoir capacity is reduced.

If, then, irrigated acreage is dependent on reservoir capacity, what should be the criteria for project life? This is a question that has never been answered satisfactorily. With few exceptions, large reservoirs so far constructed in the West have economic lives well in excess of 100 years. The economic value of a reservoir during its useful life should be based, not only on the strictly economic benefits that are obtained from its construction as measured by comparison with costs, but on the intangible returns that come from a sustained irrigation economy in an area with little or no other development.

The possibility of prolonging the life of a reservoir hinges upon our success in developing economical techniques for either moving some of the sediment out of the reservoir or reducing the rate of sediment contribution to the reservoir. From our present state of knowledge it is apparent that by far the greater part of the incoming sediment load must be trapped in a reservoir in the early stages of its life, and that the movement of sediment out of the reservoir will be uneconomical, because of cost of removal as compared with cost of storage or because of undesirable use of water. Because the early studies made it perfectly clear that the sediment load of streams would eventually reduce or deplete reservoir capacity and render reservoirs of limited or no value, there has been considerable interest in means of evacuating sediment from reservoirs. Many proposals for methods of sediment removal were made, from sluicing to dredging. None of the methods proposed has ever been put to practical use in the West.

Operation of Elephant Butte Reservoir on the Rio Grande, Lake Mead on the Colorado River, and Conchas Reservoir on the South Canadian River brought the phenomenon of density currents to the fore. It was clearly evident that some flows, heavily laden with sediment upon entering a reservoir, plunge beneath the surface water owing to their greater density and travel long distances downlake practically intact. Density currents are responsible for the deposition of sediments of low weight per unit volume that occupy a relatively large amount of space in the lowest parts of a reservoir, and they have engendered a considerable amount of interest and discussion concerning design of reservoir outlets expressly for evacuation of density currents. The fact that reservoir outlets are not yet so designed is due largely to two factors: (1) The movement of density currents is not yet fully predictable; and (2) the amount of water that must be released from the reservoir for such a purpose must be large. Studies of sediment movement and deposition in Lake Mead will aid in 
further understanding the density-current problem and so help to solve the problem of moving the greatest amount of sediment through the reservoir with the least use of water.

Prolonging reservoir life by reducing sediment inflow is dependent on the potentiality for reducing erosion and sediment movement in streams through watershed control. It is unfortunate that knowledge is so limited regarding the effect of watershed management in terms of reduction of sediment movement in streams. It is known that relatively small areas within western drainage basins contribute disproportionately large quantities of sediment to streams. Within these areas the factors of geology, soils, topography, vegetation, and climate are as critical, from the standpoint of sediment production, as anywhere in the United States. Many of these areas are practically uninhabited and have little present economic value, but they are of considerable local importance; because they are largely within the public domain or Indian reservations, their administration poses many problems for the agency responsible for their use.

It should be stated frankly that not enough is known about the erosion problem to evaluate fully a management program. For example, how well do present rates of sediment movement represent the rates to be expected over a long period of years? Is the long-term rate more or less than the present rate? What stage of gully development provides the greatest amount of sediment load to streams; and in what stage of gully development are we at the present time? To what extent can vegetation be increased in areas of low rainfall; and to what extent will such increases reduce rates of runoff and erosion? These and many other questions cannot be answered at the present time. They will be unanswered for a long time in the future, unless impetus is added to the rate at which investigations are undertaken.

The effect of sediment accumulation in reservoirs upon the quantity and quality of the available water supplies is not apparent at first glance. It should be pointed out that all reservoirs exact a certain water cost for their storage facilities, by reason of evaporation from their water surfaces. As water evaporates, there is some increase in concentration of dissolved solids in the water remaining in the reservoir. In areas where the average evaporation exceeds the average precipitation, therefore, the water in the stream is diminished in quantity and deteriorated in quality by reservoir storage.

Evaporation losses in the West are high, varying from location to location but probably averaging about 50 inches per year. Thus for every acre of exposed water surface in a reservoir, enough water is lost to irrigate as much as two acres of land. The total area of water surface in western reservoirs is measured in thousands of acres, and the magnitude of the price paid for water stored, in terms of water loss, can be readily visualized.

Sediment accumulation in most reservoirs tends to increase the area of exposed water surface per unit of water stored. Thus reservoir sedimentation increases losses from evaporation. But of far greater importance is the fact that most sediment deposits are fertile enough to encourage growth of types of vegetation that consume large amounts of water. It is now considered that the loss of water from reservoir areas having heavy sediment deposits is practically constant from year to year, and that this is due to combined transpiration and evaporation demands and is not dependent upon the area of exposed water surface alone.

Water losses through transpiration can be reduced by providing drainage of the sediment deposits and a channel to carry the streamflow, but these also hasten the movement of sediment into the reservoir area and thus increase the rate of depletion of storage capacity. The whole problem of transpiration and evaporation losses from reservoir areas and from channel deposits upstream from reservoirs is so important that it is the subject of intensive study at the present time. The work now being done toward control of phreatophytic growth in the Southwest shows considerable promise, and water losses from this source may ultimately be shown to be controllable. Increased use of ground-water storage may reduce the amount of surface storage required, thus resulting in a lower loss of water through evaporation. Doubtless it is the fond hope of all water users dependent upon reservoir storage that, as the existing reservoirs become useless by sediment accumulation, new reservoirs can be formed to replace them. It is true that there are numerous damsites and reservoir sites not yet occupied, but their number is diminishing, and some have been rendered unsuitable by reason of development of more favorable sites. A case in point is the Boulder Canyon site, once studied and then passed over in favor of the Black Canyon site for Hoover Dam, and now untenable because it is within the area of sediment accumulation in Lake Mead.

Construction of new reservoirs and dams-even if sites were available - does not provide a satisfactory solution to the problem. With the construction of a new, alternate reservoir for storage, the water losses must inevitably increase, because the evaporation from the new water-surface area is added to the evapotranspiration from the abandoned, sediment-filled reservoir.

Future progress will be dependent on further study of the phenomena of reservoir sedimentation. The 
Lake Mead survey is a survey of but one of the many reservoirs in the West. Other reservoirs have been surveyed and the amount of data available for analysis is growing year by year. Investigations as complete as those at Lake Mead are expensive and can be undertaken only at infrequent intervals, but these serve the special purpose of increasing our understanding of the problems of reservoir storage.

\section{REFERENCES CITED}

Follett, W. W., 1913, Silt in the Rio Grande: El Paso, Tex., Internat. Boundary Comm.-Comm. Equitable Distribution of the Waters of the Rio Grande, $102 \mathrm{p}$.

Fortier, S., and Blaney, H. F., 1928, Silt in the Colorado River and its relation to irrigation: U.S. Dept. Agriculture Tech. Bull. 67, $94 \mathrm{p}$.

Stabler, Herman, 1911, Some stream waters of the Western United States: U.S. Geol. Survey Water-Supply Paper $274,188 \mathrm{p}$. 


\section{INDEX}

\begin{tabular}{cc} 
& Page \\
A & \\
\hdashline & v-vi
\end{tabular}

$\begin{array}{llr}\text { Acknowledgments............................ } & \text { V-vi } \\ \text { “Alkali problem," in irrigated downstream lands... } & 124\end{array}$ Alluviated basins ............................ 33; pl.4

Alluvium, Recent, dead storage of ............. 29-30 Ames, F. C., Hydrographic survey; summary of results. . .

Vertical control

See also Ullom, M. R.; and Speert, J. L.

Ames, F. C., Kennon, F. W., and Langbein, W. B., tables..................... 87-88

Amount of sediment in Lake Mead, average chemical composition............ 197-198

median particle size .................... 197

potential economic use................... 199-200

rate of sedimentation

volume.............................. 195

weight_................................... 195-196

See also Reservoir storage.

Analyses, chemical, bottom sediments, gas _... 191-192 chemical, lake sediments, water and air-dry moisture content ................... 153 water of inflow, outflow, and in basins. 108 physical, sediment particles .............. 153-154 statistical, water budget..................... 97-98

Anderson, E. R., and Pritchard, D. W., Circulation and evaporation......... 125-147

Area and capacity tables..................... 83-94

computation program

See also A mount of sediment in Lake Mead; and Reservoir storage.

Aztec sandstone, Valley of Fire....................

B

Bacterial activity, relation to heating of sediment.......................... 190-191

relation to hydrogen-ion concentration of water-...- 192-193

relation to sediment compaction

Bacteriology and biochemistry of the sediments......................... 187-193

bacterial populations, comparison with marine and natural lake sediments, raw sewage

migration.

189

physiologial groups. .........-189-190

techniques of study

total............ 188-189

biochemical oxygen demand ................ 190

effects of biochemical action............... 190-193

physical and chemical character............ 187

sampling and analysis_..................... 9

summary and discussion.................... 193

Bank storage at the lake, evaluation for water budget..................... 95, 99-102

future

Basin and Range physiographic province, relation to the lake.................. 22

tectonic instability in

Basin deposits, Tertiary ..................... 14-16

Basin management, for future control of sedimentation -

Basins of the lake, in computation of capacity and sediment..................... 88

sresific conductance of water -

Bedrock structure ......................... 18-20
Bendix Aviation Corp., report................. $\quad$ Pag

Biochemical action on bottom sediments, compaction......................... 192-193

effects

evolution of gas -........... 191-192

heating .................................. 190-191

Biochemical oxygen demand, measurement in bottom sediments 190-191

Black Canyon of the Colorado River, geologic setting - . Co........................

igneous complex ......................... 17-18

specific conductance of water in . . . . . . .

volcanic rocks. ...............................

Black Mountains, geologic history

rocks of

ntains area, block movement

ackman, Birt. See Geddes, R. P., Jr.

Blaisdell, W. C., Low-frequency depth-recording equipment ................ $59-66$

Borate, West End mine, Callville Basin........ 14-15 Boulder Basin of Lake Mead, geologic setting... 11 gypsum solution by lake ................ 212

Boulder Basin, reservoir storage data........... 88-93 triangulation net, 1917-48 ........ $45-46$

Boulder Canyon, Cambrian rocks............... 12-13 Cretaceous volcanic rocks . . . . geologic history

gypsum, Muddy Creek formation ......... 15

solution by lake water................ 118 post-1935 subsidence ......................... 33-35 quality of water.................... 118-119, 120 reservoir storage data.................... 88-89 rocks of ...

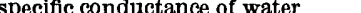

subsidence center......................... 33-37

Boulder Wash group

Bowen ratio .............................. 143

Bridge Canyon reservoir, sediment intercep-

tion . . . .

c

Calico salt mines, solution by lake water ..... 118, 123

Callville Basin, Cretaceous rocks near.......... 14 geologic history ............................ 20 igneous and crustal activity . ............. 17, 18 Muddy Creek formation . .................. 15 physiographic unit

West End borate mine.................. 14-15

Cambrian rocks.............................. 12, 12-13

Cane Springs bench mark ................... 31, 37

Carboniferous rocks, Grand Bay and Iceberg Canyon............................ pl

Grand Wash Cliffs...................... 13

Cenozoic rocks

Channel roughness........................... 237

Character of the accumulated sediment ...... 149-186;

analyses, chemical

analyses, density, porosity, and specific weight of particles gas volume in place.................. 154 particle size......................... 154-156 specific gravity of sediment particles.... 153

water and air-dry moisture content $\ldots \ldots$ calcium carbonate
Page

Character of the accumulated sediment-Con chemical properties........................ 183-186 clay minerals............................ 184 Colorado delta coring and sampling..................... 150-152 delta growth and structure delta physiography.......... 158-166; pls. 12, 20-24 delta texture and stratification density, porosity, and specific weight..... 153-154 distribution................................ 156-158 cores and samples.................... 149

from small tributaries.................... 158-159 gas content, deltas gas volume in place laboratory studies ........................ 152-156 methods of investigation.................. 149-152 organic content ............................ 185-196 organization of work and equipment........ $8-9$ particle size............................... 154-156 physical properties of the deltas.......... 173-183 specific gravity of particles................... 153 specific weight, deltas . . . spectrographic analyses.................... 184 temperature .............................. 181-183

Virgin delta water content and air-dry moisture content. 152-153 water content and porosity, deltas _....... 177-178 Character of the inflowing water....... 103-113; pl. 26 density currents........................ 109-113 dissolved solids, variations................ 108-109 sources suspended load, Colorado River......... 103-107 other sources temperature.............................. 107 See also Chemistry of the water.

Chemehuevi formation, altitude of ............ 16 character and distribution ................. 16-17

Chemical and physical properties, lake water... 9

Chemical changes, water within reservoir...... 122 Chemical character of the bottom sediment, Hoover Dam .................... 187-188 Chemical composition, Colorado delta....... 197-198 Chemical constituents of infiowing and outflowing water, comparison concentration by evaporation............... 123 precipitation ............................. 123 solution, bed and bank materials........... 123 stabilization by reservoir storage _............ 124

Chemical constituents of inflowing streams, source

Chemistry of the water............ 115-124; pls. 17, 18 concentration by evaporation ............... 123 dissolved solids, relation to temperature _. 119-121 variation in -.................... 115-119 effect of reservoir storage.................. 121-124 precipitation of dissolved constituents ...... 123 program of investigation.................. 115 quality, inflowing and outflowing water .. 121-123 solution of reservoir bed and bank materials_

124

Chinle formation......................... 14, 17

Circulation and evaporation.......... 125-147; pl. 18 See also Circulation in the lake and Evaporation from the lake. 
Page Circulation in the lake, general analysis . . . . . 127-128 observational program, stations and cruises.- 126127; $\mathrm{pl}, 18$ oceanographic techniques $\quad 125$ analysis of general and seasonal data.. 127-139 data of monthly cruises. . ...... 126-127; pl. 18 tonguelike distributions . . . . . Wüst's core method. ................. 126 seasonal analysis of data, fall $\ldots . . . . .134-136$ spring ............................ 128-131 summer ........ 131-134

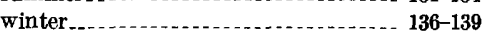
summary of patterns. . . . . . . . . . . . . . 139-140 temperature-salinity diagram............ 126,127

Climatic factors. . . .

Colorado delta, bottomset beds........... 164-168 chemical similarity to Mississippi River delta........................... 198

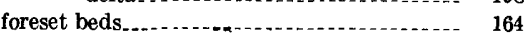
growth and structure physiography ........................ 158-165 relations of gas content, organic content, and temperature gradient. ........... 181

sediments of $156-157$

chemical analyses. . . . . . . . . . . . . . 183

organic content

specific weight of deposit. . . .............. $\quad 179$

topset beds.

ultimate slope and volume............... 215-217

vertical distribution of temperature, bottom. set beds. . . -

Colorado Plateaus province, Paleozoic and Mesozoic rocks. ...

relation to the lake................... 11, 22, 28

source of sediments . .

tectonic stability . . . .

Colorado River, channel in Lake Mead, change in slope and width.............. 206 channel in Lake Mead, cruise stations. ..... 127 freshets, effect on lake stage .............. 57 sediment distribution along. . ......... pl. 13

sediment eoring. ........................... 149

geologic history ........................ 20

loeation of basin.

Pleistocene character

sediment load to lake.................. 196-197

turbidity currents in Lake Mead ..... 202-206

Colorado River at Grand Canyon, annual runoff-suspended load relation, $1947-49$

future fiow.

sedimentation factors, seasonal variation, October 1947-February 1949. 106 suspended load....... 103-106 suspended-sediment sampling . . ...........

Colorado River Compact of 1922 allocation of water rights. . . . . . . . . . . . . 239-240

Colorado River Upper Basin, depletions ....... 235 development. . . . . . . . . . . . . . 238-241 sediment removed, 1911-1934_.............. 234

Communication facilities ...................... 10

Compaction of sediments, relation to bacterial and biochemical action . . . . _... 192-193 relation to subsidence................... 36

Consultants ....... v-vI

Control structures, construction and operation $\quad 5$

Convergence, Colorado River and Lake Mead. pl. 17

Colorado River and Lake Mead, chemistry of water......... 108, 118

circulation pattern

station locations, eirculation studies. $126 ; \mathrm{pl} .17$

Core sampling. See Equipment and instruments and Sediments.

Cretaceous rocks Cruise stations, circulation studies ..... 126-127; pl. 18 Cummings, G. B. See also Smith, W. O.

Cummings, G. B., and Mongan, C. E., Jr., Evaluation of the echo sounding .... 68-69

\section{D}

Davis Dam area, Chemehuevi formation......

Dead storage. See Bank storage; and Residual storage.

Deformation, effect on capacity of lake. .......

Hoover Dam area, relation to impounded water.

31-32

Muddy Mountains

See also Subsidence.

Deltas, erosion of front

upvalley extension of .

See also Character of accumulated sediment

and Colorado delts.

Density currents, definition. . . .............. 109

factor in future design of reservoirs....... . 246-247

Density currents in Lake Mead, antecedent conditions at Grand Canyon............ 111

at bottom of lake..................... 112-113 at cofferdam, sedimentation relative to . .... 113 at Hoover Dam 113 initial evidence, $1935-36 \ldots \ldots \ldots$. . . . $109-110$ investigations, 1936-49. . . . . . . . . . . . . 110-111 record of 111-113

relation to sediment surface in the lake . . 111-112

Devonian rocks, Grand Wash Cllffs

Dissolved solids, infiowing and outflowing water, relation to solution of lake-bed materials . . . . . . . . . . . . .

inflowing and outfiowing water, seasonal relation to discharge, Grand Canyon and Willow Beach gaging stations, 1934-35.

inflowing water seasonal relation to other sedimentation factors, Grand Canyon

lake water, concentration by evaporation .95 $116,121,123$

concentration in surface samples...... 116,118 effect of mixing in lake storage ........ 121,129 geographic variations .................. 118-119 movement with spring floods ........ 116, 118 precipitation of constituents. ........ 123-124 relation to soluble rocks of bed and

bank relation to water temperature......... 119-121

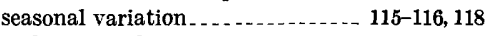
stabilization by water storage _.......... 124 stratification with depth

released water............................ 121

Diversions, below lake

Domestic use of water, significance of reservoir storage data . .

Drainage basin tributary to Lake Mead, effect of water development on river flow _ 238-240

general description.

geology.

-

physiography ......... 21-22

sediment $\ldots \ldots \ldots . . .24,26-30$

streamfiow $23,25-26$

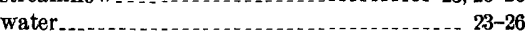

Drought, 1942-51, relation to suspended load.. 237-238

Echo sounding. See Sounding and Survey of the lake.

Economic use of sediments, potential _...... 199-200 Elastic yielding in bedrock, relation to subsidence....

Elephant Butte Reservoir, early sediment studies. upvalley extension of delta

Energy budget, advected energy .................. Bowen ratio

effective back radiation

energy storage

radiation from sun and sky

reflected sun and sky radiation

summary of terms.

Energy-budget equation.
17

Energy liberation by radioactivity ............ 191

Energy storage ................................. 143

Equipment and instruments, bathythermograph boats and hydrographic equipment.. 7-8, 9-10,149

Colorado River sampler, evaluation . . . . . 232-23\& conductivity bridge $\ldots \ldots \ldots \ldots \ldots$ depth-integrating sampler, D-43, evaluation $\ldots \ldots \ldots$....................... 232-233

depth-recording, $50 \mathrm{kc}$ U.S. Navy NGB-3......... 8, 65, 66-68; pl. 11 14.25 kc, U.S. Navy NJ-8... 8, 59-63, 68, 69; pl. 9 U.S. Navy NK-6 portable _.......... 8, $63-64,66,68 ; \mathrm{pl} .10$ Foerst sampler . . . . . . . . . . . . . . . . 115, 151, 187 Hoover Dam permanent gage installation . $\quad 52$ Nansen bottle .......................... 115, 127 organization of............ 7-10 radiation counter. 191 Secchi disc . . . . . . . . . . . . . . . . 126, 127, 128, 132 shore signal......................... 42; pl. $5 B$ temperature-measuring, for bottom sedi-

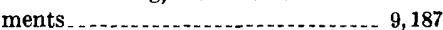

transit, Wild T-1 repeating water-stage gages, permanent and auxiliary _. 52,53 water-stage recorders. . ................. 7,53

Erosion, amount required for filling lake .......- $\quad 228$

Erosion, at shore, evidence obtained............ 71 in tributary drainage basin, requirement for filling lake...................... 228-229

Erosion in the reservoir ..... 209-213; pls. 16, 24, 27-29 landslides.................... 209, 212; pls. 1, 27, 28 solution, bed and bank materials . . . . . . . 212-213 surface of delta front .................... 213: pl. 24

Evaporation from the lake, calculation of rates. 143-145 comparison of calculated and pan-evaporation rates ......... 145-146 concentration of constituents by ........... 123 effect on water loss and quality .......... 247 energy budget.................. 141-143 evaluation for water budget ........... . 97, 98-99 relation to accumulated sediment............ 247 techniques for determining F

Fall, salinity and clrculation patterns in

lake

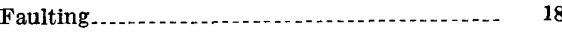

Faults, Grand Wash

present movement along

relation to level divergences . . . . . ......... 33

Field facilities. ............................. 7-8

Flocculation, in turbid underfiows............ 206

Flood control and river regulation, significance of reservoir storage data . . . . . . . . 83,84

Fortification Hill, altered lava ............... 18

Fossils, marine, Paleozoic rocks................... tree trunks, shinarump member, Valley of

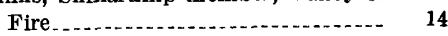
G

Gas, evolution in bottom muds, by bacterial action ........................... 191, 192

See Character of accumulated sediments, gas content and gas volumes.

Geddes, R. P., Jr., and Blackman, Birt, High frequency depth-recording equipment

Geodetic surveys .......... 31-38 first-order leveling, Cane Springs bench mark ........... 31, 37

1935 basis net, computations .......... 37,86 special adjustments................ 31 topographis maps. ................. 31, 37

1940-41 31 water storage during

1949-50 . 31-32 water storage during ............... 31 organization of work and equipment...... 9 
Geologic history

Page

Geologic setting of Lake Mead........ 11-20; pls. 1, 2 Geology, tributary drainage basin of the lake . $_{22-23}$ Gila River, Ariz., sediment studies............. $\quad 245$ Glauberite, Muddy Creek area Glenn Canyon reservoir, upstream sediment interception ..................... 239-241

Gould, H. R., Amount of sediment Character of the accumulated sediment... 149-186 Erosion in the reservoir ................... 209-213 Sedimentation in relation to reservoir utilization ...................... 215-229 Turbidity currents. . . . . . See also Thomas, H. E.

Gradients, Colosado River 216 Carboniferous rocks, tilting ................ 18

Grand Bay, Lake Mead.

reservoir storage data.

origin .

physiography

Grand Canyon, Colorado River at relation of

Colorado River at, relation of monthly runoff to sediment load, 935-49..... 236-238 rocks of ................. 12,14

Grand Wash Cliffs rocks of -

Grand Wash fault zone, alluviation

Grand Wash trough..

Chemehuevi formation.

igneous rocks southwest of

Gregg Basin, Lake Mead..

reservoir storage data. ................... 88-93

Ground-water storage. See Bank storage.

Ground-water withdrawal, relation to Las Vegas cone of depression............

Gypsum, Muddy Creek formation, effect on quality of lake water. ...............

$\mathrm{H}$

Havasu Lake..

History, geologic

Hoover Dam.

3,11 intake towers, quality-of-water studies...... 119 lower outlet gates, sediment requirement for filling to permanent water-stage gage at.............. 52 discrepancies of record.............. 56 purposes........................... 3, 83-84

Hoover Dam area, Chemehuevi formation.... . 16-17 differential subsidence............ 37-38 igneous complex......................... 17

relation of sediment surface to density current............................. 112 temperature and salinity of lake water...... 119

Hoover Dam level net..................... 32, 38; pl. 3

Hoover powerplant.......................... 3,84

Hoover Dam reference datum, 1948-49 survey ... $\quad 38$

Horizontal control. See Mapping, Survey of Lower Granite Gorge; and Survey of the lake.

Horse spring formation, distribution and character. -

volcanic ash in

Howard, C. S., Character of the inflowing water.................... 103-113

Chemistry of the water

Hualpai formation. . . . . .

Hualpai Wash, landslides.............. 209; pl. 28

type section, Hualpai formation

Hydrogen-ion concentration, relation to sediment compaction .............. 192, 193

Hydrographic surveys.

Iceberg Canyon, carboniferots rocks, tilting _... pl. 2 Chemehuevi formation................. faulting . rocks....
Iceberg Canyon, topography

Page

Inflow, evaluation for water budget........ 95, 97,98

Inflowing and outflowing water, chemical constituents ................... 121-122, 123

Inflowing water. See Character of the inflowing water; and Chemistry of the water.

Instrumentation. See Equipment and instruments.

Interflow currents in the lake................ 203

Introduction......... $3-30$

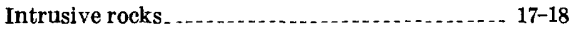

Irrigated acreage, relation to reservoir capacity _- 246

Irrigation, significance of reservoir storage data for

Jurassic rocks $\mathbf{J}$

\section{$\mathbf{K}$}

Kaibab limestone

Kennon, F. W. See Ames, F. C., and Speert, J. L.

L

Lake deposits, Horse Spring formation Muddy Creek formation Lake Heffiner, evaporation tests . . . . . . . . . . . . 98-99 Lake Mead, location, formation, and size ..... $\quad 3,4$ source of sediments the problem ..................... 3-5 topographic setting

Lake Mohave effect on storage capacity of reservoir....212; pls. 28,29

Langbein, W. B, Water budget See also Ames, F. C., and Thomas, H. E

Las Vegas Bay, solution and terracing by lake.. 212

Las Vegas cone of depression, relation to groundwater withdrawal.................. 34-35

Las Vegas Wash, Cretaceous lava................

Las Vegas Wash-Callville Basin area, Cretaceous rocks

Lees Ferry, discharge records extrapolation of runoff record.

Leifson, Gunnar, Survey of the lake _ $39-40$ Level changes since 1935, Boulder Canyon area. . . . . .

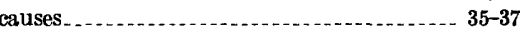
datum discrepancies, Lower Granite Gorge 74,76 effect on life of reservoir. . . . .............. 243-244 effect on reservoir capacity ............ $37-38$ future................................. 223 geologic features ......... 33 Hoover Dam level net................... 7, 37-38 measured and predicted, comparison ...... 37 pattern of development relation to structure . . . . . . . . . . relation to water and sediment load........ 35

Level net, relation to geologic features.......... 33

Leveling data .................... 31-32; pls. 3, 4 contours of altitude changes, 1935 to $1950 \ldots . . .34$ interpretation ........................ 33-39; pl. 4 pattern and profiles of divergences. . . .... 33; pl. 4

Life of the reservoir downwarping of floor effect of sediment compaction............. 242-243 evaluation of existing sediment inflow records.

forecast by observed rates of sediment accumulation ..................... 231-232 future rates of sediment accumulation . . . 240-241

Yuma-Grand Canyon correlations "normal" rate of sediment accumulation .. 232-240 rate of sediment outflow................ 240-241 solution of material of floor. . . . . . . . ... 243-24 techniques for prolonging..... water development upstream............ 238-240

Location of area
Longwell, C. R., Geologic setting of Lake Mead_ 11-20 Interpretation of the leveling data ........... 33-38

Lower Granite Gorge, compactness of sediment. $\quad 149$ cross sections, 1935 and 1948-49 ............ 77 floating survey base. $\ldots \ldots \ldots$ profiles of thalweg......................... 80 reservoir storage data ...................... 88-93 sediment sampling . . topography ...................... 73 ; pl. $16 A$

MeCall, Lt. C. C., Communications facilities sounding operations ...................... 58-59 Maddock, Thomas, Jr., The sediment problem in reservoirs . ................... 245-248

Manganese, Muddy Creek formation ........... 15 Mapping, bottom and surface sediments, organization of work and equipment.... $7-8$

projections .

See also Survey of Lower Granite Gorge and Survey of the lake.

Maps and charts, field computation for ......... 8

Mesozoic rocks. ............................... 14

Methane, evolution by biochemical action .... 191-192 chemical analyses

Metropolitan Water District of Southern California, cooperative investigations...

Middle Rocky Mountains physiographic province, relation to the lake...........

Mississippi River delta, chemical similarity to Colorado delta.

115

21

Moenkopi formation, Valley of Fire

Mongan, C. E., Jr. See Cummings, G. B.

Muddy Creek formation, basalt in ............ 18 effect of solution on storage capacity ...... 212-213 inundated saline beds.................... 15 manganese............................... 15 solution by lake water................... 118, 121 varied deposition and structure............ 15

Muddy Creek valley, Chemehuevi formation... 17 geologic setting. ............................. 11

Muddy Mountains, Cretaceous and Cenozoic deformation.

Cretaceous rocks near ...................... 18

Horse Creek formation, chemical precipitates in 14

Overton fanglomerate.................. 14

Napoleons Tomb, Hualpai limestone cap....... National Research Council, Committee on Density Currents, Eubcommittee on Lake Mead . . . . . . . investigations, 1937-46.......... 110-113 115 National-Simplex-Bludworth, Inc., report...... 59-63

$$
0
$$

Operations, comments on................... 9-10 Organic matter in bottom sediments, measurement by BOD tests. .............. 191 Organization of work and equipment Outflow, measurement for water budget ....... 95,97 Outflowing and inflowing water, chemical constituents. . . . . . . . . . . . . . . 121-122, 123

Overflow currents in the lake............... 202-203

Overton Arm, Lake Mead . . . . .............. 11 quality of water. .................... 118, 121, 123 reservoir storage data...................... 88-93 rock solution by lake ................. 118, 123, 212 specific conductance of water........... 115 Overton Arm area, Mesozoic rocks........... 14 Overton Arm triangulation net 1947-48 . . . . . . . 46, 49 Overton fanglomerate. . . . . . . . . . . . . . . . . . 14 Muddy Mountains................... 14 volcanic ash in ............................. 17 Oxygen-reduction potential, relation to sediment compaction................ 192, 193

Paleozoic rocks. ..................... 13-14 Pampel, L. C., Survey of Lower Granite Gorge _. 73-81 
Page

Parkin, E. J., Precise leveling . . ................ 31-32 Particle size, material transported by turbidity currents ..................... 206 median, in total sediment . . . . . . . . . . 196 suspended and deposited sediment...... 106-107 suspended sediment, Colorado River . . . 104-106

Permian red beds, Grand Wash Cliffs......... 13

Photography, underwater equipment ....... 9

Physical character of bottom sediments......... $\quad 187$

Physiography, tributary drainage basin of the lake.................. 21-22

Pierce Basin, Lake Mead ... . . .

reservoir storage data

Pleistocene deposits, Chemehuevi formation.... 16-17

Pleistocene Lake Chemehuevi, delta deposits in

depth relative to Lake Mead .............. 16

inflowing ancestral Colorado River ........ 16, 17

Pliocene rocks . . ............................ 15-16

Potholes and gravel deposits, altitude in Hoover Darn area_. . . . . . . . . 16-17

Power generation........................... 84

relation to reservoir capacity . . . . . . . . . . . 84, 246

Precambrian rocks

Precipitation, evaluation for water budget.. 97,99-102 patterns, 1942-51. . . . . . .

Precise leveling, ............ . 6, 7, 9, 31-32; pl. 3

Pritchard, D. W. See Anderson, E. R.

Profiles, thalweg of Lower Granite Gorge, 1935 and 1948-49.

Publications, reports in advance form .........

\section{$\mathbf{R}$}

Radiation, effective back.. 142 142 sun and sky . Radioactivity, in heating of bottom sediments...................... 191, 193

References cited ... . . ..................... 5, 10 $20,30,38,71-72,81,88,102,113,124,146-147$, $186,193,207,213,229,244,248$

Reservoir area, computation of . . . . . . . . table ................................. 89 Reservoir bottom, organization for mapping -.. 7-8

Reservoir capacity, computation of .......... 86-87 effect of subsidence on summary of changes, $1935-48$ table.

Reservoir filling, future critical stages.......... 219

Reservoir operation, predictions ... . . . . . . . 225-228

Reservoir storage................... 83-93

chemical changes of water in

computation for water budget.......... 96, 97, 101 effect on water quality . . . . . . . . . . . . . . . 121-124 junctions of Hoover Dam............... . . 83-84 sediment - 92-93 See alsn Amount of sediment in Lake Mead and Water budget.

Reservoir tables..... 89-93 computations, for 1948-49 survey . . ......... 86-87 original_......... phases of . . . . deseription of ............... 87-88 significance of ............................ 83

Reservoir utilization. relation to sedimentation . . . 215-229

Reservoir volume, by basins. 91 miscellaneous changes, relation to life of reservoir. 241244

Residual storage............................ 226-228 See also Bank storage.

Rio Grande River, sediment studies........... 245 River discharge, relation to turbidity currents.

\section{$\mathrm{S}$}

Saline deposits inundated by Lake Mead Salinity and thermal properties of lake water. organization of work

Salt domes, Virgin River valley

Saltcedar, Tamarix

Sediment, accumulated. See Character of accumulated sediment.

accumulated in Lake Mead, evidence obtained..............................

accumulation in reservoirs, effect on evaporation

effect on water quality

prevention . . . . . . . . 246............... 247

amount. See Amount of sediment in Lake Mead; Reservoir storage.

amount and distance transported by turbidity currents . ................. 205

average chemical composition concentration in Colorado River, evaluation of early computations ........... 233

estimation of "normal" rate . . _.......... 232-241

total volume, accumulated in Lower Granite Gorge ..................... 76-

accumulated in the lake $\ldots \ldots \ldots \ldots . . .92,93$

Sediment and auxiliary tables. ............. 92,93

computation of . 87

Sediment filling of Lake Mead, compaction _.. 217-218

complete . . . . . 219..................... 221 amount of erosion required . . . . . . 228

future pattern .

halfway estimation of amount accumulated.....- $\quad 223$ extent of delta deposits . . . . . . prediction of lake conditions............ $\quad 223$ water-storage capacity, inerease by gate operation........................ 223

terminal slope and residual storage . . . . $224-228$

to sills of lower outlet gates, Hoover Dam . . .......................... 223-221

Sediment in infiowing water, suspended and deposited load, correlation of sizes ... 106-107

suspended load from Colorado River.. 103-104, 107 particle-size analysis................. 104-106 seasonal relation to other sedimentation factors suspended load from other sources........ 107 Sediment in tributary drainage system, bed load.. 28-29 channel changes. ......................... 29

dead storage ............................. 29-31)

irregularity of transport . . . .

live storage ................................ 29

records of .

source of $\ldots \ldots \ldots$

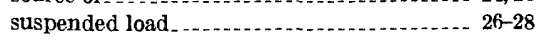

Sediment inflow, variations in rate . . ........ 234-240

Sediment load and runoff, effect on life of reservoir.

234-235

Sediment on bottom, bacterial populations in - 188-190 bacteriological studies . . . . . . . . . 187-188

biochemical oxygen demand ............... 190

compaction by blochemical action . ...... 192-193

effects of biochemical action . . . . . . . . . . 190-193

migration of bacteria . .

physical and chemical character ......... 187-190

relation of temperature to bacterial action. 187 ,

190-191

relation of temperature to radiation ........ 191

summary and discussion ............... 193

Sediment outfiow, variations in rate ......... 240

Sediment problem in reservoirs............ 245-248
Page

Sediment ranges, Lower Granite Gorge ........ 76;

pls. $14,15 B$

87,92

Sediment-runoff relations, factor in life of reservoir . . . . . 235-238

Sediment-storage capacity, above permanent spillway level . . . . . . . . 215-217 relation to water-storage capacity $\ldots \ldots \ldots$ terminal stage ......................... 224-228

Sedimentation, early studies $\ldots \ldots \ldots \ldots$

estlmation of rate $\ldots . . .191-197$

future pattern .......................... 218-228

in Lake Mead, control by outflow _ 225-228, 240-241 control by upstream reservoirs...- 239-240, 246 effect on life of reservoir . . . . . . . . 231-244 effect on utilization of reservoir. ..... 215-229

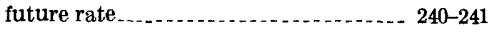
implication for the problem in reser-

voirs . . . .

in relation to reservoir utilization. ....... $215-229$

loss of storage by

Sedimentation dynamics, study required....... 245

Sedimentation and salinity surveys, cooperative program.......................

Sediments, extent and distribution, techniques of determination................. 7

physical and chemical character . ........ 187-188 particle size . . . . relation to bacterial and biochemical action.......................... 187-193 sampling operation and equipment..... $\quad 8$ techniques of determination.......... 7

Sediments in Lake Mead ..................... 149-248 accumulation rate, "normal" ............. 232-240 amount at complete filling _................ 231

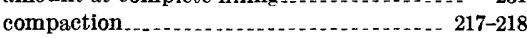
deposits at Hoover Dam in relation to density currents in lake............. 112-113 distribution. . . . estimated dates of complete filling .......... 242 inflow rate ........ 234-240 inflow records, evaluation . . . . . . . 232-234 outfiow rate . . . . . . . . . . . . . . . . $240-241$ particle size, distribution by lake areas _. . 197, 198 relation to Colorado River runoff and sediment load. .

sounding of eross sections............. pls. $15 B, 20$ temperature gradients in . ................. 152 the problem . . ungaged increments. . . . volumes in storage, $1948 \ldots \ldots \ldots \ldots$. . . . . $87-88,92,93$ See also Amount of sediment, Chalacter of sediment: Reservoir storage; Turbidity currents.

Sediments in Lower Granite Gorge, distribution. $\quad 78$.

measurement of cross sections ........ 76-78; pl. 15 See also Survey of Lower Granite Gorge.

Seiches, effect on water stage ............ 55-56, 57 Seismic activity in area, 1935-48. . . relation to reservior loading and sediment compaction................... 35-36, 74-75

Shoreline triangulation. . . .

shore signals..................... 42 ; pl

Sisler, F. D., Bacteriology and biochemistry of the sediments................... 187-193 Slope of lake surface, effect on wate stage _... $\ldots 56,57$ Slumping, at lake shore, evidence obtained . . . . . 70-71

in Virginia Canyon ................ 118, 209; pl. 27 Smith, W. O., Organization of the work and equipment.................... 7-10

Smith, w. O., Vetter, C. P., and Cummings, G. B., Summary of results.......... 1-2 Soluble rocks of area, relation to water quality ... 118 


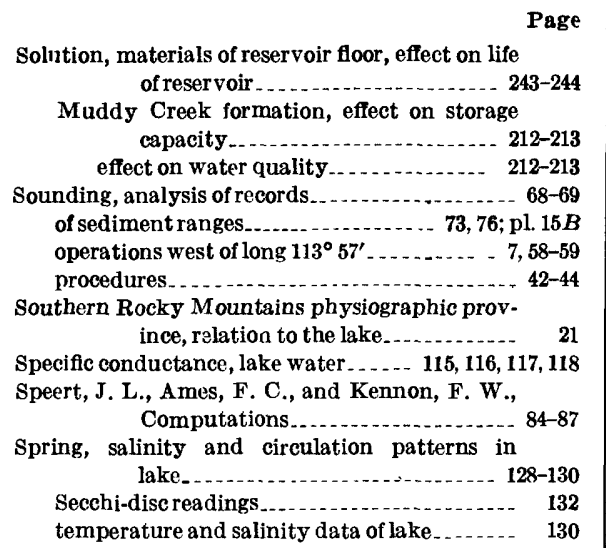

Stage, evaluation for water budget............. 96, 101

Stanley, J. W., Significance of area. capacity. and sediment tables................. 83-84 tables.......................... 83-84

Stratification of lake waters.

Stratigraphy of area......... 11-18

Streamflow entering the lake, water year $1948 \ldots \ldots$

Structure of bedrock . . . . . . . . . . .

- Subsidence. See Level changes.

Summer, salinity and circulation patterns in lake.............. 132-134

Survey of Lake Mead 1948-49 .......... 39-72; pls. 5-13 evidence obtained . . ................ 70-71 general procedure horizontal control, closure adjustments . fieldwork.

geodetic coordinates

geographic posit

map projection .

office computations

operations.

purpose

requirements

survey areas ......................... 45-51

triangulation. ............................ 44-51

plans and methods. . ... .......... 39-40

procedurcs, establishing horizontal control

sounding operations . . . . . . . $43-44,58,68,151$ analysis of records .

boat sheets and smooth sheets. ......... . . 42-43

depth-recording equipment, high-frequency low-frequency . . . . . . . . . . . 59-66; pls. 9, 10

method procedure..................... 42-43; pl. $5 B$

summary of results..................... 69-71

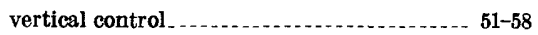
auxiliary gage installations..... _. . . $52-53$ common gage datum . . . 5 . 53-54 evaluation of discrepancies............... 56-57 Hoover Dam permanent gage........... 52 operations ............................. 51

reference datum .

scope of work $\ldots$. $51-52$

water-stage recorders. ................ 53

water-stage records. . . . . . . . . . . analysis................... 54

Survey of Lower Granite Gorge...... 73-81, pls. 14-16 computing the coordinates............... 76 cross sections, 1935 and 1948-49............. 77 distribution of sediment.

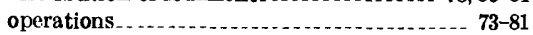

Survey of Lower Granite Gorge-Continued post-1935 subsidence 74,76 profiles of thalweg. purpose.

relief messurement sediment distrib sediment ranges. . . sediment volumes....................... $74,76,78$

Surveying techniques and datums.......... $73-74,76$ triangulation net

vertical control.

$\mathrm{T}$

Tamarix gallica, saltcedar...

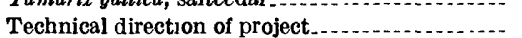

Tectonic stability, Colorado Plateau

Temperature, bottom sediment, relation to bacterial action . . . ......... 9, 187, 190-191

bottom sediment, relation to radiation...... 191

Colorado River at Grand Canyon, seasonal relation to other sedimentation factors

inflowing water

lake water, relation to dissolved solids, biochemical activity, season, and depth.................... 119-121

Temple Bar area, reservoir storage data......... 88-93

Terminal slope ................. 226, 227

Tertiary basin deposits. ..................... . 14-16

Thalweg, in Lower Granite Gorge, profiles..... 80

The Temple, Hualpai limestone cap........... 16

Thomas, H. E., Drainage basin tributary to Lake Mead..........................

Thomas, H. E., Gould, H. R., and Langbein, W. B., Life of the reservoir... ..... . . 231-244

Three Kids district, manganese................. 15

Tide, effect on water stage

Tilting, regional, post-1935..... 33-34, 36-37 See also Level changes since 1935.

Tonto platform, Lower Granite Gorge area. 73,

Topography of area..............

Topography of lake bottom, at terminal stage of reservoir..................... 227

Transpiration, effect on water loss an. quality -- $\quad 247$

evaluation for water budget.......... 97,99

Treaty, with United States of Mexico, 1944 _.. 221, 240

Tree-ring records, in extrapolation of runoff records.......................... 235

Triangulation, work and equipment........... 7

Triangulation net, of Lower Granite Gorge.... $\quad 74$ of the lake...... 44-51

Triassic rocks

Turbidity currents ........... 201-208; pls. 17, 20, 26 amount of sediment and distance of travel $205-206$ change in slope and width of channel. ..... 206 in Virgin River...... 206-207 interfiows. ................................ 203 overflows....... 202-203 relation to river discharge and lake stratification 202-204 size of suspended particles................. 206 underflows . . . . velocity, density, and thickness... . . . . 204-205

\section{$\mathbf{U}$}

Ullom, M. R., and Ames, F. C., Outline of procedures........ $40-4$

Underflow currents in the lake . . . . . . . 203-204 velocity, density, and thickness... . . . . 204-205
U.S. Bureau of Reclamation, cooperation..._ 127, 152 reports. . . .............. 3-5; 73-81; 83-84; 245-248 functions at Lake Mead and downstream control structures................... investigations, flow of density currents into lake............................. 5, 115 Office of River Control, Boulder City .... 10

U S. Coast and Geodetic Survey, report ........ 31-32 precise leveling 1935, relevelings 1940-41 and 1949-51.............. vi, 7,9

U.S. Geological Survey, cooperation reports.................. 41-44, 44-51, 51-57, 69-72 suspended-sediment sampling, Colorado and Virgin Rivers............ 3,5

U.S. Navy, Bureau of Ships, cooperative report. $68-69$ radio equipment....................... 10 monthly cruises. . . . . . . .

Electronics Laboratory, report.......... 9

Hydrographic Office, cooperative reports $39-43$

U.S. Weather Bureau, cooperation, 1948-49 _... 127 University of Califoraia, Seripps Institution of Oceanography, report............. 187-193

Scripps Institution of Oceanography, sampling and analysis..................

\section{V}

Valley of Fire, Mesozoic formations.............

Vertical control. See Mapping; Survey of Lower Granite Gorge; Survey of the lake.

Vetter, O. P. See also Smith, W. P.

The Lake Mead problem.... 3-5

Vetter, C. P., and Stanley, J. W., quoted . . . 225-226

Virgin Basin, Lake Mead.................. 11 gypsum and anhydrite solution by lake... 118, 212

Virgin Basin triangulation net, 1947-48 . . ...... 46, 48

Virgin Canyon, quality of water $\ldots \ldots \ldots$ slumping .............. specific conductance of water ............. 115

Virgin Canyon-Pierce Basin triangulation net, 1947-48. . . .

Virgin delta, growth and structure.......... 172-173 physiography......... 165-166

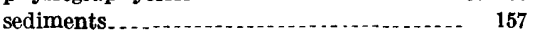

Virgin-Detrital trough, geologic history ........ $\quad 20$ physiography............................. 11

Virgin Mountains, Cretaceous rocks near..... - 14 faulting............ 18 physiography profile of level divergences............... 33 rocks....................................... 12

Virgin River, suspended-sediment sampling.... 3

Virgin River channel in lake, coring of accumulated sediment.............. 149

Virgin River turbidity currents in Lake Mead............. 206-207

Virgin River valley................ 11 Chemehuevi formation . 17 rock salt and glauberite, Muddy Creek formation ...............................

Volcanic rocks, Cretaceous and Tertiary....... 17

Volcanism, history of........................ 18

$\mathbf{W}$

Water and air-dry moisture content, in lake sediments................................ 153

Water and sediment, load, in relation to level changes............................... 35 volume by basins..... 87.91 .92 


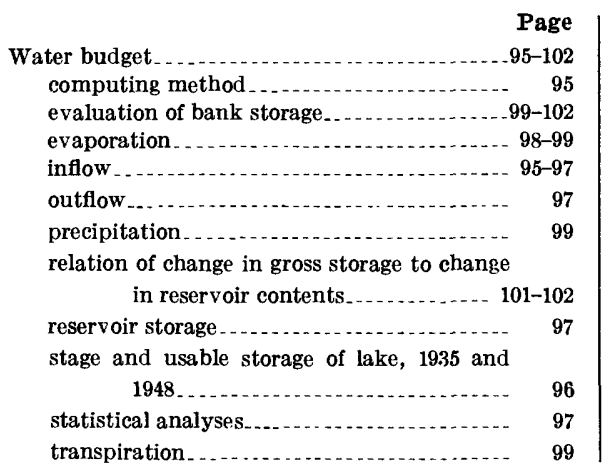

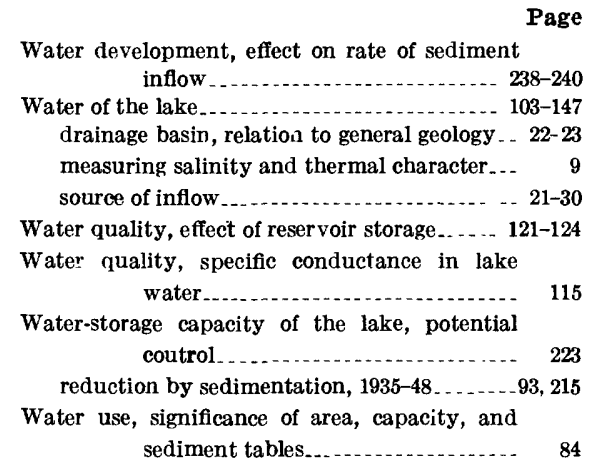

Page

Wave-built terraces

Wave-cut terraces, effect on water-storage capacity . . . . . . . . . . . . . . . 212; pl. $29 \mathrm{~A}$

West End mine, borate deposits........... 14-15

Wilson, R. M., Horizontal control... ......... 44-51

Wind, effect on lake stage . . . . . . . .

effect on operations

Wyoming Basin physiographic province, relation to the lake. . .

$\mathbf{Y}$

Yale University, reports. . . .............. . 11-20; 33-38

Yuma, Ariz., suspended-sediment records..... 234 

.

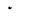

